Barbara Literska

Nineteenth-Century

Transcriptions of Works

by Fryderyk Chopin

\title{
Volume 16
}

Eastern European Studies

in Musicology

Edited by Maciej Gołąb 
This book is the first monographic study of nineteenth-century transcriptions of Chopin's music. The work is based on the quantitatively and qualitatively rich source material, which formed the basis for considerations from the perspective of social history, music analysis and aesthetics. Thanks to these multiple perspectives, as well as the time range and the source base, this study may contribute to the history of the reception of Chopin's work in nineteenth-century culture; it may also prove significant in overcoming the attitude that aesthetically deprecates transcriptions and in adopting a different stance, regarding such adaptations as valuable texts of musical culture.

Barbara Literska is Dean of the Faculty of Arts and Professor of Musical Education at the University of Zielona Góra. She specializes in nineteenth- and twentieth-century music history and theory, reception of Chopin's music and the works of the eminent Polish composer Tadeusz Baird. 
Nineteenth-Century Transcriptions of Works by Fryderyk Chopin 


\title{
Eastern European Studies in Musicology
}

Edited by Maciej Gołąb

\author{
Editorial board \\ Mikuláš Bek (Brno) \\ Gražina Daunoravičienè (Vilnius) \\ Luba Kyjanovska (Lviv) \\ Mikhail Saponov (Moscow) \\ Adrian Thomas (Cardiff) \\ László Vikárius (Budapest)
}

Volume 16 
Barbara Literska

\title{
Nineteenth-Century Transcriptions of Works by Fryderyk Chopin
}

\author{
Translated by John Comber
}

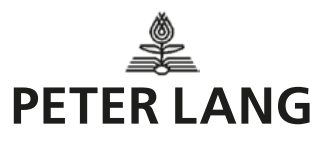




\section{Bibliographic Information published by the Deutsche Nationalbibliothek}

The Deutsche Nationalbibliothek lists this publication in the Deutsche Nationalbibliografie; detailed bibliographic data is available online at http://dnb.d-nb.de.

\section{Library of Congress Cataloging-in-Publication Data}

A CIP catalog record for this book has been applied for at the Library of Congress.

The Publication is founded by Ministry of Science and Higher Education of the Republic of Poland as a part of the National Programme for the Development of Humanities in 2017-2018, project number 21H 16002284 . This publication reflects the views only of the authors, and the Ministry cannot be held responsible for any use which may be made of the information contained therein.
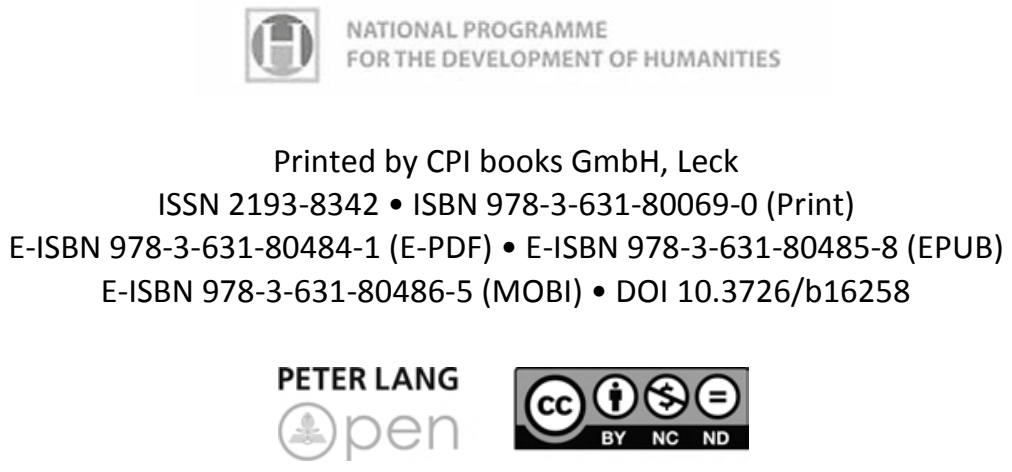

Open Access: This work is licensed under a Creative Commons Attribution Non Commercial No Derivatives 4.0 unported license. To view a copy of this license, visit https://creativecommons.org/licenses/by-nc-nd/4.0/

(C) Barbara Literska, 2020

Peter Lang - Berlin · Bern · Bruxelles · New York · Oxford · Warszawa - Wien

This publication has been peer reviewed.

www.peterlang.com 


\section{Contents}

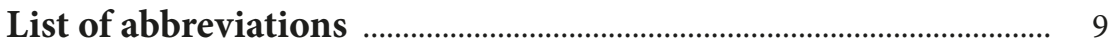

Introduction ……………………………………………………………..... 13

1 Transcriptions of works by Chopin as sources for research into the reception of his music in nineteenth-century musical culture - methodological issues ....................................... 15

1.1 The subject and terminology .................................................................. 15

1.2 The source material ............................................................................. 19

2 Composers, publishers and receivers: transcriptions of works by Chopin in nineteenth-century cultural communication ............................................................................... 27

2.1 Works by Chopin and their transcriptions in nineteenth-century musical culture - quantitative aspects ................................................. 30

2.2 The musical professions of the transcribers of Chopin's works .......... 46

[1] Performers: instrumentalists, singers ........................................... 49

[2] Composers ……………………………………........................ 59

[3] Organisers of musical life ............................................................. 66

2.3 The economic and legal conditions behind the dissemination of transcriptions during the nineteenth century ...................................... 69

2.4 The cultural contexts of the social reception of transcriptions of works by Chopin (taking nineteenth-century Wrocław as an example)

3 Between adhering to substance and trivialising content: a systematics of nineteenth-century transcriptions of works by Chopin

3.1 The adopted criteria of the systematics 
3.2 Substantial transcriptions ................................................................. 128

3.3 Structural transcriptions ......................................................................... 139

3.4 Syntactic transcriptions ........................................................................ 153

3.5 Recontextual transcriptions …………………....................................... 162

3.6 Functional transcriptions ...................................................................... 182

3.7 The diffusion of 'ideal types' ............................................................... 191

4 Nineteenth-century transcriptions of works by Chopin as a form of the manifestation of artistic values in the musical culture of the nineteenth century: Trivialmusik?

4.1 The category of Trivialmusik and its effect on the valuation of transcriptions

4.2 The value of transcriptions of Chopin's works within the context of the adopted criterion

4.3 Transcriptions of Chopin's works as documents of stylistic changes in nineteenth-century European music

Conclusion. Contemporary transcriptions of works by Chopin: prospects for further research

Appendix 243

1 Selected literary texts from vocal-instrumental transcriptions .......... 243

2 List of Michał Biernacki 252

List of figures 257

List of examples 259 


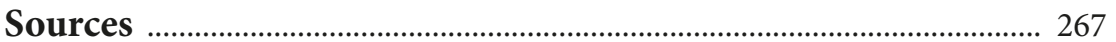

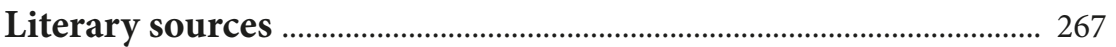

Musical sources …….............................................................................. 269

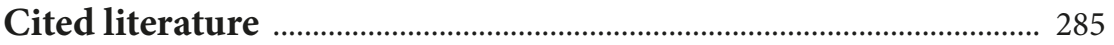

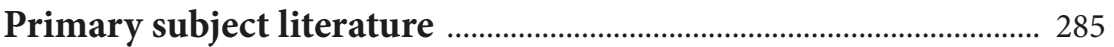

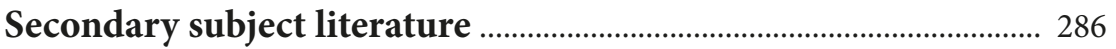

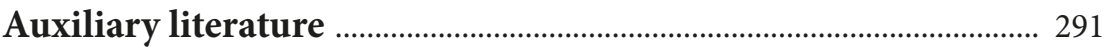

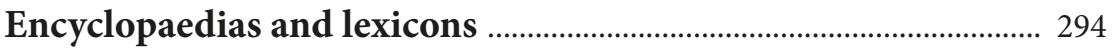

Index of names and musical titles .................................................... 297 



\section{List of abbreviations}

BBQL Eitner Robert: Biographisch-Bibliographisches Quellen-Lexikon der Musiker und Musikgehlerten der christlichen Zeitrechnung bis zur Mitte des 19. Jahrhunderts, 10 vols (Leipzig, 1900-1904); repr. 11 vols (Wiesbaden, 1959-1960)).

BRML Brockhaus Riemann-Musiklexikon. Digitale Bibliothek Directmedia 2001 Band 38.

BUBG Fétis, François-Joseph, Biographie universelle des musiciens et bibliographie générale de la musique, 8 vols +2 supplements (Paris, 1860-1880).

CT Józef Michał Chomiński and Teresa Dalila Turło, Katalog dziet Fryderyka Chopina / A Catalogue of the Works of Frederick Chopin (Cracow, 1990).

Deutsch Otto Erich Deutsch, Musikverlagsnummern. Eine Auswahl von 40 datierten Listen 1710-1900 (Berlin, 1961).

Devriès Anik Devriès and François Lesure, Dictionnaire des éditeurs de musique français, ii: De 1820 à 1914 (Geneva, 1988).

EGMW Encyklopädie der gesammten musikalischen Wissenschaften, oder Universal Lexicon der Tonkunst, ed. Gustav Schilling, 6 vols + supplement (Stuttgart, 1835-1842).

EM Encyklopedia Muzyki [Encyclopaedia of music], ed. Andrzej Chodkowski (Warsaw, 1995).

EMab Encyklopedia Muzyczna. Część biograficzna AB [Music encyclopaedia: biographical part AB], ed. Elżbieta Dziębowska (Cracow, 1979).

EMcd Encyklopedia Muzyczna. Czesść biograficzna CD [Music encyclopaedia: biographical part CD], ed. Elżbieta Dziębowska (Cracow, 1984).

EMM Encyklopedia Multimedialna PWN 1998 [CD-ROM]

Fl flute

Ga D. M. Garvelmann, Thirteen transcriptions for piano solo of Chopin's Waltz in D flat, op. $64 \mathrm{nr} 1$ (The minute Waltz) by Rafael Joseffy, Moritz Rosenthal, Isidor Philip, Max Laistner, Max Reger, Giuseppe Ferrata, Michael Zadora, Moritz Moszkowski, Aleksander Michałowski, Joe Furst and published for the first time the pastische of Kaikhoshru Shapurji Sorabji (New York, 1969). 
GD

Ho

HRML

KFCS

KSJP

KTL

MCL

MEM

MGG

NGD

NGD2nd

NML

Org.

P 1904-1910 Universal-Handbuch der Musikliteratur, ed. Franz Pazdirek (Vienna, 1904-1910) Bd. H.

Pfte pianoforte

SłS

Grove's Dictionary of Music and Musicians, ed. Eric Blom, i (London, 1954).

Hofmeister Adolf, Handbuch der musikalischen Literatur oder Verzeichniss der im deutschen Reiche und in den angrenzenden Ländern erschienenen Musikalien auch musikalischen Schriften, Abbildungen und plastischen Darstellungen mit Anzeige der Verleger und Preise (Leipzig, vols from 1852-1919).

Hugo Riemanns Musik Lexikon, ed. Alfred Einstein, 2 vols (Berlin, 1929).

Korespondencja Fryderyka Chopina [Correspondence of Fryderyk Chopin], ed. Bronisław Edward Sydow (Warsaw, 1955).

Komputerowy Słownik Języka Polskiego i Słownik Wyrazów Obcych [Computer dictionary of Polish and dictionary of foreign words]. PWN 1998 [CD-ROM] Paul Frank, Kurzgefaßtes Tonkünstlerlexikon, ed. Wilhelm Altmann, 12th edn (Leipzig, 1926).

Musikalisches Conversations-Lexikon, ed. Hermann Mendel, 11 vols + supplement (Berlin, 1870-1883).

Mała Encyklopedia Muzyki [Concise encyclopaedia of music], ed. Stefan Śledziński (Warsaw, 1981).

Die Musik in Geschichte und Gegenwart, ed. Friedrich Blume. Bd I (Kassel 1949-51); Sachteil 1 (Kassel 1994); Sachteil 9 (Kassel 1998).

The New Grove Dictionary of Music and Musicians, ed. Stanley Sadie (London, 1980).

The New Grove Dictionary of Music and Musicians, 2nd edn, ed. Stanley Sadie (London, 2001).

Alfred Einstein, Das Neue Musik Lexikon, nach dem 'Dictionary of modern Music and Musicians'. Herausgegeben von

A. Eaglefield-Hull übersetzt und bearbeitet von Alfred Einstein, 11th edn (Berlin, 1926).

organ

Słownik synomimów [Dictionary of synonyms], Andrzej

Dąbrówka, Ewa Geller and Ryszard Turczyn (Warsaw, 1996). 
SMP Stownik muzyków polskich [Dictionary of Polish musicians], ed. J. M. Chomiński, 2 vols (Cracow, 1964-67).

SMPD Albert Sowiński, Stownik muzyków polskich dawnych i nowoczesnych kompozytorów, wirtuozów, śpiewaków, instrumentalistów, lutnistów, organmistrzów, poetów lirycznych i miłośników sztuki muzycznej zawierający krótki rys historii muzyki w Polsce [Dictionary of Polish musicians past and present: composers, virtuosos, singers, instrumentalists, lutenists, organ-masters, lyric poets and lovers of the art of music, containing a brief historical outline of music in Poland] (Paris, 1874; repr. Warsaw 1982).

STL Słownik terminów literackich [Dictionary of literary terms], ed. Janusz Sławiński, 3rd edn (Wrocław, 1998).

SWO Słownik wyrazów obcych [Dictionary of foreign words], ed. J. Tokarski (Warsaw, 1980).

SZM Gustaw Roguski, Słowniczek znakomitszych muzyków [Concise dictionary of major musicians] (Warsaw, 1906).

Vc violoncello

Vl viola

Vn violin

Whistling's C. F. Whistling's Handbuch der musikalischen Literatur, ed.

A. Hofmeister, i (Leipzig, 1844). 



\section{Introduction}

The practice of drawing on other composers' ideas and works is a universal phenomenon in the history of music. Many composers have enhanced their knowledge of the art by studying and copying the works of other masters. That engenders a desire to imitate the musical ideas of others and to recompose them in a more or less creative way. The process of transcribing the works of Fryderyk Chopin began in the 1830s and continues today, albeit in a modified form.

The subject of Chopin transcriptions, although present in the awareness of musicologists, has yet to be treated to a monographic study, being merely signalled in studies of a limited scope. ${ }^{1}$ This state of affairs may explain the lack of relevant documentation enabling the subject to be addressed from a broader research perspective. The first work to present the huge volume of Chopin transcriptions published during the nineteenth and twentieth centuries was the Katalog dziet Fryderyka Chopina / A Catalogue of the Works of Frederick Chopin by Józef Michał Chomiński and Teresa Dalila Turło, published in 1990. ${ }^{2}$ That unique source of valuable information formed the inspiration and foundation for research into the little-known subject of Chopin transcriptions.

The present book is the first monographic study of Chopin transcriptions. For two main reasons - the specificities of the processes in music history and the huge amount of source material - the issue has been confined to nineteenthcentury transcriptions. ${ }^{3}$ This book is based on the quantitatively and qualitatively rich source material, which formed the basis for considerations from the perspective of social history, music analysis and aesthetics. Thanks to these multiple perspectives, as well as the time range and the source base, this study may contribute to the history of the reception of Chopin's work in nineteenth-century culture; it may also prove significant in overcoming the attitude that aesthetically deprecates transcriptions and in adopting a different stance, regarding such adaptations as valuable texts of musical culture.

This work is informed by several main aims: (1) to define the qualitative and quantitative economic, legal and socio-cultural conditions in which transcriptions functioned in nineteenth-century musical culture; (2) to present a systematic approach to nineteenth-century transcriptions; (3) to evaluate transcriptions on

\footnotetext{
1 See 'Primary subject literature'.

2 CT, 338-397.

3 The reasons for this limitation will be discussed in more detail in the second chapter.
} 
the basis of axiological criteria. My extensive discussion of nineteenth-century transcriptions and proposed approach to them merely outline the subject. This book, the fruit of several years' research into nineteenth-century transcriptions of Chopin's compositions, is not the only possible approach to the subject, but it is the first proposition for tackling the phenomenon.

The present book is a considerably abridged version of my doctoral dissertation, prepared at the Institute of Musicology of the University of Warsaw. The public defence of that dissertation took place on 18 December 2002, and its outcome was confirmed by the Board of the History Faculty of Warsaw University in January 2003. A year later, this book was published in Cracow by Musica Iagellonica. Over the many years during which this work took shape, I was helped at every stage by many kind individuals. I am sincerely grateful to Teresa Lewandowska (Library of the Fryderyk Chopin Society in Warsaw), Mariola Nałęcz (National Library in Warsaw), Bożena Jankowska (Toruń University Library) and Marek Romańczyk (Wrocław University Library) for all their assistance with documenting sources. For their valuable hints, I am grateful to Professors Zofia Helman, Irena Poniatowska and Jeffrey Kallberg. For their evaluation of my dissertation, I am grateful to its reviewers: Professors Małgorzata Woźna-Stankiewicz, Alina Żórawska-Witkowska and Andrzej Tuchowski. Their comments inspired the ultimate shape of this book. I am particularly grateful to Professor Maria Zduniak, who gave me access to unpublished source material collected in preliminary library searches over many years. My greatest thanks go to my supervisor, Professor Maciej Gołąb, who accompanied me with great dedication and commitment in the realisation of this difficult undertaking and also helped bring about the publication of this book, fifteen years later, in an English translation. 


\section{Transcriptions of works by Chopin as sources for research into the reception of his music in nineteenth-century musical culture - methodological issues}

\subsection{The subject and terminology}

The word transcription comes from the Latin transcriptio. Its equivalents in other languages are transcrizione (Italian), transcription (French) and Bearbeitung (German). A transcription is a rewriting of a musical text by means of other 'musical meanings', depending on the performance apparatus or the artistic competence of the transcriber. One basic aim of musical transcriptions is to obtain an artistic reworking that sounds different to and departs from the original to a specified degree. Similar terms are 'arrangement' and 'paraphrase'. Whilst an arrangement involves reorganising and recomposing a piece, transcription is devoid of that creative element. In musical reality, the two terms both involve reworking a musical composition, treated as a model for successive transformations. There are also elements that differentiate the two terms; these can be found in encyclopaedic and non-encyclopaedic definitions. ${ }^{4}$ Polish terminology is inexact: the meanings of the two related terms transkrypcja and aranżacja are not sufficiently specified and there is no reference to their etymology. Each of them is perceived as signifying a reworking of a composition for concert or artistic purposes. The words aranżacja and aranżowanie are often used in relation to popular music, ${ }^{5}$ while in relation to 'classical music' one speaks of transkrypcja and transkrybowanie. The lack of cohesion is evident in definitions of aranżacja and transkrypcja in Polish music encyclopaedias, ${ }^{6}$ from

4 Encyclopaedic definitions include 'Aranżacja', 'Transkrypcja' and 'Parafraza' in MEM, 52, 1009, 749; 'Aranżacja', 'Transkrypcja' and 'Parafraza' in EM, 49, 907, 672.

Non-encyclopaedic definitions include Lissa, 'Inspiracje', 72-73; Bączyk, 'Z problematyki', 7-37; Pociej, 'Próby', 14-15.

5 Zofia Lissa draws attention to this in Inspiracje, 72.

6 Aranżacja is reworking a composition for the purposes of concert performance and above all study for different forces than in the original. In a transkrypcja, as a variety of aranzacja, the musical substance remains the same despite the transferral to different forces. Transkrypcja is the least creative kind of aranzacja (EM, 49; MEM, 52).

Transkrypcja is reworking a composition for different forces. This is a similar term to aranżacja, 'but most often assumes an artistic purpose to the reworking and 
which it is difficult to determine which term has the broader semantic range and whether transkrypcja is a variety of aranżacja or vice versa. In the definition of transkrypcja, two basic features distinguishing this phenomenon from aranzacja are given: the artistic aim of a transcription (this argument is unconvincing, since the same aim appears in the definition of aranżacja) and the fact that the object of a transkrypcja is a whole work, whereas aranzacja involves merely parts of a work (this argument is also deflated by the definition of aranżacja). There are also contradictory opinions regarding a transkrypcja itself, now defined as the effect of rather uncreative procedures (in the definition of aranżacja), now as a rich creative practice (in the definition of transkrypcja). So the definitions are cross-explained and indistinct. We find similarly unclear definitions, equating one term with the other, in general lexicographic publications. ${ }^{7}$ Non-lexical sources carry similarly descriptions, invoking the above-mentioned encyclopaedic definitions. The difficulty with separating these two basic notions (and derivative terms) stems from the source - from Romantic times. It turns out that the nomenclature employed in those times was also marked by a lack of clarity. This was pointed out by Irena Poniatowska, evoking the figure of Franz Liszt, who used many different terms for his reworkings. ${ }^{8}$ This gave rise to two

presentation of the work in an integral version'. A transkrypcja is generally farther removed from the original than an aranżacja; 'fantasias and paraphrases are examples of free transkrypcja' (EM, 907; MEM, 1009).

7 In KSJP and EMM, we find the following definitions: a transkrypcja is a musical reworking of a composition for a different instrument, voice or ensemble than in the original; the work is notated using a different system than in the original; an aranzacja is a musical reworking of a composition for a different musical instrument or ensemble than in the original; in jazz, the reworking of a theme is juxtaposed with improvised fragments; in popular music, it is an instrumentation of a sketch of a work or even the melody alone; a parafraza is an instrumental, often virtuosic, musical work in the form of a fantaisie on themes from other compositions, such as operas or songs; it was popular during the nineteenth century.

8 Poniatowska, Muzyka fortepianowa, 317. In Poniatowska's opinion, Liszt originally conceived of a transcription as a piano arrangement of a song, expanded with virtuosic passages of improvisation; a partition pour piano was a transcription that brought new elements to the original work; a reworking for orchestra was called an orchestral transcription. Liszt defined other free reworkings of themes as Bearbeitung, Fantaisie, Illustration, Paraphrase, Reminiscences and Souvenirs. This information is confirmed in BRML, 10576, where the author points to Thematisches Verzeichnis der Werke von Fr. Liszt (Leipzig, 1855; 1877), in which Liszt specifies the following terms: Bearbeitungen, Fantasien, Reminiszenzen, Illustrationen, Paraphrasen, Klavierauszügen and Transkription. Unfortunately, no Polish library is in possession of this catalogue of 
meanings of the term 'transcription', functioning on an equal footing during the nineteenth century: as a synonym of all reworkings and as a literal transferral of an orchestral, ensemble or vocal composition to piano.

The terms transcription, arrangement and paraphrase also function in English. The key word, with the broadest semantic scope, is arrangement, which is 'an adaptation: the musical counterpart of literary translation..$^{9}$ It is also defined as 'the reworking of a musical composition, usually for a different medium from that of the original. ${ }^{10}$ The term arrangement can be understood in many different ways: as the transferral of a composition from one performance medium to another, with the composition either enhanced or expanded or else simplified, and with or without a change of forces. An arrangement can be a literal reproduction of the original, and transcription can signify adapting a work to a new performance medium while preserving the features of that new medium, admitting of changes to the original, but not as great as with a paraphrase. ${ }^{11}$ So in each case the effect of the recomposition procedures may vary: it can be a simple, almost literal transcription or a complicated paraphrase. However, in the opinion of Malcolm Boyd, definitions of 'arrangement', 'transcription' and 'paraphrase' are not universally accepted. ${ }^{12}$ Polish lexicographic sources are also supplemented by Boyd's remarks concerning yet another meaning of the word 'transcription', understood as a copy of a musical work 'translated' from entablature into modern musical notation. ${ }^{13}$ Such a definition of musical transcription is close to a linguistic definition, signifying the rewriting of an old text in orthography that is as close as possible to present-day usage. ${ }^{14}$

A somewhat different solution to the problem of reworkings is advanced by Hans Engel, who used the single term Bearbeitung for around a dozen varieties

Liszt's works, which is an important source for the present considerations. Alan Walker points to different terminology employed by Liszt, in particular 'transcription' and 'paraphrase'. See Walker, 'Liszt', in NGD2nd, xiv:767-8.

9 GD, i:223.

10 NGD, i:627.

11 GD, i:223.

12 'In either case some degree of recomposition is usually involved, and the result may vary from a straightforward, almost literal, transcription to a paraphrase which is more the work of the arranger than of the original composer. It should be added, though, that the distinction implicit here between an arrangement and a transcription is by no means universally accepted'. Boyd, 'Arrangement', in NGD, i:627.

13 Only in EM do we find the following: 'In a broader sense, intabulations of vocal works in lute and keyboard tablatures are also transcriptions'. See 'Transkrypcja', in EM, 907.

14 See 'Transkrypcja', in EMM. For a linguistic definition, see STL, 541. 
of the compositional practice of refashioning works - a practice that has varied down the ages. ${ }^{15} \mathrm{He}$ treated Transkription, understood as an artistic adaptation of instrumental or vocal music for keyboard instruments, as one of the kinds of Bearbeitung. Engel used the term Bearbeitung in relation to refashioned works, themes, melodies and movements, and above all in relation to multipartite works. A Bearbeitung can represent a new compositional form (a whole work), a new version of a musical composition (part of a work - a theme, melody, movement or section) or an arrangement of a musical work for different forces. In each of these cases, a reworking can either be reduced to a simple, technical arrangement, retaining the form of the original composition, or else considerably transform the reworked composition into an individual form contrasting with the original version of the work. Engel distinguishes eleven categories of reworking. The first of them comprises reworkings in a contrapuntal style (Bearbeitungen im kontrapunktischen Stil), parodies and paraphrases. This category covers not only reworkings of other composers' works, but above all reference to compositional practice as broadly understood. Consequently, it is the least relevant to our study. The second category consists of Baroque reworkings of other composers' works which present a literal rewriting of a composition for different forces (these are primarily 'translations' from one instrument to another). One special example here is that of so-called self-transcriptions, where composers borrow from their own works; this involves the adaptation not so much of entire works as of individual themes. Engel also distinguishes reworkings which represent an artistic refashioning of instrumental or vocal music for keyboard instruments (organ, piano) and those which are instrumental arrangements of vocal music (e.g. a French chanson); the latter influenced the emergence and development of sonata form. Another category comprises arrangements for piano and organ which mainly discharge two basic functions: research (reductions of largescale vocal-instrumental works) and popularisation (versions for piano for four hands). The sixth category is formed by compositions representing vocal arrangements of instrumental works. Another category comprises reworkings of instrumental works for a larger performance apparatus with the addition of a text (e.g. for choir, for orchestra or for choir and soloists), and this is juxtaposed with the category in which the forces are reduced - e.g. from orchestral to chamber. Engel gives a number of examples involving the modernisation of existing orchestral versions (these are arrangements from orchestra for orchestra). The enlargement of symphony orchestras during the eighteenth and nineteenth

15 Engel, 'Bearbeitung', in MGG, i:1458-66. 
centuries gave rise to new versions of works, with considerably enhanced sound. A separate type consists of dual versions of a single work; reworkings of existing compositions made by the same composer (e.g. Ravel's Pavane pour une infante défunte for piano and for orchestra) or by a different composer (e.g. Franz Xavier Süssmayr's version of Mozart's Requiem in D minor, K. 626). The last kind of Bearbeitung distinguished by Engel consists of scholarly arrangements involving the palaeographic 'translation' of an old notation into a new notation.

The term Bearbeitung is presented differently by Gesine Schröder, ${ }^{16}$ who employs a problematic key, rather than an historical key like Engel. She gives a definition of the notion itself, discusses different forms of the phenomenon and accounts for the causes and aims of its functioning in musical practice. This rich approach is complemented by Thomas Bösche's legal conditions relating to the existence of reworkings as broadly understood. ${ }^{17}$ According to Schröder, the term Bearbeitung means varying, supplementing, reconstructing, improving, decomposing, creating a new composition and changing the sound of the original work (model). ${ }^{18}$ Arrangement and Transkription are among the modes of existence of Bearbeitung, and they are strictly linked to a change of forces. According to Schröder, arrangements were usually motivated by social stimuli, whereas transcriptions resulted from a demand for compositions characterised by superior artistic qualities.

The above definitions treat the question of reworkings or adaptations in a broad and detailed way, describing all the possible forms of their functioning. Importantly, however, these changes as a whole are subordinated to the key terms arrangement (Eng.) and Bearbeitung (Ger.).

\subsection{The source material}

The basic material for research into Chopin transcriptions consists of 324 music prints. ${ }^{19}$ These are direct sources which speak for themselves. That material is

16 Schröder, 'Bearbeitung', in MGG Sachteil, i:1321-31.

17 Bösche, in ibid., 1331-4.

18 'Bearbeitung nennt man allgemein den Umgang mit einer [...] Vorlage, der diese abwandeln, sie ergänzen, fertigstellen, rekonstruieren, verbessern, dekomponieren, neukomponieren, nachdichten oder ihr eine andere klanglische Façon leihen, sie einem anderen Genre oder Zweck anpassen kann'. Ibid., 1321-2.

19 In deliberately forgoing a survey of manuscript sources, I was guided primarily by their far lesser impact compared to prints. In my opinion, the question of transcriptions in manuscripts merits separate research. There are extant manuscripts by such composers as Zygmunt Noskowski, Nikolay Rimsky-Korsakov and Auguste Franchomme. 
complemented by indirect sources, comprising opinions published in nineteenthcentury music encyclopaedias, concert guides and the press or contained in Chopin's correspondence. Indirect sources form the basis for research into Chopin reception. Thanks to transcriptions, we can study musical reception, ${ }^{20}$ which, unlike the reception of music, concerns other areas of human activity: literature, art and academic thought. This is a new field of research into the resonance of Chopin's music, previously overlooked. Research to date has been based on reception as broadly understood - as the 'history of a work's impact' on social awareness, ${ }^{21}$ artistic creation (music, literature, theatre, film, art), concert life and scholarly work. ${ }^{22}$ There is also a perceived need to study Chopin reception in his epoch, at a given historical moment and cultural location. ${ }^{23}$ Of primary importance to research into the scope and quality of reception are comparative procedures, which concern concert life and the world of publishing. ${ }^{24}$ The publishing of Chopin's works, ${ }^{25}$ related to a certain social context that had a great effect on the composition and form of his works, and consequently on the production of their various social meanings, is a crucial aspect of nineteenth-century Chopin reception. The existence of two kinds of sources - direct (musical) and indirect (literary) - provides grounds for a wide-ranging approach to the subject, enabling us to present the musical features of transcriptions while taking account of the crucial historical-social context, as well as entitling us to pass judgment on particular transcriptions.

Transcriptions are the main source on which our knowledge is based and to which the present work is devoted. Yet that source replicates events that have already existed, namely, Chopin's first editions, which should be considered as the primary sources. Their existence was the sine qua non for the creation of the huge open collection of transcriptions. Given such a large number of transcriptions, it is difficult to establish the primary sources on which composers based them Chopin's first editions or perhaps existing transcriptions. Hypothetically, we

20 The wording and definition of Ewa Czernek in 'Transkrypcje', 4.

21 See Poniatowska, 'Chopin - Paradygmaty', 11-24.

22 See Michałowski, 'Popularyzacja i recepcja', in Bibliografia, 171-96.

23 Cf. Lissa, 'Problemy', 7-26; Pisarenko, 'Wyraz', 27-43; Lissa, 'Recepcja'; Poniatowska, 'Twórczość', 100-112; Chechlińska, 'Chopin w kontekście', 60-67.

24 On concert life, see Ludvová, 'Twórczość, 107-24.

On publishing, see Prychodko, 'Bibliografia,' 141-51; Grabowski, 'Francuskie oryginalne wydania,' 115-50; Kallberg, 'Chopin in the marketplace', in Chopin at the Boundaries, 161-214.

25 Samson, 'Chopin reception'. 
can assume that transcriptions produced within a short period of time from the date of the first edition referred directly to that edition, whereas transcriptions representing further links in the chain of existing copies could have been based either on first editions or else on those copies. Also hypothetically, we may consider that transcriptions issued by French publishers, for example, referred to first editions published there. And although it is impossible to indicate a secure source for each and every transcription, there is no doubt that they must have been works in circulation. ${ }^{26}$

Given these difficulties with unequivocally establishing primary sources, my analytical research procedure drew on comparative (auxiliary) sources, namely, Chopin's originals published in the Complete Works of Frédéric Chopin edited by Ignacy Jan Paderewski, Ludwik Bronarski and Józef Turczyński. All 324 transcriptions were dated on the basis of five catalogues:

- Otto Erich Deutsch, Musikverlagsnummern. Eine Auswahl von 40 datierten Listen 1710-1900 (Berlin, 1961),

- Adolf Hofmeister, Handbuch der musikalischen Literatur oder Verzeichniss der im deutschen Reiche und in den angrenzenden Ländern erschienenen Musikalien auch musikalischen Schriften, Abbildungen und plastischen Darstellungen mit Anzeige der Verleger und Preise (Leipzig, volumes from 1852-1919),

- Anik Devriès and François Lesure, Dictionnaire des éditeurs de musique français, ii: De 1820 à 1914 (Geneva, 1988),

- The Catalogue of Printed Music in the British Library to 1980 (London, 1982),

- Józef Michał Chomiński and Teresa Dalila Turło, Katalog dzieł Fryderyka Chopina / A Catalogue of the Works of Frederick Chopin (Cracow, 1990).

Two of them (Deutsch and Devriès) make it possible to establish the publication date on the basis of plate numbers and the publisher's address (Devriès). Two others (The Catalogue and Hofmeister) are catalogues of music publications containing information on approximate publication dates, the publisher's name and address and the price of the print. Chomiński and Turło's Catalogue was helpful in dating copies not included in the other four catalogues.

The research material of the present book comes from the holdings of the following Polish libraries: the university libraries of Cracow, Torun and Wrocław,

26 An exception to this rule is Antoni Orłowski’s Mazur z motywów Koncertu (f-moll op. 21) [Mazur from motifs of the Concerto (in F minor, Op. 21)] for piano, published by Antoni Brzezina of Warsaw in 1830 (see CT, 348). The original composition was written in 1829 and first published by Wessel \& $\mathrm{C}^{\circ}$ in England on 25 May 1836 (see CT, 107). 
the libraries of Katowice Music Academy, Warsaw Music Society and the Fryderyk Chopin Society in Warsaw, and also the National Library in Warsaw. The initial characterisation of this material given below is intended to show how representative it is with regard to the phenomenon under analysis (nineteenthcentury transcriptions). The characterisation is based on two basic criteria: the forces for which a transcription was produced and its publisher. With regard to forces, the collection of 324 transcriptions falls into four main groups:

- piano transcriptions (106),

- transcriptions for solo instruments and piano (188),

- vocal-instrumental transcriptions (26),

- transcriptions for ensemble (4).

Piano transcriptions represent a heterogeneous group. The clear majority consist of transcriptions for piano for four hands (68), although a considerable group is formed by transcriptions for solo piano (36), with arrangements for two pianos of only marginal significance (2). The group of transcriptions for solo instruments and piano (188 copies) is dominated by adaptations for two instruments, violin (88) and cello (80), followed by flute (19) and organ (1). The transcriptions for voice and piano (26) represent an interesting group. In the years 1882-1911, the Warsaw publishing firm of Gebethner \& Wolff presented a series entitled Utwory Fryderyka Chopina ułożone do śpiewu [Works by Fryderyk Chopin arranged for singing]. ${ }^{27}$ These compositions are grouped into four thematic blocks: (1) Zbiór śpiewów polskich [Collection of Polish songs $],{ }^{28}$ comprising sixteen Chopin songs and an arrangement of the Prelude in A major, Op. 28 No. 7 (by Piotr Maszyński); (2) Zbiór najpiękniejszych melodyi ułożonych do śpiewu [Collection of the most beautiful melodies arranged for singing], ${ }^{29}$ featuring arrangements of seven mazurkas by various composers; ${ }^{30}$ (3) transcriptions of fifteen mazurkas by Pauline Viardot; ${ }^{31}$ (4) a collection of

27 Dated after CT, 338-97.

28 Gebethner \& Wolff, Warsaw, 1890, 1897, 1919. Dated after CT, 380 and 371-3.

29 Gebethner \& Wolff, Warsaw, 1866, 1880, 1882, 1893, 1897, 1898, 1911. Dated after CT, $350-4$ and 357.

30 'Zakochana' [The Love-Lorn Lassie], Op. 7 No. 2; 'Tęsknota' [Longing], Op. 6 No. 4; 'Zemsta dziewczyny' [A girl's revenge], Op. 24 No. 3; 'To nie on' [It's not him], Op. 24 No. 1; 'Terkotka' [The Cuckoo], Op. 30 No. 2; 'Dziewczyna mazowiecka' [Mazovian girl], Op. 17 No. 1; 'Czyjaż wina?’ [Who’s to blame?], Op. 50 No. 2.

31 Gebethner \& Wolff, Warsaw, 1866-1922. Dated after CT, 350-60: 'Szesnaście lat' [Seize ans], Op. 50 No. 2; 'Kochaj mnie' [Aime-moi], Op. 33 No. 2; 'Zalotna' [Coquette], Op. 7 No. 1; 'Ptaszyna' [L'oiselet], Op. 68 No. 2; 'Rozstanie’ [Séparation], Op. 24 No. 
Mélodies, ${ }^{32}$ which contains arrangements of six other Chopin compositions with Polish words by Jan Chęciński. ${ }^{33}$ This group of transcriptions replicates the French edition Six mélodies transcrites pour chant et piano (to words by Jules Ruelle) published by E. Girod of Paris in $1860 .{ }^{34}$ Of these four groups, one consists of original works by Chopin, while the other three are arrangements of his works. Interestingly, both the originals and the transcriptions functioned in musical life alongside one another as equally valid forms of Chopin's lyric output. ${ }^{35}$ The group of arrangements for voice and piano comprises 15 mazurkas, 4 waltzes, 5 nocturnes, 1 prelude and the single Berceuse. The transcriptions for ensemble - chamber ensemble or orchestra - are represented by an entirely marginal group of examples. And this is characteristic not just of our study material, but of the phenomenon of transcriptions in general, as is confirmed by analysis of the Catalogue by Chomiński and Turło. ${ }^{36}$ Scrutiny of the forces of these ensemble settings shows that string orchestra and female choir are new ensembles in this respect, whereas the other performance media (piano, soprano, violin, cello, organ) are familiar from earlier examples. In the research material presented here, there are no choral arrangements for male and mixed choir, be it with or without instrumental accompaniment. Evidence of the presence of such arrangements in nineteenth-century musical culture is provided by Irena Chomik..$^{37}$

In seeking a plane of comparison for this research material, I can refer to the only source material that is general accessible, presented by Chomiński and Turło. ${ }^{38}$ Subjected to comparison were the number of transcriptions and the date of publication (Table 1), and the number of transcriptions and the place of publication (Table 2). One easily notes that in the former relationship there is a similar

1; 'Przed mazurem' [La fête], Op. 6 No. 4; 'Biedne serce' [Faible cœur], Op. 7 No.

3; 'Dzieweczka' [La jeune fille], Op. 24 No. 2; 'Kołysanka' [Berceuse], Op. 33 No.

3; 'Pierwsza para' [La danse], Op. 50 No. 1; 'Do pięknej' [La beauté], Op. 67 No. 1; 'Opuszczona' [L'Inondation], Op. 7 No. 3; 'Swaty' [Beau rossignol], Op. 17 No. 4 and Op. 14 No. 1; 'Sanna' [Les traîneaux], Op. 59 No. 1.

32 Gebethner \& Wolff, Warsaw, 1867. Dated after CT, 339, 354, 361, 364, 365, 369.

33 Berceuse, Op. 57; 'Na łące' [Dans la prairie], Op. 15 No. 1; 'Żal' [Plainte], Op. 9 No. 1; 'Piosnka miłości' [Chanson d’amour], Op. 62 No. 1; 'Powiastka' [Fabliau], Op. 30 No. 1; 'Cisza nocy' [Aspiration], Op. 9 No. 2.

34 Dated after CT, 339, 354, 361, 364, 365, 369.

35 My own wording, designed to distinguish compositions with an added verbal text.

36 CT, 338-97.

37 Chomik, 'Warszawskie Towarzystwo', 263-92.

38 CT, 338-97. 
Table 1: Number of transcriptions published in successive decades.

\begin{tabular}{lcc}
\hline $\begin{array}{l}\text { Date of } \\
\text { publication }\end{array}$ & $\begin{array}{l}\text { Group of transcriptions } \\
\text { after CT }\end{array}$ & $\begin{array}{l}\text { Source material of } \\
\text { the present book }\end{array}$ \\
\hline $1830-39$ & 18 & 13 \\
$1840-49$ & 155 & 12 \\
$1850-59$ & 75 & 9 \\
$1860-69$ & 223 & 27 \\
$1870-79$ & 179 & 85 \\
$1880-89$ & 836 & 120 \\
$1890-99$ & 365 & 47 \\
$1900-09$ & 618 & 9 \\
$1910-19$ & 500 & 2 \\
total: & 2969 & 324 \\
\hline
\end{tabular}

rule for both collections: the point of climax falls in the 1880s. The divergences occur after 1900: in the CT collection there is a tendency for growth, while in the source collections there is a clear decline in the number of transcriptions. The source material characterised here does not reflect the specificities of the work of all European publishing firms, and the hierarchy it reveals is merely approximate to that contained in CT. According to that catalogue, most active were German publishers (53.4\%), followed by French (12.9\%), Polish (from the Congress Kingdom and Galicia, $9.6 \%)$, British (7.5 \%) and Russian (6.3\%). Interestingly, Austrian (4.3\%), American (2.7 \%) and Italian (1.9\%) firms had only a marginal role in propagating transcriptions of Chopin's works. In the collected source material of this treatise, the largest number of transcriptions were published in Germany $(77.7 \%),{ }^{39}$ followed by Poland $(9.8 \%),{ }^{40}$ then France $(6.1 \%) .{ }^{41} \mathrm{~A}$ few

39 Germany is represented by the following:

Leipzig: F. Kistner, J. H. Zimmermann, Breitkopf \& Härtel and C. F. Peters;

Brunswick: H. Litolff;

Berlin: A. M. Schlesinger.

40 These are the Warsaw publishers: A. Brzezina, Gebethner \& Wolff, J. Kaufmann, G. A. Sennewald, A. Rajchman, C. Witanowski and Hoesick.

41 France is represented by Paris publishers: Brandus, E. Girod, Heugel \& Fils, S. Richault, Richault et Cie Editeurs, J. Hamelle, M. Schlesinger, Benoît Ainé, E. Gérard and A. Durand \& Fils. 
Table 2: Number of transcriptions published in different countries in 1830-1919.

\begin{tabular}{lcc}
\hline Publishers & $\begin{array}{l}\text { Group of transcriptions } \\
\text { after CT }\end{array}$ & $\begin{array}{l}\text { Source material of } \\
\text { the present book }\end{array}$ \\
\hline German: & 1587 & 252 \\
French: & 383 & 20 \\
Polish: $^{\text {a }}$ & 287 & 32 \\
British: & 223 & 1 \\
Russian: & 189 & 8 \\
Austrian: & 129 & 4 \\
American: & 81 & 6 \\
Italian: & 57 & 0 \\
Czech ${ }^{\text {: }}$ & 14 & 0 \\
Swiss: & 5 & 0 \\
Hungarian & 5 & 0 \\
Dutch: & 3 & 1 \\
Swedish: & 3 & 0 \\
Belgian: & 2 & 0 \\
Argentinian: & 1 & 0 \\
total: & $\mathbf{2 9 6 9}$ & $\mathbf{3 2 4}$
\end{tabular}

a Publishing firms from the Congress Kingdom and Galicia.

${ }^{\mathrm{b}}$ Bohemian and Hungarian publishers could be assigned to the group of Austrian publishing firms, since at that time Bohemia was not a sovereign state, but an Austrian province, while Hungary was part of the dualist monarchy of Austria-Hungary. However, following that line of thinking, I would have to omit 'Polish publishers' and employ a 'Partition' nomenclature.

${ }^{\mathrm{c}}$ As above.

examples represent Russian (2.4 \%), American (1.8\%), ${ }^{42}$ Austrian (1.2\%) and British publishers. ${ }^{43}$ One feature common to both collections is the clear domination of German material.

On the basis of the two relationships presented above (the number of transcriptions against the time and place of their publication), the research material in my possession displays a character similar to the collection of sources included in the above-mentioned Catalogue. ${ }^{44}$ The source material I have

42 E. Schubert \& $\mathrm{C}^{0}$.

$43 \mathrm{I}$ am in possession of just one transcription from Augener.

44 CT. 
gathered also takes account of the instruments most often used during the nineteenth century. However, this data should not be absolutised, since the source material is not complete. It represents just a sample, and the above numbers and lists are designed to underscore its approximate representative and reliable character with regard to the problem in hand. 


\section{Composers, publishers and receivers: transcriptions of works by Chopin in nineteenth-century cultural communication}

The aim of this chapter is to forge a picture of the musical reception of Chopin through the form of transcription in nineteenth-century European musical culture. That aim will be served by resolving many detailed questions. Transcriptions as the subject of historical research will be closely profiled in terms of quantity and quality and will be described as a subject of compositional work, an object of publishing work and a 'product' with its 'consumers' - performers, listeners and reviewers. The quantitative profile will show the scale of transcribing and reveal certain preferences in the choice of original compositions. The aim of the further considerations will be to obtain answers to a number of questions. Who composed the transcriptions - what class of musicians? Was the quality of their musical training reflected in the quality of the transcriptions they produced? One issue of crucial importance to the cultural scope and dimensions of Chopin's musical reception will be to determine the place of transcriptions in the publishing market. We can resolve that issue by answering detailed questions. Which publishers popularised transcriptions? How many copies did they print? Another issue that needs resolving is that of the legal conditions behind the practice of transcribing. Answers to these questions will enable us to determine the place of transcriptions in nineteenth-century publishing work and their legal status. In order to trace a picture of Chopin's musical reception, its social context will be outlined. The ultimate question, which is the reception of his music, identified with 'the description of its institutional functioning, ${ }^{35}$ will be exemplified by musical life in nineteenth-century Wrocław.

I will study transcriptions produced during the period 1830-1919. The duration of the phenomenon of transcription has been defined mainly on the basis of the nature of the subject of research itself, and also on the basis of the changes that occurred in music history, connected with political and social events. Analysis of the information contained in the Chomiński and Turło Catalogue shows that the first Chopin transcriptions appeared shortly after the publication of their originals, during the period from 1830 to $1838 .{ }^{46}$ These are adaptations

45 Lissa, Wstęp, 145.

46 CT, 338-97. 
of the Mazurka in B flat major, Op. 7 No. 1, ${ }^{47}$ Mazurka in D major, Op. 24 No. $3,{ }^{48}$ Introduction and Polonaise brillante in C major, Op. $3{ }^{49}$ Grand Duo concertant in E major, ${ }^{50}$ Rondo in C minor, Op. $1,{ }^{51}$ Trio in G minor, Op. $8^{52}$ and part of the Concerto in F minor, Op. $21 .{ }^{53}$ The earliest dated is Antoni Orłowski's transcription of the Concerto in F minor from 1830, entitled Mazur z motywów Koncertu [Mazur from motifs of the Concerto]. The reworking concerns only part of the original composition - just a few motifs from its last movement. One unquestionable asset of this adaptation is the fact that it was the first published composition referring to a Chopin manuscript. ${ }^{54}$ Although Chomiński and Turło classified this work as a transcription, ${ }^{55}$ from our point of view it is merely a reminiscence of Chopin's work. The year 1833 seems more distinctive. Of the three arrangements published that year, the composers of two are known, although full information is known only about the third adaptation, Friedrich Kalkbrenner's Variations brillantes for solo piano. ${ }^{56}$ And although that arrangement goes far beyond the framework of a pure transcription (it is rather a new composition - a set of variations on the Mazurka in B flat major, Op. 7 No. 1 for which Chopin's work was merely the inspiration), it is the first such extensive reference to a published Chopin composition. ${ }^{57}$ And only in that sense can one justifiably highlight this historical fact both in the present work and in the Catalogue. ${ }^{58}$

47 CT, 350. This is a transcription for piano from 1833.

$48 \mathrm{CT}, 354$. This is a transcription for piano from 1835.

49 CT, 373. These are transcriptions for piano from 1837, for piano for four hands from 1837, for two pianos from 1834, for violin and piano from $c .1834$ and for viola and piano from 1838 .

$50 \mathrm{CT}, 339$. One transcription for piano for four hands from 1839 and three transcriptions for violin and piano from the years 1833, 1833 and 1834 .

51 CT, 382. These are six transcriptions for piano for four hands from the years 1834, $1835,1835,1836,1836$ and 1838 .

52 CT, 388. One transcription from $c .1834$.

53 CT, 348. Part of the Allegro vivace scored for piano, 1830.

54 Widely known published versions date from no earlier than 1836. Information after CT, 106-7.

55 Ibid.

56 CT, 350.

57 The earliest edition of this mazurka dates from December 1832. It was published by F. Kistner of Leipzig in a set of five mazurkas, Op. 7 (Cinq Mazurkas pour le Pianoforte...). See CT, 113.

58 A similar example of a composer drawing creatively on a Chopin model is Robert Schumann's Variations sur un Nocturne de Chopin. However, we do not know the exact year this work was written; according to information contained in the preface to a new 
The unequivocal pinpointing of the year 1830 as marking the start of the process of the transcribing of Chopin is based solely on musical premises. The closing date for the phenomenon of nineteenth-century transcriptions, meanwhile, based on the nature of the material and changes in music history connected with the most crucial political and social events at that time, was set at 1919. I adopted this date during the initial phase in my research, based on the Chomiński \& Turło Catalogue, which showed that transcriptions produced up to that date represent a homogeneous complex in terms of forces (there are no instruments signalling later times, such as ukulele, balalaika, bayan, zither or mandolin orchestra). Just as crucially, the years 1920-29 saw a fall in the number of transcriptions being published. The second argument in favour of this date was based on irrefutable political-social premises: after the First World War, Europe entered a new era of civilisation. Works discussing world history during the nineteenth century contain a variety of periodisations,${ }^{59}$ but many of them concur that the nineteenth century began with the outbreak of the French Revolution of 1789 and ended with the conclusion of the First World War. ${ }^{60}$ That political watershed was not linked to any distinct musical-cultural watershed. The borderline between nineteenth- and twentieth-century music is based on a change in the pitch organisation of the musical material, and the distinct negation of the tonal system in compositional practice had already occurred in 1908, when Arnold Schönberg 'broke the barriers of the past aesthetic' with his Book of the Hanging Garden, Op. $15 .^{61}$ That beginning, known as the 'hemitonic watershed, ${ }^{32}$ bore consequences in the form of twelve-note technique, which reached a wide audience in 1924, with the first performance of Schönberg's Serenade for voice and instruments. ${ }^{63}$ And although the search for a new order and a new

edition (Variationen über ein Nocturne von Chopin (g-moll, op. 15 nr 3) für Klavier ergänzt und herausgegeben von Joachim Draheim. Breitkopf \& Härtel Wiesbaden 1992. Edition Breitkopf 8151), the work is dated to approximately 1833-6.

59 Bazylow, Historia; Pajewski, Historia; Żywczyński, Historia; Łazuga, Historia.

60 In the works of Mieczysław Żywczyński and Janusz Pajewski, this period is divided into two subperiods: 1789-1870 and 1871-1918. However, as Pajewski writes, the year 1871 is conventionally adopted as a caesura in nineteenth-century history. 'It is a turning point in political history (the defeat of France and the emergence of Germany's hegemony in Europe), important in social history (the Paris Commune), but does not represent a watershed for either economic or cultural history' (Historia, 5).

61 Gołąb, Dodekafonia, 21.

62 Chomiński and Wilkowska-Chomińska, Historia, 200.

63 Schaeffer, Maly informator, 265. 
organisation of sounds in composition practice is marked by the date 1908, fully conscious actions, backed by theoretical thinking, occurred close to $1920 .{ }^{64}$

The transcribing of Chopin's works, begun in 1830, has continued to the present day. It is a continuously evolving process, in which it is difficult to point to a single work that clearly brings the sequence of nineteenth-century transcriptions to an end. The difficulties are compounded by the plethora of existing adaptations and the impossibility of gaining access to each and every one of them. In my belief, such a state of affairs, allied to the political, social and musical situation and to the very nature of transcription, allows us to adopt the year 1919 as marking the end to nineteenth-century transcriptions of Chopin's works.

\subsection{Works by Chopin and their transcriptions in nineteenth- century musical culture - quantitative aspects}

The main source for quantitative profiling is the Catalogue of the Works of Frederick Chopin by Chomiński and Turło. The Catalogue's list of transcriptions is based on arrangements of 201 original works (of the 230 compositions by Chopin). Those numbers indicate the massive scale of Chopin transcription during the nineteenth century. At this point in our considerations, we are interested in the dynamic behind the quantitative development of transcription over the course of the nineteenth century, as well as grasping certain trends in the figures.

The quantitative information taken from the Catalogue is presented here in the form of tables organised according to genre, which appear on the last pages of this subchapter. ${ }^{65}$ In order to indicate the circumstances surrounding the production of transcriptions, the dates of the original work's composition (Comp.) and publication (Pub.) are given in the tables. The period when the transcriptions were written is divided into decades, and it should be noted that adaptations straddling decades (e.g. 1879-1882) are assigned to the earlier decade (in this case the 70s). For this reason, the numbers of transcriptions in particular decades differs slightly from those given in the Catalogue, but their overall total is the same. Furthermore, although we are interested here in nineteenthcentury transcriptions, the table contains all transcriptions, even from the twentieth century. Their inclusion gives a broader perspective on the research subject, enabling it to be holistically presented, and points to the existence of a separate

64 Gołąb, Dodekafonia, 38.

65 CT, 338-97. 
research problem (nineteenth-century transcriptions). Placed beneath each generic table are graphs conveying the quantitative dynamic behind the production of transcriptions.

The transcribing of etudes (Table 3) began during the 1840s, so ten years after the originals were composed. Interest in this genre gradually increased from the 1860 s onwards. A clear watershed occurred during the 1880s, but the heyday of etude transcriptions occurred during the first five decades of the twentieth century. Dating from earlier years (1840-99) are single examples, representing $15.5 \%$ of the total. The graph clearly shows that the transcribing of etudes reaches a climax in the first decade of the twentieth century (during which $14.1 \%$ of all transcriptions were produced) and extends into the 1950s. This is a significant period, during which $75.6 \%$ of all etude transcriptions were written. After that fifty-year period, the transcribing of etudes clearly dwindles. It is interesting to note that during the nineteenth century every single one of Chopin's etudes was transcribed at least once, which is not the rule in Chopin transcription in general. Of the twenty-seven Chopin etudes, the most popular during both the nineteenth and the twentieth century were the following: in F minor, Op. 25 No. 2, E major, Op. 10 No. 3, C sharp minor, Op. 25 No. 7, E flat minor, Op. 10 No. 6, C major, Op. 10 No. 1, A minor, Op. 10 No. 2 and G flat major, Op. 10 No. 5. The Etude in E major was particularly fashionable during the twentieth century. The Etudes, Op. 25 Nos. 2 and 7 and Op. 10 Nos. 3 and 6 stand out for their singing melodic line, whereas Op. 10 Nos. 1,2 and 5 are figurational compositions in a rapid tempo.

Nearly all of Chopin's preludes were subjected to some sort of transcription (Table 4), with the exception of the Prelude in D major, Op. 28 No. 5. Distinct interest in this genre occurred rather late compared to the date of its publication, not until the 1880s. Nevertheless, nineteenth-century transcriptions represent $45.1 \%$ of all the arrangements of this genre. The graph line is undulating, with three points of climax (the years 1880-89, 1910-19 and 1960-69). In terms of the quantity of transcriptions, four pieces stand out among the twenty-four transcribed preludes (in A major, Op. 28 No. 7, C minor, Op. 28 No. 20, E minor, Op. 28 No. 4 and D flat major, Op. 28 No. 15), which were popular in this respect during both the nineteenth and the twentieth century. The Preludes in A major, No. 7, C minor, No. 20 and E minor No. 4 are short compositions in a slow tempo, characterised by a transparent texture and design. Those features may have determined the increased interest among performers - not just pianists, but also other instrumentalists. It should be added that the material transcribed was not always a whole composition, but sometimes just a part. That was the case with the Prelude in D flat major, No. 15, from which transcribers usually 


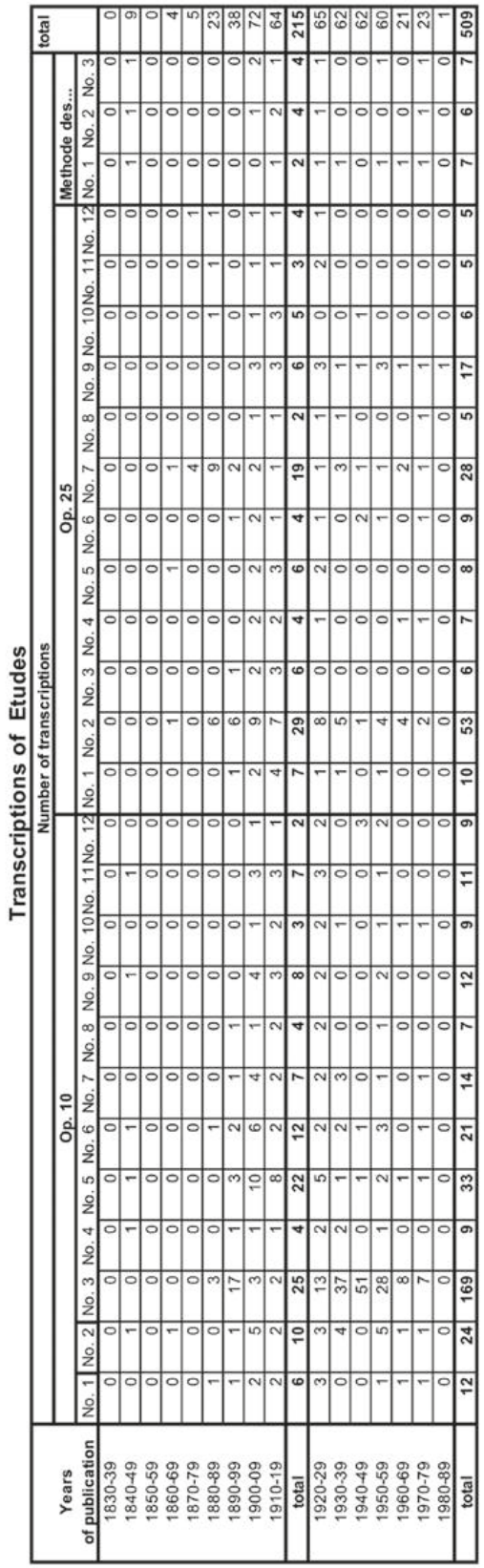




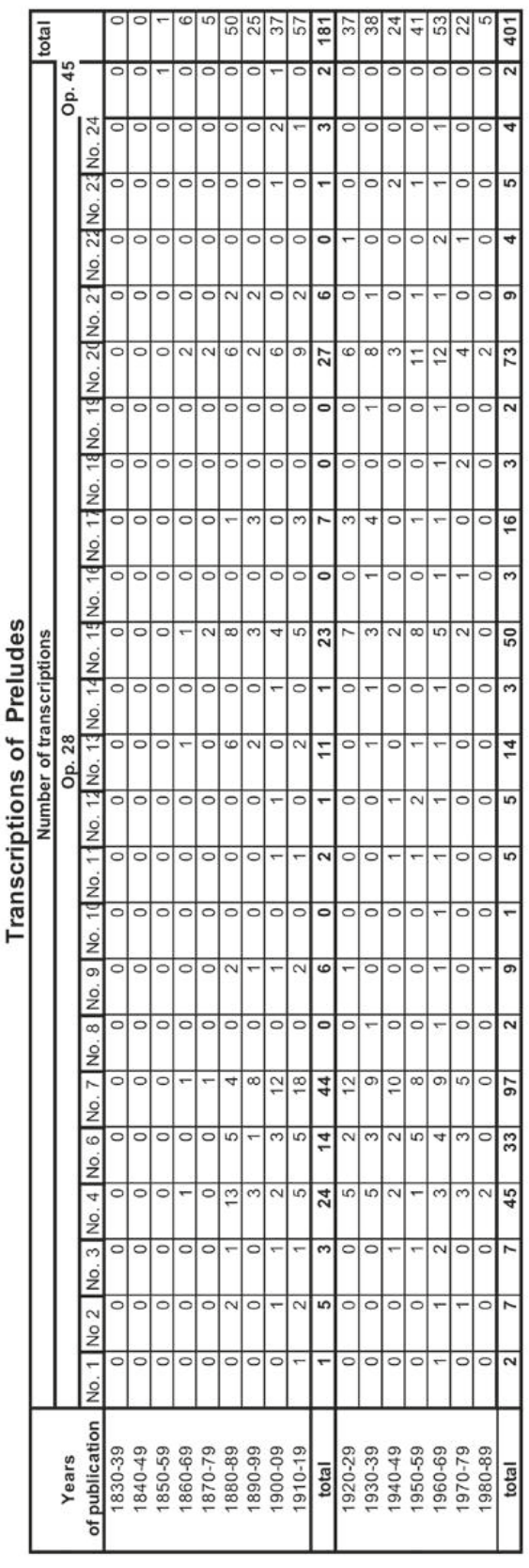


took the opening section (bars 1-27). In all four examples, one notes the songfulness, smoothness and succinctness of the distinctly presented melody. That condition is met also by other preludes transcribed in greater number (Nos. 6 , 13,17 and 21).

Of the fifty-seven Chopin mazurkas (Table 5), forty-six were transcribed, each of them at least several times. This genre was exceptionally popular among transcribers during the nineteenth century, when $76.6 \%$ of all mazurka transcriptions were produced. Two decades of the nineteenth century in particular witnessed a huge explosion of mazurka arrangements: 1880-89 and 1900-09. That is visible on the graph, which also shows the gradual fall in the number of transcriptions over the period from 1910 to 1980 . As much as $62.2 \%$ of the total consists of transcriptions of works from Chopin's Opp. 6, 7, 17, 24 and 33. Of the forty-six mazurkas transcribed, five of them stand out the most: in B flat major, Op. 7 No. 1, D major, Op. 33 No. 3, A minor, Op. 7 No. 2, G minor, Op. 24 No. 1 and F sharp minor, Op. 6 No. 1. All these pieces are characterised by a transparent formal and harmonic design and a distinctive 'kujawiak' melodic line.

The changing quantities of polonaise transcriptions (Table 6) do not show any distinct trends. Of the fifteen polonaises transcribed, five of them make up $87.3 \%$ of the total: Op. 40 No. 1, Op. 3, Op. 22, Op. 26 No. 1 and Op. 53. Three of them are particularly prominent: the Polonaise in C major, Op. 3 was frequently transcribed during the nineteenth century but was almost entirely overlooked during the twentieth century, being supplanted by the Polonaise in A flat major, Op. 53, which enjoyed unwaning popularity among transcribers, as did the Polonaise in A major, Op. 41 No. 1. Arrangements of the latter constitute $41.3 \%$ of all polonaise transcriptions (from the nineteenth and twentieth centuries), which breaks down as follows: $31.7 \%$ in the nineteenth century; $54.5 \%$ in the twentieth century. The graphic line is undulating, with three notable climaxes (1880-89, 1900-09 and 1940-49), which are reached in a gradual way.

Songs (Table 7) were frequently transcribed, from several to even several dozen times. They began to appear during the 1860 s, shortly after the publication of the original collection. Song transcriptions peaked in the years 1910-19 and maintained a high level over the next decade. Comparing this table with the previous tables, one notes a very even distribution of transcriptions of each song over successive decades. However, two songs stand out in quantitative terms: 'Życzenie' [A Maiden's Wish] and 'Pierścien' [The Ring]. Neither of them is formally complicated, and in character, metre and rhythm they refer to Chopin's mazurkas; they also deal with similar subjects. 


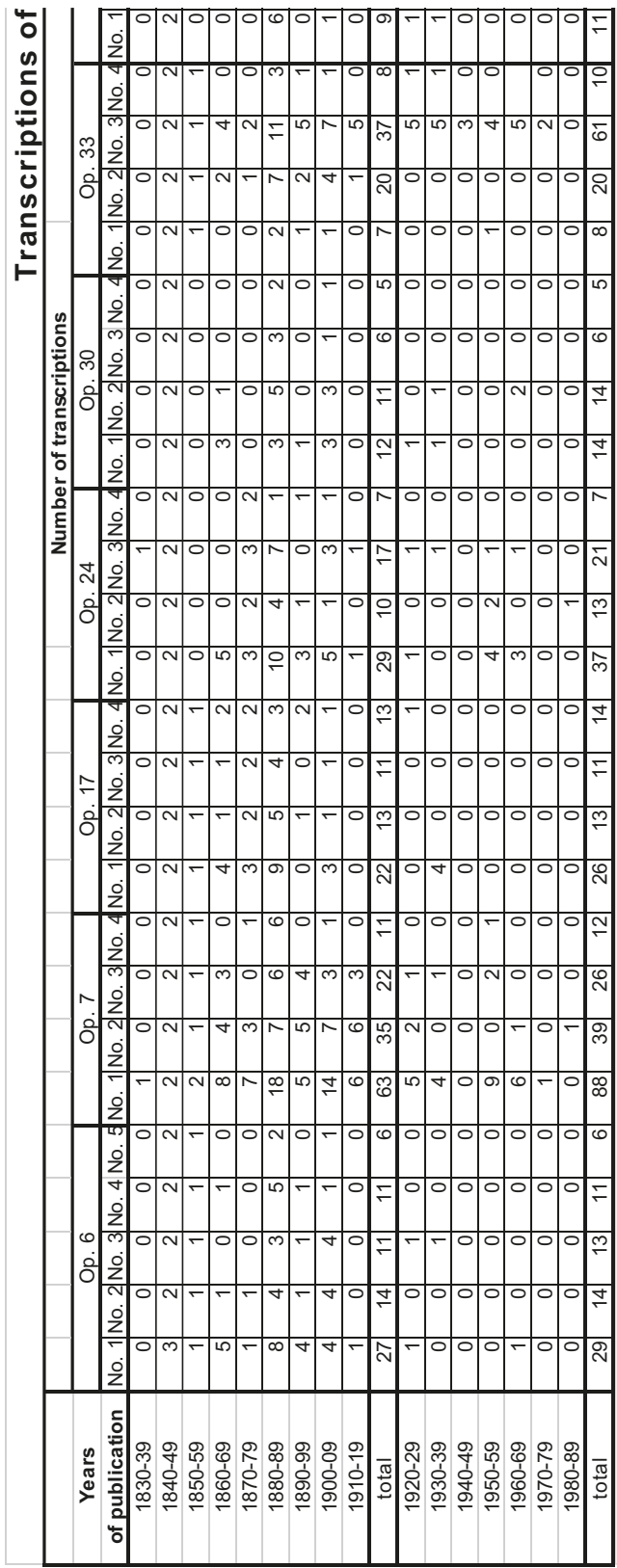




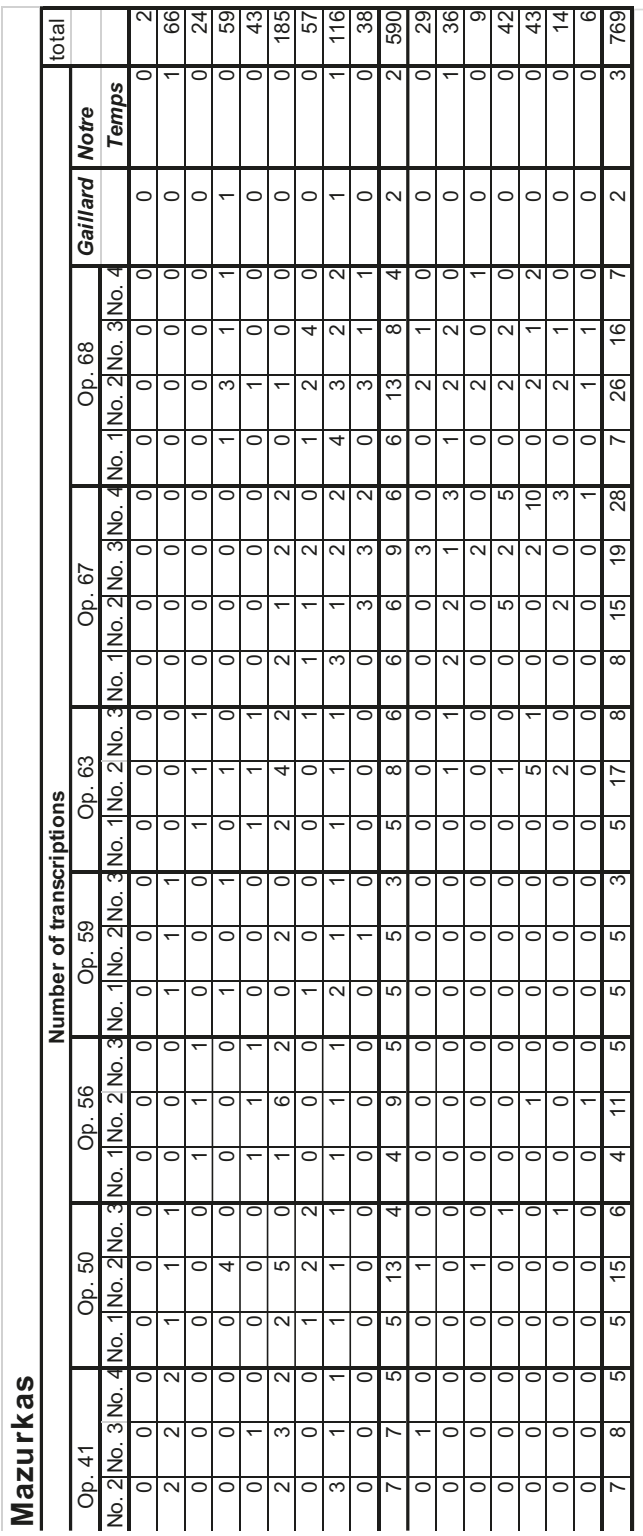


Transcriptions of Polonaises

\begin{tabular}{|c|c|c|c|c|c|c|c|c|c|c|c|c|c|c|c|c|}
\hline \multirow{3}{*}{$\begin{array}{c}\text { Years } \\
\text { of publication }\end{array}$} & \multicolumn{15}{|c|}{ Number of transcriptions } & \multirow[t]{3}{*}{ total } \\
\hline & \multirow[t]{2}{*}{ Op. 3} & \multirow[t]{2}{*}{ Op. 22 } & \multirow{2}{*}{\multicolumn{2}{|c|}{\begin{tabular}{|c|l|} 
Op. 26 \\
No. 1 & No. 2 \\
\end{tabular}}} & \multirow{2}{*}{$\begin{array}{r}\text { Op. } \\
\text { No. } 1\end{array}$} & \multirow{2}{*}{$\left|\begin{array}{l}40 \\
\text { No. } 2\end{array}\right|$} & \multirow{2}{*}{ Op. 44 } & \multirow[t]{2}{*}{ Op. 53 } & \multirow[t]{2}{*}{ Op. 61} & \multicolumn{3}{|c|}{ Op. 71} & \multicolumn{3}{|c|}{ Op. posth. } & \\
\hline & & & & & & & & & & No. 1 & No. 2 & No. 3 & $\begin{array}{l}\text { flat } \\
\text { major }\end{array}$ & \begin{tabular}{|l|} 
G sharp \\
minor
\end{tabular} & $\begin{array}{l}G \text { flat } \\
\text { major }\end{array}$ & \\
\hline $1830-39$ & 4 & 0 & 0 & 0 & 0 & 0 & 0 & 0 & 0 & 0 & 0 & 0 & 0 & 0 & 0 & 4 \\
\hline $1840-49$ & 6 & 2 & 3 & 3 & 1 & 1 & 1 & 1 & 1 & 0 & 0 & 0 & 0 & 0 & 0 & 19 \\
\hline $1850-59$ & 1 & 0 & 0 & 0 & 0 & 0 & 0 & 0 & 0 & 1 & 0 & 0 & 0 & 0 & 0 & 2 \\
\hline $1860-69$ & 9 & 0 & 2 & 1 & 1 & 1 & 0 & 1 & 0 & 0 & 0 & 0 & 0 & 1 & 0 & 16 \\
\hline $1870-79$ & 3 & 1 & 2 & 1 & 2 & 0 & 0 & 1 & 0 & 0 & 0 & 0 & 0 & 0 & 2 & 12 \\
\hline $1880-89$ & 6 & 12 & 9 & 0 & 9 & 2 & 0 & 3 & 0 & 0 & 0 & 0 & 0 & 1 & 0 & 42 \\
\hline $1890-99$ & 0 & 1 & 0 & 1 & 11 & 1 & 0 & \begin{tabular}{l|l}
0 \\
\end{tabular} & 0 & 0 & 0 & 0 & 0 & 0 & 0 & 14 \\
\hline $1900-09$ & 8 & 2 & 3 & 2 & 11 & 3 & 1 & 3 & 1 & 1 & 2 & 1 & 0 & 1 & 1 & 40 \\
\hline 1910-19 & 0 & 1 & 0 & 0 & 19 & 0 & 0 & 1 & 0 & 0 & 0 & 0 & 0 & 0 & 0 & 21 \\
\hline total & 37 & 19 & 19 & 8 & 54 & 8 & 2 & 10 & 2 & 2 & 2 & 1 & 0 & 3 & 3 & 170 \\
\hline $1920-29$ & 1 & 3 & 1 & 0 & 5 & 0 & 0 & 0 & 0 & 0 & 0 & 0 & 0 & 0 & 0 & 10 \\
\hline $1930-39$ & 0 & 1 & 0 & 0 & 16 & 0 & 0 & 1 & 0 & 0 & 0 & 0 & 0 & 0 & 0 & 18 \\
\hline $1940-49$ & 0 & 0 & 0 & 0 & 15 & 0 & 0 & 27 & 0 & 0 & 0 & 0 & 0 & 0 & 0 & 42 \\
\hline $1950-59$ & 1 & 1 & 2 & 0 & 20 & 2 & 0 & 8 & 0 & 0 & 0 & 0 & 0 & 0 & 0 & 34 \\
\hline $1960-69$ & 0 & 3 & 0 & 0 & 8 & 1 & 0 & 1 & 0 & 0 & 0 & 0 & 0 & 0 & 0 & 13 \\
\hline $1970-79$ & 0 & 0 & 0 & 0 & 3 & 0 & 0 & \begin{tabular}{l|l}
0 \\
\end{tabular} & 0 & 0 & 0 & 1. & 2 & 0 & 0 & 6 \\
\hline $1980-89$ & 0 & 0 & 0 & 0 & 0 & 0 & 0 & 0 & 0 & 0 & 0 & 0 & 0 & 0 & 0 & 0 \\
\hline total & 39 & 27 & 22 & 8 & 121 & 11 & 2 & 47 & 2 & 2 & 2 & 2 & 2 & 3 & 3 & 293 \\
\hline
\end{tabular}

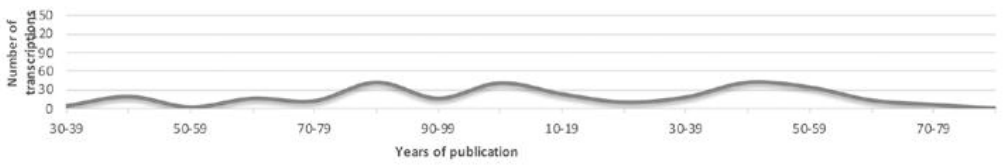

Table 6: Polonaises.

Nocturnes (Table 8), like songs, were frequently transcribed above all during the nineteenth century. Their first transcriptions began to appear ten years after the publication of the originals, and a distinctive increase occurred during the 1880s; another peak is noticeable during the years 1900-09. Among the transcriptions of twenty nocturnes, clearly the most popular work was the Nocturne in E flat major, Op. 9 No. 2, transcriptions of which make up $36.3 \%$ of all nineteenth-century nocturne transcriptions. There are also a considerable number of adaptations of the Nocturnes in $\mathrm{B}$ major, Op. 32 No. 1, G minor, Op. 37 No. 1 and F minor, Op. 55 No. 1. The most popular of these four works, the Nocturne in E flat major, Op. 9 No. 2, is calm in character and distinguished by its cantilena melodic line, played espressivo dolce.

Waltzes (Table 9) were transcribed continuously, in both the nineteenth and the twentieth century. They aroused the interest of transcribers almost immediately after the publication of the originals. Of the fifteen waltzes transcribed, seven of them form a distinct core $(82.1 \%$ of the whole collection, and $84 \%$ of nineteenth-century transcriptions). The most frequently transcribed were the Waltzes in D flat major, Op. 64 No. 1, A minor, Op. 34 No. 


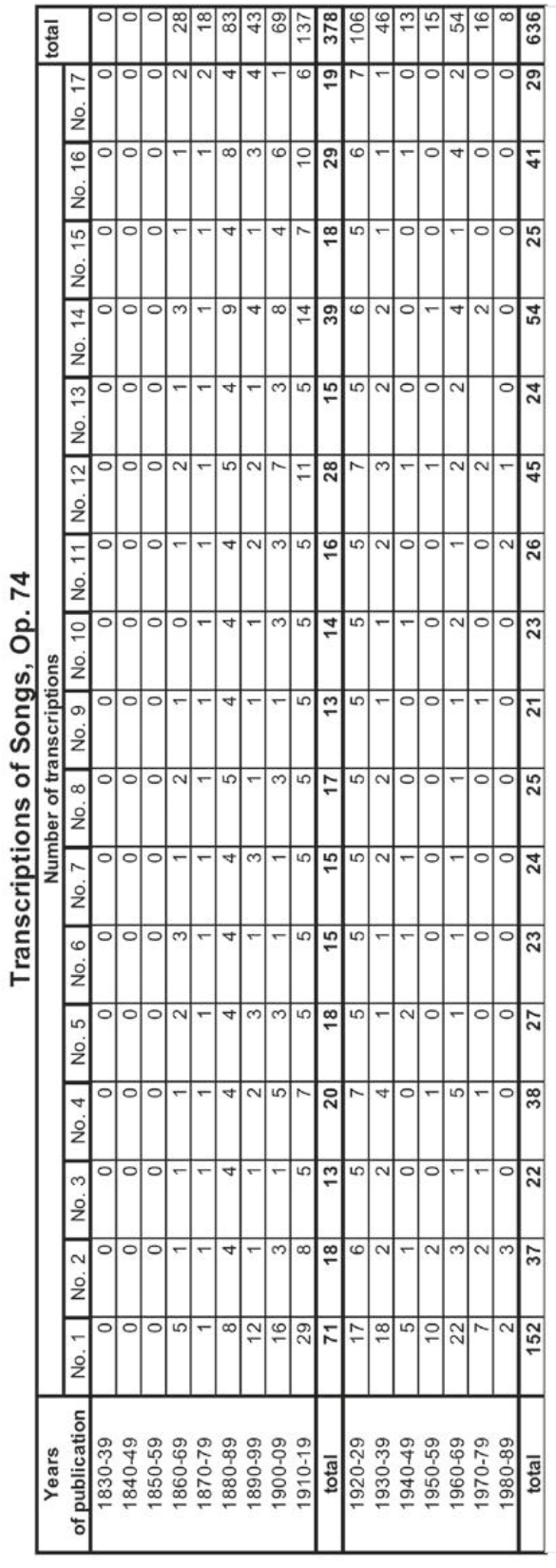




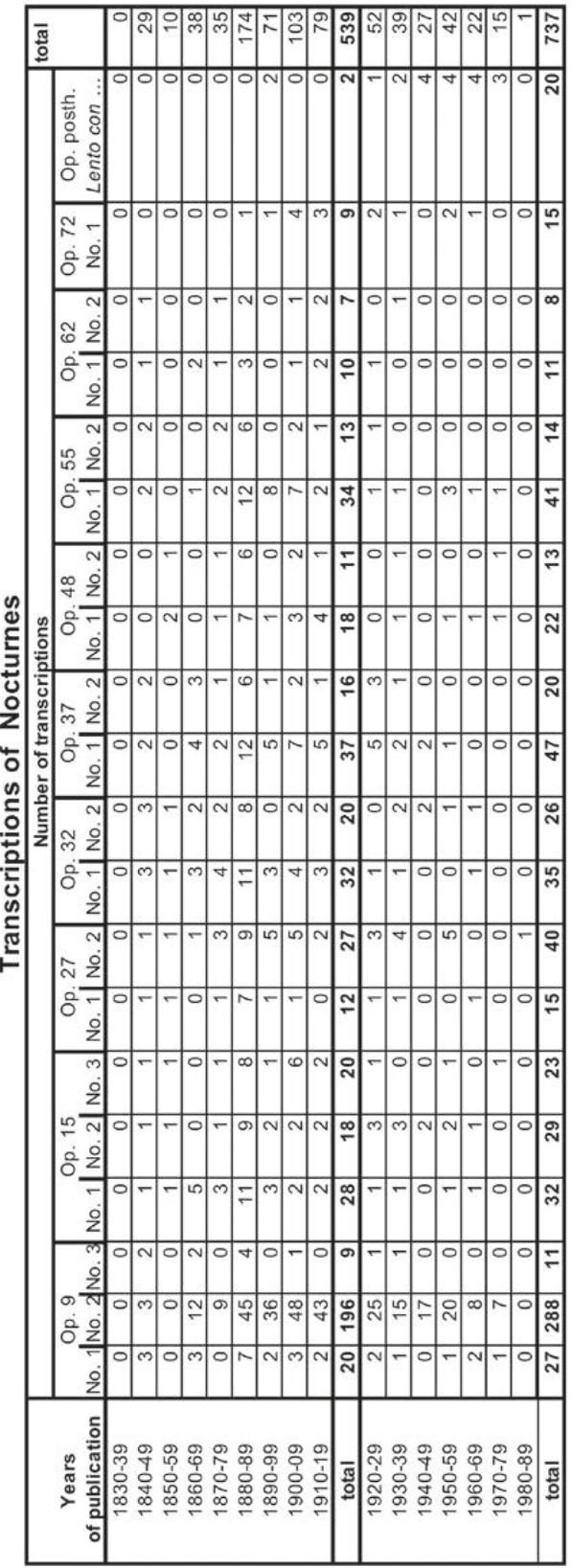


Transcriptions of Waltzes

\begin{tabular}{|c|c|c|c|c|c|c|c|c|c|c|c|c|c|c|c|c|}
\hline \multirow[b]{2}{*}{$\begin{array}{c}\text { Years } \\
\text { of publication }\end{array}$} & \multicolumn{15}{|c|}{ Number of transcriptions } & \multirow[t]{2}{*}{ total } \\
\hline & Op. 18 & $\begin{array}{l}\text { Op. } 34 \\
\text { No. } 1\end{array}$ & \begin{tabular}{|l|} 
Op. 34 \\
No. 2
\end{tabular} & \begin{tabular}{|l} 
Op. 34 \\
No. 3
\end{tabular} & Op. 42 & \begin{tabular}{|l} 
p. 64 \\
No. 1
\end{tabular} & \begin{tabular}{|l|} 
Op. 64 \\
No. 2 \\
\end{tabular} & \begin{tabular}{|l} 
Op. 64 \\
No. 3
\end{tabular} & \begin{tabular}{|l}
$p .69$ \\
No. 1
\end{tabular} & $\begin{array}{l}0 \text { p. } 69 \\
\text { No. } 2\end{array}$ & $\begin{array}{l}\text { Op. } 70 \\
\text { No. } 1\end{array}$ & $\begin{array}{l}\text { Op. } 70 \\
\text { No. } 2\end{array}$ & $\begin{array}{l}\text { Op. } 70 \\
\text { No. } 3\end{array}$ & $\begin{array}{l}\text { A flat } \\
\text { major }\end{array}$ & $\begin{array}{c}\mathrm{E} \\
\text { minor }\end{array}$ & \\
\hline $1830-39$ & 0 & 0 & 0 & 0 & 0 & 0 & 0 & 0 & 0 & 0 & 0 & 0 & 0 & 0 & 0 & 0 \\
\hline $1840-49$ & 3 & 3 & 2 & 2 & 2 & 0 & 0 & 0 & 0 & 0 & 0 & 0 & 0 & 0 & 0 & 12 \\
\hline $1850-59$ & 1 & 1 & 1 & 1 & 0 & 1 & 1 & 1 & 1 & 1 & 0 & 0 & 0 & 0 & 0 & 9 \\
\hline $1860-69$ & 7 & 6 & 7 & 2 & 1 & 5 & 2 & 1 & 1 & 1 & 0 & 0 & 0 & 0 & 1 & 34 \\
\hline $1870-79$ & 3 & 4 & 4 & 3 & 1 & 4 & 6 & 2 & 1 & 0 & 0 & 0 & 0 & 0 & 3 & 31 \\
\hline $1880-89$ & 21 & 11 & 29 & 8 & 6 & 27 & 14 & 5 & 2 & 1 & 1 & 2 & 1 & 0 & 2 & 130 \\
\hline $1890-99$ & 6 & 3 & 9 & 2 & 2 & 15 & 5 & 4 & 0 & 0 & 1 & 0 & 0 & 0 & 0 & 47 \\
\hline $1900-09$ & 8 & 6 & 10 & 2 & 2 & 19 & 6 & 2 & 2 & 2 & 2 & 1 & 1 & 0 & 3 & 66 \\
\hline $1910-19$ & 5 & 0 & 9 & 0 & 0 & 13 & 2 & 0 & 1 & 1 & 0 & 0 & $\underline{0}$ & 0 & 3 & 34 \\
\hline total & 54 & 34 & 71 & 20 & 14 & 84 & 36 & 15 & 8 & 6 & 4 & 3 & 2 & 0 & 12 & 363 \\
\hline $1920-29$ & 5 & 2 & 7 & 2 & 1 & 10 & 9 & 1 & 2 & 2 & 4 & 2 & 1 & 0 & 1 & 49 \\
\hline $1930-39$ & 5 & 3 & 5 & 3 & 2 & 16 & 8 & 1 & 1 & 4 & 3 & 0 & 1 & 1 & 1 & 54 \\
\hline $1940-49$ & 5 & 0 & 2 & 3 & 0 & 14 & 9 & 0 & 5 & 2 & 2 & 1 & 1 & 0 & 0 & 44 \\
\hline $1950-59$ & 10 & 3 & 9 & 4 & 2 & 17 & 21 & 0 & 7 & 12 & 3 & 3 & 2 & 0 & 1 & 94 \\
\hline $1960-69$ & 2 & 4 & 10 & 0 & 1 & 5 & 18 & 0 & 1 & 8 & 3 & 2 & 2 & 0 & 3 & 59 \\
\hline $1970-79$ & 1 & 0 & 2 & 0 & 0 & 3 & 6 & 0 & 0 & 0 & 0 & 0 & 2 & 0 & 0 & 14 \\
\hline $1980-89$ & 0 & 0 & 1 & 0 & 0 & 0 & 1 & 0 & 0 & 2 & 0 & 1 & 0 & 0 & 0 & 5 \\
\hline total & 82 & 46 & 107 & 32 & 20 & 149 & 108 & 17 & 24 & 36 & 19 & 12 & 11 & 1 & 18 & 682 \\
\hline
\end{tabular}

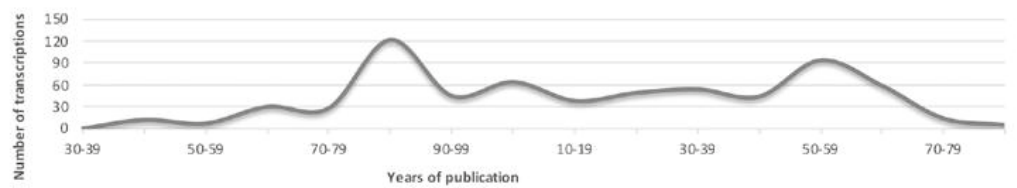

Table 9: Waltzes.

2 and E flat major, Op. 18. It would seem that while the latter two works are conducive to transcribing, in terms of both tempo and also the distinctness of the harmonies and form, the Waltz in D flat major could deter some transcribers with its tempo and virtuosity. However, it was the most frequently transcribed.

The other Chopin genres were adapted to a much lesser extent (Table 10), although here too certain compositions stand out (Berceuse, Op. 57, Impromptu in A flat major, Op. 29 and Impromptu in C sharp minor, Op. 66). The quantitative profile of larger-scale works - ballades, fantasies, scherzos and sonatas - is presented in Table 11, while the figures relating to the concertos are given in Table 12. One may be surprised at the singling-out of the Funeral March, which is part of the Sonata in B flat minor, Op. 35, but its arrangements constitute such a large group that it merits separate treatment. The Funeral March possesses the largest collection of transcriptions of any single work during the nineteenth century, and only the Nocturne in E flat major, Op. 9 No. 2 can compare in this respect (196 transcriptions). 


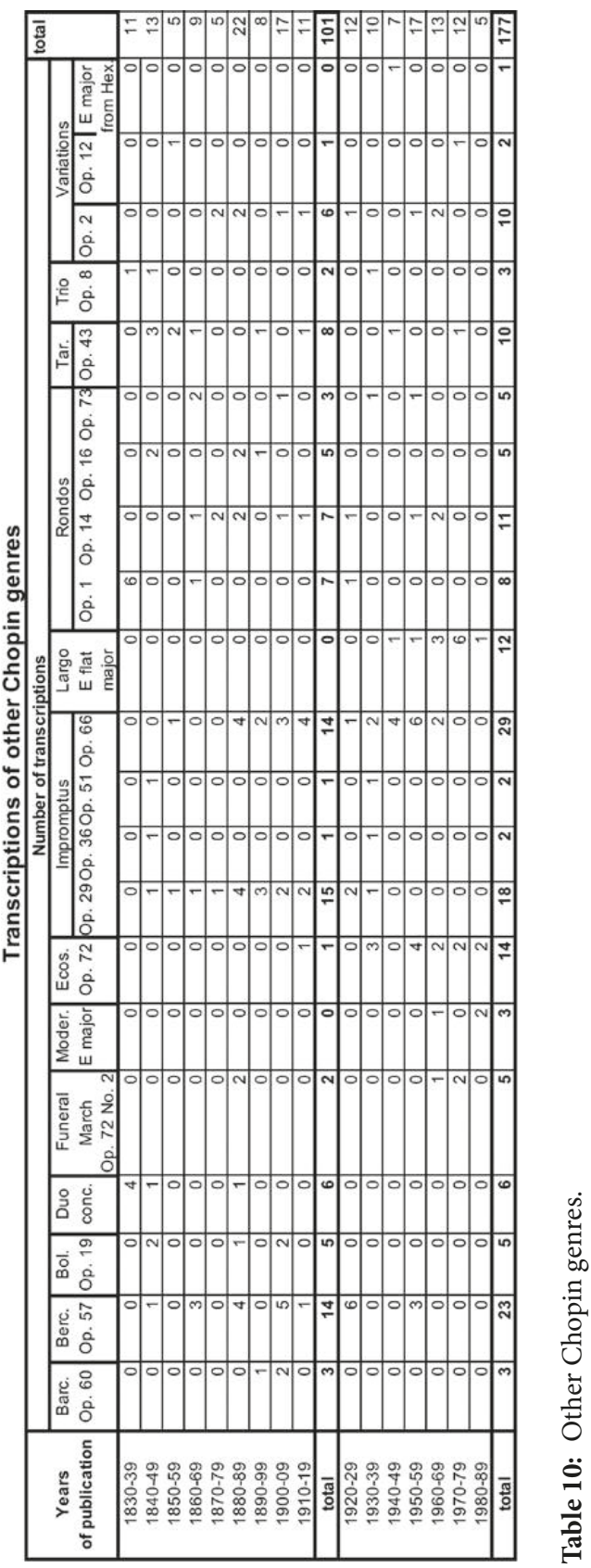


Transcriptions of large-scale works

\begin{tabular}{|c|c|c|c|c|c|c|c|c|c|c|c|c|c|c|c|c|}
\hline \multirow{3}{*}{$\begin{array}{c}\text { Years } \\
\text { of publication }\end{array}$} & \multicolumn{15}{|c|}{ Number of transcriptions } & \multirow[t]{3}{*}{ total } \\
\hline & \multicolumn{4}{|c|}{ Ballades } & \multicolumn{2}{|c|}{ Fantasies } & \multicolumn{4}{|c|}{ Scherzos } & \multicolumn{4}{|c|}{ Sonatas } & \multirow{2}{*}{\begin{tabular}{|l|}
$\begin{array}{l}\text { Funeral } \\
\text { March }\end{array}$ \\
\end{tabular}} & \\
\hline & Op. 23 & Op. 38 & Op. 47 & Op. 52 & Op. 13 & Op. 49 & Op. 2d & Op. 31 & Op. 39 & Op. 54 & Op. 4 & Op. 35 & Op. 58 & \begin{tabular}{|l|} 
Op. 65 \\
\end{tabular} & & \\
\hline $1830-39$ & 0 & 0 & 0 & 0 & 0 & 0 & 0 & 0 & 0 & 0 & 0 & 0 & 0 & 0 & 0 & 0 \\
\hline $1840-49$ & 2 & 0 & 0 & 0 & 0 & 0 & 0 & 0 & 1 & 1 & 0 & 0 & 0 & 1 & 1 & 6 \\
\hline $1850-59$ & 0 & 1 & 1 & 1 & 1 & 1 & 1 & 2 & 0 & 0 & 0 & 1 & 1 & 1 & 10 & 21 \\
\hline $1860-69$ & 0 & 4 & \begin{tabular}{l|l}
0 \\
\end{tabular} & 0 & 0 & 0 & 0 & 0 & 0 & 0 & 0 & 0 & \begin{tabular}{l|l}
0 \\
\end{tabular} & 1 & 19 & 24 \\
\hline $1870-79$ & 0 & 1 & \begin{tabular}{l|l}
0 \\
\end{tabular} & 0 & 2 & 0 & 0 & 0 & 0 & 0 & 0 & 0 & \begin{tabular}{l|l}
0 \\
\end{tabular} & 1 & 14 & 18 \\
\hline $1880-89$ & 1 & 4 & \begin{tabular}{l|l}
0 \\
\end{tabular} & 1 & 3 & 4 & 1 & 1 & 0 & 0 & 0 & 0 & 1 & 2 & 84 & 102 \\
\hline $1890-99$ & 0 & 1 & 0 & 0 & 0 & 1 & 0 & 1 & 0 & 1 & 0 & 1 & 3 & 1 & 48 & 57 \\
\hline $1900-09$ & 0 & 5 & \begin{tabular}{l|l}
0 \\
\end{tabular} & 0 & 3 & 1 & 0 & 1 & 2 & 0 & 0 & 1 & \begin{tabular}{l|l}
0 \\
\end{tabular} & \begin{tabular}{l|l}
4 \\
\end{tabular} & 72 & 89 \\
\hline $1910-19$ & 0 & 0 & \begin{tabular}{l|l}
0 \\
\end{tabular} & 0 & 1 & 2 & 0 & 0 & 0 & 0 & 1 & 0 & \begin{tabular}{l|l}
0 \\
\end{tabular} & 2 & 46 & 52 \\
\hline total & 3 & 16 & 1 & 2 & 10 & 9 & 2 & 5 & 3 & 2 & 1 & 3 & 5 & 13 & 294 & 369 \\
\hline $1920-29$ & 0 & 4 & 0 & 0 & 1 & 1 & 0 & 0 & 0 & 0 & 0 & 0 & 0 & 0 & 21 & 27 \\
\hline $1930-39$ & 0 & 0 & \begin{tabular}{l|l}
0 \\
\end{tabular} & 0 & 1 & 0 & 0 & 0 & \begin{tabular}{l|l}
0 \\
\end{tabular} & 0 & 0 & 0 & \begin{tabular}{l|l}
0 \\
\end{tabular} & 1 & 9 & 11 \\
\hline $1940-49$ & 2 & 0 & \begin{tabular}{l|l}
0 \\
\end{tabular} & 0 & \begin{tabular}{l|l}
0 \\
\end{tabular} & 1 & 0 & 0 & 0 & 1 & 0 & 0 & \begin{tabular}{l|l}
0 \\
\end{tabular} & 0 & 3 & 7 \\
\hline $1950-59$ & 0 & 2 & 1 & 0 & 1 & 0 & 0 & 0 & 0 & 0 & 0 & 0 & 0 & 1 & 16 & 21 \\
\hline $1960-69$ & 0 & 0 & \begin{tabular}{l|l}
0 \\
\end{tabular} & 0 & 2 & 0 & 0 & 0 & 0 & 0 & 0 & 0 & 0 & 0 & 6 & 8 \\
\hline $1970-79$ & 0 & 1 & \begin{tabular}{l|l}
0 \\
\end{tabular} & 0 & 0 & 0 & 0 & 0 & 0 & 0 & 0 & 0 & \begin{tabular}{l|l}
0 \\
\end{tabular} & 0 & 5 & 6 \\
\hline $1980-89$ & 0 & 0 & \begin{tabular}{l|l}
0 \\
\end{tabular} & 0 & 0 & 0 & 0 & 0 & 0 & 0 & 0 & 0 & 5 & 1 & 1 & 7 \\
\hline total & 5 & 23 & 2 & 2 & 15 & 11 & 2 & 5 & 3 & 3 & 1 & 3 & 10 & 16 & 355 & 456 \\
\hline
\end{tabular}

Table 11: Large-scale works.

The sum total of nineteenth-century transcriptions comes to 2,969 , so more than fourteen times the number of original works (201), which points clearly to the considerable part played by transcriptions in the musical reception of Chopin. A quantitative profile of the body of nineteenth-century arrangements may be broken down into a few points:

1. Comparing the number of nineteenth-century adaptations of particular genres, we obtain a distinct hierarchy. On first appearance, it might seem that the number of transcriptions results from the number of original works, that the most numerous genres have the largest numbers of transcriptions. Yet that is not the case. For instance, the numerically large collection of Chopin etudes has far fewer arrangements than the numerically more modest sets of nocturnes, waltzes and songs, and all tendencies are shattered by the Marche funèbre (Table 13). Taking into account the average number of transcriptions corresponding to one original work, among four selected genres we obtain the following numbers: Sonata 79;66 Nocturne 25.6; Song 19.8; Waltz 19.1; Mazurka 10.3.

66 Including the 'Funeral March' Sonata, Op. 35. 


\begin{tabular}{|c|c|c|c|c|}
\hline \multirow[b]{2}{*}{$\begin{array}{c}\text { Years } \\
\text { of publication }\end{array}$} & \multicolumn{3}{|c|}{ Number of transcriptions } & \multirow[t]{2}{*}{ total } \\
\hline & Op. 11 & Op. 21 & $\begin{array}{c}\text { Op. } 46 \\
\text { Allegro } \\
\text { de concert }\end{array}$ & \\
\hline $1830-39$ & 0 & 1 & 0 & 1 \\
\hline $1840-49$ & 1 & 0 & 0 & 1 \\
\hline $1850-59$ & 1 & 1 & 1 & 3 \\
\hline $1860-69$ & 3 & 2 & 0 & 5 \\
\hline $1870-79$ & 3 & 3 & 0 & 6 \\
\hline $1880-89$ & 13 & 9 & 3 & 25 \\
\hline $1890-99$ & 4 & 3 & 0 & 7 \\
\hline $1900-09$ & 5 & 3 & 1 & 9 \\
\hline $1910-19$ & 4 & 2 & 0 & 6 \\
\hline total & 34 & 24 & 5 & 63 \\
\hline $1920-29$ & 5 & 4 & 0 & 9 \\
\hline $1930-39$ & 6 & 3 & 0 & 9 \\
\hline $1940-49$ & 3 & 5 & 1 & 9 \\
\hline $1950-59$ & 10 & 7 & 0 & 17 \\
\hline $1960-69$ & 1 & 3 & 0 & 4 \\
\hline $1970-79$ & 2 & 1 & 0 & 3 \\
\hline $1980-89$ & 0 & 0 & 0 & 0 \\
\hline total & 61 & 47 & 6 & 114 \\
\hline
\end{tabular}

Table 12: Piano concertos.

2. In each generic group, there are several stand-out original compositions, which have been the subject of the largest number of adaptations (Table 14).

3. Examining the quantitative proportions between nineteenth- and twentiethcentury transcriptions, one notes the clear predominance of nineteenthcentury arrangements; the sole exceptions in this regard are the etudes and the preludes (Table 15).

4. The transcribing of Chopin began in 1830 with a reworking prepared by Antoni Orłowski and has continued uninterrupted till today. ${ }^{67}$ Over the space of ninety years, there were periods when transcribers were particularly active: $1880-1890,1900-1909$ and 1909-1919. That may be due to

67 We have no statistics for the last thirteen years. Orłowski transcribed parts of the Allegro vivace from the Concerto in F minor, Op. 21. 
Table 13: Quantitative comparison of Chopin's originals and transcriptions.

\begin{tabular}{lll}
\hline Genre & QUANTITY & \\
\cline { 2 - 3 } & Chopin originals & $\begin{array}{l}\text { Nineteenth-century } \\
\text { transcriptions of Chopin's } \\
\text { works }\end{array}$ \\
\hline Mazurkas & 57 & 590 \\
Nocturnes & 21 & 539 \\
Songs & 19 & 378 \\
Waltzes & 19 & 363 \\
Sonatas & & $22+294=316$ \\
Etudes & 4 & 215 \\
Preludes & 27 & 181 \\
Polonaises & 25 & 170 \\
Concertos & 16 & 63 \\
Impromptus & 3 & 31 \\
Ballades & 4 & 22 \\
Rondos & 4 & 22 \\
Fantasies & 4 & 19 \\
Scherzos & 2 & 12 \\
\hline
\end{tabular}

a 294 of these are transcriptions of just one movement of the B flat minor Sonata, the Marche funèbre.

Table 14: Chopin compositions with the most transcriptions.

\begin{tabular}{lc}
\hline Work of Chopin & Number of transcriptions \\
\hline Sonata in B flat minor, Op. 35 & 294 \\
Nocturne in E flat major, Op. 9 No. 2 & 196 \\
Waltz in D flat major, Op. 64 No. 1 & 84 \\
‘Życzenie’ [A Maiden's Wish], Op. 74 No. 1 & 71 \\
Mazurka in B flat major, Op. 7 No. 1 & 63 \\
Polonaise in A major, Op. 40 No. 1 & 54 \\
Prelude in A major, Op. 28 No. 7 & 44 \\
Polonaise in C major, Op. 3 & 37 \\
Concerto in E minor, Op.11 & 34 \\
Etude in C sharp minor, Op. 25 No. 7 & 19 \\
Ballade in F major, Op. 38 & 16 \\
\hline
\end{tabular}

a The clear majority of transcriptions concern the second movement of this concerto: the Romance Larghetto. The whole concerto was only transcribed several times for easy piano, for piano for four hands and for harmonium.

${ }^{\mathrm{b}}$ The first movement of this composition, Andantino, was transcribed particularly often. 
Table 15: Generic ranking of transcriptions.

\begin{tabular}{llc}
\hline Genre & Number of transcriptions & \\
\cline { 2 - 3 } & nineteenth century & twentieth century \\
\hline Mazurkas & 590 & 179 \\
Nocturnes & 539 & 198 \\
Songs & 378 & 258 \\
Waltzes & 363 & 319 \\
Sonatas $^{\mathrm{a}}$ & $22+294$ & $8+61$ \\
Etudes $^{\text {Preludes }}$ & 215 & 294 \\
Polonaises & 181 & 220 \\
Concertos & 170 & 123 \\
Impromptus & 63 & 51 \\
Ballades & 31 & 20 \\
Rondos & 22 & 10 \\
Fantasies & 22 & 7 \\
Scherzos & 19 & 7 \\
\hline
\end{tabular}

a The first of the totals concerns arrangements of whole sonatas; the second total relates to the Marche funèbre from the Sonata in B flat minor, Op. 35.

the universal interest in Chopin's music during those decades, expressed in the first works written about the composer and in the heightened activity of German, French, British, Russian, Italian, American and Polish publishers. ${ }^{68}$

68 Works about Chopin from that period include the following: Franz Liszt, Chopin (Paris 1852); Louis Enault, Frédéric Chopin (Paris 1856); Henri Barbedette, Chopin. Essai de critique musicale (Paris 1861); Marceli Antoni Szulc, Fryderyk Chopin i utwory jego muzyczne [Fryderyk Chopin and his musical works] (Poznań, 1873); Maurycy Karasowski, Fryderyk Chopin. Życie, listy, dzieła [Fryderyk Chopin: his life, letters and works] (Dresden 1877, 1878; New York 1878; Cincinnati 1881; Warsaw 1882); Frederick Niecks, Frederick Chopin as a Man and Musician (London 1888, 1900); James Huneker, Chopin: The Man and his Music (1900); Hugo Leichtentritt, Friedrich Chopin (Berlin 1905); Mieczysław Karłowicz, Nie wydane dotychczas pamiątki po Chopinie [Hitherto unpublished Chopin souvenirs] (Warsaw 1906); Ferdynand Hoesick, Chopin, życie i twórczość [Chopin: his life and work] (Warsaw 1910-1911). This list is given after Poniatowska, Twórczość (102), and Anders, Mieczysław Karłowicz (268-9).

The question of publishers is addressed further into this study. 


\subsection{The musical professions of the transcribers of Chopin's works}

The existence of a huge amount of Chopin transcriptions is an historical fact a social and aesthetic phenomenon. Although the actual term 'transcription' (as already mentioned) was first used by Franz Liszt for piano settings of the songs, ${ }^{69}$ the phenomenon of transcribing works was a widespread musical practice during the nineteenth century. This mode of 'compositional' work was adopted by a wide range of composers, from professionals to dilettantes. One of the questions that arise when analysing transcriptions is that of the transcribers themselves. Who arranged Chopin's works and what was their motivation for doing so? There is a very long list of composers of Chopin arrangements in the Catalogue of Chomiński and Turło. ${ }^{70}$ The sheer number of individuals interested in Chopin's music proves its great popularity, in both the nineteenth and the twentieth century. ${ }^{71}$ Such a broad social reception undoubtedly attests to the greatness and universality of Chopin's music, and it also gives the lie to the widespread opinion of its exclusively piano character (these are largely transcriptions for different forces). One cannot trivialise the statistics (2,969 transcriptions and a host of transcribers), which speak unequivocally of the scale of the phenomenon. Its qualitative aspect will be presented here on the basis of the creative environment in which the transcribers worked.

The figure of a transcriber is linked to several elements that may influence the form of the transcription: level of musical training, nationality and historical time. So it is interesting to examine the extent to which those three factors could have affected the quality of transcriptions, and so also the quality of the reception of Chopin's music with regard to transcriptions. The list of professional musicians to have arranged Chopin's works includes Fritz Kreisler, Pablo Sarasate, Auguste Franchomme, Leopold Grützmacher, Emil Prill, Rafael Joseffy, Moriz Rosenthal, Pauline Viardot-García, Franz Liszt, Mieczysław Karłowicz, ${ }^{72}$ Ferruccio Busoni, Max Reger, Nikolay Rimsky-Korsakov, Mily Balakirev, Alexander Glazunov and Leopold Godowsky. They are nineteenthcentury instrumental virtuosi, singers and composers. These musicians and others (less well known) no doubt had a variety of motives for arranging

69 See Poniatowska, Muzyka fortepianowa, 317; also BRML, 10576.

70 CT, 479-503.

71 Exactly 1501 individuals, more than half of them active during the twentieth century.

72 This information is given after Anders, Mieczysław Karłowicz, 210-11. No such notes appear in CT. 
Chopin's music. Transcriptions could have been written, for instance, for personal reasons (friendship with Chopin ${ }^{73}$ ), repertorial reasons (a wish to expand one's repertoire with familiar and esteemed works ${ }^{74}$ ), didactic reasons (the popularisation of Chopin's music through a different performance medium ${ }^{75}$ ) or commercial reasons (the fashion for Chopin and his music, and consequently profits from publishing such arrangements ${ }^{76}$ ). Quite a large group is formed by individuals whose names are not familiar to music lovers today and cannot be found in the major music lexicons. ${ }^{77}$ That does not mean, however, that they were bad composers. From information contained in works published during the nineteenth century and the early twentieth century, ${ }^{78}$ we learn that they were professionals, helping to forge the nineteenth-century musical culture of Europe. Those lexicons formed the material basis for our research, key among them being the dictionaries edited by Mendel, Einstein, Frank and Sowiński, ${ }^{79}$ with less information gleaned from the lexicons prepared by Schilling, Fétis, Eitner and Roguski. ${ }^{80}$

Mendel's lexicon provides exhaustive profiles of these figures, but due to the time of publication it often fails to cover the whole of a musician's work. Crucially, it does cover nearly all the major figures in musical life at that time. We find more concise, but also exhaustive, biographical notes in both works edited by Einstein, with Hugo Riemanns Musik Lexikon particularly valuable for heuristic purposes. The title of Frank's dictionary indicates the succinctness

73 The friendship between Franchomme and Chopin bore fruit in two collaborative works: the Grand Duo concertant and the Sonata in G minor, Op. 65. Franchomme produced many transcriptions of Chopin compositions for cello and piano.

74 Sarasate and Kreisler often turned to Chopin's music as material for virtuosic arrangements.

75 Emil Prill, a virtuoso flautist and teacher; we know of his transcriptions of Chopin waltzes and mazurkas for flute and piano.

76 During the second half of the nineteenth century, particularly in France, a fashion arose for everything Chopin: music, attire (gloves à la Chopin) and lifestyle. That may be the category to which we should ascribe a number of easy arrangements for piano and for piano for four hands. Barbara Zakrzewska-Nikiporczyk writes of the cult of Chopin and his music in 'Reception', 65-95.

77 e.g. in NGD; NGD2nd.

78 EGMW, BUBG, SMPD, SZM, BBQL, KTL, NML.

79 MCL (Mendel), NML and HRML (Einstein), KTL (Frank), SMPD (Sowiński).

80 EGMW (Schilling), BUBG (Fétis), BBQL (Eitner), SZM (Roguski). 
of the biographical notes it contains; however, it does provide a basis on which to establish the time a given individual lived and specify the character of his or her musical activities. Particularly helpful for establishing the biographies of Polish transcribers proved to be Sowiński's dictionary, while Roguski’s popular pocket-sized edition gives us an idea of the state of musical awareness among Poles in the early twentieth century. ${ }^{81}$ Schilling's encyclopaedia proved of little use on account of its time range, which coincided to only a minimal extent with the lives of transcribers. Equally sporadic are references to the studies of Fétis and Eitner, which possess rather a dearth of information of interest to us here.

All the lexicons listed here made it possible to prepare a survey of the musical professions of transcribers - the authors of the present work's source material. ${ }^{82}$ As the criterion for systematising this personal presentation, I chose the primary musical speciality of each transcriber. Hence the division into three main groups: [1] active instrumentalists and singers; [2] composers, [3] organisers of musical life. In my critical approach to the source material, I was guided by two criteria: in the case of well-known figures, I reduced the available biographical information; in the case of unknown figures, I presented what is sometimes rather trifling information, but often the only information available. My task was principally to introduce little-known figures, which accounts for the apparent neglect of excellent composers and the highlighting of minor composers. The first group is internally complex, and its variety is linked to the performance forces. It comprises pianists, violinists, cellists, flautists and vocalists, who produced arrangements for piano, for solo instrument with piano accompaniment, for vocal-instrumental forces and for ensembles. Also internally diversified is the third group, which consists of individuals holding a variety of functions: performers, organisers and teachers. Editors of musical publications should also be included in this group.

81 This dictionary was published in the series Książki dla wszystkich by M. Arct of Warsaw in 1906. Its author was a professor at the Warsaw Institute of Music.

82 There are seventy-seven names. Despite our best efforts, we failed to establish biographical information for nine arrangers: J. de Groot, N. Kashkin, G. Leo, A. Michaelis, C. Morley, E. Rohde, M. Rosen, H. Roubier and L. Schulz. 


\section{[1] Performers: instrumentalists, singers}

The group of pianists to have produced Chopin transcriptions is represented by concert musicians, given here in alphabetical order: Carl Bial, ${ }^{83}$ Carl Czerny, ${ }^{84}$ Ferdinand Dulcken, ${ }^{85}$ Giuseppe ${ }^{85}$ Ferrata, ${ }^{86}$ Leopold

83 Carl Bial (1833-1892), initially associated with Wrocław, then with Berlin, where he was taught music and performed in concert. Together with his younger brother, the violinist Rudolf Bial, he toured Africa and Australia. He settled in Berlin as an esteemed music teacher. He wrote salon pieces for piano and also songs, the prints of which were well received. Information after MCL, i:623; HRML, i:168.

84 Carl Czerny (1791-1857), a pupil of Beethoven, an Austrian pianist and teacher. As the lexicon author relates, he was first taught by his father. His huge compositional output, numbering more than one thousand opuses, includes piano etudes, collected in Schule der Geläufigkeit, Kunst der Fingerfertigkeit, Schule des Virtuosen and other publications, and a considerable number of sacred works (Masses, oratorios and others), as well as orchestral and chamber works. Czerny also wrote a composition handbook (Kompositionslehre) and a history of music (Umriss der ganzen Musikgeschichte). A detailed list of his compositions, with the accent on his piano works, which contributed to the development of piano technique, is contained in the lexicon from 1929, but no one mentions existing transcriptions of Chopin for piano for four hands. Information after KTL, 77; SZM, 19; HRML, i:362.

85 Ferdinand Quentin Dulcken (1836-1902), an English pianist and composer who often performed his own works in concert. Up to 1863 , he lived and worked in Warsaw, where he was an esteemed musician. After the January Uprising, he left for France, then visited Germany, where he performed a great deal. According to Sowiński, Dulcken's pianistic talent was 'highly regarded by the connoisseurs', even though he was accused of playing too forcefully. He was known among his peers for his piano works and his dramatic works (incl. the one-act idyll Wiestaw to words by Krystyn Ostrowski), published in Warsaw and abroad. The information given by Sowiński is incomplete, due to the date of the publication of his dictionary (1874) and of Dulcken's death (1902). Other nineteenth-century lexicographic sources (EGMW, ii:506; BUBG, ii:75) mention only Dulcken's mother, Ferdinand David's sister Louise Dulcken. From twentiethcentury lexicons, we learn that he was also a piano teacher, and his compositional oeuvre numbers around two hundred works (e.g. SMP, i:121).

86 Giuseppe Ferrata (1865-1928) came from one of the oldest and most important families in Italy. He was the nephew of Cardinal Giuseppe Ferrata, a long-serving papal secretary. His piano teachers included Giovanni Sgambati. He was also a pupil of Liszt, with whom he travelled around Europe as an accompanist and second pianist. From 1890 to 1892 he lived in America, taking part in a variety of performances, and he also led a piano class at the New College in New Orleans. His repertoire included works by Scarlatti, Beethoven, Dreyschock, Mendelssohn, Hiller, Sheremetiev, Chopin, Liszt, Schumann, Tausig, Paderewski, Sgambati, Saint-Saëns and Grieg. Einstein stresses that Ferrata was a composer of well-received piano works ('gut aufgenommener [jedno 
Godowsky, ${ }^{87}$ August Hänsel, ${ }^{88}$ Rudolf Hasert, ${ }^{89}$ Rafael Joseffy, ${ }^{90}$ Friedrich Kalkbrenner, ${ }^{91}$ Richard Kleinmichel, ${ }^{92}$ Franz Liszt, Karol

słowo] Klaviersachen'), as well as a Small Mass, Op. 15, Mass for male choir and organ, Op. 18, String Quartet in G major, Op. 28, Chorsinfonie in D flat major, Op. 40, choral works, sacred and profane songs and works for piano and violin. Information after NML, 187; HRML, i:499.

87 Leopold Godowsky (1870-1938), an excellent pianist who toured America (1884) and performed widely in Europe. He was also celebrated as the composer of many transcriptions and arrangements, including 53 Studies on Chopin's Etudes. His performance art is documented in recordings of thirty-eight works by Chopin. Information after KTL, 126; HRML, i:623; Kański, Dyskografia, 81.

88 August Hänsel, a municipal musician in Zittau from 1830 to 1848, composer of a host of original piano works. Information after P 1904-1910, vol. H, 81; MGG, Sachteil, ix:2469.

89 Rudolf Hasert (1826-1903) was a concert pianist for a time, and was also known as a composer of piano works, including two arrangements of Chopin's song 'Leci liście' [Leaves are falling], Op. 74 No. 17. According to Mendel, Hasert was an excellent German pianist, son of a professor of theology, who first taught him piano. From 1848 to 1850, he was a pupil of Theodor Kullak (piano) and Siegfried Dehn (composition) in Berlin. He performed with much success in Sweden, Denmark and elsewhere. From 1861 to 1869 , he lived in Berlin, working as a music teacher and composer (writing mainly piano arrangements and transcriptions, which he published under a pseudonym, as well as his own piano and vocal works). In 1865, he embarked on a clerical career, working as a pastor in Straussberg and then Rathenow. In connection with his new work, he began composing sacred music. Information after MCL, v:79-80; HRML, i:713; KTL, 147.

90 Rafael Joseffy (1852-1915), a Hungarian pianist, who began learning piano at the age of eight. He studied in Budapest, then in Leipzig (1866) with Ernst Wenzel and Ignaz Moscheles. From 1868 to 1879, he was a pupil of Tausig in Berlin, and in the summer of 1870 and 1871 he took lessons from Liszt in Weimar. His first public performance came in Berlin in 1870, and he went on to perform in many European cities. He made his American debut in New York in 1870. He often played Brahms with Theodore Thomas's orchestra. He wrote salon works, studies on themes by Czerny, Henselt and Moscheles, and also a School of Advanced Piano-Playing (1892). He was also known as a Chopin specialist, from editions of his works published by Schirmer. Information after HRML, i:713, 841; NML, 311.

91 Friedrich Wilhelm Michael Kalkbrenner (1785/1788-1849), a German virtuoso pianist, well known among his peers (Chopin considered becoming his pupil) and still celebrated today. In 1824, he joined Camille Pleyel in founding a piano manufactory. His compositional output contained chamber works, and above all piano works in the style brillant. His vast output is documented by a rich list of published works in Hofmeister's catalogue (see Whistling's, i:184-185).

92 Richard Kleinmichel (1846-1901) is described as a German pianist and composer. He was a pupil at the Leipzig Conservatory (1863-1866), before working as a trained musician in Hamburg, Leipzig, Gdańsk and Berlin. Also probably in Berlin, he performed 
Mikuli, ${ }^{93} \quad$ Józef $\quad$ Nowakowski, ${ }^{94}$ Moritz ${ }^{2}$ Rosenthal, ${ }^{95}$ Hermann

as a concert pianist. His considerable and diverse oeuvre includes operas, symphonies, chamber works, piano studies, songs, choral works and piano reductions of operas. Information after KTL, 190; NML, 333.

93 Karol Mikuli (1819/1821-1897), a Polish pianist of Moldovan origins, who was a very active concert pianist. Over a ten-year period (1848-1858), he performed in France, Austria, Russia and Romania. He was a pupil of Chopin (1844-1847), which undoubtedly helped developed his pianistic skills and contributed to his celebrity. He was a composer, conductor and teacher, and he also completed medical training. In 1858, he settled in Lviv, where he worked as director of the Galician Music Society, a director and teacher at the Conservatory and a conductor of symphonic concerts. In 1887, he founded a piano school, which he ran with his wife. In that same year, due to illness (persecution complex), he withdrew from musical life and lived in isolation. He wrote many piano works, including mazurkas, preludes, waltzes, polonaises and nocturnes, as well as chamber works, choral works, solo songs and arrangements of folk songs. He also produced the counterpoint handbook Der Canon and a collected edition of the works of Chopin (Leipzig: Kistner). In the opinion of Albert Sowiński, "he became very popular within a short time in Poland and abroad' (SMPD, 258). Information after SMPD, 258-259; KTL, 255; HRML, ii:1178.

94 Józef Nowakowski (1800-1865), a famous Polish musician, an 'excellent pianist and composer, one of the best teachers in Warsaw' (SMPD, 286). He was a fellow student of Chopin's under Elsner and Würfel at the Warsaw Conservatory. As a pianist, he performed in France, Italy and Germany. While living in Paris, in 1846-1847, he published Etudes dedicated to Chopin. From 1847, he worked mainly as a teacher and was one of the most highly regarded piano teachers in Warsaw. He also wrote a pianoplaying school that was highly popular during the nineteenth century (1850). His compositional oeuvre includes symphonic works (two symphonies, four overtures), piano works and orchestral transcriptions of works by Chopin, Schubert and Moniuszko. Nowakowski's output was highly esteemed by his peers, as Sowiński writes: 'In general, Nowakowski's piano compositions are fluid and marked by good taste and excellence; they are also well led, which proves his great proficiency and knowledge of his art' (SMPD, 287-288). Information after HRML, ii:1284; SMPD, 286-288.

95 Moriz (Moritz, Maurice, Maurycy) Rosenthal (1862-1946) was a pupil of Karol Mikuli at the Lviv Conservatory, of Rafael Joseffy in Vienna, and of Franz Liszt in Weimar and Rome. He is regarded as one of Liszt's finest pupils. At the age of fourteen, he began his pianistic career with a concert in Vienna, before travelling around Europe and the US. He was regarded as one of the leading pianists of the turn of the twentieth century, an excellent Liszt interpreter and a performer with a rich dynamic scale. He wrote several piano compositions (Romance in G major, Prelude in F sharp and a Nocturne, Variationen über ein eigenes Thema) and co-wrote, with Ludvig Schytte, Schule des höheren Klavierspiels. Technische Studien bis zur höchsten Vollendung. He also published several articles and masterclass lessons in The Etude. He recorded around thirty Chopin compositions. Information after KTL, 330; NML, 540; HRML, ii:1547-1548. Information about this pianist also appears in SMP, ii:151; Ga, 99; Kański, Dyskografia, 91. 
Scholtz, ${ }^{96}$ Giovanni Sgambati, ${ }^{97}$ the organist Renaud de Vilbac ${ }^{98}$ and Michael von Zadora ${ }^{99}$. These pianists transcribing Chopin included musicians with a solid all-round training, aware of the qualities of Chopin's music, as it appeared in their artistic biography regardless of whether it was particularly close to them or lay on the margins of their interests. These musicians represent various nationalities: Polish, German, Italian, Moldovan, American, Hungarian and British. They performed in Europe, America, Africa and Australia. We may assume, therefore, that the transcriptions by these composers were produced mainly for concert purposes $^{100}$ and represented an accordingly high musical

96 Hermann Scholtz (1845-1918), a German artist who gained his musical training in Leipzig and Munich. As a pianist, he readily performed works by Chopin, and as a composer he left excellent arrangements of the middle movements of Chopin's two concertos for solo piano. He also edited Chopin's works for Peters. In addition, he wrote a number of piano works (concertos, piano trios, sonatas, variations, minor works and songs with piano). Information after KTL, 357; HRML, ii:1644-1645; NML, 575.

97 Giovanni Sgambati (1841/1843-1914), an Italian virtuoso pianist, composer and conductor. As a conductor, he promoted the works of his teacher, Liszt, and also compositions by Wagner, Schumann and Brahms. Little is known about his concert work. Emphasised in the literature is the fact that he was one of the few nineteenthcentury Italian composers of instrumental music (he wrote two symphonies, an overture, a Requiem, a Te Deum, piano quintets, a String Quartet in C sharp minor, Op. 18, a Piano Concerto in G minor, Op. 15, minor piano pieces and songs). Information after KTL, 375; HRML, ii:1696-1697, EM, 809.

98 Renaud de Vilbac (1829-1884), a French organist and composer, who was a splendid improviser, his technique on a par with that of Saint-Saëns and Lefébure-Wély. His performance art could be admired at the Church of St Eugène in Paris, where he was organist. He trained at the Paris Conservatoire in piano, organ and composition. He composed two operas, orchestral works, salon pieces, transcriptions of operas for solo piano and duets. He arranged works by Chopin for piano for four hands and for two pianos. Information after KTL, 426; HRML, ii:1941.

99 Michael von Zadora (1882-1946), a pianist whose repertoire included works by Bach, Beethoven, Schubert, Chopin, Liszt, Alkan and Busoni. He entered the Paris Conservatoire in 1899 as a pupil of Leschetizky and Busoni. He was a professor of Lviv Conservatory and then of the Institute of Musical Art in New York. He wrote piano works (preludes, Kirgisische Skizzen, Cake Walk) and piano transcriptions (incl. Schubert's Lachen und Weinen, Paganini's Caprice No. 19, Buxtehude's Prelude and Fugue and several preludes and fugues by J. S. Bach). He performed under the pseudonym Pietro Amadis and recorded around eighty discs with music by the abovementioned composers, including ten works by Chopin. Information after KTL, 462, NML, 718; HRML, ii:2059; Ga, 101; Kański, Dyskografia, 95.

100 This is confirmed by information on the title pages of transcriptions: zum Concert... 
standard. ${ }^{101}$ Consequently, they required performers of a suitable standard pianists who were not necessarily the transcribers themselves. The audiences of these high-quality transcriptions tended to comprise musical connoisseurs who sought a suitable level of music and performance, which they associated with the names of virtuosi. It would be incredibly difficult to piece together the exact concert repertoire of these pianists, indicating the time and place of their concerts. We may assume, however, that they were the first performers of their own transcriptions. And as their composers, they could enhance them with new elements, linked to their nationality and to the individual features of their pianistic style.

The professionalism of a transcriber is expressed not just in his or her ability to produce elaborate and difficult adaptations, but also in composing transcriptions of middling difficulty that remain faithful to the original work. Besides this, the fact of being a pianist does not limit a musician to transcribing solely for piano. Such examples include Ferdinand Quentin Dulcken and Józef Nowakowski, who both wrote transcriptions of Chopin's music for voice and piano. Given the musical activities of these pianist transcribers, one may confidently assert that the reception of Chopin via their intermediary was of superior calibre.

In nineteenth-century performance practice, the violin family, which arose in the mid sixteenth century, still maintained a lofty status, which was underscored and boosted by the rich violin literature and the large number of violin virtuosi. As Alfred Einstein writes, in the nineteenth century 'The real, new virtuosity [...] occupied itself particularly with two instruments, the violin and the piano.'102 The plethora of violin virtuosi was led by Niccolò Paganini, who around 1820 began performing in the finest European concert halls. He had a number of rivals and successors: the Poles Karol Lipiński and Henryk Wieniawski, ${ }^{103}$ the

101 These include transcriptions by Bial, Ferrata, Godowsky, Hänsel, Hasert, Joseffy, Kalkbrenner, Mikuli, Rosenthal, Scholtz, Sgambati and Zadora.

102 Einstein, Music in the Romantic Era, 50.

103 Karol Józef Lipiński (1790-1861) was associated with the musical life of Lviv as leader (from 1909) and then conductor of the local orchestra. From 1839, for a period of twenty years, he worked in Dresden as leader of the operatic orchestra. He made numerous concert tours around most of Europe (Italy, Russia, Ukraine, Lithuania, France, the UK, Denmark, Germany, Austria). He wrote violin works (solo, with orchestra or chamber ensemble), songs and arrangements for violin and piano. Albert Sowiński emphasised the grandeur of his musical personality, regarding him as a master who could boast a splendid career as virtuoso and composer. That opinion is confirmed by Oskar Kolberg: 'His violin compositions [...] do not belong among 
Germans Ferdinand David and his pupil August Wilhelmj, ${ }^{104}$ the Spaniard Pablo Sarasate, ${ }^{105}$ the Hungarian Eduard Reményi ${ }^{106}$ and the Austrian Fritz Kreisler ${ }^{107}$. Most of these excellent instrumentalists produced

trifles, as they were not conceived for mechanical display'. Information after SMPD, 230-234; MCL, vi:339-342; EGMW, iv:407-411.

104 Ferdinand David (1810-1873), a German musician, a pupil of Ludwig Spohr and Moritz Hauptmann in Basel and many years later (from 1843) a teacher of Joseph Joachim and August Wilhelmj in Leipzig. He worked with Felix Mendelssohn: from 1835 as leader of the Gewandhaus orchestra and also as an 'adviser' on the composition of Mendelssohn's Violin Concerto in E minor and as its first performer. David's compositional output includes mainly violin works, playing schools for violin, numerous arrangements for violin and symphonic works. He played an important role as a propagator of eighteenth- and nineteenth-century violin music, and many of his arrangements of works by Bach, Beethoven, Händel, Haydn, Mendelssohn, Moscheles, Mozart, Paganini, Schubert, Spohr, Viotti and others were included in pedagogic collections. Information after KTL, 79; HRML, i:372-373; MCL, iii:82-83.

August Emil Daniel Wilhelmj (1845-1908), a German virtuoso violinist who performed in Europe, America, Australia and Asia. Professor of violin at the Guildhall School of Music in London, author of violin transcriptions and virtuosic cadenzas for concertos. Information after MCL, xi:356-360; SZM, 94; NML, 703-704; KTL, 451; HRML, ii:2028-2029.

105 Pablo Sarasate (1844-1908), a virtuoso violinist, a pupil of Jean Delphin Alard at the Paris Conservatoire. His concert repertoire was based on his own compositions (including numerous transcriptions) and works dedicated to him. He was famed as a great virtuoso and esteemed for his brilliant technique and inspired interpretations. Information after KTL, 340; MCL, ix:50-51; NML, 558; HRML, ii:1590-1591.

106 Eduard Reményi (1830-1898), a Hungarian violinist and composer of violin works, who studied at the Vienna Conservatory from 1842 to 1845 . In the years 1849-1850, he toured the US. He accompanied Johannes Brahms in concerts given in 1853. From 1875, he lived in Paris, but he died in San Francisco. Information after MCL, viii:302; KTL, 371-318.

107 Fritz Kreisler (1875-1962), an Austrian violinist and composer, a pupil of Léo Delibes, Joseph Hellmesberger and Joseph Lambert Massart, who at the age of twelve graduated from the Paris Conservatoire with the gold medal. As well as many transcriptions, he also wrote his own works for violin; popular pieces, showstoppers and works modelled on the Italian Baroque. Information after HRML, i:953; NML, 351; KTL, 201. 
violin versions of works by Chopin. ${ }^{108}$ They were joined by a number of less prominent musicians (including violists), such as Julius Conus, ${ }^{109}$ Nikolay Galkin, ${ }^{110}$ Friedrich Hermann, ${ }^{111}$ August Schulz,${ }^{112}$ Edmund Singer, ${ }^{113}$

108 There is no information about any Chopin arrangements written by Henryk Wieniawski.

109 Julius Conus (1869-1942), brother of George, from a Russian family of musicians. We know that he spent the last twenty-one years of his life in Paris. He was a concert violinist and a composer, his works including a Violin Concerto in E minor and minor violin works. Information after KTL, 73; HRML, i:340.

110 Nikolay Vladimirovich Galkin (1856-1906), a Russian violinist associated with St Petersburg. He trained with Kamiński and Auer at the St Petersburg Conservatory, with Joachim in Berlin, with Sauret in Paris and with Wieniawski in Brussels. He made numerous concert tours of Germany, France, Belgium, the Netherlands and Russia. In 1877, he settled in St Petersburg, where he worked as a conductor, teacher and composer of violin music. Information after HRML, i:563.

111 Friedrich Hermann (b. 1828), an excellent German virtuoso, whose musical personality was shaped by Ferdinand David and Felix Mendelssohn. As a viola player, he was among the foremost virtuosi of his day. He was an esteemed chamber musician, a member of the Leipzig String Quartet, and first viola of the Gewandhaus orchestra and the theatre orchestra in Leipzig. He had numerous compositions published (symphonies, a capriccio for three violins, violin etudes, a duet for violin and cello, and a string quartet). He made many transcriptions of the works of the classics (symphonies by Beethoven, Mendelssohn, Schumann) and produced piano reductions of violin concerti by Viotti and Kreutzer. Information after MCL, v:201.

112 August Schulz (1837-1909), a violinist with the court orchestra in Brunswick, a pupil of Joachim in Hanover and composer of the opera Der wilde Jäger, as well as solo and choral songs. Information after HRML, ii:1665.

113 Edmund Singer (1831-1912), a violinist who pursued a rich concert life, performing with success in Vienna, Paris and Leipzig, with the Gewandhaus orchestra (1851). He held a succession of posts: from 1856 to 1862 he was successor to Laub and Joachim as violinist in Weimar, and he was subsequently professor of violin at the Stuttgart Conservatory. His compositional oeuvre includes mainly violin works and arrangements of many Classical works, as well as cadenzas to violin concertos by Beethoven and Brahms. Together with Max Seifriz, he published a school of violin playing: Grosse theoretisch-praktische Violinschule. 
Adolf Sonnenfeld, ${ }^{114}$ Karol Studziński ${ }^{115}$ and Stanisław

Taborowski ${ }^{116}$.

In the nineteenth century, the cello was treated almost on a par with the violin, as is attested to by numerous transcriptions made by a number of cellists who

114 Adolf Gustaw Sonnenfeld (1837-1914) learned violin with Ferdinand David and studied composition at the Leipzig Conservatory with Moritz Hauptmann and Ernst Friedrich Richter. He was an orchestral violinist (with the Bach and Bilse orchestras), an organiser of musical life (in 1867, he organised a 'Warsaw Orchestra'), a conductor (from 1899, he conducted the orchestra of the Teatr Ludowy), wrote works for the stage (operas, operettas, a comic opera, a ballet) and light works, as well as many arrangements for violin and piano of popular works by various composers, which he published under the pseudonym Adolfson. Maria Zduniak also writes about this musician's concert work, drawing on information from the nineteenth-century press of Wrocław. However, none of the nine source lexicons cited here includes Sonnenfeld, which attests to the local, mostly Warsaw, character of his musical work. Information after SMP, ii:195; Zduniak, Muzyka, 110, 279.

115 Karol Studziński (1828-1883), a Polish viola player and composer active in Cracow and Warsaw. He was active not just as an instrumentalist - a member of Apolinary Kątski's string quartet and a viola player with the Teatr Wielki orchestra. He also taught singing and solfeggio at the Warsaw Institute of Music, for which he employed his own handbook Początki śpiewu [Rudiments of singing] (1871), and he also established the finest vocal quartet in Warsaw. He composed two Masses and songs. Albert Sowiński emphasised above all the sacred and vocal strand in his oeuvre (Modlitwa do Matki Boskiej [Prayer to the Mother of God], two Masses, Ojcze nasz [Our Father] for voices), writing: 'Masses in religious style with pure harmonies, especially the second, in which the serious style is infused with piety'. His violin work, meanwhile, was signalled in laconic fashion: 'violinist, member of the Warsaw orchestra'. Information after SMPD, 370.

116 Stanisław Taborowski (b. 1830) was known first and foremost as an outstanding virtuoso who performed in Poland (Warsaw, Cracow, Poznań, Wrocław, Ciechocinek). He possessed a comprehensive musical training (he was a pupil of Fenz and Billi in Odessa before continuing his studies in St Petersburg and then in Brussels with Leonard), which he drew upon as a teacher at the Hochschule für Musik in Berlin. As Albert Sowiński writes: 'Within a short time, he earned a reputation as a consummate virtuoso [...]. His beautiful playing secured him numerous advocates in the most important artistic circles'. He was also a composer of violin works, including Śpiew łabędzi [Swansong] for violin and piano, a Concerto for violin and orchestra, Skarga dziewczyny [A girl's complaint] for violin and orchestra dedicated to Liszt and arrangements of Tartini sonatas, as well as orchestral works (including Uwertura intermezzo [Overture intermezzo], the Titan overture and Pas redoublé for military band). Information after SMPD, 381-382; MCL, x:58-59. 
participated actively in concert and didactic life. The best known among them were Auguste Franchomme, ${ }^{117}$ Adrien-François Servais ${ }^{118}$ and Karl Davidoff;; ${ }^{119}$ lesser lights included Robert Bockmühl and Leopold Grützmacher. ${ }^{120}$ The violinists, violists and cellists, like the pianist transcribers, were mostly professionals. They were first and foremost soloists who made a name for themselves in Europe, America, Australia and Asia. For many others, the major occupation was ensemble playing (chamber ensemble or orchestra). Bearing in mind their multi-faceted musical work (including teaching), one may state that the transcriptions they produced may satisfy two basic functions: enhancing

117 Auguste-Joseph Franchomme (1808-1884), a well-known cello virtuoso who performed with Liszt and Chopin. He worked with the latter on the composition of two works: the Grand Duo concertant and the Sonata in G minor, Op. 65. Information after KTL, 108; MCL, iv:13-14; HRML, i:532-533.

118 Adrien-François Servais (1807-1866), the Belgian 'Paganini of the cello. He presented his musical artistry in concert (from 1843 to 1848 , he toured Europe), teaching (from 1848 as professor of cello at the Brussels Conservatory) and composition work (he wrote three concertos, sixteen fantasias for cello and orchestra, capriccios for cello and piano, and duets for cello and piano based on operatic motifs). Information after HRML, ii:1693; KTL, 373-374; SZM, 82.

119 Karl Yulyevich Davidoff (1838-1899), a Russian pupil of Heinrich Schmidt in Moscow, Carl Schuberth in St Petersburg and Moritz Hauptmann in Leipzig. He was an orchestral musician (first cello of the Gewandhaus orchestra in Leipzig from 1860 to 1862 and of the Imperial Opera from 1862 to 1882). As a composer, he was renowned for his cello works, including numerous transcriptions. He also wrote a school for cello playing. Information after KTL, 79; HRML, i:373; MCL, iii:83-84.

120 Robert Emile Bockmühl (b. 1812 in Frankfurt am Main), a cello virtuoso and composer of cello works. He published many of his own arrangements of operatic themes (Bellini, Meyerbeer) and fantasies based on the music of Chopin, Schubert and others. He made a significant contribution to expanding the literature for his instrument, writing a school for cello playing and a cello concerto. His brother (also Robert Emile), born in Frankfurt am Main in 1820 (or 1822), was an excellent orchestral violinist. Information after MGL, ii:63; KT., 46; Whistling's i:42.

Leopold Grützmacher (1835-1900), a cellist with an all-round musical education (he studied cello with Karl Drechsler and music theory with Friedrich Schneider), who worked in Leipzig (as a member of the Gewandhaus and theatre orchestras), Schwerin (first cello of the court chapel, the Hofkapelle), Prague (in the Landestheater orchestra) and Weimar (first cello and salon virtuoso). He composed cello works and wrote many cello arrangements of works by Chopin. He came from a musical family, and his brother Friedrich Wilhelm Ludwig (1832-1903) and son Friedrich (1866-1919) were both cellists. Information after KTL, 136; HRML, i:669. 
the concert repertoire (e.g. the arrangements of Sarasate and Lipiński) and enhancing the didactic repertoire, introducing violinists, violists and cellists to the Chopin literature (e.g. the transcriptions of Grützmacher). So their recipients consisted of the concert-going public and amateur musicians (violinists, violists and cellists).

Besides the piano and the violin, the most commonly used instrument for music making in the drawing-room was the flute. That popularity resulted no doubt from the qualities of the instrument's subtle, 'sinusoidal' sound, and also significant were the changes in design introduced by Theobald Böhm in 1832 . That growth in interest, coupled with a lack of literature for the instrument, forced flautists - performers and teachers - to adapt works for piano and other instruments. ${ }^{121}$ Among those to have produced flute transcriptions were Wilhelm Barge, ${ }^{122}$ Ferdinand Büchner, ${ }^{123}$ Wilhelm Popp ${ }^{124}$ and Emil Prill ${ }^{125}$. The authors of flute transcriptions were professional musicians and experts on their instrument. Among their number, only Prill was a concert virtuoso, so it was through him that

121 Profiled here are the authors of transcriptions from our source material. A full presentation of composers of flute transcriptions can be found in Busch-Salmen, Bemerkungen 224-234.

122 Wilhelm Barge (1836-1925) was an esteemed instrumentalist, a flautist with the Gewandhaus orchestra in Leipzig, who wrote flute compositions and arrangements. Information after KTL, 26.

123 Ferdinand Büchner (b. 1825) was solo flautist of the Imperial Theatre in Moscow from 1856. He was also co-founder and professor of the Moscow Conservatory and wrote his own flute works: concertos, studies and Vortragstücke. Information after HRML, i:246.

124 Wilhelm Popp (1828-1903), a flautist, composer and teacher, was associated with Hamburg from 1867 (first flute of the Hamburg Philharmonic). He left a large number (more than four hundred) of his own compositions, of a didactic character, as well as transcriptions (including of Stanisław Moniuszko's 'Prząśniczka' [The spinstress] and many works by Chopin). Information after KTL, 301.

125 Emil Prill (1867-1940), a German flute virtuoso from a family with musical traditions: his father and his brothers, Paul and Karl, were also musicians. He began learning flute with his father and continued with Joachim Andersen. He performed in concert with his brothers in Germany, Sweden, Denmark and Russia. He was first flute of the Hamburg Philharmonic and then the Royal Opera Orchestra in Berlin. As a teacher, he worked at the Hochschule für Musik in Berlin. He wrote a school for flute playing (in the old and Böhm systems), a guide to the flute literature, Führer durch die Flötenliteratur, Grosser Katalog enthaltend über 7500 Nummern (1899) and a number of flute works and transcriptions (including of Chopin waltzes and mazurkas). Information after NML, 503; HRML, ii:1430. 
transcriptions reached concert halls in Germany, Sweden, Denmark and Russia. The character of the musical activity of the remaining flautists and the form of the transcriptions themselves allow us to surmise that they were designed for didactic and didactic-popularising purposes, although most of them could also be presented in public concerts. Hence the recipients of these adaptations could have been amateur flautists (e.g. the arrangements by Büchner), frequenters of bourgeois salons (Prill, Popp) and audiences of a relatively small number of public concerts (Prill).

The only singer to have produced vocal transcriptions of Chopin was Pauline Viardot-García. ${ }^{126}$ Arrangements of that kind were also produced by leading figures in Polish musical life at that time, centred on Warsaw: the composers Adam Münchheimer and Ludwik Grossman, the conductor Piotr Maszyński and the pianist Karol Studziński. Their transcriptions were performed by the Lutnia choir of Warsaw, among others. The Italian composer Luigi Bordèse also wrote vocal versions.

\section{[2] Composers}

Being a composer is a precondition for assigning a person to the second group of transcribers. So we will be focussing here not on performers, but above all on composers. This group comprises the following: Mily Balakirev, Ferruccio Busoni, Alexander Glazunov, Leopold Godowsky, Franz Liszt, Mieczysław Karłowicz, Zygmunt Noskowski, Max Reger and Nikolay Rimsky-Korsakov, as well as Luigi Bordèse, ${ }^{127}$ Ludwik Grossman, ${ }^{128}$ Johann

126 Pauline (Michelle Ferdinande) Viardot-García (1821-1910), the best known and most interesting singer of the nineteenth century, of towering vocal virtuosity. She was a personal acquaintance of Chopin and performed with him. In concerts in Paris (1842) and England (1848), she performed transcriptions of his mazurkas with French texts. She sang Polish versions in Warsaw in 1857-1858. Viardot had a beautiful almost alto voice and outstanding acting ability, and she was also fluent in Polish, which contributed to the popularity of her performances in Poland. Information after HRML, ii:1936; KTL, 425; MCL, xi:48-50.

127 Luigi Bordèse (1815-1886), a graduate of Naples Conservatory who wrote mainly vocal-instrumental compositions (the opera I promesse sosi, Masses, a requiem) and songs, he was also the author of teaching literature - schools of singing, solfeggio and other publications. Information after HRML, i:206; MCL, i:137; MCL, v:303.

128 Ludwik Grossman (1835-1915/1917), a Polish composer whose output encompasses stage works (the comic opera Duch wojewody [The ghost of the voivode], the opera Rybak $z$ Palermo [The fisherman from Palermo] and operettas), orchestral works (three overtures and two ballet suites), piano works, and choral and solo songs. He 
Valentin Hamm, ${ }^{129}$ August Horn, ${ }^{130}$ Adam Münchheimer, ${ }^{131}$ Martin Röder, ${ }^{132}$

was a pupil of August Freyer in Warsaw and Carl Friedrich Rungenhagen in Berlin. Besides composing, he worked as a music teacher (at the Noble Institute in Warsaw) and was a concert pianist and organist. In 1857, he opened the musical instrument shop Hermann und Grossman. According to Sowiński, all of Grossman's compositions were highly popular in concert halls and salons alike. He was also esteemed as an organist. And as Sowiński emphasises, although Grossman was absorbed by 'a multitude of interests', he did not cease to work 'with the utmost love of his art' (SMPD, 141). Information after SMPD, 141-142; KTL, 135; HRML, i:666.

129 Johann Valentin Hamm (1811-1875), a German composer in nearly all the musical genres (operas, symphonies, overtures, military compositions, quintets, quartets and part songs), although famed solely for his songs, marches, dances and potpourris. $\mathrm{He}$ owed his musical training to the tuition he received from 1830 at the Musikinstitut in Würzburg, where he acquired theoretical and practice knowledge in violin and piano. From 1831, he was a viola player with the theatre orchestra in Würzburg, before becoming first violin and a piano teacher. Information after MCL, iv:507-508; KTL, 144.

130 August Horn (1825-1893), a German composer and music teacher. He wrote the opera Die Nachbarn (1875) and works for mixed choir, but his reputation rested mainly on his numerous arrangements of symphonies, operas and other works for piano for four and eight hands. Besides his arrangements, his only works to be published were minor piano pieces, songs and choral works. He is known for a whole cycle of Chopin arrangements, Compositionen von Friedrich Chopin für Pianoforte zu vier Händen übertragen, published by Peters of Leipzig in 1880-1885 in four volumes: waltzes, mazurkas, polonaises and nocturnes. Information after HRML, i:782; KTL, 167.

131 Adam Münchheimer (1830-1904), a Polish composer and conductor. From 1850, he held a succession of posts in Warsaw: violinist with the orchestra of the Teatr Wielki, musical director and head of the ballet, opera conductor, director of the Warsaw Opera and professor of the Institute of Music. He composed operas, orchestral music, chamber works, and choral and vocal works (songs). He produced an orchestration of Chopin's Concerto in E minor, Op. 11 and also vocal transcriptions of the Waltz in A minor, Op. 34 No. 2, entitled 'Stroskana' [Troubled]. The stature of his output during the nineteenth century is described by Sowiński: 'Münchheimer's compositions are highly regarded, striking in their spontaneity and characteristic songfulness, marked by a meticulous arrangement of parts and great technical expertise' (SMPD, 279). As in the case of Adolf Gustaw Sonnenfeld, we find no information about Adam Münchheimer in any of the nine source lexicons, which indicates that during the nineteenth century he was perceived as a local, exclusively Polish, composer. Information after SMPD, 278-280; SMP, ii:61-62; EM, 586.

132 Martin Röder (1851-1895), a composer and former pupil of the Königliche Hochschule in Berlin. He lived in Milan from 1873 to 1880, where he was chorus 
Xaver Scharwenka ${ }^{133}$ and Nikolay Sokolov ${ }^{134}$. There is a clear division here into superior composers who influenced the course of music history and less prominent composers. The output of these composers is highly diverse and abounds in stage works and large vocal-instrumental compositions, as well as chamber and solo works. Consequently, their transcriptions lay on the margins of their output. Unfortunately, it is impossible to establish today how that music was received. Were it not for the biographical information available, it would be even more difficult to find detailed information about their musical activities. There is no doubt that these composers played some role in propagating Chopin's music in their environments (Russian, German, Italian and Polish). The quality of that transmission is documented in the adaptations themselves. Horn's transcriptions are simple adaptations for piano for four hands, Scharwenka's transcriptions are for two pianos, and others are for voice (Bordèse, Grossman, Münchheimer, Röder, Sokolov), violin (Hamm) and orchestra (Köhler-Wümbach). The form of the piano versions suggests that they were of a popularising character, enabling the original composition to be performed by two people. The vocal settings are clearly designed with popularisation in mind, as is indicated by their musical

master at the Teatr dal Vermio and also founder (in 1875) and conductor of the Società del Quartetto Corale. From 1880, he worked in Berlin as a singing teacher and then a teacher at the Scharwenka Conservatory. From 1887, he worked in Dublin as musical director. He spent the last years of his life in Cambridge, near Boston. His compositional output includes operas (Petro Candiano IV, Giuditta, Vera), two oratorios (Maria, Magdalena), two symphonies, chamber music and songs. Information after MCL, supplement, 397; KTL, 327; HRML, ii:1532.

133 Xaver Scharwenka (1850-1924), a German composer and pianist, brother of Ludwig. He wrote operas, symphonies, four piano concertos, chamber works and piano works (salon dances, studies). He also wrote a Methodik des Klavierspiels (Leipzig 1907). He was a pupil of Theodor Kullak and performed a great deal in Germany. In 1881, he founded the Scharwenka Conservatory in Berlin (1881-1992), of which he was director. As a teacher, he also worked in New York and from 1891 was a professor of the New York Conservatory that later bore his name. Information after KTL, 344; HRML, ii:1604-1605.

134 Nikolay Alexandrovich Sokolov (1859-1922), a Russian composer associated with St Petersburg, where he was taught composition by Johannsen and Rimsky-Korsakov. He was a teacher of theory at the Hofsängerkapelle, a professor of theory at the conservatory and then inspector of the Chorakademie. He wrote two ballets, symphonies, piano works, violin works, choral works and other pieces. He also wrote a handbook of harmony and counterpoint, Die Grundlagen der Polyphonie, which remained unpublished. Information after HRML, ii:1720; NML, 606. 
construction, the verbal text and the titles of the publications (e.g. Romanse i pieśni [Romances and songs], Zbiór najpiękniejszych melodyi ułożonych do śpiewu [Selection of the most beautiful melodies arranged for voice] and of the transcriptions themselves ('Dziewczyna mazowiecka' [Mazovian girl], 'Stroskana' [Troubled], 'Amorettenreigen'). Köhler-Wümbach's orchestral version of the Marche funèbre from the Sonata in B flat minor, Op. 35 bears the hallmarks of a functional transcription, intended for funerals.

As Chomiński and Turło write: 'With the aim of enhancing the list of arrangers with the names of the most outstanding composers, works on Chopin themes by Kalkbrenner, Rachmaninov and Mompou have been treated as piano transcriptions. [...] as has - as a kind of exception - Władysław Żeleński’s paraphrase Roma. [...] Also included in the list of transcriptions are suites comprising orchestral arrangements of several works.'135 These last works include Mily Balakirev's four-part Suite for orchestra. ${ }^{136}$ This was treated as a 'Token of respect for the Committee for the Building of a Monument to Fryderyk Chopin in Warsaw' on the hundredth anniversary of the composer's birth. ${ }^{137}$ The successive parts of the Suite are transcriptions of works by Chopin: the Préambule is the Etude in E flat minor, Op. 10 No. 6, the Mazurka is the Mazurka in A flat major, Op. 41 No. 3, the Intermezzo is based on the Nocturne in G minor, Op. 15 No. 3, and arranged in the Finale is the Scherzo in C sharp minor, Op. 39. The work was published by J. H. Zimmermann of Leipzig in $1909 .{ }^{138}$ Each of the movements is characterised by different forces (the weakest are movts I and III, the richest movts II and IV) and a different degree of recomposition of the original. Balakirev made a substantial contribution to the propagation of Chopin's music in Russia as a pianist, the composer of arrangements for orchestra, piano and choir, and also the publisher of Chopin's sonatas. He helped to bring added splendour to the Polish solemnities marking the centenary of the composer's birth. For Ferruccio Busoni, transcribing was a crucial aspect of his creative art. ${ }^{139}$ He produced a piano arrangement of the

\section{CT, 55.}

136 This work is not included in the list of instrumental compositions in EMab, 178.

137 Information contained on the title page of the arrangement.

138 Dated after information given in the score.

139 He arranged music by Bach, Beethoven, Brahms, Cornelius, Cramer, Gade, Goldmark, Mendelssohn, Novácek, Schubert, Schumann, Wagner, Weber and Weil. On the basis of Chopin's Prelude in C minor, Op. 28 No. 20, he composed Variationen und Fuge in freier Form über F. Chopins c-moll-Präludium for piano (Breitkopf \& Härtel 1888 - that year and place of publication are given in CT, 381; a different date (1885) is given by Michał Bristiger in EMab (467), but he does not give the place of publication). However, this is a new composition and does not belong among Chopin transcriptions. 
Polonaise in A flat major, Op. $53\left(1909^{140}\right)$. Another composer, Alexander Glazunov, turned to five compositions in his orchestral suite Chopiniana (known from 1909 as Les Sylphides), published in $1894 .{ }^{141}$ This composer also wrote an orchestral adaptation of the Nocturne in C minor, Op. 48 No. 1, which exists only in manuscript. ${ }^{142}$ Glazunov also produced cello transcriptions of the Etude in E flat minor, Op. 10 No. 6 and the Etude in C sharp minor, Op. 25 No. $7 .{ }^{143}$ Leopold Godowsky wrote a collection of Studien für Pianoforte über die Etüden von Chopin, comprising five volumes and fifty-three arrangements based on twenty-six Chopin etudes. ${ }^{144}$ There are twenty-eight reworkings from opus 10, twenty-one from opus 25 and four from Méthode des méthodes. This collection was published successively from 1898 by

140 Dated after CT, 376.

141 The orchestral suite Chopiniana, Op. 46 originally comprised four movements (I. Polonaise in A major, Op. 40 No. 1; II. Nocturne in F major, Op. 15 No. 1; III. Mazurka in C sharp minor, Op. 50 No. 3; IV. Tarantella in A major, Op. 43). It was composed in 1892, performed in St Petersburg in 1893 under the baton of Nikolay Rimsky-Korsakov and published in 1894 by Belaieff of Leipzig. At the urging of Mikhail Fokine, Glazunov then orchestrated one more work by Chopin (the Waltz in C sharp minor, Op. 64 No. 2 ) and incorporated it in the suite as the fourth movement, with the Tarantella remaining as the last piece in the suite. Thus was produced the five-part orchestral suite to the ballet Chopiniana, choreographed by Fokine. That ballet was first performed in a charity concert on 10 February 1907 at the Mariinsky Theatre in St Petersburg. Further modifications were made to Chopiniana: the parts of the ballet were increased to eight (as was the orchestral suite), Fokine introduced new choreography and a temporary change of title to Ballet to Music by Chopin, with the subtitle Reverie romantique (premiere at the Mariinsky Theatre in St Petersburg on 8 March 1908). Yet in the Polish premiere at the Teatr Wielki in Warsaw (6 December 1908) and in the next St Petersburg performance (19 February 1909), this composition was titled Chopiniana. This ballet comprised eight separate parts based on arrangements of Chopin's works by Maurice Keller and Alexander Glazunov (I. Polonaise in A major, Op. 40 No. 1; II. Nocturne in A flat major, Op. 32 No. 2; III. Waltz in G flat major, Op. 70 No. 1; IV. Mazurka in D major, Op. 33 No. 3; V. Mazurka in C major, Op. 67 No. 3; VI. Prelude in A major, Op. 28 No. 7; VII. Waltz in C sharp minor, Op. 64 No. 2; VIII. Waltz in E flat major, Op. 18).

The title Les Sylphides was given to this composition by Serge Diaghilev for the ballet's premiere at the Théâtre du Châtelet on 2 June 1909, which featured new orchestrations of seven of Chopin's works by Igor Stravinsky, Nikolay Tcherepnin and Anatoly Lyadov. In the first part, Diaghilev used the Prelude in A major, Op. 28 No. 7 instead of the Polonaise in A major, Op. 40 No. 1. This ballet is still performed in its eight-part version under both titles: Chopiniana (used mainly in Poland) and Les Sylphides (in the West).

142 Information after CT, 368.

143 Lev Ginzburg writes about this transcription in 'Rosyjskie transkrypcje', 45-51.

144 This collection does not include the arrangement of the Etude, Op. 25 No. 7. 
Schlesinger of Berlin (1898-1903; 1909-1913; 1914). The same publisher also issued 22 Chopin - Studien für die linke Hand allein (1915), which is a reduction of the five-volume work. Transcriptions by this composer were also published by Schirmer of New York $(1899,1903,1909)$ and Muzyka of Moscow $(1968) .{ }^{145}$ Franz Liszt produced numerous piano transcriptions of songs by Schubert and Schumann, works by J. S. Bach, and operatic fantasies on themes from operas by Mozart, Verdi and Wagner. From the Chopin repertoire, he chose six songs ('Życzenie' [A Maiden's Wish], 'Wiosna' [The Spring], 'Pierścień' [The Ring], 'Hulanka' [Drinking Song], 'Moja Pieszczotka' [My Enchantress] and 'Narzeczony' [The Bridegroom's Return]), which he set in 6 Chants polonaises op. 74 de Fr. Chopin for piano. They were published by A. M. Schlesinger of Berlin c.1860 ${ }^{146}$ Max Reger's Fünf Spezialstudien für Pianoforte, published in Leipzig by Josef Aibl in 1898-1903, ${ }^{147}$ contains piano transcriptions of the Waltz in D flat major, Op. 64 No. 1, Grande Valse in A flat major, Op. 42, Waltz in C sharp minor, Op. 64 No. 2, Etude in G sharp minor, Op. 25 No. 6 and Impromptu in A flat major, Op. 29. ${ }^{148}$ This collection was enriched with a sixth work: another arrangement of the Waltz in D flat major, Op. 64 No. $1 .{ }^{149}$ We know much less about transcriptions by other composers. Władysław Żeleński based his paraphrase Roma, from $1910{ }^{150}$ on two compositions: the Fantaisie in F minor, Op. 49 and the Prelude in C minor, Op. 28 No. 20. Zygmunt Noskowski wrote a dozen or so transcriptions for various forces (voice and piano, easy piano, orchestra, orchestra and choir). ${ }^{151}$ They were written between 1888 and 1900, and most of them exist in manuscripts held at PWM Edition in Cracow and in the libraries of the Warsaw Music Society and the Fryderyk Chopin University of Music in Warsaw. Nikolay Rimsky-Korsakov also left in manuscript several transcriptions for string orchestra (Mazurkas in G major, Op. 50 No. 1 and C major, Op. 56 No. 2, Nocturnes in B flat minor, Op. 9 No. 1, E flat major, Op. 9 No. 2 and G minor, Op. 37

145 The dating and publisher's name come from notes included in this five-volume collection and from CT, 339-340.

146 Dating after Deutsch, 22. The plate number of this collection is 4858; the catalogue gives the year 1859 for numbers $4742-4812$ and 1860 for numbers 4884-4922.

147 Dated after CT, 344, 346, 391.

148 Cf. Lissa, 'Inspiracje', 67-99.

149 This information is given by Peter Andraschke in 'Chopin w opracowaniach', 79-92. This transcription is dated to 1904-1910 and comes from Universal Edition of Vienna (cf. CT, 392).

150 See CT, 381.

151 These arrangements were of the Etudes, Op. 10 No. 3 and Op. 25 No. 12, the Mazurkas, Op. 17 No. 1, Op. 33 No. 2 and Op. 68 No. 3, the songs, Op. 74, the Polonaise, Op. 53 and the Marche funèbre from Op. 35. 
No. 1). These are accessible in the Saltykov-Shchedrin Library in St Petersburg, and their composition is dated to $1884-1885 .{ }^{152}$ Mieczysław Karłowicz turned to Chopin compositions to improve his mastery of instrumentation. Around 1898, he produced three versions of the Prelude in C minor, Op. 28 No. 20 for brass ensemble (two trumpets, four horns, three trombones, tuba) and three versions of the Berceuse, Op. 57 for full orchestra. Unfortunately, those transcriptions are lost, and their existence is evidenced solely by the sheet music and book inventories of the Karłowicz Section of the Warsaw Music Society. ${ }^{153}$

In producing their transcriptions, these outstanding composers were guided primarily by artistic considerations and the desire to perfect their compositional craftsmanship; their transcriptions were tributes to the great composer. Only Godowsky ascribed a didactic aim to his transcriptions, although knowing the degree of their difficulty, one realises that they were not popularising arrangements, but were addressed to an elite group of performers. The small number of 'compositional' transcriptions had different groups of recipients. The greatest popularity among pianists was gained by the readily performed Chants polonaises by Liszt, Glazunov's Chopiniana was familiar to audiences from ballet shows, ${ }^{154}$ and Balakirev's Suite, expressive of his admiration for Chopin, was intended for music lovers to whom Chopin's music was particularly dear. Godowsky's etudes were the subject of concert presentations, and they were recorded much later. In 1900, the American James Huneker prophesied that Godowsky had written his etudes for future generations, no doubt for the generation of Rosenthal. ${ }^{155}$ Huneker also advised his readers against delving into the problem of respect for Chopin's music. ${ }^{156}$ Another author, Harold Schonberg, wrote in the mid twentieth century, in The New York Times, about the diverse ways in which the Etudes were rendered more complicated and called them fantastic exercises, raising the level of pianistic technique to a degree that even

152 Cf. CT, 356, 357, 361, 363, 367.

153 Anders, Mieczysław Karłowicz, 210.

154 Michał Biernacki esteemed this composition as excellent (see Biernacki, 'Transkrypcje', 488).

155 'Außerdem, [...], schreibt er für die nächste Generation - vermutlich eine Generation von Rosenthals'. Information from the booklet for the CD: GODOWSKY: The Complete Studies on Chopin's Etudes, perf. Marc-André Hamelin. Hyperion Records 1998-1999, 56.

156 'erteilte anderen den weisen Rat, sich nicht zu fragen, ob Godowsky Chopin Ehrfurcht erwiesen habe'. Ibid. 
Liszt had not dreamed of. ${ }^{157}$ In the cited reactions by critics, one sees above all admiration of Godowsky's work, while a matter of less importance, albeit signalled by Huneker, was the problem of respect for the original works. In light of these opinions, Godowsky's Etudes are above all splendid material for improving piano technique and developing sensitivity. And that was the aim pursued by Godowsky. Less well known were the arrangements made by Reger and Busoni, and the transcriptions by Noskowski and Rimsky-Korsakov, existing solely in manuscripts, had limited possibilities for becoming widely known. Karłowicz's transcriptions were probably never performed and were familiar to few people. ${ }^{158}$

\section{[3] Organisers of musical life}

Among arrangers, one can distinguish a group of people who helped to organise musical life. For the purposes of their various activities, they created adaptations that served two basic aims: teaching at an elementary level and popularising 'high' music. This group is represented by Richard Hoffmann, ${ }^{159}$ Jan Łusakowski, ${ }^{160}$

157 'wahrscheinlich die allerschwierigsten Stücke, die je für Klavier komponiert wurden. Es sind fantastische Übungen, welche die Klaviertechnik in Höhen treiben, die nicht einmal Liszt sich erträumt hat'. Ibid.

158 They were no doubt familiar to Adolf Chybiński and Jerzy Młodziejewski (see Anders, Mieczystaw Karłowicz, 210).

159 Richard Hoffmann (1844-1918) studied instrumentation and composition with F. Spohr and S. Jadassohn. He taught instrumentation at Leipzig Conservatory, wrote special schools for orchestral instruments (viola, French horn, trombone, tuba and trumpet) and produced numerous orchestral arrangements. He published the works Katechismus der Musikinstrumente (1903), Praktische Instrumentationslehre (1893) and Neuen Führer durch die Violin- und Viola-Literatur (1909), as well as many other 'instructive' compositions for piano, string instruments and brass instruments. His interest in Chopin is reflected in nine transcriptions for violin and piano and for piano quintet. Information after HRML, i:770-771; KTL, 165.

160 Jan Łusakowski (1857/1860-1917), although initially a concert pianist, ultimately devoted himself to teaching, in connection with which he published piano works of a didactic character (incl. piano transcriptions of songs by Stanisław Moniuszko from the Spiewnik szkolny [School songbook] for 1, 2 and 3 parts) and wrote a Zbiór łatwych utworów na piano [Collection of easy pieces for piano] which he 'revised and fingered'. That collection was published in the Młody Muzyk series by M. Arct of Warsaw. Aimed at amateurs or beginners, it contained repertoire by various composers and was arranged according to three levels of difficulty: I - very easy, II - easy, III - slightly more difficult. It is significant that Łusakowski did not arouse the interest of any author of a nineteenth-century lexicon, even Albert Sowiński, who produced a Polish dictionary. Information after SMP, i:346; Błaszczyk, Dyrygenci. 
Piotr Maszyński, ${ }^{161}$ Friedrich Mockwitz, ${ }^{162}$ Alfred Edward Moffat, ${ }^{163}$ Christian Gottlieb Müller, ${ }^{164}$ Franz Louis Schubert, ${ }^{165}$ Gustav

161 Piotr Maszyński (1855-1934), mainly involved with the Lutnia male-voice choir of Warsaw. In founding that choir, Maszyński set an example for the bigger cities of the Congress Kingdom, in which Lutnia choral societies were subsequently founded. All his work in composing, conducting and publishing was linked to Lutnia, for which he arranged Polish folk songs and solo songs, composed works for male and mixed choir, published song collections and produced many choral transcriptions of Chopin. For male choir, he arranged the Fantaisie in F minor, Op. 49 (Przebudzenie [Awakening]); the songs, Op. 74 Nos. 4, 5, 11 and 7 (Marzenie [Dreams]; the Preludes, Op. 28 Nos. 20 and 9 (Wschód słońca [Sunrise]). For mixed choir, he transcribed the songs, Op. 74 Nos. 1 and 4; the Prelude in A major, Op. 28 No. 7 (Marzenie [Dreams]) (see CT, 346, $371,372,380,382$ ). Maszyński made a significant contribution to musical education in Warsaw by founding, in 1884, a music school under the auspices of the Warsaw Music Society. His pedagogic work is reflected in his methodological works devoted to singing in schools. Information after HRML, ii:1129; NML, 410-411.

162 Friedrich Mockwitz (1785-1849) was a remarkably talented musician. He learned piano and singing in Dresden. From 1809, he became known for his arrangements of instrumental compositions for piano for four hands (Arrangements von Instrumentalenstücken). He was one of the first to produce easy piano versions of symphonies, concertos and quartets by Haydn, Mozart, Beethoven and others. He also initiated the transcribing of Chopin for piano for four hands (Mazurkas, Op. 7 Nos. 1-4, pub. F. Kistner, Leipzig; Two Nocturnes, Op. 32, pub. A. M. Schlesinger, Berlin; Three Nocturnes from Op. 9, pub. F. Kistner, Leipzig). His transcriptions are dated 1837, 1839 and 1844. Of his own compositions, Twelve Waltzes were published by Breitkopf \& Härtel of Leipzig. Information after MCL, vii:161.

163 Alfred Edward Moffat (b. 1866), a Scottish composer and publisher who worked in Berlin for small publishers from 1889 to 1899 and then (in 1899) moved to London. He produced many arrangements of early music (Händel and Purcell). Of Chopin compositions, he chose several (Impromptu-Fantaisie, Op. 66, 'Życzenie' [A Maiden's Wish], Op. 74 No.1, Preludes, Op. 28 Nos. 4 and 13), which he transcribed for violin and piano, cello and piano, and choir. Information after NML, 425.

164 Christian Gottlieb Müller (1800-1863), a composer of operas, symphonies, church compositions and vocal works. As a conductor and composer, he was associated with Leipzig (also as a violinist with the theatre orchestra) and then Altenburg. He wrote solid arrangements of Chopin for piano for four hands. Information after KTL, 264.

165 Franz (Ferdinand?) Louis Schubert (1804-1868) was a well-known composer of piano arrangements, including dozens of transcriptions of Chopin for piano for four hands. He was one of the few to propose adaptations of large-scale works: the Ballades in F major, Op. 38 and in A flat major, Op. 47, Fantaisie in F minor, Op. 49, Polonaise-Fantaisie in A flat major, Op. 61 and Scherzo in B minor, Op. 20. He wrote 
Zanger ${ }^{166}$ and Ernst David Wagner ${ }^{167}$. From the biographical notes of these individuals, we may conclude that for them the preparation of transcriptions was an important task, which served above all their didactic work and often represented considerable creative output.

Ordering the transcribers according to their primary profession reveals a relationship between that profession and the intention of their transcriptions. Concert musicians and composers produced artistic versions, while all the others prepared easier versions for didactic and popularising purposes. The universality of the profession of musicians, being at once performer, composer and teacher, explains why even first-rate artists produced didactic transcriptions. So the profile of transcribers accounts for the diversity of the adaptations, indicating their didactic, popularising, artistic or concert character. Irrespective of that primary musical profession, two groups emerge among transcribers: [1] the most accomplished musicians, whose quantitative contribution to the transcribing of Chopin was quite small; [2] professional composers who helped to shape nineteenth-century musical culture, but whose star later dimmed. This paradox results from many factors, above all the cult and respect which great nineteenth-century composers bestowed upon Chopin's original work, a negative attitude towards the idea of imitation and a wish to create their own music. It would seem that the much more numerous musicians of the second group were motivated by other considerations and no doubt sought to popularise Chopin's music through their numerous adaptations. The second group, which made

handbooks on instrumentation (Instrumentationlehre) and composition (Vorschule zum Komponieren) and schools of playing on various instruments (incl. oboe, trumpet and clarinet). Information after KTL, 361.

166 Gustav Zanger (b. 1848) was also associated with church music, at first as a pupil of the Institute of Church Music in Berlin, and from 1894 as a musician active in Koenigsberg. He wrote choir books, organ studies, choral compositions, songs and other works (incl. Chopin transcriptions for violin, cello and piano for four hands). Information after KTL, 463; HRML, ii: 1974.

167 Ernst David Wagner (1806-1883) wrote arrangements for easy piano and for two pianos which, like his school for piano playing for children (Kinderklaviermusik, Op. 45 from 1913) and numerous piano studies, were intended for didactic purposes. The other side of his musical work was linked to sacred music. As cantor of the Matthäuskirche (1838) in Berlin, organist of the Trinitatiskirche in Berlin (1848) and Royal Director of Music (Königlicher Musikdirektor), he composed motets, books of psalms, songs and chorales. He also wrote the oratorio Johannes der Täufer and the treatise Die musikalische Ornamentik (1869). Information after MCL, vii:191-192; KTL, 432. 
the greatest contribution to the work of transcribing Chopin, is very large and difficult to characterise. That results from the lack of information about those composers in scholarly lexicons. However, of the seventy-eight individuals who produced our source material, only ten could not be identified, while information about the others can be found in nineteenth-century source lexicons, which attests to their contribution to the musical culture of their times. The work of all the transcribers clearly points to the secondary character of the adaptations they produced; ${ }^{168}$ this kind of 'output' accompanied the principal strand. Thanks to transcriptions, Chopin's music experienced a great 'augmentation', and the transcribers, who were responsible for the quality of that transmission, were the most crucial link in that process.

\subsection{The economic and legal conditions behind the dissemination of transcriptions during the nineteenth century}

The most crucial link in the process of 'augmenting' Chopin's oeuvre was formed by the institutions whose activities made it possible to disseminate transcriptions. Nineteenth-century Europe was characterised by a multitude of publishing firms, as we learn from the catalogues of Hofmeister, Deutsch, and Devriès and Lesure. ${ }^{169}$ An exhaustive bibliography of German music publishers was prepared by Hans-Martin Plesske, the specificities of French publishers are discussed by Krzysztof Grabowski, and Polish music publishing has been the subject of studies by Tadeusz Frączyk, Maria Prokopowicz, Barbara ZakrzewskaNikiporczyk, Krzysztof Mazur and Władysław Hordyński. ${ }^{170}$

The first publishers of Chopin's works were Izydor Józef Cybulski (engraving) and Antoni Brzezina (lithography) in Warsaw and the Viennese publishers Tobias Haslinger and Pietro Mechetti. When Chopin was living in Paris, his original works and their transcriptions were published in three versions in London (Wessel), Paris (Maurice Schlesinger) and Leipzig (Breitkopf \& Härtel). Chopin transcriptions were disseminated through many other major publishers: Kistner

168 Only for Horn, Łusakowski, Mockwitz, Moffat, Hoffmann and Schubert was the transcribing of the works of other composers a primary activity.

169 See Bibliography.

170 Plesske, Bibliographie, 135-222; Grabowski, 'Francuskie oryginalne wydania'; Frączyk, Warszawa, 235-307; Prokopowicz, 'Z działalności', 33-49; Prokopowicz, 'Wydawnictwo'; Zakrzewska-Nikiporczyk, Muzyczny Ruch; Mazur, 'Polskie edytorstwo', 51-89; Hordyński, Katalog. 
and Peters in Leipzig, A. M. Schlesinger in Berlin, Litolff in Brunswick, Schott's Söhne in Mainz, Hamelle, Benoît Ainé, Gérard and Durand \& Fils in Paris, Bessel in St Petersburg, Jurgenson and Meikov in Moscow, and Kaufmann in Warsaw. It was through these publishers that transcriptions reached a large number of consumers in Germany, France, Russia and Poland.

One of the crucial features of publishing work is the print-run of particular titles. For our research, the size of the print-runs for transcriptions would be reliable information regarding the scale and scope of the musical reception of Chopin. Unfortunately, nineteenth-century music prints bear no direct information about print-runs and reprints, ${ }^{171}$ and information of this sort is also not given in any of the known publishing catalogues; only laborious and time-consuming archive searches might bring significant results. Wishing to present the scope and scale of transcribing based on the work of publishers, we can only rely on individual editions, that is, on the number of titles issued by a given publisher. For the map of the scope of transcriptions to be full and exact, this issue will be sketched on the basis of the source material for this book and on information concerning editions of all transcriptions of Chopin's works given in the Catalogue of Chomiński and Turło. ${ }^{172}$ That comparison is assisted by the tables given below and by graphs produced using the Excel computer program.

The most active Polish music publishers were Gebethner \& Wolff and Michał Arct, both based in Warsaw. These two firms published easy arrangements for piano and for piano for four hands, as well as Pauline Viardot's arrangements for voice and piano of Chopin mazurkas. They were active essentially during the second half of the nineteenth century, with a temporary lull during the 70 s (Table 16). Transcriptions issued by Russian publishers are popular versions for voice and piano, published in the series Romances and Songs, which also includes arrangements by instrumentalists, such as Conus and Wilhelmj. These publishing firms made a substantial contribution to disseminating Chopin transcriptions (Table 17). The work of French publishing firms in disseminating transcriptions is presented in Table 18. Although the number of published transcriptions changed, French publishers remained active throughout the whole of the period of interest to us here (1830-1919). They published adaptations by major composers of instrumental versions (Sarasate, Franchomme, Reményi, Vilbac) and vocal versions (Ruelle). The large number of publishers in Germany guaranteed continuity to the process of the publishing of transcriptions (Table 19). Breitkopf \&

171 See CT, 34.

172 For information on this subject, see CT, 384-388. 
Table 16: Number of transcriptions published by Polish firms.

\begin{tabular}{|c|c|c|c|c|}
\hline \multirow[t]{3}{*}{ Years } & \multicolumn{4}{|c|}{ Number of transcriptions } \\
\hline & \multicolumn{2}{|c|}{ Gebethner \& Wolff } & \multicolumn{2}{|c|}{ M. Arct and others ${ }^{a}$} \\
\hline & $\overline{\mathrm{OS}^{\mathrm{b}}}$ & CTS $^{c}$ & OS & CTS \\
\hline $1830-1839$ & & & 1 & 1 \\
\hline \multicolumn{5}{|l|}{$1840-1849$} \\
\hline \multicolumn{5}{|l|}{$1850-1859$} \\
\hline $1860-1869$ & 5 & 13 & & 6 \\
\hline $1870-1879$ & & 2 & 1 & 2 \\
\hline 1880-1889 & 5 & 17 & & 2 \\
\hline $1890-1899$ & 11 & 49 & 7 & 37 \\
\hline 1900-1909 & & 25 & 1 & 45 \\
\hline 1910-1919 & & 30 & & 58 \\
\hline total: & 21 & 136 & 10 & 151 \\
\hline
\end{tabular}

${ }^{a}$ Warsaw: B. Rudzki; F. Hoesick; M. Idzikowski. Cracow: S.A. Krzyżanowski; T. Gieszczykiewicz.

${ }^{\mathrm{b}}$ OS - own sources, that is, studies forming the source basis for the present work.

${ }^{c}$ CTS - sources from the Chomiński and Turło Catalogue.

Härtel reigned supreme in this area from the 1840s through to the 70 s. The $80 \mathrm{~s}$ were dominated by Litolff of Brunswick and Peters of Leipzig. German firms published mainly transcriptions by German composers. The work of German publishers was bolstered by Austrian firms, which 'specialised' in transcriptions for piano for four hands (Table 20). The English market was dominated by two London firms: Wessel and Augener. According to Chomiński and Turło's Catalogue, the distribution of editions of transcriptions is regular and points to their constant and substantial contribution to disseminating transcriptions (Table 21). Italian and Dutch publishers made only a symbolic contribution (Table 22). During the 1870s, and especially at the start of the twentieth century, interest in Chopin spread to Sweden and America, and transcriptions also began to be produced there (Table 23). The summary (Tables 24 and 25) is served by the collective data from Chomiński and Turło and the source material.

According to my own sources, it was the German, Polish and French editions that bore a decisive influence on the dissemination of the transcriptions they contained. Yet that picture is only verified by the publisher profiling of the Chomiński/Turło Catalogue collection, as it refers to the work of nearly all of the publishers disseminating transcriptions, which in the nineteenth century were highly fashionable. Data from both my own collection and the Catalogue 
Table 17: Number of transcriptions published by Russian firms.

\begin{tabular}{|c|c|c|c|c|c|c|}
\hline \multirow[t]{3}{*}{$\overline{\text { Years }}$} & \multicolumn{6}{|c|}{ Number of transcriptions } \\
\hline & \multicolumn{2}{|c|}{$\begin{array}{l}\text { W. Bessel, } \\
\text { St Petersburg }\end{array}$} & \multicolumn{2}{|c|}{$\begin{array}{l}\text { P. Jurgenson, } \\
\text { Moscow }\end{array}$} & \multicolumn{2}{|c|}{ Others $^{a}$} \\
\hline & $\overline{\text { OS }}$ & CTS & OS & CTS & OS & CTS \\
\hline \multicolumn{7}{|l|}{$1830-1839$} \\
\hline \multicolumn{7}{|l|}{$1840-1849$} \\
\hline \multicolumn{7}{|l|}{$1850-1859$} \\
\hline $1860-1869$ & & & & & & 2 \\
\hline $1870-1879$ & & & & 1 & & 21 \\
\hline $1880-1889$ & 1 & 5 & & 3 & 2 & 4 \\
\hline 1890-1899 & 1 & 9 & 3 & 20 & 1 & 6 \\
\hline 1900-1909 & & 2 & & 6 & & 16 \\
\hline 1910-1919 & & 20 & & 8 & & 66 \\
\hline total: & 2 & 36 & 3 & 38 & 3 & 115 \\
\hline
\end{tabular}

a Kiev: N. D. Kashkin and L. Idzikowski. St Petersburg: A. Johansen, N. Davingof and P. Seliverstov. Moscow: A. Gutheil and K. Meikov.

Table 18: Number of transcriptions published by French firms.

\begin{tabular}{|c|c|c|c|c|c|c|c|c|c|c|c|c|}
\hline \multirow[t]{3}{*}{ Years } & \multicolumn{12}{|c|}{ Number of transcriptions } \\
\hline & \multicolumn{2}{|c|}{ E. Gérard } & \multicolumn{2}{|c|}{ E. Girod } & \multicolumn{2}{|c|}{$\begin{array}{l}\text { Durand \& } \\
\text { Fils }\end{array}$} & \multicolumn{2}{|c|}{ Benoît Ainé } & \multicolumn{2}{|c|}{$\begin{array}{l}\text { M. } \\
\text { Schlesinger }\end{array}$} & \multicolumn{2}{|c|}{ Others $^{\mathrm{a}}$} \\
\hline & OS & CTS & OS & CTS & OS & CTS & OS & CTS & OS & CTS & OS & CTS \\
\hline $1830-9$ & & & & & & & & & & 6 & & 1 \\
\hline $1840-9$ & & & & & & & & & 2 & 1 & & 3 \\
\hline $1850-9$ & & & & & & & 2 & & & & & 4 \\
\hline $1860-9$ & 2 & 21 & 3 & 12 & & & 3 & 5 & & & 2 & 60 \\
\hline $1870-9$ & & 6 & & & 2 & 3 & & & & & 2 & 27 \\
\hline $1880-9$ & & 1 & & & & & & & & & 2 & 56 \\
\hline $1890-9$ & & & & & & 9 & & & & & 1 & 41 \\
\hline $1900-9$ & & & & 1 & & 1 & & & & & & 75 \\
\hline $1910-9$ & & & & & & 5 & & & & & & 45 \\
\hline total: & 2 & 28 & 3 & 13 & 2 & 18 & 5 & 5 & 2 & 7 & 6 & 312 \\
\hline
\end{tabular}

${ }^{a}$ Mainly Paris-based publishers, including E. Alexandre, L. Bathlot, L. Bonnefond, L. Brandus, A. Choudens, G. L. Costallat, J. Evette, J. A. Hamelle, Heugel, A. Leduc and S. Richault. 


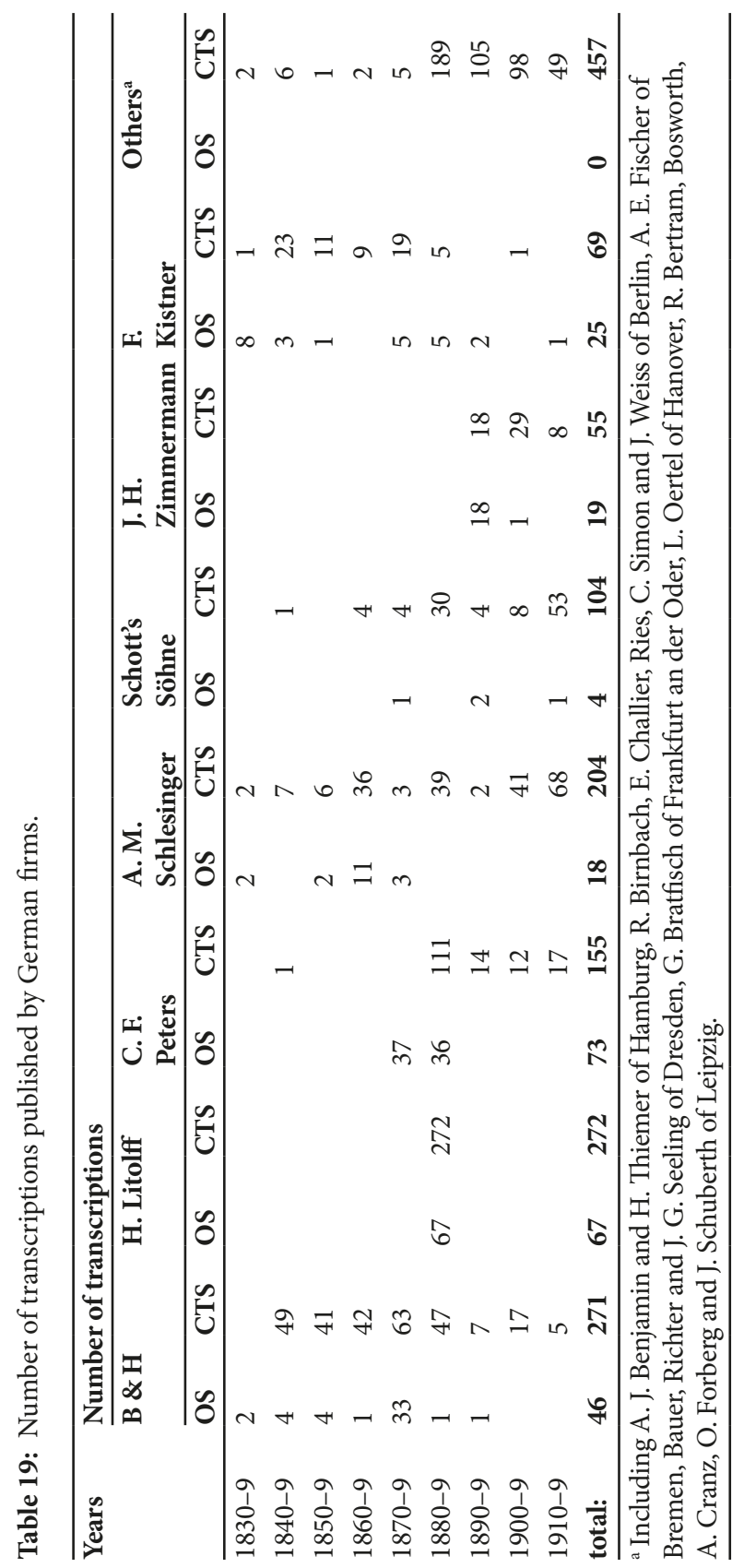


Table 20: Number of transcriptions published by Austrian firms.

\begin{tabular}{|c|c|c|c|c|}
\hline \multirow[t]{3}{*}{ Years } & \multicolumn{4}{|c|}{ Number of transcriptions } \\
\hline & \multicolumn{2}{|c|}{ P. Mechetti and others, ${ }^{\mathrm{a}}$ Vienna } & \multicolumn{2}{|c|}{ UE, Vienna } \\
\hline & $\overline{\mathrm{OS}}$ & CTS & OS & CTS \\
\hline \multicolumn{5}{|l|}{$1830-1839$} \\
\hline $1840-1849$ & 3 & 7 & & \\
\hline 1850-1859 & & 1 & & \\
\hline \multicolumn{5}{|l|}{$1860-1869$} \\
\hline $1870-1879$ & & 1 & & \\
\hline 1880-1889 & & 2 & & \\
\hline \multicolumn{5}{|l|}{ 1890-1899 } \\
\hline 1900-1909 & 1 & & & 101 \\
\hline 1910-1919 & & & & 17 \\
\hline total: & 4 & 11 & $\mathbf{0}$ & 118 \\
\hline
\end{tabular}

${ }^{a}$ Viennese publishers: T. Haslinger, C. A. Spina and Umlauf.

Table 21: Number of transcriptions published by British firms.

\begin{tabular}{|c|c|c|c|c|c|c|}
\hline \multirow[t]{3}{*}{ Years } & \multicolumn{6}{|c|}{ Number of transcriptions } \\
\hline & \multicolumn{2}{|l|}{ Augener } & \multicolumn{2}{|l|}{ Wessel } & \multicolumn{2}{|c|}{ Others $^{a}$} \\
\hline & OS & CTS & OS & CTS & OS & CTS \\
\hline $1830-1839$ & & & & 5 & & 0 \\
\hline $1840-1849$ & & & & 56 & & 1 \\
\hline $1850-1859$ & & & & 4 & & 7 \\
\hline $1860-1869$ & & & & & & 11 \\
\hline $1870-1879$ & & 1 & & & & 16 \\
\hline $1880-1889$ & 1 & 6 & & & & 27 \\
\hline $1890-1899$ & & 3 & & & & 31 \\
\hline 1900-1909 & & 12 & & & & 31 \\
\hline 1910-1919 & & 0 & & & & 12 \\
\hline total: & 1 & 22 & $\mathbf{0}$ & 65 & $\mathbf{0}$ & 136 \\
\hline
\end{tabular}

${ }^{a}$ E. \& P. H. Ashdown, Boosey, S. A. Chappell, E. Novello, A. Weekes and J. Williams.

collection help to trace a map of publishers contributing to the dissemination of transcriptions that accords with the facts. As more information becomes available, that map may be supplemented, although the hierarchy established here will remain unaffected. German, Polish, British and Russian publishers made 
Table 22: Number of transcriptions published by Italian and Dutch firms.

\begin{tabular}{|c|c|c|c|c|c|c|c|c|}
\hline \multirow[t]{3}{*}{ Years } & \multicolumn{8}{|c|}{ Number of transcriptions } \\
\hline & \multicolumn{4}{|c|}{ Italian - various ${ }^{\mathrm{a}}$ Ricordi } & \multicolumn{2}{|c|}{$\begin{array}{l}\text { Dutch } \\
\text { - various }^{\text {b }}\end{array}$} & \multicolumn{2}{|c|}{$\begin{array}{l}\text { B. J. Smitt \& Co, } \\
\text { Amsterdam }\end{array}$} \\
\hline & OS & CTS & OS & CTS & OS & CTS & OS & CTS \\
\hline \multicolumn{9}{|l|}{$1830-1839$} \\
\hline \multicolumn{9}{|l|}{$1840-1849$} \\
\hline \multicolumn{9}{|l|}{$1850-1859$} \\
\hline \multicolumn{9}{|l|}{$1860-1869$} \\
\hline $1870-1879$ & & 2 & & 1 & & & & \\
\hline $1880-1889$ & & 15 & & 1 & & 1 & & \\
\hline $1890-1899$ & & & & 4 & & & & \\
\hline 1900-1909 & & 8 & & 17 & & 2 & 1 & \\
\hline 1910-1919 & & 9 & & & & & & \\
\hline total: & $\mathbf{0}$ & 34 & $\mathbf{0}$ & 23 & $\mathbf{0}$ & 3 & 1 & $\mathbf{0}$ \\
\hline
\end{tabular}

Table 23: Number of transcriptions published by Swedish and American firms.

\begin{tabular}{|c|c|c|c|c|c|c|}
\hline \multirow[t]{3}{*}{ Years } & \multicolumn{6}{|c|}{ Number of transcriptions } \\
\hline & \multicolumn{2}{|c|}{ Swedish - various } & \multicolumn{2}{|c|}{$\begin{array}{l}\text { G. Schirmer, } \\
\text { New York }\end{array}$} & \multicolumn{2}{|c|}{ American - various } \\
\hline & $\overline{\mathrm{OS}}$ & CTS & OS & CTS & OS & CTS \\
\hline \multicolumn{7}{|l|}{$1830-1839$} \\
\hline \multicolumn{7}{|l|}{$1840-1849$} \\
\hline \multicolumn{7}{|l|}{$1850-1859$} \\
\hline \multicolumn{7}{|l|}{$1860-1869$} \\
\hline $1870-1879$ & & & & & 1 & 1 \\
\hline $1880-1889$ & & & & & & 1 \\
\hline $1890-1899$ & & & & 1 & 1 & 2 \\
\hline 1900-1909 & & 3 & 3 & 26 & 2 & 23 \\
\hline 1910-1919 & & & & 11 & & 16 \\
\hline total: & $\mathbf{0}$ & 3 & 3 & 38 & 4 & 43 \\
\hline
\end{tabular}

${ }^{a}$ Including W. Jacobs of Boston, C. Fischer, J. W. Stern and E. Schuberth \& Co. of New York. 


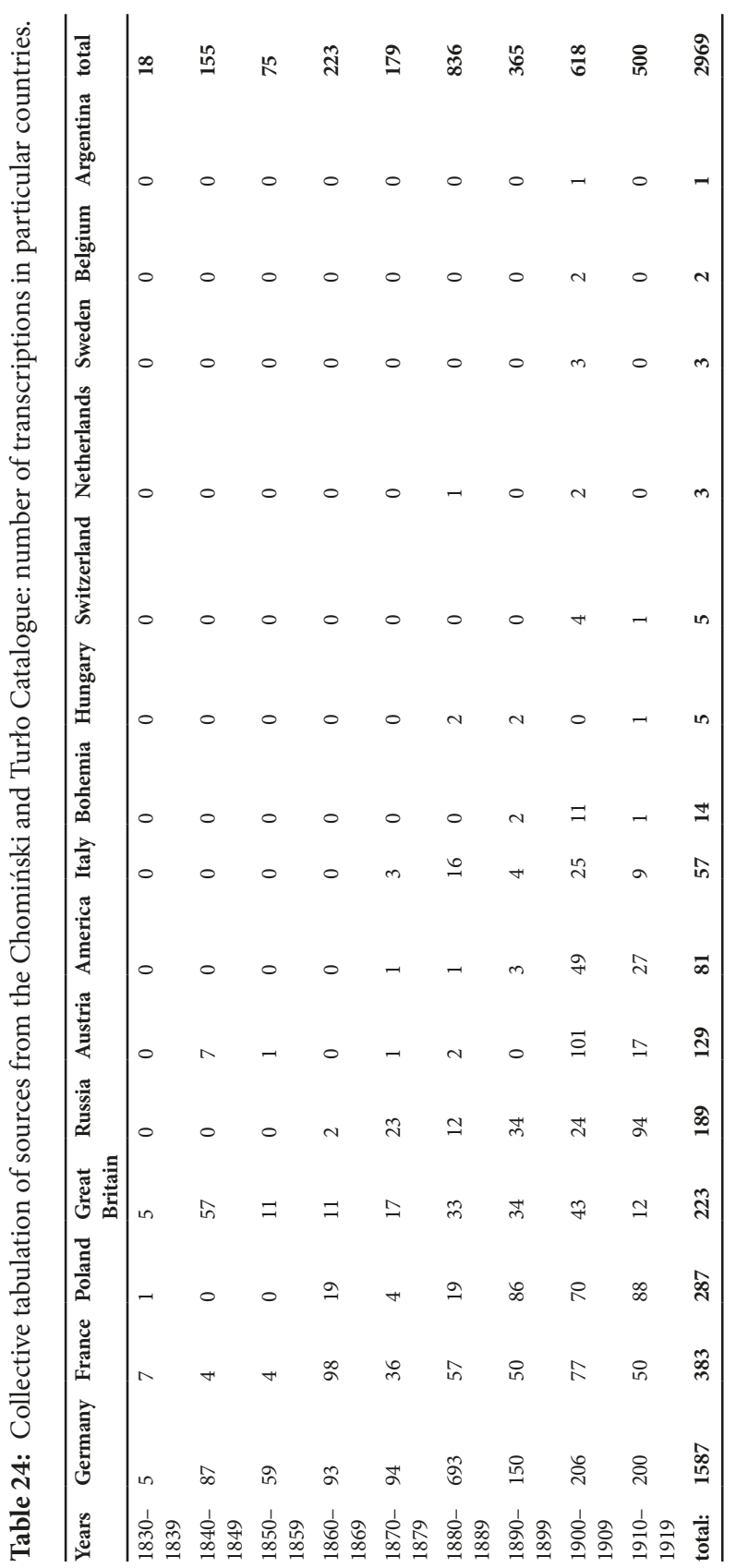


Table 25: Collective tabulation of own sources: number of transcriptions in particular countries.

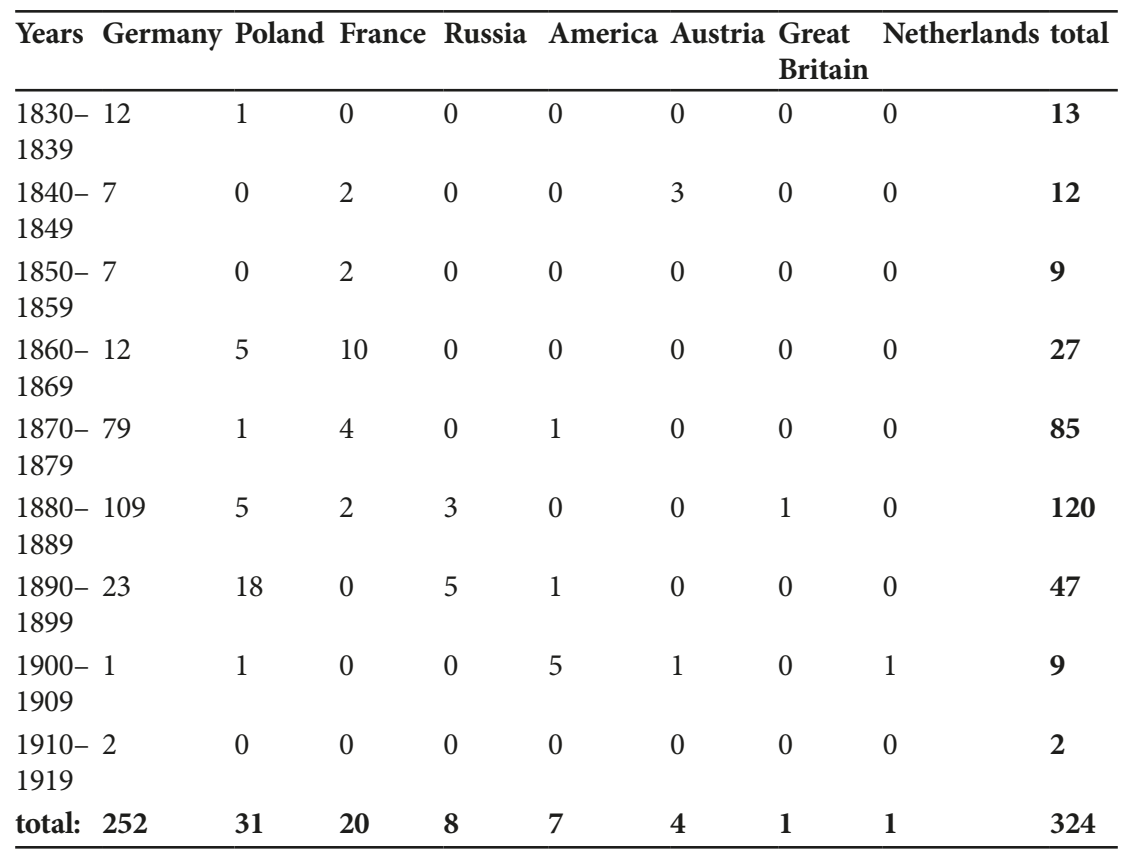

a substantial contribution, while the participation of the other four groups of publishers in this process was marginal.

Taking account of the complementary results of research into both sets of sources enables one to state that German firms were most active in this area. Their work in publishing transcriptions began in 1830 and continued uninterrupted over subsequent decades, peaking in the years 1880-1889. A somewhat weaker position in this hierarchy is held by French publishers, who began working in this area during the 1830s and were particularly active during the 60s. These conclusions result above all from the sum totals of information concerning each of the two sets of sources examined here, and only the dominance of German publishers during the period $1880-1889$ is characteristic of both sets. This publishing market for transcriptions of works by Chopin certainly resulted from the publication of his original compositions. From $c .1880$, collected editions of his works began to appear, critically edited by Chopin experts and scholars (Carl Reinecke, Ignaz Friedman, Claude Debussy, Charles Klindworth, Karol Mikuli, Louis Köhler, 
Hermann Scholtz, Riccardo Vitali, Stefano Golinelli, Xaver Scharwenka, Eduard Mertke, Raoul Pugno). Particularly distinguished in this respect is the German publisher Breitkopf \& Härtel, which from 1878 to 1880 published the first edition of Chopin's complete works, Erste kritisch durchgesehene Gesammtausgabe, ${ }^{173}$ thereby helping to reinforce Chopin's image as a great Romantic. ${ }^{174}$ Collected editions were issued by many leading firms: Universal Edition of Vienna (Pugno 1902), B. Schott's Söhne of Mainz (1880-1885, 1909; Scharwenka 1909-1913; Emil Sauer 1917-1920), G. Schirmer Inc. of New York (Mikuli 1894-1898; Mikuli and Huneker 1915-1918), Edizione Ricordi of Milan (Vitali 1879-1880), C. F. Peters of Leipzig (Scholtz 1879, 1904-1907). H. Litolff's Verlag of Brunswick (Köhler 1880-1885), P. Jurgenson of Moscow (Klindworth 1873-1876; 1897; 1898-1916), Gebethner \& Wolff of Warsaw (Kleczyński 1882, 1902) and Augener of London (Klindworth 1879). ${ }^{175}$ It would seem, however, that an equally crucial factor in stimulating the work of transcribers in Germany around the turn of the nineteenth century was the huge economic expansion of the German Reich and the corresponding growth in prosperity especially in bourgeois circles.

The places of residence of all the transcribers and the places of publication allow us to create a map of the scope of Chopin transcriptions. Unfortunately, the lack of information relating to the size of print-runs makes it impossible to determine more precisely that scope and the intensity of the phenomenon.

Transcriptions involve existing works, often written by other composers, so it is an activity based on interfering with other people's property. One particular instance of transcription is self-transcription, where the composer also wrote the original piece. The methods and motivation behind transcribing varied, and it was a very popular activity, since there were not yet any regulations governing this type of 'output'. There was no such thing as copyright in the seventeenth and eighteenth centuries assuring composers of the sole rights to their works. During the Enlightenment, all kinds of technical and artistic output began to be appreciated, with the creators of material and immaterial products regarded as their owners. France was the cradle of the protection of creative rights (technical, literary and artistic), as was expressed in two laws: in 1791, the legal protection of inventions; in 1793, the protection of literary and artistic works. This question

173 The full title reads as follows: Friedrich Chopin's Werke. Herausgegeben von Woldemar Bargiel, Johannes Brahms, August Franchomme, Franz Liszt, Carl Reinecke, Ernst Rudorff. Erste kritisch durchgesehene Gesammtausgabe. See CT, 257.

174 Samson, 'Chopin reception', 97-101.

175 After CT, 252-290. 
was ultimately resolved with the Berne Convention on the protection of literary (scientific) and artistic property of $1886 .{ }^{176}$ During the first half of the nineteenth century, publishing rights were in force, thanks to a decree of 19-24 June $1794 .{ }^{177}$ Chopin, when living in France, possessed the same rights as French composers. So he sold his compositions to publishers, who purchased full rights to them and could make them available to transcribers or cede those rights to other publishers on the territory of France. It was important that the first registered edition of a work occur in France. In cases where a first edition was issued abroad and a publisher succeeded in issuing that work as a reprint from abroad without the composer's consent, that work automatically became 'public property', accessible to everybody. And it was those two elements - 'public property' and the extensive rights of a publisher at the moment he acquired a given composition - that provided very easy access to first editions and enabled them to be used in full. ${ }^{178}$

Those principles held sway in France during the first half of the nineteenth century, but on 5 December 1887 the Berne Convention of 9 September 1886 came into force. ${ }^{179}$ Under that convention, artistic and literary output was subject to international protection, with penal and civil liability for infringing an author's rights. Important for our considerations is article 6 bis of the 1928 version of the convention: '(1) Independently of the author's economic rights, and even after the transfer of the said rights, the author shall have the right to claim authorship

176 See Bełszyńśki, Prawo, 8.

177 We learn about the publishing procedure relating to Chopin's original works in France from Krzysztof Grabowski’s article’ Francuskie oryginalne wydania', 115-155.

178 Mieczysław Tomaszewski, in his systematics, distinguishes a quantitatively substantial group of often anonymous 'editorial transcriptions', produced to a publisher's commission and intended for music making in the home. These were arrangements for piano for four hands published almost simultaneously to the original versions. This practice was particularly widespread among German publishers, and it concerns nearly all the Chopin compositions published during his lifetime. Wessel published arrangements of this kind under the single title 'Solo \& Duet', which meant playing solo and four-handed on a single piano. The lion's share of such arrangements were published during the composer's lifetime. See Tomaszewski, Fryderyk Chopin - zycie twórcy.

179 The text of the convention was altered and supplemented many times: in Paris (1896), Berlin (1908), Berlin again (1914), Rome (1928), Brussels (1948), Stockholm (1967) and Paris (1971 and 1979) (see Janusz Barta and Ryszard Markiewicz, Prawo autorskie [Copyright] (Warsaw, 1999), 361). Poland, as a member of the International Union for the Protection of Literary and Artistic Works, did not ratify the Brussels text, so on 1 January 1965 it was bound by the text passed in Rome. 
of the work and to object to any distortion, mutilation or other modification of, or other derogatory action in relation to, the said work, which would be prejudicial to his honor or reputation'. In article 12 of the 1908 version, we read: 'The following shall be especially included among the unlawful reproductions to which the present Convention applies: unauthorized indirect appropriations of a literary or artistic work, such as adaptations, musical arrangements, transformations of a novel, tale, or piece of poetry into a dramatic piece and vice versa, etc., when they are only the reproduction of that work, in the same form or in another form without essential alterations, additions, or abridgments, and do not present the character of a new original work.' ${ }^{180}$ This paragraph applies to most Chopin adaptations, with the exception of Liszt's paraphrases and others that 'present the character of a new original work. Therefore, if this law had been observed during the nineteenth century, the phenomenon of Chopin transcriptions could have been of a different character. The problem is that the duration of the legal protection of an artistic work was not exactly specified; not until the 1948 conference was it decided that it would constitute the lifetime of the author plus a minimum of fifty years after his death. ${ }^{181}$ And even if such regulations had applied during the nineteenth century, the final year for the protection of Chopin's work would have been 1899. So illegal transcriptions would have been those produced between 1887 (the date the legal act arose) and 1899.

So the legal instruments in force during the nineteenth century had not the slightest influence on transcriptions produced at that time. There were also few voices of protest against the procedure of 'distorting and mutilating' an original work. They appeared in the form of the above-mentioned open letter to publishers issued by Hector Berlioz in the press and in the correspondence of Chopin himself. Michał Biernacki, in a special edition of the Echo Muzyczne on the fiftieth anniversary of Chopin's death, wrote as follows:

they represent waltzes, mazurkas, nocturnes, polonaises, miscellanea, extracts, why, even etudes, in reworkings that are usually paltry, workmanlike, reckoning neither with the chosen subject nor with the properties of the instrument which they 'delight', and so often mutilating and masking the ideas of the musical Raphael, as Heine called him. ${ }^{182}$

180 Both these paragraphs come from the Roman text of the convention contained in the Law Gazette of 21 November 1935 no. 84, item 515: 'THE BERNE CONVENTION OF 9 SEPTEMBER 1886 ON THE PROTECTION OF LITERARY AND ARTISTIC WORKS revised in Berlin on 13 November 1908 and in Rome on 2 June 1928'.

181 Bełszyński, Prawo autorskie, 10.

182 Biernacki, 'Transkrypcje'. 
Those words referred only to a certain group of arrangements which were, in Biernacki's opinion, worthless collections of transcriptions - 'cheap editions' published by Peters, Litolff, Schubert and Schmidt. In the same text, Biernacki also presented a sizeable group of worthy arrangements. ${ }^{183}$

A similarly dualistic attitude towards arrangements was evinced by Chopin himself, who expressed his disapproval, yet at the same time, without issuing his clear opposition, gave his consent for them. In the first of a series of three letters to Tytus Woyciechowski, Chopin merely stated the facts:

The young Moriolówna sent me a laurel wreath; even today I received poems from someone or other. Orłowski has composed a lot of mazurkas and waltzes on themes from my Concerto; Sennewald, Brzezina's partner, asked me for my portrait, but I couldn't allow it, as that would have been too much at once, and I have no wish to be wrapped up in butter, as happened with Lelewel's portrait. ${ }^{184}$

Orłowski's arrangements, like the laurel wreath, poem and portrait, expressed a listener's admiration of Chopin for his wonderful playing in the concert given in Warsaw on 17 March 1830. Of the four forms of that admiration, only the desire to immortalise Chopin's likeness met with the composer's distinct opposition; the remainder, including Orłowski's arrangements, were received without comment - without delight and without aversion to the arrangements themselves. In his next letter, however, he expressed his dissatisfaction that those adaptations had been published:

Apropos, among the amusing items of news is the fact that Orłowski has made mazurkas and galopades from my themes, which, however, I asked him not to have printed. ${ }^{185}$

This information represents a postscript to a lengthy letter, and it clearly shows Chopin's displeasure with the adaptations themselves, which he found rather frivolous, and above all his unhappiness at their publication. In the third letter, he justifies his indecision, and thereby consents to the publication of the transcriptions. We find his motivation for such an attitude by placing those words in the broader context of the letter:

Dmuszewski is ever the same, telling lies, creating various scandals for himself; I ran into him yesterday, and he gave me the hilarious piece of news that he would place some sort of sonnet for me in the Courier. I asked him for the love of God not to do anything

183 A full list of the worthy arrangements can be found in the Appendix: 'List of Michał Biernacki'.

184 Letter of 27 March 1830. Chopin's Polish Letters, 148.

185 Letter of 10 April 1830. Chopin's Polish Letters, 154. 
stupid; 'it's already in print', he answered with a servile smile, thinking that I probably ought to be pleased at the honour I had received. Oh, what favours misunderstood! Once again those whom I have wronged will have the opportunity to sneer. As far as the mazurkas on themes of mine are concerned, a mercantile desire for profit has taken the upper hand. I don't wish to read anything more of what people are writing about me, or listen to what they say. ${ }^{186}$

It seems that Chopin was overwhelmed by his celebrity and the interest shown in him in the press and in conversations in society. His disapproval of the arrangements concerned not so much their quality (there is no mention of this), but the fact that their existence contributed to his fame; they were 'favours misunderstood'. Ultimately, however, the financial gains he derived from their publication led the composer to find peace with the world and with himself.

In a letter to his family, Chopin wrote positively about the arrangements by his friend Auguste Franchomme:

Today at 4 I have friends visiting from Tours - (Forest), for whom I promised to play the sonata with Franchomme. He rewrote, as you know, my Sonata with march for orchestra - and he brought me one notturno yesterday to which he set the words to $O$ salutaris, and which sings well. ${ }^{187}$

In the 1840s, performing with Pauline Viardot at the Salle Pleyel in Paris $\left(1842^{188}\right)$ and in England, Chopin agreed to the performance of his mazurkas in versions for voice and piano with a French text. He wrote about this in a letter to Wojciech Grzymała:

And yesterday, at a concert in Covent Gard[en], Mrs Viardot sang my mazurkas, and they made her repeat them. She came to see me with her husband upon her arrival. I returned the visit, but I didn't find them in. She was wearing a different face than in Paris, and, without my asking, she sang my things. She appeared in Sonnambula in the same theatre as Brisi, Persiani, Alboni, Mario, etc. That theatre (Covent Gard[en]) competes with the Queen's theatre (Haymarket), where Lind and Lablache are performing. Mrs Lind also appeared for the first time in Sonnambula. [...] Mrs Viardot had less success. ${ }^{189}$

He also mentions this in a letter to an unknown addressee in Paris:

186 Letter of 17 April 1830. Chopin's Polish Letters, 155.

187 Letter of 8-9 June 1847. Chopin's Polish Letters, 417.

188 That concert took place on 21 February 1842, and Auguste Franchomme also performed.

189 Letter of 13 May 1848. Chopin's Polish Letters, 437. 
I saw Mrs Viardot here again, most charming. She was so kind as to sing my mazurkas in a concert at her theatre, even though I had not asked her to at all. ${ }^{190}$

In the content of both these letters, we do not notice any antipathy on Chopin's part with regard to Viardot's arrangements, but rather satisfaction that they were performed by such an excellent singer. Chopin was not averse to transcribing himself, and he produced several transcriptions of his own works, two of which are known: arrangements of the Rondo in C major, NE 15 for two pianos (the original version is for one piano) and the Grand Duo concertant in E major for piano for four hands (the original is for piano and cello).

Throughout the nineteenth century, there were no robustly positive or negative assessments of Chopin transcriptions. Much later, Janusz Miketta, on the pages of Ruch Muzyczny, condemned vocal versions of Chopin and also the music adapted for the ballet Les Sylphides, declaring that Chopin's perfect music was untouchable, which made dancing and singing it tantamount to sacrilege. ${ }^{191}$ A similar attitude was adopted by Krystyna Kobylańska, who described adaptations of Chopin's works as 'beautiful things with fake noses, rouged, with shortened legs, or on stilts. ${ }^{192}$ Irena Poniatowska also assigned arrangements and transcriptions to the trivial sphere of the popularity of Chopin's works. ${ }^{193}$ In my opinion, Kobylańska's paraphrase undeservingly disqualifies all transcriptions to the same extent as Poniatowska's aesthetic classification homogenises a qualitatively diverse body of sources. It should be stressed that besides a number of popular (easy) arrangements, we also have transcriptions produced by such composers as Liszt, Reger and Kreisler. Such unequivocally negative attitudes towards transcriptions were characteristic of twentieth-century thinking on music and accorded with an idea contained in the above-mentioned article 12 of the law on the protection of intellectual and creative property. Although Chopin's compositions were written too late to be covered by such protection, the safeguarding of a composer's personal rights applies continuously and may always be used as an argument when the effects of a transcriber's work violate a work's integrity or undermines the good name of the composer of the original work. However, this is a very slippery matter, since no law fixes the norms and limits of 'iconoclastic' arrangements and interpretations of familiar works. As Janusz Barta writes: 'A sense of the inability

190 Letter of 1 June 1848. KFCS, ii:247.

191 Miketta, 'Chopin zabronił'.

192 Kobylańska, 'Transkrypcje', 8. The author drew on Chopin's words (from a letter to his family, Paris 1847) referring to Kolberg's arrangements of traditional folk melodies.

193 See round-table discussion 'Znajomość dzieła Chopina', 262. 
to directly interfere in the writing and publishing of arrangements and ignorance of the original composer's attitude towards them may engender a legal oversensitivity among third parties in relation to the violation of the reputation of recognised masters through the representation of their output in a modified form. Yet in determining the limits to the free usage of works no longer in copyright, one cannot entirely overlook the value of the newly written reworkings and arrangements. ${ }^{194}$ So assessments of the phenomenon of Chopin transcriptions in both the nineteenth and the twentieth century are based on aesthetic and sociohistorical criteria, with legal criteria the least significant.

\subsection{The cultural contexts of the social reception of transcriptions of works by Chopin (taking nineteenth-century Wrockaw as an example)}

The context of a musical work is expressed through the definition of its social causes, the indication of social traces left in the work and the social production of its meanings (the dissemination of those meanings). ${ }^{195}$ In light of the profiling of transcribers and the publishing market, two questions arise. Did the sociocultural situation stimulate the work of both and affect the choice and character of the works written and published? Is that social trace visible in Chopin transcriptions?

The two strands of Hausmusik and Salonmusik were characteristic of nineteenth-century European musical culture. ${ }^{196}$ Music making in the home was based on the bourgeois Biedermeier style. ${ }^{197}$ Hausmusik was linked to the

194 Barta, 'Dzieło', 113.

195 See Samson, 'Chopin reception', 92.

196 Both terms are precisely explained in the commentary to Robert Schumann's 'Album for youth'. See Appel, 'Hausmusik'.

197 The source of Hausmusik may be sought in the treatise 'Die Familie' by the German art historian Wilhelm Heinrich Riehl (1828-1897). Riehl's work was supported by his friend, the German artist Ludwig Richter, who in his works represented German life and the bourgeois family. We are familiar with his cycle of works depicting the four seasons of the year: In the Winter (1858), Spring (1859), Summer (1860) and Autumn (1861), in which he illustrated the relations that occur between different aspects of family life (religion, home and contacts with nature). Wishing to fix an image of the German bourgeois family in the memory of future generations, he also wrote a collection of simple songs designed for music making in the home, titled Hausmusik. The fifty songs were written by Riehl, an amateur composer, to words by German poets. See Appel, 'Hausmusik'. 
image of a German bourgeois family which spent its entire social and cultural life in peace, which favoured meetings among family, friends and acquaintances. 'House music' was closely related to the place it was cultivated. It accompanied everyday life in the home, so was warm, sincere music, devoid of the barriers, finery and exaltation of the salons and concert halls. The task of Hausmusik was to emotionally soothe those involved and to separate them from the musical grand monde. In domestic music making, the musicians (singers and instrumentalists) were at the same time also the listeners; thus the division into performers and audience was blurred. Music making in bourgeois homes was based on playing the piano, which stood in nearly every home, in its 'proper' guise or in 'substitute versions' (Flügel, Tafelklavier, Pianino). ${ }^{198}$ The Hausmusik repertoire was varied, covering not only various kinds of medley, potpourri, collections of popular songs, reworkings, and so on, but also original music. According to an opinion presented in Neuen Musik-Zeitung in 1902, Hausmusik was 'professional music, genuinely passionate, religiously exalted and created in genuine concentration', with examples including Schumann's Kinderszenen and Mendelssohn's Songs without Words. ${ }^{199}$

Hausmusik as thus defined impressed its semantic and social mark on Chopin transcriptions issued by German publishers. The 'domestic' character of numerous arrangements is suggested by their publication in popular collections and by their forces: they were scored for piano for four hands, for easy piano and for voice and piano. One must remember, however, that those features enabled people to become acquainted with the great music of Fryderyk Chopin and, crucially, in most arrangements the form of that music remained unaltered, the only possible differences deriving from the responsibility for their performance being shared by two people.

The repertoire of nineteenth-century salon music - music intended for the elegant, distinguished society that gathered in the drawing-rooms of wealthy townsfolk and aristocrats - was based mainly on French music. ${ }^{200}$ Alongside

198 In 1838, Moritz Saphir, in the German periodical Der Humorist, presented a satire on the then fashionable piano playing: 'There is no instrument more dreadful in the world than the piano. [...] the piano is torture from which no one is safe. [...] Since the piano appeared, no one has had any peace, and the word "peace" itself is merely an empty sound, devoid of all meaning' (Appel, 'Hausmusik', 27).

199 'Tiefgründigkeit, echte Leidenschaft, religiöse Erhebung und andachtsvolle Erbauung' (Fellinger, 'Die Begriffe', 140).

200 That was the profile traced by the Hamburg correspondent of Neue Zeitschrift für Musik. See Fellinger, 'Die Begriffe', 133. 
piano compositions (for piano or with piano accompaniment), one of the forms of music making in the salons consisted of chamber music (mainly string quartets by such composers as Zemlinsky and Debussy). ${ }^{201}$ The commercialisation that engulfed music during the second half of the nineteenth century brought the opportunity of financial gain, which encouraged serious musicians to write salon pieces and publish them under pseudonyms. ${ }^{202}$ Thus arose a dual division into high and low music. The former was free from the musical demands of the public, so from the tastes of potential listeners; low music, meanwhile, kept those tastes in mind. The different appraisals of salon music resulted from the different ways in which it was understood. The boundaries between good and bad salon music were always fluid and depended on individual works. Such a state of affairs is confirmed by the above-quoted opinions of nineteenth-century figures to have influenced culture, who often displayed a kind of dualism in their definitions of salon music. ${ }^{203}$

During the nineteenth century, the term 'salon' had many different uses. ${ }^{204}$ Robert Schumann, for instance, employed the notions of Salonvirtuosen (Eduard

201 Such music was played at art exhibitions in elite Paris salons. In 1906, as part of the cyclic exhibitions held at the Grand Palais des Champs-Elysées in Paris under the patronage of the Société Nationale des Beaux Arts, a music section was established, based on contemporary chamber works.

202 For example, the esteemed chapel-master and composer Friedrich Wilhelm Tschirch published his trifling salon pieces under the pseudonym Alexander Czersky. See Worbs, 'Salonmusik', 124.

203 This opinion is given here after Fellinger, 'Die Begriffe', 131-141.

204 According to Fellinger ('Die Begriffe', 131-141), the origins of salon culture date back to seventeenth-century France. The salon was the venue for social gatherings among aristocratic circles in Paris, a place for literary and political discussion. The first salon of this kind was the Hôtel de Rambouillet, opened in 1608 and functioning until 1659. In that circle, people rested whilst reading together, performing plays and listening to music, and later (during the eighteenth century) philosophical subjects were also addressed. In its broader meaning, which endured for three centuries (from the seventeenth to the nineteenth), the word 'salon' defined a locum of exclusive society life. It could refer to a guest room set aside for social gatherings, an exhibition room or even an exhibition itself (like the events held regularly at the Salon Carré in the Louvre, where paintings by living artists were presented; in this context, the word 'salon' meant an art exhibition at the Louvre). In the seventeenth and eighteenth centuries, musical presentations discharged a secondary role, while in the nineteenth century they became a key component of salon reality. This fact was linked to the new awareness of composers and the new role of their output: they could choose the quality and the intention of the music they wrote. 
Röckel, Theodor Döhler, Sigismond Thalberg), Salonkomponisten (J. Stocks) and Salonspieler (Thalberg). He also spoke of salon manners (Salonmanier) and works (sentimentales or brillante Salonstücke). In 1836, Schumann distinguished two kinds of salon characteristic of his day: aristocratic and bourgeois. ${ }^{205}$ The former type defined a circle of enlightened people for whom music was an important art. This salon remained under the patronage of the aristocracy and the intellectual auspices of prominent, great composers. The second type was dubbed 'tea circles' (Teekränzen), for which music merely made conversation more pleasant; so it was an art of little importance, which discharged a social function.

Within 'high' salon music, Schumann distinguished three varieties: (1) the superior form of salon music that was the music of Chopin, (2) virtuosic music, (3) romantic-leaning music. ${ }^{206}$ And assessments of this salon music, as broadly understood, varied. Chopin's Waltz in A flat major, Op. 42, for example, was described as a 'salon piece of the noblest art. ${ }^{207}$ Similarly appraised was the salon music of Thalberg, whom Schumann placed higher than his predecessor (Czerny), although over time he noticed a distinct decline in the quality of such music among the pupils of Thalberg and Bellini. In 1843, he was already questioning its value, drawing attention to its superficiality, which resulted from a combination of sentimentality and bravura piano playing. It clearly became low music aimed at dilettantes. ${ }^{208}$ Schumann had a special term for compositions based on arrangements of themes from other works: 'kleiner Salonstil'.

It was not just Schumann who passed judgment on salon music. From 1853, we have Friedrich Wieck's term 'bessere Salonmusik', which was represented by Chopin nocturnes and waltzes, and compositions by Stephen Heller, Schilhoff, Henselt and Carl Meyer. ${ }^{209}$ Somewhat later, in 1865, Louis Köhler, in characterising the piano literature, distinguished five genres in which salon pieces and works of 'Unterhaltungsmusik' could be found, clearly distinguished from compositions of the exercise and study kind, works from the Classical and neo-Romantic literature (Beethoven, Brahms, Schumann, Kirchner, Klengel, Chopin's sonatas) and virtuosic works (Czerny, Hummel, Herz, Thalberg). Another author, Louis Ehlert, distinguished low ('niedrigster') and high ('höchster Gattung') genres of music. To the former, he assigned salon music; among the latter, he included compositions by Bach, Beethoven, Schumann, Franz, Brahms, Kirchner and

205 Fellinger, 'Die Begriffe', 132.

206 Ibid., 134.

207 'Ein Salonstück der nobelsten Art' (ibid.).

208 Ibid., 135.

209 Ibid., 153. 
Kiel. Yet that same Ehlert, in 1879, with works by great nineteenth-century composers in mind (Mendelssohn, Chopin, Rubinstein, Liszt, Gounod, SaintSaëns, Schubert), defined salon music as 'graceful, devoid of triviality and base thoughts', as 'music for the educated world.' ${ }^{210} \mathrm{~A}$ duality in the understanding and judgment of salon music was also indicated by Eduard Krüger, who in 1878 defined it as 'dilettantish amusement in the parlour and the salon, which varies wildly between great virtuosity and mystical holiness.211 Elsewhere, he used the word 'Salon' in a positive sense when evoking Viardot-García, Gounod and Saint-Saëns, stating that 'the salon is the temple of domestic music making (Hausmusik ${ }^{212}$ )', whereby he conflated two musical-sociological phenomena: Salonmusik and Hausmusik.

During the 1870s, a new term appeared, 'moderne Salonmusik', this time defining unequivocally the morphological features of works thus described. These were compositions in the style of Italian arias, distinguished by their cantilena melody and the symmetrical design of their musical sentences, and intended for piano for four hands, piano, violin, cello or flute and piano. The term 'moderne Salonmusik' was normally used for works written to public commission, marked by the tastes of those who commissioned them, often intended for beginners playing solely for pleasure ('Unterhaltungsmusik'). ${ }^{213}$ Also dating from those times is the term 'vornehme Salonmusik' (elegant salon music), which was used in reference to the music of Max Reger.

According to views characteristic of the nineteenth century, the salon music of those times was varied and fell into two semantic ranges: artistic and nonartistic. Both the art understood as pseudo-art, or 'niedrige Salonmusik', and its opposite, 'high', or 'gehobene', salon music endured into the early twentieth century. The question of 'niedrige Salonmusik' was discussed by Hans Christof Worbs, who defined it as popular, simple, direct and sentimental music for the masses. ${ }^{214}$ Unlike high music, closely linked to the compositional act of creation, salon music was perceived as an act of craftsmanship. Worbs pointed out that salon music was linked above all to ladies from the bourgeoisie who played the piano at every time and in every place. With this observation, he assimilated

210 Ibid., 138.

211 'Dilettantischen Vergnügungen im Zimmer und Salon, die weder ausschweifen in monströser Virtuosität noch mystischer Heiligkeit' (Ibid., 137).

212 Ibid.

213 This state of affairs is evidenced by a collection entitled Moderne Salonmusik zur Anregung und Unterhaltung, published in the music shop of P. Pabst in Leipzig in 1889.

214 Worbs, 'Salonmusik', 121-128. 
salon music with Hausmusik. Worbs unequivocally presented this music as a kitsch, sentimental property of music making in the home, in which women led the way. To back such an assessment, he drew on a term used by nineteenthcentury music critics who classified it as 'suitable nourishment for the musical riff-raff'.215

This very general profile of two forms of nineteenth-century musical life, Hausmusik and Salonmusik, was based on German musicological thinking. ${ }^{216}$ As can be seen, the character of these phenomena and their interpenetration prevents us from giving clear, concise definitions. Detailed information on the subject of salon music can also be found in the work of Irena Poniatowska, ${ }^{217}$ who precisely characterises salon compositions and defines the features of their basic musical elements. ${ }^{218}$

Both 'house' and 'salon' music were closely linked to the musical realities of the nineteenth century. They were phenomena of a social character, since they were associated not so much with specific musical genres and their unequivocal structure and character, as with the place where music was made and the social class to which the music was addressed. The selection of specific repertoire resulted from the musical training of the salon-goers and the German bourgeoisie, since compositions regarded as 'salon' could be heard just as well during family music making, and the standard example of Hausmusik, Robert Schumann's Kinderszenen, could also be performed in the salon. And for the same reasons, arrangements of works by Chopin are termed both Haus- and Salonmusik. That is confirmed by the chamber-like character of the forces employed, which made it possible to perform an adaptation not only for a large audience, but also for a small group of listeners gathered in a bourgeois parlour or an aristocratic salon.

A clear social trace in transcriptions generated their meanings: in the collection of Chopin arrangements, we find some that may present the so-called kleiner Salonstil, representing (according to Schumann's definition) work based on arrangements of themes from other compositions. Ascribed to the 'Unterhaltungsmusik' strand should be primarily those Chopin arrangements which do not have the character of an exercise or a study and are not highly

215 'Rechte Kost für den musikalischen Pöbel' (Ibid., 124).

216 Above all, articles contained in Studien zur Musikgeschichte des 19. Jahrhunderts.

217 Poniatowska, Muzyka fortepianowa, 233-240.

218 Ibid., 196-309. 
virtuosic compositions. Adaptations corresponding to the term 'moderne Salonmusik' are transcriptions for piano, for piano for four hands, for violin, for cello or for flute and piano intended for beginners. Representative of 'vornehme Salonmusik' and 'bessere Salonmusik' are the refined arrangements by Liszt, Reger, Godowsky, Viardot and others. However, that production of the meanings of Chopin arrangements creates terminological turmoil and is not conducive to a clear classification of transcriptions. We realise that the same adaptations could have been (and indeed were ${ }^{219}$ ) performed for a broad audience gathered in concert halls, upon which they acquired another meaning: they became concert works.

The historical changes in music reception, understood as the way a musical work is heard, interpreted and experienced, can be traced on the basis of the crucial element of culture that is music criticism. ${ }^{220}$ That provides the principal material for studying music reception in a particular time and milieu. ${ }^{221}$ From our considerations thus far, we know that transcriptions were present throughout Europe and undoubtedly functioned within the strands of 'salon' and 'house' music. They also contributed to concert life, as we learn from the abovementioned letters by Chopin. The question of the reception of transcriptions in light of nineteenth-century music criticism has yet to attract the interest of scholars, so the attempt made here is of a pioneering character. The issue worded in the title of this subchapter indicates a distinct confinement of the research field to the city of Wrocław. ${ }^{222}$ That limitation was necessary due to the character of the concert reviews themselves and also the problems with accessing them: the only way of gathering together these scattered opinions was to survey the press from the period $1830-1900 .^{223}$

During the second half of the nineteenth century, Wrocław was a powerful industrial and cultural centre, expanding economically in a similar way

219 Proof to this effect is provided by further considerations regarding the musical reception of Chopin in nineteenth-century Wrocław.

220 Lissa, Wstęp, 145.

221 Ibid., 243.

222 This subchapter could not have been written in this form were it not for the huge assistance of Prof. Maria Zduniak, who gave me access to unpublished source materials gathered over the course of many years' library searches.

223 This timescale results from research conducted by Maria Zduniak, which gave rise to a 'Chronological list of performances of works by Polish composers in Wrocław during the nineteenth century'. On the basis of that list, which the professor made available to me, I was able to set about surveying Wrocław periodicals. 
to other European cities. ${ }^{224}$ The development of the city's musical culture, subordinated to economic pressures, served the large burgher class and was expressed in the work of the opera house, in active concert life, in the church music movement and in widespread music making in the home. Lying on a main communications route, Wrocław was able to welcome many outstanding figures of the musical world who were familiar in Warsaw, Poznan, St Petersburg, Dresden, Leipzig, Berlin, Vienna, Paris and London. ${ }^{225}$ As Maria Zduniak writes: 'Throughout the nineteenth century and in the early twentieth century, travelling musicians willingly and frequently visited Wrocław. Among the well-known instrumentalists, conductors and vocalists to perform in Wrocław were the Pixis brothers, Ludwig Spohr, Angelica Catalani, Henriette Sontag, Johann Nepomuk Hummel, Niccolò Paganini, Clara Schumann, Henri Vieuxtemps, Ole Bull, Anton Rubinstein, Franz Liszt, Hector Berlioz, Heinrich Wilhelm Ernst, Sigismond Thalberg, Hans von Bülow, Jenny Lind, Richard Wagner, Adelina Patti, Pauline Viardot-García, Johannes Brahms, Pablo Sarasate, Désirée Artôt, Joseph Joachim, Edvard Grieg, Ferruccio Busoni, Pietro Mascagni, Eugène Ysaÿe, Felix Weingartner, Jacques Thibaud, Jan Kubelik, Richard Strauss, Wilhelm Backhaus, Artur Schnabel, Serge Koussevitzky, Wilhelm Furtwängler, Pablo Casals, Josef Szigeti, Alfred Cortot, Carl Flesch and Frederick Lamond. ${ }^{226}$ Although the economic and cultural standing of Wrocław allows us to judge that the quality of the reception of Chopin transcriptions there was close to that in other centres, that represents just a fragment of the full picture that we would obtain by analysing the press of the centres of European cultural life of those times: Berlin, Paris, Vienna and London. However, that is an extremely difficult and laborious challenge for researchers, requiring many years of library and archive searches.

224 Looking at nineteenth-century Europe from the perspective of the great social and cultural centres like London and Paris, one may be surprised at the choice of Wrockaw to present the issue of the presence of transcriptions in concert life. That surprise will be overcome, however, by familiarity with the source material. Information concerning public performances of transcriptions of works by Chopin in concert halls during the nineteenth century is hard to come by, which makes the information about Wrocław something of a rarity. Witnessing the wealth of material from Wrocław, one may speculate as to the scale of such material in Paris or London; that certainly represents material for a separate study, or even many years of research by a dedicated team.

225 See Zduniak, Muzyka, 14-17.

226 Ibid., 161-162. 
Indirect sources for such research are provided by the valuable studies of Maria Zduniak. ${ }^{227}$ Direct sources comprise concert announcements and reviews in the Breslauer Zeitung and Schlesische Zeitung. Announcements appeared in both those leading Wrocław newspapers, while reviews were published mainly in the former, two or three days after a concert. They took the form of very lengthy column pieces, published on the first or second page of the morning edition of the newspaper (Morgenblatt). Cultural events were also noted in the monthly Schlesische Provizialblätter, where theatrical events were discussed in detail in the 'Theaterbrief' rubric, while subscription concerts were merely mentioned in the Schlesische Chronik, which referred readers to the daily press (BZ and SZ). Yet not all the concerts announced in the press were subsequently reviewed. With this in mind, press sources may be divided into two groups: announcements and reviews. From the former, we learn of the date, venue and programme of a concert and also its performers; from the latter, we learn of the details of the performance and the assessment of the audience and the critics. All the source material, gathered as the result of a meticulous survey of microfilms, is included in an appendix to this study.

Based on information contained in Maria Zduniak's 'Chronological list of performances of works by Polish composers in Wrockaw during the nineteenth century', I have prepared a 'Chronological list of performances of Chopin transcriptions in nineteenth-century Wrocław' (Table 26). Due to the large amount of information, it has been treated as an integral part of this chapter and forms the starting point for detailed discussion, organised according to the following questions: (1) Who performed the transcriptions? (2) Who wrote the transcriptions? (3) Which Chopin compositions were transcribed? (4) What was the quantitative contribution made by transcriptions to the musical reception of Chopin? (5) Of what character were the concerts in which transcriptions were performed? (6) How were the transcriptions assessed in the press?

Transcriptions were performed by Heinrich de Ahna, Désirée Artôt (twice), Leopold Auer, Michael Banner, Antonio Bazzini, Franz Bendel, Wanda Bogdani, Adolf Brodsky, Hans von Bülow, Bernhard Cossmann (twice), Leopold Damrosch (twice), Josef Drechsler, Adolf Fischer, Jettka Finkenstein, Ossip Gabrilowitsch, Charles Gregorowicz, Richard Himmelstoss, Lilli Höhnen, Mathilde Kaufmann, Paul Kindt, Julius Klengel, Lili Lehmann, Jenny Lind, Louis Lüstner, Alice Mattersdorff, Elza Menzel, Regina Moszkowska, David Popper, Alfred Reisenauer, Moriz Rosenthal (twice), Pablo Sarasate (five times), Paulina

227 Ibid.; Zduniak, 'Fryderyk Chopin', 17-27; Zduniak, 'Chronologiczny'. 
Table 26: Chronological list of performances of Chopin transcriptions in nineteenthcentury Wrocław.

\begin{tabular}{|c|c|c|c|c|c|}
\hline Date & $\begin{array}{l}\text { Author of } \\
\text { transcription }\end{array}$ & Title of work & Performer & Venue & $\begin{array}{l}\text { Source of } \\
\text { information }^{\mathrm{a}}\end{array}$ \\
\hline 04.06 .1855 & $\begin{array}{l}\text { Antonio } \\
\text { Bazzini }\end{array}$ & $\begin{array}{l}\text { Marche funèbre } \\
\text { from Op. 35, } \\
\text { transcription for } \\
\text { violin and piano }\end{array}$ & $\begin{array}{l}\text { Antonio } \\
\text { Bazzini - violin } \\
\text { Klose - piano }\end{array}$ & $\begin{array}{l}\text { Wrocław } \\
\text { University } \\
\text { Music Hall }\end{array}$ & $\begin{array}{l}\text { BZ } 1855 \text { no. } 256 \text {, } \\
\text { p. } 1673 \text { - rev. }\end{array}$ \\
\hline 18.02 .1858 & $\begin{array}{l}\text { Otto } \\
\text { Goldschmidt }\end{array}$ & $\begin{array}{l}4 \text { Mazurkas for } \\
\text { voice and piano }\end{array}$ & $\begin{array}{l}\text { Jenny } \\
\text { Lind - soprano }\end{array}$ & $\begin{array}{l}\text { Municipal } \\
\text { Theatre }\end{array}$ & $\begin{array}{l}\text { BZ } 1858 \text { no. } 81 \text {, } \\
\text { p. } 377 \text { - ann. } \\
\text { BZ } 1858 \text { no. } 85 \text {, } \\
\text { p. } 389 \text { - rev. }\end{array}$ \\
\hline 17.09 .1859 & $\begin{array}{l}\text { Leopold } \\
\text { Damrosch }\end{array}$ & $\begin{array}{l}\text { Marche funèbre } \\
\text { from Op. 35, } \\
\text { transcription for } \\
\text { violin and piano }\end{array}$ & $\begin{array}{l}\text { Leopold } \\
\text { Damrosch - violin }\end{array}$ & $\begin{array}{l}\text { Wrocław } \\
\text { University } \\
\text { Music Hall }\end{array}$ & $\begin{array}{l}\text { BZ } 1859 \text { no. } 433 \text {, } \\
\text { p. } 2144 \text { - ann. }\end{array}$ \\
\hline 21.01 .1861 & $\begin{array}{l}\text { Leopold } \\
\text { Damrosch }\end{array}$ & $\begin{array}{l}\text { Marche funèbre } \\
\text { from Op. 35, } \\
\text { transcription for } \\
\text { violin and piano }\end{array}$ & $\begin{array}{l}\text { Leopold } \\
\text { Damrosch - violin }\end{array}$ & $\begin{array}{l}\text { Wrocław } \\
\text { University } \\
\text { Music Hall }\end{array}$ & M. Zduniak's list \\
\hline 21.11 .1861 & $\begin{array}{l}\text { Józef } \\
\text { Nowakowski }\end{array}$ & $\begin{array}{l}\text { Scherzo in B flat } \\
\text { minor, Op. } 31 \text {, } \\
\text { transcription for } \\
\text { orchestra }\end{array}$ & $\begin{array}{l}\text { Legnica Orchestra } \\
\text { cond. Beniamin } \\
\text { Bilse }\end{array}$ & $\begin{array}{l}\text { Liebich } \\
\text { Hall }\end{array}$ & $\begin{array}{l}\text { BZ } 1861 \text { no. } 545 \text {, } \\
\text { p. } 2689 \text { - ann. }\end{array}$ \\
\hline 20.02 .1862 & $\begin{array}{l}\text { Józef } \\
\text { Nowakowski }\end{array}$ & $\begin{array}{l}\text { Scherzo in B flat } \\
\text { minor, Op. } 31 \text {, } \\
\text { transcription for } \\
\text { orchestra }\end{array}$ & $\begin{array}{l}\text { Legnica Orchestra } \\
\text { cond. Beniamin } \\
\text { Bilse }\end{array}$ & $\begin{array}{l}\text { Liebich } \\
\text { Hall }\end{array}$ & $\begin{array}{l}\text { BZ } 1862 \text { no. } 85 \text {, } \\
\text { p. } 399 \text { - ann. }\end{array}$ \\
\hline 29.01 .1863 & $\begin{array}{l}\text { Josef } \\
\text { Drechsler }\end{array}$ & $\begin{array}{l}\text { Grande Polonaise } \\
\text { (Op.?), } \\
\text { transcription for } \\
\text { piano and violin }\end{array}$ & $\begin{array}{l}\text { Josef Drechsler } \\
\text { - violin }\end{array}$ & $\begin{array}{l}\text { Liebich } \\
\text { Hall }\end{array}$ & $\begin{array}{l}\text { BZ } 1863 \text { no. } 47 \text {, } \\
\text { p. } 239 \text { - ann. }\end{array}$ \\
\hline 31.01 .1871 & $\begin{array}{l}\text { Bernhard } \\
\text { Cossmann }\end{array}$ & $\begin{array}{l}\text { Nocturne in E flat } \\
\text { major, Op. } 9 \text { No. } 2 \text {, } \\
\text { transcription for } \\
\text { cello }\end{array}$ & $\begin{array}{l}\text { Bernhard } \\
\text { Cossmann - cello }\end{array}$ & $\begin{array}{l}\text { Springer } \\
\text { Hall }\end{array}$ & $\begin{array}{l}\text { BZ } 1871 \text { no. } 55 \text {, } \\
\text { p. } 380 \text { - rev. }\end{array}$ \\
\hline 30.01 .1872 & $\begin{array}{l}\text { August } \\
\text { Wilhelmj }\end{array}$ & $\begin{array}{l}\text { Nocturne in D } \\
\text { flat major, Op. } \\
27 \text { No. } 2 \text {, } \\
\text { for violin and } \\
\text { orchestra }\end{array}$ & $\begin{array}{l}\text { August } \\
\text { Wilhelmj - violin }\end{array}$ & $\begin{array}{l}\text { Springer } \\
\text { Hall }\end{array}$ & $\begin{array}{l}\text { BZ } 1872 \text { no. } 48, \\
\text { p. } 396 \text { - ann. } \\
\text { BZ } 1872 \text { no. } 52 \text {, } \\
\text { p. } 427 \text { - rev. }\end{array}$ \\
\hline 20.02 .1872 & $\begin{array}{l}\text { Franz } \\
\text { Liszt }\end{array}$ & $\begin{array}{l}\text { transcription of } \\
\text { two songs }\end{array}$ & $\begin{array}{l}\text { Hans } \\
\text { von Bülow }\end{array}$ & (?) & M. Zduniak's list \\
\hline 21.01 .1873 & $\begin{array}{l}\text { August } \\
\text { Wilhelmj }\end{array}$ & Nocturne (Op.?) & $\begin{array}{l}\text { August } \\
\text { Wilhelmj - violin }\end{array}$ & $\begin{array}{l}\text { Springer } \\
\text { Hall }\end{array}$ & $\begin{array}{l}\text { BZ } 1873 \text { no. } 33 \text {, } \\
\text { p. } 284 \text { - ann. } \\
\text { BZ } 1873 \text { no. } 37 \text {, } \\
\text { p. } 310 \text { - rev. }\end{array}$ \\
\hline
\end{tabular}


Table 26: Continued

\begin{tabular}{|c|c|c|c|c|c|}
\hline Date & $\begin{array}{l}\text { Author of } \\
\text { transcription }\end{array}$ & Title of work & Performer & Venue & $\begin{array}{l}\text { Source of } \\
\text { information }^{\mathrm{a}}\end{array}$ \\
\hline 27.02 .1873 & $\begin{array}{l}\text { August } \\
\text { Wilhelmj }\end{array}$ & Nocturne (Op.?) & $\begin{array}{l}\text { Louis } \\
\text { Lüstner - violin }\end{array}$ & $\begin{array}{l}\text { Springer } \\
\text { Hall }\end{array}$ & $\begin{array}{l}\text { BZ } 1873 \text { no. } 95 \text {, } \\
\text { p. } 779 \text { - ann. }\end{array}$ \\
\hline 28.02 .1873 & $\begin{array}{l}\text { Franz } \\
\text { Bendel }\end{array}$ & $\begin{array}{l}\text { 'Piosnka litewska' } \\
\text { [Lithuanian Song], } \\
\text { Op. } 74 \text { No. 16, } \\
\text { transcription for } \\
\text { piano }\end{array}$ & $\begin{array}{l}\text { Franz Bendel - } \\
\text { piano }\end{array}$ & $\begin{array}{l}\text { Hotel } \\
\text { Śląski }\end{array}$ & $\begin{array}{l}\text { BZ } 1873 \text { no. } 99 \text {, } \\
\text { p. } 809 \text { - ann. } \\
\text { BZ } 1873 \text { no. } 103 \text {, } \\
\text { p. } 834-835 \text { - rev. }\end{array}$ \\
\hline 13.08 .1873 & Müller-Berghaus & $\begin{array}{l}\text { Scherzo (Op.?), } \\
\text { transcription for } \\
\text { orchestra }\end{array}$ & $\begin{array}{l}\text { Wrocław Concert } \\
\text { Orchestra }\end{array}$ & $\begin{array}{l}\text { Liebich } \\
\text { Hall }\end{array}$ & $\begin{array}{l}\text { BZ } 1873 \text { no. } 373 \text {, } \\
\text { p. } 2938 \text { - ann. }\end{array}$ \\
\hline 25.01 .1876 & $\begin{array}{l}\text { August } \\
\text { Wilhelmj }\end{array}$ & $\begin{array}{l}\text { Larghetto, } \\
\text { for violin } \\
\text { Romanza, for violin }\end{array}$ & $\begin{array}{l}\text { August } \\
\text { Wilhelmj - violin }\end{array}$ & $\begin{array}{l}\text { Springer } \\
\text { Hall }\end{array}$ & $\begin{array}{l}\text { BZ } 1876 \text { no. } 39 \text {, } \\
\text { p. } 9 \text { - ann. } \\
\text { BZ } 1876 \text { no. } 43 \text {, } \\
\text { p. } 1 \text { - rev. }\end{array}$ \\
\hline 02.01 .1877 & $\begin{array}{l}\text { Paulina } \\
\text { Viardot-García }\end{array}$ & $\begin{array}{l}\text { Mazurka, } \\
\text { transcription for } \\
\text { voice }\end{array}$ & $\begin{array}{l}\text { Lilli Lehmann } \\
\text { - soprano }\end{array}$ & $\begin{array}{l}\text { Springer } \\
\text { Hall }\end{array}$ & $\begin{array}{l}\text { BZ } 1877 \text { no. } 4 \text {, } \\
\text { p. } 1 \text { - rev. }\end{array}$ \\
\hline 23.01 .1877 & $\begin{array}{l}\text { Pablo } \\
\text { Sarasate }\end{array}$ & Nocturne (op.?) & $\begin{array}{l}\text { Pablo } \\
\text { Sarasate - violin }\end{array}$ & $\begin{array}{l}\text { Springer } \\
\text { Hall }\end{array}$ & $\begin{array}{l}\text { BZ } 1877 \text { no. } 40 \text {, } \\
\text { p. } 2 \text { - rev. }\end{array}$ \\
\hline 13.03 .1877 & $\begin{array}{l}\text { Adolf } \\
\text { Fischer (?) }\end{array}$ & $\begin{array}{l}\text { Nocturne (Op.?), } \\
\text { transcription for } \\
\text { cello }\end{array}$ & Adolf Fischer - cello & $\begin{array}{l}\text { Springer } \\
\text { Hall }\end{array}$ & $\begin{array}{l}\text { BZ } 1877 \text { no. } 120 \text {, } \\
\text { p. } 11 \text { - ann. } \\
\text { BZ } 1877 \text { no. } 124 \text {, } \\
\text { p. } 1 \text { - rev. }\end{array}$ \\
\hline 01.12 .1877 & $\begin{array}{l}\text { Paulina } \\
\text { Viardot-García }\end{array}$ & $\begin{array}{l}\text { 'Aime-moi', } \\
\text { Mazurka, Op. } 33 \\
\text { No. 3, transcription } \\
\text { for voice }\end{array}$ & $\begin{array}{l}\text { Désirée Artôt - } \\
\text { Padilla - soprano }\end{array}$ & $\begin{array}{l}\text { Liebich } \\
\text { Hall }\end{array}$ & $\begin{array}{l}\text { BZ } 1877 \text { no. } 560 \text {, } \\
\text { p. } 8 \text { - ann. } \\
\text { BZ } 1877 \text { no. } 562 \text {, } \\
\text { p. } 2 \text { - rev. }\end{array}$ \\
\hline 29.01 .1878 & $\begin{array}{l}\text { Bernhard } \\
\text { Cossmann }\end{array}$ & $\begin{array}{l}\text { Marche funèbre, } \\
\text { transcription for } \\
\text { cello }\end{array}$ & $\begin{array}{l}\text { Bernhard } \\
\text { Cossmann - cello }\end{array}$ & $\begin{array}{l}\text { Springer } \\
\text { Hall }\end{array}$ & $\begin{array}{l}\text { BZ } 1878 \text { no. } 45 \text {, } \\
\text { p. } 10 \text { - ann. } \\
\text { BZ } 1878 \text { no. } 51 \text {, } \\
\text { p. } 2 \text { - rev. }\end{array}$ \\
\hline 14.07.1878 & $?$ & $\begin{array}{l}\text { Mazurka (Op.?), } \\
\text { transcription for } \\
\text { voice }\end{array}$ & $\begin{array}{l}\text { Wanda } \\
\text { Bogdani }\end{array}$ & $\begin{array}{l}\text { Teatr } \\
\text { Victoria }\end{array}$ & M. Zduniak’s list \\
\hline 10.12 .1878 & $\begin{array}{l}\text { Pablo } \\
\text { Sarasate }\end{array}$ & $\begin{array}{l}\text { Nocturne (Op.?), } \\
\text { transcription for } \\
\text { violin }\end{array}$ & $\begin{array}{l}\text { Pablo } \\
\text { Sarasate - violin }\end{array}$ & $\begin{array}{l}\text { Wrocław } \\
\text { Concert } \\
\text { Hall }\end{array}$ & $\begin{array}{l}\text { BZ } 1878 \text { no. } 581 \text {, } \\
\text { p. } 2 \text { - rev. }\end{array}$ \\
\hline 18.10 .1879 & $?$ & $\begin{array}{l}\text { Marche funèbre, } \\
\text { transcription for } \\
\text { orchestra }\end{array}$ & $\begin{array}{l}\text { Orchestra } \\
\text { cond. E. Strauss }\end{array}$ & $\begin{array}{l}\text { Wrocław } \\
\text { Concert } \\
\text { Hall }\end{array}$ & $\begin{array}{l}\text { BZ } 1879 \text { no. } 487 \text {, } \\
\text { p. } 6 \text { - ann. }\end{array}$ \\
\hline
\end{tabular}


Table 26: Continued

\begin{tabular}{|c|c|c|c|c|c|}
\hline Date & $\begin{array}{l}\text { Author of } \\
\text { transcription }\end{array}$ & Title of work & Performer & Venue & $\begin{array}{l}\text { Source of } \\
\text { information }^{a}\end{array}$ \\
\hline 04.11 .1879 & $\begin{array}{l}\text { David } \\
\text { Popper }\end{array}$ & $\begin{array}{l}\text { Nocturne (op.?), } \\
\text { transcription for } \\
\text { cello }\end{array}$ & $\begin{array}{l}\text { David } \\
\text { Popper - } \\
\text { cello }\end{array}$ & $\begin{array}{l}\text { Wrocław } \\
\text { Concert } \\
\text { Hall }\end{array}$ & $\begin{array}{l}\text { BZ } 1879 \text { no. } 515 \text {, } \\
\text { p. } 7 \text { - ann. } \\
\text { BZ } 1879 \text { no. } 519 \text {, } \\
\text { p. } 2 \text { - rev. }\end{array}$ \\
\hline 16.03 .1880 & $\begin{array}{l}\text { Paulina } \\
\text { Viardot-García }\end{array}$ & $\begin{array}{l}\text { Mazurka (Op.?), } \\
\text { transcription for } \\
\text { voice }\end{array}$ & $\begin{array}{l}\text { Désirée Artôt - } \\
\text { Padilla - soprano }\end{array}$ & $\begin{array}{l}\text { Wrocław } \\
\text { Concert } \\
\text { Hall }\end{array}$ & $\begin{array}{l}\text { BZ } 1880 \text { no. } 127 \text {, } \\
\text { p. } 7 \text { - ann. } \\
\text { BZ } 1880 \text { no. } 131 \text {, } \\
\text { p. } 2 \text { - rev. }\end{array}$ \\
\hline 08.03 .1881 & $\begin{array}{l}\text { Heinrich } \\
\text { de Ahna }\end{array}$ & $\begin{array}{l}\text { Romanza from } \\
\text { the Concerto in } \\
\text { E minor, } \\
\text { Waltz in D flat } \\
\text { major, Op. } 64 \text { No. } \\
\text { 1, transcription for } \\
\text { violin }\end{array}$ & $\begin{array}{l}\text { Heinrich } \\
\text { de Ahna - violin }\end{array}$ & $\begin{array}{l}\text { Wrocław } \\
\text { Concert } \\
\text { Hall }\end{array}$ & $\begin{array}{l}\text { BZ } 1881 \text { no. } 111 \\
- \text { ann. } \\
\text { BZ } 1881 \text { no. } 115 \text {, } \\
\text { p. } 1 \text { - rev. }\end{array}$ \\
\hline 29.09 .1881 & $\begin{array}{l}\text { August } \\
\text { Wilhelmj }\end{array}$ & Nocturne (Op.?) & Paul Kindt - violin & $\begin{array}{l}\text { Wrocław } \\
\text { Concert } \\
\text { Hall }\end{array}$ & M. Zduniak's list \\
\hline 10.11 .1881 & $\begin{array}{l}\text { Franz } \\
\text { Liszt }\end{array}$ & Chant polonais & Elza Menzel - piano & $\begin{array}{l}\text { Wrocław } \\
\text { University } \\
\text { Music Hall }\end{array}$ & $\begin{array}{l}\text { BZ } 1881 \text { no. } 525 \text {, } \\
\text { p. } 8 \text { - ann. }\end{array}$ \\
\hline 28.02 .1882 & $\begin{array}{l}\text { August } \\
\text { Wilhelmj }\end{array}$ & Nocturne (Op.?) & $\begin{array}{l}\text { Richard } \\
\text { Himmelstoss } \\
\text { - violin }\end{array}$ & $\begin{array}{l}\text { Wrocław } \\
\text { Concert } \\
\text { Hall }\end{array}$ & $\begin{array}{l}\text { BZ } 1882 \text { no. } 145 \text {, } \\
\text { p. } 12 \text { - ann. } \\
\text { BZ } 1882 \text { no. } 154 \text {, } \\
\text { p. } 2 \text { - rev. }\end{array}$ \\
\hline 04.10 .1883 & $\begin{array}{l}\text { Julius } \\
\text { Klengel }\end{array}$ & $\begin{array}{l}\text { Nocturne (Op.?), } \\
\text { transcription for } \\
\text { cello }\end{array}$ & $\begin{array}{l}\text { Julius } \\
\text { Klengel - cello }\end{array}$ & $\begin{array}{l}\text { Wrocław } \\
\text { Concert } \\
\text { Hall }\end{array}$ & $\begin{array}{l}\text { BZ } 1883 \text { no. } 693 \text {, } \\
\text { p. } 8 \text { - ann. } \\
\text { BZ } 1883 \text { no. } 699 \text {, } \\
\text { p. } 2 \text { - rev. }\end{array}$ \\
\hline 21.11 .1885 & $\begin{array}{l}\text { August } \\
\text { Wilhelmj }\end{array}$ & $\begin{array}{l}\text { Nocturne (?), } \\
\text { transcription for } \\
\text { violin }\end{array}$ & $\begin{array}{l}\text { Teresina } \\
\text { Tua - } \\
\text { violin }\end{array}$ & $\begin{array}{l}\text { New } \\
\text { Exchange } \\
\text { Hall }\end{array}$ & $\begin{array}{l}\text { BZ } 1885 \text { no. } 817 \text {, } \\
\text { p. } 9 \text { - ann. }\end{array}$ \\
\hline 17.01 .1886 & $\begin{array}{l}\text { Pablo } \\
\text { Sarasate }\end{array}$ & $\begin{array}{l}\text { Nocturne in E flat } \\
\text { major, Op. } 9 \text { No. } 2 \text {, } \\
\text { transcription for } \\
\text { violin }\end{array}$ & $\begin{array}{l}\text { Pablo } \\
\text { Sarasate - violin }\end{array}$ & (?) & M. Zduniak's list \\
\hline 03.03 .1887 & $\begin{array}{l}\text { Pablo } \\
\text { Sarasate }\end{array}$ & $\begin{array}{l}\text { Nocturne in E flat } \\
\text { major, Op. } 9 \text { No. } 2 \text {, } \\
\text { transcription for } \\
\text { violin }\end{array}$ & $\begin{array}{l}\text { Teresina } \\
\text { Tua - violin }\end{array}$ & (?) & M. Zduniak's list \\
\hline 05.11 .1888 & $\begin{array}{l}\text { Franz } \\
\text { Liszt }\end{array}$ & Chant polonais & $\begin{array}{l}\text { Mathilde } \\
\text { Kaufmann - piano }\end{array}$ & $\begin{array}{l}\text { New } \\
\text { Exchange } \\
\text { Hall }\end{array}$ & $\begin{array}{l}\text { BZ } 1888 \text { no. } 778, \\
\text { p. } 15 \text { - ann. }\end{array}$ \\
\hline
\end{tabular}


Table 26: Continued

\begin{tabular}{|c|c|c|c|c|c|}
\hline Date & $\begin{array}{l}\text { Author of } \\
\text { transcription }\end{array}$ & Title of work & Performer & Venue & $\begin{array}{l}\text { Source of } \\
\text { information }^{\mathrm{a}}\end{array}$ \\
\hline 04.11 .1890 & $\begin{array}{l}\text { August } \\
\text { Wilhelmj }\end{array}$ & $\begin{array}{l}\text { Nocturne in E flat } \\
\text { major, Op. } 9 \text { No. } 2 \text {, } \\
\text { transcription for } \\
\text { violin }\end{array}$ & $\begin{array}{l}\text { Charles } \\
\text { Gregorowicz } \\
\text { - violin }\end{array}$ & $\begin{array}{l}\text { Wrocław } \\
\text { Concert } \\
\text { Hall }\end{array}$ & $\begin{array}{l}\text { BZ } 1890 \text { no. } \\
772, \text { p. } 9 \text { - ann. } \\
\text { BZ } 1890 \text { no. } 778 \text {, } \\
\text { p. } 2 \text { - rev. }\end{array}$ \\
\hline 23.10 .1892 & $\begin{array}{l}\text { Franz } \\
\text { Liszt }\end{array}$ & Chant polonais & $\begin{array}{l}\text { Alfred } \\
\text { Reisenauer - piano }\end{array}$ & $\begin{array}{l}\text { New } \\
\text { Exchange } \\
\text { Hall }\end{array}$ & $\begin{array}{l}\text { BZ } 1892 \text { no. } 745 \text {, } \\
\text { p. } 14 \text { - ann. } \\
\text { BZ } 1892 \text { no. } 748 \text {, } \\
\text { p. } 3 \text { - rev. }\end{array}$ \\
\hline 01.12 .1892 & $\begin{array}{l}\text { Georg } \\
\text { Riemenschneider }\end{array}$ & $\begin{array}{l}\text { Nocturne (op.?), } \\
\text { transcription for } \\
\text { orchestra }\end{array}$ & $\begin{array}{l}\text { Wrocław Concert } \\
\text { Orchestra } \\
\text { cond. } \\
\text { G. Riemenschneider }\end{array}$ & $\begin{array}{l}\text { Wrocław } \\
\text { Concert } \\
\text { Hall }\end{array}$ & $\begin{array}{l}\text { BZ } 1892 \text { no. } 844 \text {, } \\
\text { p. } 11 \text { - ann. }\end{array}$ \\
\hline 02.02 .1893 & $\begin{array}{l}\text { Franz Liszt } \\
\text { Moriz Rosenthal }\end{array}$ & $\begin{array}{l}\text { Chant polonais } \\
\text { Waltz in D flat } \\
\text { major, Op. } 64 \text { No. } \\
\text { 1, Study for piano }\end{array}$ & $\begin{array}{l}\text { Moriz } \\
\text { Rosenthal - piano }\end{array}$ & $\begin{array}{l}\text { New } \\
\text { Exchange } \\
\text { Hall }\end{array}$ & $\begin{array}{l}\text { BZ } 1893 \text { no. } 82 \text {, } \\
\text { p. } 11-\text { ann. } \\
\text { BZ } 1893 \text { no. } 88 \text {, } \\
\text { p. } 2-3-\text { rev. }\end{array}$ \\
\hline 13.02 .1893 & $\begin{array}{l}\text { Franz } \\
\text { Liszt } \\
?\end{array}$ & $\begin{array}{l}\text { Chant polonais } \\
\text { Op. } 74 \text { no. } 5 \text { - } \\
\text { 'Moja pieszczotka' } \\
\text { [My Enchantress] } \\
\text { Nocturne (Op.?) }\end{array}$ & $\begin{array}{l}\text { Moriz Rosenthal } \\
\text { - piano }\end{array}$ & $\begin{array}{l}\text { New } \\
\text { Exchange } \\
\text { Hall }\end{array}$ & $\begin{array}{l}\text { SZ } 1893 \text { no. } 109 \text {, } \\
\text { p. } 16 \text { - ann. } \\
\text { SZ } 1893 \text { no. } 115 \text {, } \\
\text { p. } 2 \text { - rev. }\end{array}$ \\
\hline 06.03 .1893 & $\begin{array}{l}\text { Paulina } \\
\text { Viardot-García }\end{array}$ & $\begin{array}{l}\text { 'Coquette', } \\
\text { Mazurka, Op. } 7 \text { No. } \\
\text { 1, transcription for } \\
\text { voice }\end{array}$ & $\begin{array}{l}\text { Jettka } \\
\text { Finkenstein - voice }\end{array}$ & $\begin{array}{l}\text { Wrocław } \\
\text { Concert } \\
\text { Hall }\end{array}$ & $\begin{array}{l}\text { BZ } 1893 \text { no. } 163 \text {, } \\
\text { p. } 16 \text { - ann. }\end{array}$ \\
\hline 22.03 .1893 & Pablo Sarasate & $\begin{array}{l}\text { Nocturne in E flat } \\
\text { major, Op. } 9 \text { No. } 2 \text {, } \\
\text { transcription for } \\
\text { violin }\end{array}$ & $\begin{array}{l}\text { Pablo } \\
\text { Sarasate - violin }\end{array}$ & $\begin{array}{l}\text { Wrocław } \\
\text { Concert } \\
\text { Hall }\end{array}$ & $\begin{array}{l}\text { BZ } 1893 \text { no. } 205 \text {, } \\
\text { p. } 11 \text { - ann. } \\
\text { BZ } 1893 \text { no. } 211 \text {, } \\
\text { p. } 2 \text { - rev. }\end{array}$ \\
\hline 03.01 .1895 & $\begin{array}{l}\text { Georg } \\
\text { Riemenschneider }\end{array}$ & $\begin{array}{l}\text { Polonaise in A } \\
\text { major, Op. } 40 \text {, } \\
\text { transcription for } \\
\text { orchestra }\end{array}$ & $\begin{array}{l}\text { Wrocław Concert } \\
\text { Orchestra }\end{array}$ & $\begin{array}{l}\text { Wrocław } \\
\text { Concert } \\
\text { Hall }\end{array}$ & $\begin{array}{l}\text { BZ } 1895 \text { no. } 4 \text {, } \\
\text { p. } 9 \text { - ann. }\end{array}$ \\
\hline 19.01 .1895 & Pablo Sarasate & $\begin{array}{l}\text { Nocturne in E flat } \\
\text { major, Op. } 9 \text { No. } 2 \text {, } \\
\text { transcription for } \\
\text { violin }\end{array}$ & $\begin{array}{l}\text { Ludwig } \\
\text { Wiedemann - violin }\end{array}$ & $\begin{array}{l}\text { New } \\
\text { Exchange } \\
\text { Hall }\end{array}$ & $\begin{array}{l}\text { BZ } 1895 \text { no. } 47 \text {, } \\
\text { p. } 7 \text { - ann. }\end{array}$ \\
\hline 20.02 .1895 & Pablo Sarasate & $\begin{array}{l}\text { Nocturne in E flat } \\
\text { major, Op. } 9 \text { No. } 2 \text {, } \\
\text { transcription for } \\
\text { violin }\end{array}$ & $\begin{array}{l}\text { Adolf } \\
\text { Brodsky - violin }\end{array}$ & $\begin{array}{l}\text { Wrocław } \\
\text { Concert } \\
\text { Hall }\end{array}$ & $\begin{array}{l}\text { BZ } 1895 \text { no. } 126 \text {, } \\
\text { p. } 11 \text { - ann. } \\
\text { BZ } 1895 \text { no. } 133 \text {, } \\
\text { p. } 1 \text { - rev. }\end{array}$ \\
\hline
\end{tabular}


Table 26: Continued

\begin{tabular}{|c|c|c|c|c|c|}
\hline Date & $\begin{array}{l}\text { Author of } \\
\text { transcription }\end{array}$ & Title of work & Performer & Venue & $\begin{array}{l}\text { Source of } \\
\text { information }^{\mathrm{a}}\end{array}$ \\
\hline 06.01 .1897 & $\begin{array}{l}\text { Paulina } \\
\text { Viardot-García }\end{array}$ & $\begin{array}{l}\text { 'Coquette', } \\
\text { Mazurka, Op. } 7 \text { No. } \\
\text { 1, transcription for } \\
\text { voice }\end{array}$ & $\begin{array}{l}\text { Erika } \\
\text { Wedekind - } \\
\text { coloratura soprano }\end{array}$ & $\begin{array}{l}\text { Wrocław } \\
\text { Concert } \\
\text { Hall }\end{array}$ & $\begin{array}{l}\text { BZ } 1897 \text { no. } 10, \\
\text { p. } 9 \text { - ann. } \\
\text { BZ } 1897 \text { no. } 16 \text {, } \\
\text { p. } 2 \text { - rev. }\end{array}$ \\
\hline 28.02 .1897 & $\begin{array}{l}\text { Paulina } \\
\text { Viardot-García }\end{array}$ & $\begin{array}{l}\text { 'Aime-moi', } \\
\text { Mazurka, Op. } 33 \\
\text { No. 3, transcription } \\
\text { for voice }\end{array}$ & $\begin{array}{l}\text { Regina } \\
\text { Moszkowska - } \\
\text { soprano }\end{array}$ & $\begin{array}{l}\text { Wrocław } \\
\text { University } \\
\text { Music Hall }\end{array}$ & $\begin{array}{l}\text { BZ } 1897 \text { no. } 148 \text {, } \\
\text { p. } 18 \text { - ann. } \\
\text { BZ } 1897 \text { no. } 151 \text {, } \\
\text { p. } 3 \text { - rev. }\end{array}$ \\
\hline 10.03 .1897 & Leopold Auer & $\begin{array}{l}\text { Nocturne in D } \\
\text { flat major, Op. } \\
27 \text { No. } 2 \text {, } \\
\text { transcription for } \\
\text { violin }\end{array}$ & $\begin{array}{l}\text { Leopold Auer } \\
\text { - violin }\end{array}$ & $\begin{array}{l}\text { Wrocław } \\
\text { Concert } \\
\text { Hall }\end{array}$ & $\begin{array}{l}\text { BZ } 1897 \text { no. } 172 \text {, } \\
\text { p. } 10 \text { - ann. } \\
\text { BZ } 1897 \text { no. } 178 \text {, } \\
\text { p. } 1 \text { - rev. }\end{array}$ \\
\hline 02.12 .1897 & $\begin{array}{l}\text { Franz } \\
\text { Liszt }\end{array}$ & Chant polonais & $\begin{array}{l}\text { Paulina Szalit - } \\
\text { piano }\end{array}$ & $\begin{array}{l}\text { New } \\
\text { Exchange } \\
\text { Hall }\end{array}$ & $\begin{array}{l}\text { BZ } 1897 \text { no. } 838 \text {, } \\
\text { p. } 12 \text { - ann. } \\
\text { BZ } 1897 \text { no. } 850 \text {, } \\
\text { p. } 1 \text { - rev. }\end{array}$ \\
\hline 04.12 .1897 & $\begin{array}{l}\text { August } \\
\text { Wilhelmj }\end{array}$ & $\begin{array}{l}\text { Nocturne in D flat } \\
\text { major, Op. } 27 \text { No. } \\
2 \text {, transcription for } \\
\text { violin }\end{array}$ & $\begin{array}{l}\text { Michael Banner } \\
\text { - violin }\end{array}$ & (?) & $\begin{array}{l}\text { BZ } 1897 \text { no. } 850, \\
\text { p. } 13\end{array}$ \\
\hline 26.01 .1898 & $\begin{array}{l}\text { Pablo } \\
\text { Sarasate }\end{array}$ & $\begin{array}{l}\text { Nocturne in E flat } \\
\text { major, Op. } 9 \text { No. } 2\end{array}$ & $\begin{array}{l}\text { Pablo } \\
\text { Sarasate - violin }\end{array}$ & $\begin{array}{l}\text { Wrocław } \\
\text { Concert } \\
\text { Hall }\end{array}$ & $\begin{array}{l}\text { BZ } 1898 \text { no. } 61 \text {, } \\
\text { p. } 11 \text { - ann. } \\
\text { BZ } 1898 \text { no. } 67 \text {, } \\
\text { p. } 1 \text { - rev. }\end{array}$ \\
\hline 08.12 .1898 & $\begin{array}{l}\text { Müller } \\
\text { - Berghaus }\end{array}$ & $\begin{array}{l}\text { Polonaise in A flat } \\
\text { major, Op. } 53\end{array}$ & $\begin{array}{l}\text { Wrocław Concert } \\
\text { Orchestra }\end{array}$ & $\begin{array}{l}\text { Wrocław } \\
\text { Concert } \\
\text { Hall }\end{array}$ & $\begin{array}{l}\text { BZ } 1898 \text { no. } 859 \text {, } \\
\text { p. } 13 \text { - ann. }\end{array}$ \\
\hline 17.10 .1900 & $\begin{array}{l}\text { Franz } \\
\text { Liszt }\end{array}$ & Chant polonais & $\begin{array}{l}\text { Ossip } \\
\text { Gabrilowitsch } \\
\text { - piano }\end{array}$ & $\begin{array}{l}\text { Wrocław } \\
\text { Concert } \\
\text { Hall }\end{array}$ & $\begin{array}{l}\text { BZ } 1900 \text { no. } 729 \text {, } \\
\text { p. } 11 \text { - ann. } \\
\text { BZ } 1900 \text { no. } 735 \text {, } \\
\text { p. } 1 \text { - rev. }\end{array}$ \\
\hline
\end{tabular}

${ }^{a}$ 1. press: announcements (ann.), reviews (rev.); 2. M. Zduniak's list.

Szalit, Teresina Tua (twice), Erika Wedekind, Ludwig Wiedemann and August Wilhelmj (three times), and by the Legnica Orchestra and Beniamin Bilse (twice), the Eduard Strauss Orchestra and the Wrocław Concert Orchestra (four times). Those musicians sometimes included their own transcriptions in their repertoire, as well as well-known transcriptions by Sarasate, Liszt and Wilhelmj.

The breakdown of transcriptions according to genre shows that the listed artists based their performances on the following: 
- nocturnes for orchestra; violin; cello (22 times),

- mazurkas for voice (11),

- songs (9, including Liszt's Chant polonais 8 times),

- Marche funèbre in B flat minor from Op. 35 for orchestra; cello; violin (4),

- polonaises for violin (3),

- Scherzo in B flat minor, Op. 31 for orchestra (3),

- waltz for violin (1).

The first concert listed by Maria Zduniak which included a transcription of the Marche funèbre took place on 4 June 1855; the last such concert was held on 17 October 1900. Within that time-span, fifty-three concerts of interest to us were given, and their numbers break down as follows over successive decades:

1850-1859: three

1860-1869: four

1870-1879: seventeen

1880-1889: eleven

1890-1899: seventeen (plus one in 1900).

That distribution reinforces the statistics presented earlier. ${ }^{228}$ This specificity of concert life in Wrocław was affected also by the political situation, which consolidated the Polish environment above all in the cultural domain.

Most of these concerts were part of a subscription series of symphonic concerts organised with great success by the Wrocław Orchestral Society (Breslauer Orchesterverein), founded in 1862, at the city's largest concert venue, the Wrocław Concert Hall (Breslauer Concerthaus), which seated more than $1200 .{ }^{229}$ Other concert venues were the Liebich Hall and the university's Music Hall, with a capacity of 300-400. As Maria Zduniak stresses, subscription concerts organised by numerous music societies (including the Orchesterverein) were among the finest musical traditions in the city, since they enabled people to hear masterworks of the musical literature, ${ }^{230}$ as well as including music by Polish composers, with Chopin foremost among them. ${ }^{231}$ Crucially, these concerts, featuring Chopin transcriptions on their programme, could have attracted large

228 See subchapter 2.1. 'Works by Chopin and their transcriptions in nineteenth-century musical culture - quantitative aspects'.

229 See Zduniak, Muzyka, 88-89.

230 Ibid., 100.

231 The reception of Chopin's music in nineteenth-century Wrocław was presented in the above-cited source: Zduniak, 'Fryderyk Chopin'. 
audiences. Adopting a chronological key, we can piece together a picture of the reception of Chopin transcriptions at that time, and the most crucial aspect will be the assessment of the transcriptions performed. ${ }^{232}$

Here is what the reviewer Adolf Friedrich Hesse wrote about a concert given by the Italian virtuoso violinist Antonio Bazzini: ${ }^{233}$

Unser verehrter Konzertgeber faßte den Konzertsatz mit Kühnheit an, und kam im Allgemeinen über die Unebenheiten vieler Stellen gut hinaus. Er erhielt nach jedem Solo stürmischen Beifall, und die von ihm sehr geschickt gemachte, brillante und enorm schwierige Kadenz machte Furore. Außer diesem Konzerte spielte Hr. Bazzini noch den von ihm für die Violine mit Pianobegleitung übertragenen Trauermarsch von Chopin, unsprünglich in B-moll komponirt, hier nach A-moll transponirt. Der Vortrag dieses tiefsinnigen Stückes war bezaubernd schön; in der Kantilene, hier C-dur, entwickelte der Konzertgeber eine Weichheit und einen Schmelz des Tones, wie wir sie bei dem Violinkonzerte in dem Grade nicht gewahrten. Der Künstler hat uns damit entzückt. [...] In der Fantasie dramatique entwickelte der berühmte Künstler seine ganze Virtuosität. Die Komposition ist modern und für den heutigen Geschmack des großen Publikums berechnet; sie giebt einem Geiger der neuern Schule Gelegenheit, sich im vollen Glanze zu zeigen. [...] Wir danken dem berümten Künstler Bazzini für den uns verschafften Genuß.234

A violin version of the Marche funèbre from Op. 35 was very well received by both the audience and the reviewer. The structure of Chopin's composition gave

232 The original text of the cited reviews is printed in Gothic. In the present work, it is rendered in modern script, with the original grammatical forms retained. The English translations are based on my own Polish translations, proofread by the German scholar Katarzyna Trychoń-Cieślak, to whom I am sincerely grateful.

233 He lived from 1818 to 1897.

234 'The esteemed performer played a concerto movement (the first movement of Beethoven's Concerto in D major) with great calmness, mastering all the difficulties. He received tumultuous applause, and his incredibly difficult and marvellous cadenza caused quite a furore. Besides that concerto, Bazzini played his own arrangement of Chopin's Marche funèbre for violin and piano, which was transposed from its original key of B flat minor to A minor. The performance of this reflective and deeply moving work was delightfully lovely; in the cantilena, in the key of $\mathrm{C}$ major, the violinist displayed a smoothness, subtlety and softness of sound that we had not noticed in his performance of the violin concerto (Beethoven). In this, the artist delighted us. [...] In the Fantaisie dramatique, this well-known artist displayed all his virtuosity. This composition is modern and suited to the tastes of today's wide audiences; it gives a representative of the new violin school the opportunity to show himself to full effect. [...] We thank the renowned artist Bazzini for the raptures that we experienced and that quite captivated us.' BZ 1855/256, 1673. 
the violinist the opportunity to present a soft, velvety tone. Within the context of the performed works, this transcription was received as a valuable work, not pandering to cheap tastes.

Jenny Lind, a Swedish soprano known throughout Europe and America, gave three concerts in Wrocław. Her excellent reception from the Wrocław audiences and reviewers confirmed the opinion expressed by Chopin himself, who had admired her singing ten years earlier in England:

I recently heard Miss Lind in Sonnambula. She sang most beautifully. I made her personal acquaintance. ${ }^{235}$

I had met J. Lind - and with her card she very graciously sent me the most perfect stall. I was sitting well, so I heard well. She is an original Swede, not in the usual light - but in some sort of polar auroras. She makes a huge effect in Sonnambula. - She sings remarkably purely and assuredly, and her piano is so constant - and as straight as a hair. ${ }^{236}$ I was at dinner yesterday with J. Lind, who thereafter, until midnight, sang Swedish things for me. It is a distinctive character, as ours is distinctive. We have something Slavic, they something Scandinavian, which are completely different, but we are nearer to each other than the Italian is to the Spaniard. ${ }^{237}$

I have met Miss Lind. She is a charming person and a brilliant singer. ${ }^{238}$

The announcement of the Wrocław concert by Jenny Goldschmidt (née Lind) and the accompanying biographical note indicated a notable musical event. ${ }^{239}$ In the second half of that concert, the singer performed four mazurkas for voice with an Italian text to piano accompaniment. The transcriber was her husband, the pianist Otto Goldschmidt. In one of the two accounts to have appeared after the singer's third and last concert in Wrocław, the reviewer (A. F. Hesse) confirmed her professionalism:

Ihre chromatische Scala bis in das hohe Es und zurück, die Kadenz mit den verminderten gebrochenen Septimeakkorden u. gaben Zeugniß von einer Ausbildung, die nichts zu wünschen übrig läßt. ${ }^{240}$

235 Letter to Adolf Gutmann of 6 May 1848. KFCS, ii:244.

236 Letter to Wojciech Grzymała of 11 May 1848, Chopin's Polish Letters, 435.

237 Letter to Wojciech Grzymała of 13 May 1848, Chopin’s Polish Letters, 437.

238 Letter to an unknown addressee in Paris, 1 June 1848, KFCS, ii:247.

239 BZ, 1858/81, 377 (announcement); BZ, 1858/83, 385 (biographical note).

240 'The chromatic scale of her voice, reaching up to a high e flat, the cadenza with spread seventh chords and others (figures indicating her vocal artistry) attest to her musical professionalism, which leaves nothing to be desired. BZ, 1858/85, 389. 
And here is what he wrote about Goldschmidt's arrangements:

Die Chopinschen Mazurken, von Hrn. O. Goldschmidt mit vielem Geschmack zusammengestellt, haben uns sowohl in der reizenden Vortragsweise, sowie in melodischer und harmonischer Beziehung einen Hochgenuß gewährt. ${ }^{241}$

Goldsmith's Recueil de Mazourkas was well received. The critics admired its melodic layer, which may be associated with the voice part, and the harmonic layer, associated with the piano accompaniment. Hesse stressed that the quality of these arrangements was manifest in the fusion of the vocal and piano parts, in their melodic and harmonic relations. Unfortunately, we do not know which of Chopin's mazurkas were transcribed. The lack of exact information attests to a superficial or rather irresponsible treatment of Chopin's music. A similar situation occurred with Bazzini's performance of a transcription of the Marche funèbre from Op. 35, which could be identified solely from the key (transposed from the original B flat minor to A minor). Such inaccuracies of information relating to concerts also concerned the output of other composers.

In the eighth concert organised by the Wrocław Concert Society, held on 31 January 1871, alongside outstanding works of the world literature (the overture to Weber's Euryanthe; an orchestral excerpt from Wagner's Die Meistersinger von Nurnberg; Schumann's Symphony in D minor), a transcription of the Nocturne in E flat major, Op. 9 No. 2 for cello and orchestra was performed by the transcriber, the cellist Bernhard Cossmann, whom the reviewer dubbed the 'Joachim of the cello' - not just a virtuoso, but a true artist:

Joachim des Violoncells. [...] Derselbe gehört zu der sehr Einen von Meistern, die ihr Instrument weniger als Virtuosen, denn Künstler behandeln. ${ }^{242}$

Unfortunately, the author does not assess the compositions themselves, but only names them, focussing attention on the cellist:

241 'Chopin's mazurkas arranged into a cycle with great discernment by O. Goldschmidt ensured us of great delights, thanks both to the sumptuous performance and to the melodic and harmonic relations.' Ibid.

242 'The Joachim of the cello. [...] He is of that order of maestri who treat their instrument less virtuosically and more artistically. (They are not so much virtuosi as artists of their instrument.)' BZ, 1871/55, 380. 
Der Künstler spielte ein Concert von Eckert, mit Orchester, Lied von Schubert, ein Notturno von Chopin und eine Tara(ntella) eigner Composition, welche letztere er auf stürmisches Verlangen wiederholen mußte. ${ }^{243}$

The tone of admiration for Cossmann's playing and for his own composition allows us to assume that the admiration also concerned, indirectly, the transcription. This artist performed again in Wrocław on 29 January 1878. His programme featured solo works: Scholz's Capriccio all' Ungarese, Popper's Papillon and Chopin's Marche funèbre. Here is what one anonymous reviewer observed:

Seine technische Bravour konnte er in dem Capriccio all' Ungarese von Bernhard Scholz und dem schwierigen Concertstück Papillons von Popper in vollstem Maße bekunden, als Meister in der Behandlung der Cantilene zeigte er sich in Vortrag des Chopin'schen Trauermarsches. Die Leistungen des Künstlers wurden höchst beifällig aufgenommen. ${ }^{244}$

The arrangement was probably Cossmann's own transcription of the Marche funèbre.

August Wilhelmj was a guest of concerts in Wrocław several times. In the eighth subscription concert of the Wrocław Concert Society, held on 30 January 1872 in Springer Hall, among seven other compositions (by Lachner, Paganini, Berlioz, Liszt and Weber), the violinist performed a transcription of a Chopin nocturne. ${ }^{245}$ Only from a review by R. Schneider do we learn that it was the Nocturne in D flat major, Op. 27 No. 2. Like the first movement of Paganini's violin concerto, which preceded it, this work was played effectively and with great virtuosity; it was a highly energetic and thrilling presentation. It is difficult to ascertain whether this was a version for solo violin or with orchestral accompaniment. The reviewer's lofty appraisal concerned Wilhelmj's violin playing, and only indirectly the 'paraphrase' that he wrote:

Professor Wilhelmi als Violinvirtuos rechtfertigte nicht nur seinen Ruf, er wußte durch die hohe Vollendung seiner ans Fabelhafte grenzenden Technik und durch die entzückende Innigkeit seines Vortrags auf die Zuhörer einen enthusiasmirenden

243 'The artist played a concerto by Eckert with orchestra, a song by Schubert, a Chopin nocturne and a Tarantella of his own composition, which had to be played again at the distinct request of the audience.' BZ, 1871/55, 380.

244 'He displayed his technical bravura in a Capriccio all' Ungarese by Bernhard Scholz, showed his consummate artistry in Popper's difficult Papillons and proved himself a master of cantilena while playing Chopin's Funeral March. All the works were received with great appreciation from the audience.' BZ, 1878/51, 2.

245 See BZ, 1872/48, 396. In 1878, this venue was rebuilt to become the Breslauer Concerthaus, which had two halls: a large space for 1200 people and a small 600 -seater. 
Eindruck zu machen. War es im ersten Satze des Paganini'schen Concerts die Virtuosität in den glänzenden Passagen, die Staunen erregte, so war es in den folgenden Gaben: Paraphrase des Chopin'schen Des-dur Nokturn (in D), Air von J.S. Bach, Abendlied von Rob. Schumann. ${ }^{246}$

According to an announcement and a review of another concert, on 21 January 1873, Wilhelmj performed his own violin arrangements of three compositions: an Albumblatt by Richard Wagner (first performance), a Chopin nocturne and Schumann's Abendlied. An anonymous reviewer (signed with the letter F.) wrote as follows:

Hier glänzte der Techniker, während in der Ausführung der drei folgenden Nummern (Albumblatt von Wagner, Notturno von Chopin, Abendlied von Schumann) an erster Stelle der sinnige Künstler sich unverkennbar documentirte. In welchen Zauber poetischer Auffassung war nicht das Abendlied getaucht: so muß es gesungen werden. Die höchst gelungene Bearbeitung aller drei Piecen, unter denen uns die geschmackvolle Instrumentation des Wagner'schen Klavierstücks besonders interessirte, ist das Werk des Vortragenden. Wäre es uns doch vergönnt dies seltene Talent, welches mit rauschendem Beifall überschüttet wurde, bald wieder in diesen Räumen zu begrüßen. ${ }^{247}$

We cannot establish, however, which Chopin nocturne was performed; it may have been the D flat major, Op. 27 No. 2, which he performed earlier. Three years later, on 25 January 1876, in the seventh subscription concert of the Orchesterverein, Wilhelmj performed violin arrangements of a Chopin Romanza and Larghetto. ${ }^{248} \mathrm{~A}$ reviewer identified by the initials P. S. recalled the

246 'As a violin virtuoso, Professor Wilhelmj not only confirmed his reputation, thanks to his great mastery and his technique, stretching the bounds of reality (bordering on the fabulous), but also, thanks to the wonderful expressivity of his performance, he made an enthusiastic impression on the listeners. If in the first movement of Paganini's concerto one admired the virtuosity contained in the dazzling scale passages, it was also present in the subsequent compositions: a paraphrase of Chopin's Nocturne in D flat major, J. S. Bach's Aria and Schumann's Abendlied'. BZ, 1872/52, 427.

247 'Here [in the earlier performed Violin Concerto in B minor by Raff] the performer astonished us with his technique, whilst in his rendition of the next three compositions (Wagner's Albumblatt, Chopin's Nocturne and Schumann's Abendlied), he showed himself primarily as a highly expressive and sensuous artist. Yet the Abendlied has to be sung, however poetical its interpretation. The most successful arrangement of the three compositions is the work of the performer; the one that most intrigued us with its consummate taste was the instrumentation of Wagner's piano composition. May it be granted us to host once again this exceptional talent, who was regaled with tumultuous applause.' BZ, 1873/37, 310.

248 BZ, 1876/39, 9. 
words uttered by Berlioz in 1868, highlighting Wilhelmj's extraordinary, noble and refined sound ('eminente, bezaubernde und edle Ton'). On the Chopin transcriptions, we read:

Seine Leistung, erreichte in dem arrangirten Chopin'schen Larghetto einen Gipfel, auf den ihm kaum ein zweiter deutscher Geiger folgen dürfte. Ueber seine virtuosen Eigenschaften eingehender $\mathrm{zu}$ sprechen, will uns nach unserem ausführlichen vorjährigen Berichte unnöthig erscheinen. Nur sei bemerkt, daß wir unter diesen im Hinblick auf seine Romanze nicht gerade das Compositions=Talent verstanden wissen wollen. Der Beifall war enthusiastisch. ${ }^{249}$

In the transcription of the Larghetto, the violinist reached the pinnacle of his performance art, flaunting his cantilena and ornamental playing. The transcriptions were rewarded with applause from the audience.

The concert by the pianist Franz Bendel was of the character of a piano recital. Its announcement does not give the programme, but it is exactly described in a review. ${ }^{250}$ Bendel presented a dozen or so diverse piano compositions: two of his own works, two of his paraphrases (Brahms's Wiegenlied and Chopin's 'Piosnka litewska' [Lithuanian Song]), two compositions by Liszt, a Gavotte in $\mathrm{G}$ minor by Bach, a Schubert Minuet, a Pergolesi Aria, his own arrangement of the Egmont overture, a piano sonata by Schubert, Schumann's Etudes symphoniques, Op. 13 and Beethoven's Sonata in A flat major, Op. 26. The rendition of the paraphrases of the songs by Brahms and Chopin were deemed elegant and technically superior:

und zwei gleichfalls von ihm herrührende Paraphrasen über Brahms's Wiegenlied und Chopin's Litthauisches Lied, in deren elegantem und technisch selbstverständlich vollkommenem Vortrag er excellirte. ${ }^{251}$

Much greater admiration was aroused by his renditions of compositions by Liszt, Schumann and Beethoven. The pianist's performance was very highly rated by

249 'In the arrangement of Chopin's Larghetto, his excellence reaches heights that could not be scaled by any other German violinist. After our exact account from last year, it seems superfluous to speak of the details of his virtuosity. It should be noted that in respect to his Romanza we were unable to discern his compositional talent. The applause was enthusiastic.' BZ, 1876/43, 1 .

250 BZ, 1873/99, 809 (announcement).

251 'and both his paraphrases of Brahms's Lullaby and Chopin's Lithuanian Song, in which he fascinated us with his elegant and of course technically perfect rendition'. BZ, $1873 / 103,834-835$. 
both the reviewer (S.) and the audience, which rewarded him with thunderous applause.

The sixth subscription concert of the Wrocław Orchestral Society was graced by an appearance from the Berlin-based soprano Lilli Lehmann. She ended it with a graceful and bravura rendition of a mazurka by Pauline Viardot. An anonymous reviewer described it as a 'piquant study piece': ${ }^{252}$

Zum Schlusse sang die Künstlerin eine von Frau Viardot-Garcia für den Gesang eingerichtete Mazurka von Chopin mit unterlegtem französischen Texte, ein pikantes Gabinetsstückchen, mit einschmeichelnder Grazie und vollendeter Bravour. Stürmischer Beifall belohnte diese treffliche Leistung. ${ }^{253}$

Lehmann's performance was rewarded with tremendous applause.

Pablo Sarasate played Chopin transcriptions in five Wrocław concerts. On 23 January 1877, at the Springer Hall, he performed his own arrangement of a Chopin nocturne. That transcription was an encore piece, a token of gratitude to the audience for the tumultuous ovation that met his earlier bravura performance of his own two Spanish Dances:

für den brausenden Beifall, der nach den letzten Tönen erschallte, dankte der Künstler durch den hinreißend schönen Vortrag eines Nocturno von Chopin. ${ }^{254}$

In a concert on 10 December 1878 , he also performed a Chopin nocturne that is difficult to identity:

Herr Sarasate spielte außerdem ein Notturno von Chopin mit hinreißender Schönheit. ${ }^{255}$

We may surmise that the term 'hinreißend Schönheit' refers both to the performance and to the transcription.

An announcement of Sarasate's concert on 22 March 1893 does not contain any information about the performance of a transcription, but it was noted in a review: ${ }^{256}$

252 'ein pikantes Gabinetsstückchen'. BZ, 1877/4, 1.

253 'To close, the artist sang, with remarkable grace and bravura, a piquant study composition - a Chopin mazurka with French text adapted for voice by Mrs Viardot-García. Huge applause greeted that exquisite presentation.' BZ, 1877/4, 1.

254 'for the thunderous applause that rang out after the closing strains, the artist thanked the audience with a delightfully lovely rendition of a Chopin nocturne'. BZ, 1877/40, 2.

255 'In addition, Sarasate gave a delightfully lovely rendition of a Chopin nocturne'. BZ, 1878/581, 2.

256 BZ, 1893/205, 11 (announcement). 
Von den auf allgemeines, strümisches Verlagen gewährten Zugaben gefiel das es-dur Notturno von Chopin am besten. Es ist allerdings bei der Uebertragung für die Violine durch verschiedene schwer zu motivirende virtuose Zuthaten verunstaltet worden, aber trotzdem kann man sich es bei so vorzüglicher Ausführung gefallen lassen. ${ }^{257}$

The reviewer, Emil Bohn, referred also to the form of the transcription and suggested that Chopin's Nocturne in E flat major, Op. 9 No. 2 had been excessively deformed. Sarasate was again a guest in a subscription concert of the Breslauer Orchesterverein. According to the programme, he performed the Second Violin Concerto in D minor by Max Bruch, and as we read in a review: ${ }^{258}$

Selbstverständlich wurde Herr Sarasate zu einigen Draufgaben gedrängt. Zuerst kam er spanisch. [...] Die zweite Exstra=Gabe war Chopin es-dur-Notturno. Chopinische Klavierkompositionen sind den Sängern, Violinisten und Violoncellisten eine willkommene Beute; man schlachtet sie nach Herzenslust aus. Daß dabei dem genialen Klavierromantiker schweres Leid zugefügt wird, ist schon wiederholt bemerkt worden. Das es-dur-Notturno kann davon ein Lied singen; die Umgestaltungen, die es sich von den Meistern der Geige hat geniallen lassen müssen, sind geradezuschreckhaft. Aber, was thuts? Sarasate singt es so einschmeicheind herunter, daß man auf jede kritische Unwandlung verzichtet und ihm auch da mit Behagen folgt, wo er den Rhythmus und die Deklamation förmlich auf den Kopf stellt. ${ }^{259}$

This is the first time that a reviewer referred in such detail to a transcription itself and criticised it. He pointed to excessive virtuosity - a feature that considerably flattens and alters the original work, to the detriment of Chopin. This review confirms the great popularity of the Nocturne in E flat major, Op. 9 No. 2 among singers, violinists and cellists at that time.

257 'Of the additional compositions, not listed in the programme, but performed to the universal and clamorous demand of the audience, Chopin's Nocturne in E flat major was the most popular. In its transferral to the violin, as a result of the addition of various virtuosic elements that are difficult to justify, it was disfigured, although that may be accepted in such an excellent performance.' BZ, 1893/211, 2.

$258 \mathrm{BZ}, 1898 / 61,11$.

259 'Sarasate was naturally encouraged to play on. He began "in Spanish". [...] The second surprise was Chopin's Nocturne in E flat major. For singers, violinists and cellists, Chopin's piano compositions have proved a pleasant sacrifice, exploited often and at will. The fact that the brilliant Romantic of the piano is caused great pain at the same time has been emphasised many times. The Nocturne in E flat major is very tuneful, whereas the distortions that might appear brilliant to violin virtuosi are utterly appalling. But what can one do? Sarasate plays in such a captivating way that one forgoes all critical comments and follows him with contentment even where he turns the rhythm and narrative of Chopin's original on its head.' BZ, 1898/67, 1. 
Adolf Fischer, of Paris, one of the best known cello virtuosos, a pupil of Servais, performed in Wrocław on 13 March 1877. In one account of that concert, we find solely a mention that

Herr Fischer spielte außer dem genannten Concerte ein Nocturno von Chopin und ein Bravourstück von Popper, Papillon, mit vollendeter Virtuosität. ${ }^{260}$

We do not know which nocturne this was, for what precise forces it was scored or who produced it. One reviewer ('?') merely confirmed the fact that a cello version of a Chopin nocturne was performed, without writing anything about the qualities of the arrangement or the reactions of the audience.

On 29 November 1877, at the Liebich Hall, a couple of artists familiar to Wrocław audiences from Italian opera shows performed: Mariano and Désirée Padilla. In the opinion of the reviewer ('?'), Mrs Désirée Artôt Padilla, boasting a mezzo-soprano voice ('mittellage Stimme'), had a certain mannerism (her voice was too shrill) that became accentuated over time and affected the quality of her performance of works by Händel and Schumann. It was less injurious to her presentation of 'Aime-moi', a bravura composition in the style brillant:

minder störend traten sie in dem brillant gesungenen Bravourstück Aime-moi hervor. ${ }^{261}$

The audience did not share the reviewer's opinion, since it received the female soloist's performance with great applause. In this instance, too, Chopin's composition did not feature in the concert announcement, and it was treated in the margins of the review. Quite surprising here is the appraisal of Viardot's arrangement as bravura and style brillant.

It is hard to determine whether a transcription of some Chopin nocturne was performed in a concert on 4 November 1879. Although it does appear in the announcement, ${ }^{262}$ according to the reviewer, Max Kalbeck, it was not actually performed. ${ }^{263}$ However, the Austrian cellist and composer David Popper did play compositions not included in the announcement: Schumann's 'Träumerei' (Kinderszenen, Op. 15 No. 7) and an arrangement of Schubert's song 'Du bist die Ruh'.

260 'Besides the above-mentioned concerto [a cello concerto by Carl Reinecke], Fischer performed, with great virtuosity, a Chopin nocturne and Popper's show-stopping work Papillon. BZ, 1877/124, 1.

261 'They [the errors] were less offensive in the perfectly sung, show-stopping composition "Aime-moi". BZ, 1877/562, 2.

$262 \mathrm{BZ}, 1879 / 515,7$.

$263 \mathrm{BZ}, 1879 / 519,2$. 
A performance by the violinist Heinrich de Ahna as part of the tenth subscription concert of the Breslauer Orchesterverein on 8 March 1881 was widely commented on. We read the following about the performances of two transcriptions:

In zwei nach Chopin für die Violine bearbeiteten Solostücken, der Romanze aus E-moll-Concert und dem bekannten Minutenwalzer hatte Herr de Ahna vollauf Gelegenheit, seine große Virtuosität und seinen musikalischen Geschmack zu zeigen. Transkriptionen besonders Chopin'scher Clavierstücke sind nicht zu befürworten, weil sie immer an Originalität einbüßen; doch soll man bei dem entschiedenen Mangel an kleinen passenden Solostücken für die Violine nicht gar so streng sein, darf sich sogar freuen, wenn einem das Deffekt so pikant servirt wird. ${ }^{264}$

Despite this opinion, the transcriptions were to the liking of audience and reviewer alike:

Herr de Ahna war so freundlich, den Walzer nach allgemeinem Beifall da capo zu spielen. ${ }^{265}$

Further evidence that violin and cello arrangements of Chopin's Nocturne in E flat major, Op. 9 No. 2 were frequently included in concert repertoire comes from a performance by the violinist Richard Himmelstoss. After J. S. Bach's Violin Concerto in A minor, he performed several short compositions, with that Chopin nocturne, in Wilhelmj's arrangement, particularly impressive:

Unter den kleineren Piecen ragte ein besonders geschmackvoll und sauber gespieltes Notturno von Chopin=Wilhelmi hervor. ${ }^{266}$

The cellist Julius Klengel, from Leipzig, performed in an elite concert on 4 October 1883. A reviewer (C. P.) praised his wonderful technique and clean intonation. The artist displayed his dazzling virtuosity in his own compositions, and the beautiful, sweeping and songful sound of his cello touched the listeners

264 'In the two Chopin arrangements for solo violin - the Romanza from the Concerto in E minor and the well-known "Minute" Waltz - Mr de Ahna had the opportunity to display his great virtuosity and musical taste. Transcriptions, especially of Chopin's piano works, are unacceptable, since they often lose features of the original composition. However, given the decided lack of short compositions for solo violin, one must not be too severe, and one may even be glad if the defect is served in such a piquant way.' BZ, 1881/115, 1 .

265 'Mr de Ahna was so kind as to perform the transcription of a Chopin waltz again, after universal applause'. BZ, 1881/115, 1 .

266 'Among the short compositions, particularly distinguished was the Chopin Nocturne, in Wilhelmj's arrangement, played with great taste and purity.' BZ, 1882/154, 2. 
through a 'well-known Chopin nocturne. ${ }^{267}$ It was probably Klengel's own arrangement, as we can judge from the following extract from the review:

Während dies Sprühfeuer von Virtuosität, welches die eigenen Compositionen des Herrn Klengel: Intermezzo, Capriccio und Variations capricieuses ausströmten (ohne an sich musikalisch werthvoll zu sein) überall zünden mußte, haben zwei kleinere Stücke: Sarabande (mit Gavotte) von Bach und das bekannte Chopinsche Nocturno, mit schönem, breitem Ton und in jeder Beziehung fein vorgetragen, auch dem Musikkenner denjenigen wirklich ästhetischen Genuß bereitet, der nun einmal nur von dem Gesangsvermögen des Instruments ausgeht. ${ }^{268}$

In a concert on 4 November 1890, the violinist Charles Gregorovich, from Berlin, ${ }^{269}$ performed the 'inevitable' ('unvermeidlich ${ }^{270}$ ) Nocturne in E flat major, Op. 9 No. 2 by Chopin:

Man bewundert die Virtuosität, aber das Herz bleibt kalt dabei. Aus dem Chopin’schen Nocturno ließe sich etwas Rechtes machen, aber die Herren Geiger bringen es nicht über sich, das zarte Stück mit Verbesserungen und Ueberladungen zu verschonen, und noch weniger, es rhythmisch bestimmt zu spielen, wie der Componist es gewollt hat. ${ }^{271}$

This brief profile again confirms the huge popularity of arrangements of that Nocturne for violin and for cello. It also contains its lofty appraisal, classifying it as a work with considerable emotional charge, superior to the merely superficial and show-stopping virtuosic compositions.

Alfred Reisenauer, a German pianist and composer who went on numerous concert tours, also performed in Wrocław. On 23 October 1892, at the New Exchange Hall (Sala Nowej Giełdy), he gave a recital comprising twelve compositions. ${ }^{272}$ The three Chopin works included one transcription. Emil

267 'das bekannte Chopin'sche Nocturno', BZ, 1883/699, 2.

268 'Whilst the fire of virtuosity which raged in Klengel's compositions - an Intermezzo, a Capriccio and Variations capricieuses (which in themselves had no musical value) was inevitably ignited all over, two short pieces, namely, a Bach Sarabande (with Gavotte) and a well-known Chopin Nocturne, subtly and precisely played in every respect, presented a beautiful broad sound and also provided aesthetic pleasure to the refined musical connoisseur, resulting from the presentation of the "vocal" possibilities latent in the instrument.' BZ, 1883/699, 2.

$269 \mathrm{BZ}, 1890 / 772,9$.

$270 \mathrm{BZ}, 1890 / 778,2$.

271 'One admires the virtuosity, but the heart remains cold. It is possible to do something good with Chopin's nocturne, but violinists are incapable of saving this subtle composition with improvements, let alone playing it in the rhythm set by the composer.' BZ, 1890/778, 2.

272 See BZ, 1892/745, 14. 
Bohn's lengthy review confirms the exalted atmosphere of this artistic event. $\mathrm{He}$ describes the Chant polonais as a subtle and refined composition, which was performed alongside two works by Domenico Scarlatti and the middle section of Schubert's Impromptu in A flat major. ${ }^{273}$ The reviewer was mightily impressed by the paraphrase:

Von den Stücken zarteren Charakters gelangen vorzüglich Chopins Chant polonais, zwei Sätze von Domenico Scarlatti und der Mittelsatz des Schubertschen as-dur Impromptus; der Hauptsatz des letzgenannten Werkes wurde wohl mit tadelloser Geläusigkeit gespielt, aber zu wenig straff in der Rhythmisirung gehalten. ${ }^{274}$

The wording used in both the announcement and the review points solely to Chopin as the composer, with no mention of Liszt. This is a crucial feature of the reception of Chopin's music, involving a lack of distinction between the original music and the transcription. This feature is visible in many programmes and reviews from musical events held in Wrocław.

Moriz Rosenthal, in his first concert, on 2 February 1893, played, among other works, his own arrangement of the Waltz in D flat major, Op. 64 No. 1 and Liszt's paraphrase of Chopin's song 'Życzenie’ [A Maiden's Wish]. The reviewer wrote the following about the waltz arrangement:

Schwierigkeiten auf Schwierigkeiten gethürmt worden, aber der Walzer ist dadurch nicht verbessert worden. So interessant es ist, zu hören, wie leicht und elegant Herr Rosenthal all diese Geschraubtheiten erledigt, so wenig gerade durch seine knappe Kürze hervorragendes Stück als Versuchsobjekt für Klaviristische Spielereien aufgegrissen wird. ${ }^{275}$

Despite the technical difficulties, the artist performed this transcription with remarkable lightness and elegance, yet Rosenthal's elaborate arrangement could

273 The opus number of the Schubert composition is not specified. As we know, he left three impromptus in that key: one from Op. 90 and two from Op. 142.

274 'Among compositions of a noble character, we have Chopin's exquisite Chant polonais, two compositions by Domenico Scarlatti and the middle section of Schubert's Impromptu in A flat major. The main part of this last composition was played impeccably, although discipline was occasionally lacking in the rhythmic domain.' BZ, $1892 / 748,3$.

275 'The performance difficulties mounted up, but they did not contribute to any improvement in the composition. It is interesting to hear how lightly and elegantly M. Rosenthal executes all the grandiloquence, but one can hardly approve of the fact that, precisely through its succinctness, this marvellous work of Chopin's is torn apart like an object for experimental essays of various kinds - piano fun and games.' BZ, 1893/88, 2 . 
not trump the quality of Chopin's original. The performance of Chant polonais, in which 'all the demons of piano playing were released', was of a completely different character: ${ }^{276}$

In den beiden Schlußnummern des Programms, in der Lisztschen Paraphrase über das erste polnische Lied von Chopin und noch mehr in der Don Juan=Fanfare desselben Komponisten wurden alle Dämonen des Klavierspiels entfesselt. ${ }^{277}$

With these observations, the reviewer clearly passed judgment on the arrangements, placing Liszt's paraphrase decidedly above Rosenthal's transcription. The programme of the second concert, given on 13 February 1893, included three Chopin compositions: the Mazurka in B minor, Op. 33 No. 4, the Waltz in A flat major, Op. 44 and a nocturne. The reviewer (Ernst Flügel) writes only about the last work:

Chopin's vorgeführtes Nocturne befindet sich nicht unter den 19 nach Opuszahlen geordneten Kompositionen dieses Ramens, das Stück ist auch gar nicht von Chopin, sondern von Liszt, der eine Chopin'sche Melodie Meine Freundin" in bekannter Weise für Clavier bearbeitet hat ( $\mathrm{Nr} 5$ der Chants polonais op. 74 de Chopin transcrits pour le Piano par Liszt). ${ }^{278}$

This remark speaks of the character of the nocturne, but it does not clearly point to its author, who could have been either Liszt or Rosenthal. ${ }^{279}$ It is also hard to divine the sense of citing Liszt's paraphrase of Chopin's song. Perhaps it was on the concert programme? So once more information given in the press about Chopin compositions is inaccurate.

The repertoire of the violinist Adolf Brodsky included Pablo Sarasate's arrangement of the Nocturne in E flat major, Op. 9 No. 2:

Die Sarasatesche Bearbeitung des Chopinschen es-dur Notturno haben alle Violinisten, die guten wie die schelchten, in ihre Protektion genommen. Sie ist eine ärge Versündigung am Originale, in das sie Dinge hineinträgt, die damit in gar keiner

276 'wurden alle Dämonen des Klavierspiels entfesselt', BZ, 1893/88, 2.

277 'In the two compositions that concluded the programme, the Lisztian paraphrase of Chopin's first Polish song and Liszt's Don Juan=Fanfare, all the demons of piano playing were released.' BZ, 1893/88, 2.

278 'The performed Chopin nocturne cannot be found among his nineteen compositions in that genre; it is not entirely a Chopin composition, but comes from Liszt, who also wrote a well-known piano arrangement of Chopin's song 'My Enchantress'. SZ, $1893 / 115,2$.

279 Chomiński and Turło (Catalogue) do not give either Liszt or Rosenthal as the author of a transcription of any of Chopin's nocturnes. 
Beziehung stehen. Ein Virtuose wie Brodsky sollte sich die Mühe nicht verdrießen lassen der Sarasatesche Umarbeitung einmal neben die Original=Ausgabe zu legen und wenigstens die schlimmsten Willkürlichkeiten herauszukorrigiren. Es wird noch immer genug des Dankbaren übrig bleiben, und die Klavierspieler werden sich dann nicht mehr darüber zu ärgern, daß ein an musikalischen Schönheiten so reiches Stück bis zur Karikatur entstellt wird. ${ }^{280}$

This is another negative appraisal of Sarasate's arrangement. A similar assessment was received also by the performer, who showed no concern for Chopin's original.

The performance by the coloratura soprano Erika Wedekind, an opera singer from Dresden, also included a Chopin transcription. It was not signalled in the announcement of her concert, but was included no doubt in item 4 of the programme, covered by a single word: 'Lieder.'281 The transcription of the Mazurka in B flat major, Op. 7 No. 1 for voice and piano was negatively appraised by the reviewer (Emil Bohn):

hätte der Komponist hören können, was der Arrangeur aus seiner hübschen Mazurka gemacht hat, er würde sich im Grabe umgedrecht haben. ${ }^{282}$

The reviewer did not give the name of the transcriber, but it was probably Pauline Viardot, and the arrangement bore the title 'Coquette. Knowing Chopin's positive attitude towards Viardot's arrangements, we may assume that the reviewer's opinion is highly subjective.

The performance by Regina Moszkowska, of Berlin, filled the evening of 28 February 1897 in the Music Hall of the University, and it included 'Aimemoi' - the Mazurka in B flat major, Op. 7 No. 1, in Viardot's arrangement. The reviewer (Derck) did not assess the arrangement itself, focussing on the rather poor rendition. Crucially for our considerations, he specified the author of the transcription and the work on which it was modelled.

280 'Sarasate's arrangement of Chopin's Nocturne in E flat major is willingly played by good and bad violinists alike. This adaptation is a profanation of the original, into which he introduces elements that have nothing in common with it at all. A virtuoso of the calibre of Brodski ought to spare no pains to compare Sarasate's arrangement with the original and at least revise the most offensive changes. Perhaps then pianists would not get upset that a work so rich in musical beauty is turned into a caricature.' BZ, 1895/133, 1 .

$281 \mathrm{BZ}, 1897 / 10,9$.

282 'If the composer could hear what the arranger has done with his lovely mazurka, he would certainly turn in his grave.' BZ, 1897/16, 2. 
Professor Leopold Auer, a violinist from St Petersburg, graced the eleventh subscription concert of the Breslauer Orchesterverein. From the press announcement, we learn that the fourth item on the programme was to have comprised solo violin works by Chopin, Arensky and Popper. ${ }^{283}$ So the announcement was mistaken, as Auer actually played violin transcriptions of Popper and Chopin. According to the reviewer (Bohn), the violinist followed Popper's virtuosic work with his own version of the Nocturne in D flat major, Op. 27 No. 2:

Eine Uebertragung des Chopinschen Notturnos op. $27 \mathrm{nr} 2$ konnte weniger erwärmen, der schwärmerische Ausdruck wurde nicht immer-scharf getroffen und die Intonation entbehrte stellenweise der absoluten Reinheit. ${ }^{284}$

The assessment of this transcription, also not given directly, is rather positive, pointing to the nobility of Chopin's music. It was spoiled by the flawed interpretation.

The performance by Ossip Gabrilowitsch, a pianist from St Petersburg, who played on 17 October 1900, drew a lengthy review. Only from a brief mention do we learn that the artist performed the Chant polonais in G major extremely delicately and gently: ${ }^{285}$

Sehr weich, um nicht zu sagen weichlich, klang ein polnisches Lied von Chopin in Lisztscher Uebertragung. ${ }^{286}$

These passages speak volumes about the place and role of transcriptions in the concert life of Wrocław.

1. Transcriptions were performed in major symphonic concerts, which had varied programmes, with large-scale works from the world literature, ${ }^{287}$ as

283 BZ, 1897/172, 10.

284 'The transcription of Chopin's Nocturne, Op. 27 No. 2 aroused less interest; its exalted, dreamy and romantic expression was not always fully captured, and the intonation was occasionally devoid of the utmost clarity. BZ, 1897/178, 1.

285 BZ, 1900/729, 11.

286 'Chopin's Polish song in Liszt's arrangement sounded very delicate, not to say overly delicate.' BZ, 1900/735, 1.

287 For example: J. S. Bach, organ prelude in E flat major, Violin Concerto in A minor; Beethoven, Symphonies Nos. 1, 5 and 6, overtures Leonora I, Leonora III, Piano Concerto No. 4 in G major, overture The Consecration of the House; Berlioz, overture Le carnaval romain; Bizet, orchestral suite L'Arlésienne; Brahms, Violin Concerto, Symphonies, Nos. 2 and 4; Tchaikovsky, Violin Concerto; Dvořák, overture Carnival; Haydn, Symphony in D major; Liszt, symphonic poem Les préludes; Mendelssohn, overtures to Ruy Blas and A Midsummer Night's Dream, The Hebrides, Symphony in A minor; Mozart, 'Jupiter' Symphony, Symphonies in G minor, E flat major and D 
well as excerpts from operas by Rossini and Bellini, often performed alongside waltzes by Johann Strauss and other orchestral compositions. ${ }^{288}$

2. Chopin arrangements were also included on the programmes of major piano recitals, appearing alongside compositions by Beethoven, Liszt, Schumann, Händel, Scarlatti, Schubert and Weber.

3. Chopin adaptations often filled a point on a concert programme that was enigmatically termed 'solo works' (Solostücke) in the press announcement. Audiences only learned of the special content at the concert. These pieces were often treated as encores.

4. The fact that Chopin reception created by press reports was not always of the highest quality is attested to by the frequent lack of reliable information about transcriptions and their authors. One characteristic feature of many announcements and reviews is a lack of distinction between original output and transcriptions.

5. Reviewers' appraisals of transcriptions were not of a uniform character. Some made no distinction between original work and arrangements, others did note the difference but offered no assessment, and others still negated it entirely. Comments negating the value of arrangements date from the end of the nineteenth century. The rejection of all attempts at 'distorting' the true picture of a composer should be identified with the then intense cult of great composers, linked to historicism in music history.

6. Chopin transcriptions were generally liked by large audiences.

7. According to press announcements, not only adaptations of works by Chopin were performed at that time, but also arrangements of works by other composers. ${ }^{289}$

This sample of nineteenth-century European musical reality demonstrates the lively presence of transcriptions in cultural events of the highest calibre. Such were the symphonic concerts organised by the Wrocław Concert Society and piano recitals by great pianists. According to Maria Zduniak, between 1830 and 1914, some 1500 concerts featured music by Chopin, of which 1390 were

major; Saint-Saëns, Orchestral Suite in D major; Schubert, Symphonies in B minor and C major; Schumann, Symphony No. 2 in C major; Wagner, overtures to Tannhäuser, Die Meistersinger von Nurnberg; Weber, overture to Euryanthe, Oberon; Wieniawski, Violin Concerto.

288 For example, Johann Strauss's Wiener Blut, Béla Kéler's Deutscher Kaiser-Marsch.

289 Bach-Liszt, Prelude and Fugue in A minor; Bach, Toccata in F major orchestrated by Heinrich Esser. 
based on original compositions. Transcriptions represented just $7.34 \%$ of the Chopin repertoire, ${ }^{290}$ so they were of marginal significance for the propagation of Chopin's music in the concert hall. Thus the material presented here belies the widespread assumption of the ubiquitous presence of Chopin transcriptions in nineteenth-century concert repertoires.

Transcription is a specific field of musical activity that has always accompanied a principal strand of output. During the nineteenth century, it was a peculiar mass medium, as it helped to popularise Chopin's music. The crucial elements in that process were the transcribers, the transcriptions they produced, the publishers, the performers and the audiences. The quality of the musical reception of Chopin by means of transcription was varied and depended on the transcriber, the performer and the social context, expressed in the place and form of the presentation and in the kind of audience to which the transcriptions were addressed. The artistic, 'concert' strand of this reception is very narrow, identified with high class authors and with excellent performers displaying their talents in prestigious public concerts. Decidedly broader is the bourgeois strand, closely linked to the practice of Haus- and Salonmusik and with composers whose arrangements belonged solely to the era in which they were written. The map of the publishing firms and the nationalities of the transcribers indicate the scope of this reception, which in both these strands characterised a considerable part of nineteenth-century Europe. ${ }^{291}$ And although Chopin himself 'did not write for the masses, as observers repeatedly emphasised, beginning with George Sand and Liszt, and the reception of music during the nineteenth century did not cover all social strata, ${ }^{292}$ it was through the intermediary of 'salon' and 'house' transcriptions that his music reached a substantial swathe of recipients, while incidental concert presentations were of limited effect.

The poet, writer and literary historian Jerzy Pietrkiewicz, a professor of Polish literature at London University, has stated that: 'none [...] of the Polish writers enjoys such a reputation abroad as Chopin, simply because the success of a foreign writer depends on his presence in translation - a presence that must be renewed, and Polish literature had no luck with translators. ${ }^{293}$ Travestying those

290 See Zduniak, Muzyka, 258.

291 This was the area stretching from Warsaw across to St Petersburg, Moscow, Vienna, Paris, London and Berlin back to Warsaw.

292 Poniatowska, 'Twórczość, 101.

293 Pietrkiewicz, 'Literatura', 217. 
words, one might perversely consider that Chopin's 'translators' during the nineteenth century were the numerous transcribers of his works. And although they were not always excellent 'translations', they certainly influenced the popularity and presence of Chopin's music in Europe at that time. 


\section{Between adhering to substance and trivialising content: a systematics of nineteenth-century transcriptions of works by Chopin}

\subsection{The adopted criteria of the systematics}

The huge number and great variety of Chopin adaptations makes it essential to adopt a systematics that presents them in the broadest possible spectrum. When I began work on this study, there was no ready model relating to Chopin transcriptions ${ }^{294}$ I drew inspiration from Leopold Godowsky's systematics, referring solely to his own fifty-three arrangements of Chopin etudes, ${ }^{295}$ contained in the five-volume work Studien über die Etüden von Chopin. ${ }^{296}$ Godowsky preceded

294 At the initial point in the research, the sole reference was Andrzej Henryk Bączyk's ' $\mathrm{Z}$ problematyki transkrypcji', in which the author outlines the issue of transcription in the output of Johann Sebastian Bach, employing two basic criteria for the classification of Bach transcriptions: forces and verbal text. As a result of applying the former criterion, he distinguishes the following groups of transcriptions: (1) reducing the sound, (2) expanding the sound, (3) altering the sound layer without any quantitative change in forces, (4) from one solo instrument to another solo instrument. The application of the latter criterion led to the distinction of the following types: (1) altering the text, (2) adding text, (3) abandoning the text. In seeking to order Chopin transcriptions according to Bączyk's typology, we would arrive at the following results. In the group of transcriptions reducing the sound, we would have to include only adaptations of ensemble works by Chopin, and those constitute a small part of his output. Equally small would be the group of transcriptions expanding the sound, since there are few Chopin transcriptions scored for a large performance apparatus. Only the next two groups would contain a considerable number of examples. The criterion of verbal text, meanwhile, could only be employed in the second point, where the whole group of transcriptions with added text would be included (e.g. mazurkas in the arrangements of Pauline Viardot), and the third point, represented by purely instrumental arrangements of Chopin songs. The above ordering, although possible, does not present many other important aspects of the functioning of Chopin transcriptions.

295 Godowsky arranged twenty-six etudes, omitting Etude, Op. 25 No. 7. He produced twenty-eight arrangements from Op. 10, twenty-one from Op. 25 and four from Méthode des méthodes.

296 Godowsky, Studien (dated according to an entry in the music). This collection was first published by Schlesinger of Berlin in 1898, then in 1898-1903, 1909-1913 and 1914. Those transcriptions were also published by other firms: Schirmer of New York (1899, 
his arrangements with a lengthy commentary. In the introduction (Einleitung), he set out the aims of his work:

Die 53 Studien, welche auf 26 Chopin-Etüden aufgebaut sind, verfolgen einen dreifachen Zweck: die mechanischen, technischen und musikalischen Möglichkeiten des Klavierspiels zu bereichern, die eigentümliche, der polyphonen, polyrhythmischen und polydynamischen Arbeit zugängliche Natur des Instruments weiter zu entwickeln und die Möglichkeiten der Tonkoloristik zu vermehren. [...] Die 53 Chopinstudien eignen sich für den Konzertgebrauch ebenso wie für das Privatstudium. ${ }^{297}$

In his 'Personal remarks' ('Persönliche Bemerkungen'), Godowsky pointed to the aesthetic and ethical responsibility that weighed upon him, resulting from turning to the works of other composers and creating arrangements of different kinds (transcriptions, paraphrases, variations):

Da bestritten wird, ob ein Komponist das (ästhetische und ethische) Recht hat, Werke eines anderen Komponisten zu benutzen, um auf deren Themen und Motiven freie Bearbeitungen, Transkriptionen, Paraphrasen, Variationen aufzubauen, möchte der Autor einem solchen Einwand begegnen und erklären, daß es seiner Meinung nach dabei ausschließlich auf die künstlerische Absicht und Qualität seiner Arbeit ankommt. Der Autor hielt es für das Verständigste und Verständlichste, auf der soliden unanfechtbaren Basis der Chopin-Etüden dieses Werk, das die Kunst des Klavierspiels fördern soll, aufzubauen, weil die Chopin-Etüden als Tonstücke in Etüdenform allgemein als eine künstlerische Höchstleistung im Gebiet der mechanisch-technisch wertvollen, wie geistig-inhaltisch bedeutenden Klavierliteratur anerkannt sind. Da der Autor gegen jede und jegliche Änderung des Originaltextes einer Komposition ist, wenn diese eben im Original vorgetragen wird, würde er jeden Künstler verdammen, der im geringsten in ein Werk von der Bedeutung der Chopinschen Etüden hineinpfuschen wollte. Die Original-Etüden Chopins bleiben aber hier völlig unangetastet; sie behalten ihre ewige Bedeutung nach wie vor. Der Autor glaubt sogar, daß, bei emsigem Studium der vorliegenden Versionen, sich manche bislang verborgenen Schönheiten der OriginalEtuden dem aufmerksamen Leser enthüllen werden. ${ }^{298}$

1903, 1909), and Muzyka of Moscow (1968). The dating and the publisher names come from notes included in this five-volume collection and from CT, 339-340.

297 'The fifty-three studies based upon twenty-six Etudes of Chopin have manifold purposes. Their aim is to develop the mechanical, technical and musical possibilities of pianoforte playing, to expand the peculiarly adapted nature of the instrument to polyphonic, polyrhythmic and polydynamic work, and to widen the range of its possibilities in tone colouring. [...] The fifty-three studies are to be considered in an equal degree suitable for concert purposes and private study? Godowsky, Studien, i:III.

298 'To justify himself in the controversy which exists regarding the aesthetic and ethical rights of one composer to use another composer's works, themes, or ideas, in order to freely build upon them new musical creations, such as arrangements, transcriptions, 
Godowsky's 'General remarks' ('Allgemeine Bemerkungen') relate to aspects of technique and performance: ${ }^{299}$ the pianist's position, the positioning of the hands, markings of dynamics, agogics, phrasing, pedalling, etc. The author devotes separate remarks to his arrangements for left hand ('Besondere Bemerkungen über die Studien für die linke Hand allein'):

Mit den 22 Studien für die linke Hand allein will der Autor die allgemein herrschende Ansicht, daß die linke Hand weniger entwicklungsfähig sei als die rechte, widerlegen. [...] Wenn es möglich ist, mit der Linken allein Werke auszuführen, die eigentlich für zwei Hände gadacht sind - welche Aussichten eröffnen sich da dem zukünftigen Tonsetzer, der diese Errungenschaft auf beide Hände ausdehnen darf! ${ }^{300}$

The composer classified his fifty-three arrangements in five main groups ('Die verschiedenen Gattungen der Chopinstudien'). ${ }^{301}$ This gives us insight into his thinking and shows the purpose of successive arrangements.

The first group consists of 'strict transcriptions':

Reine Transkriptionen - Studien, in denen der Originaltext so genau beibehalten ist, als es eine Übertragung für die linke Hand zuläßt. ${ }^{302}$

paraphrases, variations, etc., the author desires to say that it entirely depends upon the intention, nature and quality of the work of the so-called transgressors. As the Chopin studies are, as compositions in etude form, universally acknowledged to be the highest attainment in the realm of beautiful pianoforte music combined with indispensable mechanical and technical usefulness, the author thought it wisest to build upon their solid and invulnerable foundation, for the purpose of furthering the art of pianoforte playing. Being averse to any alterations in the original texts of any master works when played in the original form, the author would strongly condemn any artist for tampering ever so little with such works as those of Chopin. The original Chopin studies remain as intact now, as they were before any arrangements of them were ever published; in fact, the author claims, that after assiduously studying the present versions many hidden beauties in the original studies will reveal themselves even to the observant student.' Godowsky, Studien, i:IV.

299 Ibid., V.

300 'In writing the twenty-two studies for the left hand alone, the author wishes to oppose the generally prevailing idea that the left hand is less responsive to development than the right. [...] If it is possible to assign to the left hand alone the work done usually by both hands simultaneously, what vistas are opened to future composers were this attainment to be extended to both hands!' Ibid., VII.

301 Ibid., VIII.

302 'Strict transcriptions - studies in which the text of the original is as closely followed as an adaption for the left hand would allow' Ibid. 
In the second group ('free transcriptions'), Godowsky distinguishes four subgroups:

Freie Transkriptionen - Studien, in denen der Text entweder

a. in freier Behandlung,

b. in der Umkehrung,

c. in Kombination mit einer anderen Etüde,

d. in Nachahmung und Charakter einer anderen Etüde erscheint. ${ }^{303}$

The third group contains 'cantus firmus transcriptions':

Cantus Firmus=Bearbeitungen. Studien, in denen der Text der Original-Etüde von der Rechten getreu auf die Linke übertragen ist, während die Rechte dazu in freier Erfindung kontrapunktiert. ${ }^{304}$

The fourth group comprises 'versions in the form of variations':

Bearbeitungen in Variationform. Studien, in denen der Text der Original-Etüde als Grundlage für freie Variationen benutzt wird. ${ }^{305}$

The fifth and last group contains 'metamorphoses':

Metamorphosen - Studien, bei denen Charakter, Zeichnung und Rhythmus des Originaltextes verändert werden, während die Form als solche gewahrt bleibt, wenngleich die melodischen und harmonischen Umrisse oft beträchtlich abweichen. ${ }^{306}$

Of the five main groups, the largest is the second (31 transcriptions, 23 of which comprise subgroup 2a), the smallest the fifth (only two transcriptions). The sixth group, not named, but distinguished by Godowsky ('Folgende, schon vorher eingereihte Studien können auch zu dieser Gattung gezählt werden'307),

303 'Free transcriptions - studies in which the text is either

a. freely treated;

b. inverted;

c. combined with another study;

d. is being imitated through the medium of another study' Ibid.

304 'Cantus Firmus transcriptions - studies in which the text of the original study in the right hand is strictly adhered to in the left hand of the version while the right hand is freely treated in a contrapuntal way'. Ibid.

305 'Versions in form of Variations - studies in which the text of the original etude is used as a basis for free variations'. Ibid.

306 'Metamorphoses - studies in which the character, design and rhythm of the original text are altered while the architectural structure remains intact'. Ibid.

307 'The following studies might also be mentioned under this heading'. Ibid. 
is represented by sixteen transcriptions. These are adaptations of a diffusive character, combining features from two groups - the fifth and another (second, third or fourth). Most frequently combined are the fifth and third groups (seven examples); combinations with group $2 \mathrm{a}$ and with group $2 \mathrm{~b}$ have three examples each; two examples result from combination with group 4; just one example depicts a combination of the fifth type with $2 \mathrm{~d}$.

Godowsky's studies are characterised by a high level of technical difficulty and demand musical maturity of the pianist. ${ }^{308}$ Godowsky specifies his goal: to create material worthy of a great pianist, in both technical and musical terms. Consequently, he combines superior music with serious pianistic problems. Turning to what he considers to be Chopin's most valuable etudes, Godowsky aspires to developing and improving pianistic technique. Despite such stated aims, the key to classifying the etudes is not pianistic issues but composition technique, ranging from a simple translation to far-reaching metamorphoses. The pianistic problems are only detailed in isolated arrangements, as in Studies No. 36, ${ }^{309}$ termed a Terzenstudie (study in thirds), No. 38, ${ }^{310}$ a Sextenstudie (study in sixths), and No. 28b, ${ }^{311}$ a Studium in Oktaven (study in octaves). ${ }^{312}$

As already mentioned, the above systematics refers solely to Godowsky's arrangements; it does not take account of the character and form of other Chopin transcriptions and so is not fully suited to the source material in our possession. However, its inspirations in the systematics proposed below are self-evident. Given the lack of a ready-made methodological model, my research work was aimed primarily at finding a key to a clear and logical presentation of nineteenth-century Chopin transcriptions. My first attempt at their classification took account of four basic criteria for division: performance, morphology, function and culture. ${ }^{313}$ The first criterion described arrangements in terms of forces and covered transcriptions for solo piano, for piano with accompaniment, for voice and instrument and for chamber ensemble or orchestra. Such a division resulted from the specificities of the available range of nineteenth-century instruments. The morphological criterion concerned

308 This opinion is not shared by Elżbieta Szczepańska-Malinowska, 'Dyskretny'. Godowsky's arrangements are also discussed by Barbara Taraszkiewicz in 'Transkrypcje'.

309 An arrangement of the Etude in G sharp minor, Op. 25 No. 6.

310 An arrangement of the Etude in D flat major, Op. 25 No. 8.

311 An arrangement of the Etude in F minor, Op. 25 No. 2.

312 See Godowsky, Studien, i:II.

313 Literska, Dziewiętnastowieczne transkrypcje. 
the degree to which Chopin's musical material was deformed, and it took account of three basic categories: transcriptions where the material was simplified, rendered more difficult or on a similar level. Another aspect of the existence of transcriptions was signalled by the functional criterion. Its task was to point to the basic roles of transcriptions, hence the division into functional, didactic, artistic and popularising arrangements. The task of the fourth criterion, concerning cultural aspects, was to signal two problems: the existence in adaptations of universal or local (national) features. The above systematics, which facilitates a wide-ranging characterisation of Chopin transcriptions, formed the framework for a complex approach to the problem under analysis. As the basis for the theoretical-systematic part of my considerations, I adopted the typology of Maciej Gołąb, ${ }^{314}$ which clearly focusses our attention on the object of research, which is ultimately 'the process of Chopin reception, observed from the angle of the history of particular transcriptions. ${ }^{315}$ Gołąb's systematics was treated as the starting point and was subsequently developed, with examples more extensively documented, detailed features discussed and the musical features of successive groups of transcriptions clarified.

Gołąb begins his systematics by positing two basic methodological premises. According to the first of those premises, definitions of successive types of transcription are linked to 'a hierarchy of ontic aspects of the musical work'; ${ }^{316}$ that is, substance, texture, syntax, form and expression. The second premise concerns the assessment of the distinguished types of transcription, and it is based on the assumption that 'the farther the features of a given type of transcription depart from Chopin's original, the more its value "declines". ${ }^{317}$ That point of departure results from traditional art theory, according to which the artistic value of adaptations depends on their capacity for evoking the expression of the original. This systematics is informed by varying degrees of interference by the transcriber in the original work; it ranges from transcriptions which alter the original the least to those in which the modification concerns nearly all the determinants of the work (Table 27). The classification proposed by Gołą takes account of two interconnected aspects: the morphological and the aesthetic. In the present

314 Ibid., 25-44.

315 Gołąb, Dziewiętnastowieczne transkrypcje, 25.

316 Ibid., 25.

317 Ibid. 
Table 27: Systematics of transcription according to Maciej Gołąb.

\begin{tabular}{|c|c|c|c|}
\hline $\begin{array}{l}\text { Type of } \\
\text { transcription }\end{array}$ & $\begin{array}{l}\text { ESSENTIAL } \\
\text { CONDITION }{ }^{\mathrm{a}}- \\
\text { the feature that } \\
\text { enables this type of } \\
\text { transcription to be } \\
\text { distinguished }\end{array}$ & Main subtypes & Definition \\
\hline $\begin{array}{l}\text { 1. Substantial } \\
\text { transcription }\end{array}$ & $\begin{array}{l}\text { Inviolability of } \\
\text { the MUSICAL } \\
\text { SUBSTANCE of the } \\
\text { original work. }\end{array}$ & $\begin{array}{l}\text { 1.1. Transcription } \\
\text { transmitting the } \\
\text { sound layer } \\
\text { 1.2. Transcription } \\
\text { multiplying the sound } \\
\text { layer }\end{array}$ & $\begin{array}{l}\text { Exact transcription of the } \\
\text { entire substance of a work } \\
\text { for a new performance } \\
\text { medium. }\end{array}$ \\
\hline $\begin{array}{l}\text { 2. Structural } \\
\text { transcription }\end{array}$ & $\begin{array}{l}\text { Qualitative change of } \\
\text { TEXTURE. } \\
\text { Inviolability of } \\
\text { original syntax and } \\
\text { form. }\end{array}$ & $\begin{array}{l}\text { 2.1. Transcription } \\
\text { expanding the texture } \\
\text { 2.2. Transcription } \\
\text { altering the } \\
\text { arrangement of textural } \\
\text { layers }\end{array}$ & $\begin{array}{l}\text { Preservation of the tonal, } \\
\text { syntactic and formal } \\
\text { substance of the work; } \\
\text { qualitative change of } \\
\text { texture. }\end{array}$ \\
\hline $\begin{array}{l}\text { 3. Syntactic } \\
\text { transcription }\end{array}$ & $\begin{array}{l}\text { Modification of the } \\
\text { SYNTAX of Chopin's } \\
\text { original. }\end{array}$ & $\begin{array}{l}\text { 3.1. Transcription } \\
\text { reducing the syntax } \\
\text { 3.2. Transcription } \\
\text { expanding the syntax }\end{array}$ & $\begin{array}{l}\text { Preservation of only } \\
\text { the main categories of } \\
\text { syntax; modification of its } \\
\text { secondary elements. }\end{array}$ \\
\hline $\begin{array}{l}\text { 4. Recontextual } \\
\text { transcription }\end{array}$ & $\begin{array}{l}\text { Destruction of } \\
\text { the FORM of the } \\
\text { original work, distinct } \\
\text { disintegration of the } \\
\text { aesthetic paradigm of } \\
\text { its formal unity and } \\
\text { cohesion. }\end{array}$ & $\begin{array}{l}\text { 4.1. Reductive } \\
\text { transcription } \\
\text { 4.2. Contaminative } \\
\text { transcription }\end{array}$ & $\begin{array}{l}\text { Autonomisation of } \\
\text { formal components } \\
\text { or combination of } \\
\text { components (or whole } \\
\text { works) with other works } \\
\text { (or their components). }\end{array}$ \\
\hline $\begin{array}{l}\text { 5. Functional } \\
\text { transcription }\end{array}$ & $\begin{array}{l}\text { Glaring changes } \\
\text { to one or more } \\
\text { ontic aspects of the } \\
\text { work, resulting in } \\
\text { the lowering of its } \\
\text { aesthetic value. }\end{array}$ & $\begin{array}{l}\text { 5.1. Technical-didactic } \\
\text { transcription } \\
\text { 5.2. Simplified } \\
\text { transcription }\end{array}$ & $\begin{array}{l}\text { Trivialisation of the } \\
\text { content of works for } \\
\text { strictly pragmatic } \\
\text { purposes. }\end{array}$ \\
\hline
\end{tabular}

a I added this column to further clarify the adopted criteria. 
work, I maintain a distance with regard to his axiological premises and adopt only the first, morphological, methodological premise. ${ }^{318}$

Invoking Godowsky's systematics once again, in order to compare it with that of Gołąb, only the 'strict transcription' directly corresponds to our substantial type. The group of 'free transcription' is more diverse, and from the point of view of our systematics it covers the structural and formal types. Arrangements of a cantus firmus correspond to the structural type, whereas transcriptions 'in the form of variations and metamorphoses' can be assigned to the syntactic and formal types. In Godowsky's commentary, I see no distinct difference in terms of composition technique between free transcription and metamorphosis. The difference is merely intuitively discernible in the actual names, since metamorphoses bear the titles Polonaise, Mazurka, Tarantella, Capriccio, Toccata, Nocturne, Walse and Menuetto. Both systematics - Godowsky's and Gołąb's - share an assumption of the violation of 'ontic aspects of the original', but that is effectuated within a slightly different range of issues relating to musical composition. ${ }^{319}$

For the purposes of the systematics that underpins our further considerations, I propose to explain key notions employed within it. The necessity of introducing the term 'musical substance' resulted from the unsuitability of the semantic fields pertaining to the notions generally employed: the semantically restrictive term 'sound material' and the overly broad term 'musical material.' The term 'musical substance', characteristic of Hans Mersmann's theory of form and of the views of Zofia Lissa, is directly drawn, for the purposes of the present considerations, from Hans Heinrich Eggebrecht's theory of musical structure (composition). ${ }^{320}$ The reference solely to Eggebrecht's views is motivated by an affinity between the definition proposed here and his understanding of the term 'substance.' The differences between these two definitions of 'musical substance' can be reduced to a few points: [1] Eggebrecht uses the word 'substances', we use 'musical substance'; [2] in Eggebrecht, there are four basic substances, ${ }^{321}$ we have only one;

318 The question of the value of transcriptions will form the basis of the final chapter in this dissertation: Chapter 4. 'Nineteenth-century transcriptions of works by Chopin as a way of manifesting artistic qualities in the musical culture of the nineteenth century: Trivialmusik?'

319 We will return to this issue when analysing three versions of Chopin's Etude, Op. 10 No. 7.

320 Eggebrecht, 'Uwagi'.

321 (1) movements, sections or other formal components (theme, motif, bar, group of bars), (2) precompositional complexes of elements (e.g. seventh chord; fifth-octave chord), (3) aspects (dynamics and timbre of a note), (4) textures (in the sense of technique - pedal, imitation). 
[3] our musical substance corresponds to just one of Eggebrecht's substances (the 'precomposed complex of elements'), while we always have three elements rhythm, melody and harmony. These are systematically treated as the compositionally primary melodic, harmonic and metrorhythmic sound material, coordinated by the relationship between the pitch and duration of a note. The two definitions share the consideration of substance from the point of view of a whole composition (musical structure).

Texture concerns the way in which musical substance is organised in terms of sound and space; it points to the existence of 'sound layers' in a musical work. This term 'sound layer' does not refer to any of the familiar theories of Roman Ingarden, Heinrich Schenker or Nicolai Hartmann; ${ }^{322}$ it does refer to the concept of Ewa Czernek. ${ }^{323}$ As she sees it, a layer is 'an autonomously sounding pattern contained in the sound structures of a given musical work'. A crucial determinant for establishing the number of layers in an arrangement is its homogeneity or heterogeneity of sound. The former characterises a one-layer work, while the latter determines a work with multiple layers. Ewa Czernek states that the complexity of the piano texture in each work by Chopin enables one to distinguish 'textural sound layers' within it. This remark also concerns Chopin transcriptions for other forces.

Our understanding of musical syntax is based on a linguistic definition according to which syntax is 'the study of the construction of utterances, their component parts, of the ways and means by which they are separated or joined together, causing them to be arranged in a grammatical-communicative whole. ${ }^{324}$ In music, therefore, syntax is a system of elements - motifs, phrases, sentences and periods - and its principal category consists of musical sentences or phrases. The mutual relations between these syntactic components imply a higher structural and aesthetic category, which is the musical form.

Form is understood as the overall architectural, structural outline of a work. Such a view accords with the approach of Carl Dahlhaus, for whom the term form 'suggests $[\ldots]$ the outline of the whole, relations over wide stretches. ${ }^{325}$ Form is the result of syntactic procedures reflected in overall structure of a higher order. It shows the hierarchy of the various elements of syntax, imparting specific

322 Ingarden, The Musical Work; Schenker, Der freie Satz; Hartmann, 'Warstwy'.

323 Czernek, 'Transkrypcje', 63.

324 KSJP.

325 Dahlhaus, Schoenberg, 260. 
functions to them (idea, theme, bridge). From the aesthetic point of view, form is a ready-made, audible product. ${ }^{326}$

The action of transcribing, involving the reworking of original compositions, intrinsically guarantees changes, which may concern many different elements of a musical work. In the first two groups of transcriptions, substantial and structural, one of the main objects of our analysis will consist of textural sound layers. In our observations, we will be guided by the specifications of Ewa Czernek, ${ }^{327}$ who analysed five Chopin transcriptions by Karol Lipiński in terms of the number and arrangement of sound layers. ${ }^{328}$ She identified three ways in which those transcriptions were shaped: the transmission of layers (characterised by agreement between the number and arrangement of layers in a transcription and in its model), the multiplication of layers (linked to an increase in the number of layers in a transcription) and the reduction of layers. Consequently, she distinguished four models of transcription. She presented the procedure of multiplication by means of models 1 and 3, with transmission represented by models 2 and 4. The reduction of layers was absent from these five transcriptions.

Model 1 represents the situation of a switch from the single layer of an original composition to two layers in a transcription. Model 3, meanwhile, shows a switch from two to three layers. Generally speaking, the number of layers was altered, so we may speak of their multiplication. In my view, however, although model 3 ultimately points to multiplication (it is visible in the accompaniment layer), it also presents elements of the transmission of sound layers (the solo layer is based on transmission). And this problem of the existence of two procedures in a single transcription contributed to the identification of a third type in the substantial group: diffusive transcriptions. Yet we will speak of diffusive types only when the two procedures are used in diachronic order.

Model 2 depicts a situation in which we have a distinct change in forces. We do not note here any change in the number of sound layers; the two original layers are merely transferred in the transcription to different performers. The difference between models 2 and 4 concerns the number of original layers.

326 Ibid.

327 Czernek, 'Transkrypcje', 77-87.

328 These are Karol Lipiński's transcriptions of the following works: the Nocturnes in B flat minor, Op. 9 No. 1 and in E flat major, Op. 9 No. 2, the Polonaises in C sharp minor, Op. 26 No. 1 and in E flat minor, Op. 26 No. 2, and the Tarantella in A flat major, Op. 43. 
MODEL I

ORIGINAL

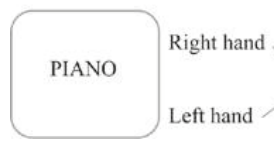

TRANSCRIPTION

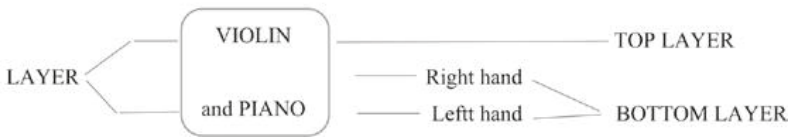

Model 1: Multiplication of sound layer, first option.

MODEL II

ORIGINAL

TRANSCRIPTION

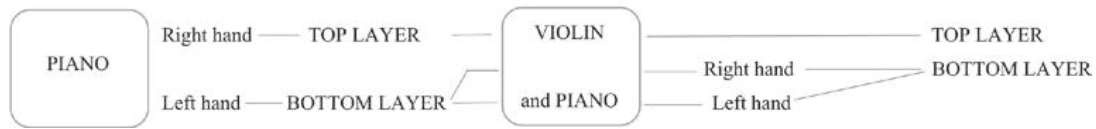

Model 2: Transmission of sound layer, first option.

MODEL III

ORIGINAL

TRANSCRIPTION

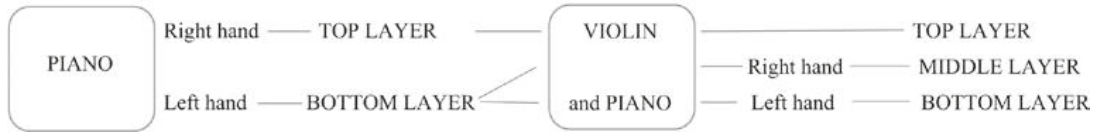

Model 3: Multiplication of sound layer, second option.

Model 2 presents a two-layered original and transcription; model 4 three layers in each. In both models, the number of sound layers remains the same. It should be noted that Ewa Czernek was analysing violin transcriptions of Chopin, which explains why the models could undergo modification in our analyses due to the use of a different solo instrument and a different construction of the original.

The four basic models distinguished by Ewa Czernek are ideal types, suited solely to the examples of substantial transcriptions chosen by her. Due to two basic factors - the different design of Chopin's originals and the forces for which the transcriptions were made - these models cannot be applied to the classification of all the material under analysis. Nevertheless, they formed the starting point 
MODEL IV

ORIGINAL

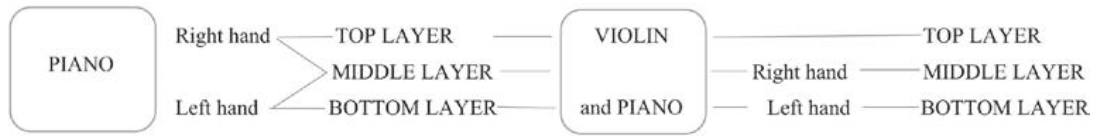

Model 4: Transmission of sound layer, second option.

for distinguishing subgroups in the first two groups of transcriptions: substantial and textural.

\subsection{Substantial transcriptions}

The type of the substantial transcription is nothing other than the simplest transcription or 'translation' of an original work for different forces, most often for duet, more rarely for larger ensemble. The sine qua non of this type of transcription is the inviolability of Chopin's musical substance, which is linked to the preservation of its determinants: melody, harmony, metre and rhythm. Changes to the other elements - agogics, dynamics and articulation - are admissible insofar as they result from the technical capacities of the instrumental or vocalinstrumental forces employed. When these conditions are satisfied, the original composition may be subjected to procedures of transmission or multiplication.

Multiplication involves increasing the number of sound layers, and transmission is characterised by the agreement of the number and the arrangement of the sound layers in the transcription in relation to the original, so it is their transferral to a different performance medium. By distinguishing these ways of transforming the original, we can divide works into two subgroups: transcriptions transmitting sound layers; transcriptions multiplying sound layers. In the former subgroup, we are dealing with the transferral of the piano layer of the original to two (or more) performers. The transmission of sound layers to a different performance medium can entail minor changes in agogics, dynamics and articulation, and often also in key, resulting directly from the capacities of that medium. The latter subgroup contains those arrangements in which at least one original layer is multiplied. That multiplication may be linked to a change of instrumental forces, which equates to obtaining a new sound. Multiplication can also result from different procedures applied by the transcriber, such as the highlighting of secondary sonorities or the lengthening of rhythmic values. It often occurs 
that both procedures are employed in diachronic order in a single transcription, which we will define as the diffusive type within the substantial group. Yet never does the transmission or the multiplication of sound layers alter the substance of the original work, which is crucial to the classification of a transcription to the substantial group.

Many of Chopin's compositions are characterised by a distinct division into leading voice and accompanying voices, which results from the homophonic texture. In addition to distinguishing the number of sound layers in a composition or a transcription, we must also specify the function that they discharge, whether they are solo or accompanying layers. The number of 'functional' layers does not always agree with the total number of layers in a composition. In addition, the relative location of layers may differ: a solo layer will not always be above an accompanying layer in the sense of register. Also crucial is the question of the performers' responsibility (resulting from the new forces) for realising the work, expressed in two dispositions: parity or subordination, one to the other. Thus the number of layers, as well as their function, mutual location and relationship (parity or subordination) will be crucial aspects in the ensuing analyses.

For the sake of the clarity, I decided to present three examples from each main group of transcriptions, in the assumption that they each possess two basic subtypes and a diffusive subtype.

Key to the presentation of the substantial type is one original work, which we will examine in successive 'embodiments'. This modus operandi will make it easier to indicate differences in the approach to the raw material, which is Chopin's work. We will juxtapose transcriptions of the same work representing the two main subtypes - transmitting and multiplying - and the diffusive subtype. The ultimate aim of these analyses is to produce a model of an 'ideal type' of substantial transcription, characterised by constancy in the disposition of the sound layers and in the treatment of the musical material itself. ${ }^{329}$

I now propose to trace the process of the modification of the Waltz in A minor, Op. 34 No. 2 in three selected transcriptions. The first was written by Ferdinand David, and it comes from a collection of Walzer. ${ }^{330}$ In his transcription of this waltz, David proceeded in a rather schematic way: he gave the leading, solo part

329 F. Chopin - F. David, Waltz [in A minor], Op. 34 No. 2, Vn+Pfte,

F. Chopin - E. Prill, Waltz [in A minor], Op. 34 No. 2, Fl+Pfte,

F. Chopin - A. Horn, Waltz [in A minor], Op. 34 No. 2, Pfte 4 hands.

330 Published by Breitkopf \& Härtel of Leipzig in 1871. Dated after Deutsch, 10. The collection contains the Waltzes, Op. 34 Nos. 2 and 3, Op. 42 and Op. 64 Nos. 1, 2 and 3. 
to the violin and reduced the piano to the role of accompanying instrument. The solo layer of the original work was transmitted to the violin part, with minimal changes resulting from the instrument's capacities (raising the register of the leading melody in bars 1-16, 152-204). One consistently applied procedure in this arrangement is the expansion downwards of the register, through the use of octave doublings on the strong beat. This effect does not result in the multiplication of the accompaniment layer, but does alter its character, making it more forceful and distinct. Occasionally, these octaves are extended to the duration of a whole bar (bars 53-54, 69-70).

The accompaniment layer, represented in the original by various combinations of plans, is realised in the transcription by the piano, with the original order largely retained: it surrounds the solo layer (bars 1-16, 97-104, 153-168, 189204) or sounds beneath it (bars 17-28, 36-96, 104-152). The only difference in the arrangement of the functional layers is visible in bars 169-188, where the accompaniment in the top plan (right hand) of the original is given to the piano while the original solo from the piano's left hand is taken by the violin, which plays this melodic passage two octaves higher. The reversal of the pattern of twonote chords (bars 29-32), clearly resulting from the violin's capacities, also led to a minor disturbance in the arrangement of the functional layers: at this point, the solo layer dominates the accompaniment.

In this adaptation, David employed the transmission and multiplication of the sound layers. The principle of transferral is visible in the forging of the violin part, which is given the original solo layer. The multiplication proceeds synchronically and occurs in several passages of this arrangement. Over the course of sixteen bars (bars 53-68), extended notes of the bass voice, doubled at an octave, create a new, highly distinctive sound layer. This multiplication does not result solely from David's inventiveness, but is encoded in a way in Chopin's original; the transcriber merely singles it out and presents it as a separate sound layer. We also encounter multiplication in a sixteen-bar passage which appears three times over the whole of the original and the transcription (bars 1-16, 152-168, 189-204). The three presentations are identical; only bar 196 differs in the arrangement of the notes from its related bars 8 and 160. The difference is minimal (the note $e$ is missing) and hard to explain, since it does not result from any clear musical premises.

The original sixteen-bar period is composed of three layers: the top layer comprises two-note chords, the middle layer a voice led in linear fashion, and the bottom layer a drone (pedal), emphasising the root of the tonic and the root of the dominant in the key of A minor. The outer layers serve as accompaniment, and the middle layer executes the solo. In the transcription, this section 
undergoes multiplication, whilst the arrangement of the original functional layers is retained (the solo layer between the accompaniment layers). Exact multiplication is applied to the layer of two-note chords. This is broken up into two voices led in linear fashion, the independence of which is suggested by a different textural notation. The top layer is based on passagework derived from notes that are present in the Chopin in both the solo and accompaniment layers. The bottom voice brings out the original melody, but here it is sharpened by a different notation of the rhythmic value (we have one minim instead of two tied crotchets). In this and the next two identical sixteen-bar segments, multiplication concerns the accompaniment layer, and in effect, from the original three-layered construct, we obtain a four-layered one. In the above-mentioned section (bars 169-188), David added an extra layer, comprising members of successive chords which exist in the Chopin. He directly 'corrects' the composer, supplementing what he sees as 'missing' members of the original chords. They are mainly roots (less often a third or an altered fifth), doubled at an octave and positioned on strong beats in the bar.

To sum up, David's adaptation displays different ways of multiplication, which result from the following:

1. the doubling of the bass line with the addition of new notes only presumed to exist in the original (Example 1);

2. the doubling of the bass line with the simultaneous extension of the rhythmic values, which enables this voice to be led in linear fashion (Example 2);

3. an ostensible change of texture - vertical two-note chords broken up into two voices led in linear fashion (Example 3).

Thus David proceeds according to both models of multiplication, altering a three-layered construct into a four-layered one (bars 1-16, 153-168, 191-204) and a two-layered construct into a three-layered one (bars 16-188). For the reasons outlined above, this adaptation is representative of the multiplying type of substantial transcription.

Emil Prill arranged six Chopin waltzes for flute and piano (Sechs Walzer von Fr. Chopin für Flöte und Klavier), which included the Waltz in A minor, Op. 34 No. $2 .^{331}$ In his transcription, Prill employs minor changes to the musical substance (bars 29-36 and 97-104), but they adhere to the spirit of the original. These modifications involve adding notes which constitute parallel sixths in

331 Published by C. F. Peters of Leipzig in 1878. Dated after Deutsch, 14. 


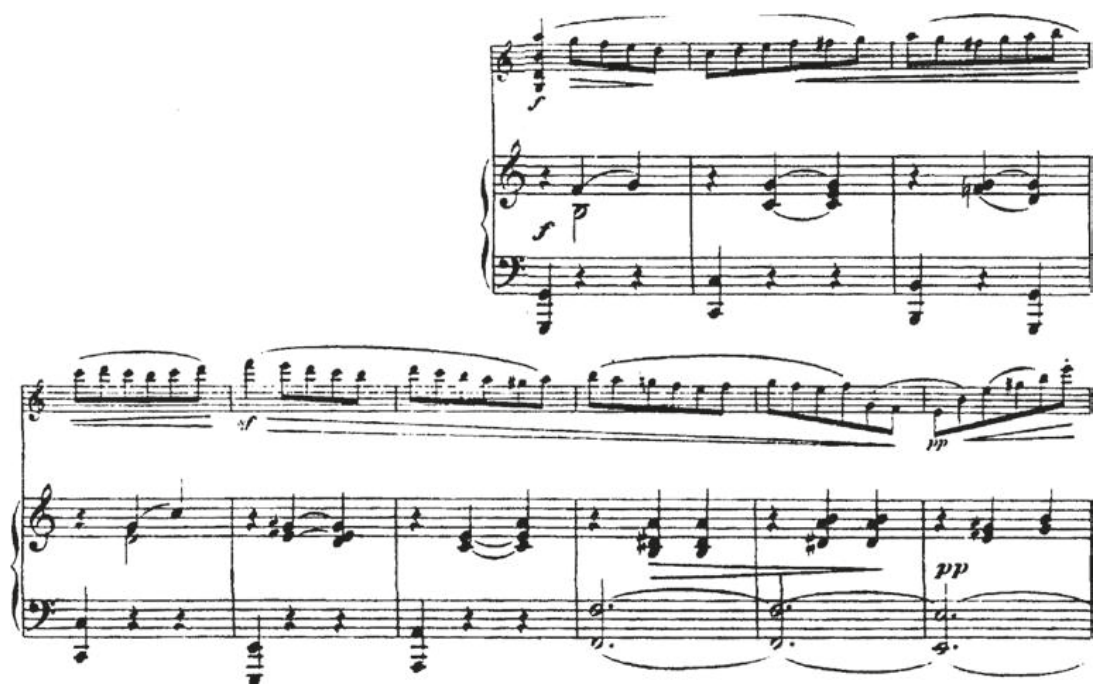

Example 1. F. Chopin - F. David, Waltz [in A minor], Op. 34 No. 2, Vn+Pfte (Leipzig: Breitkopf \& Härtel, 1871), bars 169-177.

relation to the solo part, which is not an original idea of Prill's, but an anticipation of the parallel thirds and sixths employed by Chopin in the following bars (bars 37-52). Another modification is the anticipation of some notes with their simultaneous doubling (bars 37-52, 105-120) in the piano's right hand. These procedures do not bring a qualitative change, but only colour this section of the arrangement, also helping to blend the sound of the two instruments (Example 4).

The design of Chopin's original composition results from the generally binding division into two layers: a leading melody and a chordal accompaniment. This waltz is characterised by shifting colours, since Chopin places the leading melody in different registers of the piano. Thus his original presents a modified twoor three-layered model in which the 'solo layer' and the 'accompaniment layer' occur in different combinations. By way of example, the 'accompaniment layer' is formed by two outer voices and the 'solo layer' is placed between them (bars 1-16, 29-36, 97-104, 152-168, 189-204). Another arrangement (bars 17-152) involves placing the solo in the top voice (right hand) and the accompaniment in the bottom two voices (left hand). A third way of arranging the solo and accompaniment layers is to invert the order from the second way: the solo is below the accompaniment (bars 169-188). 

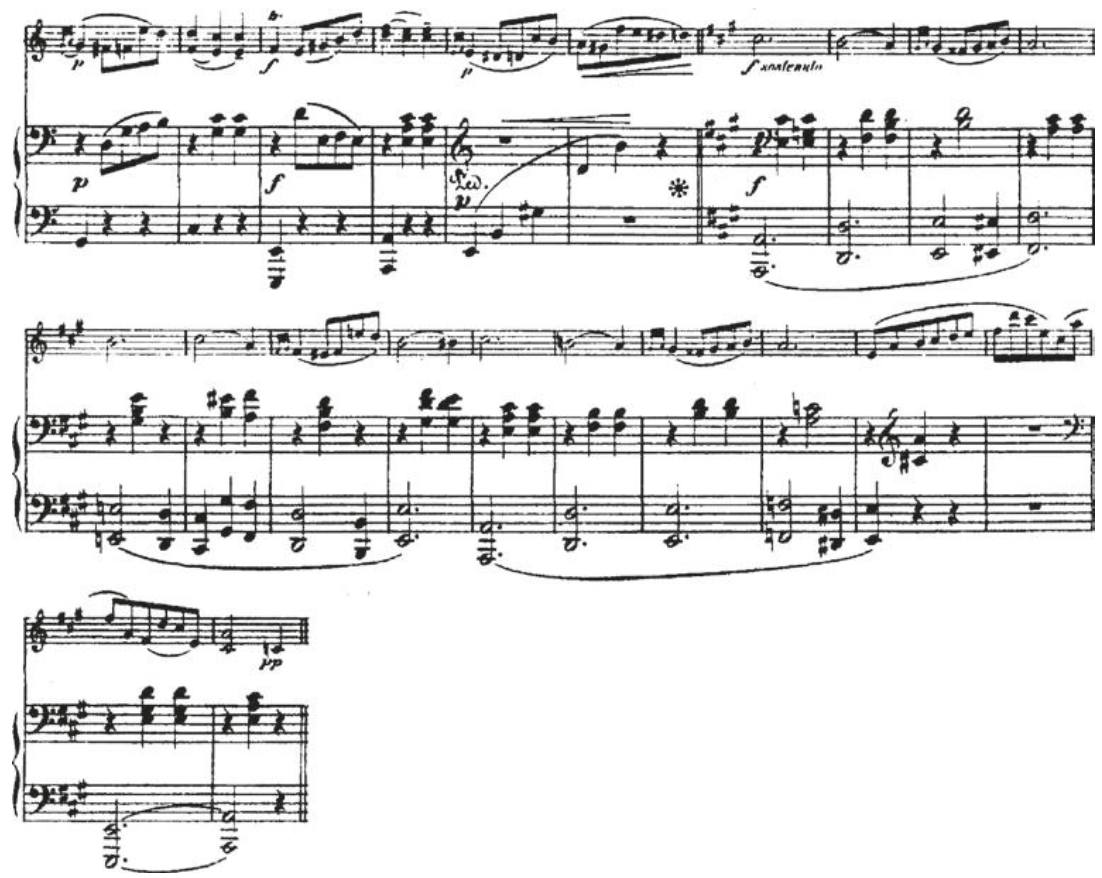

Example 2. F. Chopin - F. David, Waltz [in A minor], Op. 34 No. 2, Vn+Pfte (Leipzig: Breitkopf \& Härtel, 1871), bars 47-68.

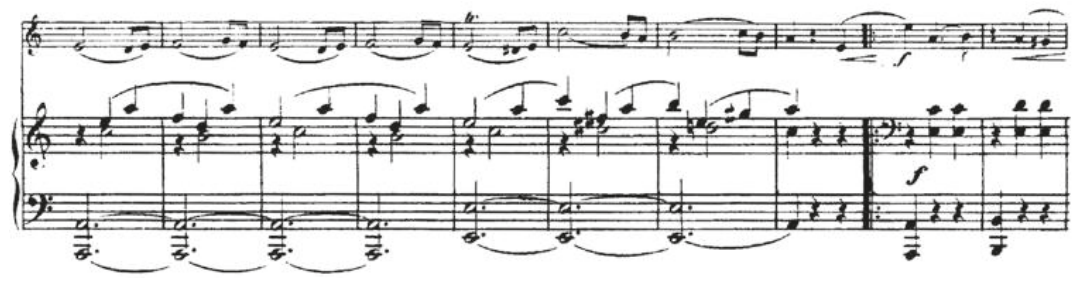

Example 3. F. Chopin - F. David, Waltz [in A minor], Op. 34 No. 2, Vn+Pfte (Leipzig: Breitkopf \& Härtel, 1871), bars 9-18. 


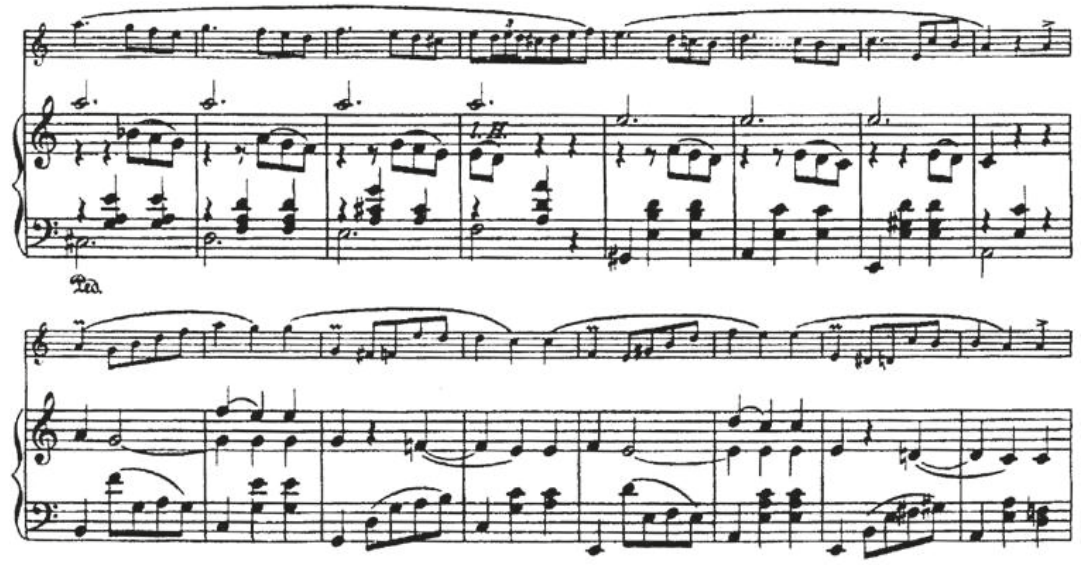

Example 4. F. Chopin - E. Prill, Waltz [in A minor], Op. 34 No. 2, Fl+Pfte (Leipzig: J. H. Zimmermann, 1893), bars 97-112.

In the transcription, due to the limited compass of the flute, the first arrangement is half presented and the third disposition is impossible to retain. In the last case, this section is realised according to the first model: the solo layer given to the flute is its highest voice, and the accompaniment layer is realised by the piano (Example 5). In this section, we also find the multiplication of the sound layers, involving the creation of a bass voice, based on components of Chopin's functions. And it would seem that the creation of this new layer and the swapping of the 'drone' layer for an 'ostinato' layer (bars 1-16, 153-168, 189-204) were motivated by technical considerations relating to performance and serve to synchronise the playing of the two musicians. In his arrangement, Prill essentially employs the transmission of the sound layers, and he is 'forced into' multiplication by the performance apparatus. Hence this flute arrangement presents the diffusive type in the substantial group.

One special group among transcriptions consists of arrangements for piano for four hands. All of August Horn's waltz transcriptions of this type are based on a fixed set of changes to Chopin's original content, which are also employed by other transcribers. Those changes have little to do with the elementary components of the musical substance. We should list here minor modifications to the following elements: 

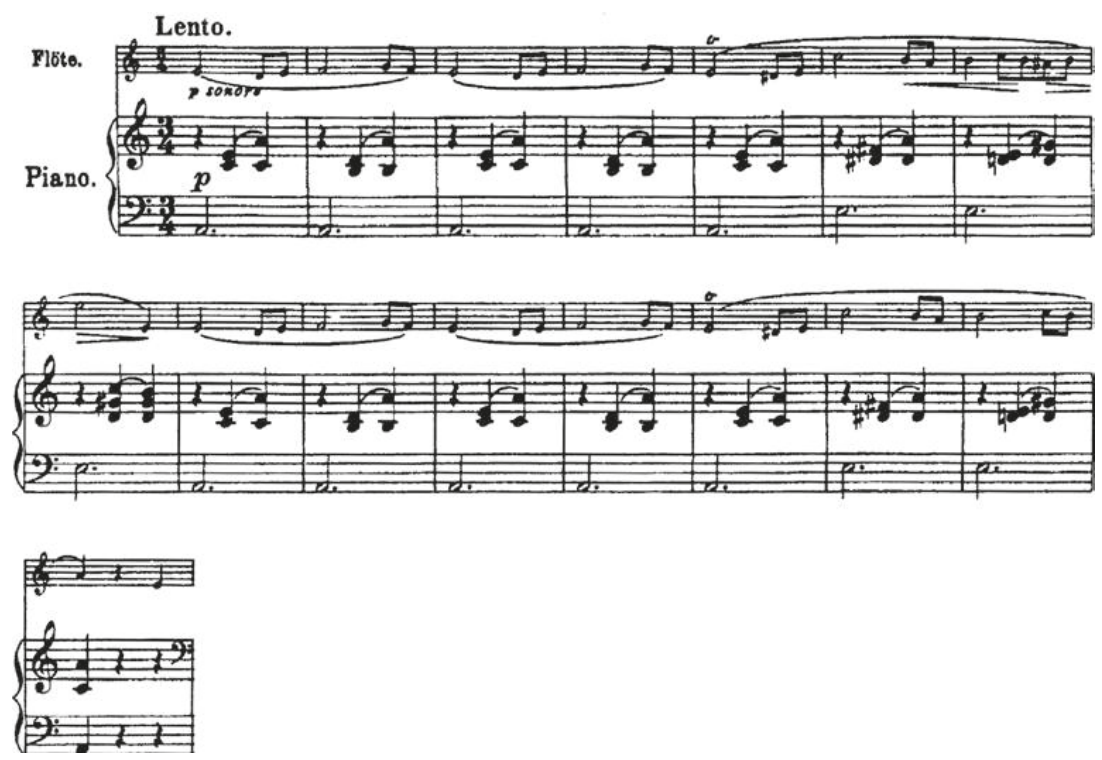

Example 5. F. Chopin - E. Prill, Waltz [in A minor], Op. 34 No. 2, Fl+Pfte (Leipzig: J. H. Zimmermann, 1893), bars 1-16.

- rhythm (the extension of rhythmic values in the bottom plan for a whole bar);

- harmony (the removal of a chord member or a different chord disposition, doublings of chord members, the addition of chord members or, less frequently, the addition of a chord);

- melody (octave doublings, additions to the melody, changes to the register of notes, enharmonic simplifications).

Considerably less frequent is interference in the musical form, involving slight abridgement or division. The fixed set of procedures employed by Horn to adapt Chopin's works alter their character; they become less bravura and brillante. ${ }^{332}$

332 Depending on the degree to which the above-mentioned modifications of the original material are employed, these adaptations may bear the hallmarks of one of several groups of transcriptions: substantial, structural, syntactic or recontextual. Crucial here is the final result of the transcriber's work, whether or not it alters the quality of the original. If an adaptation qualitatively accords with the original, we may assign it to the substantial group, whilst other transcriptions, distinguished by qualitative change, disturbing the Chopin idiom, can be ascribed to the remaining groups. 

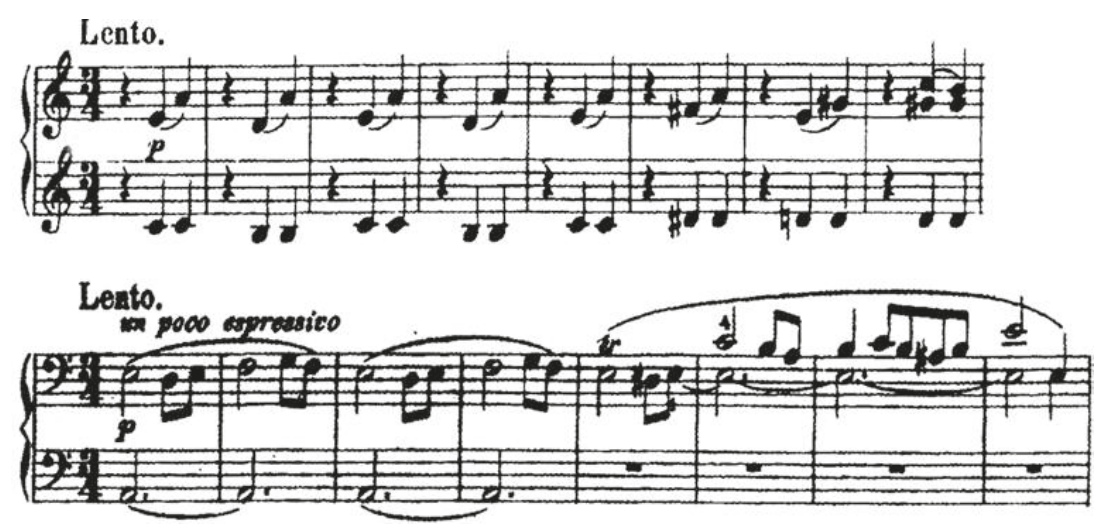

Example 6. F. Chopin - A. Horn, Waltz [in A minor], Op. 34 No. 2, Pfte 4 hands (Leipzig: C. F. Peters, 1878), bars 1-8.

In the transcription of the Waltz in A minor, Op. 34 No. 2 for piano for four hands, we note above all the transmission of the sound layers, involving the 'writing out' of the original material for two performers (Example 6). Horn does not even enter into the detailed arrangement of the sound layers and effects a mechanical division: he assigns the bottom layer (the left hand of the original) to the secondo part and the top layer (the right hand) to the primo part, where we note only octave reinforcement over a short segment (bars 29-35); apart from that, it accords with the original. In the secondo part, only the rhythmic values in the bass are extended (bars 45-54). This transmission is interesting due to the lack of any distinct change in the performance apparatus and consequently of the tonal colouring of the work as a whole. Much of the voluminous literature for four-handed piano represents the type of transcription transmitting the sound layer, which is a subtype of the substantial transcription (see Table 27).

Based on this analysis, the group of substantial transcriptions can be ascribed a number of distinctive features, comprising two main aspects. The first concerns the quantity, functions and mutual disposition of the sound layers. The second indicates the way in which the transcriber interferes with the musical substance, which is violated in only a 'superficial' way. Ewa Czernek's models, concerning the transformation of the original, can be found solely in parts of the transcriptions; they do not apply to whole transcriptions. Hence those models 
were simply a point of departure, a study tool that made it possible to present the ways in which a transcriber worked and to ultimately set in order the large group of substantial transcriptions.

Most often employed is the transmission of sound layers, with the thematic layer of the original (not always the top voice) assigned to the soloist (violin, flute), while the remaining layers are played by the piano. ${ }^{333}$ Multiplication can concern every layer and is expressed through the following procedures:

- the doubling of one or more of the original layers;

- the extension of rhythmic values in the bottom voice, often with simultaneous octave doubling;

- the eliciting of a new independent voice from material existing in the original.

The first procedure is strictly related to tone colour, with a new shading to the sound, and it results from the introduction of a new instrument. The other two kinds of multiplication do not require the introduction of another performance medium, since they can also apply to a piano part. The number of layers in the arrangement is conditioned by the design of the original, yet multiplication in a transcription usually yields (as indicated by the above examples) one extra layer.

As already mentioned, the sound layers discharge specific functions in the work. Consequently, we can distinguish layers of a higher order: the solo and accompaniment layers. In this instance, too, we can speak of a model, with particular tasks assigned to particular layers. The solo layer of the arrangement coincides with the voice that dominates in the homophonic original, whilst the accompaniment layer can have a simple (one layer) or complex (two or more layers) design. The mutual disposition of these higher-order layers (solo and accompaniment) in a transcription is usually constant: the solo is above the accompaniment, which does not always agree with Chopin's original disposition.

In the majority of substantial transcriptions, there exists a fixed hierarchy to the voices. The new medium (e.g. violin or flute) is always treated as superior in relation to the piano. ${ }^{334}$ That relationship is expressed in the design of the entire transcription being subordinated to the new instrument. One frequently encountered element, which assists the actions mentioned above, is the use of 'pure' transmission, involving the faithful transferral of Chopin's material for piano as accompaniment or four-handed piano. In this type of substantial transcription, we note minor alterations to the musical material, the presence of

333 This pattern may occasionally be modified.

334 Occasional exceptions to this principle do occur. 
Table 28: The scope of changes in the substantial type of transcription.

\begin{tabular}{|c|c|}
\hline ELEMENT & SCOPE OF CHANGES \\
\hline Melody & $\begin{array}{l}\text { Melodic simplification. } \\
\text { The addition of notes to the melody. }\end{array}$ \\
\hline Harmony & $\begin{array}{l}\text { An increase in the number of chord members, supplementing notes that } \\
\text { were 'missing' in the original. }\end{array}$ \\
\hline & The use of keys that are comfortable for the given instrument. \\
\hline Rhythm & $\begin{array}{l}\text { Difficult rhythmic passages replaced by easier ones. } \\
\text { A change of rhythmic values resulting from the rhythm introduced to the } \\
\text { setting of a vocal text (in transcriptions with the addition of a verbal text, } \\
\text { for voice(s) and piano). } \\
\text { Extending rhythmic values on the strong beat (particularly used in } \\
\text { arrangements of waltzes and nocturnes, and also in versions for piano for } \\
\text { four hands). }\end{array}$ \\
\hline Tempo & A change to the original tempo (rarely employed). \\
\hline Articulation & $\begin{array}{l}\text { The introduction of different means of articulation than in the original. } \\
\text { This is encountered mainly in arrangements for string instruments. }\end{array}$ \\
\hline Colouring & $\begin{array}{l}\text { A change of performance apparatus (the primary principle in this group } \\
\text { of transcriptions). } \\
\text { A change to the register of the leading melody (this often occurs in } \\
\text { arrangements for cello, due to the compass of that instrument; it is less } \\
\text { frequent in transcriptions for violin or flute). }\end{array}$ \\
\hline Dynamics & $\begin{array}{l}\text { Enhanced with new dynamic degrees, filling out the contour of the } \\
\text { original dynamic sequences (present in practically every transcription, to } \\
\text { varying degrees). }\end{array}$ \\
\hline of & The multiplication of components (often used). \\
\hline sound & $\begin{array}{l}\text { The expansion of the compass of the sound material, resulting from the } \\
\text { range of the instruments used. } \\
\text { Narrowing the compass of the sound material (e.g. in cello arrangements, } \\
\text { conditioned by the range of the instrument). }\end{array}$ \\
\hline
\end{tabular}

which is justified by the technical capacities of the new performance apparatus. And it should be stressed that they are not of a reductive character; they do not impoverish Chopin's original substance (Table 28). Among the changes distinguished here, the greatest differences occur in the dynamic element, but without modifying the substantial foundation of the original.

The model substantial transcription is based on two basic ways of changing the layers: transmission and multiplication. Our analyses show that the types presented in the systematics (transmission, multiplication) and the diffusive type that combines them possess their representatives and form groups 
of various quantity. The most numerous examples can be found in the diffusive type, followed by the multiplication type, with far fewer examples of the transmission type.

\subsection{Structural transcriptions}

The difference between substantial and structural transcription is a difference of degree, comparable to the difference between the transcription of a composition and its artistic 'translation'. Substantial transcriptions are characterised by moderation; they are devoid of 'extras', while in structural arrangements the transcriber introduces new means of expression. According to Maciej Gołąb’s definition: 'A structural transcription is where means of musical homology (structural analogy) are used to highlight relations between elements of its musical texture which potentially exist in the original. ${ }^{335}$ So one assigns a transcription to the structural type based on qualitative changes of texture, which may be accompanied by quantitative modifications and changes to the musical substance. Another essential condition is a lack of changes in the harmonic, syntactic and formal domains of the work. Two basic subtypes can be distinguished within the type of the structural transcription. In the first of them, the texture is significantly expanded (through the use of numerous doublings of chord members, the use of additional registers and the considerable expansion of the compass of the sound material) and revised. The second type features a change to the disposition of the textural layers.

The structural type of transcription occurs mainly in piano works, and to a considerable extent it concerns compositions written by outstanding pianists, virtuosos and composers (Liszt, Busoni, Reger). Textural analysis will bring out qualitative changes occurring in the sound layers which result from considerable modifications of their basic motifs. For the purposes of this presentation, we will point to the existence of motifs that underpin Chopin's original and to their various transformations, which we will term 'distinct variants of Chopin's motifs' and 'hidden variants of Chopin's motifs. ${ }^{336}$ And as in the case of substantial transcriptions, our analysis will be based on three selected transcriptions. ${ }^{337}$

335 Gołąb, Dziewiętnastowieczne transkrypcje, 28-29.

336 My own term.

337 F. Chopin - L. Godowsky, Etude [in C major], Op. 10 No. 7, Pfte, first version, F. Chopin - L. Godowsky, Etude [in C major], Op. 10 No. 7, Pfte, second version, F. Chopin - L. Godowsky, Etude [in C major], Op. 10 No. 7, Pfte, third version. 

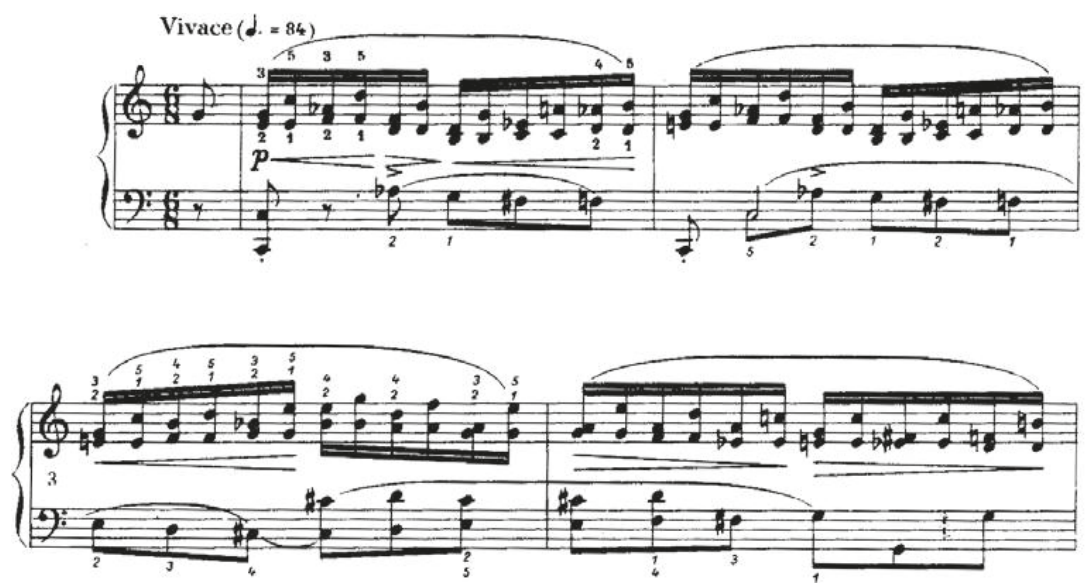

Example 7. F. Chopin, Etude [in C major], Op. 10 No. 7, Pfte (Cracow: PWM, 1981), bars 1-4.

Structural transcription is perfectly exemplified by the arrangements of Leopold Godowsky, which represent extensive research material and a source of knowledge about the composer's motivation. ${ }^{338}$ Our analysis will deal with three versions of Chopin's Etude in C major, Op. 10 No. $7 .^{339}$ The first version belongs to the group which Godowsky calls Reine Transkriptionen.

Chopin's original is in two (bars 1-43, 48-59) and three (bars 44-47) layers. The 'bass' bottom layer is realised in linear fashion; its intervallic contour is characterised by the predominance of small steps, including the presence of 'leading notes'. It is based on a four-bar sentence which is transformed many times over the course of the piece (Example 7). The 'soprano' top layer consists of two voices, with the upper voice clearly dominant. The linear writing of this layer is dominated by the interval of a fourth, while its vertical realisation is based on the intervals of a third and a sixth. The 'alto' middle layer (from bars 44-47) is based on essential features of both layers: stepwise progressions in the linear contour and two-part writing in thirds in the vertical layer. Among the three layers, it is difficult to distinguish one that is clearly dominant, representing the solo

338 This collection was discussed in detail in subchapter 3.1. 'The adopted criteria of the systematics'.

339 Published by G. Schirmer of New York in 1903. A later edition was issued by Schlesingersche Buch \& Musikhandlung of Berlin in 1014. Dates given in the editions. 
part, and a subordinate accompaniment part. For this reason, all three layers will be regarded as functionally equal. In this Etude, we can distinguish three motifs that form the basis of Chopin's compositional work:

- a linear 'bass' motif of a second $\alpha$,

- a linear 'soprano' motif of a fourth $\beta$

- a vertical, 'soprano-alto', sixth-third motif $\gamma$.

Examining Godowsky's arrangement, we first check the number of layers, the presence of the three motifs and their modifications. In the disposition of the textural layers, a basic change has occurred: the original bottom layer has been moved to the top voice, while the original top layer appears beneath it. This change of register, and consequently of colouring, is characteristic of arrangements that alter the disposition of textural layers. This way of switching registers is an example of the transmission of sound layers. Through the considerable modification of the original motifs, Godowsky also eliminates the middle sound layer from the three-layer section, transmitting to the other layers only some of its elements (bars 44-47). That layer can be sought in the top voice of the adaptation, where the existing quaver pulse is realised as if in inversion to the original form.

Since Godowsky introduces so many transformations to the original material, I propose to analyse two aspects of his work: the use of easily recognisable 'distinct variants of Chopin's motifs' (Examples 8,9) and 'hidden variants of Chopin's motifs' that are difficult to identify (Example 10). The former accord with the logic of the original; they are consistently realised in a single layer from the beginning of the transcription to the end. The 'hidden variants of Chopin's motifs' that are hard to distinguish, meanwhile, are often based on highly modified original motifs or bring out motifs that are secondary in the Chopin. The aim of this analysis is to present the ways in which the original is revised and its thematic layer weakened.

Distinct variants of Chopin's motifs.

Looking at Example 8, we see that the shifted 'bass' layer is based on a modified motif $\alpha$, presented in three-note units. The basic motif is often surrounded by the interval of an octave. In this way, Godowsky multiplies and highlights notes which in the Chopin are of little importance (e.g. bar 1) or absent altogether (e.g. bar 3). He also alters the musical substance (e.g. in bar 3 he gives the note $c$ on the third quaver instead of the original $c$ sharp). The situation is similar in a different segment (bars 34-39), where motif $\alpha$, although present and distinctly recognisable, is 'buried' in a flurry of notes. 


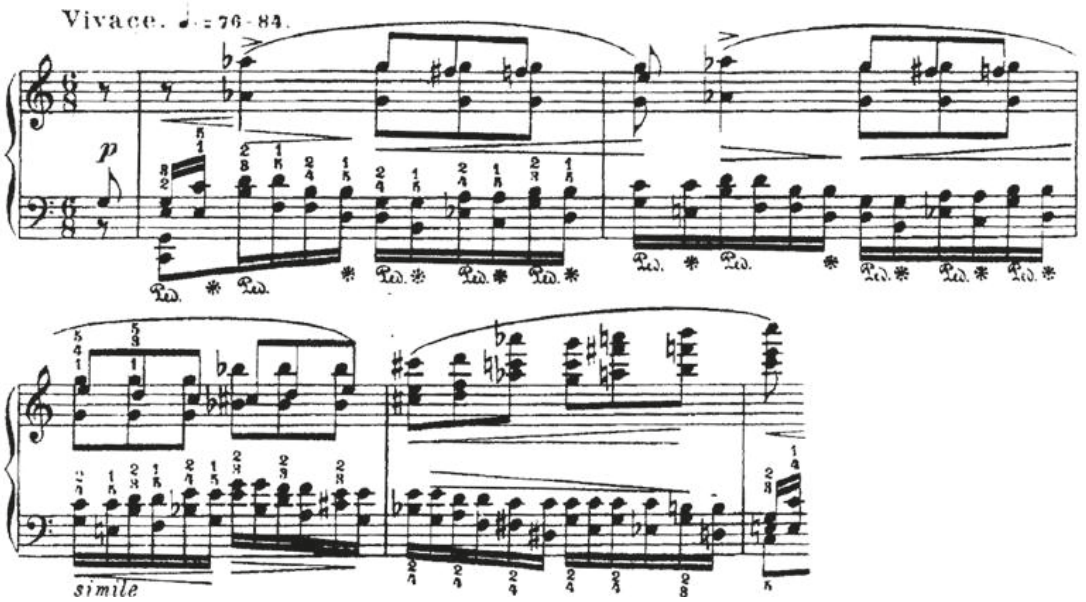

Example 8. F. Chopin - L. Godowsky, Etude [in C major], Op. 10 No. 7, Pfte, first version (New York: G. Schirmer, 1903), bars 1-5.
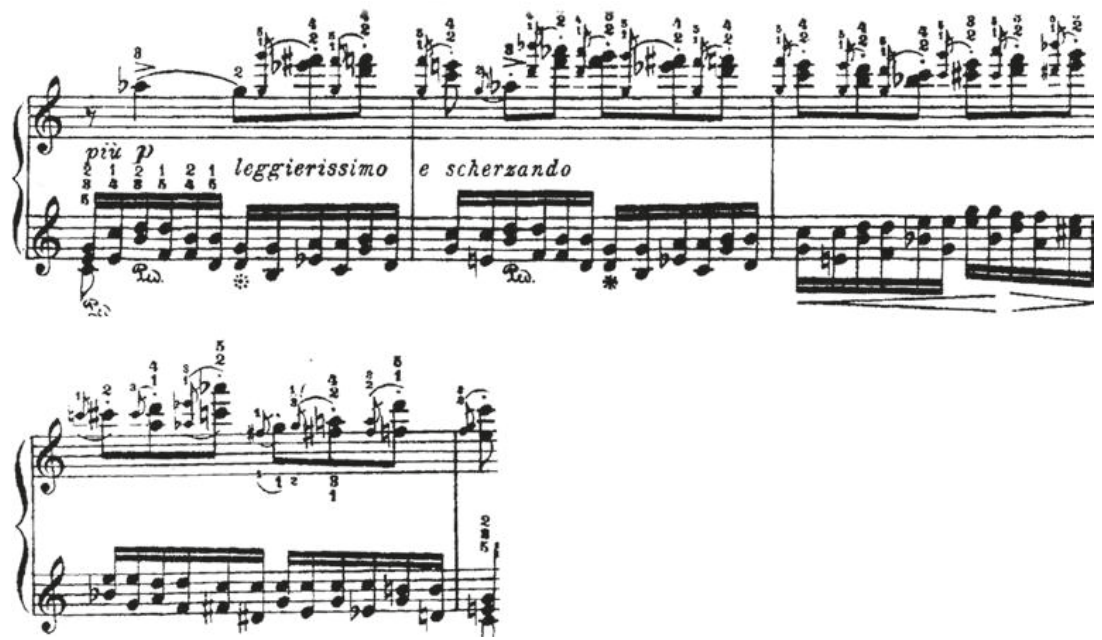

Example 9. F. Chopin - L. Godowsky, Etude [in C major], Op. 10 No. 7, Pfte, first version (New York: G. Schirmer, 1903), bars 9-13. 


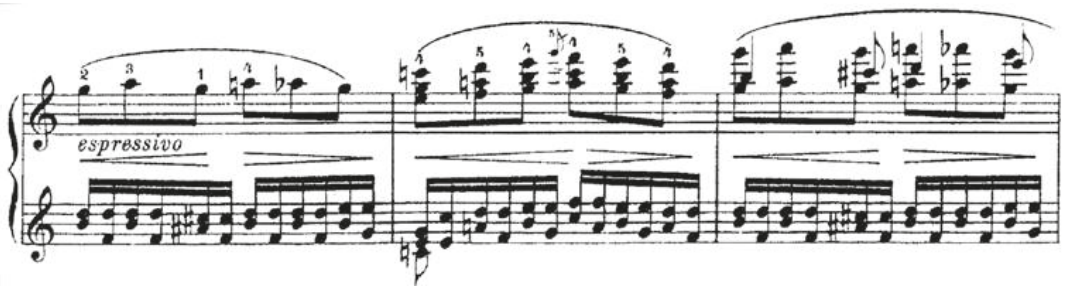

Example 10. F. Chopin - L. Godowsky, Etude [in C major], Op. 10 No. 7, Pfte, first version (New York: G. Schirmer, 1903), bars 45-47.

In bars 9-13 (Example 9), Godowsky sharpens the stepwise motif $\alpha$, particularly its 'leading notes', presented here in the form of grace notes. So while in the opening segment (bars 1-8) Godowsky drowns out the 'bass' layer, he subsequently (bars 9-16) brings out its original contour from the dense sound, while at the same time splitting its basic motif $\alpha$ between registers.

Hidden variants of Chopin's motifs.

The linear 'soprano' fourth motif $\beta$ in Godowsky's version is all but nonexistent. It is hidden to the bounds of discernibility in the part of the left hand and played in the opposite direction to the original (descending). Its contour is now dominated by intervals of a third, second and fifth. Thus the rising linear fourth motif is altered to a falling passage motif, in which the fourth is treated on a par with the third and fifth (bars 1-15,34-40). In another section, it is present in its proper top layer, but loses there its linearity, becoming a vertical motif (bar 46). The musical material of the right hand in bar 46 may also be interpreted as the inversely realised middle layer of the original (Example 10).

This range of interpretations of what Godowsky is doing here points to his accordance with Chopin's motivic writing, which he nevertheless refashions in many ways. In neglecting motif $\beta$, he also alters the vertical sixth-third motif $\gamma$, basing it mainly on intervals of a sixth and a fourth. And although those changes made it possible to retain the original harmonies, they weakened the motivic idiom of the original considerably. In bars 17-29 (Example 11), Godowsky emphasises different members of the original chords, also employing notes not present in the Chopin (e.g. in bar 17 the note $g$ sharp; in bar 20 the notes e flat and c sharp; in bar 21 e sharp; in bar 22 blat, a flat and $e$ sharp). He also transfers notes of the 'soprano-alto' layer to the 'bass' layer (bars 17-21, top voice). One example of his use of a 'hidden variation of Chopin's motif' covers bars 15-33.

The overriding principle behind Godowsky's work is 'total inversion', upending the original arrangement of the layers, the interval patterns and the model of the 

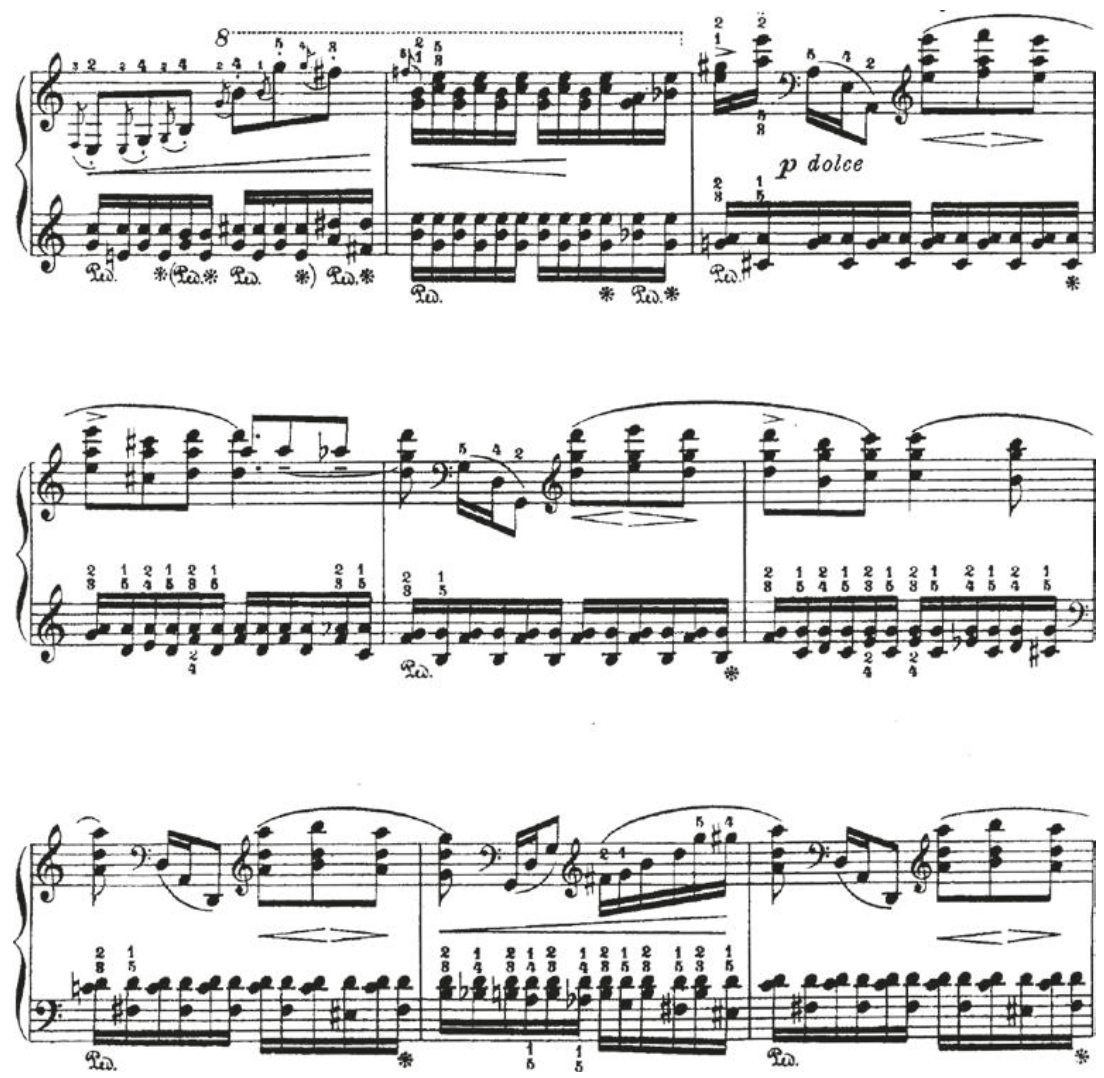

Example 11. F. Chopin - L. Godowsky, Etude [in C major], Op. 10 No. 7, Pfte, first version (New York: G. Schirmer, 1903), bars 15-23.

chords, but retaining the formal outline of the original. The design of this adaptation of the Etude in C major, Op. 10 No. 7 reflects the type of texture with a change to the arrangement of the layers, since there is no new independent layer here, but only those which appear in the original. This example is not (as Godowsky himself relates) a pure translation or transcription (Reine Transkription), but rather an extensive writing-out and composing-out of the original (see Example 11).

Since Godowsky preceded his voluminous collection with a lengthy commentary, we can and ought to refer to it. Example 11 shows his different understanding of the term Reine Transkription, not corresponding to our 'substantial transcription'. It would appear that its form can be explained not in terms of 
composition technique, but above all with regard to pianistic rendition. There are distinct technical considerations here: the octaves in the right hand and the twonote chords in the left. Particularly accentuated is the question of increasing the left hand's skill in the quick execution of two-note chords (the lower members of which are of primary importance), based on small values. The motoric character of this arrangement, resulting from the constant semiquaver pulse, is signalled in the very title: Toccata.

Godowsky assigned his second version of the Etude in C major (in the key of G flat major), Op. 10 No. 7 to the group of arrangements combining Cantus Firmus = Bearbeitungen with Metamorphosen. New elements here, immediately noticeable, are the slowing of the tempo (from Vivace to Allegretto espressivo) and the transposition of the whole piece to the key of $\mathrm{G}$ flat major. Referring to the three motifs on which the original is built, one should state that Godowsky retains the original motivic writing: the linear 'bass' second motif $\alpha$, the linear fourth motif $\beta$ and the vertical sixth-third motif $\gamma$, the most important being motif $\beta$. This arrangement is based on both of the fundamental layers of the original: the 'soprano-alto' and the 'bass'. Godowsky subjects them to textural procedures: transmission, multiplication and switching their relative positions. These layers are also modified in terms of intervals and rhythm. In the linear and vertical intervallic contour, we often encounter inversion.

The switching of the textural (sound) layers in terms of their relative positions occurs in several sections (Example 12). The register of the 'soprano-alto' layer is transferred to the lowest layer (bars $1-8,23-25,38-48,52-55$ ) or the middle layer (bars 16-21, 29-34, 37). In some bars, certain pitches are altered slightly, although with no change of harmony. The original 'bass' layer based on the second motif $\alpha$ is moved above the 'soprano-alto' layer (bars 1-8); it is the middle layer in the three-layered construction (bars 9-14) and most often the bottom voice.

The multiplication of sound layers is a basic textural procedure. The composing-out of the 'bass' layer resulted in the appearance of a third layer in the bottom voice of the transcription (bars 7-8, and especially distinct in bars 9-16). This layer is forged from a constantly repeated two-note unit comprising the root of the dominant and the root of the tonic in the key of $\mathrm{G}$ flat major. In this simple way, the two textural layers are multiplied into three. And although the multiplication is clear in the notation, in performance it is perceived as a strengthening of the top 'soprano-alto' layer. The multiplication looks much more interesting in bars 16-21 and 29-34 (Example 13), generating the textural layer in the top voice. This is of a complementary character and is based on the three familiar motifs. In bars 37-48, meanwhile (Example 14), although the composer introduces a new layer, which clearly refers to the 'soprano-alto' layer, he also abandons the 'bass' 

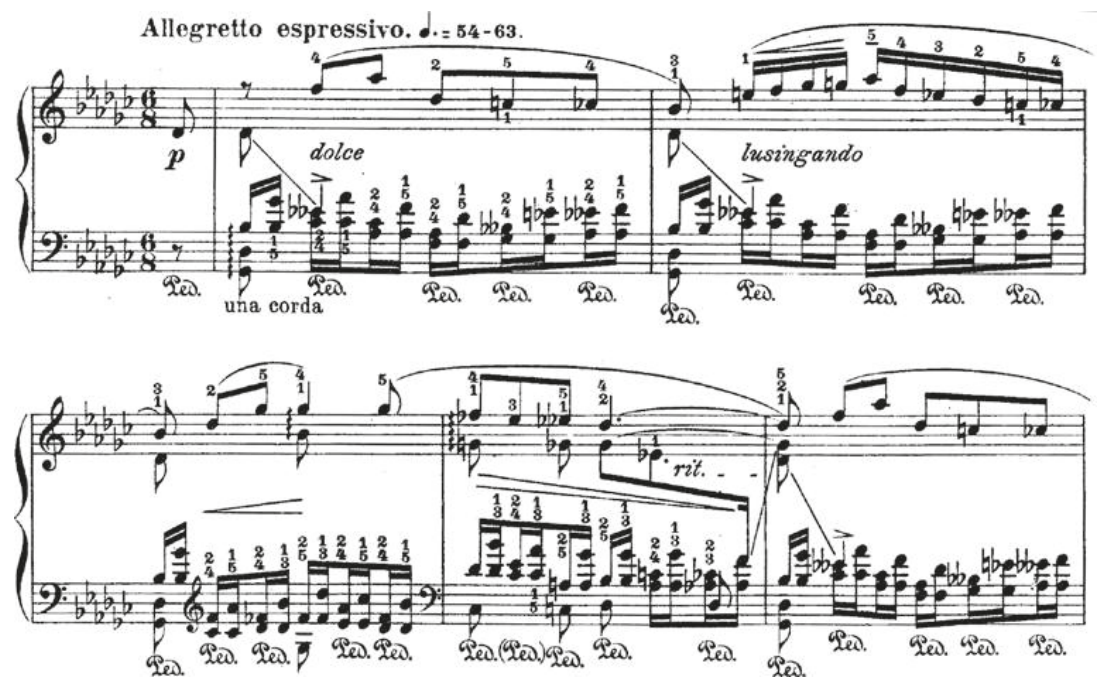

Example 12. F. Chopin - L. Godowsky, Etude [in C major], Op. 10 No. 7, Pfte, second version (New York: G. Schirmer, 1903), bars 1-4.

layer. So this is an example not of multiplication, but of transmission, combined with the considerable modification of the original material. This new layer is intervallically altered in relation to its related 'soprano-alto' layer; its contour is inverted, with a leap down instead of up (bars 40-45).

The intervallic and rhythmic modification of Chopin's motifs leads to the existence in the transcription of two kinds of motif: 'distinct' and 'hidden. The 'distinct motifs' are arrangements of $\beta$ and $\gamma$. Over the course of almost eight bars (bars 1-8), the left hand of the adaptation is based on the original 'soprano-alto' layer, merely transposed to the new key of $G$ flat major. Here too the mutually dependent motifs $\beta$ and $\gamma$ remain in the original order, that is, in two-part writing, where the upper voice is based on a semiquaver fourth motif and the lower voice moves in smaller steps (cf. Example 12). In bars 8-16, the 'sopranoalto' layer returns to its proper position: it is performed above the 'bass' layer. Yet here it is modified, with the hierarchy between its two component parts inverted (Example 15). Thus the voice built by motif $\beta$ appears beneath the voice that supports it, and together they give the modified motif $\gamma$. These changes stabilise the top voice in intervallic terms, through the abandonment of leaps of a fourth, and that voice is now based on the repetition of selected notes. In this way, Godowsky revises the textural arrangement of the original, interfering more 

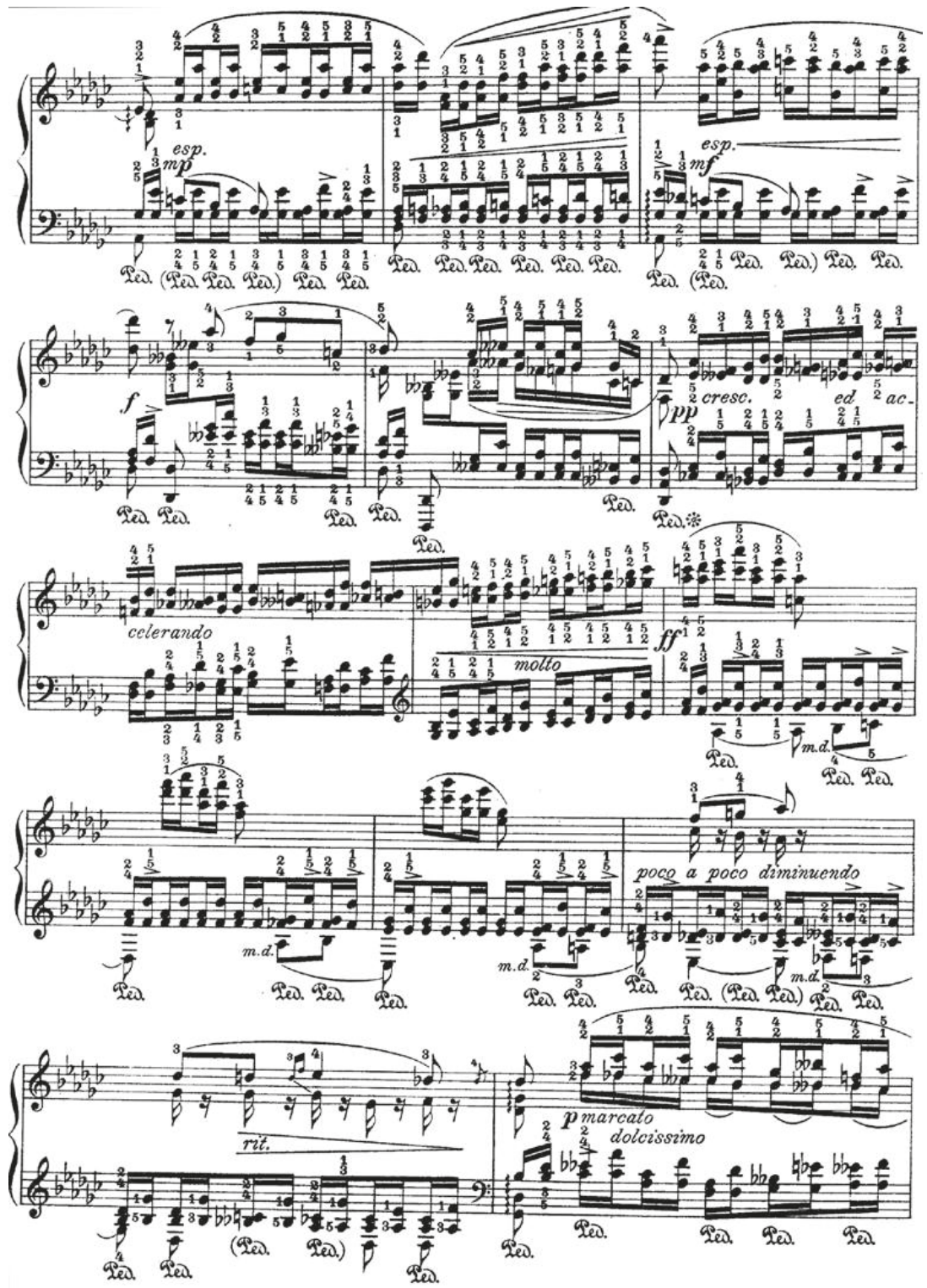

Example 13. F. Chopin - L. Godowsky, Etude [in C major], Op. 10 No. 7, Pfte, second version (New York: G. Schirmer, 1903), bars 21-34. 

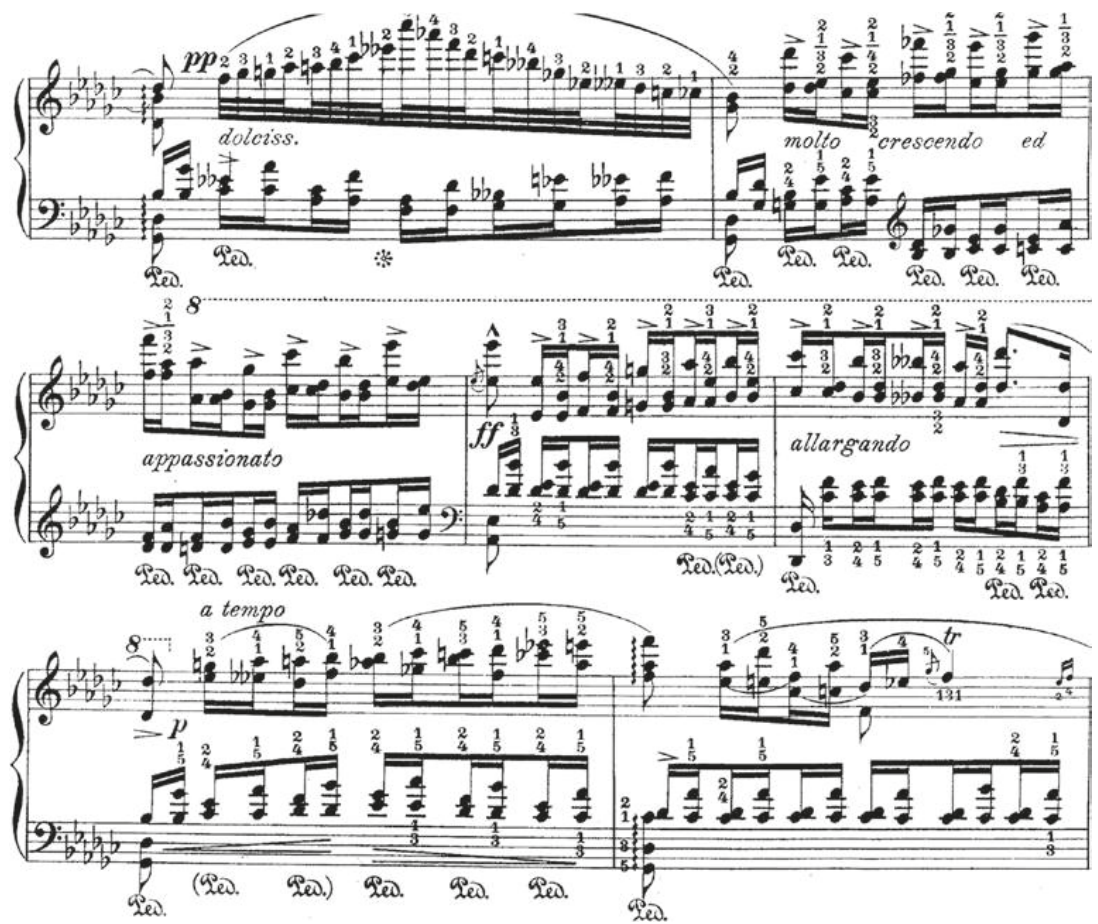

Example 14. F. Chopin - L. Godowsky, Etude [in C major], Op. 10 No. 7, Pfte, second version (New York: G. Schirmer, 1903), bars 39-45.

deeply - in the construction of a single layer. In addition, the textural changes are accompanied by rhythmic modifications, involving the use of an irregular division (triplets in bar 14).

The 'hidden motifs' concern modifications of motif a (cf. Example 13), variants of which appear throughout almost the whole transcription (bars 1-13 with added notes; 16-21, 29-34 in inversion). Improvised passages are frequently used. They are dominated by semiquaver motion based on the motivic writing of the 'soprano-alto' layer (e.g. in bars 48-51), with the original harmonic plan retained (Example 16). Since our three motifs are strictly linked to the textural layers, on the strength of the above ordering we may state that the constant in this adaptation is the 'soprano-alto' layer. It is retained in a distinctly recognisable form, such that it constitutes a specific cantus firmus in this new composition. 


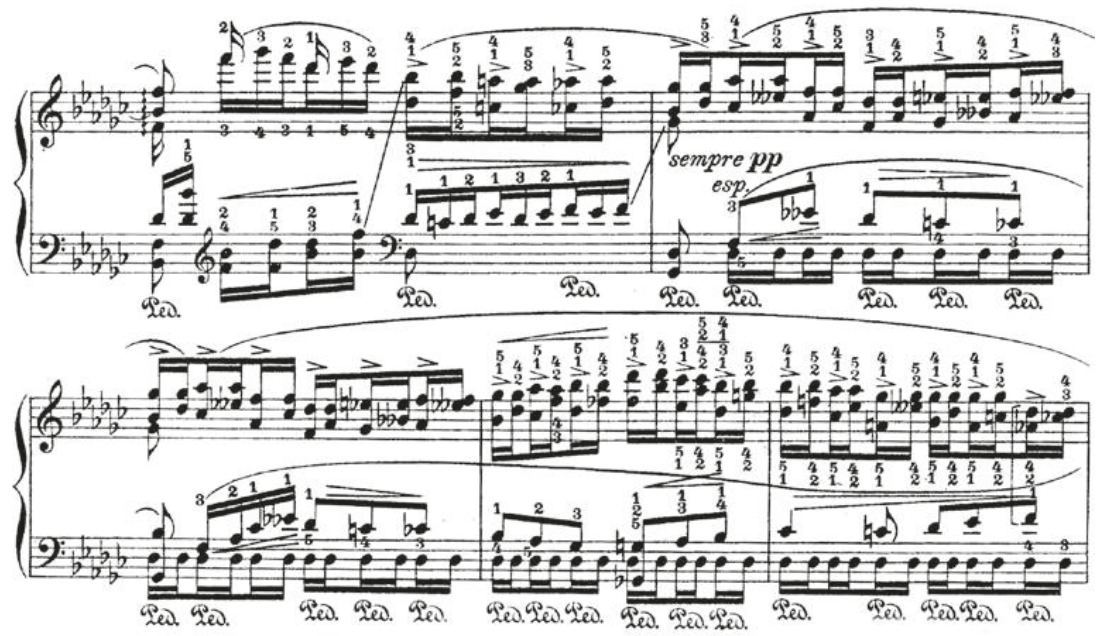

Example 15. F. Chopin - L. Godowsky, Etude [in C major], Op. 10 No. 7, Pfte, second version (New York: G. Schirmer, 1903), bars 8-12.
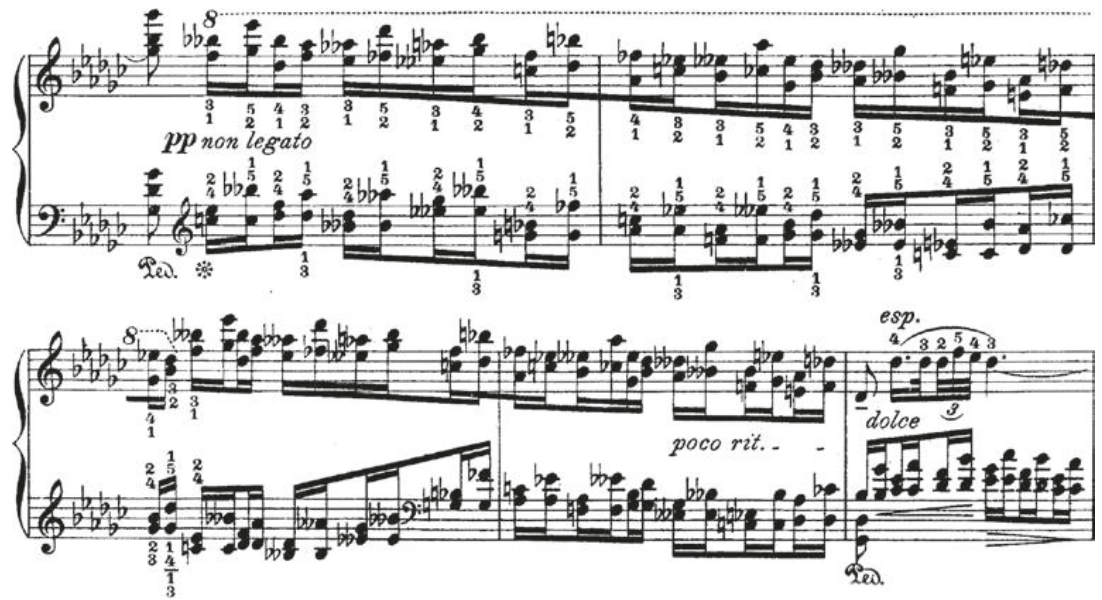

Example 16. F. Chopin - L. Godowsky, Etude [in C major], Op. 10 No. 7, Pfte, second version (New York: G. Schirmer, 1903), bars 48-52. 


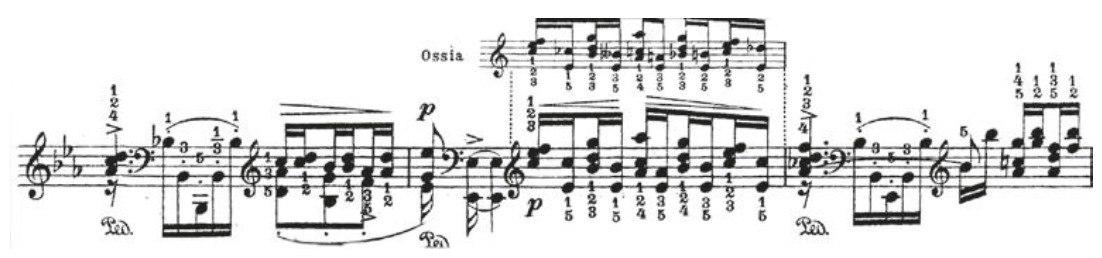

Example 17. F. Chopin - L. Godowsky, Etude [in C major], Op. 10 No. 7, Pfte, third version (New York: G. Schirmer, 1903), bars 43-45.

The new layers are also clearly based on motifs $\beta$ and $\gamma$. Thus Godowsky reversed the order existing in the original, hiding motif $\alpha$ and foregrounding the linear motif $\beta$. Quite remarkable here is how he derives a new figure, characterised by a calm, undulating and pulsating melody, from the motoric figure of the original. This redefining of Chopin's figures, abandoning the motoric element in favour of the melodic, is favoured by a whole range of procedures: the subdivision of rhythmic values (e.g. bars $2,39,46)$, the use of irregular divisions (e.g. bars 6-8), numerous ornaments (grace notes, trills, arpeggios) and less often dotted rhythms (bar 7). The slowing of the tempo and the change of key to G flat major also fundamentally altered the character of the new composition, which Godowsky called a Nocturne. In his arrangement, there is a clear qualitative change to the texture, resulting from its expansion and from the switching of the arrangement of the textural layers. So, according to our systematics, this arrangement should be assigned to the structural group of a diffusive character.

Godowsky also produced a third version of the Etude in C major (in E flat major), Op. 10 No. 7, which he scored for left hand only. Thus his work involved adapting the original to a new performance texture. Generally retained were the original quantity and disposition of the sound layers. Even in the three-layered passage (bars 44-47), we find a middle sound layer (Example 17). Godowsky based his arrangement on three motifs $\alpha, \beta$ and $\gamma$, which he modified to varying degrees. The 'distinct motifs' in this etude are transformations of Chopin's motif $\beta$. Of its original structure, Godowsky left the top notes, although they are not reached by leaps of a fourth. In this way, he derived a melody based on intervals of a second and a third from a linear fourth motif (e.g. bars 1-4, Example 18). This way of proceeding was clearly imposed by the performance apparatus and the wish to remain faithful to Chopin's harmonic writing. And it would seem that as a result of such changes the original motif $\gamma$ has no raison dêtre. Yet it does exist; it is still often based on intervals of a third and a sixth, although other intervals do occur. Its basic feature - a two-note unit - consistently reappears throughout 


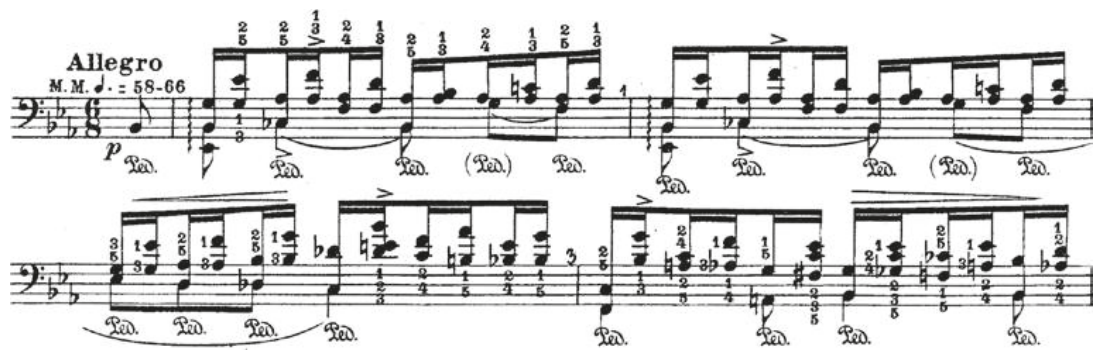

Example 18. F. Chopin - L. Godowsky, Etude [in C major], Op. 10 No. 7, Pfte, third version (New York: G. Schirmer, 1903), bars 1-4.

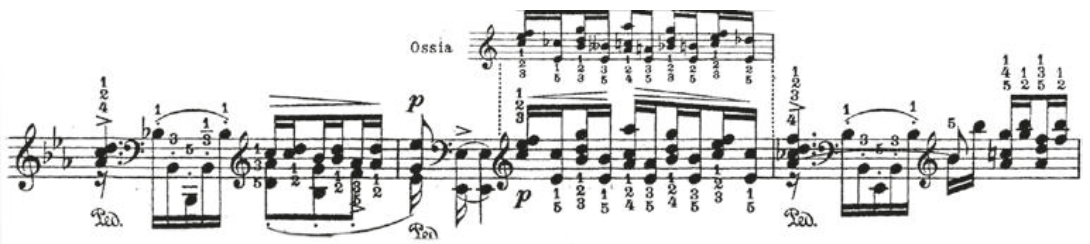

Example 19. F. Chopin - L. Godowsky, Etude [in C major], Op. 10 No. 7, Pfte, third version (New York: G. Schirmer, 1903), bars 43-45.

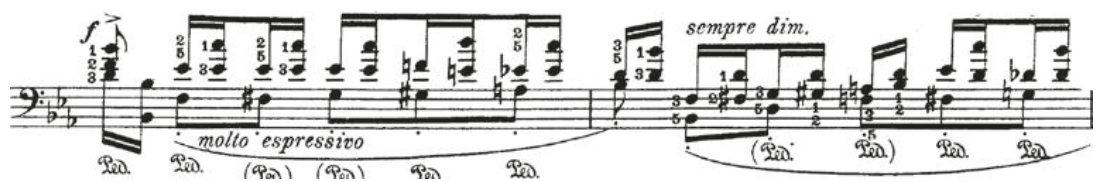

Example 20. F. Chopin - L. Godowsky, Etude [in C major], Op. 10 No. 7, Pfte, third version (New York: G. Schirmer, 1903), bars 29-30.

the arrangement. In bar 44 (Example 19), motif $\beta$ is based on an inverse treatment of the interval (leaps down instead of up) and a rearrangement of successive notes - now those which form that new melody fall on the strong beat in a rhythmic group.

The arrangement of the 'bass' layer motif is of the 'hidden motif' kind. It is presented in a fragmentary form (bars 1-4, cf. Example 18) or a more developed, chromaticised form (bars 29-30, cf. Example 20). Godowsky classified this arrangement as a Freie Transkription, in which the text is freely arranged (in 
freier Behandlung). And that is indeed the situation here, while the syntax, form and harmonic outline of the original are retained. The aim of this transcription was precisely stated as a study for the left hand, and all the modifications of the original material served that end. While the use of a slower tempo (Allegro) is understandable, the purpose of the change of key from $\mathrm{C}$ major to $\mathrm{E}$ flat major is less clear. The need to adapt the original to the performance capabilities of the pianist's left hand caused numerous alterations to the musical substance - the change of interval structure in the motifs, the introduction of numerous notes that are foreign to Chopin's version and the foregrounding of the 'soprano-alto' layer. These changes resulted in a qualitative change to the original, which ultimately enabled this adaptation to be assigned to the subtype expanding the texture.

One invariable feature of these three arrangements of Chopin's Etude in C major, Op. 10 No. 7 is the retention of the formal and harmonic outline of the original. Yet in each of them we find different ways of revising the original. Their classification in the textural type was determined by the features described above: the expansion of the texture or (and) the rearrangement of the textural (sound) layers. The expansion of the texture was linked to the extension of the sound field (compass), with a rise in the overall volume, as a result of the consistent increasing of notes, and also to multiplication, to an increase in the number of sound layers. The switching of the sound layers, which may be defined as a switching of plans, occurred in the first two arrangements. The idea for the first study was to strengthen the motoric element, which gave rise to the Toccata. In the second study, the overriding element was melody, tunefulness and a smooth flow, aimed at obtaining a nocturne character. In the third study, Godowsky placed the emphasis on the technical element, enhancing the proficiency of the left hand and the considerable chromaticisation of the sound material. So a qualitative change to the original was made in each of the adaptations, as a result of the drawing out and strengthening of its latent textural possibilities.

Summing up the results of the analysis of selected structural transcriptions, attention should be drawn to several laws that govern them. As in the substantial group, arrangers transmit and multiply the sound layers derived from the original material. Yet that original material (motifs, sentences) undergoes much more serious modifications than with the substantial type. They are of a structural nature, since they determine connections occurring over a limited space and direct our attention to the actual creation of the work. ${ }^{340}$ Such a shape to the

340 I invoke here the definition of Carl Dahlhaus, 'Form', 260-261. 
arrangements was achievable thanks to the outstanding skills of the arranger. $\mathrm{He}$ proceeded much more boldly with Chopin's original, making textural changes to its musical substance: to the melody, rhythms, dynamics (in this case strictly related to the volume of sound), articulation, agogics and harmonies. The melody underwent colouristic changes, as a result of its shifting to distant registers; it also altered its intervallic structure as a result of numerous modifications to its underlying motifs. The rhythm often underwent subdivision and irregular divisions, whilst the articulation and, in particular, the agogics introduced an additional possibility for making considerable changes to the original. The harmonic modifications did not alter the functional outline of the original, but they did enrich it considerably, thanks to the chromaticisation of the sound material and its multiplication. All these changes resulted from a wish to introduce considerable technical complications in each of the transcriptions, which not without reason were defined as studies for piano.

\subsection{Syntactic transcriptions}

The third group contains transcriptions in which composers made changes to the musical syntax. According to Maciej Gołąb, author of the present systematics, 'the scope of the changes in [...] a syntactic transcription also extends to some elements of musical syntax, although not to an extent that would violate the work's formal identity. This means that although secondary elements of musical syntax may be either removed or more or less modified (transformed) in a replica thus conceived, its basic thematic substance, the order in which the musical ideas occur, must be preserved intact, in accordance with the work's formal disposition. Yet the scope of changes of a syntactic character is something more than an ordinary arrangement (transcriptio): it is the start of the work's formal transformation (transformatio). ${ }^{341}$ The elements of syntax which possess secondary formal significance comprise the following: the introduction or elimination of repeats, introductions, virtuosic cadenzas or 'other interpolations of formal musical categories. ${ }^{342}$ We distinguish two subgroups of syntactic transcriptions: transcriptions which reduce the original musical syntax and transcriptions which expand the original musical syntax. In the former type, we most often notice the elimination of repeats of musical sentences; in the latter type, the expansion of motifs and sentences. In order to confirm the actual

341 Gołąb, Dziewiętnastowieczne transkrypcje, 31.

342 Ibid. 
existence of the syntactic type, the analytical material presented here is quite extensive. The aim of these analyses is first and foremost to present the ways in which the original musical syntax is transformed (curtailed or extended), and also the ways in which the musical texture and substance are modified. Whilst the cornerstone of a syntactic transcription is a change of syntax, it may (but need not) be accompanied by modifications of texture and substance. As in the analyses conducted hitherto, the order to the transcriptions discussed is conditioned by their dates; they are arranged in historical, diachronic sequence. In this way, our morphological analysis is ordered by the historical factor and, inasmuch as available examples allow, the generic factor.

The present discussion will deal first of all with musical syntax and indirectly with form. The working method will involve primarily comparing the structural schema of the transcription with that of Chopin's original. The method of analysis was based on a traditional theoretical concept of form. The proposed structural schemata will comprise the musical syntax, distinguished by a suitable number of musical sentences, and the musical form, integrating component parts on a higher level. ${ }^{343}$ The task of the indicated 'tonal plan' is merely to highlight the chords which form the axis of harmonic sequences in a particular section. Hence it does not include the whole harmonic wealth of the originals and the adaptations. This mode of presentation characterises the discussion of the syntactic and formal groups. Besides the primary task, which is to indicate syntactic differences between the transcription and the original, we will also profile the musical substance and the texture. This method of analysis will create a full picture of the transcriber's work. The examples given below will show changes to the musical syntax of the original. ${ }^{344}$

The Waltz in D flat major, Op. 64 No. 1 has been transcribed many times. Martin Roeder produced a version for soprano and piano. ${ }^{345}$ In order to present

343 Unlike syntax, form imparts a formal function to musical entities, turning them into themes, ideas, refrains, episodes, bridges, etc.

344 F. Chopin - M. Roeder, 'Amorettenreigen' - Waltz [D flat major], Op. 64 No. 1, voice+Pfte,

F. Chopin - E. Rohde, 'Piosnka litewska' [Lithuanian Song], Op. 74 No. 16, Pfte, F. Chopin - R. Hasert, 'Leci liście' [Leaves are Falling], Op. 74 No. 17, Pfte.

345 Published by Bote \& Bock of Berlin in 1888, dated after Deutsch, 9. Roeder wrote the music and the words, translating an Italian text by Zanardini into German and altering the original title 'Ridda d'Amorini' to 'Amorettenreigen'. 
Schema 1: Structure of the original composition: F. Chopin, Waltz in D flat major, Op. 64 No. 1.

\begin{tabular}{|c|c|c|c|}
\hline Form & A & $\mathrm{B}$ & A \\
\hline Syntax & $a \quad a_{1} \quad b_{(a)} b_{(a)}$ & $c c_{1}^{\prime} c^{\prime} c_{2}$ & a' $a^{\prime} \quad a_{1} \quad b_{(a)} b_{(a)}^{\prime} b_{(a)} b_{(a)}^{\prime}$ \\
\hline Number of bars & $48+8 \quad 8 \quad 8$ & 8888 & $\begin{array}{lllllll}4 & 4 & 8+8 & 8 & 8 & 8 & 8\end{array}$ \\
\hline Tonal plan & D flat major & D flat major & D flat major \\
\hline
\end{tabular}

Schema 2: Structure of the transcription: F. Chopin - M. Roeder, Waltz in D flat major, Op. 64 No. 1.

\begin{tabular}{|c|c|c|c|}
\hline Form & A & B & A \\
\hline Syntax & $\mathrm{a} \quad \mathrm{a}_{1} \mathrm{~b}_{(\mathrm{a})} \mathrm{b}_{(\mathrm{a})}{ }^{\prime} \mathrm{b}_{(\mathrm{a})}{ }^{\prime}$ & $c c_{1}^{\prime} c^{\prime} c_{2}$ & $\begin{array}{llll}\text { a' a } & a_{1} & b_{(a)} & b_{(a)}^{\prime} \\
b_{(a)}\end{array}$ \\
\hline Number of bars & $\begin{array}{llll}48+8 & 8 & 8 & 8\end{array}$ & 8888 & $\begin{array}{llllll}4 & 4 & 8+8 & 8 & 8 & 8\end{array}$ \\
\hline Tonal plan & D flat major & D flat major & D flat major \\
\hline
\end{tabular}

the modification of the syntax, we must look at the syntactical-formal scheme of the original Waltz in D flat major (Schema 1).

Roeder reduced the syntax by the eight-bar sentence $b_{(a)}$ ' in both sections A. So altogether he omitted sixteen bars, although that enabled him to retain the structure of the original (Schema 2). Interesting here is the part of the soprano solo voice. As the melodic line of the original was difficult to sing, the arranger added a melody based on foreign notes preceding members of Chopin's chords. In this transcription, we find the interpolation of the original musical text, since it is retained in its entirety, and only its significance was altered, as a result of the addition of vocal improvisation and the introduction of a verbal text (Example 21). This change of semantic context is reinforced by the marking con grazia and the omission of the tempo marking. This is a principle similar to that in the Bachian literature, when Charles Gounod added his own melody to J. S. Bach's Prelude in $\mathrm{C}$ major. And if we removed the vocal layer from Roeder's transcription, we would obtain Chopin's original with minimal substantial modifications (no trill on the first note in bar 1) and a reduction of the syntax (Example 21).

The second subgroup of syntactic transcription consists of arrangements in which the original musical syntax is expanded. Eduard Rohde's arrangement of the 'Piosnka litewska' [Lithuanian Song] differs only minimally from the 

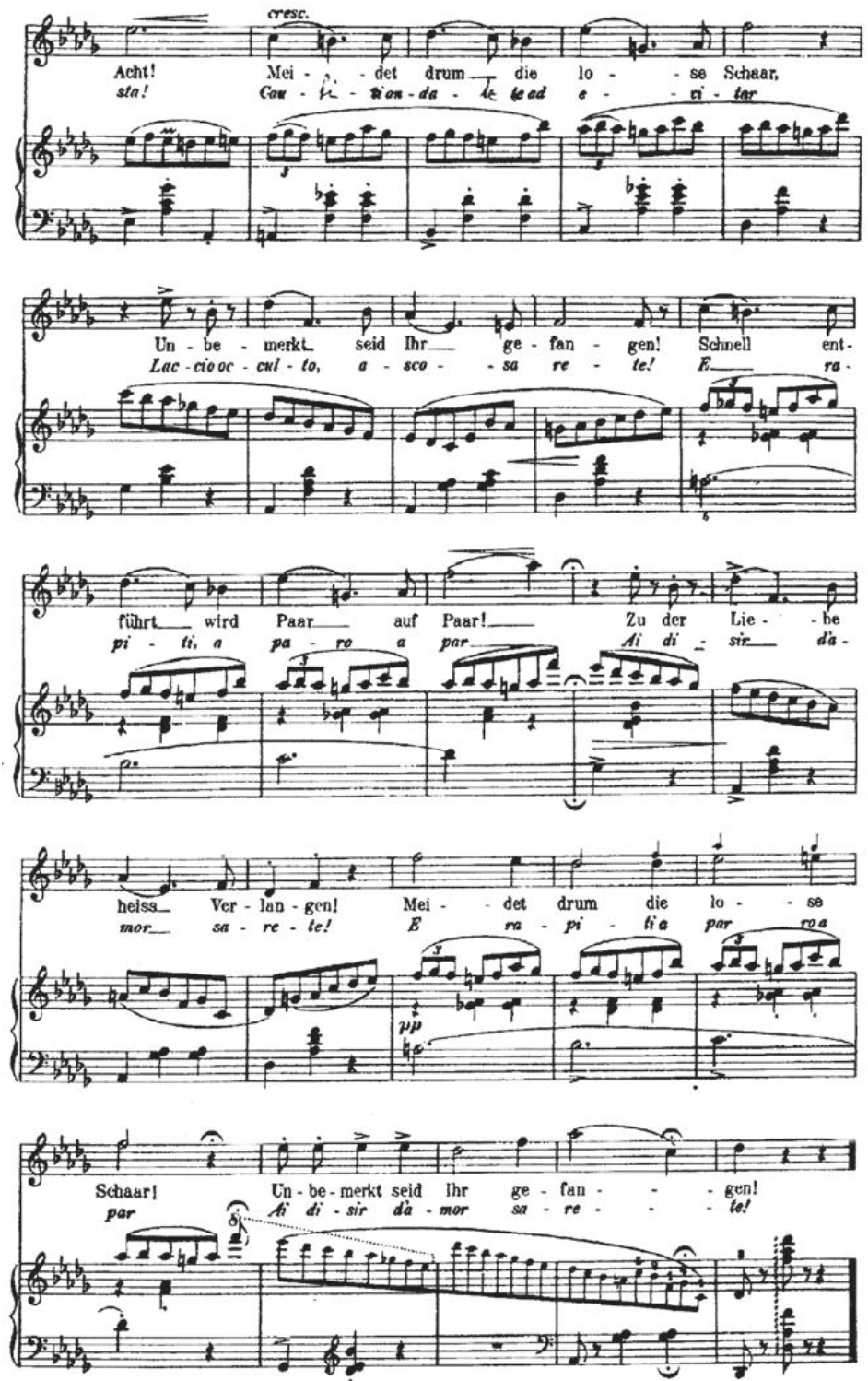

Example 21. F. Chopin - M. Roeder, 'Amorettenreigen' - Waltz [in D flat major], Op. 64 No. 1, voice+Pfte, German text M. Roeder (Berlin: Bote \& Bock, 1888), bars 100-125. 
Schema 3: Structure of the original composition: F. Chopin, 'Piosnka litewska' [Lithuanian Song], Op. 74 No. 16.

\begin{tabular}{llllll}
\hline Form & introd. & A & B & $A^{\prime}$ & coda \\
Syntax & $\mathrm{a}$ & $\mathrm{b} \mathrm{b}$ & $\mathrm{cd} \mathrm{e}$ & $\mathrm{b} \mathrm{b}^{\prime}<$ & $\mathrm{a}^{\prime}$ \\
Number of bars & 6 & 44 & 684 & 47 & 5 \\
Tonal plan & F major & F major & D minor - & F major & F major \\
& & & A minor - & & \\
& & C major & & \\
\hline
\end{tabular}

Schema 4: Structure of the transcription: F. Chopin - E. Rohde, 'Piosnka litewska' [Lithuanian Song], Op. 74 No. 16.

\begin{tabular}{llllll}
\hline Form & introd. & A & B & $A^{\prime}$ & coda \\
Syntax & $\mathrm{a}$ & $\mathrm{b} \mathrm{b}$ ': & $\mathrm{c} \mathrm{d} \mathrm{e}$ & $\mathrm{b} \mathrm{b}^{\prime}<$ & (a) \\
Number of bars & 6 & 44 & 684 & 47 & 6 \\
Tonal plan & F major & F major & $\begin{array}{l}\text { D minor }- \\
\text { A minor }-\end{array}$ & F major & F major \\
& & & C major & \\
\hline
\end{tabular}

structure of the original (Schema 3). ${ }^{346}$ It is expanded in syntactic terms in its closing section by just a single bar (Schema 4 ).

The fundamental difference between this transcription and the original involves the introduction of passagework in both plans, the acceleration of the movement through the use of semiquaver groups, the use of a broad compass, with a tendency for frequent successions of distant registers, the increase in the number of notes in chords and the presence of a short virtuosic cadenza. These features determine the character of this transcription as a concert work, rendered more difficult in its musical material (Example 22). The aim of invoking this example is to draw attention to the difference in the approach to syntax, which depends to a considerable extent on the forces of the original. In most instances, Chopin's original is scored for piano, and only the songs and a few other compositions are based on different forces. When Chopin's piano original was transcribed for different forces (violin, voice or flute with piano accompaniment), we most often note the addition of an introduction and the expansion of the coda or cadence. Where a song is transcribed and its original forces reduced

346 Published by A. M. Schlesinger of Berlin in 1874. Dated after Deutsch, 22. 

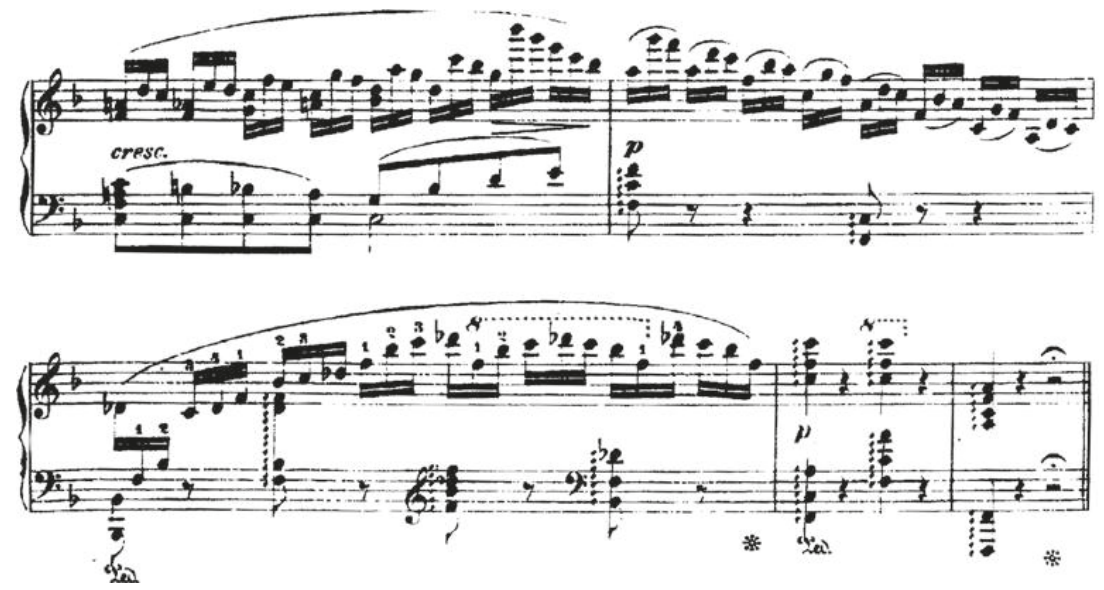

Example 22. F. Chopin - E. Rohde, 'Piosnka litewska' [Lithuanian Song], Op. 74 No. 16, Pfte (Berlin: A. M. Schlesinger, 1874), bars 44-48.

to a single instrument, namely, piano, it turns out that the transcriber's work concerns above all the actual musical substance, as well as the disposition and number of sound layers and, to the least degree, the syntax, since the lack of a second performer obviates the need for an introduction. A slightly different task is fulfilled by the coda, the dimensions of which may increase, out of a desire for dazzling display. Yet although this is characteristic of the above arrangements, it cannot be transferred to all piano arrangements of songs.

Evidence to that effect is provided by a concert version (zum Conzertvortrag) of the song 'Leci liście' [Leaves are falling], Op. 74 No. 17 for piano by Rudolf Hasert (Example 23). ${ }^{347}$ Its formal disposition accords with the original (Schemata 5 and 6), but the transcriber makes changes to the syntax, extending each section, repeating and expanding the musical sentences (Schemata 7 and 8). $\mathrm{He}$ also employs other quantitative, and by the same stroke qualitative, proportions, foregrounding section $\mathrm{A}$, the content of which is also the basis for the elaborate coda (Example 24). The expansion of the syntax is accompanied by variation technique, concerning basic elements, one of the most important of which is the rhythm, which gains new motifs: [1] a demisemiquaver motif (bars 7-16, 56-70, 143-150); [2] a triplet-quaver and semiquaver motif (bars 37-47, 82-88, 90; bars $17,68-69,98-106)$. These rhythmic modifications are accompanied by

347 Published by A. M. Schlesinger of Berlin in 1861. Dated after Deutsch, 22. 


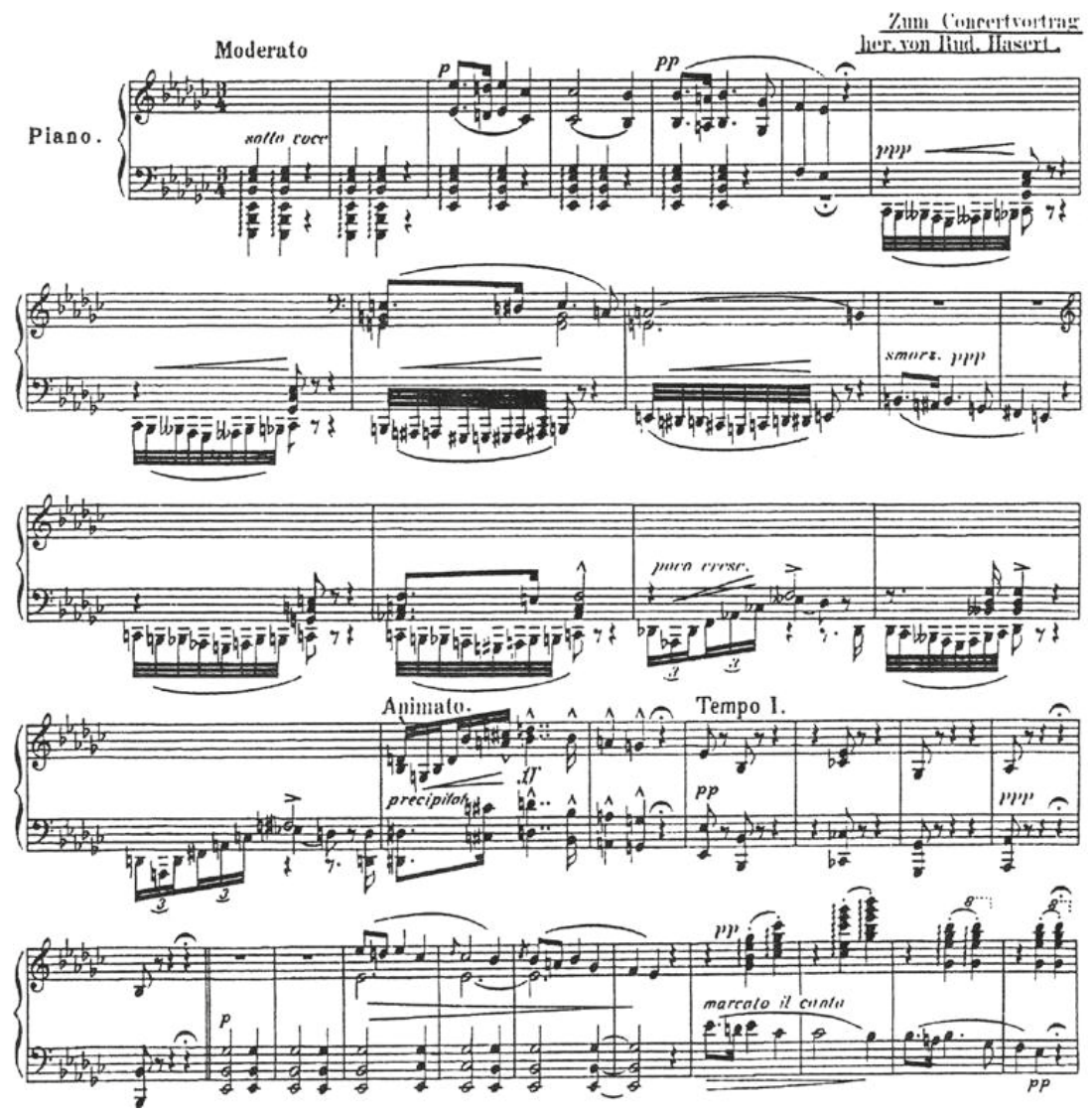

Example 23. F. Chopin - R. Hasert, 'Leci liście' [Leaves are Falling], Op. 74 No. 17, Pfte (Berlin: A. M. Schlesinger, 1861), bars 1-34.

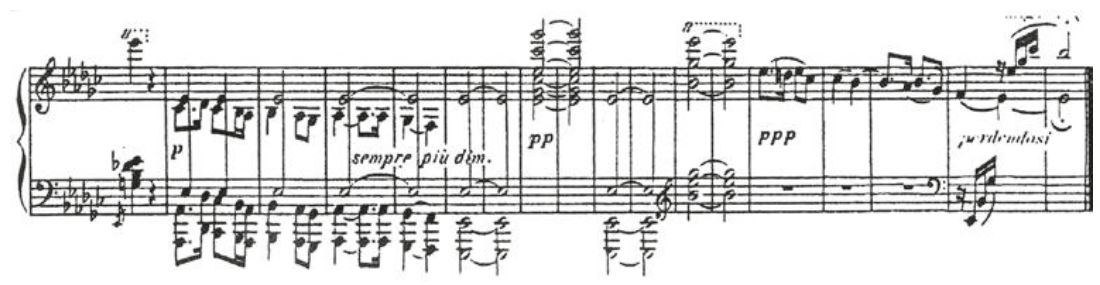

Example 24. F. Chopin - R. Hasert, 'Leci liście' [Leaves are Falling], Op. 74 No. 17, Pfte (Berlin: A. M. Schlesinger, 1861), bars 159-176. 
melodic changes: the chromaticisation of the material in the demisemiquaver bass figure and passagework in the triplet passages. Also significant for Hasert is the colouristic element, as is evident in the frequent changes of register and the expansion of the compass of the sound material. This is accompanied by the multiplication of notes, and thereby the augmentation of the sound mass. The frequently used arpeggiation also belongs to the colouristic, and at the same time articulatory, means (Example 25, bars 31-54). Hasert introduces many new terms, serving agogic-expressive differentiation (largamente, con anima, tranquillamente, precipitato, marcato il canto, un poco marcato, dramatico). Despite this accumulation of compositional means, the harmonic skeleton still agrees with the original. The only significant change, the reason for which is difficult to establish, is the different tonal relations between sections B and C, where instead of the key of $\mathrm{E}$ flat major we find B major.

Hasert also interferes in the textural domain, although this is largely based on the model existing in the original (the solo layer in the top voice and the

Schema 5: Structure of the original composition (abbr.): F. Chopin, 'Leci liście' [Leaves are Falling], Op. 74 No. 17.

\begin{tabular}{llllll}
\hline Form & A & B & C & B' & coda \\
Number of bars & 16 & 24 & 36 & 32 & 4 \\
\hline
\end{tabular}

Schema 6: Structure of the transcription (abbr.): F. Chopin - R. Hasert, 'Leci liście' [Leaves are Falling], Op. 74 No. 17.

\begin{tabular}{llllll}
\hline Form & A & B & C & B' & coda \\
Number of bars & 47 & 25 & 45 & 41 & 17 \\
\hline
\end{tabular}

Schema 7: Structure of the original composition (detailed): F. Chopin, 'Leci liście' [Leaves are Falling], Op. 74 No. 17.

\begin{tabular}{|c|c|c|c|c|c|}
\hline Form & $\mathrm{A}$ & $\mathrm{B}$ & $\mathrm{C}$ & $\mathrm{B}^{\prime}$ & coda \\
\hline Syntax & a a' a a' & $c c$ & e e $\mathrm{f}<$ & $b^{\prime}<c c$ & a \\
\hline $\begin{array}{l}\text { Number of } \\
\text { bars }\end{array}$ & 4444 & 88 & $10 \quad 88 \quad 4+4+2$ & $88 \quad 88$ & 4 \\
\hline Tonal plan & $\begin{array}{l}\text { E flat } \\
\text { minor }\end{array}$ & $\begin{array}{l}\mathrm{G} \text { flat major/E } \\
\text { flat minor }\end{array}$ & $\begin{array}{l}\text { E flat major - A flat } \\
\text { minor/E flat major - } \\
\text { A flat minor }\end{array}$ & $\begin{array}{l}\mathrm{G} \text { flat major/E } \\
\text { flat major - E flat } \\
\text { minor }\end{array}$ & $\begin{array}{l}\text { E flat } \\
\text { minor }\end{array}$ \\
\hline Metre & ${ }_{4}^{3}$ & ${ }_{4}^{2}$ & ${ }_{4}^{4}$ & ${ }_{4}^{2}$ & $\begin{array}{l}3 \\
4\end{array}$ \\
\hline
\end{tabular}



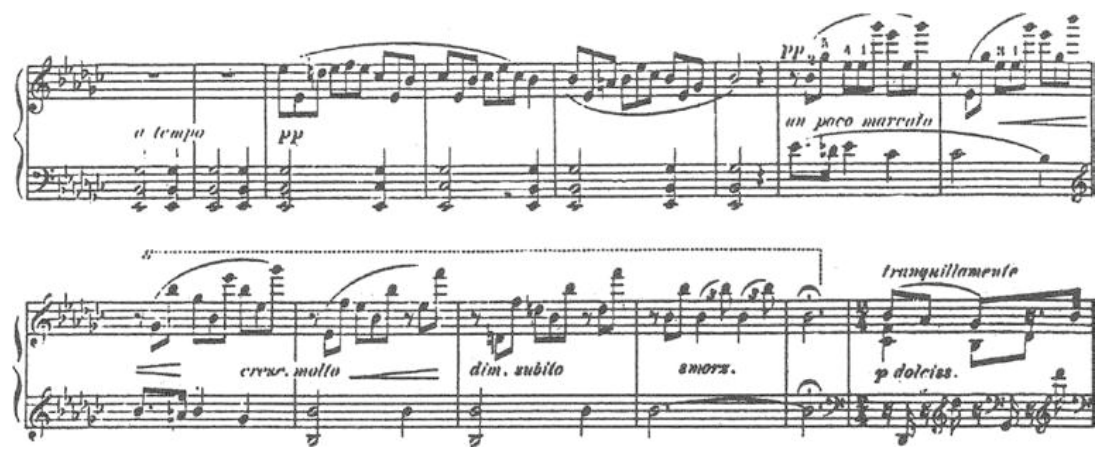

Example 25. F. Chopin - R. Hasert, 'Leci liście' [Leaves are Falling], Op. 74 No. 17, Pfte (Berlin: A. M. Schlesinger, 1861), bars 35-48.

accompaniment - Example 25). The change to this original order is particularly evident in section A (cf. Example 23, bars 1-47), where the 'functional' sound layers appear in different arrangements. These procedures are characteristic of concert arrangements of those times. So this is a virtuosic transcription, rich in performance difficulties (diatonic-chromatic passages, large interval leaps, a quick tempo in demisemiquaver passages), demanding an exceptionally proficient hand. This transcription is an example of the syntactic type expanding the syntax, on the borderline between syntactic and recontextual transcription. This group is highly diverse in terms of the quality of transcriptions and their intention. The cuts in the musical syntax usually involve relinquishing repeats of sentences in the original, resulting from different premises. They often concern popular compositions for voice and instrumental accompaniment (Roeder), but they also appear in highly professional, technically more difficult concert versions. Thus this group, although uniform in syntactic terms, is characterised by varying degrees of interference in the substance and the texture. A similar phenomenon occurs in the type expanding the syntax, where an introduction or coda is most often added. Less frequent is internal expansion, based on the repetition, or even the variation, of the original sentences.

In summing up the syntactic group, one should indicate the vast range of ways in which transcribers worked, their actions covering all the aspects of a musical composition (substantial and textural). Attempts to identify rules governing these arrangements have proved fruitless. Like the entire corpus of transcriptions, this one group is highly individualised, each example being unique of its kind. Yet the 
Schema 8: Structure of the transcription (detailed.): F. Chopin - R. Hasert, 'Leci liście' [Leaves are Falling], Op. 74 No. 17.

\begin{tabular}{|c|c|c|c|c|c|}
\hline Form & $\mathrm{A}$ & B & $\mathrm{C}$ & $\mathrm{B}^{\prime}$ & coda \\
\hline Syntax & (a) a' & c c' & d d' e e' f' & b b' c c' & a \\
\hline Number of bars & 2423 & 89 & $\begin{array}{lll}98 & 88 & 12\end{array}$ & $816 \quad 89$ & $12+5$ \\
\hline Tonal plan & $\begin{array}{l}\text { E flat } \\
\text { minor }\end{array}$ & $\begin{array}{l}\text { G flat major/E } \\
\text { flat minor }\end{array}$ & $\begin{array}{l}\text { B flat major - A flat } \\
\text { minor }\end{array}$ & $\begin{array}{l}\mathrm{G} \text { flat major/E } \\
\text { flat minor }\end{array}$ & $\begin{array}{l}\text { E flat } \\
\text { minor }\end{array}$ \\
\hline Metre & ${ }^{3}$ & ${ }_{4}^{2}$ & ${ }_{4}^{4}$ & ${ }_{2}$ & $\begin{array}{l}3 \\
4 \\
4\end{array}$ \\
\hline
\end{tabular}

systematics used in the present work is based on 'essential conditions', the existence of which enables us to set the material in order. One feature common to all transcriptions of the syntactic type is the curtailment or expansion of the syntax without the violation of the formal order of the original work.

\subsection{Recontextual transcriptions}

A change of form, equating to the destruction of the original context (formal unity) of the work, the redefining of its structural-architectural contour, is an 'essential condition' for assigning a transcription to the recontextual group. A recontextual transcription is 'a translation of a work in which the authentic formal coherence sanctioned by the sources is destroyed. ${ }^{348}$ It should be pointed out that 'the notion of form refers to the overall structural-architectural aspects of a work, in particular to the substantial integrity of fundamental categories of musical form, ${ }^{349}$ to its thematic layer. It goes without saying that all modifications of form result from far-reaching changes to the musical syntax. And as we found when analysing syntactic examples, that is not a mutual relationship: changes in syntax do not necessarily condition changes in form.

In the research material in our possession, we can distinguish two basic types of recontextual transcriptions characterised by a different way of interfering in the architectural structure of a work: its reduction or contamination. A basic tool for our considerations here will be comparative analysis of the structure of the original and of its successive transcriptions expressed in familiar schemata, and our analytical observations will be backed by musical examples. For the scope of architectural changes to be fully visible, the musical examples will be represented

348 Gołąb, Dziewiętnastowieczne transkrypcje, 34.

349 Ibid., 36. 
Schema 9: Structure of the original composition: F. Chopin, Nocturne in B flat minor, Op. 9 No. 1.

\begin{tabular}{|c|c|c|c|}
\hline Form & A & B & A \\
\hline Syntax & $\mathrm{ab}_{(\mathrm{a})} \mathrm{a}^{\prime} \mathrm{b}_{(\mathrm{a}) 1}{ }^{\prime}<$ & $c c_{1}^{\prime} c c_{1}^{\prime} d_{(c)} c_{1}^{\prime} d_{(c)} c_{1}^{\prime} e e_{1}$ & $\mathrm{a}^{\prime \prime} \mathrm{b}_{(\mathrm{a}) 1} "<$ \\
\hline $\begin{array}{l}\text { Number } \\
\text { of bars }\end{array}$ & $44 \quad 44+2$ & $\begin{array}{lllllll}44 & 44 & 4 & 4 & 4 & 4 & 109\end{array}$ & $46+6$ \\
\hline Tonal plan & $\begin{array}{l}\text { B flat minor - D flat major - } \\
\text { B flat minor }\end{array}$ & D flat major & $\begin{array}{l}\text { B flat minor } / \mathrm{B} \\
\text { flat major }\end{array}$ \\
\hline
\end{tabular}

Schema 10: Structure of the transcription: F. Chopin - J. Chęciński: 'Żal' [Plainte] Nocturne [in B flat minor], Op. 9 No. 1.

\begin{tabular}{lll}
\hline Form & introd. & $\mathrm{A}$ \\
Syntax & $(\mathrm{e})$ & $\mathrm{a} \mathrm{b}_{\text {(a) }} \mathrm{a}^{\prime} \mathrm{b}_{\text {(a) } 1}{ }^{\prime}<$ \\
Number of bars & 6 & $4444+2$ \\
Tonal plan & D minor & D minor - F major - D \\
& minor \\
\hline
\end{tabular}

in their entirety, and since modifications of form do not preclude changes of a substantial and textural nature, we will also devote attention to those aspects.

Reductive transcriptions are characterised by a distinct curtailment of the form of the original, since they are often based on just a part of the original work. This formal reduction is often done in a mechanical way, with formally significant parts of the original cut out or removed. Jan Chęciński's arrangement of the Nocturne in B flat minor, Op. 9 No. 1, entitled 'Żal' [Plainte], presents a type in which the reduction of the syntax led to the distinct shortening and revising of formal elements of Chopin's original (cf. schemata 9 and 10). ${ }^{350}$ The transcription is preceded by a six-bar introduction, which refers motivically to content ' $\mathrm{e}$ ' in the original. Yet this is a new entity, and its task is to draw the singer into the musical narrative (its tempo, key and character), since it takes the form of a cadence based on basic harmonic functions. The transcriber abandoned a considerable part of the original (sixty-seven bars), leaving only the syntactically unaltered first section A. And in such a quantitative context, this six-bar introduction represents a new formal element, in which the original function of content ' $\mathrm{e}$ ' is redefined: in the original, it built section $\mathrm{B}$, whilst in the transcription its elements constitute an introduction of little importance.

350 Published by Gebethner \& Wolff of Warsaw in 1867. Dated after CT, 361. 
The transcriber divided Chopin's material between two performers, giving the leading melody to the singer and only the accompaniment layer to the pianist (Examples 26, 27). In both layers - solo and accompaniment - there are clear changes to the musical substance and to the texture. In the accompaniment layer, the transcriber applied multiplication, expressed in the extension of the rhythmic value of the note falling on the strong beat in the bar, additionally reinforced at an octave. This remark does not relate to the six-bar introduction, the melodic-rhythmic figure of which differs from Chopin's original, since it employs small intervals filling out larger distances of a fifth or sixth. The soloist's part was simplified in rhythmic and intervallic terms, since the transcriber replaced all the irregular rhythmic groups with regular groupings (bars 9-10, 17-18, 21-24), reducing the number of notes and simplifying the distances between them. The change of the original key of $\mathrm{B}$ flat minor to $\mathrm{D}$ minor could have been dictated not just by the compass of the solo voice (soprano), but also to facilitate the notation. In this arrangement, we also find different phrasing to that of the original, characterised by the elimination of Chopin's sweeping phrases and their replacement with many shorter ones. This may be justified in terms of the vocal texture and the legibility of the verbal text (foreign to Chopin's music). Similarly motivated could have been the curtailment of the original's syntax, and consequently its musical form. In our systematics, this arrangement is an example of the reductive recontextual type.

The term 'contamination' is understood as the 'combining, connecting or merging of a variety of elements into a single whole. ${ }^{351}$ Paraphrasing a linguistic definition in the musical domain, ${ }^{352}$ contamination concerns the combining in a single whole of elements (motifs, phrases) from different musical compositions. Contamination on the level of form prompted the distinction of the group of contaminative recontextual transcriptions, which we define as transcriptions resulting from the combining of fragments from different musical compositions in a single whole. ${ }^{353}$ Paulina Viardot-García's arrangement entitled 'Faible cœur' (Pol. 'Biedne serce') is a fusion of the two mazurkas Op. 7 Nos. 2 and 3, with the

351 KSJP.

352 Ibid: '(a) the crossing and fusion of elements of two forms, two words or two expressions, (b) a word or expression arising as a result of such a crossing; Fr. contamination, Lat. conta $(g)$ minatoio, meaning "mixing (of orders)"'.

353 Mieczysław Tomaszewski, on the basis of examples by Stephen Heller, Leopold Godowsky, Mily Balakirev and Sergey Lyapunov, defines this type of merging as 'collage'. Cf. Tomaszewski, 'Obecność', 135-137. 

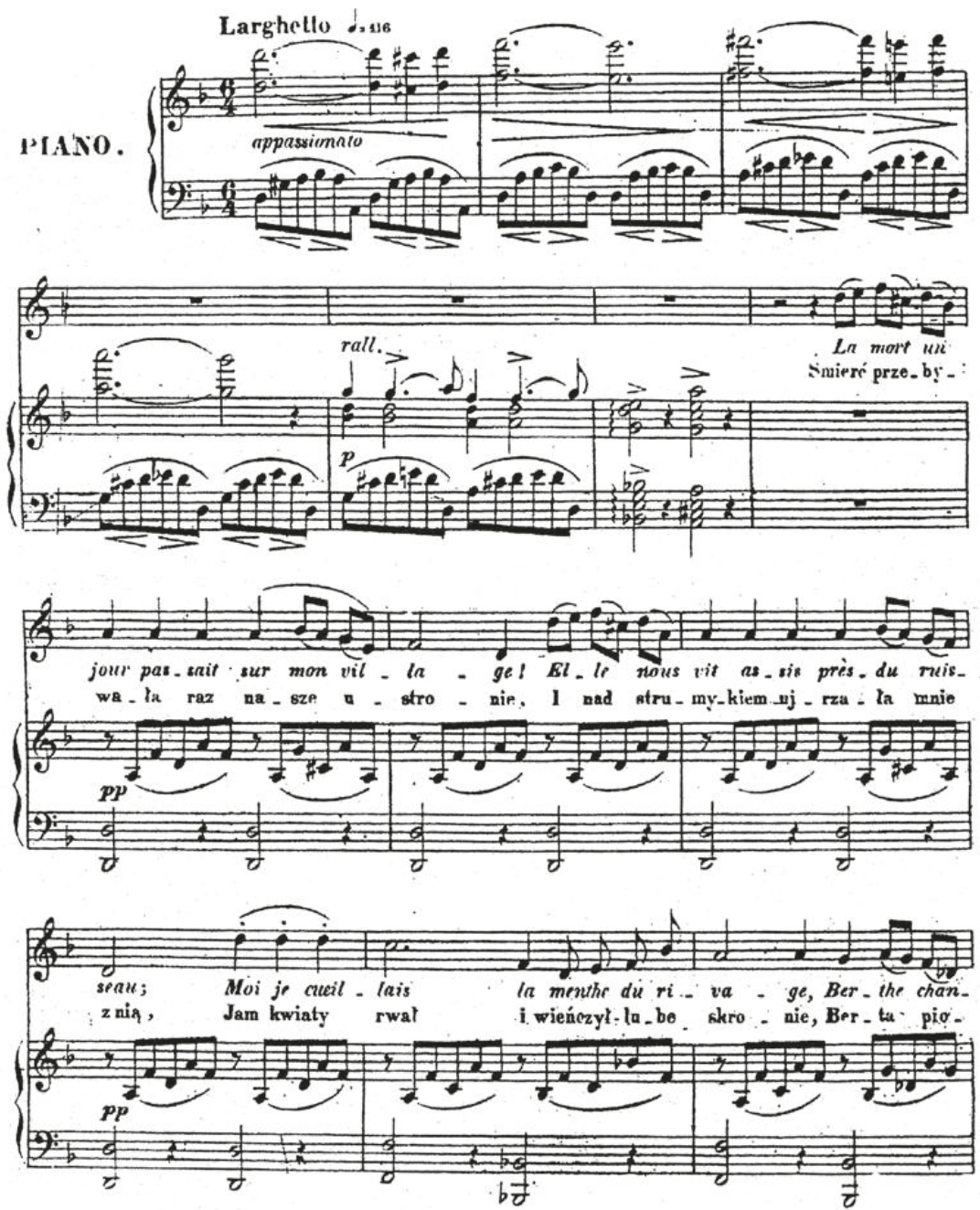

Example 26. F. Chopin - J. Chęciński, 'Żal' [Plainte] - Nocturne [in B flat minor], Op. 9 No. 1, voice+Pfte, Polish text by J. Chęciński (Warsaw: Gebethner \& Wolff, 1867), bars 1-13. 

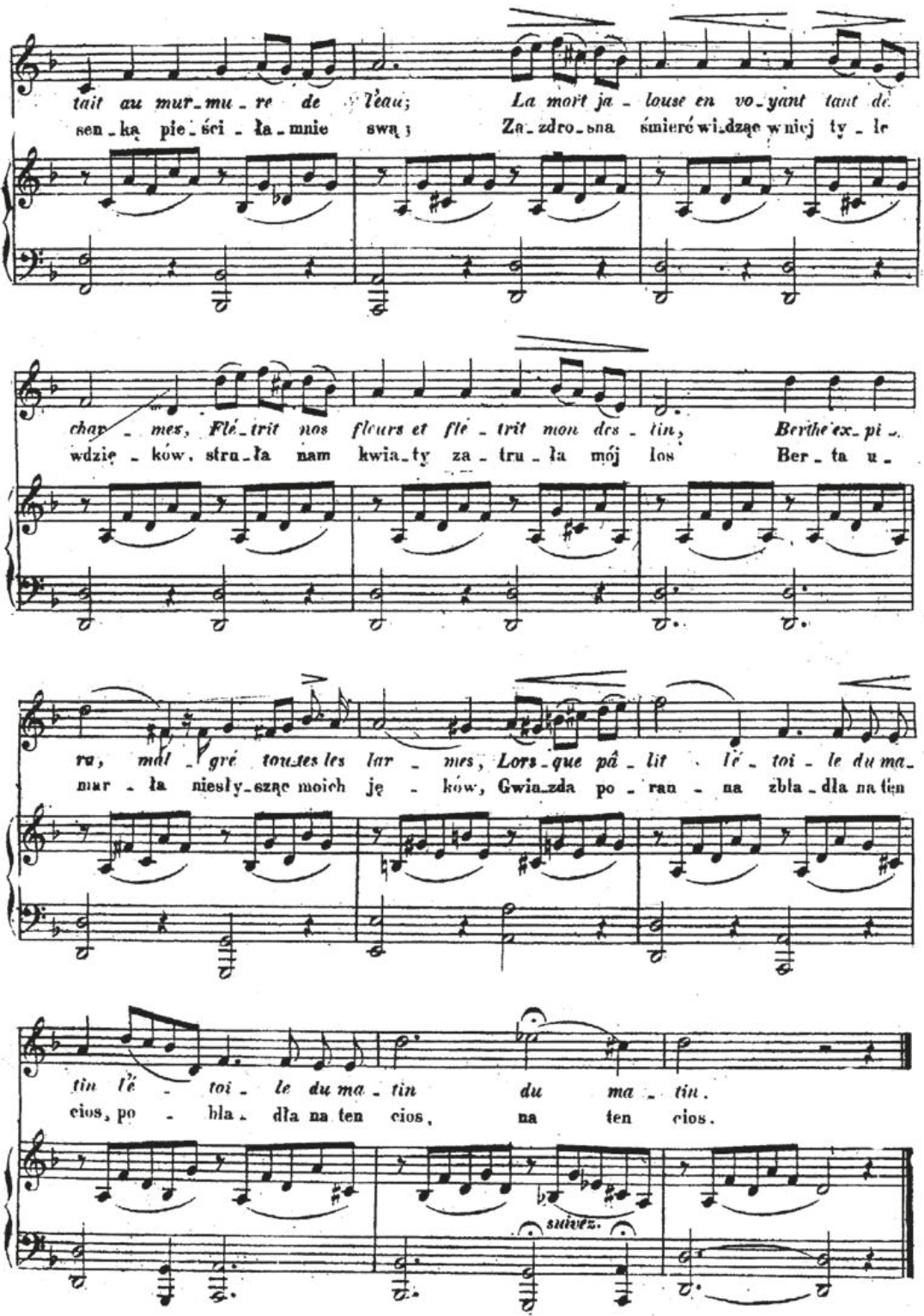

Example 27. F. Chopin - J. Chęciński, 'Żal' [Plainte] - Nocturne [in B flat minor], Op. 9 No. 1, voice+Pfte, Polish text by J. Chęciński (Warsaw: Gebethner \& Wolff, 1867), bars 14-25. 
Schema 11: Structure of the original composition: F. Chopin, Mazurka in F minor, Op. 7 No. 3.

\begin{tabular}{|c|c|c|c|c|c|c|}
\hline Form & introd. & A & B & C & bridge & A \\
\hline Syntax & a & $\mathrm{bb}_{1}$ & & $\mathrm{dd}_{1}$ e e $<$ & $\mathrm{a}$ & $b^{\prime} b_{2}<$ \\
\hline Number of bars & 8 & 88 & $4+44+4$ & $884+4 \quad 4+44$ & 8 & $8 \quad 8+5$ \\
\hline Tonal plan & F minor & F minor & $\begin{array}{l}\text { F minor/A } \\
\text { flat major }\end{array}$ & $\begin{array}{l}\text { D flat major - E flat } \\
\text { minor/D flat major }\end{array}$ & F minor & F minor \\
\hline
\end{tabular}

Schema 12: Structure of the transcription: F. Chopin - P. Viardot-García, 'Biedne serce' [Faible cour] - Mazurka [in F minor], Op. 7 No. 3. M2 = section of the Mazurka in A minor, Op. 7 No. 2.

\begin{tabular}{|c|c|c|c|c|c|c|c|c|c|}
\hline Form & introd. & A & B & C> & bridge & $\mathrm{A}$ & B & M2 & A \\
\hline Syntax & $\mathrm{a}$ & $\mathrm{bb}_{1}$ & c $\quad c_{1}$ & $\mathrm{~d} \mathrm{~d}_{1}$ & a & $b^{\prime}$ & $c^{\prime}$ & $\mathrm{m} 2 \mathrm{a}^{\prime}$ & (b) \\
\hline $\begin{array}{l}\text { Number } \\
\text { of bars }\end{array}$ & 8 & 88 & $4+4 \quad 4+4$ & 88 & 8 & 8 & 8 & $24 \quad 8$ & $11+7$ \\
\hline $\begin{array}{l}\text { Tonal } \\
\text { plan }\end{array}$ & $\begin{array}{l}\mathrm{F} \\
\text { minor }\end{array}$ & $\begin{array}{l}\mathrm{F} \\
\text { minor }\end{array}$ & $\begin{array}{l}\text { F minor } \\
\text { / A flat } \\
\text { major }\end{array}$ & $\begin{array}{l}\text { D flat } \\
\text { major }\end{array}$ & $\begin{array}{l}\mathrm{F} \\
\text { minor }\end{array}$ & $\begin{array}{l}\mathrm{F} \\
\text { minor }\end{array}$ & $\begin{array}{l}\mathrm{F} \\
\text { minor } \\
\text { / A flat } \\
\text { major }\end{array}$ & $\begin{array}{l}\text { A flat } \\
\text { major - } \\
\text { F minor }\end{array}$ & F minor \\
\hline
\end{tabular}

latter clearly dominant in terms of quality and quantity (Examples $28-34) .{ }^{354} \mathrm{In}$ the arrangement, the original structure is modified considerably (cf. Schemata 11 and 12).

Comparing the schemata of the original and the arrangement, we note changes on the level of syntax (Viardot omitted content 'e' in section C) and also of form (she expanded the section after the bridge). In effect, instead of a 21-bar ending, she introduced a much longer (74-bar), varied section. She introduced foreign content, belonging to the Mazurka in A minor, Op. 7 No. 2: a 24-bar fragment (bars 34-57 in Chopin's original), which is presented in altered keys (A flat major and $\mathrm{F}$ minor). This transcription represents the contaminative recontextual type, since it was produced as a result of the combining of fragments from two different original Chopin compositions.

Changes on the level of form are not inconsistent with modifications on other levels: substantial or textural. If we confined the analysis to the substantial domain alone, we would have to state that the arranger remained very faithful

354 Published by Gebethner \& Wolff of Warsaw in 1897. Dated after CT, 352. 
to the original. In the disposition of the musical material for two performers singer and pianist - she employed primarily the transmission (bars 9-32, 37-42, 65-80) and multiplication (bars $36,43-44,47-48,49-56,81-88,97-104$ ) of the sound layers, whilst retaining the original key (of Op. 7 No. 3), registers and compass. The introduction of a text, foreign to Chopin's work, accounts for the rhythmic modifications of the leading melody (the 'solo' layer), realised by the vocal part (the lack of a dotted rhythm in contents 'b' and 'c': e.g. bars 9-15, 36-40). Despite that contamination, Chopin's work is clearly recognisable and was approved in this form by Chopin himself.

The authors of the Catalogue identify Luigi Bordèse as the composer of an arrangement entitled 'Beau rossignol' (Pol. 'Swaty'). ${ }^{355}$ This adaptation takes material from two mazurkas, in B flat major, Op. 17 No. 1 and in A minor, Op. 17 No. 4, either of which could have formed the starting point for the formal modifications. The former is given in the title of the transcription, and its key is present throughout the arrangement. Consequently, we will refer all changes in the form noted in the transcription to the Mazurka in B flat major, Op. 17 No. 1 (cf. Schemata 13 and 14).

The transcription begins with the Mazurka in A minor, Op. 17 No. 4, using twenty-four bars of its material (bars 61-84 of the original), transposed from A major to B flat major. The Mazurka in B flat major, Op. 17 No. 1 is presented in a shortened form, with only its first, incomplete section A (bars 1-24 of the original). These two original fragments appear in this transcription in alternation, creating a new two-part form on a lower level (ABAB) and a higher level (AA). The fragments of the two mazurkas are matched in quantitative terms, with twenty-four bars of each, yet they discharge different functions. The Mazurka in A minor, Op. 17 No. 4, which appears at the beginning, is of an introductory character and is linked to a text of a similar narrative and prefatory tone. The continuation, based on material of the Mazurka in B flat major, Op. 17 No. 1, introduces greater drama and develops the action in two domains: words and music. It is difficult to determine which of the mazurkas was the first in the transcriber's intentions. As already mentioned, however, a note from the publisher points to the Mazurka in B flat major (cf. Examples 35-39).

As in the transcription 'Faible cœur', the whole of this transcription, in the substantial and textural domains, remains faithful to the originals, altering only essential elements resulting from the presence of three performers: two singers and a pianist. This transcription represents a 'patchwork' of almost literally 


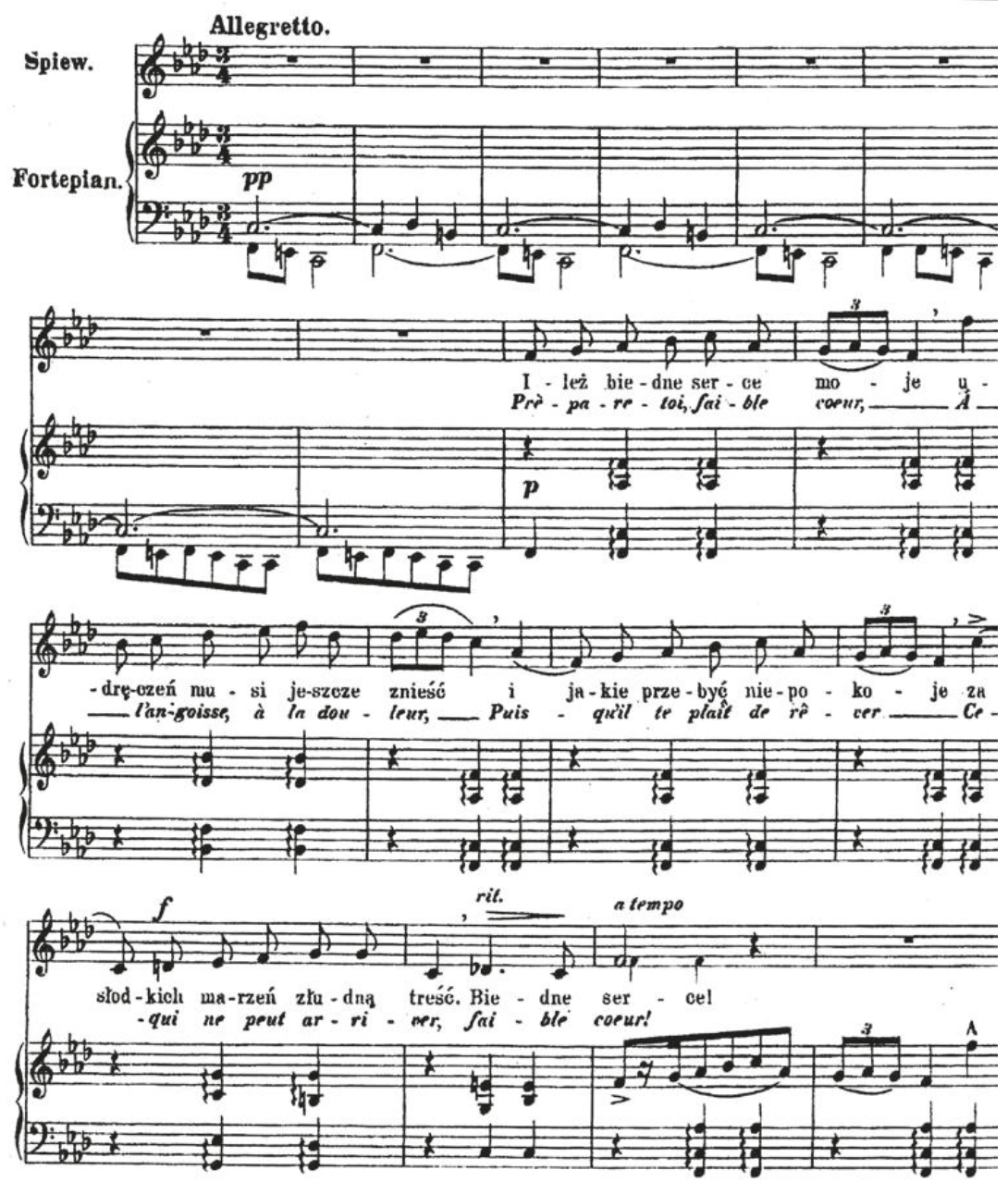

Example 28. F. Chopin - P. Viardot-García, 'Biedne serce' [Faible cour] Mazurka [in F minor], Op. 7 No. 3, voice+Pfte, Polish words by P. Maszyński (Warsaw: Gebethner \& Wolff, 1897), bars 1-18.

quoted (with a change of key or of several notes) extracts from two Chopin mazurkas, with the originals adapted to a vocal duet with piano. This mosaiclike way of creating a transcription is an example of contamination. 

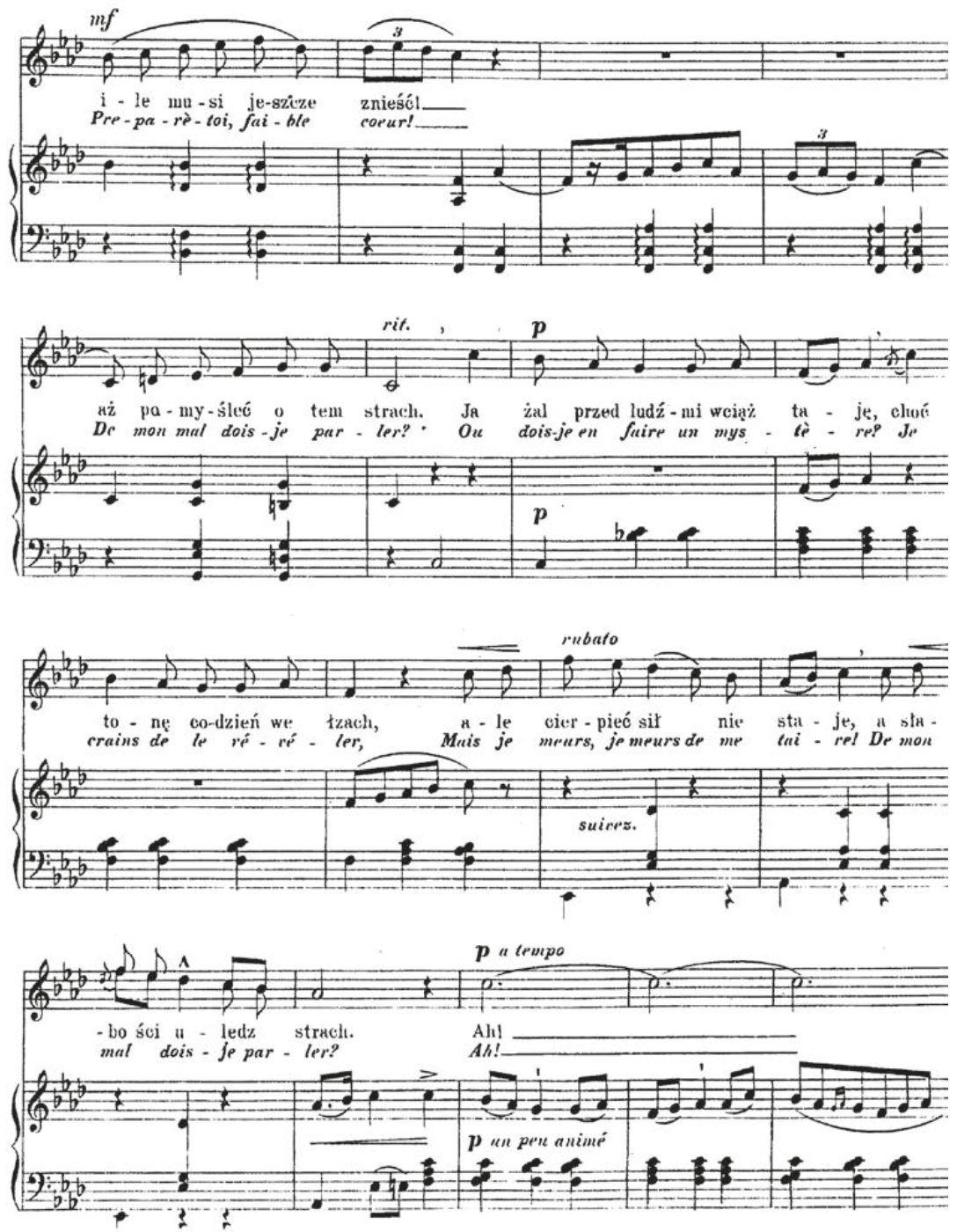

Example 29. F. Chopin - P. Viardot-García, 'Biedne serce' [Faible cœur] Mazurka [in F minor], Op. 7 No. 3, voice+Pfte, Polish words by P. Maszyński (Warsaw: Gebethner \& Wolff, 1897), bars 19-35. 

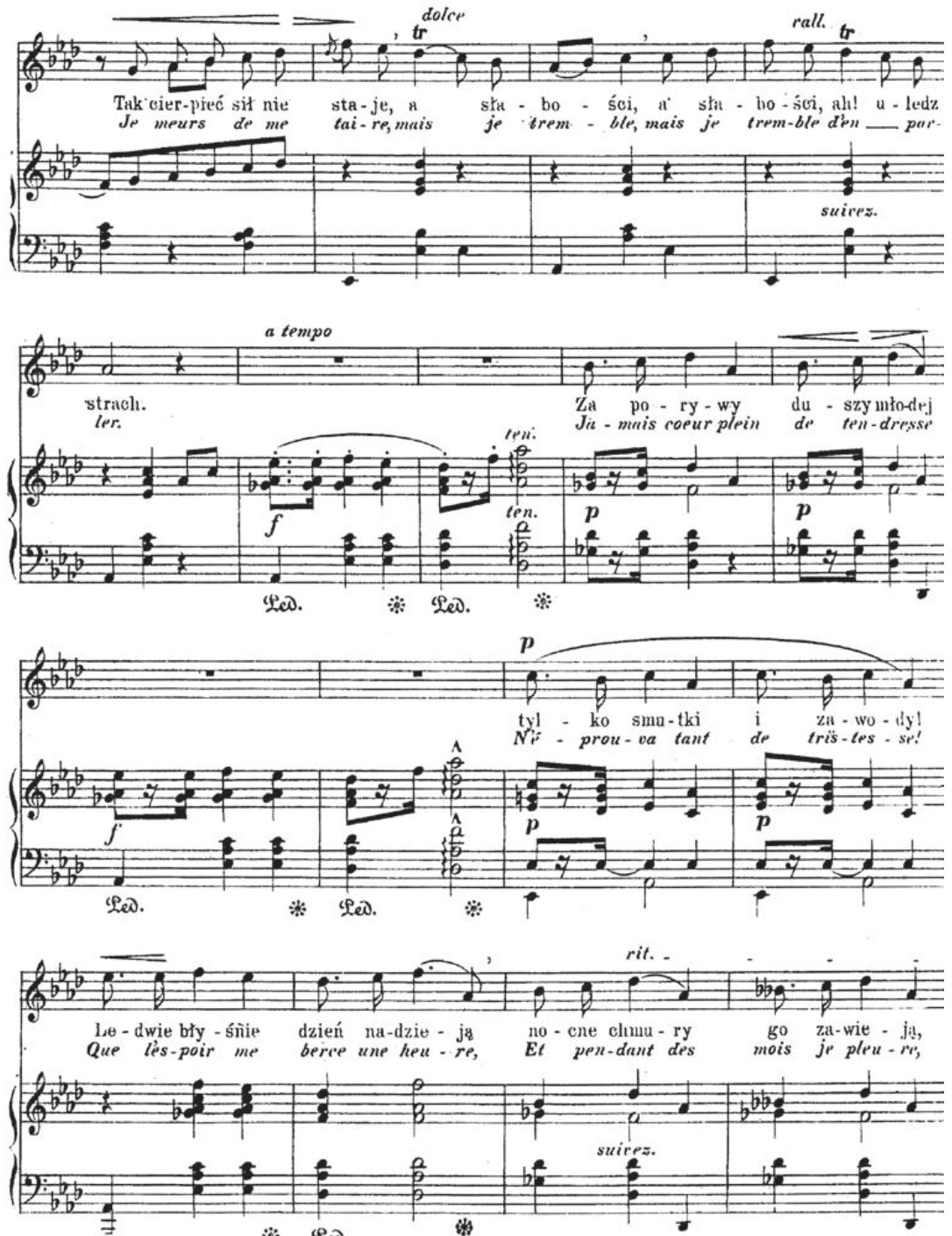

Example 30. F. Chopin - P. Viardot-García, 'Biedne serce' [Faible cœur] Mazurka [in F minor], Op. 7 No. 3, voice+Pfte, Polish words by P. Maszyński (Warsaw: Gebethner \& Wolff, 1897), bars 36-52. 

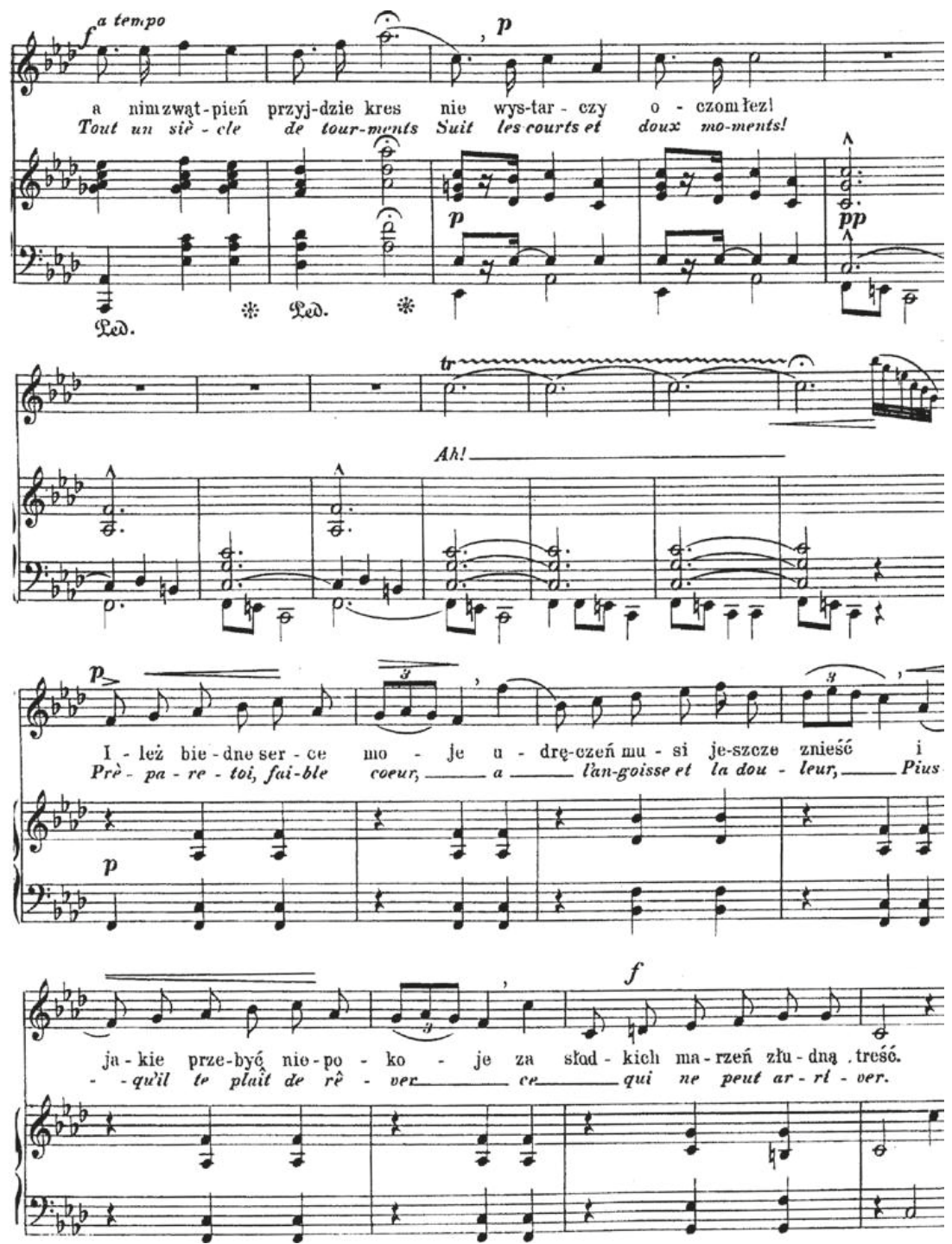

Example 31. F. Chopin - P. Viardot-García, 'Biedne serce' [Faible cœur] Mazurka [in F minor], Op. 7 No. 3, voice+Pfte, Polish words by P. Maszyński (Warsaw: Gebethner \& Wolff, 1897), bars 53-72. 

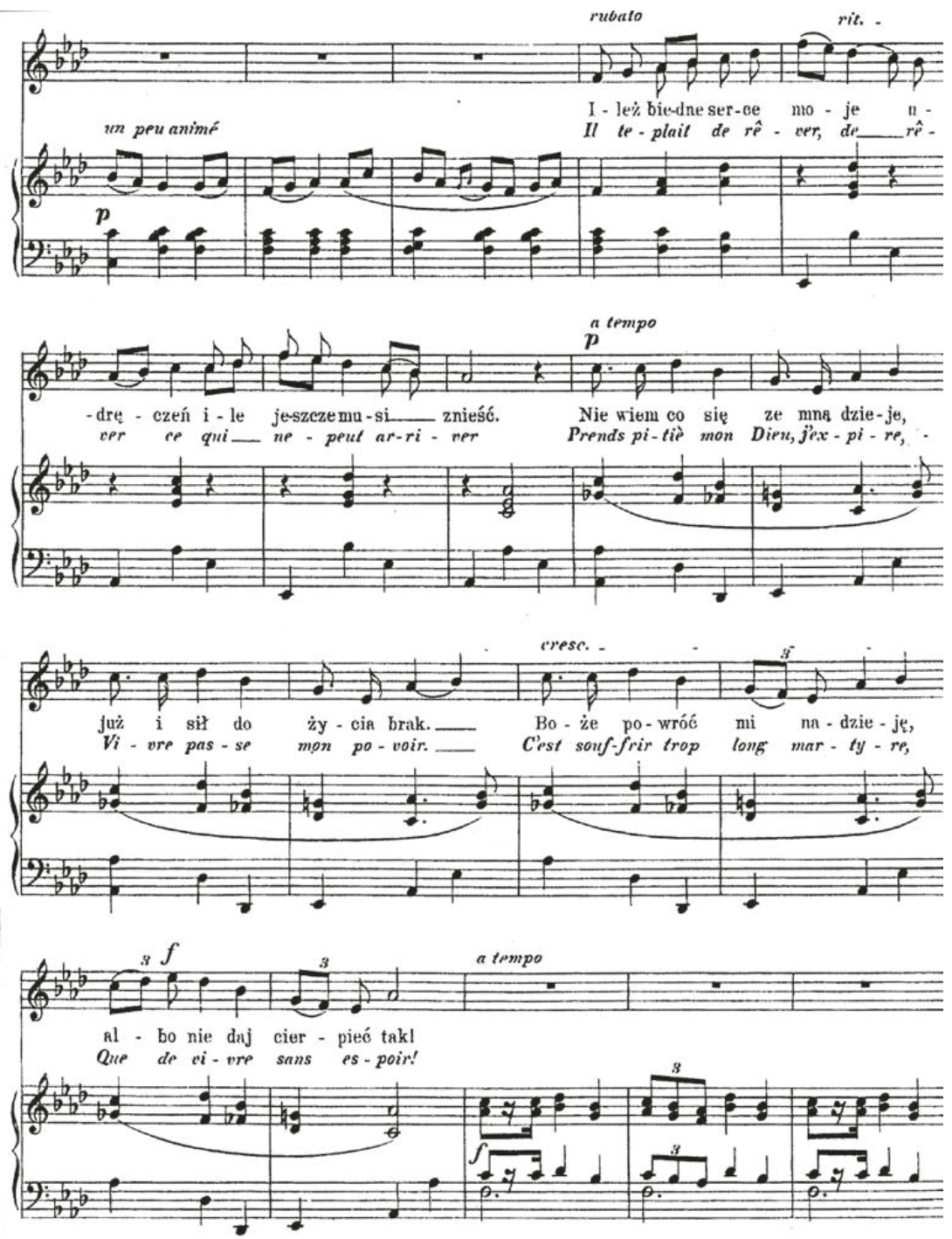

Example 32. F. Chopin - P. Viardot-García, 'Biedne serce' [Faible cœur] Mazurka [in F minor], Op. 7 No. 3, voice+Pfte, Polish words by P. Maszyński (Warsaw: Gebethner \& Wolff, 1897), bars 73-91. 

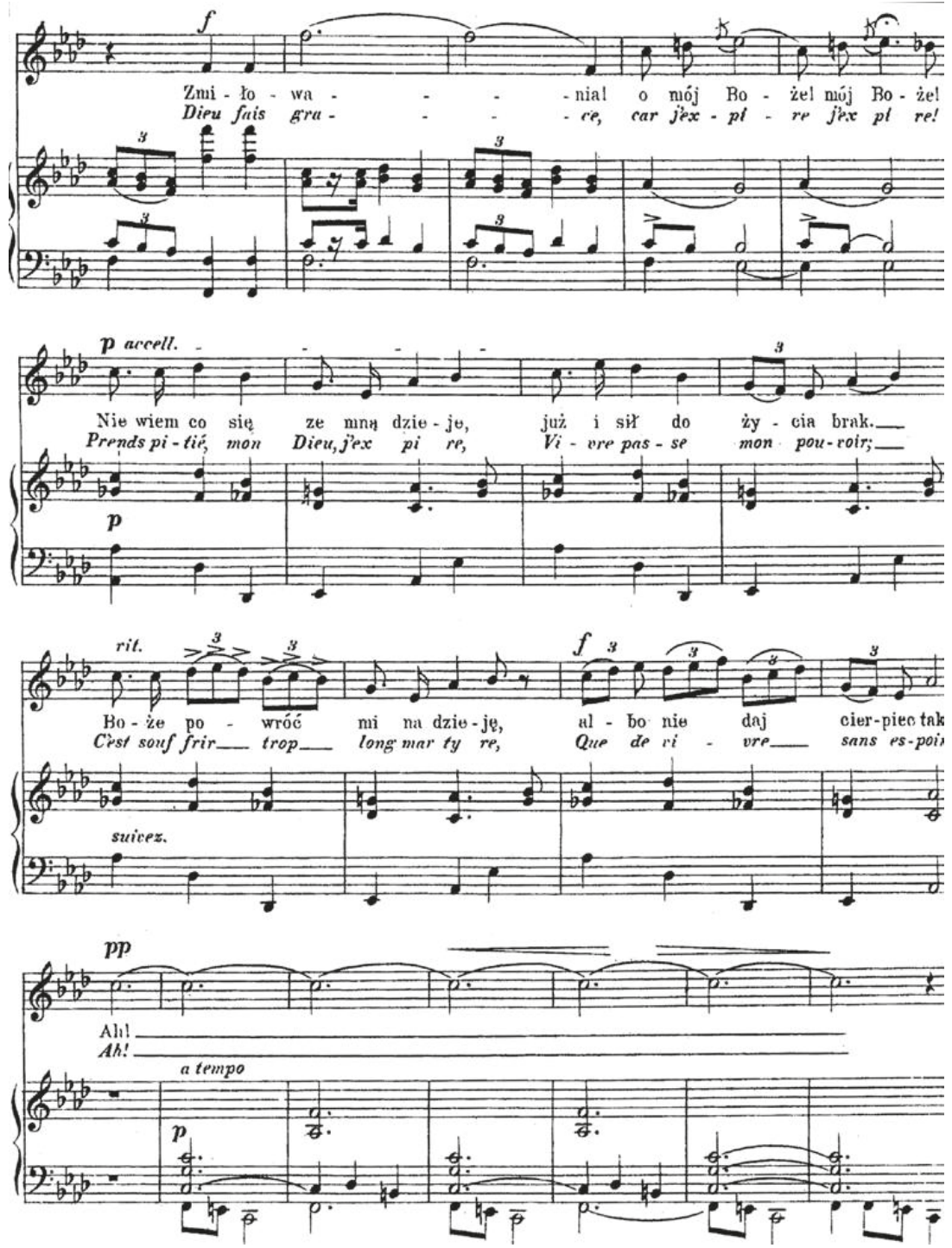

Example 33. F. Chopin - P. Viardot-García, 'Biedne serce' [Faible cœur] Mazurka [in F minor], Op. 7 No. 3, voice+Pfte, Polish words by P. Maszyński (Warsaw: Gebethner \& Wolff, 1897), bars 92-111. 

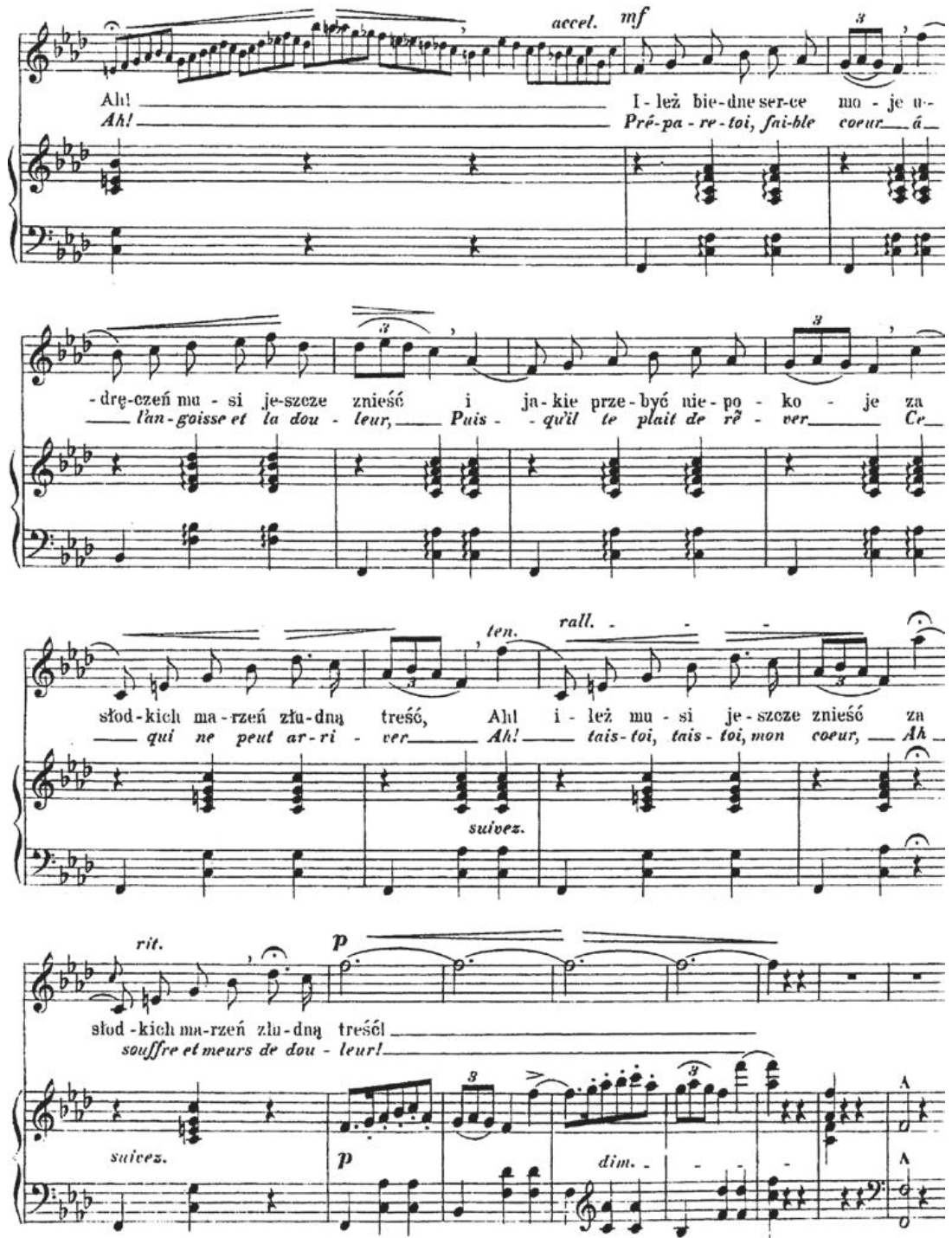

Example 34. F. Chopin - P. Viardot-García, 'Biedne serce' [Faible cour] Mazurka [in F minor], Op. 7 No. 3, voice+Pfte, Polish words by P. Maszyński (Warsaw: Gebethner \& Wolff, 1897), bars 112-130. 
Schema 13: Structure of the original composition: F. Chopin, Mazurka in B flat major, Op. 17 No. 1.

\begin{tabular}{llll}
\hline Form & A & B & A \\
Syntax & $\mathrm{a} \mathrm{b} \mathrm{a} \mathrm{b} \mathrm{a}$ & $\mathrm{cd}_{(\mathrm{c})} \mathrm{d}_{(\mathrm{c})}$ & $\mathrm{a} \mathrm{b} \mathrm{a} \mathrm{b} \mathrm{a}$ \\
Number of bars & 88888 & $48 \quad 8$ & 88888 \\
Tonal plan & B flat major & E flat major & B flat major \\
\hline
\end{tabular}

Schema 14: Structure of the transcription: F. Chopin - L. Bordèse, 'Swaty' [Beau rossignol] - Mazurka [in B flat major], Op. 17 No. 1. Introd. = introduction based on material of the Mazurka in A minor, Op. 17 No. 4 (bars 61-68 of Chopin's original); M4 = part of the Mazurka in A minor, Op. 17 No. 4 (bars 69-84); m4= sentence from the Mazurka in A minor, Op. 17 No. 4.

\begin{tabular}{lllllll}
\hline Form & introd. & M4 & A & introd. & M4 & A \\
Syntax & $\mathrm{m} 4$ & $\mathrm{~m} 4$ & $\mathrm{a} \mathrm{b} \mathrm{a}$ & $\mathrm{m} 4$ & $\mathrm{~m} 4$ & $\mathrm{a} \mathrm{b} \mathrm{a}$ \\
$\begin{array}{l}\text { Number of } \\
\text { bars }\end{array}$ & 8 & $8+8$ & 888 & 8 & $8+8$ & 888 \\
Tonal plan & B flat major & B flat major & B flat major & B flat major & B flat major & B flat major \\
\hline
\end{tabular}

There are many examples of recontextual transcriptions, but those proposed and presented here characterise the ways in which the formal identity of Chopin's work was redefined. The curtailment of Chopin's original in reductive transcriptions involved forgoing sizeable portions of the original. For this reason, these transcriptions seem the least valuable. In this shortened form, they no doubt functioned as musical 'signals' enabling listeners to recognise Chopin. This kind of formal transcription results to only a limited degree from the pragmatics of the musical text; above all, it is conditioned by a specific way of disseminating Chopin's music, involving its presentation in condensed versions. Extremely interesting are contaminative transcriptions, combining extracts from different musical compositions in a single whole. The contamination is effected in a very smooth way, on the basis of reminiscences or echoes. Transcriptions of this type are designed in a mosaic-like way, as puzzles of ready-made pieces that fit one another ideally. Yet contaminative transcriptions should not be confused with compilations or potpourris - forms that were popular in the nineteenth century. A contaminative transcription does not involve the juxtaposition of themes from one or more works, but the formal enhancement of a single dominant work with elements taken from a second composition. In our analytical examples, we encountered the fusion of two (no more) original Chopin compositions. 

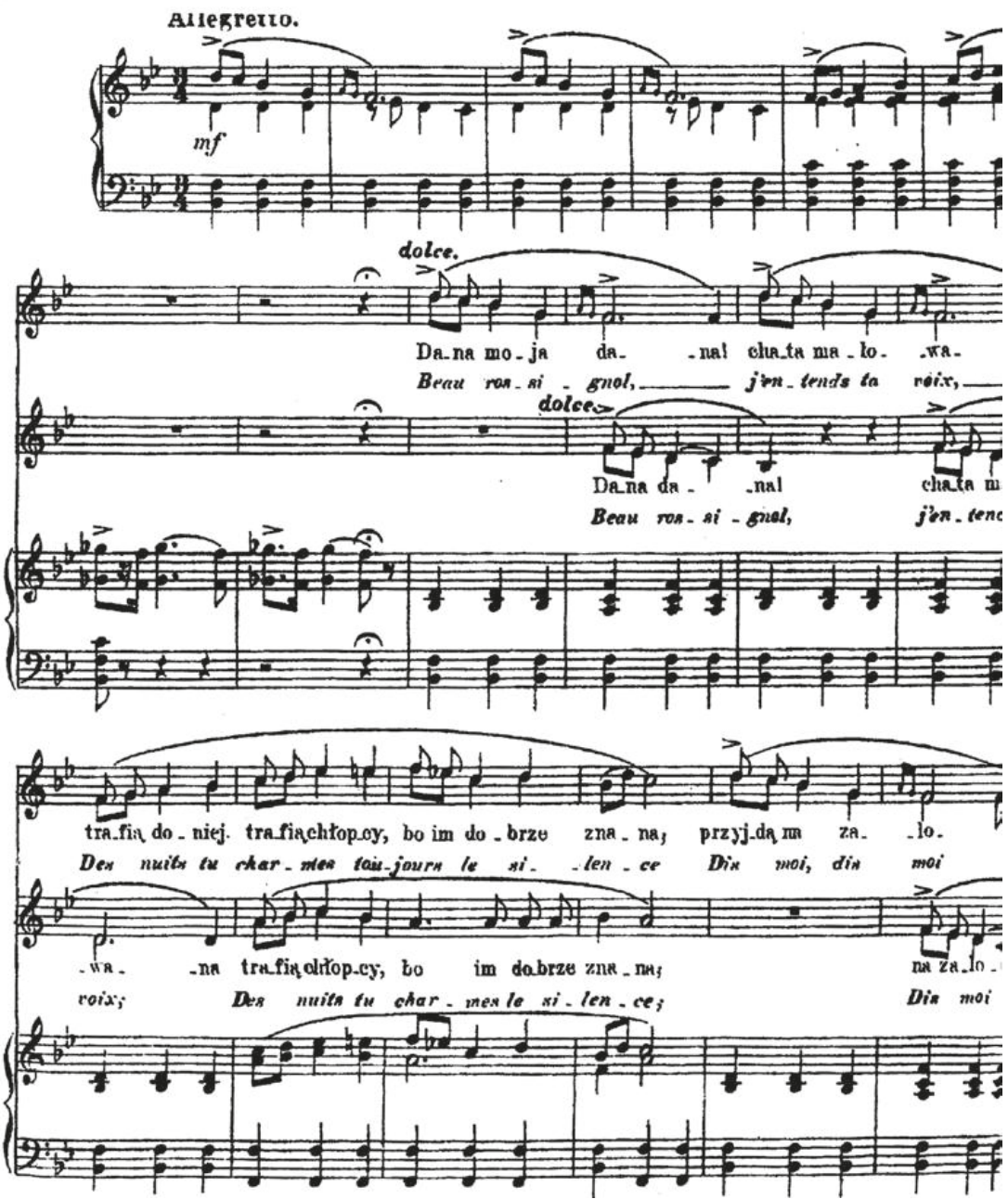

Example 35. F. Chopin - L. Bordèse, 'Swaty' [Beau rossignol] - Mazurka [in B flat major], Op. 17 No. 1, voice+Pfte, Polish words by P. Maszyński (Warsaw: Gebethner \& Wolff, 1899), bars 1-18. 

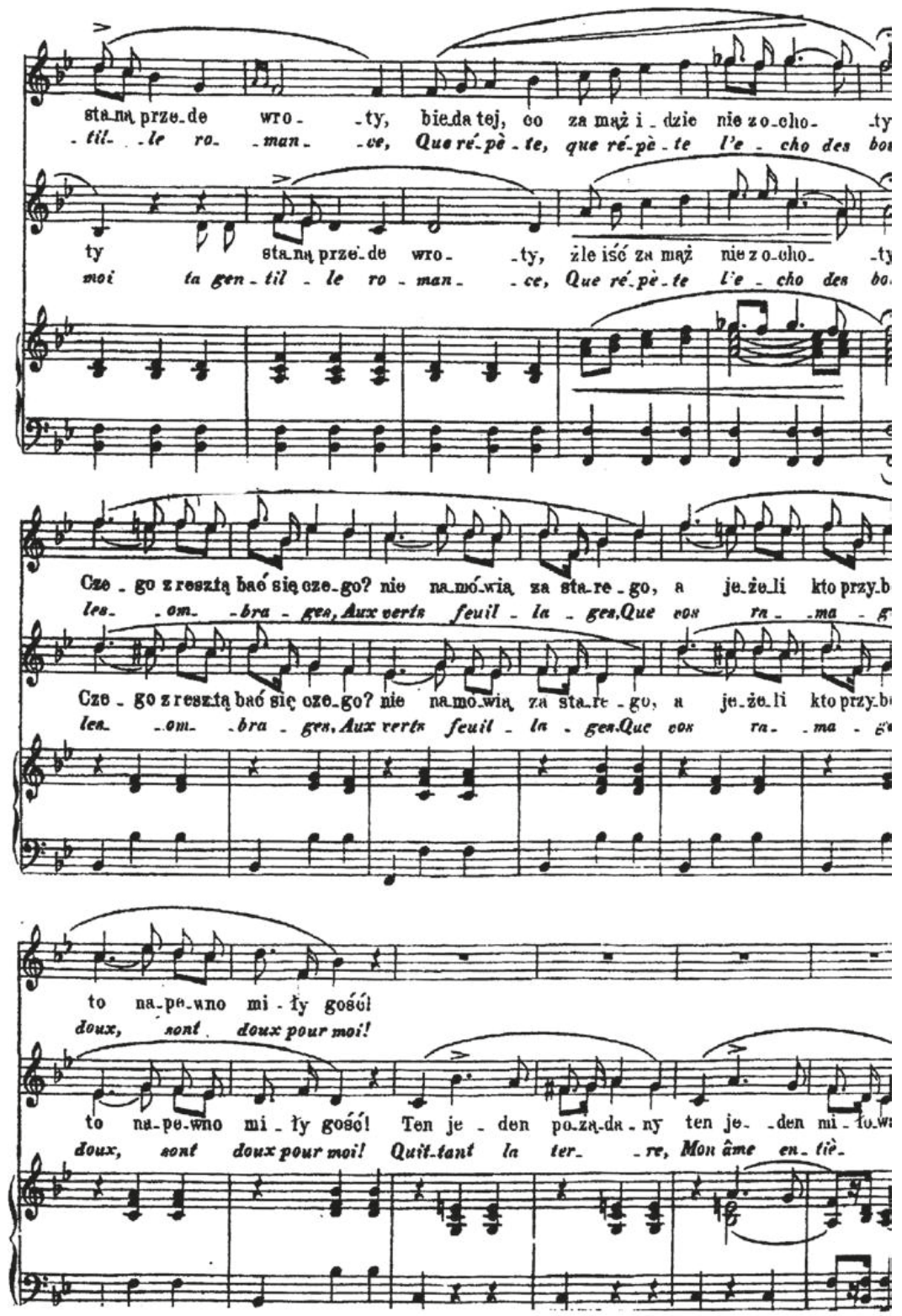

Example 36. F. Chopin - L. Bordèse, 'Swaty' [Beau rossignol] - Mazurka [in B flat major], Op. 17 No. 1, voice+Pfte, Polish words by P. Maszyński (Warsaw: Gebethner \& Wolff, 1899), bars 19-36. 


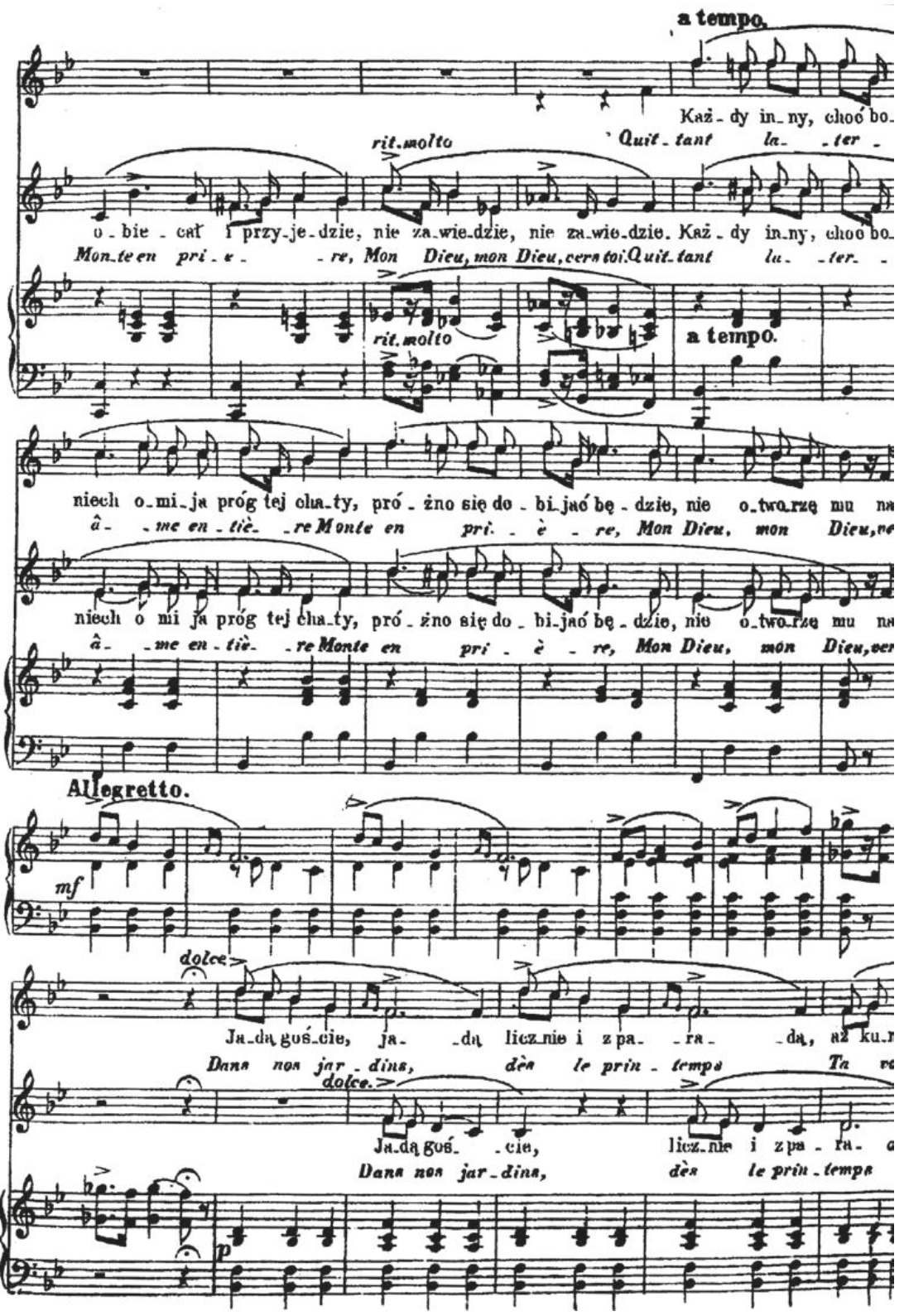

Example 37. F. Chopin - L. Bordèse, 'Swaty' [Beau rossignol] - Mazurka [in B flat major], Op. 17 No. 1, voice+Pfte, Polish words by P. Maszyński (Warsaw: Gebethner \& Wolff, 1899), bars 37-61. 


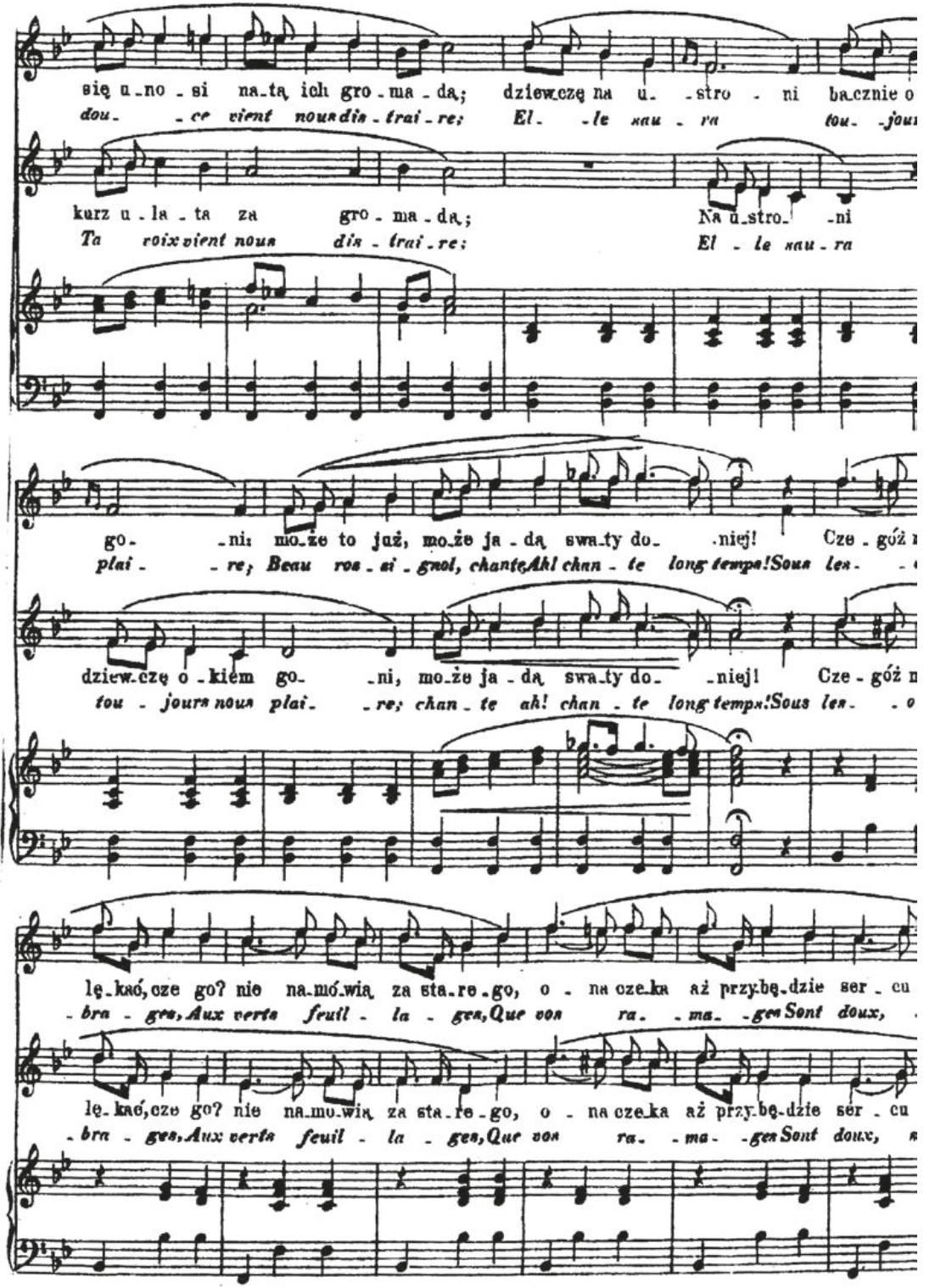

Example 38. F. Chopin - L. Bordèse, 'Swaty' [Beau rossignol] - Mazurka [in B flat major], Op. 17 No. 1, voice+Pfte, Polish words by P. Maszyński (Warsaw: Gebethner \& Wolff, 1899), bars 62-79. 


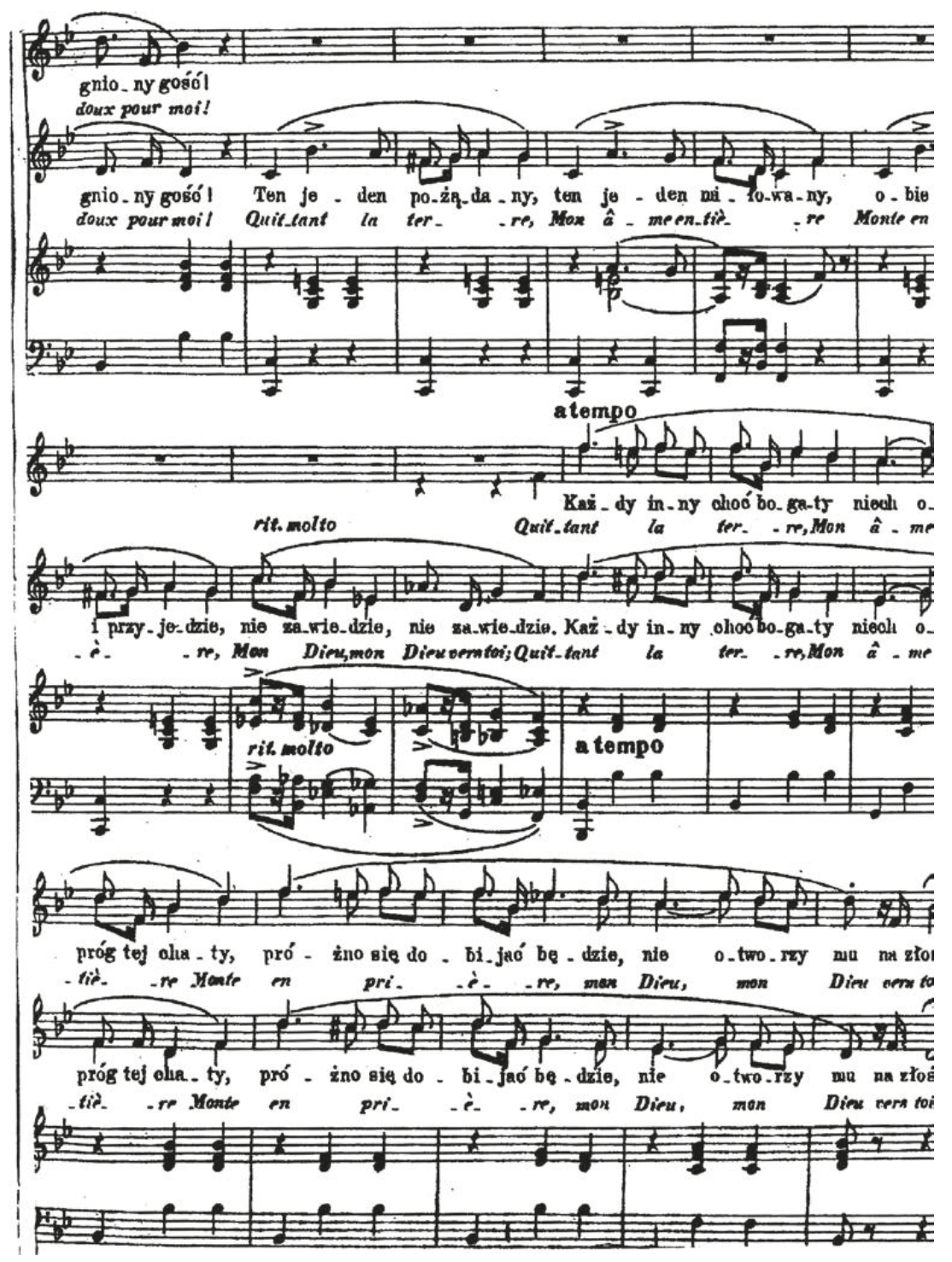

Example 39. F. Chopin - L. Bordèse, 'Swaty' [Beau rossignol] - Mazurka [in B flat major], Op. 17 No. 1, voice+Pfte, Polish words by P. Maszyński (Warsaw: Gebethner \& Wolff, 1899), bars 80-96. 


\subsection{Functional transcriptions}

The basis for distinguishing functional transcriptions is a glaring violation of one or more ontic aspects of the original work, leading to a distinct degradation of its artistic value, linked to a trivialisation of its content, which is now intended for strictly pragmatic purposes. This kind of modification may be based on a reduction of the sound layers. It often occurs that the layers are preserved while changes are applied to the actual musical substance. Also sometimes disturbed is the syntax and even the form of the original. All these changes are possible, but most crucially they result in a redefining of the quality of expression of the original work. ${ }^{356}$ Transcribers obtained this effect while attempting to impart specific didactic or practical functions to Chopin's compositions; it resulted from a wish to apply them to new tasks. 'The functionality of this type of transcription sometimes amounted to a social ritual beyond the domain of cultural musical communication per se (state celebrations, amusements, funerals, etc.). ${ }^{357}$ So a condition for the classification of transcriptions to the functional type is the simplification of the musical content (the impoverishment of the musical substance, the modification of the syntax, and even of the form), clearly resulting from its functional purpose. In our systematics, transcriptions of this kind are divided into two subgroups: technical-didactic transcriptions and simplified transcriptions.

Technical-didactic transcriptions are exemplified by Ferdinand Büchner's Sechs Etuden von Chopin für Flöte allein. ${ }^{358}$ His six flute transcriptions of Chopin etudes feature a distinct reduction of the sound layers, resulting directly from the new performance apparatus. This reduction proceeds according to a fixed principle: the top voice of the original composition is reworked, often constituting an independent sound layer.

Büchner's Etude No. 5 is based on Chopin's Etude in G flat major, Op. 25 No. 9. In the two-layered original, the bottom layer is forged by a chordal accompaniment, while the top layer, played by the right hand, is based on a single figure: octave dyads. In the flute arrangement, the technical value of this figure is partially altered, due to the one-part execution, and it may be defined as octavesecond (Example 40).

356 Where the artistic features of the original are not clearly degraded, an arrangement characterised by several changes proper to different types of transcription is defined as diffusive. This issue will be addressed in subchapter 3.7. 'The diffusion of "ideal types"'.

357 Gołąb, Dziewiętnastowieczne transkrypcje, 42.

358 Published by J. H. Zimmerman of Leipzig in 1892-1897. Dated after CT, 343. 


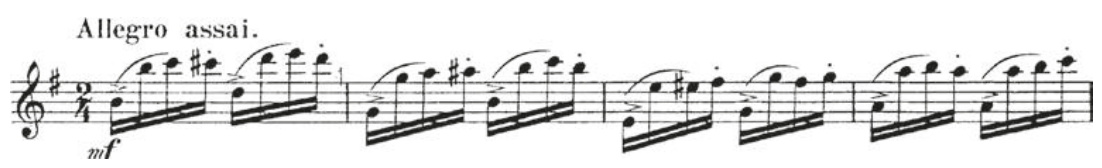

Example 40. F. Chopin - F. Büchner, Etude [in G flat major], Op. 25 No. 9, Fl (Leipzig: J. H. Zimmermann, 1892-1897), bars 1-4.

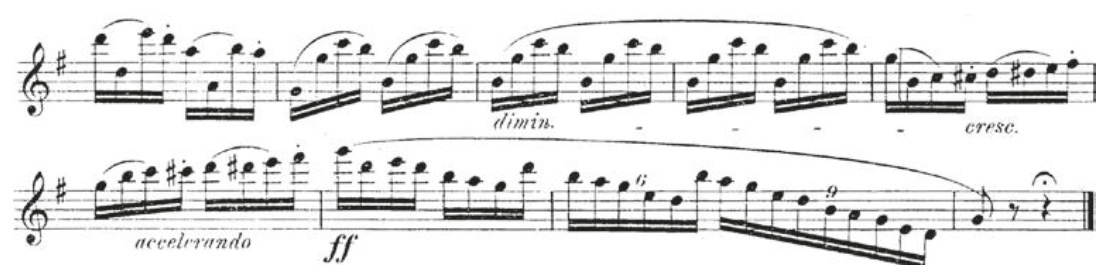

Example 41. F. Chopin - F. Büchner, Etude [in G flat major], Op. 25 No. 9, Fl (Leipzig: J. H. Zimmermann, 1892-1897), bars 44-52.

Büchner retains all the original features that can be performed on the flute: the intervallic structure, phrasing and articulation. Unfortunately, he changes the last five bars (bars 48-52), because it was impossible to translate Chopin's idea into flute texture (Example 41). So, wishing to emphasise the ending of the work, he offers a sort of virtuosic cadenza, based on ostensibly new material that results from combining intervals of a second that fill out the passagework. And only in this section does the arranger refer to the bottom layer of the original, where we note elements of the passagework (bars 46-61). The quasi-virtuosic character of this section is emphasised also by the irregular division of the rhythmic values (bars 48-52). Both this fragment and the etude as a whole point to the skilful adaptation of a piano etude to flute texture (also evidenced by the change of key from $\mathrm{G}$ flat major to $\mathrm{G}$ major).

In this transcription, it is not only the layers that are reduced, but also the substance of the retained layer, which in the Chopin is characterised by a twonote execution, dominated by octave chords, whilst in the Büchner it is necessarily in one part. Following this lead, I propose to analyse the six flute etudes from the angle of the modification of the musical substance; more precisely, the intervallic-rhythmic figures, articulation, phrasing, rhythms and interval structure.

The articulation is not the most frequent object of Büchner's interference: it is only clearly altered in Etude No. 1, which is a substantially transformed 


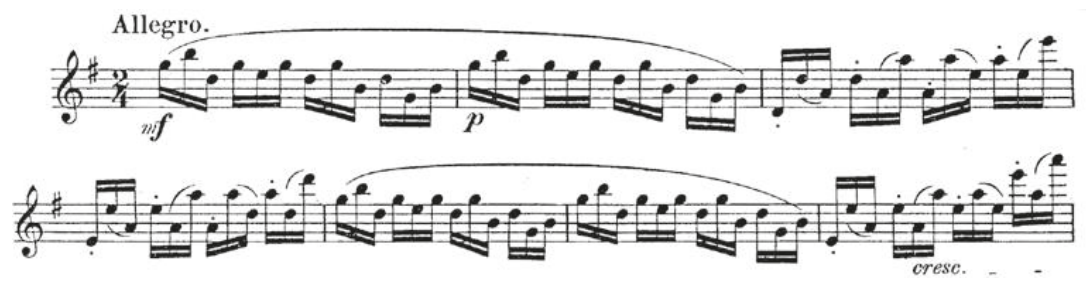

Example 42. F. Chopin - F. Büchner, Etude [in G flat major], Op. 10 No. 5, Fl (Leipzig: J. H. Zimmermann, 1892-1897), bars 1-7.

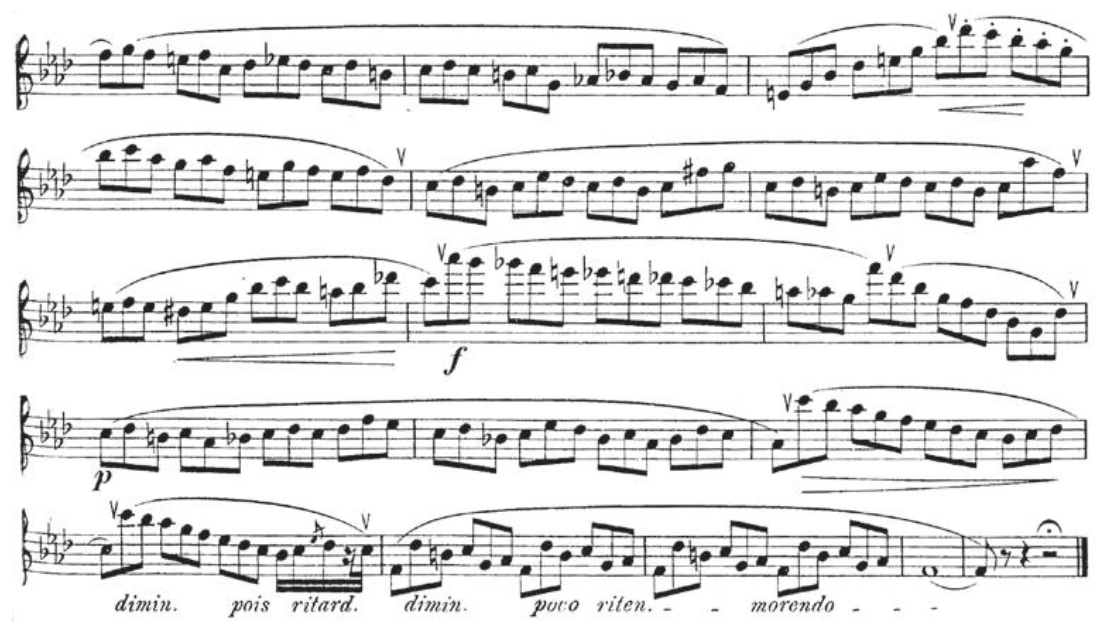

Example 43. F. Chopin - F. Büchner, Etude [in G flat major], Op. 10 No. 5, Fl (Leipzig: J. H. Zimmermann, 1892-1897), bars 55-71.

version of the Etude in G flat major, Op. 10 No. 5. While the Chopin has the marking sempre legato, in the Büchner we have a combination of legato and staccato playing, according to the pattern given in Example 42. The changes in phrasing result from the modifications to the articulation or more often from the flautist's breathing capacities (Example 43, bars 51-67). Büchner remains so faithful to Chopin's material that only in sporadic instances does he modify the pitch of the notes in the retained layer. This occurs in Etude No. 2, which is a reworking of the Etude in F major, Op. 25 No. 3, where precisely three notes are changed (from bars corresponding to bars 38 and 40 of the original), of little significance for the overall sound. We find much more distinct revisions, 


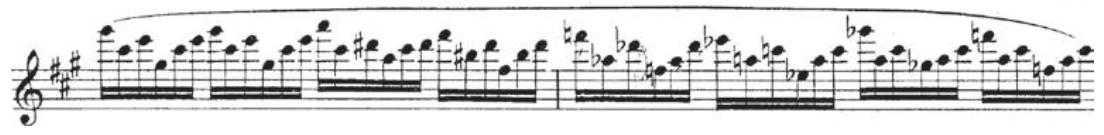

Example 44. F. Chopin - F. Büchner, Etude [in F major], Op. 25 No. 3, Fl (Leipzig: J. H. Zimmermann, 1892-1897), bars 21-22.

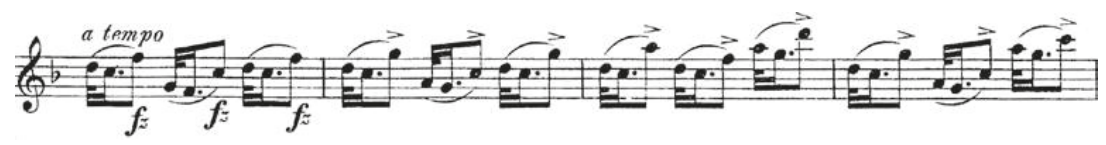

Example 45. F. Chopin - F. Büchner, Etude [in F major], Op. 25 No. 3, Fl (Leipzig: J. H. Zimmermann, 1892-1897), bars 54-57.

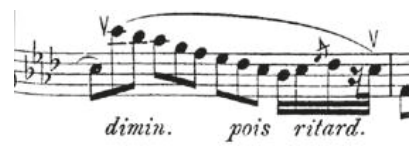

Example 46. F. Chopin - F. Büchner, Etude [in F minor], Op. 25 No. 2, Fl (Leipzig: J. H. Zimmermann, 1892-1897), bar 67.

concerning an entire figure, in only two bars of Etude No. 3 (bars 15 and 22 see Example 44).

In Etude No. 2 (Etude in F major, Op. 25 No. 3), the transcriber interfered with the rhythmic element. The regularly designed opening motif of the original was turned into a 'nervous' dotted figure, present throughout almost the entire transcription (Example 45). In Etude No. 4 (Etude in F minor, Op. 25 No. 2), we note a minor rhythmic change (bar 67 - see Example 46), justified on purely didactic grounds. This forms the basis for executing an exact, unequivocal rhythmic figure, precluded by Chopin's notation.

The syntax of successive etudes is also slightly altered:

- In Etude No. 1 (Etude in G flat major, Op. 10 No. 5), two bars are removed (bars 64 and 70 in Chopin's original). This is a clear elimination of identically repeated bars in the transcription (bars 63 and 69).

- In Etude No. 2 (Etude in F major, Op. 25 No. 3), we note the expansion of the score by the repetition of four bars (bars 4-7) and its shortening by the last two bars, which in the original are filled with chords. 
- In Etude No. 3 (Etude in A flat major, Op. 25 No. 1), the shortening by almost two bars results from the original's chords, which cannot be played on the flute.

- In Etude No. 4 (Etude in F minor, Op. 25 No. 2), the closing segment of the composition is expanded, with four bars instead of two.

- In Etude No. 5 (Etude in G flat major, Op. 25 No. 9), the last four bars of the original become five new bars.

- In Etude No. 6 (Etude in G sharp minor, Op. 25 No. 6), the last eight bars are replaced by two others. In addition, over the course of the piece, the transcriber removes a total of five bars which would have no raison dêtre in a one-part execution.

So the shortening of the syntax involved relinquishing repeated bars, which in the one-part version would have been identical. The expansion of the syntax results from the introduction of replacement material for Chopin's original material, impossible to play in a one-part flute rendition.

As already said, Büchner always arranges the top part of the original, the compass of which is adapted to the scale of the flute, its timbres (the change from flat to sharp keys, better suited to the flute) and its technical capacities. The introduction of changes in tempo, ${ }^{359}$ rhythm and thereby character seemed essential to the transcriber in order to highlight the specific technical problem contained in each etude. Etude No. 1 is designed to improve intonation in passagework and octave leaps, and also precision in the realisation of staccato and legato articulation. Etude No. 2 deals with precision in the intonation of leaps of a fifth and a fourth, accuracy in executing a dotted rhythm and smoothness and calm when performing a trill. The aim of Etude No. 3 is to develop regularity when performing motoric passages. This is an etude that demands considerable discipline of the flautist with regard to breathing, and due to the presence of an intervallic figure it may be defined as a 'passagework' etude. Similar aims apply to Etude No. 4, although its main task is performing irregular divisions; hence it may be dubbed a 'triplet' etude. A different task is assigned to Etude No. 5, which may be designated by the one word 'octaves'. In Etude No. 6, called 'tritone and chromatic', the fingering is important - the strengthening of all the fingers with the aim of increasing their proficiency in performing chromatic passages.

Büchner treated Chopin's music as material for practice, serving the improvement of the flautist's technique (intonation, articulation and technical

359 In Etude No. 1 from Vivace to Allegro; in Etude No. 2 from Allegro = 120 to Allegro = 126; in Etude No. 4 from Presto to Più Presto. 
proficiency). We may confidently state that the arranger was interested not so much in Chopin's work itself as in its technical 'ideas' that were useful for expressing specific performance problems in flute playing. Among transcriptions of Chopin's works, we find many whose existence was conditioned by the desire to enhance the literature for a given instrument, and such arrangements discharged first and foremost a technical-didactic function. Yet few of them were guided by such a far-reaching reduction of the musical substance and the syntax.

Jan Łusakowski's piano arrangement of the Nocturne in E flat major, Op. 9 No. 2 represents the simplified type in the group of functional transcriptions. ${ }^{360}$ This adaptation is characterised by the impoverishment of the musical substance and the modification of the syntax, which distinctly lowers the artistic value of the original. For a full presentation of the simplification of Chopin's original, I will employ familiar analytical methods proper to the types of transcription discussed above, and in the musical examples I will refer to transcriptions as a whole.

The design of Chopin's original is predominantly two-layered, with a single layer used only sporadically (bars 12 and 20). The top layer consists of a voice led in linear fashion, in places enhanced with two-note chords, which is the clearly dominant melody. The bottom layer, based on a single uniform rhythmic figure, serves as a chordal accompaniment.

The present transcription (Example 47) contains a number of impoverishments of the sound layers. The top layer is realised entirely in one part, with many changes to the interval structure (bars 9-16, 19, 24-32) and the rhythm of the leading melody. We note here the simplification of the interval sequences - the use of smaller intervals, the abandonment of all ornaments (trills, grace notes, runs) and the simplification of the rhythmic contour. Eusakowski bases his arrangement on just three rhythmic values: dotted quaver, quaver and semiquaver; he avoids smaller values (demisemiquavers), groupings that result from an irregular division (demisemiquaver triplets, quaver quadruplets) and dotted rhythms. The impoverishment of the substance of the lower sound layer results from its one-part realisation. Łusakowski avoids chords of two and three notes, but he remains faithful to the triple-time pulse of the original. The reduction in the number of notes in the chords entails a different sequence to the bass, led in one part - a sequence that enables Chopin's chords to be retained. The most surprising thing here is the change of metre from the original $12 / 8$ to $6 / 8$. That causes the original wide phrase to divide internally into segments half as long.

360 Published by Michał Arct of Warsaw in 1892. Dated after CT, 361. 

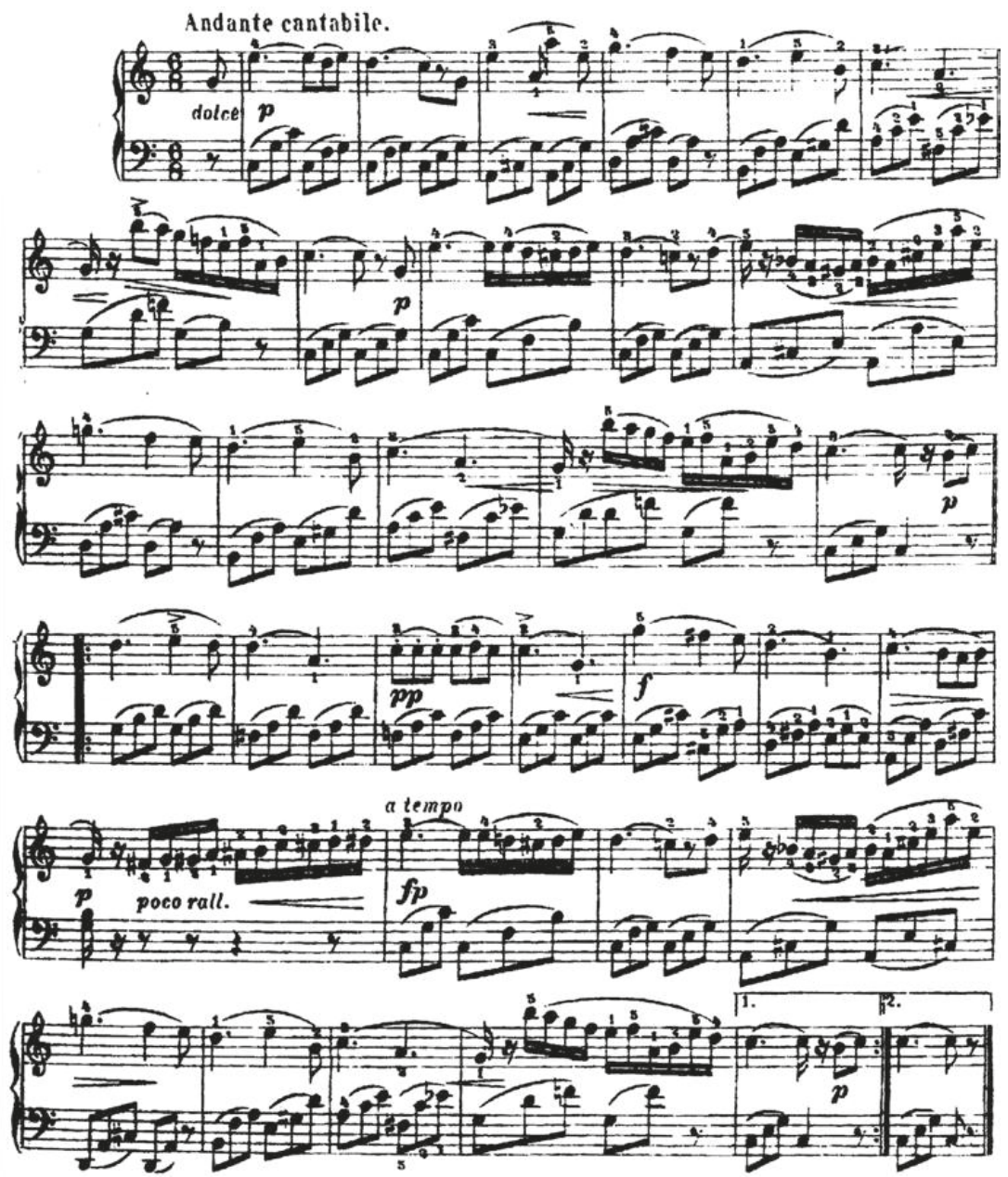

Example 47. F. Chopin - J. Łusakowski, Nocturne [in E flat major], Op. 9 No. 2, Pfte (Warsaw: M. Arct, 1892).

Also treated differently is the quaver anacrusis, which in the original is the start of a phrase and in the arrangement ends the preceding phrase (e.g. bars 4-5 of the transcription compared with bars 1-2 of the original; bars 12-13 compared with bar 6; bars 28-29 compared with bar 14). This battery of simplifications is supplemented by the change of key from $\mathrm{E}$ flat major to $\mathrm{C}$ major. The scope of the syntactic changes is shown in Schemata 15 and 16. 
Schema 15: Structure of the original composition: F. Chopin, Nocturne in E flat major, Op. 9 No. 2.

\begin{tabular}{|c|c|c|c|c|c|c|}
\hline Form & $\mathrm{A}$ & $\mathrm{B}$ & A" & B' & A" & coda \\
\hline Syntax & a a' & $\mathrm{b}_{(\mathrm{a})}$ & $a^{\prime \prime}$ & $\mathrm{b}_{(\mathrm{a})}{ }^{\prime}$ & a" & $\mathrm{C}_{(\mathrm{a})} \mathrm{C}_{(\mathrm{a}) 1}<$ \\
\hline Number of bars & 44 & 4 & 4 & 4 & 4 & 442 \\
\hline Tonal plan & $\begin{array}{l}\text { E flat } \\
\text { major }\end{array}$ & $\begin{array}{l}\text { B flat } \\
\text { major }\end{array}$ & $\begin{array}{l}\text { E flat } \\
\text { major }\end{array}$ & $\begin{array}{l}\text { B flat } \\
\text { major }\end{array}$ & $\begin{array}{l}\text { E flat } \\
\text { major }\end{array}$ & $\begin{array}{l}\text { A flat major - E flat major - } \\
\text { A flat major - B flat major - } \\
\text { E flat major }\end{array}$ \\
\hline
\end{tabular}

Schema 16: Structure of the transcription: F. Chopin - J. Łusakowski, Nocturne [in E flat major], Op. 9 No. 2.

\begin{tabular}{lllll}
\hline Form & A & A & A" & A" \\
Syntax & a a & a a & b $_{(\text {a) }}{ }^{\prime \prime}{ }^{\prime \prime}$ & b $_{(\mathrm{a})}^{\prime}{ }^{\prime \prime}$ \\
Number of bars & 88 & 88 & $88^{\prime}$ & 8 \\
Tonal plan & C major & C major & G major - C major & G major - C major \\
\hline
\end{tabular}

NB: The number of bars was doubled, due to the change of metre. This means that eight bars in the transcription correspond to four bars in the original.

Łusakowski eliminates the coda, confining himself to an excerpt that constitutes two-thirds of the original. This way of proceeding makes it impossible to follow the line of tension proper to the original; it also helps to ruin the expressive qualities of the original. Given the considerable simplifications to the musical substance, particularly in terms of metre, one may say that the interference in the syntax here is none too surprising. All the changes described here clearly degrade Chopin's original, reducing the musical substance while retaining the sound layers; they also reduce the musical syntax.

The group of functional transcriptions is characterised by a great variety of changes, which lead to a clear trivialisation of the content of Chopin's originals. It is interesting that in the research material in our possession, transcriptions of this type represent a marginal quantity. ${ }^{361}$ Of course, the degree of trivialisation

361 That group comprises the eleven examples presented here:

F. Chopin - F. Büchner, Etude [in G flat major], Op. 10 No. 5, Fl,

F. Chopin - F. Büchner, Etude [in A flat major], Op. 25 No. 1, Fl,

F. Chopin - F. Büchner, Etude [in F minor], Op. 25 No. 2, Fl,

F. Chopin - F. Büchner, Etude [in F major], Op. 25 No. 3, Fl, 
varies. In the examples cited here, the deformations are quite considerable and concern all the aspects of the work (substance, structure, syntax and form). The purpose of the creation and dissemination of adaptations of this kind was unequivocally specified in the titles of the publications. Büchner's etudes appeared in a single collection entitled Sechs Etuden von Chopin für Flöte allein. Given Büchner's pedagogic work and compositional output, ${ }^{362}$ it is highly likely that this was a useful handbook of etudes for working with young flautists. The numerous arrangements produced by Ferdinand David, a propagator of violin music of the eighteenth and nineteenth centuries, were published in collections with telling titles: Violin-Bibliothek - Tänze und Märche. In a list included on the final page of one of the collections, we find a number of transcriptions of works by other outstanding composers, such as Bach and Beethoven, which confirms the pedagogic intention of such transcriptions. The pedagogic-musical bookshop of Michał Arct in Warsaw published Młody Muzyk, which comprised 'collections of easy pieces for piano edited and fingered by J. Łusakowski', arranged into four degrees of difficulty: level 1 was 'very easy', level 2 'easy', level 3 'slightly harder' and level 4 'for better players'. Those publications were of a distinctly popularising character and intended for young amateur pianists. ${ }^{363}$

The various ways in which the original work was modified resulted from the various aims to which the transcribers aspired. For Ferdinand Büchner, most important was training and practice, whilst Łusakowski met the needs of the lowest level of musical education. The artistic degradation of Chopin's original work resulted from the different aims imparted to transcriptions of this kind.
F. Chopin - F. Büchner, Etude [in G sharp minor], Op. 25 No. 6, Fl,
F. Chopin - F. Büchner, Etude [in G flat major], Op. 25 No. 9, Fl,
F. Chopin - J. Łusakowski, Nocturne [in E flat major], Op. 9 No. 2, Pfte,
F. Chopin - J. Łusakowski, Waltz [in E flat major], Op. 18, Pfte,
F. Chopin - R. Kleinmichel, Mazurka [in D major], Op. 33 No. 3, Pfte,
F. Chopin - F. David, Waltz [in A flat major], Op. 42, Vn+Pfte,
F. Chopin - K. Davidoff, Mazurka [in B flat major], Op. 17 No. 1, Vc+Pfte.

362 He wrote many arrangements for flute and piano, a list of which can be found on the title page of the collection Sechs Etuden von Chopin für Flöte allein. They are the following: Op. 20 Nocturne, Op. 21 Conzert-Walzer, Op. 22 Grosse Russische Fantasie, Op. 27 Conzert-Walzer, Op. 28 Andante mit grosser Cadenz, Op. 32 Mazurka-Fantasie and Op. 33 Ungarische Fantasie.

363 The transcription of the Nocturne in E flat major, Op. 9 No. 2 discussed here was assigned to the third level of difficulty. 


\subsection{The diffusion of 'ideal types'}

The division of transcriptions into five basic categories results from a morphological perspective, pointing to the ontic aspects of the original work, its musical substance, texture, syntax, form and expression. That division is represented by Figure 1, where we find a systematics of 'ideal types' on a higher level (substantial, structural, syntactic, recontextual, functional) and a lower level (transmitting the sound layer, multiplying the sound layer; expanding the texture, altering the arrangement of the textural layers; reducing the syntax, expanding the syntax, reducing the form, modifying the form by contamination; the technical-didactic and simplified types). The distinguishing of the groups points to the increasingly great complexity of musical problems and their overlapping. The substantial type is informed above all by the preservation of the musical substance, often accompanied by a change of timbre, resulting from the use of a new performance apparatus, which causes the transmission or multiplication of the sound layers. In the structural group, the overriding aim of transformations is the texture, and its modifications are prioritised. In the syntactic and recontextual types, all the attention is focussed on changing the syntax or the form; it goes without saying that such changes are accompanied by changes of the substantial and textural type. The functional transcription is characterised by the artistic degradation of the original work, to which stark changes to all or several elemental aspects of the original composition contribute. The order to the groups presented here indicates the interference in ever deeper layers of the original and the accumulation and interpenetration of their features.

The systematics proposed here is based on the existence of 'ideal types', although they are not isolated from one another, since a sort of diffusion arises between them, ${ }^{364}$ involving the interpenetration of features from different categories of transcription. The phenomenon of diffusion that occurs within a single group has already been presented here. It concerns especially the substantial and structural groups and to a lesser extent the formal group. Diffusion on a higher level, between the five distinguished groups, is incorporated into this systematics and is represented by a network of connections (see Figure 2). Analysis shows that the greatest network of connections is formed by the functional

364 'Diffusion (Lat. diffusio), (1) chem, phys. The spontaneous penetration of particles of one substance into another substance in direct contact with it or of particles of the same substance from one area of a given phase into another of its areas, triggered by the disorderly thermal motion of those particles, leading to the equalisation of the concentration; (2) sociol. (a) the dissemination of elements of a culture beyond the social group which forged that culture, (b) the process through which individuals or groups adopt cultural values'. See KSLP. 


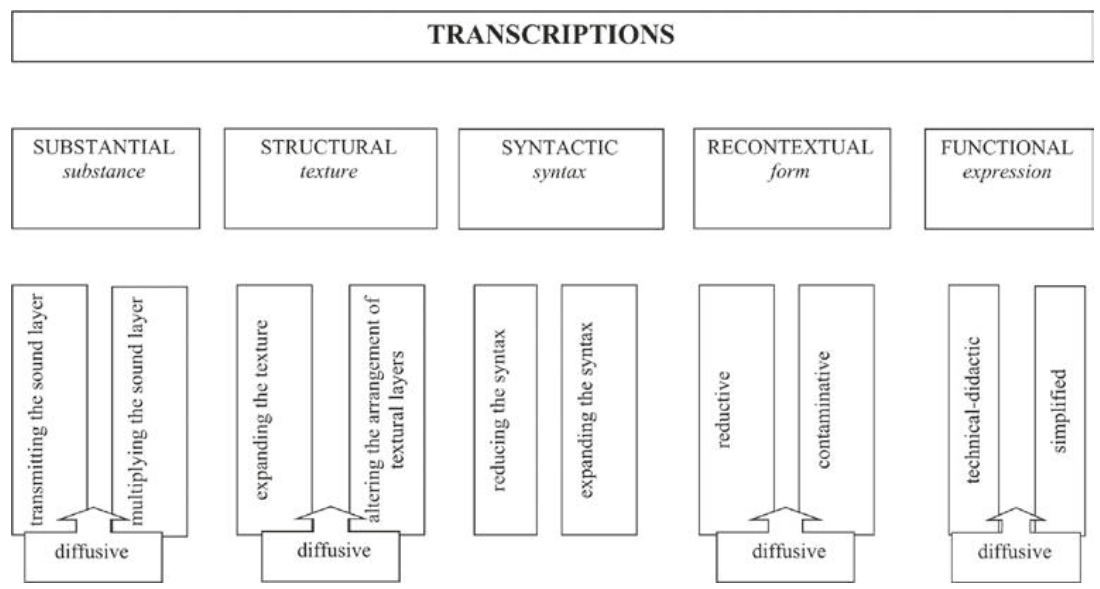

Figure 1: Theoretical model of nineteenth-century transcriptions of works by Chopin.

\section{TRANSCRIPTIONS}

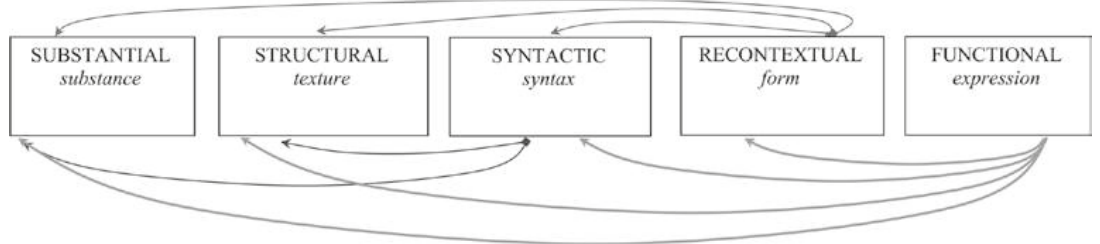

Figure 2: Network of connections in the model of nineteenth-century transcriptions of works by Chopin.

and recontextual types, to a lesser extent the syntactic type, which is directly linked to the adopted hierarchy of ontic elements of the musical work. The functional type can contain elements proper to the substantial, structural, syntactic or recontextual types. The recontextual type may be characterised by changes proper to substantial, syntactic and structural transcriptions, and the syntactic type may display links to a substantial or a structural transcription. 


\section{Nineteenth-century transcriptions of works by Chopin as a form of the manifestation of artistic values in the musical culture of the nineteenth century: Trivialmusik?}

The presentation made thus far of the question of Chopin transcriptions from an historical-social and theoretical-analytical perspective entitles us to take an aesthetic look at the phenomenon. Aesthetic reflection concerns many aspects: the work of art, the artist's creative process, aesthetic experience and the value judgments associated with it, and also the aesthetic value of the work of art. ${ }^{365}$ The work of art is widely considered to be an excellent product in artistic terms, but 'there are weighty arguments in favour of including less successful creations, of inferior quality, within the sphere of aesthetics; the fact is that these works have often fulfilled an important role in the culture of their times, that they have been representative of their epoch and helped to spread new values. Taking these aspects into account, aesthetics ceases to be the study of timeless beauty; it becomes the study of the work of art realising historically changing values the work which, rooted in a specific historical-cultural context, contains a range of qualities indicated not just by its own structure, but also by the needs of the society in which that work is created and lives. ${ }^{366}$

Transcriptions are not self-contained works of art; they are replicas of the works of Fryderyk Chopin. For obvious reasons, therefore, we will pass over two issues here: transcriptions as works of art and transcribers' creative process. We

365 See Gołaszewska, Zarys, 10.

366 Ibid., 13. A similar opinion about artistic products is expressed by Stefan Morawski: 'the work of art is (1) a multi-layered structure linked in many different ways to the historical process (on account of the material, technique, form and content, and belonging to a particular style) that brought it into existence; (2) [...] this structure is explained by going beyond it towards other historical facts, and in those procedures the art historian relies on related disciplines, ranging from the history of material culture to the history of ideas; (3) [...] this structure may itself be source material, especially if other traces of a given culture have been destroyed; (4) [...] the ontological character of the structure under consideration, the so-called work of art, cannot be reduced to material-spatial existence within a given temporal context, that is, to enduring in an unviolated or violated form from the moment it was created till a specific point or till the present day.' (Morawski, Na zakręcie, 165). 
will also overlook value judgments and the appraisal of aesthetic experiences linked to the nineteenth-century reception of Chopin transcriptions, since they were partly presented in the second chapter, based on reviews from the Wrockaw press, Chopin's correspondence, and open letters to publishers (Hector Berlioz) and to readers (Michał Biernacki, ${ }^{367}$ an anonymous subscriber ${ }^{368}$ ). Our interest is now focussed on the aesthetic value of transcriptions. A reader seeking an innovative axiological theory will not be satisfied at this point. In my aestheticevaluative approach, I am opposed to ascribing a single aesthetic value to the whole body of Chopin transcriptions, since they are not the work of a single composer, but of dozens (in the case of the present study) of transcribers, and that fact alone entails a number of different approaches.

The attempt to devise an evaluative scale is my own proposition, resulting directly from the present-day understanding and sensing of the work of art, rooted in the realities of postmodernist creative freedom. In this approach, aesthetic value identified with artistic value will be determined on the basis of the morphological features of transcriptions. This procedure will draw directly on the analyses, observations and conclusions made in the third chapter of this book and on aesthetic views on music contained in works by Władysław Tatarkiewicz, Enrico Fubini, Carl Dahlhaus, Tibor Kneif, Stefan Morawski, Antonina Kłoskowska, Ryszard Nycz and Mieczysław Dąbrowski. ${ }^{369}$ The methodological inspiration behind this chapter came from studies by Maria Gołaszewska and Stefan Morawski. ${ }^{370}$ In the successive subchapters, I will seek to answer the following questions:

[1]To what extent did the concept of Trivialmusik affect the valuation of transcriptions?

[2] What axiological criteria result from examining transcriptions from the point of view of music theory?

[3] What axiological criteria result from examining transcriptions from the cultural point of view?

367 See Appendix: 'List of Michał Biernacki'.

368 Letter from a subscriber to the editors on the transposing of themes from Chopin's Prelude in A major in Zygmunt Noskowski's variations $Z \dot{z} y c i a$ narodu [From the life of the nation]. See Echo Muzyczne, Teatralne i Artystyczne, 1902/11, 124-125.

369 Tatarkiewicz, Historia; Fubini, Historia; Dahlhaus, 'Trivial music'; Dahlhaus, 'Über die "mittlere Musik"'; Dahlhaus, 'Über musikalischen Kitsch'; Kneif, 'Das triviale Bewußtsein'; Morawski, Studia; Kłoskowska, Kultura; Nycz (ed.), Odkrywanie; Dąbrowski, Postmodernizm.

370 Gołaszewska, Zarys; Morawski, O przedmiocie. 


\subsection{The category of Trivialmusik and its effect on the valuation of transcriptions}

The decisive change that occurred in the history of nineteenth-century art had a substantial effect on the perception and appraisal of transcriptions, and it was directly linked to the division of art into 'high' and 'low', into elite and functional art. 'The conflict in question only emerged with the era of the French Revolution, with the industrialisation and urbanisation of societies, the democratisation of culture, and the growth and intensification of processes of alienation, manifest in such things as the production of art as a commodity for anonymous buyers, a commodity that was standardised, to make it cheaper and more easily accessible. ${ }^{371}$ Elite music was created by a composer - a genius, a great individual and exceptional talent, a mystic fulfilling the will of a higher Idea, who in his creative work shattered conventions and undermined stereotypes; 'low' art was created by a mediocre person, pandering to the tastes of an equally mediocre public. 'Low' output was characterised (and is still characterised) by stereotypes, conventions and accessibility, by the communicativeness of its content and the use of tried and trusted forms. ${ }^{372}$ One word that characterises 'low' or mass culture is 'triviality'. The word 'trivial' has many meanings and defines everything that is primitive, banal, simplified, schematic, mundane, unremarkable and mediocre, the wares of the boulevard, the street and the pavement, even everything non-essential or vulgar. ${ }^{373}$ Trivial is another word for crude, common, in poor taste. ${ }^{374}$ To 'trivialise' is to misinform, to render shallow, to primitivise, banalise, vulgarise and simplify ${ }^{375}$ the 'trivial' is something mediocre, schematic and banal. ${ }^{376}$ In light of these definitions, 'triviality' is a decidedly pejorative notion, unequivocally writing off whatever it is applied to. Situated poles apart, 'low' and 'high' art have their boundaries: kitsch for trivial art and the work of genius for 'high' art. ${ }^{377}$ Kitsch, as the greatest warping of art, also bears the stamp of moral degradation, since the creation of kitsch artefacts is an undignified occupation. ${ }^{378}$ The word

371 Morawski, Na zakręcie, 79.

372 Ibid., 76.

373 SłS, 51, 67, 69.

374 SWO, 781.

375 SłS, 84.

376 SłS, 97.

377 See Morawski, Na zakręcie, 76-77.

378 e.g. for Schiller, aesthetic experience was part of a moral life and a tool for shaping good comportment; hence in his essays 'Über den moralischen Nutzen ästhetischer 
'kitsch' was coined around 1880 in Munich, the then artistic capital of Germany. It was a spontaneous modernist slogan of the nineteenth and twentieth centuries, a watchword evoked against all conventional art. ${ }^{379}$ Thus everything that had been acknowledged and was valued in the eyes of the modernist artists of Munich became kitsch, a necessary, although insufficient, requirement of which was triviality. Criticism of trivial mass culture dates back to the late eighteenth century. It emerged 'from intellectual and artistic milieux and from the outset was levelled against the public, against the managers and artists of so-called mediocre or vulgar culture. The social motivation behind this criticism was linked to the evolution of the role and social standing of intellectuals and artists that accompanied the transition from an estate-based society to capitalism. ${ }^{380} \mathrm{In}$ the new social and economic situation, intellectuals and artists aspired to being spiritual leaders of the new democratic society. ${ }^{381}$ The condemnation of mass culture, branded as a mechanical mode of production and degraded through its link to the life of human masses struggling for a living, resulted from the philosophical approach to the notion of culture expressed in the views of Ruskin, Arnold, Nietzsche and Weber. In light of their philosophical thinking, culture was 'opposed to the sphere of man's natural needs, separated from all matter and freed from all biological purpose. ${ }^{382}$ Karl Rosenkranz mentioned triviality in art in his work Esthetik des Hässlichen (1853). He identified it with tedious imitation that brings nothing new. Such a view implied a corresponding hierarchy of aesthetic value: 'Rosenkranz [...] considered that beauty "on the level of ordinary correctness" is ugly, whereas a work that in many of its details is "incorrect may be beautiful'"383

Nineteenth-century music writers began commenting on triviality in music. In 1826, Hans Georg Nägeli used the term when appraising the 'Jupiter' Symphony to define an idea of Mozart's which he considered to be 'commonplace. ${ }^{384}$ Significant was Robert Schumann's attack on 'prosaic' music, as opposed to 'poetic' music. The issue of trivial music, linked to the current of popular,

Sitten' and 'Über naive und sentimentalische Dichtung' he negated the trivialisation of art of the late eighteenth century. See Kłoskowska, Kultura, 221.

379 See Dahlhaus, 'Über musikalischen Kitsch'.

380 Kłoskowska, Kultura, 214.

381 Ibid., 212-254. The author's assessment of nineteenth-century mass culture is based on a survey of the standpoints of its critics.

382 Kłoskowska, Kultura, 239.

383 Hofmann, 'Kicz', 477.

384 See Dahlhaus, 'Trivial music', 342. 
functional or mass music, became the subject of much historical, sociological and aesthetic-axiological research in our times. ${ }^{385}$ In the present considerations, I draw on the writings of Carl Dahlhaus, Tibor Kneif and Irena Poniatowska. ${ }^{386}$ A survey of the attempts at defining trivial music contained in those works will help to show transcription in their light and will move towards obtaining an answer to the question as to why and to what extent this modernist concept affected the evaluation of transcriptions.

A paradox of nineteenth-century culture was the fact that the progressive democratisation of social life enabled the development of trivial art, which was linked to the emergence of a new, bourgeois social class. The musical art practised by that class, in both its form and its character, was opposed to 'high' music, reserved for the enlightened and culturally aware. This fact is widely regarded as the social cause of the appearance of a split in art. The thesis that trivial music belonged to bourgeois musical culture, to its Haus- and Salonmusik strands, cited by many authors, is too general an assertion. I propose to compare features of transcriptions with features that led the above-mentioned authors to consider a given composition as trivial. This will enable us to adopt a stance in relation to the highly general assertion given above.

In the opinion of Irena Poniatowska, 'triviality in art is understood as the opposite of artistry.387 Trivial music arose out of a clear social demand; thus it is dependent on the receiver. That fact bears a direct influence on its basic features: simplicity, commonness, a lack of taste and a derivative character. Thus understood, trivial music acquires meaning in the context of extra-musical factors, with the effect that such output imitates 'serious' music in a simplified way. So, according to Poniatowska, copying or imitation is a negative way of proceeding, contrary to creativity, particularly when it is linked to a considerable simplification and impoverishment of valuable music. Thus one basic feature of trivial music is the imitation of 'serious' music, which is visible in the following areas:

385 A list of major works dealing with this subject is given by Irena Poniatowska in Muzyka fortepianowa, 289-293.

386 Dahlhaus, 'Trivial music'; Dahlhaus, 'Über die "mittlere Musik"'; Dahlhaus, 'Über musikalischen Kitsch'; Kneif, 'Das triviale Bewußtsein'; Poniatowska, Muzyka fortepianowa, 278-288 (chapter 'Muzyka salonowa - między sublimacją a trywializacją' [Salon music: between sublimation and trivialisation], 289-309 (chapter 'Pozamuzyczne i muzyczne wyznaczniki twórczości "masowej"' [Extra-musical and musical determinants of 'mass' output]).

387 Poniatowska, Muzyka fortepianowa, 293. 
[1]'an aspiration to expressing some poetic, literary idea'; ${ }^{388}$

[2] programmatic titles, such as valse mélancolique, valse brillante and valse de concert, designed to emphasise the mood, intention or 'nationality' of a given composition; ${ }^{389}$

[3] a rich variety of expressive markings combined with a substantial impoverishment of a work; ${ }^{390}$

[4] imitation of the style brillant, involving the use of similar ways of shaping form (segments, repeats, variation) and a similar treatment of musical elements (cantilena opposed to more or less virtuosic figurations, chords - thirds, sixths and tenths); ${ }^{391}$

[5] the adoption of forms from art music, namely, dances (e.g. waltz, polonaise, minuet, mazurka) and poetic genres (e.g. impromptu, nocturne, ballade);

[6] the lack of several forms: sonata, fugue, sonata cycle and suite.

Were we to adopt the fundamental determinant of trivial music given by Irena Poniatowska, all transcriptions would have to be assigned to this category, since they openly imitate Chopin's work and were produced to clear public demand. Yet that classification is wrong. For Poniatowska, trivial music's 'aspiration to expressing some poetic, literary idea, even if it is merely a pretext' was manifest in the titles of compositions which expressed hidden emotions and moods. ${ }^{392}$ A title was often reinforced with a subtitle, and even illustrations. Subtitles (e.g. meditation, poem, fantaisie ${ }^{393}$ ) indicated a romantic, sentimental mood, whilst illustrations (sometimes telling a pictorial tale) clearly imposed the 'content' of the music or its plot. Such 'programmatic' titles were found in 'low' salon music and referred to six basic extra-musical domains: emotions, remembrance, external reality (nature), historical circumstances, modern social and political life, and social recreation. ${ }^{394}$ This 'content invested in the title was addressed to a receiver with the mentality of a child, who does not understand music, but wants

388 Ibid., 295.

389 Ibid., 302.

390 Ibid., 300.

391 Ibid., 301.

392 Ibid., 295.

393 The author lists the idyll, elegy, musical moment, Klavierpoesien, Erzählungen, Improvisation, Fantasiestücke, Tongemälde, Aquarelle, Pastel, Tonbild, Federzeichnung, Musikalisches Bilderbuch and Albumblätt. See Poniatowska, Muzyka fortepianowa, 296.

394 Ibid., 297-299. Poniatowska discusses these features in detail. 
to partake of it. ${ }^{\prime 395}$ This aspect of the 'programmicity' of trivial music as presented by Poniatowska also concerns original editions of Chopin's compositions, since it is well known that many of his works were given such titles as Il Lamento, ${ }^{396}$ La Meditation, ${ }^{397}$ Regentropfen or $^{398}$ Souvenir d'Andalousie. ${ }^{399}$ In their Catalogue, Chomiński and Turło list 149 non-original titles suggesting the mood of a work. ${ }^{400}$ So according to Poniatowska's definition, do those compositions belong to the genre of trivial music? Of course not. The music remains intact, and only the actual procedure of imparting the titles may be considered trivial. ${ }^{401}$ The cradle of such interference on the part of publishers was England, ${ }^{402}$ followed by Russia and Germany, and to a lesser degree also France and Poland. ${ }^{403}$ In the case of Chopin transcriptions, such titles were employed on a wider scale, as is confirmed by the list included in the Catalogue (e.g. Dancing Shadows, Rends-moi l'amour, Schön war der Traum). ${ }^{404}$

As Poniatowska writes: 'For trivial, light music, most typical and quantitatively dominant were so-called character pieces with programme titles. ${ }^{405}$ As already mentioned, such programmicity conveyed in expressive terms emphasised the mood (romantique, sentimentale), intention (valse de concert, valse de salon) or

395 Ibid., 29.

396 Nocturne in B major, Op. 32 No. 1 (London: Wessel, 1837). See CT, 418.

397 Scherzo in B flat minor, Op. 31 (London: Wessel, 1837; Ashdown, 1860-1882). As the authors of the Catalogue relate (CT, 418), this title was also cited in a document signed by Chopin himself.

398 Prelude in B minor, Op. 28 No. 6 (Leipzig: Rühle, 1904-1908). See CT, 420.

399 Bolero in C major, Op. 19 (London: Wessel, 1835; Ashdown, 1860-1882). See CT, 421.

400 See CT, 415-422.

401 The 'external programmicity' of Chopin's music is discussed by Mieczysław Tomaszewski, Chopin, 716-733.

402 In the years 1830-1870, English publishers led the way in this 'aspiration to expressing some poetic, literary idea' (52 editions), followed by Russians (13), Germans (7), the French (5) and the Poles (3). Over the subsequent period, 1870-1918, the figures break down differently: Germany (23), England (18), Poland (13), the US (6), France (4) and Russia (3), and after 1918 the quantitative breakdown of this phenomenon was very even in all these countries.

403 In Poland, A. M. Szulz devised the title 'Revolutionary' Etude, Zygmunt Noskowski called the Impromptu in F sharp major, Op. 36 'Sunday in the Country' and the Ballade in A flat major, Op. 47 the story of Lorelei, while Stanisław Niewiadomski attributed to the same ballade the content of Adam Mickiewicz's literary ballad Świtezianka [The nymph of Lake Świteź]. Information after CT, 422.

404 CT, 423-441.

405 Poniatowska, Muzyka fortepianowa, 302. 
'nationality' of a composition (polonaise, czardasz). ${ }^{406}$ Of these three kinds of terms, in transcriptions we occasionally find the first two, e.g. Valse mélancolique and Etude de concert, while the third group does not apply, since the terms it comprises (polonaise, mazurka) are first and foremost associated with Chopin's output. It should be stressed that the titles of Chopin transcriptions were largely devoid of extraneous terms, but they clearly referred to the original output, as was expressed in such wordings as Walzer von F. Chopin für Violine mit Pianofortebegleitung, Nocturnes de Fr. Chopin transcrits pour violon et piano, Oeuvres de Frédéric Chopin arrangées pour le Piano a quatre mains and Fr. Chopin's 13tes Praeludium aus Op. 28. Transcription für... von Carl Mikuli. In this light, the programmicity of the titles of trivial compositions is not a property of Chopin transcriptions.

The body of transcriptions in my possession also belies the rule that the substantial impoverishment of Chopin's original is accompanied by a wealth of expressive markings. That remark concerns only a small number of virtuosic arrangements of the variation type (Friedrich Kalkbrenner ${ }^{407}$ ) or the fantaisie type (August Hänsel ${ }^{408}$ ), in which we do indeed find performance markings of that kind (brillant, élégant, con espressivo, delicato), but those works fall beyond the group of Chopin transcriptions. The situation is similar in relation to another feature, namely, the imitation of the style brillant, evident in the shaping of form and the treatment of musical elements. In a sizeable group of transcriptions, the syntax or form accords with Chopin's original, whilst repetition or variation is proper to transcriptions from the syntactic, recontextual and, above all, functional, groups. There are few instances where thirds, sixths and tenths chords are used, ${ }^{409}$ since the majority of the body of transcriptions retain the basic elements of the original, that is, its chording and melodic writing. This kind of imitation is also exemplified by the above-mentioned works by Kalkbrenner and Hänsel.

Another feature of trivial music, which is the adoption of forms from art music, namely, dances (e.g. waltz, polonaise, minuet, mazurka) and poetic genres (e.g. impromptu, nocturne, ballad), is present in the body of transcriptions. Mazurkas and nocturnes were indeed transcribed, but so were songs, waltzes

406 Ibid.

407 Friedrich Kalkbrenner, Variations brillantes for solo piano, after the Mazurka in B flat major, Op. 7 No. 1 (Leipzig: Kistner, 1833). Dated after Deutsch, 18.

408 August Hänsel, Fantaisie on the Mazurka in B flat major, Op. 7 No. 1 for piano (Dresden: Louis Bauer, c.1850). Dated after CT, 350.

409 Poniatowska, Muzyka fortepianowa, 301. 
and, to a lesser extent, ballades, fantasies and scherzos. ${ }^{410}$ Yet the adoption of these genres in the process of transcribing was strictly linked to Chopin's output and cannot be read here as a trivial procedure, but rather as an estimable reference to the sources - to Chopin's originals. What does apply here is the dearth of sonata form and sonata cycle in the body of transcriptions. As already stressed, ${ }^{411}$ that did not result from the quantitative predominance of certain genres in the Chopin oeuvre (mazurkas, nocturnes, etudes) over the much smaller pool of sonatas, concertos, ballades and scherzos or from the distance in time separating an original from its transcription. The avoidance of large-scale forms is confirmed in the choice of transcriptions: in arrangements of the Concertos in E minor, Op. 11 and in F minor, Op. 21 and the Ballade in F major, Op. 38, transcribers based their works on extracts alone: the second movements of each of them (Romance Larghetto; Larghetto), the third movement of the Concerto in F minor, Op. 21 (Allegro vivace) and the first movement of the Ballade in F major, Op. 38 (Andantino). ${ }^{412}$ Yet, despite its presence, this feature does not bear the hallmarks of triviality, but results from completely different motives.

410 Cf. subchapter 2.1 .

411 Ibid.

412 According to information contained in CT (347), there are only eleven arrangements of the whole of the Concerto in E minor, Op. 11. They are scored for easy piano (two), piano (six), piano for four hands (two) and harmonium (one). The earliest was written in 1844 by F. L. Schubert for piano for four hands. Most of these transcriptions were produced over a very wide period of time, between 1877 and 1977. Much more popular among transcribers was the second movement of that Concerto: the Romance Larghetto. In CT, there is mention of arrangements for easier piano, piano, violin and piano, violin and orchestra, and harmonium.

There are far fewer arrangements of the Concerto in F minor, Op. 21, with only eight transcriptions of the whole work, for piano, easy piano and piano for four hands. There are also few arrangements for violin and piano or for voice of selected movements from this Concerto: the Larghetto or the Allegro vivace.

Only a handful of composers translated both Concertos for other forces: August Wilhelmj produced a violin transcription (for violin and piano or violin and orchestra) and also arranged the Romance from the Concerto in E minor and the Larghetto from the F minor; Josef Löw produced an arrangement for harmonium (the Romance from the Concerto in E minor, Op. 11) and Peter August Schnecker for solo voice and quartet (the Larghetto from the Concerto in F minor, Op. 21).

The largest group comprises arrangements of the scores and the piano accompaniment of both concertos. In our source material, we find only three items scored for two pianos: two arrangements by Herrmann Scholtz, based on extracts from both of Chopin's concertos, and one by Karol Mikuli of the Allegro de concert. 
The popularity of particular genres among transcribers was probably determined by their musical properties. More precisely, the joint action of musical attributes - substance, texture, syntax and form - forging a specific kind of expression conveyed in a 'codex of the characters' (genres) of Chopin's music may explain the quality of its reception. ${ }^{413}$ Of the twelve 'characters' distinguished by Mieczysław Tomaszewski, four genres are particularly prominent: [1] the idyllic (proper to mazurkas and 'rustic' songs and visible in the slow movements of the concertos and ballades (Andantino in the Ballade in F major)); [2] the elegiac (melancholy mazurkas, some waltzes, preludes, nocturnes, polonaises and songs); [3] the nocturne (mainly nocturnes and the slow movements of the concertos); [4] the song (many genres - nocturnes, impromptus, etudes, preludes and parts of the scherzos, sonatas and concertos). Thus the features favouring transcription were lyricism (present in most of the originals, evident in a calm and singing flow to the music), sentimentalism (linked to the content of a verbal text; examples include the numerous arrangements of the songs 'Życzenie' [A Maiden's Wish], Op. 74 No. 1 and 'Pierścień' [The Ring], Op. 74 No. 14) and to a lesser extent virtuosity (the Waltz in D flat major, Op. 64 No. 1, Etudes, Op. 10 Nos. 1, 2, 5) and a national character (polonaise with the function of a national dance, one example being the Polonaise in A major, Op. 40 No. 1). Also significant may have been the dimensions of a composition and its clear, periodic design and homophonic texture. Such features are not found in less frequently transcribed forms (sonatas, scherzos, concertos and ballades) characterised by gradual development, epic narration, dramatic structure, complex piano texture, changing tonality and large dimensions. The popularity of some compositions among transcribers could have been determined by the 'dominant properties' distinguished by Tomaszewski: the qualities of being instrumental, musical, lyrical, poetical, 'folkish' and national. ${ }^{414}$ The instrumental quality of the original music, expressed in the confinement to the sound of the piano, could have stirred interest in Chopin's output among other instrumentalists and singers, manifested in the form of many transcriptions for forces not used by the composer. Musicality, as a synonym of asemanticism, is a feature that could have led to programmes being ascribed to this music, expressed in numerous arrangements

413 Mieczysław Tomaszewski stresses that the bearer of specific expressive qualities in Chopin's music is a unit smaller than the genre, which he terms 'type', distinguishing the following: idyllic, elegiac, balladic, nocturnal, chorale, march, song, dance, ludic, scherzotic, lullaby and heroic. (See Tomaszewski, Chopin, 703-716).

414 Ibid., 751-752. 
with an added title or even text. Equally crucial were the remaining features, each of which can be found in transcriptions.

The division of transcriptions into miniatures and large-scale forms (sonatas, scherzos, ballades) confirms the systematisation and evaluation of the original works, which characterised nineteenth-century reception of Chopin's music, since he left Warsaw as a well-rounded composer, on which the musical culture of 1820 s and 30s Warsaw impressed its stamp ${ }^{415}$ The principal criterion for the evaluation of music at that time was its national character, the representation of which was served by such musical means as the cultivation of national dances (mazur and krakowiak), the use of their metric-rhythmic elements in most cyclic works and the existence of 'Lydian' devices in the melodic writing. ${ }^{416}$ The style brillant, present in Warsaw during the 20s, also influenced the character of Chopin's compositions of that period. And, despite the originality of his music, it was perceived throughout almost the entire nineteenth century as Polish national music, sentimental and virtuosic. Only in the last decades of the nineteenth century did its popularity grow, winning over a wide audience, and pianists perceived in Chopin's 'piano compositions pianistic and musical quality of the highest order, exquisite texture and a classical perfection of form. ${ }^{417}$

One basic reason for the lack of sonata form and sonata cycle in transcriptions could have been nineteenth-century opinions regarding the quality of Chopin's original large-scale works. Andrzej Tuchowski, citing the extensive Chopin studies literature, as well as press reviews and announcements relating to Chopin's output, emphasised that the original romantic fantasy and powerful emotional impact of his music were the most crucial features appreciated by nearly all critics at that time. ${ }^{418}$ Regarding Chopin as a master of the miniature, commentators frequently cited his perceived inability to compose large-scale works, with the greatest reservations held with regard to his sonatas. That

415 'Chopin spent more than half his life in Warsaw. It was here that he gained his general and musical education, here that he matured as a composer and a pianist, and here that his national awareness crystallised.' (Chomiński, Chopin, 1).

416 Nationality as thus conceived was superficial and primitive, as it did not alter the musical language of those compositions; it only inserted the cited folk elements into the framework of the old harmonic and formal order. One must also remember that mazurkas and polonaises were already familiar earlier from compositions by Chopin's predecessors (Ogiński, Szymanowska, Deszczyński, Elsner, Kurpiński) and functioned in the musical tradition largely as practical forms.

417 Weber, 'Repertuar', 48.

418 Tuchowski, Integracja, 9-17. 
unfavourable nineteenth-century paradigm, accusing Chopin's sonatas of a lack of form, held sway until around 1920 and, backed by the stereotypical image of Chopin the Romantic, appealing to emotions, it exerted a decisive influence over the evaluation of his music during the nineteenth century. And that state of affairs no doubt affected indirectly the choice of Chopin's originals in the process of transcribing his work, and consequently the avoidance of large-scale works. In light of these facts, the triviality of music, expressed in the lack of sonata form and sonata cycle, is not so obvious in relation to Chopin transcriptions.

Applying the model of trivial compositions proposed by Irena Poniatowska to the body of Chopin transcriptions, we may state that it works only in relation to functional transcriptions and to a small group of 'textual' transcriptions - those which impose various meanings on Chopin's asemantic music, which thereby becomes banal, sentimental and mawkish. ${ }^{419}$ The modernist concept of Trivialmusik presented in the views of Irena Poniatowska degrades compositions which imitate excellent, highly artistic output in any way, so it clearly absorbs all kinds of transcription, without entering into their actual musical and aesthetic value.

According to Carl Dahlhaus, "trivial" means "common, shallow, quotidian, worn"' 420 'trivial music is a deficient mode of music that is simultaneously functional and artificial and represents the residue left over after autonomous music split from functional music. ${ }^{421}$ One feature of trivial music is a lack of connection between its formal elements, "trivial" refers to a music that emphasizes detail without being original.'222 According to this approach, however, the triviality concerns not the music itself, but the people who receive it; this results from a misunderstanding of the given musical form, combined with attention being directed at some trifling detail. 'Using music in a manner that is unconcerned about the original form and meaning of a work is, according to aesthetic norms, a distortion or trivialization. Breaking pieces out of their context [...] interfering with the musical text, and changing the orchestration are suspicious within the realm of aesthetics. ${ }^{323}$ According to these opinions of Dahlhaus's (who invokes Besseler ${ }^{424}$ ), the triviality of music results from two facts: the change of

419 Transcriptions of this type form part of various groups within the systematics employed in this work. Textuality is extraneous to the exclusively musical features of transcriptions.

420 Dahlhaus, 'Trivial music', 341.

421 Ibid., 343.

422 Ibid., 342.

423 Ibid., 345.

424 Besseler, 'Grundfragen'. 
its function (its way of existing) and the violation of its musical, autonomous identity, defined by its structure and performance apparatus. In addition, 'the method of publishing arrangements as texts that bear the name of the arranger just as if he were an author, expresses, even if unconsciously, the subjugation of functional music to the current norms of the aesthetic - i.e., to the concepts of identity, inviolability, and originality. ${ }^{425}$ This is a trivial way of proceeding. So Dahlhaus draws attention to two crucial aspects of triviality: it may be perceived as an immanent feature of a musical composition or as a feature proper to the receiver (the listener and the analyst). Decisive in the former case is the violation of the structure and substance of the original; in the latter instance - the change of the social context in which a composition is presented. Dahlhaus's very general, but fundamental, definitions of triviality in music clearly concern the group of transcriptions which are characterised by violation of the original, a change of performance apparatus and a change in its mode of existence. And while the first two features are unequivocal, we cannot concur with the change of function of Chopin's compositions via their transcriptions; that feature does not appear to be self-evident. Transcriptions, like Chopin's original output, were used for various purposes: concerts, teaching and social amusement; both transcriptions and Chopin's originals were lent aesthetically alien titles. So we can refer the accusation of triviality solely to musical features of transcriptions.

In Dahlhaus's opinion, trivial music is characterised by the following features: [1] a lack of formal references in a composition, as exemplified by the potpourri form, based on continual changes of content, designed to appeal to a 'distracted listener' incapable of concentrating on a large, logically presented whole; ${ }^{426}$ [2] its mass production; ${ }^{427}$ [3] 'charm', a feature that ensures it will stick in the listener's mind; [4] ornamentation, trivial effect, not permeating a musical structure, but merely appended to it; [5] 'breaks in style' (as in the potpourri technique), an intentional effect aimed at winning over an average, musically unrefined listener; this feature involves the sudden eruption of operatic intonation in a song or the use of virtuosic posturing in a chamber work; [6] 'indifference towards the origin' of the melodies used by trivial music. 'Methods of appropriation - parody and contrafactum, adaptation and arrangement - are more typical of it than those of creation; decisive is not the original purpose of a work, but its useability. ${ }^{428}$

425 Dahlhaus, 'Trivial music', 346.

426 Ibid., 356.

427 Ibid., 355.

428 Ibid., 345. 
Based on the sources in our possession, we can state that among Dahlhaus's features, only serial production characterises some of the transcriptions; to a much lesser extent, the feature of ornamentation is proper to a small group of virtuosic transcriptions, whilst 'breaks in style' can be ascribed to just a few transcriptions based on an extract from an original composition (e.g. the Ballade in F major) and to those which include new fragments not integrated with the content of Chopin's original composition (e.g. the Mazurka in F sharp minor, Op. 6 No. 1 for cello and piano by Robert Emile Bockmühl ${ }^{429}$ ). In none of the examples from the source material in our possession do we note indifference towards the origin', since the provenance is noted - the original is indicated in every transcription. In relation to the phenomenon which was present in music of the eighteenth and nineteenth centuries, Dahlhaus proposes, instead of the overly broad and bland term 'trivial music', the more suitable term 'middle music'. ${ }^{430}$ Up to the eighteenth century, both art music and 'lower' music fulfilled some functions. That was an obvious fact; they were both treated as a single musical art. Once music became divided into autonomous and functional art, during the eighteenth century (under the watchword 'art for art's sake'), all functional music (for the salon, for amusement and even sacred music) began to be suspected of triviality.

" "Middle music", like all trivial music, is something alien to art, since it arouses aesthetic reservations. ${ }^{431}$ It is characterised by the fact that it is 'notated and printed, so it occurs as a specific work by a specific composer, although according to stricter aesthetic criteria its "work character" leaves a great deal to be desired'. ${ }^{432}$ For Dahlhaus, the 'middle music' (of the salon, of amusement) of the nineteenth and twentieth centuries was representative of the trivial in music. 'Middle music [...] does not assume the role of an accompaniment, support or musical decoration to a non-musical event, so it is not functional music in the proper sense of the word, but on the other hand, unlike concert music, it does not represent a self-contained object of aesthetic contemplation [...] - without losing sight of its meaning either one can listen to it as concert music or else it may serve as a musical background'; ${ }^{433}$ the main form of this music is the potpourri.

429 The transcriber added a lengthy and banal introduction, which is foreign to the substance and expression of the original. Cf. Gołąb, Dziewiętnastowieczne transkrypcje, 31.

430 Dahlhaus, 'Über die "mittlere Musik"'.

431 Ibid., 132.

432 Ibid., 131.

433 Ibid., 132-133. 
In light of these views, for which the main argument in favour of the triviality of music is its functionality, transcription comes across as a trivial genre, since it can serve as a practical 'means' for almost every artistic and pseudoartistic situation. Yet that accusation can also be levelled at highly artistic output and the way it existed in nineteenth-century musical culture. From the previous chapter, we know that transcriptions were included alongside large-scale works on the programmes of symphonic or chamber concerts; on the other hand, compositions by esteemed composers (such as Schumann and Chopin) were regarded as highly popular salon works. So functionality is not and cannot be the sole determinant of triviality in music; if it were, then we would first have to specify the kind of that functionality - does it belong to 'high' or 'low' culture?

'Originality and integrity are fundamental concepts of nineteenth-century aesthetics - the theory of art that presupposes and creates awareness for the distinction between autonomous and functional music.'434 In Dahlhaus's modernist approach, we find an explanation for an evaluation of transcriptions which is still found today: they represent a phenomenon arousing aesthetic doubts, since they are opposed to the norms of the identity, integrity and originality of a work. So if those norms underpin that evaluation, then every attempt at imitating or adapting a work is condemned to a negative appraisal.

In the opinion of Tibor Kneif, ${ }^{435}$ transcriptions unequivocally represent a trivial genre, since they adopted a form proper to the musical culture of the nineteenth century, namely, numerous arrangements of a single work for different forces: ${ }^{436}$ voice and piano, easy piano, four-handed piano, piano and violin, piano and mandolin, piano and cello, solo violin, solo mandolin, zither, small orchestra (Bijou-Orchester), orchestra. In his opinion, that commonness of arrangements and compositions was favoured by the development of German instrument making, which imposed the 'factory-line' production of easy, simple compositions for the masses. That is how the mechanism of the creation of works of functional, trivial art worked - pieces devoid of artistic longevity, merely satisfying some temporary need. So the artistic value of trivial music equated to the satisfying of rapid and easy consumption. Triviality was a ubiquitous phenomenon in nineteenth-century culture, as Kneif maintains; it was a product of 'trivial man', frittering away his time in 'musty euphoria' ('dumpfen Euphorie'), rejecting everything that might bring confusion and disturb his oasis of tranquillity.

434 Dahlhaus, 'Trivial music' 345.

435 Kneif, 'Das triviale Bewußtsein'.

436 Interestingly, the author does not use the terms Transkription and Bearbeitung. 
Trivial man was characterised by sentimental thinking and feeling; hence a composer possessing trivial awareness showed reality in a banal and deformed way. Such a man was at home in the artistic or bourgeois salon and in cafe gardens. It was a question of mentality.

So, according to Kneif, transcriptions unequivocally constitute a category of trivial works, since they deform and thereby trivialise the received reality, that is, Chopin's originals. Thus the imitation of Chopin's original with the introduction of changes is understood as deformation; it has pejorative overtones, which is representative of the modernist view of art.

The term 'trivial music' has clearly negative connotations. It is too general, often highly subjective, relative and conventional, as one realises from the texts cited here. Moreover, as Tibor Kneif asks, does there really exist only good or only bad music? ${ }^{437}$ The difficulty with distinguishing and assessing high and low art is emphasised by Werner Hofmann: 'There is simply no avoiding value judgments, yet distinguishing between art, kitsch and trivial art is the worst of all possible premises.'438

Echoed in all the views presented here is a modernist concept which unequivocally disqualifies transcriptions. That view only began to change during the 1990s, and of ground-breaking significance was source research published in the Catalogue of the Works of Frederick Chopin ${ }^{439}$ thanks to which transcriptions found their place as an object of study worthy of interest, treated as a form of the reception of Chopin's music expressed in a succession of repeats of the same feature visible in a number of copies. Our research and the reflections considered above show that not all nineteenth-century transcriptions can be assigned to the category of Trivialmusik.

\subsection{The value of transcriptions of Chopin's works within the context of the adopted criterion}

Transcriptions, which constitute a collection of artistic artefacts, can be ascribed varying aesthetic value, which accords with the assumptions and observations of Roman Ingarden. ${ }^{440}$ That fact is possible thanks to the distinction between

437 'Gibt es denn absolut ungeniale Musik?, 'Gibt es denn absolut vollkommene Musik?' (Kneif, 'Das triviale Bewußtsein', 40).

438 Hofmann, 'Kicz', 483.

439 CT.

440 See Ingarden, 'Wartości'. 
artistic value and aesthetic value. The former 'is something that occurs in the work itself and is existentially grounded in the work'; ${ }^{441}$ the latter 'appears only in the aesthetic object in concreto, and that as a specific, distinct aspect determining the whole of that object', ${ }^{4}{ }^{42}$ and it is dependent on 'the co-creative action of the perceiver. ${ }^{243}$ It may occur, therefore, that two aesthetic objects of different value arise on the basis of a single work, since the aesthetic value of that work is dependent on the attitude of the receiver, on his or her aesthetic baggage and subconscious predilections. In our evaluative procedure, we were guided by relativism, ${ }^{444}$ on the strength of which we were able to reveal two different assessments - depending on the socio-historical situation - of our object of study. The starting point for our considerations comprises Ingarden's distinction, the stance of Giovanni Morelli (for whom a significant criterion for the assessment of an artistic object is its freshness, which lends value to the technically perfect work ${ }^{445}$ ) and also the postmodernist theory of deconstruction.

In the case of the musical work, aesthetic value is linked directly to its artistic value, and in extreme cases one may even state that they are identical. One argument in favour of this thesis is the fact that our judgment is not free from considerations of composition technique. From this perspective, further conclusions of an aesthetic nature tend towards establishing a criterion on the strength of which one transcription may be regarded as aesthetically more valuable than another; that criterion is strictly linked to the 'empirical foundation of

441 Ibid., 203.

442 Ibid.

443 Ibid.

444 Stefan Morawski distinguishes five basic axiological procedures: subjectivism, relativism, objectivism, relationism and historicism. Subjectivism and relativism define aesthetic qualities from the point of view of the aesthetic subject - his/her tastes. It is guided by 'personal [aesthetic] tastes'; relativism draws attention to the changeability of 'group tastes and verdicts', dependent on social and historical contexts. Objectivism, presupposing the duration of given objective qualities, focusses its attention primarily on the aesthetic object, and to a lesser extent on the evaluating subject. Relationism takes account of the relations between the aesthetic subject and object; it emphasises the correspondence between the reactions of those two entities. Historicism is a stance that takes account of the 'constant of the aesthetic field', that is, the given cultural situation, along with its characteristic objects and subjects of aesthetic cognition. See Morawski, 'O kryteriach aksjologicznych', 21.

445 One should not forget that 'it is of the very essence of art to transmute expression into skill'. See Wind, 'Critique', 46. 
value.. ${ }^{46}$ Analysing transcriptions as experts, we note a number of phenomena of a technical nature, and on that basis we issue an assessment of artistic value. One may say, therefore, that at this stage our research is of a scholarly character. Wishing to impart aesthetic value to transcriptions, we are guided by intuition, which is steered by our aesthetic baggage. ${ }^{447}$ Thus a basic criterion for the artistic value of a transcription is its technical mastery (métier) - an added value which is a sine qua non for our perception of an object as a work of art, while its expressive freshness enhances that value. ${ }^{448}$ Thus artistic evaluation is the basis for aesthetic evaluation. To sum up, we adopt as the criterion for the artistic value of Chopin transcriptions their professionalism, expressed in their technical proficiency, whilst our criterion for aesthetic value is the originality or novelty of the take on Chopin's work.

The question of evaluation addressed here concerns a musical composition (a transcription); the way that composition is evaluated is based on 'preferment.' ${ }^{449}$ In subjecting a set of transcriptions $Z$ to a selection based on preference, we must employ three tools: [1] a value scale $V$, which systematises $Z$; [2] a qualifying function $Q$, 'which assigns to each object $x$ from set $Z$ one place alone $q(x)$ in the scale $V ;{ }^{\prime}{ }^{450}$ [3] a selection strategy $S$, which 'gives one of two possible directions to the $V$ scale, thereby establishing the order to the preferment of its places and consequently of the objects to which those places were assigned. ${ }^{451}$ This is the most crucial tool, since it clearly directs the scale and criteria that are helpful to preferment. The defining of a suitable selection strategy makes it impossible to make contradictory choices when employing the same scale and the same criteria.

446 Morawski writes about definitions of 'value, 'evaluation' and 'criterion' in 'O kryteriach aksjologicznych', 17-27.

447 See Friedländer, 'O granicach nauki. This cognitive procedure was preferred by the Italian art scholar Giovanni Morelli, who in his research into the work of art drew attention to the expression contained in the least significant details.

448 Stefan Morawski points out that although 'artistic mastery' does not determine the axiological status of a work of art, in most cases it is an essential condition of that status. Judgments on technical qualities are of an empirical, perceptive nature. See Morawski, 'O kryteriach aksjologicznych', 22-23.

449 The following passage relating to evaluation is based on the method of Mieczysław Porębski. See Porębski, 'Mechanizmy'.

450 Ibid., 263.

451 Ibid., 264. 
The systematics of transcriptions employed in the third chapter of this work refers to the design of a musical composition. So does that morphological classification also imply an evaluative classification? Assuming that the aesthetic value of a transcription is greater the more a transcription is similar to Chopin's original, we would obtain the following hierarchy among the groups distinguished in the system of nineteenth-century transcriptions: the most valuable would be transcriptions containing a minimum number of changes, so largely retaining the expression of the original. ${ }^{452}$ Such an axiological scale derives from the views of Dahlhaus, ${ }^{453}$ speaking of the norms of a work's identity, integrity and originality, ${ }^{454}$ and it is clearly linked to the current of Trivialmusik, rejected and negated in the present work.

As the musical-theoretical basis of the evaluation of Chopin transcriptions, we adopt our own view, derived from the classical concept of mimesis - from the opinion of Aristotle, according to whom the task of an artistic object is to have an aesthetic effect on the receiver, which it achieves by means of a suitable construction. We consider mimesis to be the foundation of the artist's work. ${ }^{455}$ This is clear when we break away from its common understanding as the imitation of nature and rely on 'the original understanding of Aristotle (in his Nicomachean Ethics), who emphasises the productively creative element contained in this notion.456 To be precise, the problem lies in the relationship between the imitating subject and the imitated object. 'A decisive role in the forming of human expression is played by the prototype, given in fantasy or in reality. Its recreation awakens a person's powers and imparts to them direction and purpose - whether he wishes to gain control over that prototype or to turn into it himself.' ${ }^{457}$ The desire to shift an expressive tendency from imitation to self-representation is a question of awareness. Wishing to impart value to both these forms of creative expression, we will value more highly attempts at self-representation than attempts at

452 The notion of the expression of a work of art is linked here to its unity and individuality - features which enable us to recognise it on each successive presentation of the work, since 'a work is individual, like a person' (see Gołaszewska, 'Problem', 21).

453 Dahlhaus, 'Trivial music', 345.

454 Horst W. Janson writes about the originality of the work of art as a measure of its value. See Janson, 'Oryginalność.

455 'the notion of imitation, rejected by modern philosophy and history of art, is a fundamental notion, which we cannot do without, including in questions relating to art'. See Herbert von Einem, 'Zagadnienia', 250.

456 Ibid.

457 Ibid. 
imitation alone. The aesthetic quality postulated here is the transcriber's creative contribution to the adaptation, his/her new, and at the same time revelatory, approach to Chopin's work. The obvious condition is the transcriber's professionalism, his/her technical proficiency (métier), but the essential condition is self-expression, leading to the appearance of a new 'colouring' to Chopin's work. So the starting point is the original, the purely musical elements of which - the musical-expressive construct - was determined by Chopin himself, and we assume that the aesthetic value of a transcription rises in proportion to the level of creativity applied to Chopin's material. The problem arises as to how we should express this level of creative contribution on the part of the arranger. The term 'creative' is strictly linked to the notion of artistry, yet this creative recomposition has its limits, namely, the recognisability of the original work. Such a situation occurs in transcriptions of the type of the paraphrase, fantaisie and variations, which even in respect to copyright are treated as new, independent works. ${ }^{458}$ In compositions of this sort, Chopin's masterwork is merely the inspiration, the impulse for the creation of an expressively new work.

Attempts to create any kind of scale of aesthetic value to transcriptions are fraught with difficulty from the outset and doomed to failure, due to the existence of the subjective factor, that is, the perceiver. Yet it would be overly cautious to avoid the task altogether. In the scale of aesthetic value proposed here, we will distinguish three basic kinds of arrangement: equal, enriched and impoverished. These three terms carry an evaluative charge: equality is neutral, impoverishment signals a fall in value, and enrichment an appreciation of value. These names result directly from the morphological changes which we noted in the different groups of transcriptions. Equality brings little except a minimal dose of 'freshness'. Enrichment in the musical domain implies an increase of aesthetic value, whilst impoverishment translates directly into a disadvantageous, negative change of expression. It should be stressed that the established order in the systematics does not equate to a hierarchy of aesthetic (artistic) value of transcriptions. These terms (equality, impoverishment, enrichment) merely signal the effects of changes to the material of successive transcriptions, thereby imparting some evaluative colouring (Table 29). To confirm this state of affairs, one may cite the expressively impoverished arrangements produced by Jan Łusakowski and Ferdinand Büchner, the equal replicas of Leopold Grützmacher and Friedrich Hermann and the 'refreshingly' enriched arrangements of Leopold Godowsky, Max Reger and Michael von Zadora. The proposed schematic arrangement is obviously of a 
Table 29: The aesthetic value of different types of transcription.

\begin{tabular}{|c|c|c|}
\hline Type of transcription & Main subtypes of transcription & $\begin{array}{l}\text { Scale of aesthetic } \\
\text { value }\end{array}$ \\
\hline SUBSTANTIAL & $\begin{array}{l}\text { Transmitting the sound layer } \\
\text { Multiplying the sound layer }\end{array}$ & $\begin{array}{l}\text { EQUAL } \\
\text { EQUAL }\end{array}$ \\
\hline STRUCTURAL & $\begin{array}{l}\text { Expanding the texture } \\
\text { Altering the arrangement } \\
\text { of textual layers }\end{array}$ & $\begin{array}{l}\text { ENRICHED } \\
\text { ENRICHED }\end{array}$ \\
\hline SYNTACTIC & $\begin{array}{l}\text { Reducing the syntax } \\
\text { Expanding the syntax }\end{array}$ & $\begin{array}{l}\text { IMPOVERISHED } \\
\text { ENRICHED }\end{array}$ \\
\hline RECONTEXTUAL & $\begin{array}{l}\text { Reductive } \\
\text { Contaminative }\end{array}$ & $\begin{array}{l}\text { IMPOVERISHED } \\
\text { ENRICHED }\end{array}$ \\
\hline FUNCTIONAL & $\begin{array}{l}\text { Technical-didactic } \\
\text { Simplified }\end{array}$ & $\begin{array}{l}\text { IMPOVERISHED } \\
\text { IMPOVERISHED }\end{array}$ \\
\hline
\end{tabular}

general nature, and it should be assumed that we will find transcriptions which are not subject to this schema (e.g. the expressively rich transcription by Mily Balakirev, which belongs to the substantial-syntactic diffusive group ${ }^{459}$ ).

For that reason, this proposition merely signals one way of approaching the aesthetic value of transcriptions; it is a starting point for imparting to each separate transcription one of the three proposed evaluative colourings: the impoverishment, equality or enrichment of the expression of Chopin's work.

The final phase in the axiological process is the assessment of the aesthetic object, which amounts to indicating the qualities which determine the specific value of a work of art. Thanks to the relativist method employed here, ${ }^{460}$ we have been able to reveal two different evaluations of our object of research. Applying the criterion of the level of creative recomposing of the original, we considered creative arrangements, leading to a new quality, to be the most valuable. And that tallies with the widely perceived nature of creative work itself (with its aspiration to breaking barriers, to obtaining new qualities) and with the currently prevailing aesthetic norms: postmodernist democracy in art, ${ }^{461}$ postulating the

459 Reference to the Intermezzo from Mily Balakirev's Suite for orchestra.

460 See Morawski, 'O kryteriach aksjologicznych', 21.

461 'Postmodernism in artistic and aesthetic-literary criticism functions as the name of a period in the history of culture (in particular of art and literature), occurring after the period of modernism - counted from the end of the nineteenth century to the 1960s (with its heyday in 1910-1930)'. Quoted in Nycz, Tekstowy świat, 164. 
work's openness to a new context; ${ }^{462}$ deconstruction, requiring an active and creative approach to literature and art, which in relation to the musical text gives clear and decisive consent to transcribing. ${ }^{463}$ We find confirmation of this evaluative approach in the opinions of Herbert von Einem and in the words of Herbert Read, who asserted that an artist imitating an existing reality (in our case, the set of Chopin's originals) discovers it anew, which is expressed in a greater or lesser dose of one's own expression; so it is the 'thing' we find hardest to clarify and verbalise, but which is noticeable in one's first contact with a given transcription. 'The more original that discovery is, the more credit we shall give the artist, always assuming that he has technical skill sufficient to make his communication clear and effective.' 464

One may also adopt a different attitude and deem the value of a transcription to be greater the more it retains the features of the original. From such a realistic, 'mimetic' and 'trivial' point of view, the most valuable would be accurate translations (equal versions), more artisan than art, which alter the original to a small degree, and the least valuable would be transcriptions that depart a great deal from the original (e.g. the versions by Reger). ${ }^{465}$ The former stance, adopted here, is grounded on creativity, artistry, newness and freshness, while the now outdated latter view is based on recognising Chopin's work as an incomparable model, which accords with the opinion of Georg Kubler: 'every object attests to the existence of a requirement for which it is the solution, even when that object

462 Such an attitude is served by the basic principle of postmodernism - deconstruction, proclaiming that 'all previous interpretations [of a literary text] should be rejected and new ones proposed [...], that someone else's words ought not to constrain my own.' (Nycz, Tekstowy świat, 70). A consequence of deconstruction is 'the emancipation of the receiver's imagination from traditional and canonic interpretative obligations, from all kinds of authorities (including the once fundamental authority of the writer, author or creative artist); it leaves him one-on-one with the text as a "piece of homework" to do.' (Dąbrowski, Postmodernizm, 70-71).

463 Postmodernist views on Chopin transcriptions are represented by Piotr Wierzbicki, among others (see Wierzbicki, Życie z muzyką, 161-172).

464 Read, The Meaning of Art, 180.

465 This obvious view is presented by Herbert Read: 'If art were merely a record of the appearances of nature, the closest imitation would be the most satisfactory work of art, and the time would be fast approaching when photography should replace painting. [...] But as a matter of fact not even a savage would be deceived into thinking the photograph an adequate substitute for the work of art.' (Read, The Meaning of Art, 179-180.) Those observations, relating to painting, can successfully be applied to the relationship between Chopin's original and each individual transcription. 
is only a late copy in a long series of coarsened products far removed from the clarity and sharpness of an original. ${ }^{366}$

This axiological procedure followed the assumption, verbalised at the start of this subchapter, of the possibility of the existence of two different aesthetic values in a single artistic object. The principle of mimesis was the source from which two possible ways of evaluating transcriptions derived, and preferment, as the research method adopted here, made it possible to favour one of the two. ${ }^{467}$

Most secure - that is, least controversial - would be the historical process of a transcription's evaluation, based on nineteenth-century aesthetic paradigms. In the next subchapter, I will merely make an initial attempt to resolve one of the many 'historical' axiological issues.

\subsection{Transcriptions of Chopin's works as documents of stylistic changes in nineteenth-century European music}

The historical method of analysing the work of art asks about the conditions (climate, customs, political regime, social processes, national tradition) determining the specific shape of a work. ${ }^{468}$ Hence the basic evaluative criterion in the historical approach is the congruence of transcriptions with the time and place in which they were produced. On that basis, transcriptions displaying that congruence can be ascribed a high aesthetic value. Crucial to such judgments are the answers to two basic questions: [1] Are transcriptions clearly rooted in the culture of France, Germany, Britain, Poland, etc? [2] Have time and space affected the shape of Chopin transcriptions? Thus our aim is to indicate the degree to which transcriptions correspond to the changes in musical style that accompanied their composition.

Helpful in arriving at an answer to the first question are the views of Jim Samson, ${ }^{469}$ who in relation to social context outlined four different 'national'

466 Kubler, The Shape of Time, 38.

467 Aristotle, although on one hand imparting to mimesis primarily a cognitive function, asserting that we come to know nature through works which imitate it, on the other stated that it was the task of the artistic object to act aesthetically on the receiver, which it does through its design (see Mitosek, Mimesis, 114). The former standpoint, derived from Plato and shared by Hegel, Taine and others, reducing the aesthetic function of the work of art to a cognitive function, established a corresponding method of assessment - its value was the greater, the more realistically it reflected the objective reality.

468 See Morawski, Studia, 119.

469 Samson, 'Chopin Reception', 91-114. 
modes to the reception of Chopin's work, identified with the spread of its meanings during the second half of the nineteenth century. According to Samson, in France, thanks to French critics, Chopin's music was ascribed autobiographical features. ${ }^{470}$ It was understood in a romantic way, with its emotionality, womanly sensitivity and subtlety particularly appreciated. In Germany, during the years 1880-1885, with the contribution of the Breitkopf \& Härtel publishing firm and later analytical work led by Hugo Leichtentritt, there was an aspiration to confirming the greatness of Chopin's music and incorporating it into the canon of Romantic literature. In the Russian environment, in the compositional circle of Mily Balakirev, the original meaning of Chopin's music was revised, with its national element underscored. In Britain, meanwhile, particularly in the bourgeois environment, Chopin was perceived as a composer of salon music. Samson's conclusions are borne out by the transcriptions: in sentimental vocal arrangements by French composers, in accurate German arrangements retaining the expression of the original, and in semantic British versions. ${ }^{471}$ Such confirmation is not found solely in Russian arrangements, which are dominated by a sentimental note.

It might seem that key to resolving this question, that is, to indicating those transcriptions which are clearly rooted in German, French, British, Polish or Russian culture, would be the nationality of the transcribers. Yet such a nationality-based classification relates only to the individuals concerned; it does not imply a division among the transcriptions themselves, since the transcriber's musical fascinations need not have tallied with those of his or her nation. Evidence of the existence of certain colourings in transcriptions has been provided by Maciej Gołąb, ${ }^{472}$ who has pointed to the 'Polishness' and 'nationality' of the arrangements produced by Karol Lipiński, to the 'polymorphism' evident in the version by Jules de Groot, characteristic of French music, and to the presence of 'neo-German' elements in the transcription by August Wilhelmj. And although in the examples put forward by Gołąb the nationality of the transcribers does accord with the 'national' (Polish, French, German) features of their transcriptions, throughout the set of transcriptions as a whole such a congruence is not the rule.

470 'it seems impossible to make a clear distinction between his music and his personality', ibid., 93.

471 A great need for the semanticisation of Chopin's music arose in the second half of the nineteenth century out of the post-Romantic way of feeling, requiring extra-musical qualifiers. (See Tomaszewski, Chopin, 721). The publishing of such arrangements was led by France, Poland and Germany, followed by Russia and Britain.

472 Gołąb, Dziewiętnastowieczne transkrypcje. 
The national concept of Chopin reception proposed by Samson is not a sufficient aspect of the historical perspective on the value of our object of study, but it does indicate determinants of the four musical cultures: subtlety and delicacy in the French, reliability and accordance with the replicated model in the German, a folk flavour in the Russian and salon style in the British. Yet one would like to present transcriptions from a broader perspective, to show them through the lens of achievements that characterised the whole of nineteenth-century European music. It is impossible, however, on the basis of the research material in our possession, to recreate the wealth of nineteenth-century music. One reason for that is the principle of mimesis underpinning the act of transcribing, which refers above all to Chopin's original, and not to a given musical current or style. ${ }^{473}$ In this situation, our research will seek to indicate only 'traces' of the times in which transcriptions were produced. In accordance with the principle espoused by Morelli, ${ }^{474}$ who discerned features unequivocally pointing to the transcriber's hand in ostensibly insignificant details, we will focus in our study on details which show that a transcription belongs to a specific point in musical time-space. A criterion worded in this way does not require the presentation of complex analyses of transcriptions; it boils down to merely identifying those national and temporal 'traces'.

Over the course of nineteenth-century European music, we can distinguish supra-national trends, such as the style brillant and the instrumental virtuosity that derived from it (especially in piano and violin music). While the style brillant existed during the 20 s and 30 s, virtuosity was the province of virtually the entire nineteenth century. The 'brilliant'-style piano music of the first half of the nineteenth century employed a whole arsenal of characteristic means. ${ }^{475}$ One of the many representatives of that style was the 'minstrel of the piano', ${ }^{476}$ Friedrich Kalkbrenner, who from 1824 to 1833 was regarded as the most outstanding pianist in Europe. ${ }^{477}$ His Variations brillantes on the Mazurka in B flat major,

473 This observation is confirmed by Maciej Gołąb, who writes that 'musical transcription by its very nature offers the composer little scope for participating in changes to the musical discourse of the day'. (Gołąb, Dziewiętnastowieczne transkrypcje, 61.

474 We learn about Morelli's method for attributing works of art through the analysis of details from Max J. Friedländer's O granicach, 164-169.

475 See Jasińska, 'Problem'.

476 Poniatowska, Muzyka fortepianowa, 247.

477 See Chomiński and Wilkowska-Chomińska, Historia, 106. 

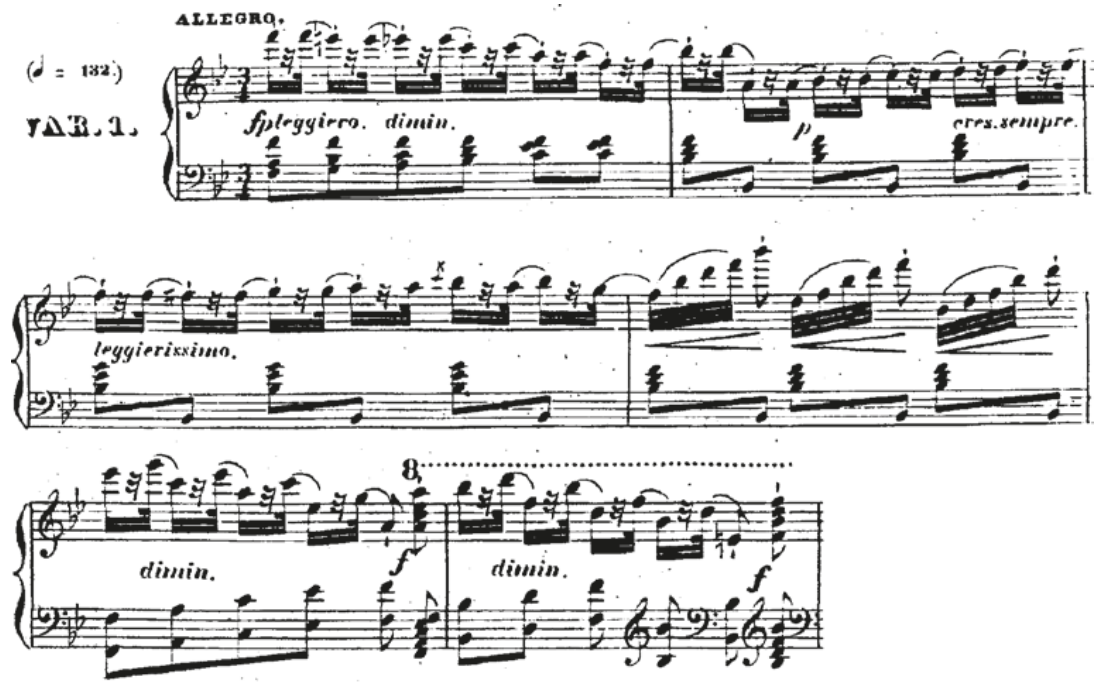

Example 48. F. Chopin - F. Kalkbrenner, Variations brillantes, after Mazurka [in B flat major], Op. 7 No. 1, Pfte (Leipzig: F. Kistner, 1833). Variation I, bars 1-6.

Op. 7 No. 1 for solo piano, from $1833,{ }^{478}$ a composition that goes far beyond the framework of pure transcription, contains a wealth of means (Examples 48-51). We find clear traces of this style in August Hänsel's Fantaisie on the Mazurka in B flat major, Op. 7 No. 1 for piano (Examples 52-53). ${ }^{479}$ Although this fantaisie also falls beyond the bounds of transcription, it does show the influence of the style brillant on the output of Chopin epigones. ${ }^{480}$

Instrumental virtuosity, a consequence of the pianistic style brillant, helped to shape the transcriptions which pianists and violinists used to display their skills. Here, we should cite arrangements by Paganini, Wilhelmj, Sarasate, Taborowski, Joseffy and many others. ${ }^{481}$ By way of example, we might invoke Stanisław Taborowski's transcription for violin and piano of the song 'Melodia' [Melody], Op. 74 No. 9. ${ }^{482}$ He significantly alters Chopin's original, in both

478 Published by F. Kistner of Leipzig in 1833. Dated after Deutsch, 18.

479 Published by L. Bauer of Dresden in 1850. Dated after CT, 350.

480 Hänsel employs passagework as well as scale and chromatic progressions in both variations.

481 Cf. subchapter 2.2.

482 Published by A. M. Schlesinger of Berlin in 1874. Dated after Deutsch, 22. 

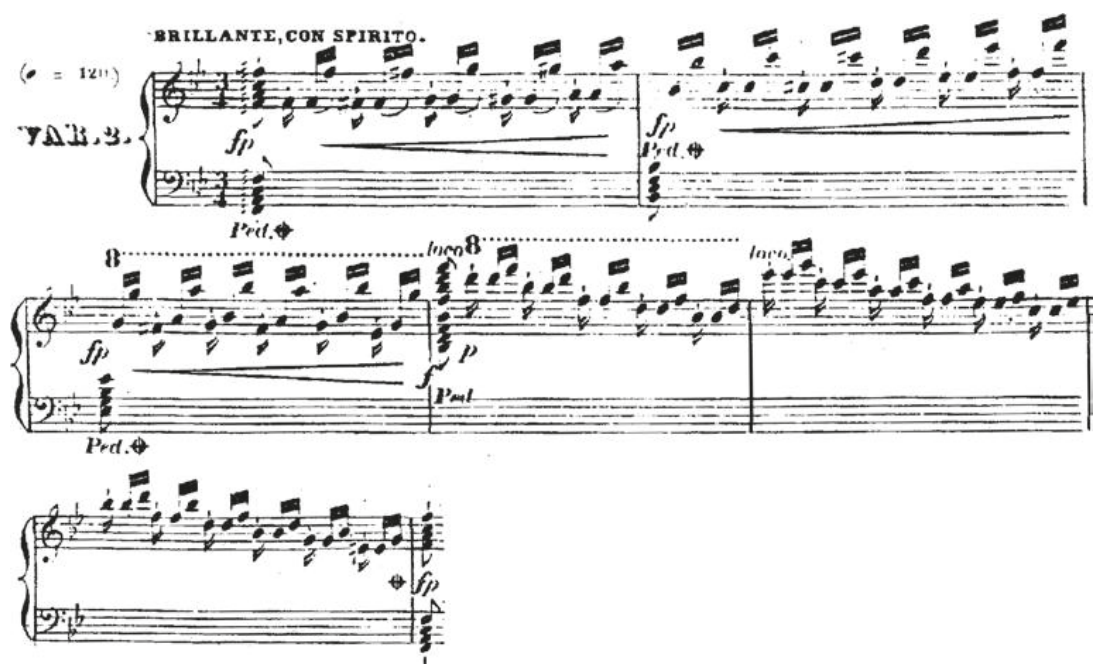

Example 49. F. Chopin - F. Kalkbrenner, Variations brillantes, after Mazurka [in B flat major], Op. 7 No. 1, Pfte (Leipzig: F. Kistner, 1833). Variation II, bars 1-6.
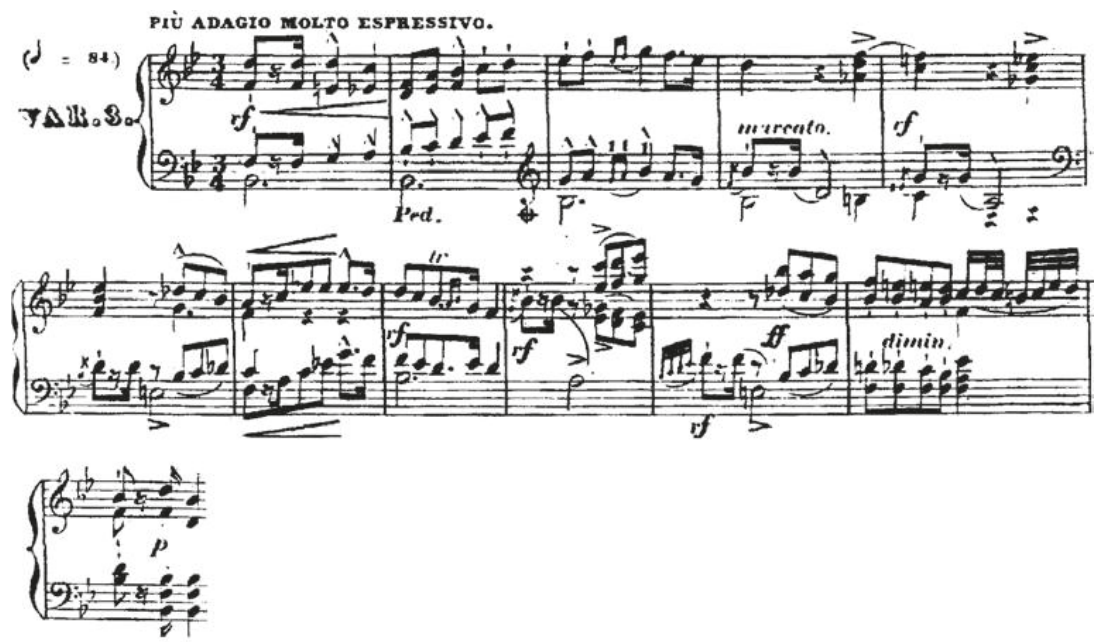

Example 50. F. Chopin - F. Kalkbrenner, Variations brillantes, after Mazurka [in B flat major], Op. 7 No. 1, Pfte (Leipzig: F. Kistner, 1833). Variation III, bars 1-12. 


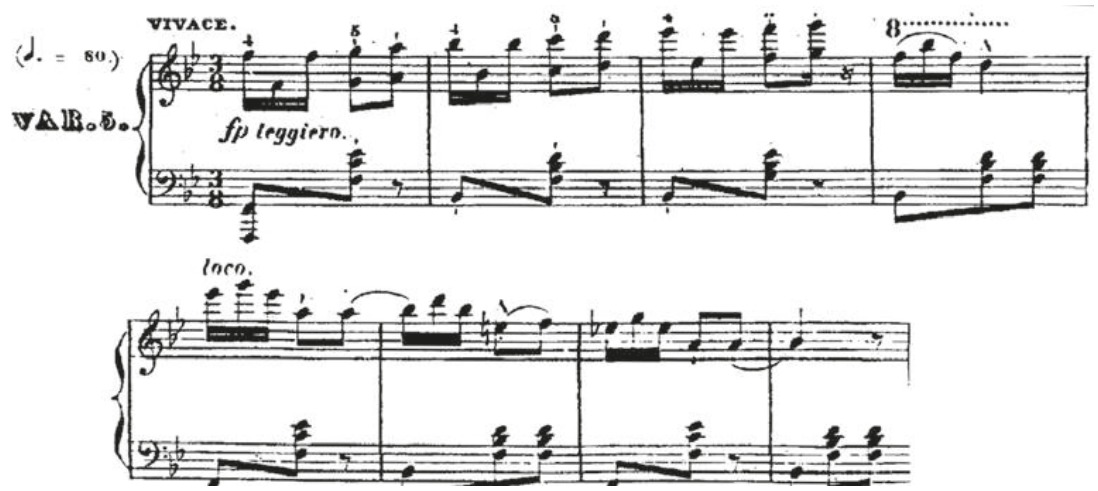

Example 51. F. Chopin - F. Kalkbrenner, Variations brillantes, after Mazurka [in B flat major], Op. 7 No. 1, Pfte (Leipzig: F. Kistner, 1833). Variation V, bars 1-8.
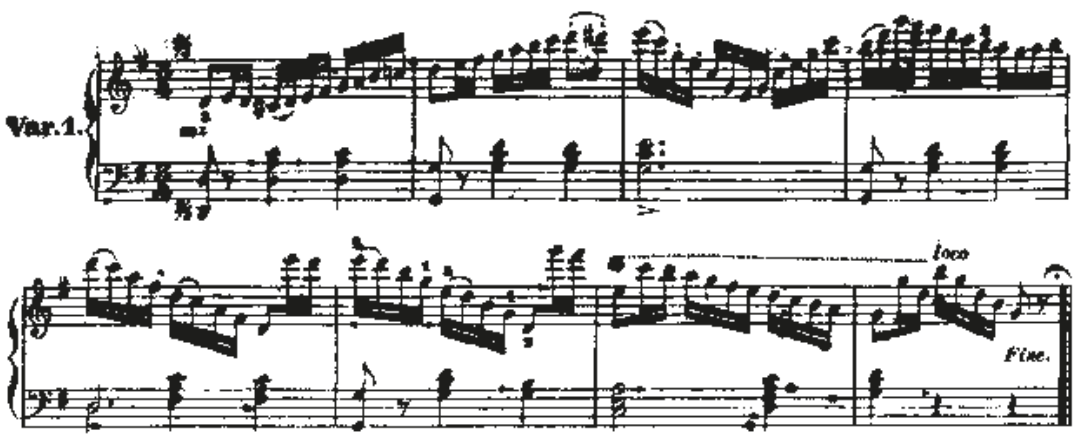

Example 52. F. Chopin - A. Hänsel, Fantaisie on the Mazurka [in B flat major], Op. 7 No. 1, Pfte (Dresden: L. Bauer, 1850), Variation I, bars 1-8.

the formal and the harmonic domain, and above all in terms of expression. The parts of the two instruments are equal. The introduction of passagework in the accompaniment makes this transcription a stormy, virtuosic work - an effect that is created partly by the extra voices and notes and the expansion of the compass up and down. The violin virtuosity occurs in the solo cadenza (Example 54).

Also of a virtuosic character is August Wilhelmj's arrangement for violin and piano of the Nocturne in E flat major, Op. 9 No. 2, particularly the closing 

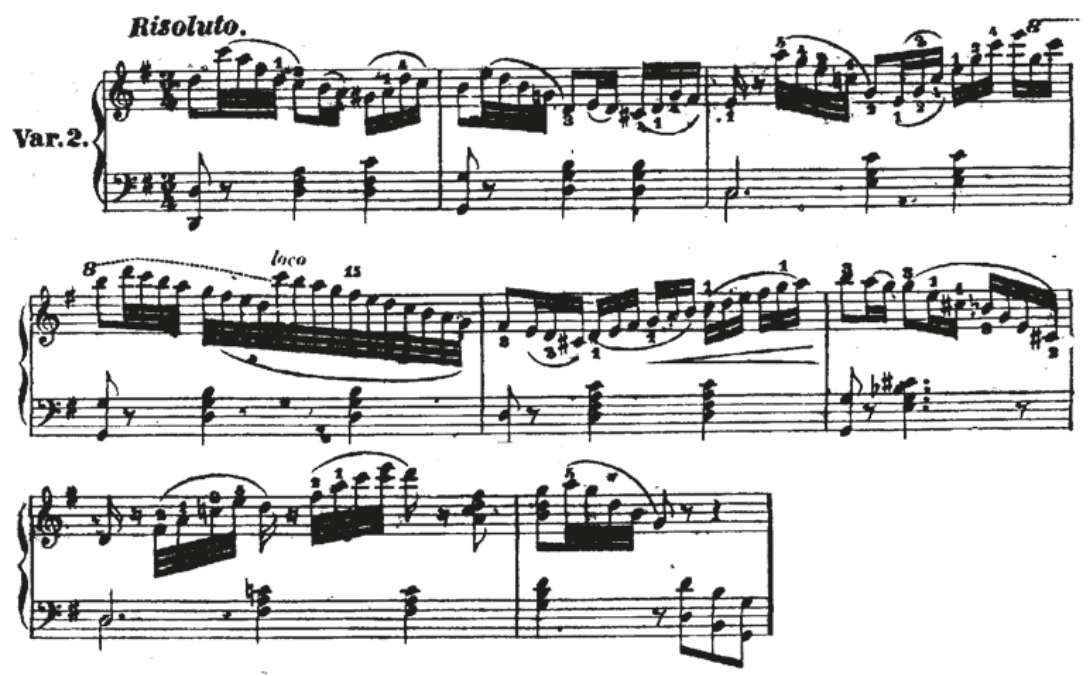

Example 53. F. Chopin - A. Hänsel, Fantaisie on the Mazurka [in B flat major], Op. 7 No. 1, Pfte (Dresden: L. Bauer, 1850), Variation II, bars 1-8.

passage, marked 'brillante' (Examples 55-56). ${ }^{483}$ This cadenza and the various techniques employed (sul tasto, glissando, harmonics, two-note chords) favour the violin. Wilhelmj, tending to his own instrument first and foremost, turned Chopin's music into a more massive piece, full of sparkle, and consequently less nocturnal.

Seeking 'national' traces in transcriptions, one may point to Auguste Franchomme's cello arrangement of the Etude in C sharp minor, Op. 25 No. $7 .{ }^{484}$ We note here not just virtuosity, but above all French accents, expressed in a subtlety of sound (signalled by Samson). Although Franchomme retained the form and the substance of the original, by changing the key (from $\mathrm{C}$ sharp minor to D minor), drawing out the Etude's latent colouristic possibilities (the low register of the theme is given to the cello) and proposing a smooth rhythm and slower tempo, he enhanced the depth and melancholy of his arrangement, thereby altering the character of Chopin's original (Example 57).

It is a well-known fact that the extremely rich and varied musical culture of the nineteenth century centred on a few main areas: vocal music (represented

483 Published by F. Kistner of Leipzig in 1873. Dated after Deutsch, 18.

484 Published by Breitkopf \& Härtel of Leipzig in 1871. Dated after Deutsch, 10. 

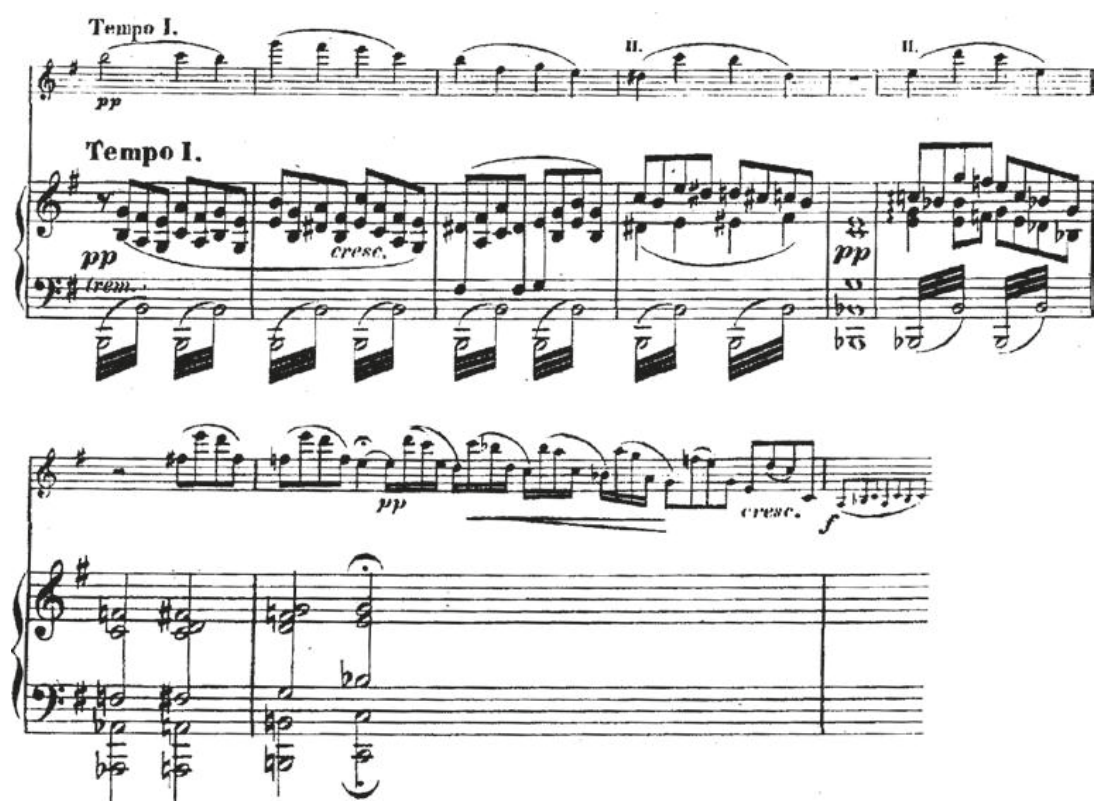

Example 54. F. Chopin - S. Taborowski, Melodia [Melody], Op. 74 No. 9, Vn+Pfte (Berlin: A. M. Schlesinger, 1874), bars 40-47.

by solo song), piano music, symphonic music and opera. A sign of the 'national currents' in music during the second half of the nineteenth century was the use of elements from different cultures (Polish, Russian, Italian, French), with composers taking up historically current themes and signalling traditional content. The national features of song output are evidenced not just by its musical form, but also by the verbal text and the values and ideas it bears. ${ }^{485}$ Vocal transcriptions clearly refer to French, Polish and Russian culture. We know that

485 Mieczysław Tomaszewski distinguishes four phases in the development of Chopin's songs: (1) the sentimental-pseudo-classical ('Precz z moich oczu' [Remembrance], 'Gdzie lubi' [A Fickle Maid]), (2) the early Romantic ('Wojak' [Before the Battle], 'Smutna rzeka' [Troubled Waters]), (3) the Romantic ('Pierścień' [The Ring], 'Leci liście' [Leaves are Falling]) and (4) the late Romantic ('Z gór, gdzie dźwigali' [Bowed 'neath their Crosses]). He emphasises that the verbal text is a crucial element affecting the classification of songs. See EMcd, 152. 


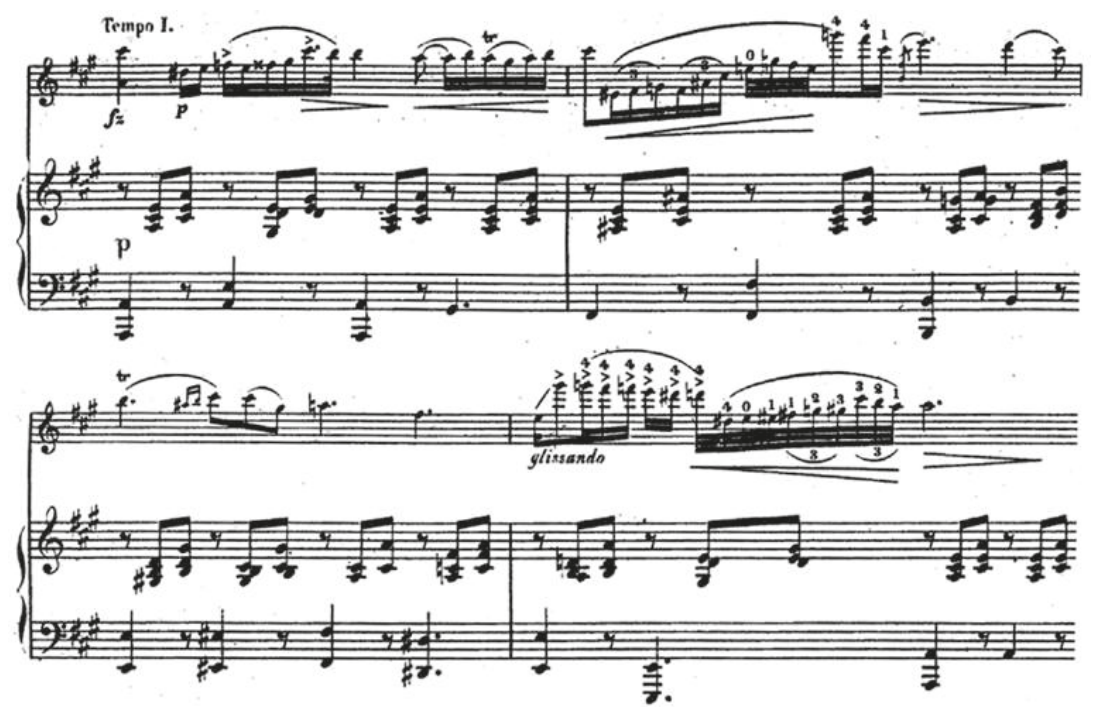

Example 55. F. Chopin - A. Wilhelmj, Nocturne [in E flat major], Op. 9 No. 2, Vn+Pfte (Leipzig: F. Kistner, 1873), bars 23-26.

there were 'no great French song-composers in the early part of the Romantic era. ${ }^{486}$ New song output with piano accompaniment appeared there during the second half of the nineteenth century, ${ }^{487}$ and the seed of that genre was sown by Hector Berlioz. Characteristic of French song of that period is the use of the name mélodie, accompanied by the rejection of features of the bourgeois romance, thanks to which it was characterised by remarkable 'color, noble sentimentality, and refined sensuousness and grace. ${ }^{3} 88$

French 'traces' in nineteenth-century song output are shown by vocal transcriptions. Although Jules Ruelle entitled his transcriptions Six mélodies transcrites pour chant et piano, their form, titles and verbal content indicate that they were designed for the salon. ${ }^{489}$ So although written during the second half of the nineteenth century, they still belong to the preceding epoch. The same

486 Einstein, Music, 184.

487 Cf. Chomiński and Wilkowska-Chomińska, Historia, 100.

488 Einstein, Music, 185.

489 These are often arrangements based on a considerable shortening of the form of Chopin's original. That form is repeated several times, with an altered verbal text, 

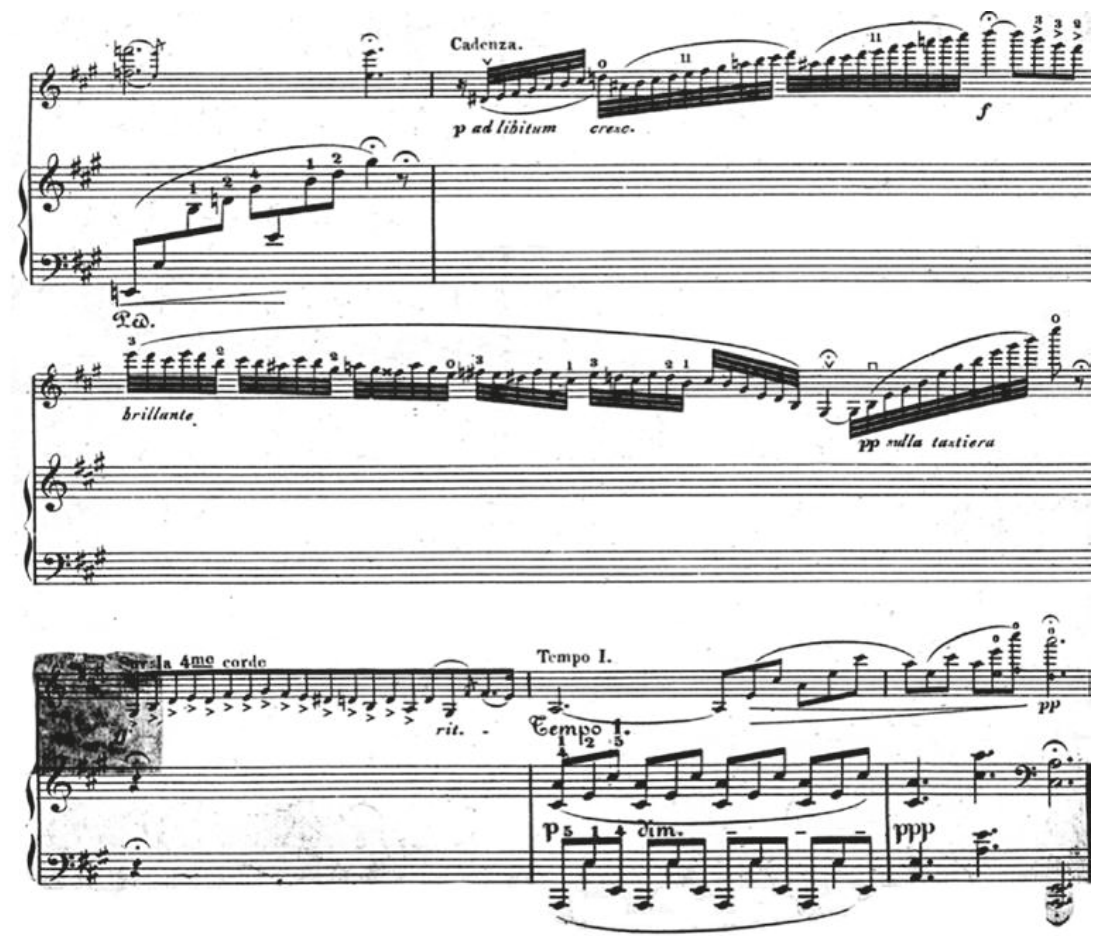

Example 56. F. Chopin - A. Wilhelmj, Nocturne [in E flat major], Op. 9 No. 2, Vn+Pfte (Leipzig: F. Kistner, 1873), bars 34-37.

applies to the transcriptions of Pauline Viardot. ${ }^{490}$ The texts of her arrangements are sentimental and romantic, speaking of wretched, unfulfilled, undesired and

so it has the structure of a stanzaic song. Cf. Appendix, 'Selected literary texts from vocal-instrumental transcriptions'.

490 Paulina Viardot wrote Six Mazourkas for solo voice and piano to French words by Louis Pomey. This collection was published in Paris in 1864. The collection contains the following mazurkas:

Op. 50 No. 2, entitled 'Seize ans',

Op. 33 No. 2, entitled 'Aime-moi',

Op. 6 No. 1, entitled 'Plainte d'amour',

Op. 7 No. 1, entitled 'Coquette',

Op. 68 No. 2, entitled 'Loiselet',

Op. 24 No. 1, entitled 'Séparation'. 

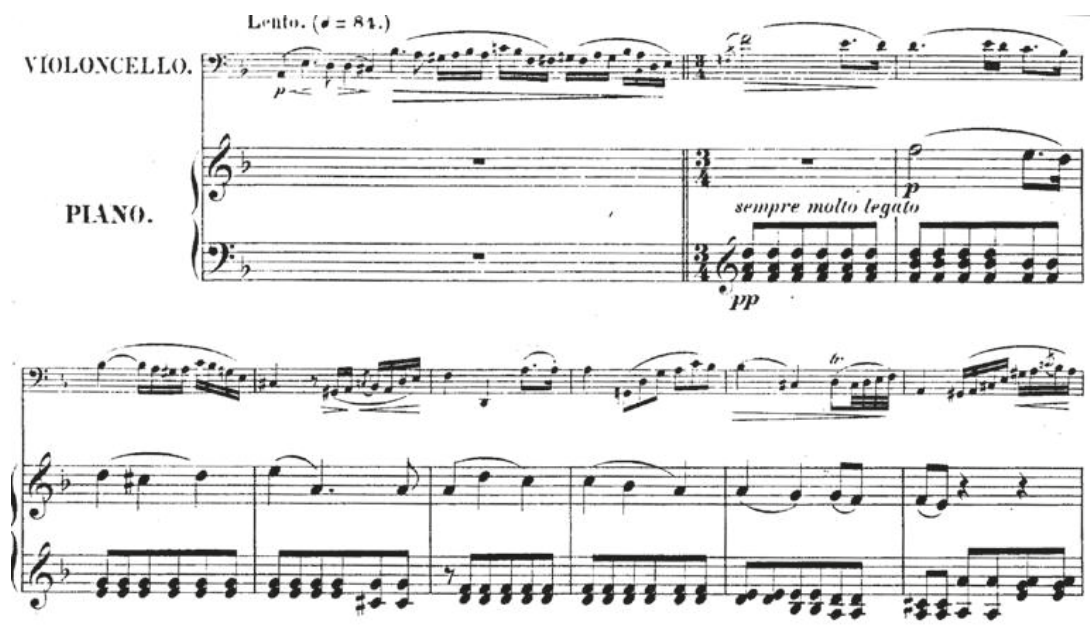

Example 57. F. Chopin - A. Franchomme, Etude [in C sharp minor], Op. 25 No. 7, Vc+Pfte (Leipzig: Breitkopf \& Härtel, 1871), bars 1-9.

unhappy love. ${ }^{491}$ Her vocal arrangement of the Mazurka in F sharp minor, Op. 6 No. 1, entitled 'Plainte d'amour', displays a schematic approach to the musical form, which is shortened through the elimination of repeats. ${ }^{492}$ Viardot also adds an introduction and a vocalise that bursts the work open from within. Both the verbal text and the purely musical procedures are clearly subordinated to the needs of French salon music (Example 58).

A 'trace' of a Russian character to a transcription is its title - Romance and accompanying Russian verbal text. Russian vocal transcriptions were published as Romances and Songs. One such example is Pyotr Shchurovsky's arrangement for voice with cello and piano of the Waltz in A minor, Op. 34 No. 2 (Example 59). ${ }^{493}$ Shchurovsky chose a performance apparatus that ideally reflected the colours that potentially exist in the original piano version. The verbal text contains a Romantic element: it directs the listener's imagination to the beauty of nature, coinciding with the beauty of a woman - a

491 See Appendix, 'Selected literary texts from vocal-instrumental transcriptions'.

492 Published by Gebethner \& Wolff of Warsaw in 1898. Dated after CT, 350.

493 Published by K. Meikov of Moscow in 1881. Dated after an entry in the score. 

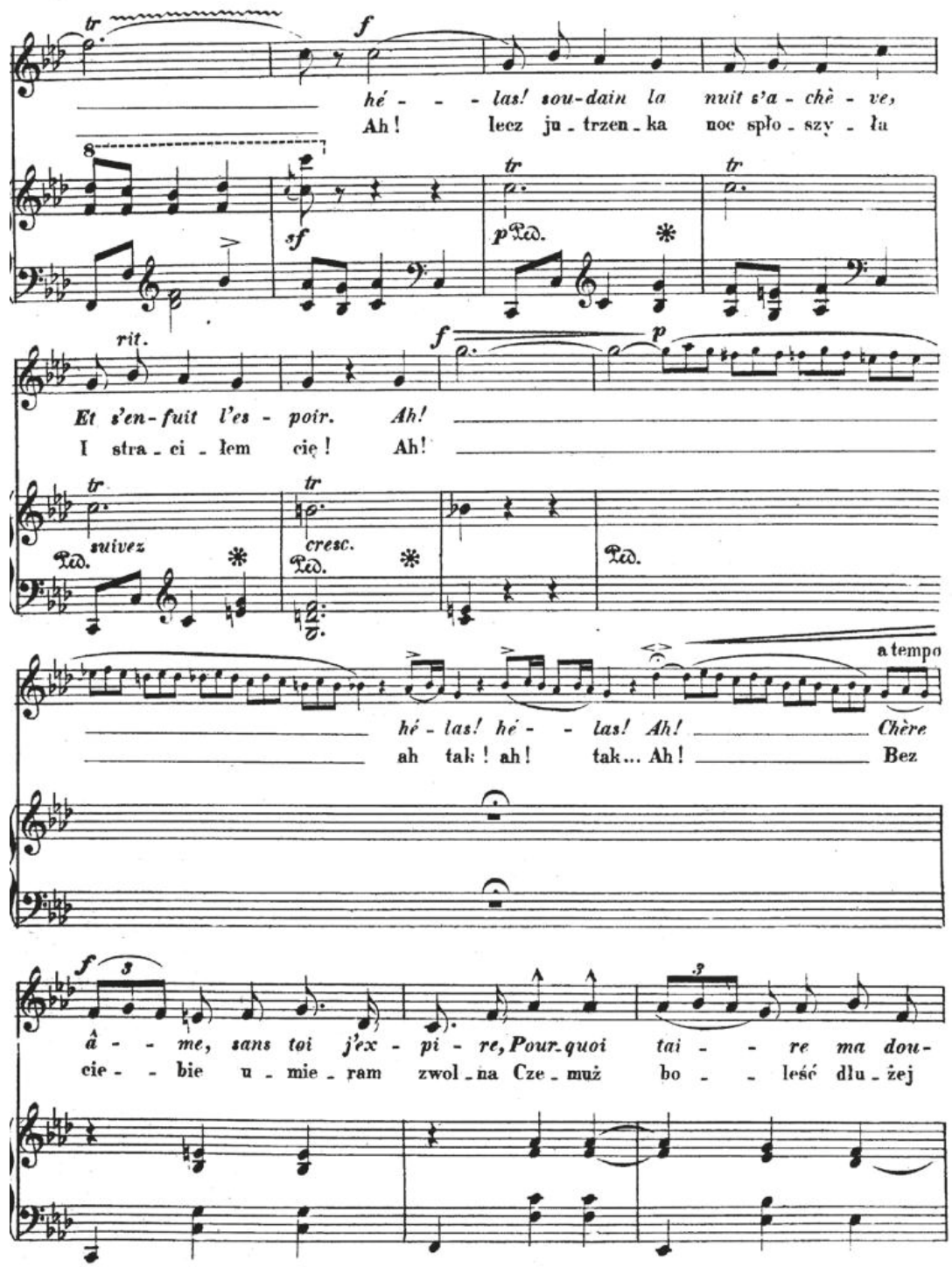

Example 58. F. Chopin - P. Viardot, 'Skarga miłości' [Plainte d'amour] - Mazurka [in F sharp minor], Op. 6 No. 1, voice+Pfte (Warsaw: Gebethner \& Wolff, 1898), bars 55-65. 

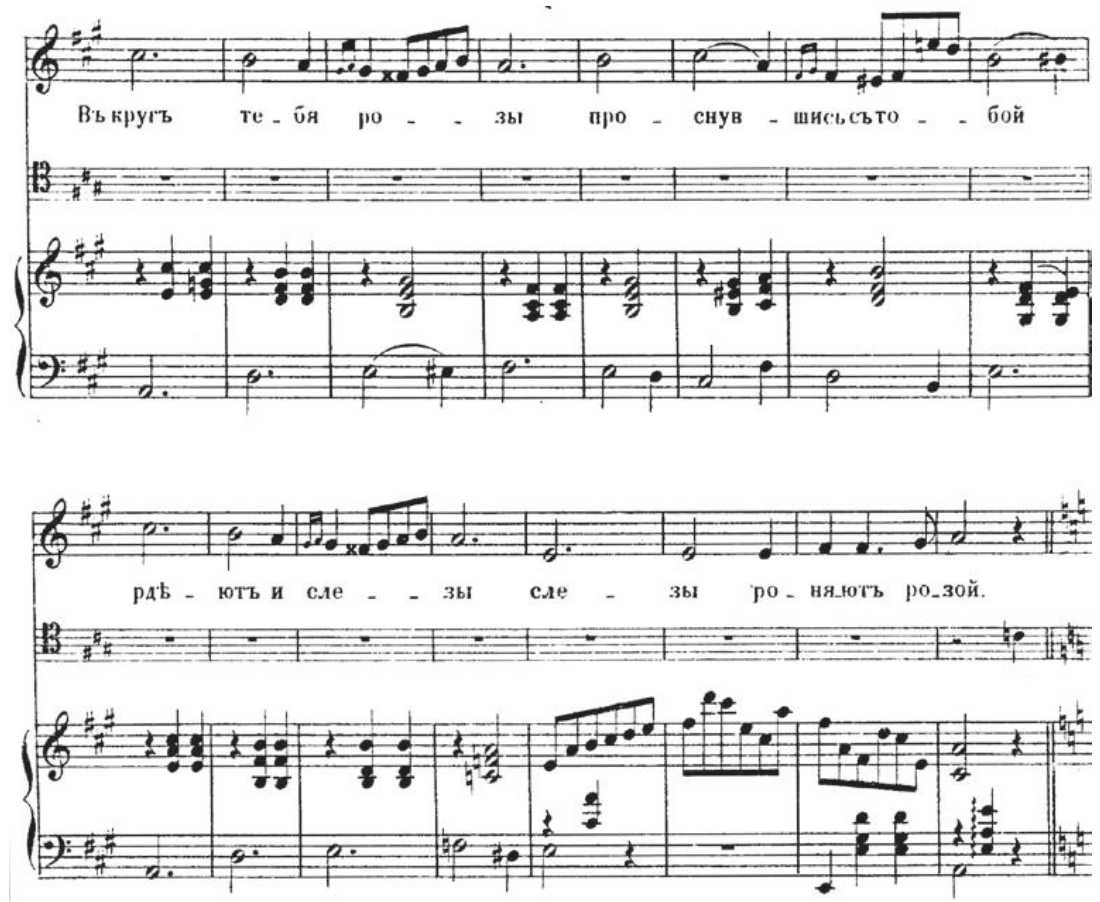

Example 59. F. Chopin - P. Shchurovsky, 'Yarkiye treli nochnykh soloviev' [The eloquent trills of the nightingales] - Waltz [in A minor], Op. 34 No. 2, voice+Pfte (Moscow: K. Meikov, 1881), bars 53-68.

comparison which lends the music a reflective character. ${ }^{494}$ Songs (simple stanzaic compositions) and romances (self-contained lyrical works) composed in Russia clearly referred to traditional folk output. They featured a generous dose of lyricism (e.g. Glinka), as well as humour and realism (e.g. Mussorgsky). Shchurovsky's transcription is dominated by lyricism and sentimentalism; there is no folklorism - that musical feature which would first signal its belonging to Russian culture.

The Polish lineage of a vocal transcription is shown by its content, which allows us to distinguish above all sentimental songs with influences of the French salon style (e.g. Karol Kurpiński's 'Laura i Filon' [Laura and Philo]). There are

494 See Appendix, 'Selected literary texts from vocal-instrumental transcriptions'. 

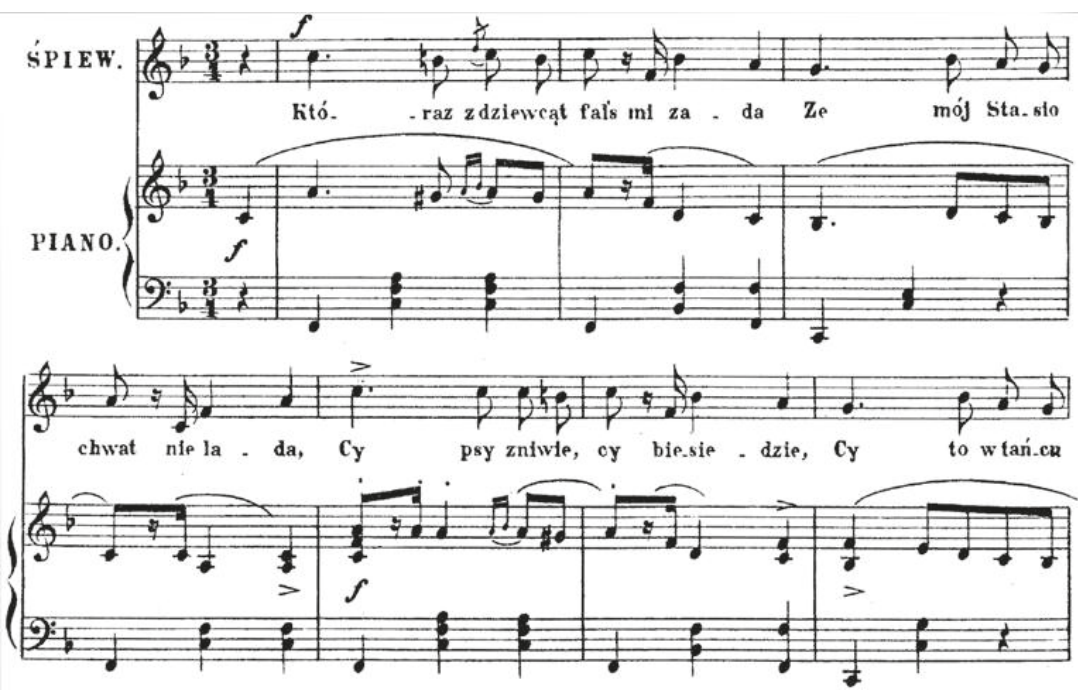

Example 60. F. Chopin - A. Münchheimer, 'Dziewczyna mazowiecka' [Mazovian girl] - Mazurka [in B flat major], Op. 17 No. 1, voice+Pfte (Warsaw: Gebethner \& Wolff, 1882), bars 1-7.

no transcriptions of historical content (such as Kurpiński's 'Warszawianka' [Song of Warsaw]), but folk elements are frequently used, referring to Polish folklore and forged after the fashion of Stanisław Moniuszko (e.g. 'Wesół i szczęśliwy' [Cheerful and content]). That verbal text is supported in a way by purely musical procedures existing in Chopin's original. In some Chopin genres (e.g. mazurkas, polonaises), we find a sort of programme, strengthened by the title and the verbal content of the vocal arrangements. The titles of transcribed mazurkas clearly refer to traditional Polish folk culture; they convey the character and temperament of the Polish people, as in Adam Münchheimer's arrangement of the Mazurka in B flat major, Op. 17 No. 1, under the title 'Dziewczyna mazowiecka' [Mazovian girl], which employs Mazovian dialect (Example 60). ${ }^{495}$ The words of vocal arrangements tell of traditional customs. ${ }^{496}$ The theme of wooing is addressed particularly often ('Terkotka' [The

495 Published by Gebethner \& Wolff of Warsaw in 1882. Dated after CT, 352.

496 See Appendix, 'Selected literary texts from vocal-instrumental transcriptions'. 
Cuckoo], 'Zemsta dziewczyny' [A girl's revenge], 'Zakochana' [The LoveLorn Lassie]), and we also find the theme of love, describing the emotional states of a person in love ('Tęsknota' [Longing], 'Faible cœur', 'Aime-moi', 'Plainte d'amour'). Thus we can speak of two kinds of text: a rustic, folkloric, story-telling type, and a lyrical type, describing feelings, but not specific situations. The texts of the transcriptions cited here can be defined as sentimental, rustic, traditional and romantic. That was the character of the titles in series of publications containing single transcriptions, e.g. Romanse i pieśni [Romances and songs], ${ }^{497}$ Wybór Ulubionych Kompozycyj na fortepian lub do śpiewu [Selection of favourite works for piano or for singing]). Most transcriptions with Polish words represent the genre of the rustic song not for dancing. ${ }^{498}$ That genre is characterised by 'simplicity, naivety and lightness. ${ }^{499}$ Arrangements of this kind also display many links to the popular bourgeois-noble romance. ${ }^{500}$ Both the type of text and the treatment of the musical material attest to the salon character of these transcriptions, ${ }^{501}$ which in the opinion of Michał Biernacki were characterised by 'charming content that was usually given a worthy setting. ${ }^{.02}$

'Traces' of New German musical culture are confirmed by Giuseppe Ferrata's Second Study on Chopin's Valse (Examples 61-63). ${ }^{503}$ This composition contains elements characteristic of the pianism of the second half of the nineteenth century. It is characterised by a massive sound to the piano, with the use of tension-filled harmonies. This proposition from Ferrata, a pupil of Liszt and Sgambati who propagated the works of Wagner, Schumann and Brahms, as well as Liszt, corresponds to the German tradition in performance and composition with which he was well acquainted. Ferrata clearly refers to Lisztian virtuosity. He presents the colouristic properties of the piano, switching rapidly between

497 Published in Moscow were arrangements of three Chopin waltzes, by Pyotr Shchurovsky (two) and Nikolay Sokolov.

498 Excluding arrangements to religious texts (e.g. by Mikuli).

499 Tomaszewski, 'Filiacje'.

500 One example of this genre is Franciszek Karpiński's 'Laura i Filon' [Laura and Philo].

501 Mieczysław Tomaszewski points to the weakness of texts by Louis Pomey, Jan Chęciński and Louis Bordèse, inadequate to Chopin's music; he rates more highly selected propositions from Tłomaczenia Szopena [Chopin translations] by Kornel Ujejski (Tomaszewski, Chopin, 724).

502 See Appendix: 'Selected literary texts from vocal-instrumental transcriptions'

503 Published by J. Fischer of New York in 1902. Dated after an entry in the score. 
Molto vivace, leggerio.
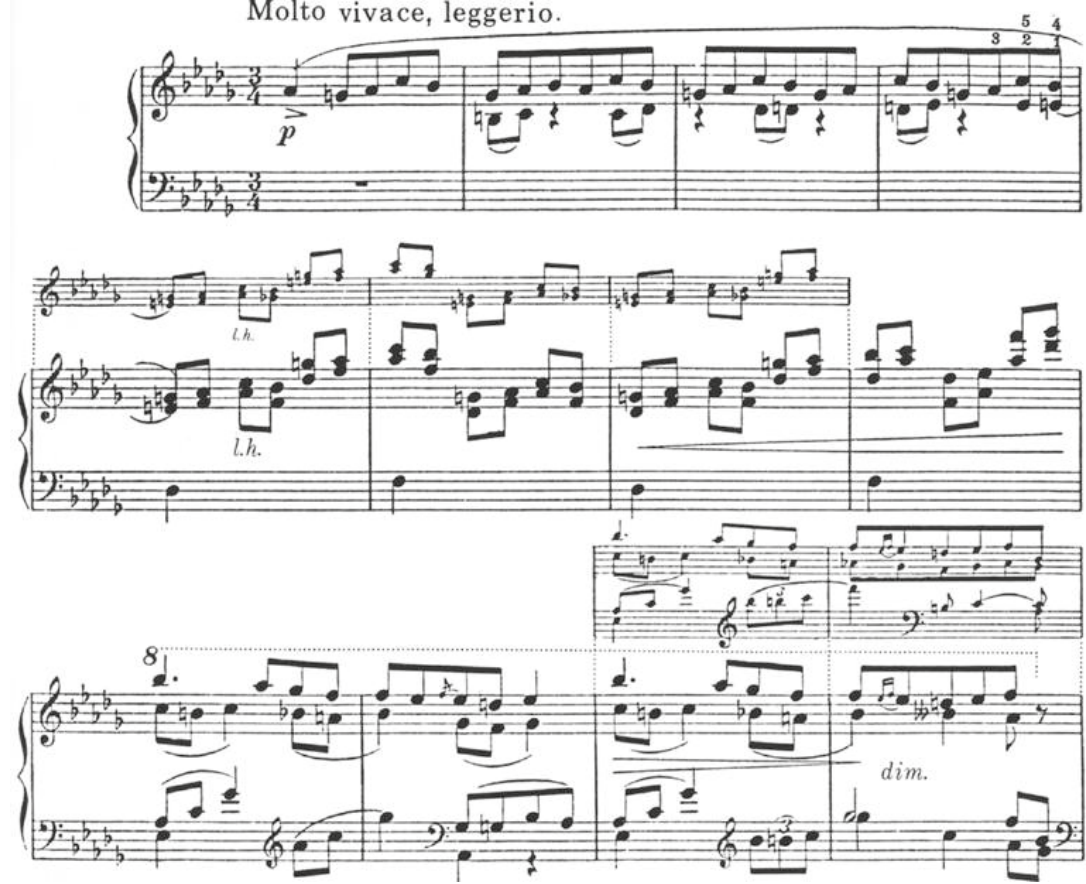

Example 61. F. Chopin - G. Ferrata, Second Study on Chopin's Valse - Waltz [in D flat major], Op. 64 No. 1, Pfte (New York: J. Fischer, 1902), bars 1-12.

distant registers and making full use of the instrument's range. It would seem that the playing with registers is one of the means of musical arrangement here, lending the work a virtuosic character. That virtuosity is also enhanced by the quasi-polyphonic texture, obliging the pianist to play precisely, and occasional arpeggios are essential given the use of widely spread chords. Ferrata clearly enriches and sharpens the harmonies, filling them with tension by means of tritone dyads. Ferrata's proposition, addressed to proficient pianists, is marked by elements characteristic of the pianism of the second half of the nineteenth century.

Also trained within the German environment was the Hungarian pianist and composer Rafael Joseffy, who studied with Wenzel, Moscheles, Tausig and Liszt. His concert repertoire frequently included works by Brahms, and as a composer he wrote studies on themes by Czerny, Henselt and Moscheles. Concealed in Joseffy's piano arrangement of the Waltz in D flat major, Op. 64 No. 1, from 1879 


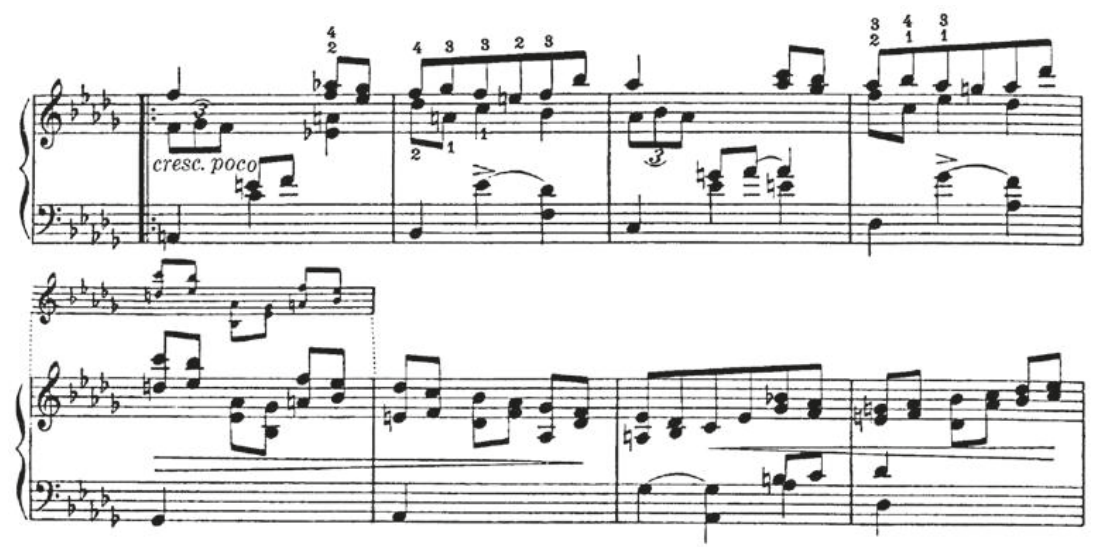

Example 62. F. Chopin - G. Ferrata, Second Study on Chopin's Valse - Waltz [in D flat major], Op. 64 No. 1, Pfte (New York: J. Fischer, 1902), bars 21-28.

(Examples 64-66), are signs of those times, such as the Wagnerian harmonies and bravura piano technique, but also impressionistic colouring. ${ }^{504}$ Joseffy made frequent use of diminished and augmented chords, employed shiftings of the same chordal figure and based successive figurations on nodal notes forming a chord ( $g$ sharp-b- $d-f)$. In one passage, Joseffy departs from Chopin's colouring and approaches the atmosphere of Debussy's Clair de lune, from the Suite bergamasque, from 1890 (published in 1905). The arranger employs an enharmonic change of key (as if following Debussy's lead in Clair de lune). Although the harmonic framework of Chopin's original is retained, the subdivision of rhythmic values, and consequently the increase in the number of notes, as well as the considerable chromaticisation of the melodic line, with frequent changes of register, draw attention not so much to the function of the chords obtained as to their colouring. One may speak of reference to or anticipation of Debussy, of the initiation and signalling of a new, modernist harmonic thinking, underscoring the timbral, colouristic and expressive properties of chords. So elements of French music, with its impressionistic subtlety of sound, are also very distinct here.

504 Published by E. Schubert \& Co. of New York in 1879. Dated after an entry in the score. 

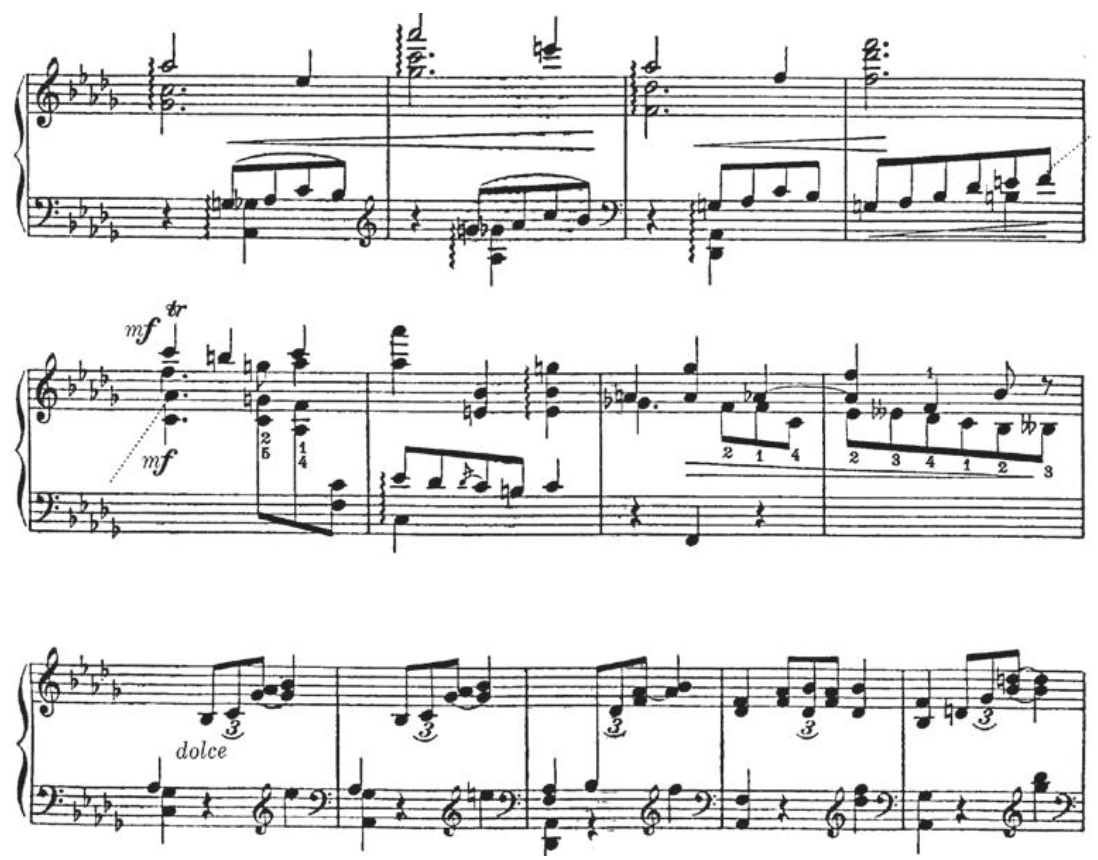

Example 63. F. Chopin - G. Ferrata, Second Study on Chopin's Valse - Waltz [in D flat major], Op. 64 No. 1, Pfte (New York: J. Fischer, 1902), bars 47-59.
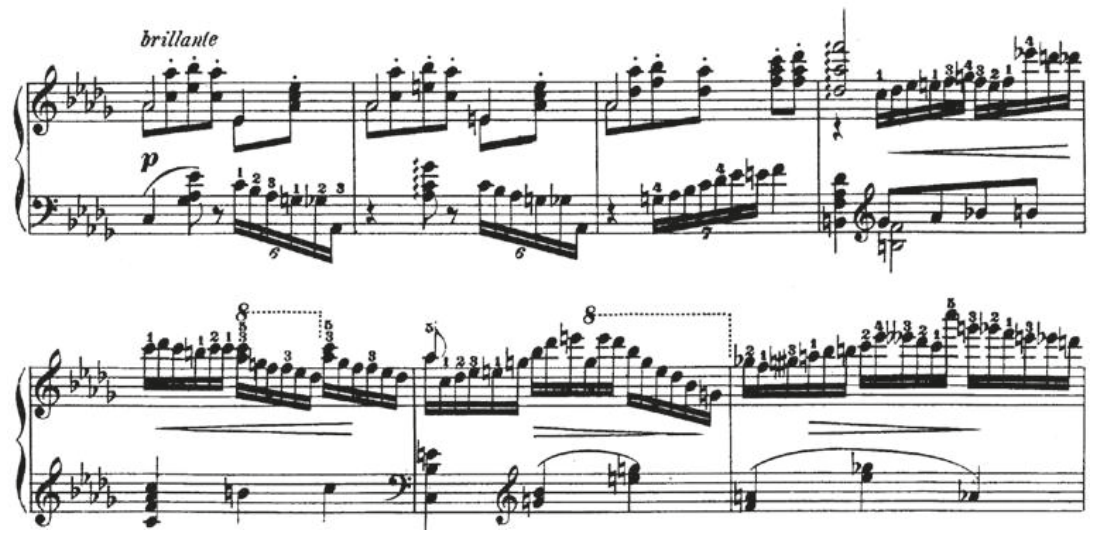

Example 64. F. Chopin - R. Joseffy, Concertstudie über den Des-dur Walzer, Op. 64 No. 1, Pfte (New York: E. Schuberth \& Co., 1879), bars 60-66. 

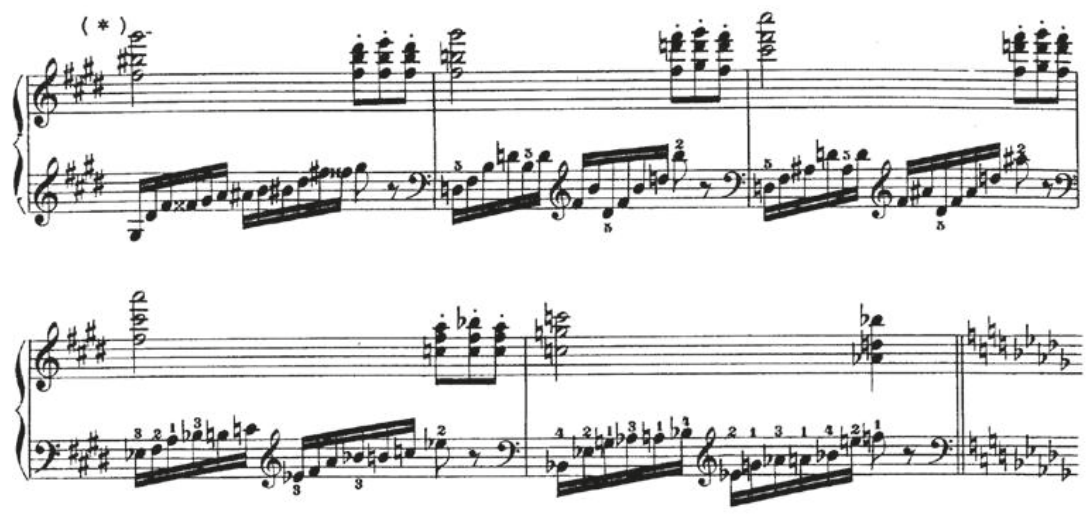

Example 65. F. Chopin - R. Joseffy, Concertstudie über den Des-dur Walzer, Op. 64 No. 1, Pfte (New York: E. Schuberth \& Co., 1879), bars 65-69.

German influences are evident in a violin version of the Nocturne in $\mathrm{G}$ minor, Op. 37 No. 1 by the German violinist and composer August Wilhelmj. ${ }^{505}$ Here, the transcriber's imagination turned towards a more massive, at times orchestral, sound (reflected also in the increased number of parts - 'Grübelei'), and the harmonic writing, enriched with foreign notes (especially suspensions), refers in a way to Wagnerian chording. We also find here ways of shaping the sound material similar to those employed by Felix Mendelssohn (the 'wandering bass' from the second movement of the 'Italian' Symphony) and Anton Bruckner (the orchestral tremolo of the 'strings' in $p p$ from the first movement of the 'Romantic' Symphony in E flat major). Very important here is the quasipolyphonic piano texture, characteristic of Romantic composers, expressed in the presence of polyphony with the simultaneous use of octave reinforcement and procedures characteristic of homophony. Wilhelmj's changes concern not so much Chopin's sound material itself (to which he tends to remain faithful), but the ways in which it is set. Especially in its closing section, this transcription points to links with nineteenth-century German music, in particular the music of Mendelssohn (Example 67).

Another German feature - a massive sound while remaining faithful to Chopin's original text - can be found in Renaud de Vilbac's arrangements for piano for four hands. Commonly used in his transcription of the Waltz in E flat 

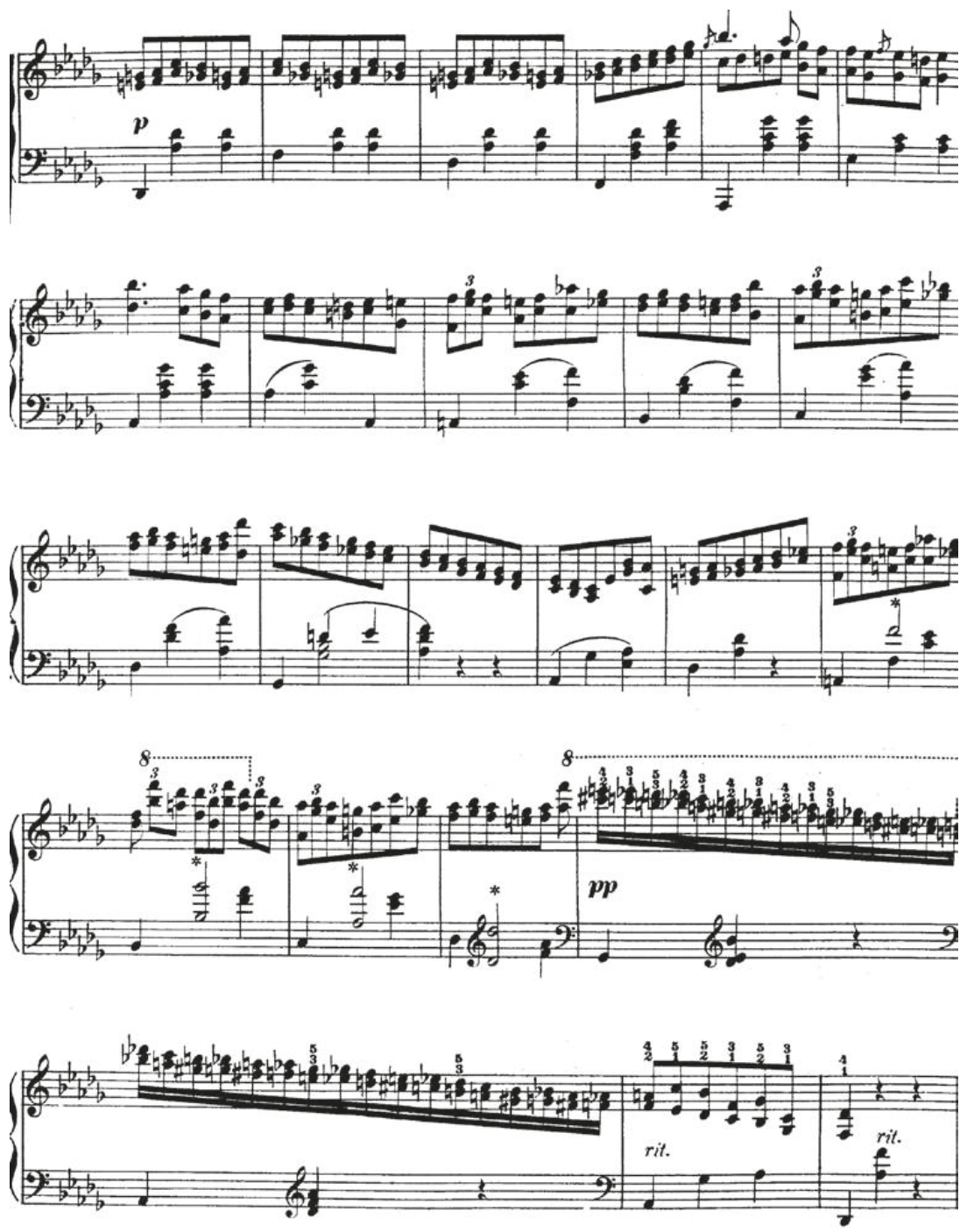

Example 66. F. Chopin - R. Joseffy, Concertstudie über den Des-dur Walzer, Op. 64 No. 1, Pfte (New York: E. Schuberth \& Co., 1879), bars 98-121. 

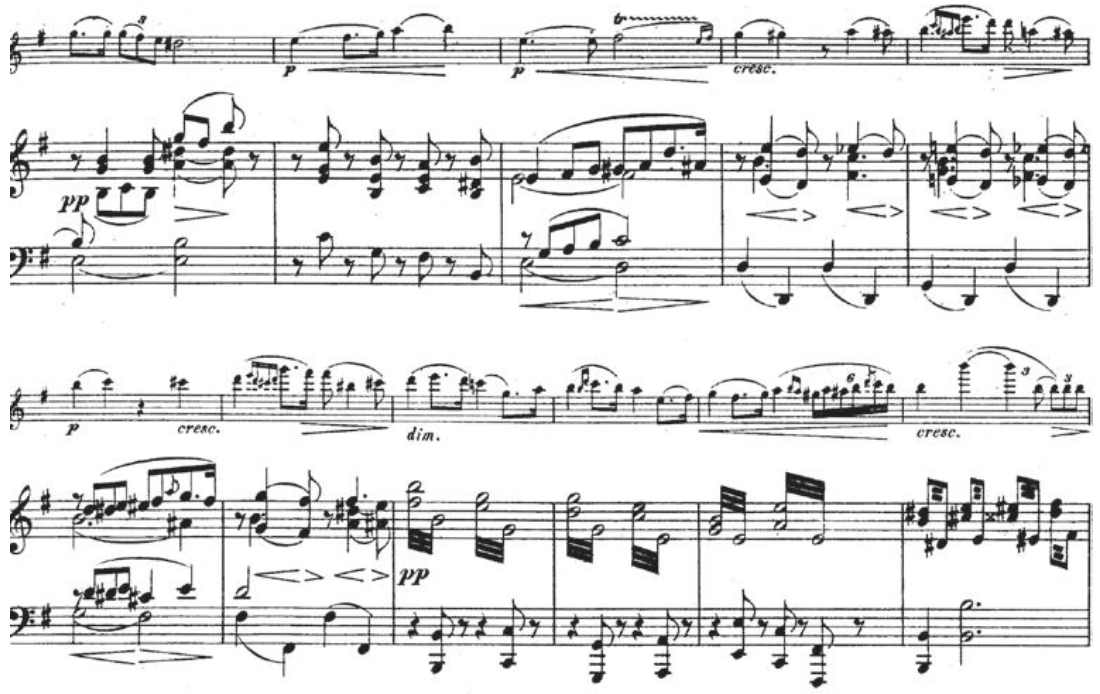

Leche

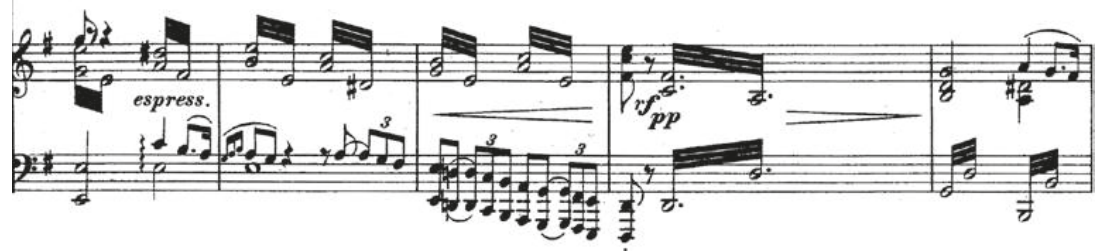

Hia

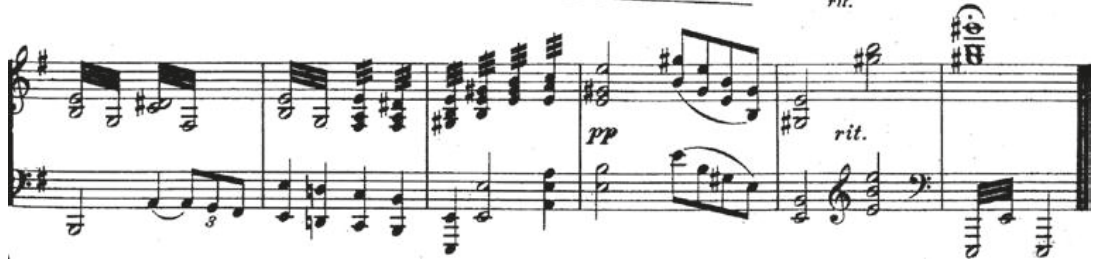

Example 67. F. Chopin - A. Wilhelmj, Nocturne [in G minor], Op. 37 No. 1, Vn+Pfte (Leipzig: Breitkopf \& Härtel, 1883), bars 65-92. 

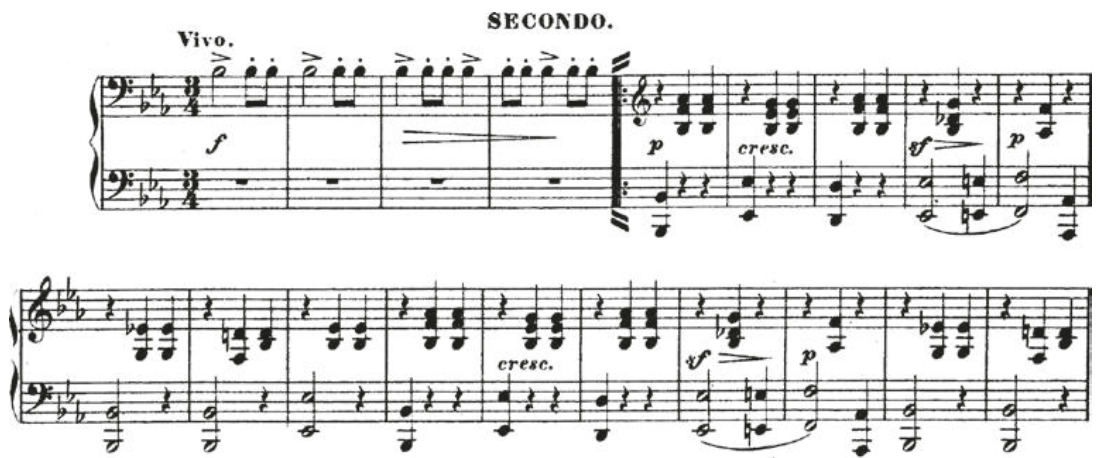

PRIMO.
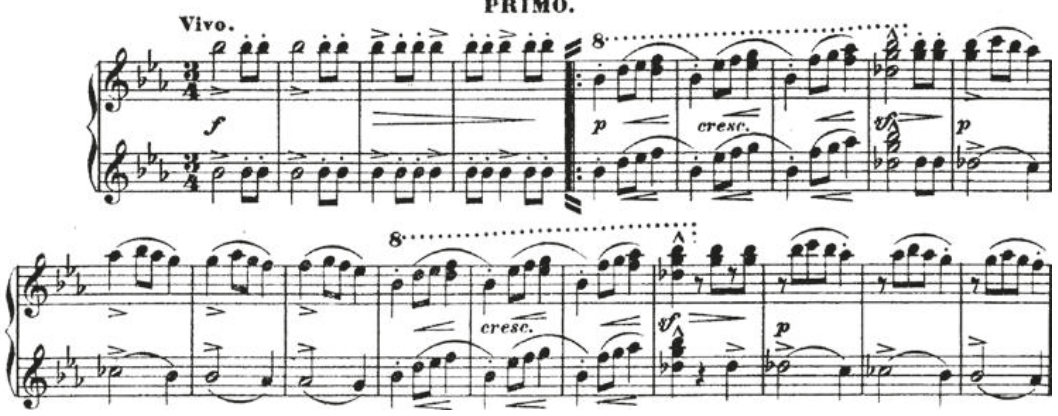

Example 68. F. Chopin - R. de Vilbac, Waltz [in E flat major], Op. 18, Pfte 4 hands (Brunswick: H. Litolff's Verlag, 1880-1885), bars 1-19.

major, Op. 18 are extensions of rhythmic values, octave doublings, changes of markings of performance and articulation (from non legato to dolce ma ben sostenuto, staccato to sostenuto, staccato to legato; the introduction of dolce), the subdivision of rhythmic values and 'broken' octaves. These changes in the secondo part affect the massive sound of the accompaniment layer. In the thematic-melodic layer of the waltz, we have the continuous reinforcement of the melody, led here in two-part octaves and with an upwards expansion of the sound register. The 'thick line' with which the transcriber redraws Chopin's subtle material results in an overemphasis of all the preserved features of the original (Examples 67-68).

To sum up, traces of the temporal and geographic provenance of transcriptions is noticeable in both the purely musical and the extra-musical (textual) domain. The Polishness of transcriptions is evident in both those layers: the former is guaranteed by the character of Chopin's music itself, the latter by the verbal text. French traces are evident in a subtlety of musical effects, the intention of 
compositions for the salon, their titles and a 'Debussian' sonoristic treatment of chords. A Russian character to arrangements is expressed in great lyricism and in a Slavic, romance-like singing, supported by the 'melody' of the Russian text. Most distinct of all are German features: dependability, expressed in a faithfulness to the substance of Chopin's original, a massiveness of sound, resulting from reference to symphonic music, and a Liszt-inspired virtuosity.

So the second question posed at the start of this subchapter receives a positive answer: a certain group of transcriptions are rooted in specific cultures, above all German, French, Russian and Polish. That fact is linked to the person of the transcriber, to his 'historical awareness' and his wish to participate in the principal discourse of the epoch. Despite the cited examples, however, the presence of 'national' transcriptions in our material is small.

Our analysis of transcriptions reveals a phenomenon that was strongly rooted in nineteenth-century musical practice. Yet many arrangements are characterised by their universality, since with regard to the 'lineage' of transcriptions or to 'traces' of their 'nationality', we should speak not so much of a distinct differentiation, but rather of their blending. That state of affairs is backed by the theory of emergent evolution, according to which a 'set of dynamic features of a specific cultural reality [existing in a given place] [...] does not entail qualitative changes within an entire system. ${ }^{506}$ Thus the changes characteristic of nineteenth-century European musical culture do not necessarily concern the whole set of Chopin transcriptions.

The evaluative criterion resulting from the social-cultural perspective orders and values the set of Chopin transcriptions in a similar way to the theoreticalmusical criterion. It assumes that Chopin's material ought to undergo transformation compatible with the time and place in which it was written. A further consequence of that assumption is the creation of transcriptions which are increasingly distant from the original.

506 Gołąb, Metodologiczne aspekty, 19-20. 



\section{Conclusion. Contemporary transcriptions of works by Chopin: prospects for further research}

As Stefan Morawski said: 'Every epoch perceives the past in the light of its own system of values; hence the constant reevaluation of works, with some falling out of circulation and others raised onto the highest pedestal. ${ }^{507}$ That rule is borne out when comparing nineteenth- and twentieth-century transcriptions (cf. Figure 3, Table 30). ${ }^{508}$ The great popularity of transcribing, the explosion of which is dated to the 1880 s, lasted for the next seven decades. The later peak in the 1950s was not so marked, but it did indicate a growth in interest, which lasted just two decades before fading very quickly.

The huge demand for Chopin transcriptions that existed in the nineteenth century was largely replaced during the twentieth century by the need to interpret Chopin's original text in many new ways. This change in the mode of Chopin reception was possible thanks to technical progress (analogue and digital notation), which created new forms (concert practice on a wide scale, festivals and competitions, numerous recordings) and lent it a global character. Through media in sound and vision and the enrichment of forms of reception, the function of transcriptions underwent a sea change. For a while, they were shunted into the margins of musical life, but in postmodern culture the 'interpretative' and the 'replicative' currents coexist with one another. ${ }^{509}$ These facts point to the directions which further research into the phenomenon of Chopin transcriptions may take. It is for future scholars to find solutions to the fundamental problems concerning twentieth- and twenty-first-century transcriptions and to reveal their specificities. A starting point may be the issues raised in the present study, but their scope must be modified. Given the different cultural and social situation, research should be directed towards two basic and internally complex research problems: [1] the modernist concept of trivial music

507 Morawski, Na zakręcie, 171.

508 The conclusions drawn below are based on the set of transcriptions documented in the CT catalogue.

509 We find them in numerous virtuosic transcriptions (e.g. by Timofei Dokshitser) and in popular jazz music (e.g. the versions recorded on the CD Tylko Chopin [Only Chopin] by the Polish jazz vocalist Lora Szafran and the band Walk Away, and a live recording by Andrzej Jagodziński’s Jazz Trio. 


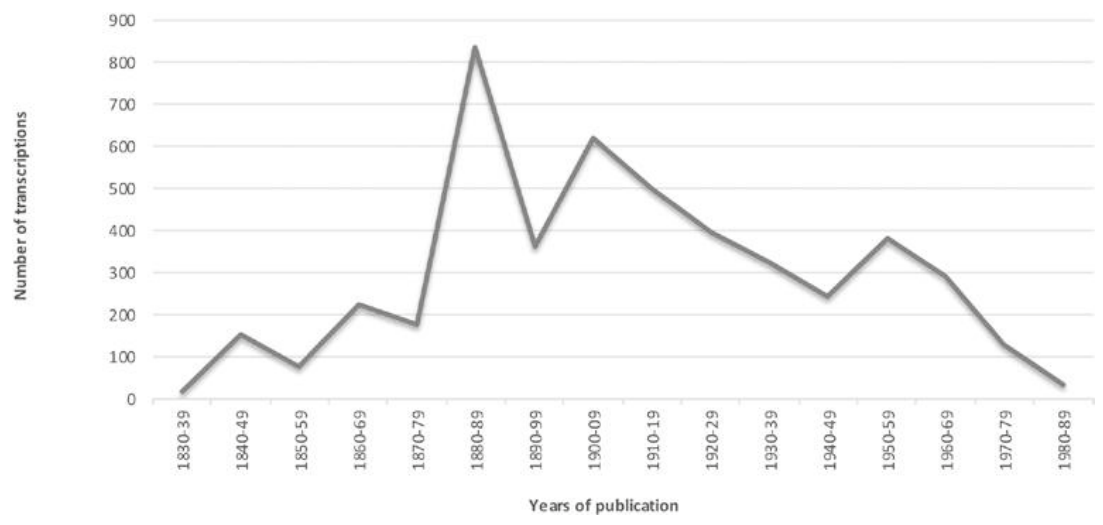

Figure 3: Numbers of transcriptions 1830-1989.

Table 30: Numbers of transcriptions 1830-1989.

\begin{tabular}{lc}
\hline Years & $\begin{array}{l}\text { Sum of all } \\
\text { transcriptions }\end{array}$ \\
\hline $1830-39$ & 18 \\
$1840-49$ & 155 \\
$1850-59$ & 75 \\
$1860-69$ & 223 \\
$1870-79$ & 179 \\
$1880-89$ & 836 \\
$1890-99$ & 365 \\
$1900-09$ & 618 \\
$1910-19$ & 500 \\
$1920-29$ & 396 \\
$1930-39$ & 323 \\
$1940-49$ & 244 \\
$1950-59$ & 383 \\
$1960-69$ & 290 \\
$1970-79$ & 131 \\
$1980-89$ & 35 \\
\hline
\end{tabular}


and Chopin transcriptions; [2] the postmodernist perspective on art and culture, transcriptions as manifestations of deconstruction in music.

With regard to the first point, it is crucial to address the existence of transcriptions at a time when they were widely negated. In that area, of considerable assistance may be the musical features of transcriptions from the years 1920-1970 and their belonging to one of the genres of 'high' or mass music. ${ }^{510}$ That scope of research should constitute the continuation of research signalled in the present study.

The second issue would concern transcriptions written after 1970. Here, the starting point is the Derridian philosophy of language and its basic research method - deconstruction, as widely discussed by Ryszard Nycz. ${ }^{511}$ Nycz stresses that in this new situation, which is changing much more quickly than in previous eras, we cannot retain systems of aesthetic and artistic value that are old or no longer adequate; the work of art must be open to a new context. And although the full range of issues relating to these transcriptions is only revealed after a thorough exploration of the source material and taking account of its musical and extra-musical contexts, we can already assume that the highly complex principal research problem may be transcription as a manifestation of deconstruction in music. This contains a number of aspects; [1] transcription in postmodern musical output (after 1970); [2] the place, role and evaluation of transcriptions in the 'high' culture of the late twentieth century; [3] the place, role and evaluation of transcriptions in the mass culture of the late twentieth century. A basic and immediate source for this research should be sheet music and recordings of Chopin transcriptions and the value judgments of artists and critics.

Janusz Sławiński has said: 'The work is an idiomatic, singular solution, [...] but here its uniqueness inevitably invokes the domain of repeatable possibilities; it makes manifest the existence of norms which represent an open opportunity for future realisations. ${ }^{512}$ The phenomenon of the transcribing of Chopin, in both the nineteenth and the twentieth century, is that domain of repeatable possibilities', the domain of mimesis, and it should be understood as one of the forms of the reception of Chopin's music - reception based not on the original, but on its copies.

510 Twentieth-century transcriptions have been written for many 'exotic' instruments in no way associated with Chopin, such as the ukulele, harmonica, wind orchestra and mandolin ensemble.

511 Nycz, Tekstowy świat.

512 Sławiński, 'Synchronia', 277. 



\title{
Appendix
}

1. Selected literary texts from vocal-instrumental transcriptions

2. List of Michał Biernacki

\section{Selected literary texts from vocal-instrumental transcriptions ${ }^{513}$ \\ NOCTURNES}

‘Żal', Op. 9 No. 1

Śmierć przebywała raz nasze ustronie. I nad strumykiem ujrzała mnie z nią, Jam kwiaty rwał i wieńczył lube skronie, Berta piosenką pieściła mnie swą;

Zazdrosna śmierć widząc w niej tyle wdzięków, struła nam kwiaty, zatruła mój los Berta umarła nie słysząc moich jęków, Gwiazda poranna zbladła na ten cios, pobladła na ten cios, na ten cios.

\section{'Plainte'}

\author{
La mort un jour passait sur mon village! \\ Elle nous vit assis près du ruisseau. \\ Moi je cueillais la menthe du rivage, \\ Berthe chantait au murmure de l'eau. \\ La mort jalousie en voyant tant de charmes, \\ Flétrit nos fleurs et flétrit mon destin, \\ Berthe expira, malgré toutes les larmes, \\ Lorsque pâlit létoile du matin
}

[text J. Ruelle/J. Chęciński music F. Chopin/?]

513 The texts presented here are copied out verbatim from the sheet music belonging to the collection of sources for this book. 


\section{MAZURKAS}

\section{'Zakochana', Op. 7 No. 2}

Jego dotąd nie ma, a duszyczka roi, ciągle przed oczyma jak zaklęty stoi. Na dobrą intencję dwa dni poszczę święcie, a nuż nie przyjedzie? Przyjedzie! Przyjedzie! Jakie on do uszka szeptał mi pieszczoty, ach! Piękny, ach! Duszka, ach! Srebrny, ach! Złoty. Tańczył tylko ze mną i raz kląkł przede mną, nuż bałamut skręci? Nie skręci! Nie skręci! Nudno czekać, a więc za to gdy przyjedzie, to ukarzę, niech poczeka, przed herbatą pewnie mu się nie pokażę. Lecz on jakiś taki żywy, w jego sercu pełno burz, bardzo będzie nieszczęśliwy, no, to z resztą wyjde juz Ale za to będę nosić ciągle przy nim śliczną różę, a gdy o nią będzie prosić nie dam tylko się zachmurzę.

Jego dotąd nie ma, a duszyczka roi, ciągle przed oczyma, jak zaklęty stoi. Ach jak kocham mamę... otwierają bramę, kasztanek na przedzie... e to proboszcz jedzie.

II.

Przyrzekał, że w Piątek a dziś już sobota, zawód na początek? Piękna mi robota! Nie myje się kostek i bez sroczki plotek... pewnie nie przyjedzie! Przyjedzie! Przyjedzie! A potem tak grzecznie podchlebiał matusi, Ach! Kocham, ach! Moim być musi, Pokłoni się matce, i ma ptaszka w klatce... a nuż panicz skrewi? Nie skrewi! Nie skrewi! Nudno czekać, a więc za to gdy przyjedzie, to ukarzę, niech poczeka, przed herbatą pewnie mu się nie pokażę. Lecz on dziwne ma kochanie, że szaleje, mówił sam. Nuż co złego mu się stanie? No, to z resztą różę dam. Ale za to pod krosienkę nie zapomnę rączki schować i to srogo a więc w rękę, dam się tylko pocałować.

\section{The Love-Lorn Lassie}

He is not yet here - $O$ where can he rove? I feel he is near, the lad that I love. He is the fairest for whom I yearn Oh could he forsake me? Nay! he will return! Sweet memiries endear him, his presence is bliss: I long to be near him, I long for his kiss! His bride would he make me, for him do I yearn Oh could he forsake me? Nay! he will return! How long doth he tarry! The moment I hear him, Away will I hurry, and haste to be near him. And should he be bold, or feign not to miss me, I'll not weep or scold, but I won't let him kiss me. Should he not relent, it shall be his loss until he repent, I'll be angry and cross! But once he has sworn, in words true and tender, To be mine own, then my heart I'll surrender.

He is not yet here - O where can he rove? I feel he is near, the lad that I love.

Hark! what sound strikes mine ear? They open the gates,

His carriage 'tis waits. O joy! he is here!

When fondly he kissed me, and whispered of love he said how he missed me, my fond cooing dove, He danced with no other, each lass tho' he knew, Oh could he love another? Nay! he will be true! He said to dear mother, I stood at his side: Tis she, or no other, shall be my fair bride! Now soon he will take me, and make me his own. Oh could he forsake me? Nay! he is mine own! How long doth he tarry! The moment I hear him, Away will I hurry, and haste to be near him. And should he be bold, or feign not to miss me, I'll not weep or scold, but I won't let him kiss me. Should he not relent, it shall be his loss until he repent, I'll be angry and cross! But once he has sworn, in words true and tender, To be mine own, then my heart I'll surrender. 
Jego dotąd nie ma, a duszyczka roi, ciągle przed oczyma, jak zaklęty stoi.

Ach, jak kocham mamę... otwierają bramę,

kasztanek na przedzie... e to proboszcz jedzie.
He is not yet here, oh where can he rove?

I feel he is near, the lad that I love.

Hark! what sound strikes mine ear? They open the gates,

His carriage 'tis waits. O joy! he is here!

[text K. Ujejski/J. Bernhoff

music F. Chopin/K. Studziński]

\section{'Zemsta dziewczyny', Op. 24 No. 3}

Jam dumnego pokochała, padł przede mną na kolana, pozna czem dziewczyna śmiała na ród męski zagniewana. A mój Boże jak on zdradzi, kocha inną szydzi ze mnie, rzekną ludzie plotkom radzi żem kochała nadaremnie. Nie, nie, ach! on kocha, on nie zdradzi taki wierny uniżony, moja główka w tem poradzi, zdradzał więc będzie zdradzony.

II.

Jam na swojem postawiła, błaga, żebrze mój litości, żebym srogą dlań nie była, dłoń oddała Jegomości.

Lecz on zawsze na usługi, kiedy wzdycha łzy mu biegną czy pokocha tak mię drugi, może lepiej iść za niego. $\mathrm{Nie}$, ach!

Ja pomszczę ród niewieści, wielbicieli znajdę roje, a mężczyźni w tej powieści będą mieć nauczkę swoję.

\section{A Girl's Revenge}

I fell for a proud man, who dropped to his knees before me, Let him see why spirited girls are angered by male behaviour. O my God, if he's unfaithful, loves another, mocking me, The gossips will say that I loved in vain.

No, no, oh woe!

He loves, he doesn't betray me, so humbly faithful,

But I'll follow my head, and a traitor will be betrayed.

II.

I put my foot down, he begs for pity,

That I'd not be stern, but give him my hand.

But he's always at my beck and call, weeps wheneer he sighs

Could another love me so? Perhaps I should say yes.

No, oh woe!

I'll avenge the line of Eve, I'll find a host of admirers, And may this tale be a lesson to all men.

[text B. Wisłocki/J. Comber

music F. Chopin/J. Nowakowski] 
'Terkotka', Op. 30 No. 2

Biedaż moja z ciotką, przezwała mnie terkotką.

Jeszcze mnie zawiąże świat a mam już piętnaście lat.

Taka plotka $\mathrm{z}$ poddasza, kawalera odstrasza, a kawaler slizga rzecz, poględnie i idzie precz. Otóż to pora i niezła pobudka, starzy od krosienek zbiegną do ogródka, niech kukułka powie czy przy tym na rowie, pójdę prędko za mąż tak, tak.

Ile więc razy kukułeczka kuknie to za wiosen tyle wezmę ślubną suknię, lecz nim zacznie kukać trzeba ją wyszukać, a Jezu najsłodszy jest ptak. Gadajże mi kuku! Krociusieńko kuku! Już mam dosyć kuku! Kukuleńko kuku! To ptaszysko kuku! W uszach wierci kuku! Krzycz że sobie kuku! Aż do śmierci kuku!. Otóż im na złość pójdę za mąż prędko złapię sobie chłopca siatką albo wędką, na ptaka konfuzyją wezmę wielką fuzyję i wymierzę prosto tak, tak.

Toż będzie terkotać żem już swoją panią na znak.

\section{The Cuckoo}

Nay! No longer can I stand it:

Aunt, you know my wish, so grant it.

I am sixteen now, and more:

Must I wait, till I'm three score?

Mind your promise last December:

I'm your only niece, remember!

All my schoolmates have got married,

$I$, your niece, alone have tarried.

Now, Auntie dear, my haste you'll pardon:

I run away into the garden, 
And ask the cuckoo: "Tell me truly:

"When will a laddie come to woo me?"

To the greenwoods I will hie me,

Lest the cuckoo should espy me,

And I shall learn from cuckoo's call,

What lot shall me, poor maid, befall.

Call once, pray only once:

"Cuckoo"! in one year then I'll wed,

"Cuckoo"! in one year then I'll wed,

"Cuckoo"! hark, he calls again:

"Cuckoo"! I cannot wait two years,

“Cuckoo!" so call til you're hoarse.

“Cuckoo"! I cannot, will not wait!

"Cuckoo"! Should a youth come, I will match him,

and to spite you, I will catch him,

love him, kiss him, and I'll hoot you,

and he'll take a gun, and shoot you!

Nay, no more I'll sit here waiting!

And the first that come a-mating

I will wed, and take my chance

And Auntie, you shall lead the dance.

[text K. Ujejski/J. Bernhoff

music F. Chopin/L. Grossman]

\section{'Dziewczyna mazowiecka', Op. 17 No. 1 Mazovian Girl}

I.

Która z dziewcząt fals mi zada, ze mój Stasio chwat nie lada.

Cy psy zniwie, cy biesiadzie,

cy to w tańcu on rej wiedzie.

Jak bzęknie podkówkami

az stal zaświeci skrami.

Jak w kólko się zakręci

to az w głowie mi się męci.

Wydać chcieli mnie rodzice za bagaca,

lec ja lice odwróciłam od natręta,

bo gdzies serce zniesię pęta?

$\mathrm{Nie}$, nie chcę je natręta,

bo gdzies serce zniesie peta?

Staś bywało gdy mi prawi,

to krwe w zyłach płynie zwawiej,

a gdy we mnie wciąż spoziera,

mnie już niebo się otwiera!

Raz nad Wisłą gdyśma stali

nadpłynęly flisy z dali,
What lass would deny

That my Stan's a dashing blade.

At the harvest, at a feast,

Or at dancing he's the best.

When he clicks his heels

The steel gives off sparks.

When we spin around

My head starts to whirl.

My parents found a wealthy man,

but I just turned away,

For how could my heart be chained?

No, I want no interloper,

For how could my heart be chained?

Sometimes Stan can make the blood

within my veins flow swiftly,

and when he sets his eyes on me,

Heaven opens before me!

Once we stood on the river bank

When rafts came from afar, 
zatsymała się gromadą, mówiąc: „To mi para!”

$\mathrm{O}$, mnie falsu nikt nie zada,

za i ja dziewa nie lada,

gdy ustroję się w Niedzielę

lec by o tym gadać wiele!

Gdy psed karcmą w dzień kiermasa

zobzias zagra obertasa,

wsycko za mym sunie torem

jak gąsięta za gąsiorem.

Nawet Wojciech siwy,

ten tez dla mnie tkliwy

i chłopiec lada jaki,

nuze do mnie w kopercaki.

Lec ja na to kieby głucha

bo mi sepce coś do ucha.

Nie ma chłopca nad Stasiecka

cała ziemia mazowiecka!

Nawet Wojciech siwy wzrok wysela za mną tkliwy.

Lec jam na to kieby głucha

bo im sepce coś do ucha.

Nie ma chłopca nad Stasiecka

cała ziemia mazowiecka!

[text J. Sęp/J. Comber

music F. Chopin/A. Münchheimer]

\section{'Biedne serce', Op. 7 No. 3}

Ileż biedne serce moje udręczeń musi jeszcze znieść

i jakie przebyć niepokoje za słodkich marzeń złudną treść.

Biedne serce!

Ileż musi znieść!

Aż pomyśleć o tem strach.

Ja żal przed ludźmi wciąż taję, choć tonę co dzień we łzach, ale cierpieć sił nie staje, a słabości ulec strach.

Ach!

Za porywy duszy młodej

tylko smutki i zawody!

Ledwie błyśnie dzień nadzieją nocne chmury go zawieją a nim zwątpień przyjdzie kres nie wystarczy oczom łez! Nie wiem co się ze mną dzieje już i sił do życia brak. a group just stopped and said: 'What a couple!'

$O$, no one would deny

That I am quite a lass, when I don my Sunday best But I could go on and on! At the fair outside the inn When they play an obertas, They all fall in behind me Like goslings in a goose's wake. Even old grey Wojciech is affectionate with me and all the lads Woo and court me gladly. But I'm deaf to all of that For something whispers in my ear. That none in all Mazovia Can compare with my Stan!

Even old grey Wojciech Lays his tender eyes on me. But I'm deaf to all of that For something whispers in my ear. That none in all Mazovia Can compare with my Stan! 
Boże powróć mi nadzieję albo nie daj cierpieć tak!

Zmiłowania!

O mój Boże!

Mój Boże!

\section{Faible cour}

Prépare-toi, faible cour,

A l'angoisse, à la douleur,

Puisqu'il te plaît de rêver

Ce qui ne peut arriver, faible cour!

Prépare-toi, faible cour!

De mon mal dois-je parler?

$\mathrm{Ou}$ dois-je en faire un mystère?

Je crains de le révéler,

Mais je meurs, je meurs de me taire!

$D$ mon mal dois-je parler?

Ah! Je meurs de me taire,

Mais je tremble, mais je tremble d'en parler.

Jamais cour plein de tendresse

Néprouva tant de tristesse!

Que l'espoir me berce une heure,

Et pendant des mois je pleure,

Tout un siècle de tourments

Suit les courts et doux moments!

Prends pitié mon Dieu, jexpire,

Vivre passe mon pouvoir.

C'est souffrir trop long martyre,

Que, de vivre sans espoir!

Dieu, fais grâce car jexpire...

Ah! Tais-toi, tais-toi, mon cour,

Ah! Souffre et meurs de douleur!

[text L. Pomey/P. Maszyński

music F. Chopin/P. Viardot]

\section{'Skarga miłości', Op. 6 No. 1}

Bez ciebie umieram $\mathrm{z}$ wolna, przed męczarnią nie ma schron, twarz śmiechu kłamać nie zdolna, gdy pęka życia nić, życia nić! Bez ciebie konam $\mathrm{z}$ wolna, przed męczarnią nie ma schron Twarz śmiechu kłamać nie zdolna, gdy w oczach łzy w sercu skon! gdy w oczach łzy w sercu skon! Niech obraz tych katuszy, 
zmieni srogość twej duszy, złagodzi twych słów gniewny ton! Bez ciebie konam $\mathrm{z}$ wolna, Czemu boleść dłużej kryć, twarz śmiechu kłamać nie zdolna gdy pęka dni smętnych nić! Dziś widziałem cię o miła, w czarodziejskim śnie lecz jutrzenka noc spłoszyła i straciłem cię!

Ach!

Bez ciebie umieram $\mathrm{z}$ wolna Czemu boleść dłużej kryć, Twarz śmiechu kłamać nie zdolna Gdy pęka dni smętnych nić! Bez ciebie konam $\mathrm{z}$ wolna, Przed męczarnia nie ma schron! Uśmiechu pragnę Niestety!

W mem sercu żal i skon!

\section{Plainte d'amour}

Chère âme, sans toi jexpire, Pourquoi taire ma douleur? Mes lèvres veulent sourire Mes yeux disent mon malheur. Hélas! Loin de toi jexpire, Que ma cruelle peine, De ton âme hautaine Désarme la rigueur.

Cette nuit dans un rêve, Je croyais te voir; Ah, soudain la nuit sachève, Et s'enfuit lespoir.

Je veux sourire. Hélas! La mort est Dans mon cœur.

[text L. Pomey/J. Chęciński music F. Chopin/P. Viardot]

\section{'Swaty', Op. 17 Nos. 4 and 1}

Dana moja dana! Chata malowana trafią do niej, trafią chłopcy, bo im dobrze znana, przyjdą na zaloty staną przede wroty, bieda tej, co za mąż idzie nie z ochoty. Czego z resztą bać się czego? Nie namówią za starego, a jeżeli kto przybędzie, 
to na pewno miły gość!

Ten jeden pożądany miłowany,

obiecał i przyjedzie,

nie zawiedzie.

Każdy inny, choć bogaty

niech omija próg mej chaty,

próżno się dobijać będzie,

nie otworzę mu na złość!

Jadą goście jadą licznie i z paradą,

aż kurzawa się unosi za tą ich gromadą,

dziewczę na ustroni bacznie okiem goni,

może to już, może jadą swaty do niej!

Czegóż ma się lękać, czego?

Nie mówią za starego,

ona czeka aż przybędzie sercu upragniony gość!

\section{Beau rossignol}

Beau rossignol, jentends ta voix,

Des nuits tu charmes toujours le silence,

Dis-moi, dis-moi ta gentille romance,

Que répète, que répète l'écho des bois.

Sous les ombrages,

Aux verts feuillages,

Que vos ramages

Sont doux, sont doux pour moi!

Quittant la terre, Mon âme entière

Monte en prière,

Mon Dieu, mon Dieu, vers toi.

Quittant la terre, Mon âme entière

Monte en prière,

Mon Dieu, mon Dieu, vers toi!

Dans nos jardins, des le printemps,

Ta voix si douce vient nous distraire,

Elle saura toujours nous plaire,

Beau rossignol, chante,

Ah! chante longtemps!

Sous les ombrages,

Aux verts feuillage,

$Q$ ue vos ramages

Sont doux, sont doux pour moi!

Quittant la terre, Mon âme entière

Monte en prière,

Mon Dieu, mon Dieu, vers toi.

Quittant la terre, Mon âme entière

Monte en prière,

Mon Dieu, mon Dieu, vers toi!

[text E. Richebourg/P. Maszyński

music F. Chopin/L. Bordèse] 


\section{WALTZES}

'Yarkiye treli nochnikh soloviev', Op. 34 No. 2

The Eloquent Trills of the Nightingales

The eloquent trills of the nightingales

Announced the coming of spring and of love. Ah!

The passion of roses, the spirit of the world

Looks to wondrous dreams heading towards the dawn.

Golden dawn, you rise full of fire in amber rays.

The roses move with you, like tears from thorn pricks.

Fiery roses, the spirit of the world

Looks to wondrous dangers heading towards the dawn

And to the wondrous emerald song of the nightingales,

Which soon fades in love.

[music F. Chopin/P. Shchurovsky]

\section{List of Michał Biernacki}

Instrumental arrangements:

6 Polnische Lieder, F. Liszt,

Arrangements for piano and orchestra, K. H. Reinecke

Piano reduction of both concertos and the Fantaisie, ${ }^{514} \mathrm{~K}$. Mikuli

Suite in seven movements for two pianos, ${ }^{515} \mathrm{~V}$. J. Hlavác

Transcriptions of the Waltz in D flat major, Op. 64 No. 1 for piano, A. Michałowski

Transcription of the Nocturne in E flat major, Op. 9 No. 2 for violin and piano, P. Sarasate

Transcriptions of two Nocturnes from Op. 9 for violin and piano, K. Lipiński

Transcriptions for violin and piano, ${ }^{516} \mathrm{~A}$. Wilhelmj

Transcriptions for violin and piano, ${ }^{517}$ F. Kreisler

Transcriptions for cello and piano of the Nocturne in E flat major, Op. 9 No. 2 and Mazurkas in F sharp minor and F minor, ${ }^{518}$ A.-F. Servais

Transcriptions for cello and piano, ${ }^{519} \mathrm{~K}$. Davidoff

Duet for two cellos based on themes of Chopin, ${ }^{520} \mathrm{M}$. Biernacki.

514 The author does not give the exact title, but probably meant the Fantaisie on Polish Airs, Op. 13.

515 This suite is based on the Etude in F minor, Op. 25 No. 2. While the etude is presented by one piano, the other introduces various Chopin themes.

516 Biernacki does not identify the transcriptions and adds that not all of them are worthy of note.

517 Here, too, we do not have exact information about the Chopin compositions, but all of Kreisler's transcriptions are interesting.

518 Biernacki does not specify the opuses and numbers of these mazurkas.

519 No indications of specific transcriptions; Biernacki states only that all of them are worthy of note.

520 There is no information about this Biernacki composition. 
Vocal arrangements ${ }^{521}$ (transcriptions of mazurkas, nocturnes, ${ }^{522}$ waltzes and other compositions by Chopin):

'Zakochana' [The Love-Lorn Lassie], transcription of the Mazurka in A minor, Op. 7 No. 2 for voice and piano, K. Studziński

'Zemsta dziewczyny' [A girl's revenge], transcription of the Mazurka in A flat major, Op. 24 No. 3 for voice and piano, J. Nowakowski

'Terkotka' [The Cuckoo], transcription of the Mazurka in B minor, Op. 30 No. 2 for voice and piano, L. Grossmann

'Tęsknota' [Longing], transcription of the Mazurka in E flat minor, Op. 6 No. 4 for voice and piano, F. Dulcken

'To nie on' [It's not him], transcription of the Mazurka in G minor, Op. 24 No. 1 for voice and piano, J. Nowakowski

'Dziewczyna mazowiecka' [Mazovian girl], transcription of the Mazurka in B flat major, Op. 17 No. 1 for voice and piano, A. Münchheimer

'Czyjaż wina' [Who's to blame?], transcription of the Mazurka in A flat major, Op. 50 No. 2 for voice and piano, E. Kania

'Wiośnianka' [Song of spring], transcription of the Mazurka in C major, Op. 33 No. 3 for voice and piano, Z. Noskowski

'Szesnaście lat' [Seize ans], transcription of the Mazurka in A flat major, Op. 50 No. 2, P. Viardot

'Kochaj mnie' [Aime-moi], transcription of the Mazurka in C major, Op. 33 No. 2, P. Viardot

'Zalotna' [Coquette], transcription of the Mazurka in B flat major, Op. 7 No. 1, P. Viardot 'Ptaszyna' [Loiselet], transcription of the Mazurka in A minor, Op. 68 No. 2, P. Viardot

'Skarga miłości' [Plainte d'amour], transcription of the Mazurka in F sharp minor, Op. 6 No. 1, P. Viardot

'Powiastka' [Fabliau], transcription of the Mazurka in C minor, Op. 30 No. 1, P. Viardot

'Przed mazurem' [La fête], transcription of the Mazurka in E flat minor, Op. 6 No. 4, P. Viardot

'Biedne serce' [Faible cœur], transcription of the Mazurka in F minor, Op. 7 No. 3, P. Viardot

'Dzieweczka' [La jeune fille], transcription of the Mazurka in C major, Op. 24 No. 2, P. Viardot

'Kołysanka' [Berceuse], transcription of the Mazurka in C major, Op. 33 No. 2, P. Viardot 'Pierwsza para' [La danse], transcription of the Mazurka in G major, Op. 50 No. 1, P. Viardot

521 In this group of arrangements, 'The charm of the content (in the vocal works) usually goes hand in hand with its fine presentation' (Biernacki, 'Transkrypcje', 488).

522 This Chopin genre was highly esteemed, second only to the mazurkas. 
'Rozstanie' [Séparation], transcription of the Mazurka in G minor, Op. 24 No. 1, P. Viardot 'Do pięknej' [La beauté], transcription of the Mazurka in G major, Op. 67 No. 1, P. Viardot 'Opuszczona' [L'inondation], ${ }^{523}$ transcription of the Mazurka in F minor, Op. 7 No. 3 , P. Viardot

'Swaty' [Beau rossignol], ${ }^{524}$ transcription of the Mazurkas in A minor and B flat major, Op. 7 No. 4 and No. 1, P. Viardot

'Sanna' [Les traineaux] ${ }^{525}$ transcription of the Mazurka in A minor, Op. 59 No. 1, P. Viardot 'Na łące' [Dans la prairie], transcription of the Nocturne in F major, Op. 15 No. 1, J. Ruelle, J. Chęciński

'Żal' [Plainte], transcription of the Nocturne in B flat minor, Op. 9 No. 1, J. Ruelle, J. Chęciński

'Piosnka miłości' [Chanson d'amour], transcription of the Nocturne in B major, Op. 62 No. 1, J. Ruelle, J. Chęciński

'Cisza nocy' [Aspiration], transcription of the Nocturne in E flat major, Op. 9 No. 2 J. Ruelle, J. Chęciński

'Amorettenreigen' [Ridda d'Amorini], transcription of the Waltz in D flat major, Op. 64 No. 1, M. Roeder

'Tęsknota' [Sehnsucht], transcription of the Waltz in A minor, Op. 34 No. 2, M. Roeder 'Stroskana' [Troubled], transcription of the Waltz in A minor, Op. 34 No. 2, A. Münchheimer 'Noc' [Night], ${ }^{526}$ Op. 57

'Pożegnanie z życiem' [Farewell to life], transcription of the Funeral March in B flat minor from Op. 35, M. Radziszewski

'Nad kołyską' [Over the cradle], ${ }^{527}$ Op. 57

'Stabat Mater', transcription of the Prelude in C minor, Op. 28 No. 20, M. Radziszewski

Duet 'Rusałka' [La fille d'onde], transcription of the Ballade in F major, Op. 38, L. Bordèse

\section{Versions for male or mixed choir}

'Piosnka litewska' [Lithuanian Song] (for male choir); 'Hulanka' [Drinking Song] (for male choir); 'Leci liście' [Leaves are Falling] (for mixed choir), M. Biernacki

Three songs ('Dwojaki koniec' [The Lovers]; 'Gdzie lubi' [A Fickle Maid]; 'Życzenie’ [A Maiden’s Wish]), P. Maszyński

'Marzenie' [Dream], transcription of the Prelude in A major, Op. 28 No. 7, P. Maszyński

'Przebudzenie' [Awakening], transcription of the Fantaisie in F minor, Op. 49, P. Maszyński

523 According to CT (p. 432), this composition was attributed to Pauline Viardot but actually composed by Louis Bordèse.

524 According to CT (p. 437), this transcription was the work of Louis Bordèse.

525 This composition, attributed to Pauline Viardot, was actually written by Louis Bordèse. See CT, 435.

526 We have no other information about the Chopin piece.

527 We have no other information about the Chopin piece or the transcriber. 
'Wschód słońca' [Sunrise], transcription of the Prelude in E major, Op. 28 No. 9, P. Maszyński

'Marzenie' [Dream] for female voices, L. Dietz ${ }^{528}$

Transcription of the Prelude in D flat major, Op. 28 No. 15 for female voices, strings, piano and harmonium, K. Mikuli

Songs by Chopin ('Śliczny chłopiec' [My Beloved]; 'Precz z moich oczu' [Remembrance]; 'Dwojaki koniec' [The Lovers]; 'Wojak' [Before the Battle]) for male choir, Z. Noskowski Arrangements of Mazurkas in C major, F major and B flat major; 529 Preludes in $\mathrm{C}$ minor and $\mathrm{G}$ major ${ }^{530}$ the Funeral March in B flat minor from Op. 35 for mixed choir and orchestra, Z. Noskowski

\section{Orchestrations:}

Mazurkas in B minor and D major, Polonaise in A flat major, Op. 53, Etude in C minor, Op. 25 No. 12, Z. Noskowski

Polonaise in A major, Op. 40 No. 1 (for large orchestra); Funeral March in B flat minor from Op. 35 (for wind orchestra); new arrangements of the orchestra part of the Concerto in F minor, Op. 21 and Fantaisie on Polish Airs, Op. 13, A. Münchheimer Instrumentation of a piano accompaniment, ${ }^{531} \mathrm{R}$. Burmeister

Orchestral suite Chopiniana, A. Glazunov.

528 No other information is given by Biernacki or in CT.

529 There is no other information about the opus or numbers of these mazurkas. They are probably the Mazurkas in B flat major, Op. 17 No. 1, in C major, Op. 33 No. 2 and in F major, Op. 68 No. 3. See CT, 494.

530 There is no other information about the opus or numbers of these preludes. They are probably the Preludes in C minor, Op. 28 No. 20 and in G major, Op. 28 No. 3. See CT, 494.

531 Biernacki does not give the title of the Chopin composition. 



\section{List of figures}

Model 1: Multiplication of sound layer, first option. ................................... 127

Model 2: Transmission of sound layer, first option. ...................................... 127

Model 3: Multiplication of sound layer, second option. .............................. 127

Model 4: Transmission of sound layer, second option. ................................ 128

Figure 1: Theoretical model of nineteenth-century transcriptions of works by Chopin. .............................................................................. 192

Figure 2: Network of connections in the model of nineteenth-century transcriptions of works by Chopin. ................................................ 192

Figure 3: Numbers of transcriptions 1830-1989. ......................................... 240 



\section{List of examples}

Example 1. F. Chopin - F. David, Waltz [in A minor], Op. 34 No. 2, Vn+Pfte (Leipzig: Breitkopf \& Härtel, 1871), bars 169-177.

Example 2. F. Chopin - F. David, Waltz [in A minor], Op. 34 No. 2, Vn+Pfte (Leipzig: Breitkopf \& Härtel, 1871), bars 47-68. ..... 133

Example 3. F. Chopin - F. David, Waltz [in A minor], Op. 34 No. 2, Vn+Pfte (Leipzig: Breitkopf \& Härtel, 1871), bars 9-18.

Example 4. F. Chopin - E. Prill, Waltz [in A minor], Op. 34 No. 2, Fl+Pfte (Leipzig: J. H. Zimmermann, 1893), bars 97-112. .... 134

Example 5. F. Chopin - E. Prill, Waltz [in A minor], Op. 34 No. 2, Fl+Pfte (Leipzig: J. H. Zimmermann, 1893), bars 1-16.

Example 6. F. Chopin - A. Horn, Waltz [in A minor], Op. 34 No. 2, Pfte 4 hands (Leipzig: C. F. Peters, 1878), bars 1-8.

Example 7. F. Chopin, Etude [in C major], Op. 10 No. 7, Pfte (Cracow: PWM, 1981), bars 1-4.

Example 8. F. Chopin - L. Godowsky, Etude [in C major], Op. 10 No. 7, Pfte, first version (New York: G. Schirmer, 1903), bars $1-5$.

Example 9. F. Chopin - L. Godowsky, Etude [in C major], Op. 10 No.

7, Pfte, first version (New York: G. Schirmer, 1903), bars

9-13.

Example 10. F. Chopin - L. Godowsky, Etude [in C major], Op. 10 No.

7, Pfte, first version (New York: G. Schirmer, 1903), bars

$45-47$.

Example 11. F. Chopin - L. Godowsky, Etude [in C major], Op. 10 No.

7, Pfte, first version (New York: G. Schirmer, 1903), bars $15-23$.

Example 12. F. Chopin - L. Godowsky, Etude [in C major], Op. 10 No.

7, Pfte, second version (New York: G. Schirmer, 1903),

bars $1-4$.

Example 13. F. Chopin - L. Godowsky, Etude [in C major], Op. 10 No.

7, Pfte, second version (New York: G. Schirmer, 1903),

bars 21-34.

Example 14. F. Chopin - L. Godowsky, Etude [in C major], Op. 10 No.

7, Pfte, second version (New York: G. Schirmer, 1903), bars 39-45. 
Example 15. F. Chopin - L. Godowsky, Etude [in C major], Op. 10 No.

7, Pfte, second version (New York: G. Schirmer, 1903),

bars 8-12.

Example 16. F. Chopin - L. Godowsky, Etude [in C major], Op. 10 No.

7, Pfte, second version (New York: G. Schirmer, 1903),

bars $48-52$.

Example 17. F. Chopin - L. Godowsky, Etude [in C major], Op. 10 No.

7, Pfte, third version (New York: G. Schirmer, 1903), bars

43-45.

Example 18. F. Chopin - L. Godowsky, Etude [in C major], Op. 10 No.

7, Pfte, third version (New York: G. Schirmer, 1903), bars

$1-4$.

Example 19. F. Chopin - L. Godowsky, Etude [in C major], Op. 10 No.

7, Pfte, third version (New York: G. Schirmer, 1903), bars

43-45.

Example 20. F. Chopin - L. Godowsky, Etude [in C major], Op. 10 No.

7, Pfte, third version (New York: G. Schirmer, 1903), bars

29-30.

Example 21. F. Chopin - M. Roeder, 'Amorettenreigen' - Waltz [in

D flat major], Op. 64 No. 1, voice+Pfte, German text

M. Roeder (Berlin: Bote \& Bock, 1888), bars 100-125.

Example 22. F. Chopin - E. Rohde, 'Piosnka litewska' [Lithuanian Song], Op. 74 No. 16, Pfte (Berlin: A. M. Schlesinger, 1874), bars 44-48.

Example 23. F. Chopin - R. Hasert, 'Leci liście' [Leaves are Falling],

Op. 74 No. 17, Pfte (Berlin: A. M. Schlesinger, 1861), bars $1-34$.

Example 24. F. Chopin - R. Hasert, 'Leci liście' [Leaves are Falling], Op. 74 No. 17, Pfte (Berlin: A. M. Schlesinger, 1861), bars 159-176.

Example 25. F. Chopin - R. Hasert, 'Leci liście' [Leaves are Falling], Op. 74 No. 17, Pfte (Berlin: A. M. Schlesinger, 1861), bars $35-48$.

Example 26. F. Chopin - J. Chęciński, 'Żal' [Plainte] - Nocturne [in B flat minor], Op. 9 No. 1, voice+Pfte, Polish text by J. Chęciński (Warsaw: Gebethner \& Wolff, 1867), bars $1-13$.

Example 27. F. Chopin - J. Chęciński, 'Żal' [Plainte] - Nocturne [in B flat minor], Op. 9 No. 1, voice+Pfte, Polish text by J. Chęciński (Warsaw: Gebethner \& Wolff, 1867), bars $14-25$. 
Example 28. F. Chopin - P. Viardot-García, 'Biedne serce' [Faible cœur] - Mazurka [in F minor], Op. 7 No. 3, voice+Pfte, Polish words by P. Maszyński (Warsaw: Gebethner \& Wolff, 1897), bars 1-18. 169

Example 29. F. Chopin - P. Viardot-García, 'Biedne serce' [Faible cœur] - Mazurka [in F minor], Op. 7 No. 3, voice+Pfte, Polish words by P. Maszyński (Warsaw: Gebethner \& Wolff, 1897), bars 19-35.

Example 30. F. Chopin - P. Viardot-García, 'Biedne serce' [Faible cœur] - Mazurka [in F minor], Op. 7 No. 3, voice+Pfte, Polish words by P. Maszyński (Warsaw: Gebethner \& Wolff, 1897), bars 36-52.

Example 31. F. Chopin - P. Viardot-García, 'Biedne serce' [Faible cœur] - Mazurka [in F minor], Op. 7 No. 3, voice+Pfte, Polish words by P. Maszyński (Warsaw: Gebethner \& Wolff, 1897), bars 53-72.

Example 32. F. Chopin - P. Viardot-García, 'Biedne serce' [Faible cœur] - Mazurka [in F minor], Op. 7 No. 3, voice+Pfte, Polish words by P. Maszyński (Warsaw: Gebethner \& Wolff, 1897), bars 73-91.

Example 33. F. Chopin - P. Viardot-García, 'Biedne serce' [Faible cœur] - Mazurka [in F minor], Op. 7 No. 3, voice+Pfte, Polish words by P. Maszyński (Warsaw: Gebethner \& Wolff, 1897), bars 92-111. 174

Example 34. F. Chopin - P. Viardot-García, 'Biedne serce' [Faible cœur] - Mazurka [in F minor], Op. 7 No. 3, voice+Pfte, Polish words by P. Maszyński (Warsaw: Gebethner \& Wolff, 1897), bars 112-130.

Example 35. F. Chopin - L. Bordèse, 'Swaty' [Beau rossignol] Mazurka [in B flat major], Op. 17 No. 1, voice+Pfte, Polish words by P. Maszyński (Warsaw: Gebethner \& Wolff, 1899), bars 1-18.

Example 36. F. Chopin - L. Bordèse, 'Swaty' [Beau rossignol] Mazurka [in B flat major], Op. 17 No. 1, voice+Pfte, Polish words by P. Maszyński (Warsaw: Gebethner \& Wolff, 1899), bars 19-36. 178

Example 37. F. Chopin - L. Bordèse, 'Swaty' [Beau rossignol] Mazurka [in B flat major], Op. 17 No. 1, voice+Pfte, Polish words by P. Maszyński (Warsaw: Gebethner \& Wolff, 1899), bars 37-61. 
Example 38. F. Chopin - L. Bordèse, 'Swaty' [Beau rossignol] Mazurka [in B flat major], Op. 17 No. 1, voice+Pfte, Polish words by P. Maszyński (Warsaw: Gebethner \& Wolff, 1899), bars 62-79. 180

Example 39. F. Chopin - L. Bordèse, 'Swaty' [Beau rossignol] Mazurka [in B flat major], Op. 17 No. 1, voice+Pfte, Polish words by P. Maszyński (Warsaw: Gebethner \& Wolff, 1899), bars 80-96.

Example 40. F. Chopin - F. Büchner, Etude [in G flat major], Op. 25 No. 9, Fl (Leipzig: J. H. Zimmermann, 1892-1897), bars $1-4$. 183

Example 41. F. Chopin - F. Büchner, Etude [in G flat major], Op. 25 No. 9, Fl (Leipzig: J. H. Zimmermann, 1892-1897), bars 44-52.

Example 42. F. Chopin - F. Büchner, Etude [in G flat major], Op. 10 No. 5, Fl (Leipzig: J. H. Zimmermann, 1892-1897), bars $1-7$. 184

Example 43. F. Chopin - F. Büchner, Etude [in G flat major], Op. 10 No. 5, Fl (Leipzig: J. H. Zimmermann, 1892-1897), bars $55-71$.

Example 44. F. Chopin - F. Büchner, Etude [in F major], Op. 25 No. 3, Fl (Leipzig: J. H. Zimmermann, 1892-1897), bars 21-22. .... 185

Example 45. F. Chopin - F. Büchner, Etude [in F major], Op. 25 No. 3, Fl (Leipzig: J. H. Zimmermann, 1892-1897), bars 54-57. 185

Example 46. F. Chopin - F. Büchner, Etude [in F minor], Op. 25 No. 2, Fl (Leipzig: J. H. Zimmermann, 1892-1897), bar 67.

Example 47. F. Chopin - J. Łusakowski, Nocturne [in E flat major], Op. 9 No. 2, Pfte (Warsaw: M. Arct, 1892). 188

Example 48. F. Chopin - F. Kalkbrenner, Variations brillantes, after Mazurka [in B flat major], Op. 7 No. 1, Pfte (Leipzig: F. Kistner, 1833). Variation I, bars 1-6. 218

Example 49. F. Chopin - F. Kalkbrenner, Variations brillantes, after Mazurka [in B flat major], Op. 7 No. 1, Pfte (Leipzig: F. Kistner, 1833). Variation II, bars 1-6.

Example 50. F. Chopin - F. Kalkbrenner, Variations brillantes, after Mazurka [in B flat major], Op. 7 No. 1, Pfte (Leipzig: F. Kistner, 1833). Variation III, bars 1-12.

Example 51. F. Chopin - F. Kalkbrenner, Variations brillantes, after Mazurka [in B flat major], Op. 7 No. 1, Pfte (Leipzig: F. Kistner, 1833). Variation V, bars 1-8. 
Example 52. F. Chopin - A. Hänsel, Fantaisie on the Mazurka [in B flat major], Op. 7 No. 1, Pfte (Dresden: L. Bauer, 1850), Variation I, bars 1-8.

Example 53. F. Chopin - A. Hänsel, Fantaisie on the Mazurka [in B flat major], Op. 7 No. 1, Pfte (Dresden: L. Bauer, 1850), Variation II, bars 1-8.

Example 54. F. Chopin - S. Taborowski, Melodia [Melody], Op. 74 No. 9, Vn+Pfte (Berlin: A. M. Schlesinger, 1874), bars 40-47. 222

Example 55. F. Chopin - A. Wilhelmj, Nocturne [in E flat major], Op. 9 No. 2, Vn+Pfte (Leipzig: F. Kistner, 1873), bars 23-26.

Example 56. F. Chopin - A. Wilhelmj, Nocturne [in E flat major], Op. 9 No. 2, Vn+Pfte (Leipzig: F. Kistner, 1873), bars 34-37. 224

Example 57. F. Chopin - A. Franchomme, Etude [in C sharp minor], Op. 25 No. 7, Vc+Pfte (Leipzig: Breitkopf \& Härtel, 1871), bars 1-9.

Example 58. F. Chopin - P. Viardot, 'Skarga miłości' [Plainte d'amour] - Mazurka [in F sharp minor], Op. 6 No. 1, voice+Pfte (Warsaw: Gebethner \& Wolff, 1898), bars $55-65$. 226

Example 59. F. Chopin - P. Shchurovsky, 'Yarkiye treli nochnykh soloviev' [The eloquent trills of the nightingales] - Waltz [in A minor], Op. 34 No. 2, voice+Pfte (Moscow: K. Meikov, 1881), bars 53-68.

Example 60. F. Chopin - A. Münchheimer, 'Dziewczyna mazowiecka' [Mazovian girl] - Mazurka [in B flat major], Op. 17 No. 1, voice+Pfte (Warsaw: Gebethner \& Wolff, 1882), bars $1-7$.

Example 61. F. Chopin - G. Ferrata, Second Study on Chopin's Valse Waltz [in D flat major], Op. 64 No. 1, Pfte (New York: J. Fischer, 1902), bars 1-12. 230

Example 62. F. Chopin - G. Ferrata, Second Study on Chopin's Valse Waltz [in D flat major], Op. 64 No. 1, Pfte (New York: J. Fischer, 1902), bars 21-28.

Example 63. F. Chopin - G. Ferrata, Second Study on Chopin's Valse Waltz [in D flat major], Op. 64 No. 1, Pfte (New York: J. Fischer, 1902), bars 47-59.

Example 64. F. Chopin - R. Joseffy, Concertstudie über den Des-dur Walzer, Op. 64 No. 1, Pfte (New York: E. Schuberth \& Co., 1879), bars 60-66. 
Example 65. F. Chopin - R. Joseffy, Concertstudie über den Des-dur Walzer, Op. 64 No. 1, Pfte (New York: E. Schuberth \& Co., 1879), bars 65-69.

Example 66. F. Chopin - R. Joseffy, Concertstudie über den Des-dur Walzer, Op. 64 No. 1, Pfte (New York: E. Schuberth \& Co., 1879), bars 98-121.

Example 67. F. Chopin - A. Wilhelmj, Nocturne [in G minor], Op. 37 No. 1, Vn+Pfte (Leipzig: Breitkopf \& Härtel, 1883), bars 65-92.

Example 68. F. Chopin - R. de Vilbac, Waltz [in E flat major], Op. 18, Pfte 4 hands (Brunswick: H. Litolff's Verlag, 1880-1885), bars 1-19. 


\section{List of tables}

Table 1: Number of transcriptions published in successive decades.

Table 2: Number of transcriptions published in different countries in 1830-1919.

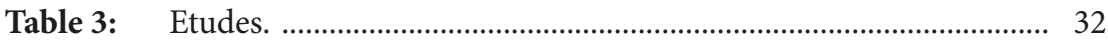

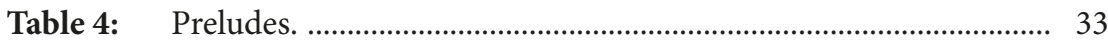

Table 5: Mazurkas. ................................................................................... 35

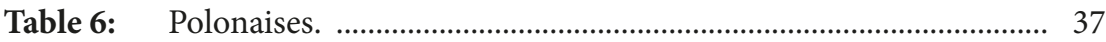

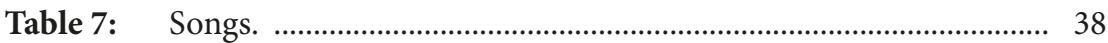

Table 8: Nocturnes. ..................................................................................... 39

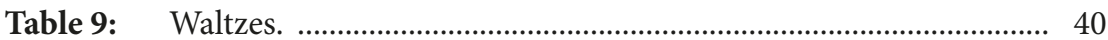

Table 10: Other Chopin genres. ................................................................ 41

Table 11: Large-scale works. .......................................................................... 42

Table 12: Piano concertos. .......................................................................... 43

Table 13: Quantitative comparison of Chopin's originals and transcriptions. .................................................................................. 44

Table 14: Chopin compositions with the most transcriptions. ..................... 44

Table 15: Generic ranking of transcriptions. ................................................. 45

Table 16: Number of transcriptions published by Polish firms. .................. 71

Table 17: Number of transcriptions published by Russian firms. ................ 72

Table 18: Number of transcriptions published by French firms. ................. 72

Table 19: Number of transcriptions published by German firms. ............... 73

Table 20: Number of transcriptions published by Austrian firms. .............. 74

Table 21: Number of transcriptions published by British firms. .................. 74

Table 22: Number of transcriptions published by Italian and Dutch

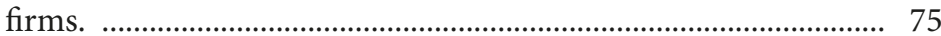

Table 23: Number of transcriptions published by Swedish and American firms. ............................................................................. 75

Table 24: Collective tabulation of sources from the Chomiński and Turło Catalogue: number of transcriptions in particular countries. .................................................................................... 76

Table 25: Collective tabulation of own sources: number of transcriptions in particular countries.

Table 26: Chronological list of performances of Chopin transcriptions in nineteenth-century Wrocław.

Table 27: Systematics of transcription according to Maciej Gołąb. ................. 123

Table 28: The scope of changes in the substantial type of transcription. ....... 138 
Table 29: The aesthetic value of different types of transcription. ............ 213

Table 30: Numbers of transcriptions 1830-1989. .................................... 240

Schema 1: Structure of the original composition: F. Chopin, Waltz in D flat major, Op. 64 No. 1.

Schema 2: Structure of the transcription: F. Chopin - M. Roeder, Waltz in D flat major, Op. 64 No. 1.

Schema 3: Structure of the original composition: F. Chopin, 'Piosnka litewska' [Lithuanian Song], Op. 74 No. 16.

Schema 4: Structure of the transcription: F. Chopin - E. Rohde, 'Piosnka litewska' [Lithuanian Song], Op. 74 No. 16.

Schema 5: Structure of the original composition (abbr.): F. Chopin, 'Leci liście' [Leaves are Falling], Op. 74 No. 17.

Schema 6: Structure of the transcription (abbr.): F. Chopin R. Hasert, 'Leci liście' [Leaves are Falling], Op. 74 No. 17. 160

Schema 7: Structure of the original composition (detailed): F. Chopin, 'Leci liście' [Leaves are Falling], Op. 74 No. 17.

Schema 8: Structure of the transcription (detailed): F. Chopin R. Hasert, 'Leci liście' [Leaves are Falling], Op. 74 No. 17.

Schema 9: Structure of the original composition: F. Chopin, Nocturne in B flat minor, Op. 9 No. 1.

Schema 10: Structure of the transcription: F. Chopin - J. Chęciński: 'Żal' [Plainte] - Nocturne [in B flat minor], Op. 9 No. 1.

Schema 11: Structure of the original composition: F. Chopin, Mazurka in F minor, Op. 7 No. 3.

Schema 12: Structure of the transcription: F. Chopin - P. ViardotGarcía, 'Biedne serce' [Faible cœur] - Mazurka [in F minor], Op. 7 No. 3. M2 = section of the Mazurka in A minor, Op. 7 No. 2.

Schema 13: Structure of the original composition: F. Chopin, Mazurka in B flat major, Op. 17 No. 1. 176

Schema 14: Structure of the transcription: F. Chopin - L. Bordèse, 'Swaty' [Beau rossignol] - Mazurka [in B flat major], Op. 17 No. 1. Introd. = introduction based on material of the Mazurka in A minor, Op. 17 No. 4 (bars 61-68 of Chopin's original); M4 = part of the Mazurka in A minor, Op. 17 No. 4 (bars 69-84); $\mathrm{m} 4$ = sentence from the Mazurka in A minor, Op. 17 No. 4. 176

Schema 15: Structure of the original composition: F. Chopin, Nocturne in E flat major, Op. 9 No. 2.

Schema 16: Structure of the transcription: F. Chopin - J. Łusakowski, Nocturne [in E flat major], Op. 9 No. 2. 


\section{Sources $^{532}$}

\section{Literary sources}

\section{Nineteenth-century lexicons ${ }^{533}$}

Einstein, Alfred, Das Neue Musik Lexikon, nach dem 'Dictionary of modern Music and Musicians'. Herausgegeben von A. Eaglefield-Hull übersetzt und bearbeitet von Alfred Einstein, 11th edn (Berlin, 1926).

Eitner, Robert, Biographisch-Bibliographisches Quellen-Lexikon der Musiker und Musikgehlerten der christlichen Zeitrechnung bis zur Mitte des 19. Jahrhunderts, 10 vols (Leipzig, 1900-1904); repr. 11 vols (Wiesbaden, 1959-1960).

Fétis, François-Joseph, Biographie universelle des musiciens et bibliographie générale de la musique, 8 vols + 2 supplements (Paris, 1860-1880).

Frank, Paul, Kurzgefaßtes Tonkünstlerlexikon, ed. Wilhelm Altmann, 12th edn (Leipzig, 1926).

Mendel, Hermann, and Reissmann, August, Musikalisches ConversationsLexikon, 11 vols + supplement (Berlin, 1870-1883).

Riemann, Hugo, Hugo Riemanns Musik Lexikon, ed. Alfred Einstein, 2 vols (Berlin, 1929).

Roguski, Gustaw, Słowniczek znakomitszych muzyków [Concise dictionary of major musicians] (Warsaw, 1906).

Schilling, Gustav, Encyklopädie der gesammten musikalischen Wissenschaften, oder Universal Lexicon der Tonkunst, 6 vols + supplement (Stuttgart, 1835-1842).

Sowiński, Albert, Słownik muzyków polskich dawnych i nowoczesnych kom-pozytorów, wirtuozów, śpiewaków, instrumentalistów, lutnistów, organmistrzów, poetów lirycznych i miłośników sztuki muzycznej zawierający krótki rys historii muzyki w Polsce [Dictionary of Polish musicians past and present: composers, virtuosos, singers, instrumentalists, lutenists, organmasters, lyric poets and lovers of the art of music, containing a brief historical outline of music in Poland] (Paris, 1874; repr. Warsaw 1982).

532 For a detailed description of sources, see subchapter 1.2.

533 This is a fundamental source for profiles of transcribers. For a detailed description, see subchapter 2.2. 
2. Concert announcements and reviews of performances of original works and transcriptions, from the nineteenth-century Wrocław periodicals Breslauer Zeitung and Schlesische Zeitung: ${ }^{534}$

BZ 1855/256, p. 1673

BZ 1858/81, p. 377

BZ 1858/83, p. 385

BZ 1858/85, p. 389

BZ 1871/55, p. 380

BZ 1878/51, p. 2

BZ 1872/48, p. 396

BZ 1872/52, p. 427

BZ 1873/37, p. 310

BZ 1876/39, p. 9

BZ 1876/43, p. 1

BZ 1873/99, p. 809

BZ 1873/103, pp. $834-835$

BZ 1877/4, p. 1

BZ 1877/40, p. 2

BZ 1878/581, p. 2

BZ 1893/205, p. 11

BZ 1893/211, p. 2

BZ 1898/61, p. 11

BZ 1877/124, p. 1

BZ 1877/562, p. 2

BZ 1879/515, p. 7

BZ 1879/519, p. 2

BZ 1881/115, p. 1

BZ 1882/154, p. 2

BZ 1883/699, p. 2

BZ 1890/772, p. 9

BZ $1890 / 778$ p. 2

BZ $1892 / 745$ p. 14

BZ 1892/748 p. 3 perf. Antonio Bazzini

perf. Jenny Lind

perf. Jenny Lind

perf. Jenny Lind

perf. Bernhard Cossmann

perf. Bernhard Cossmann

perf. August Wilhelmj

perf. August Wilhelmj

perf. August Wilhelmj

perf. August Wilhelmj

perf. August Wilhelmj

perf. Franz Bendel

perf. Franz Bendel

perf. Lilli Lehmann

perf. Pablo Sarasate

perf. Pablo Sarasate

perf. Pablo Sarasate

perf. Pablo Sarasate

perf. Pablo Sarasate

perf. Adolf Fischer

perf. Désirée Artôt-Padilla

perf. David Popper

perf. David Popper

perf. Heinrich de Ahna

perf. Richard Himmelstoss

perf. Julius Klengel

perf. Charles Gregorowicz

perf. Charles Gregorowicz

perf. Alfred Reisenauer

perf. Alfred Reisenauer

534 This is a fundamental source for the presentation of musical reception of Chopin in nineteenth-century Wrocław. For a detailed description of the sources, see subchapter 2.4 . 
BZ $1893 / 88$ p. 2

SZ $1893 / 115$ p. 2

BZ 1895/133 p. 1

BZ $1897 / 10$ p. 9

BZ 1897/16 p. 2

BZ 1897/172 p. 10

BZ 1897/178 p. 1

BZ 1900/729 p. 11

BZ 1900/735 p. 1 perf. Moriz [Maurycy] Rosenthal perf. Moriz [Maurycy] Rosenthal perf. Adolf Brodsky perf. Erika Wedekind perf. Erika Wedekind perf. Leopold Auer perf. Leopold Auer perf. Ossip Gabrilowitsch perf. Ossip Gabrilowitsch

2. Comparative sources - originals of the above-mentioned Chopin compositions published in the Complete Works of Fryderyk Chopin edited by Paderewski, Bronarski and Turczyński.

\section{Musical sources ${ }^{535}$}

1. Basic sources - music prints - transcriptions of compositions by Fryderyk Chopin. 


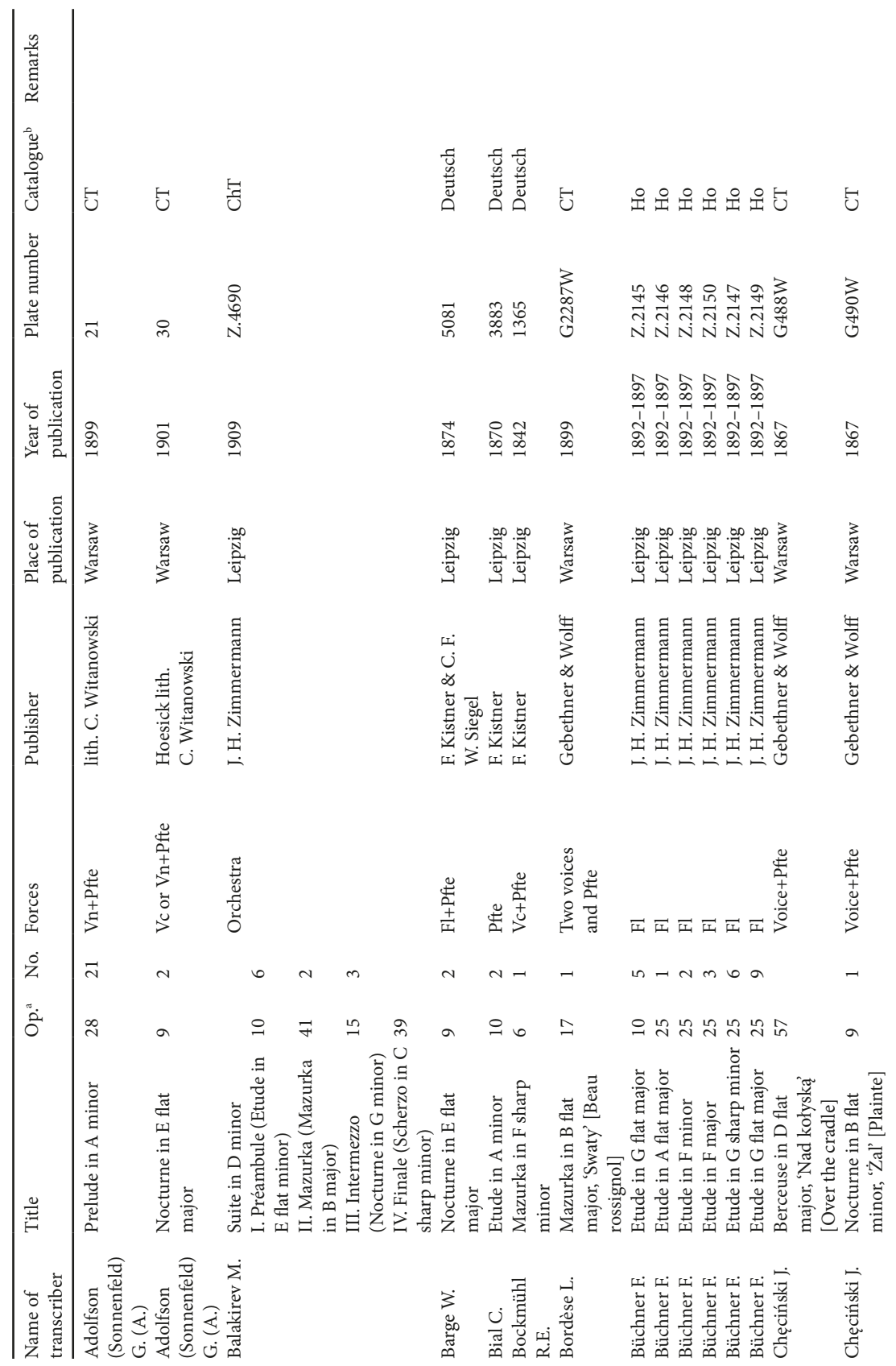




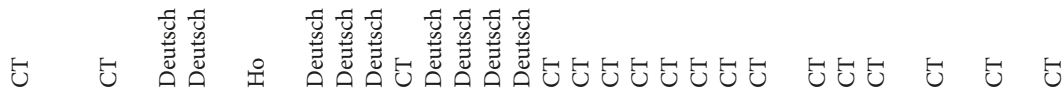

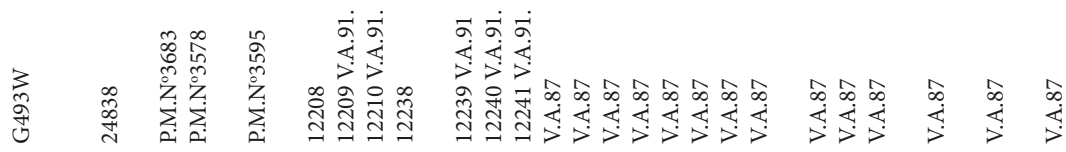

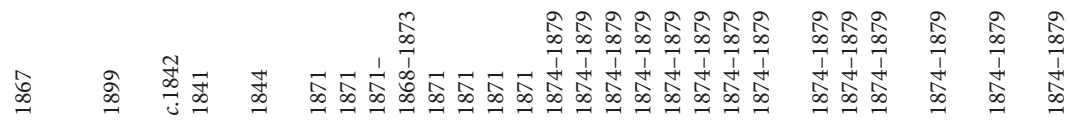

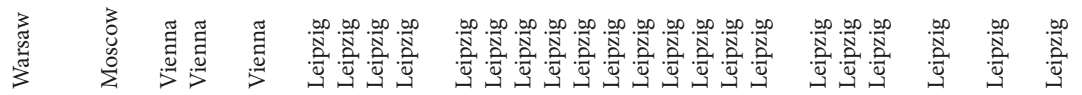

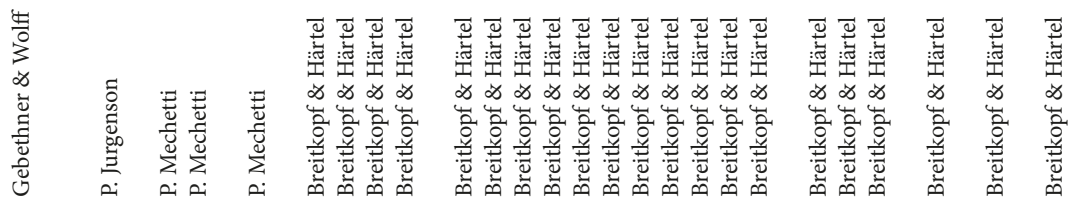

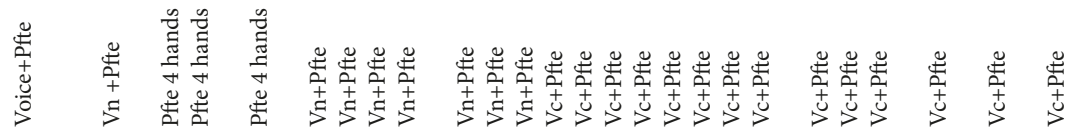

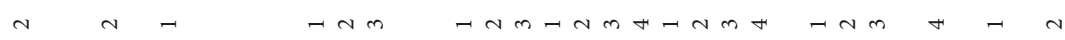

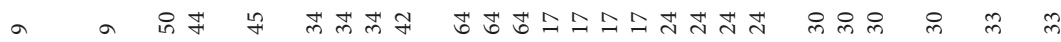

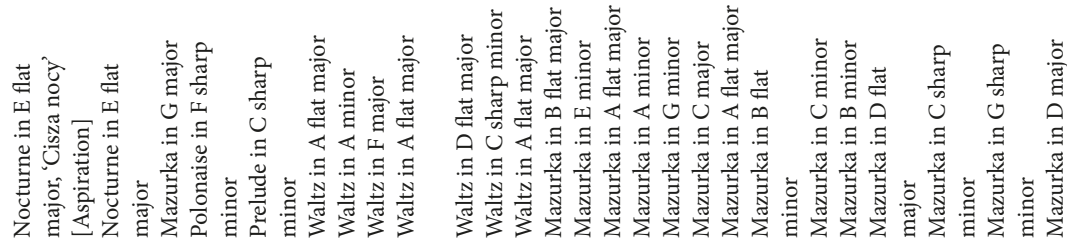

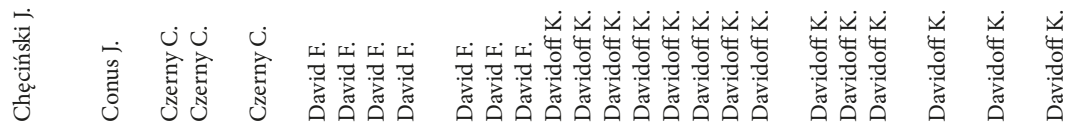




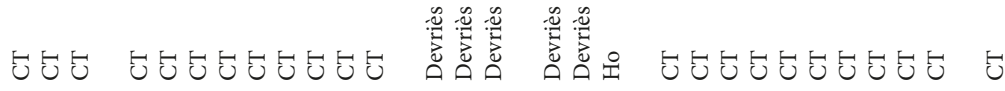

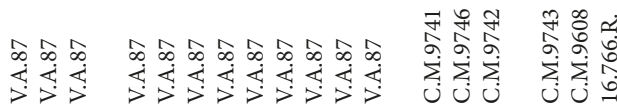

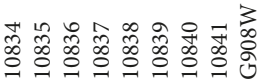

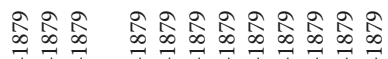
II J J J I J I

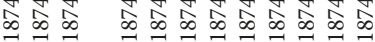

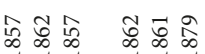

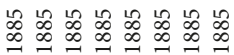

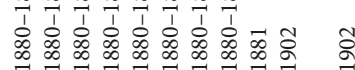

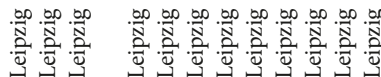

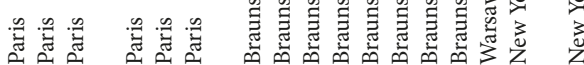

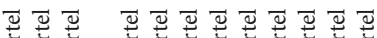

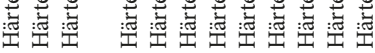

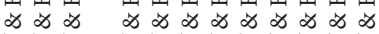

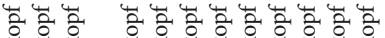

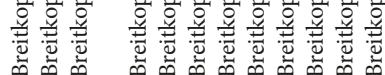

是是量 范范范

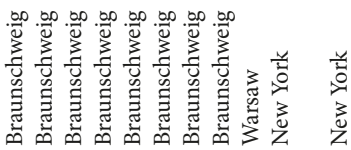

$\frac{4}{3}$ 品

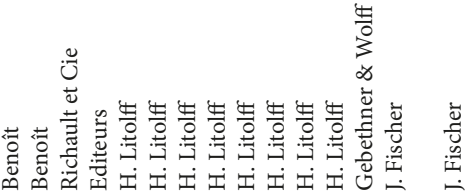

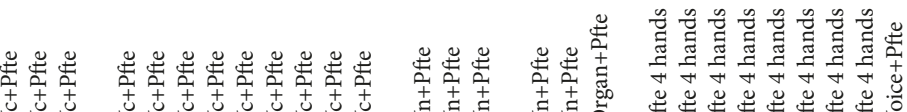

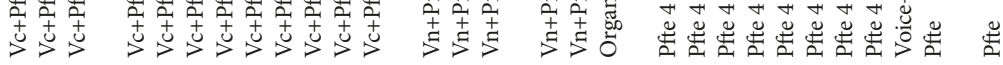

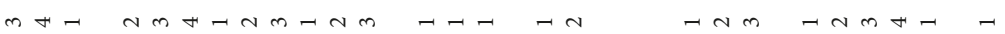

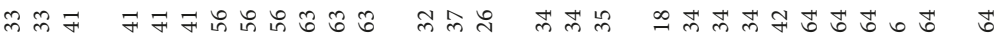

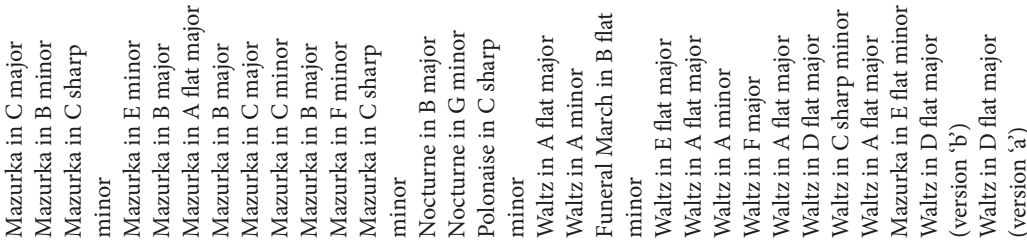

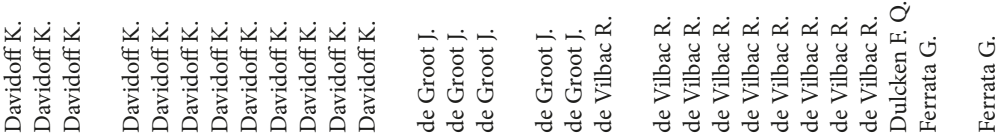




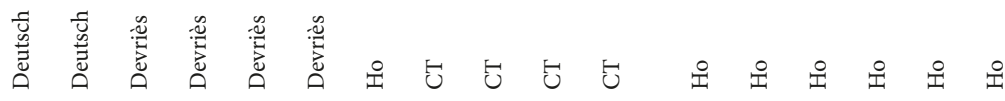

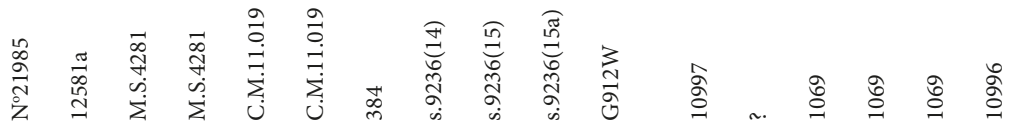

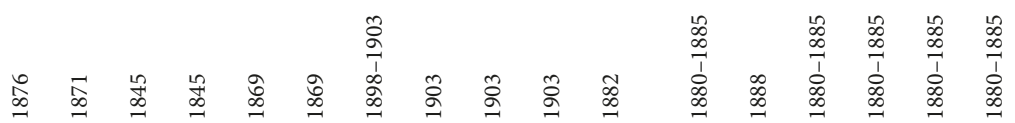

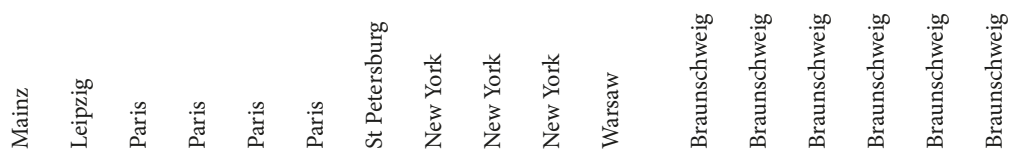

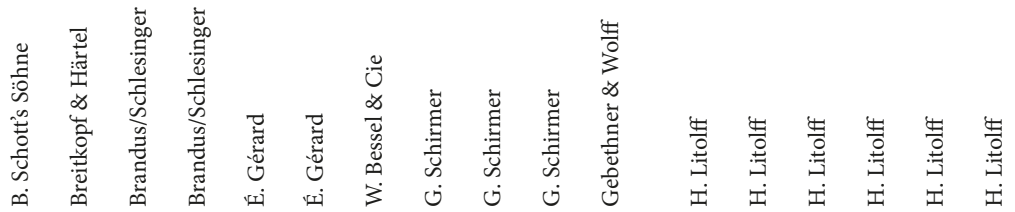

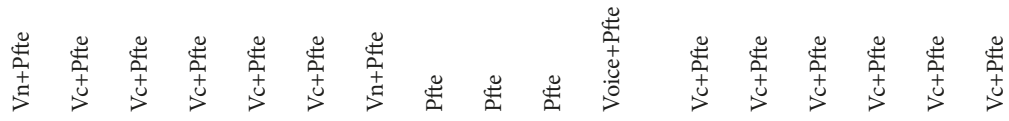

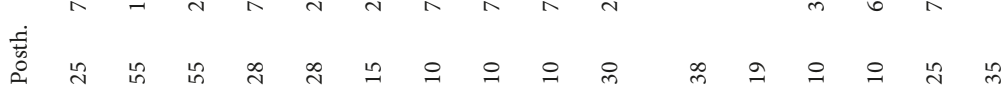

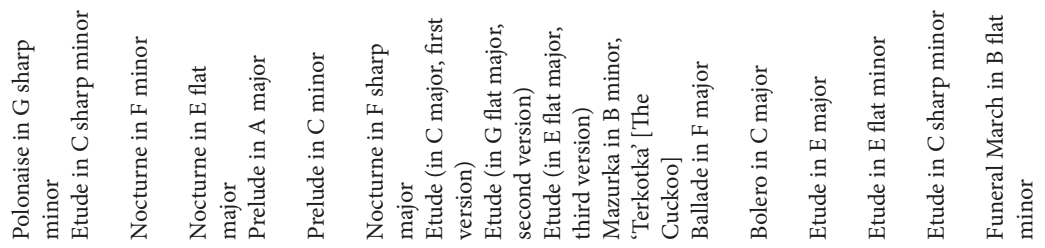

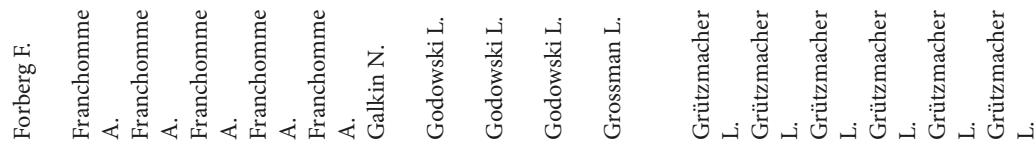


욱온

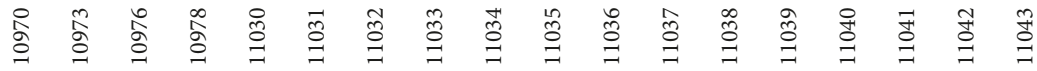

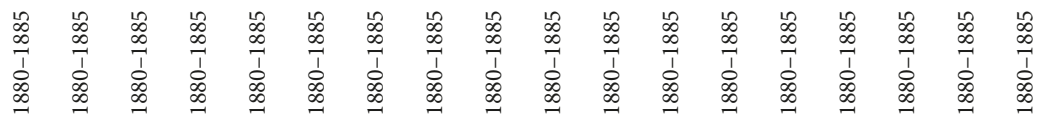

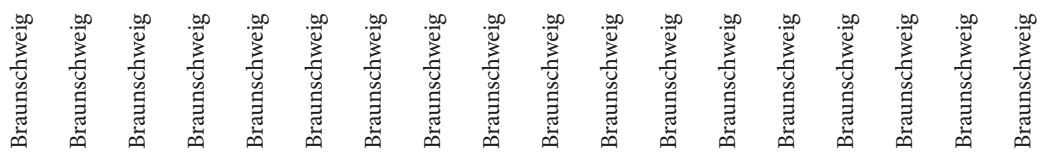

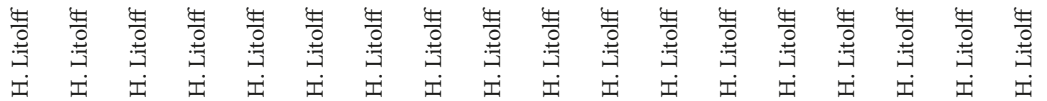

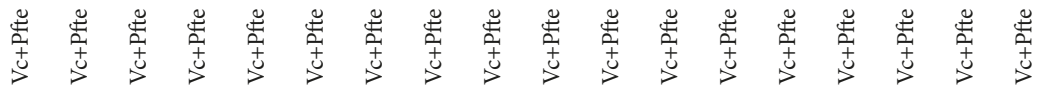

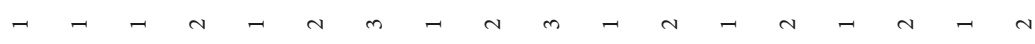

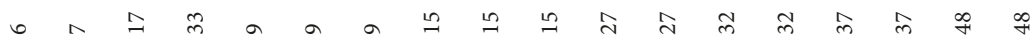

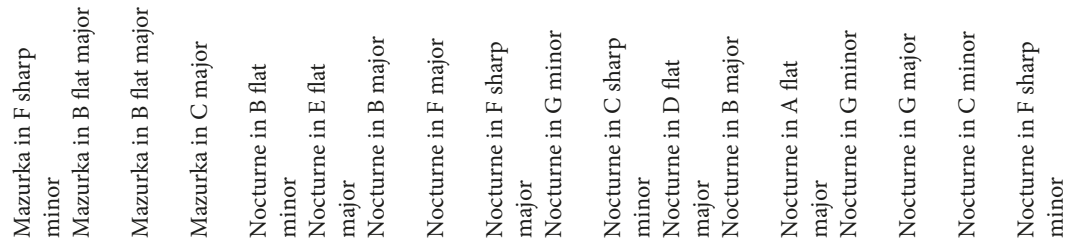

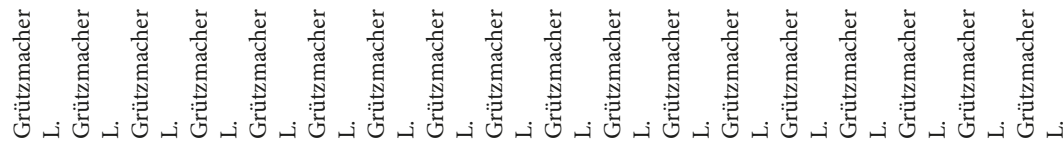




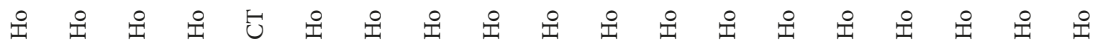

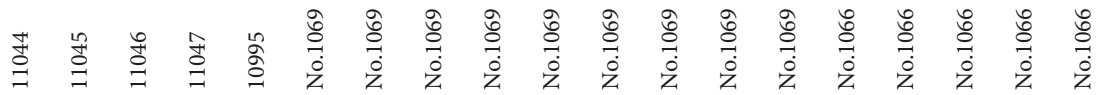

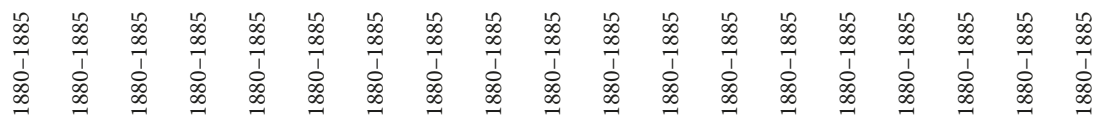

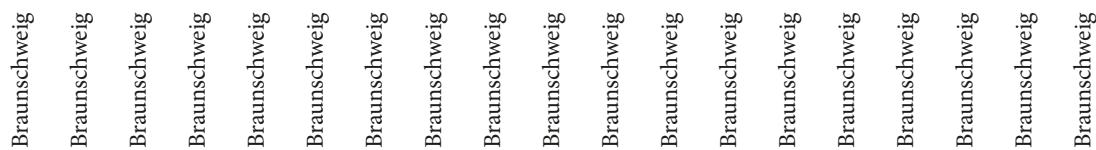

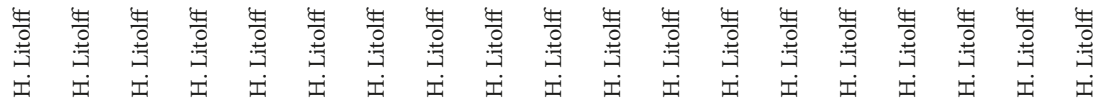

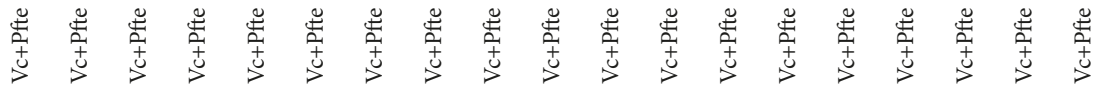

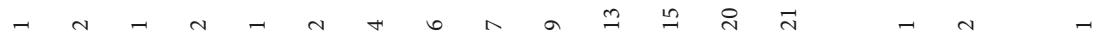

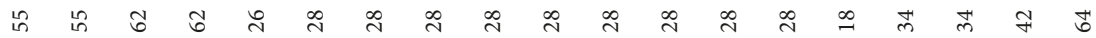

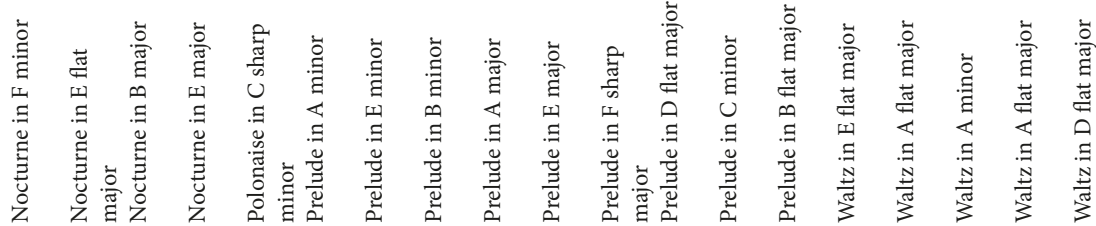

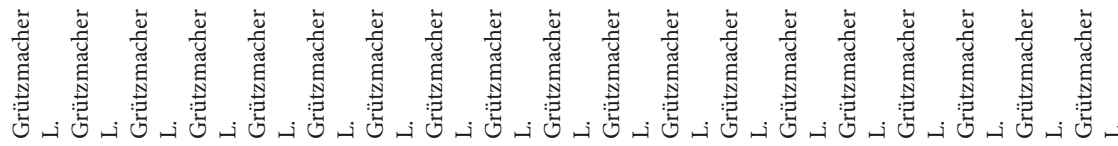




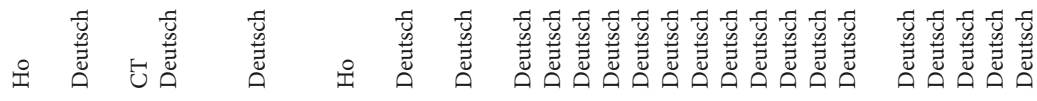

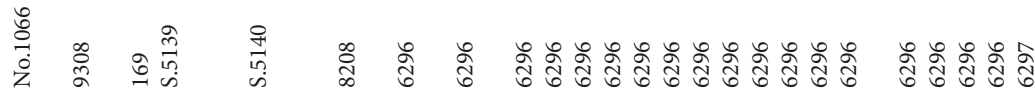

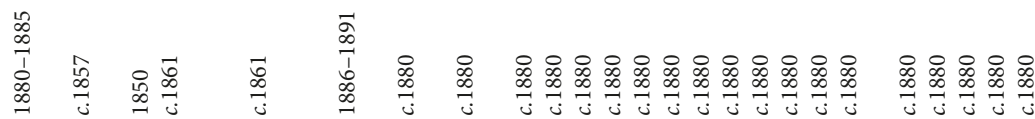

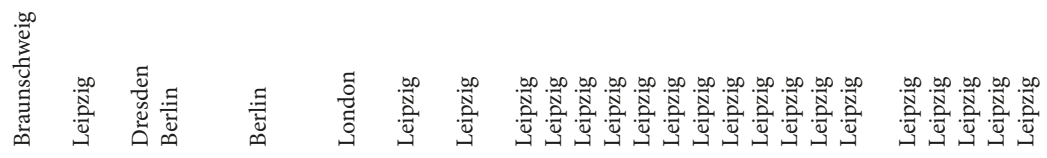

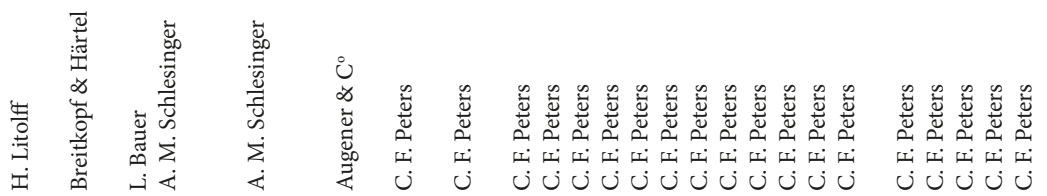

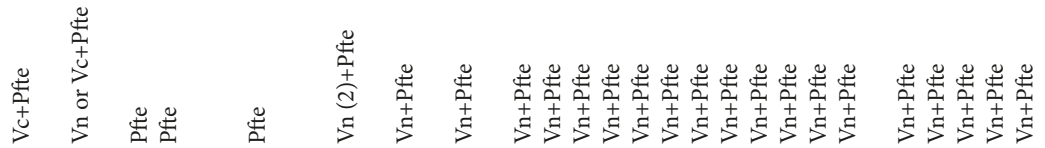

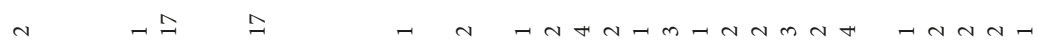
㟔监 泀 घ.

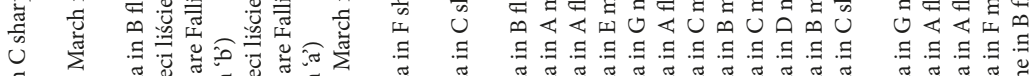

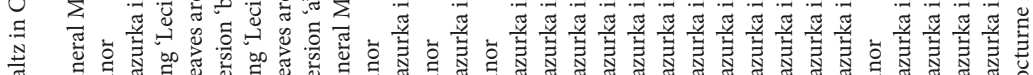

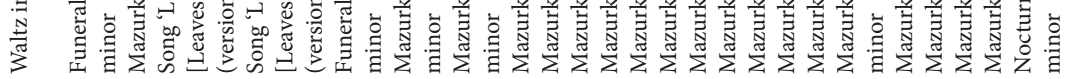

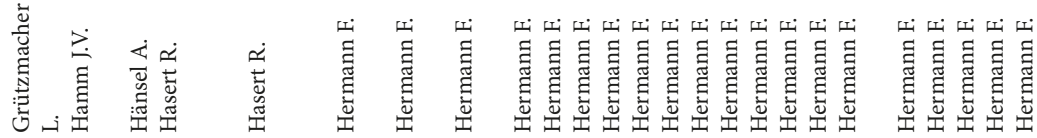




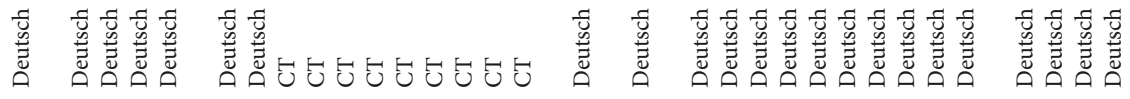

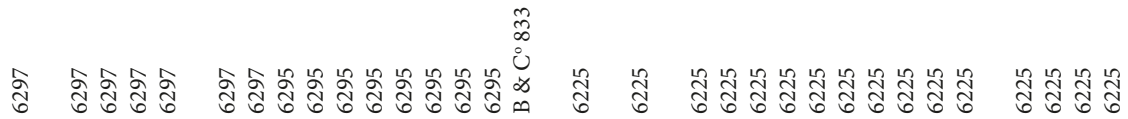
$\begin{array}{llllllll}n & n & n & n & 1 & 1 & 1 & 1 \\ \infty & \infty & \infty & \infty & \infty & \infty & \infty & \infty \\ \infty & \infty & \infty & \infty & \infty & \infty & \infty & \infty\end{array}$

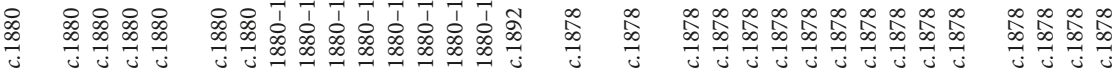

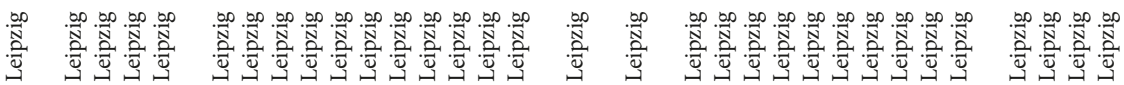

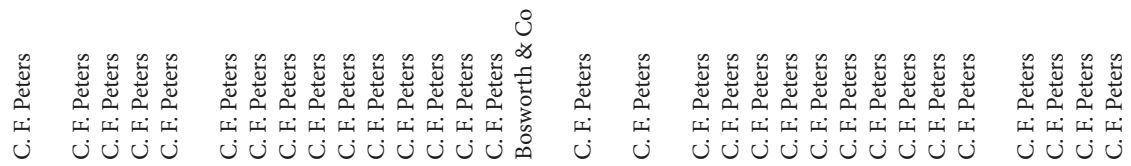

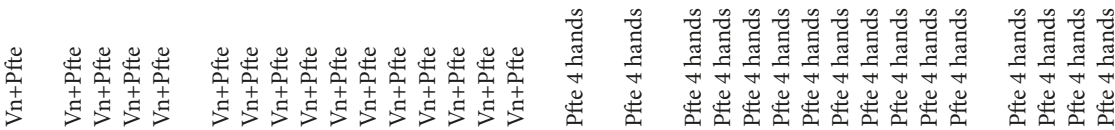

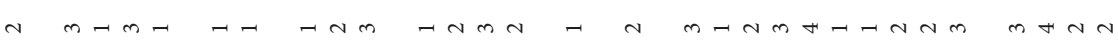

a

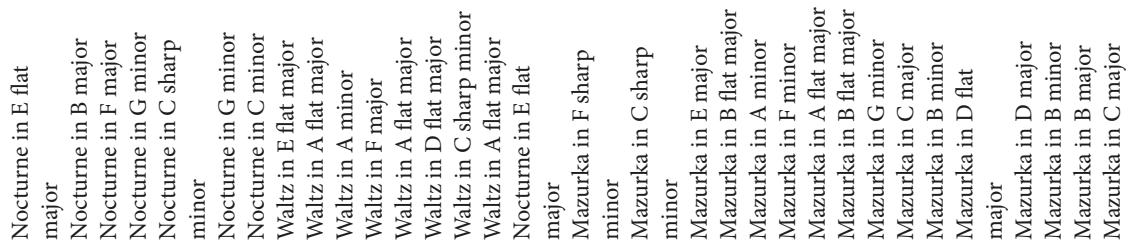

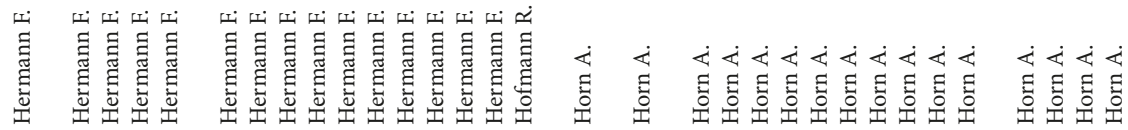




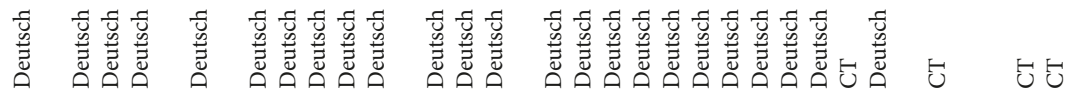

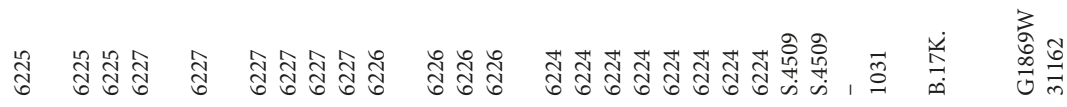

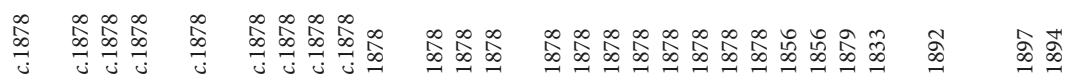

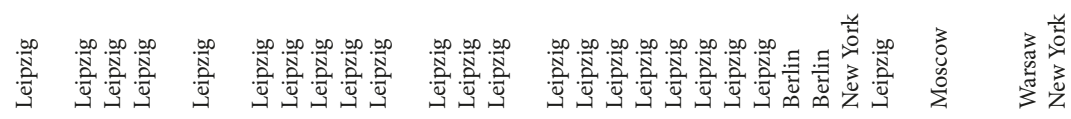

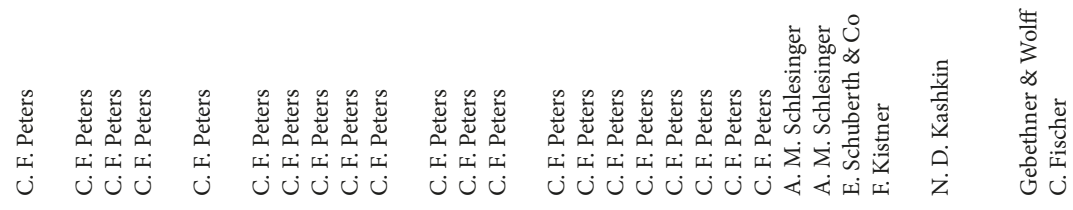

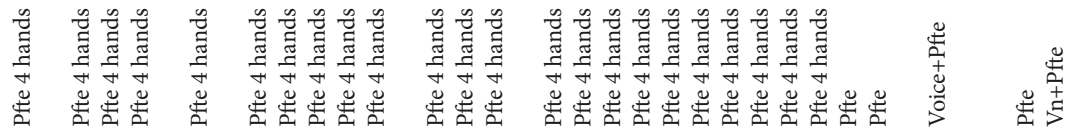

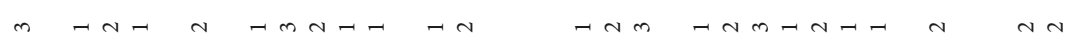

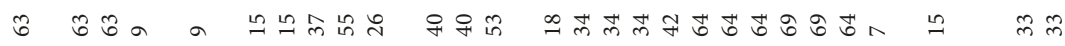

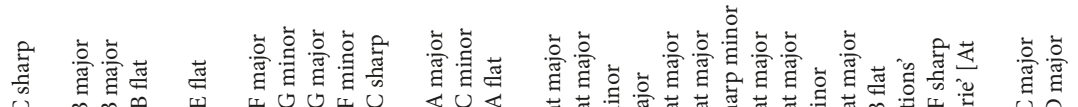
U

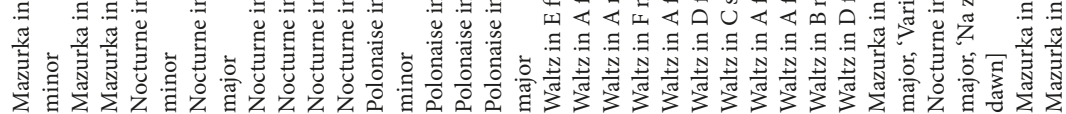

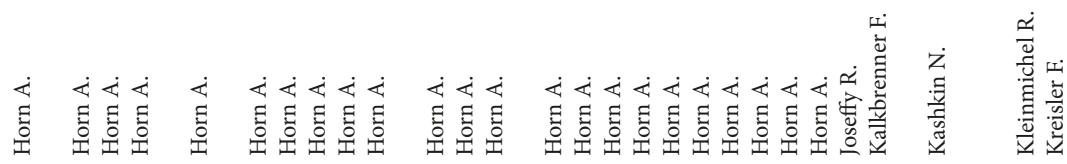




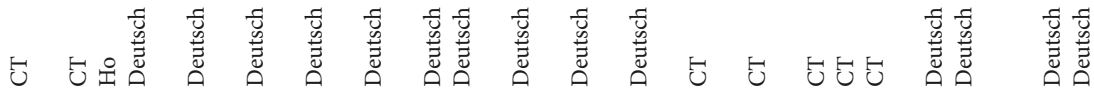

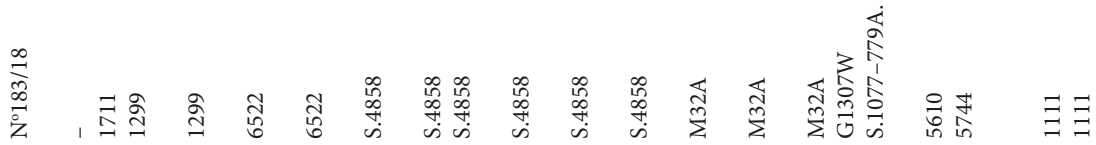
$\stackrel{\circ}{\circ}$

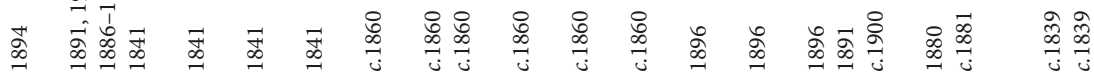

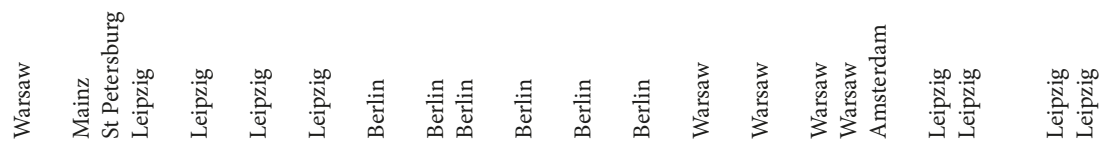

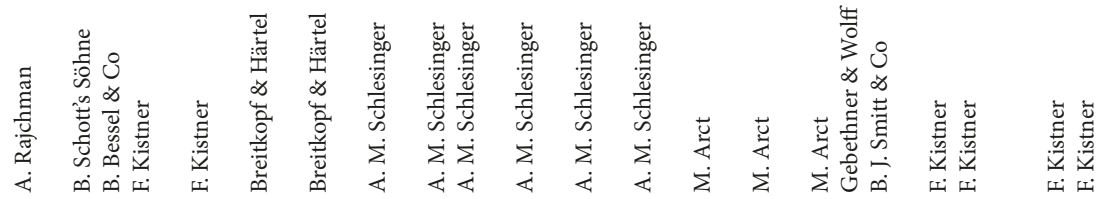

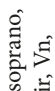

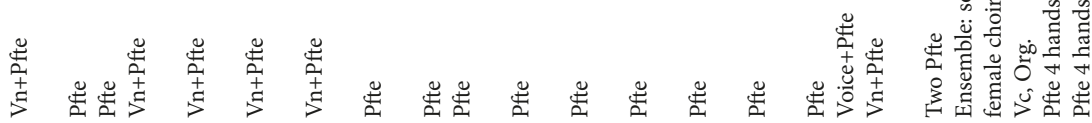

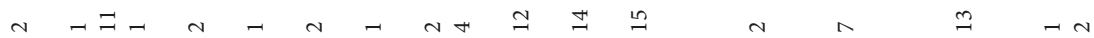

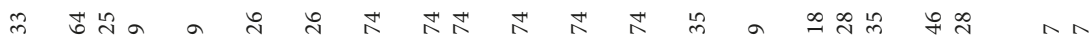

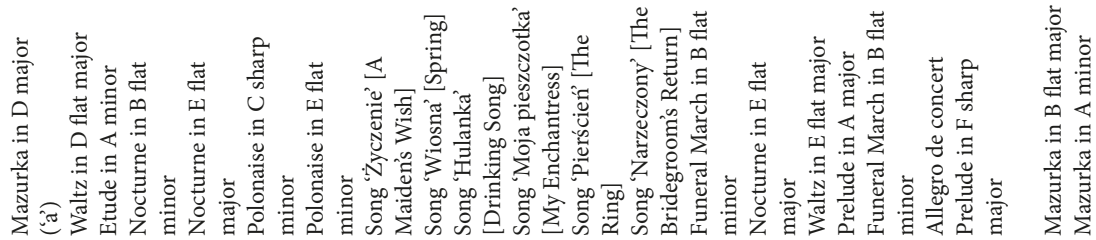

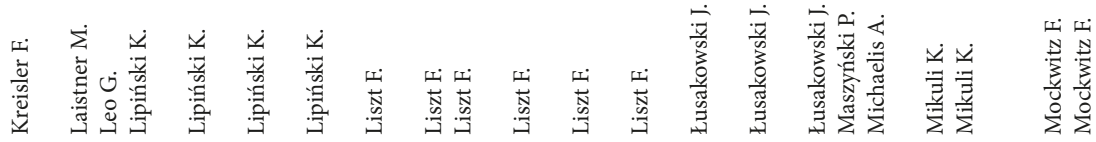




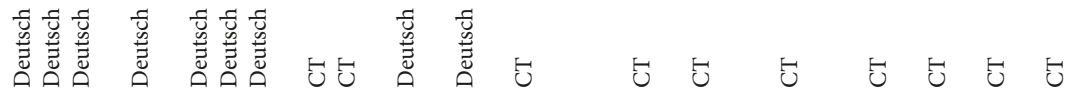

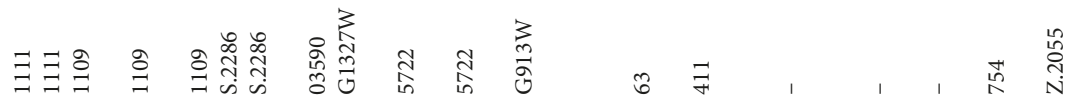

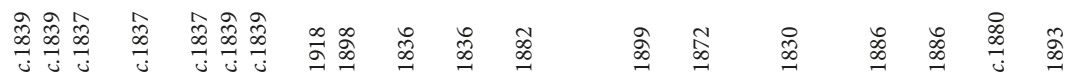

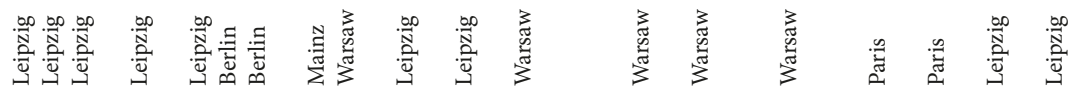

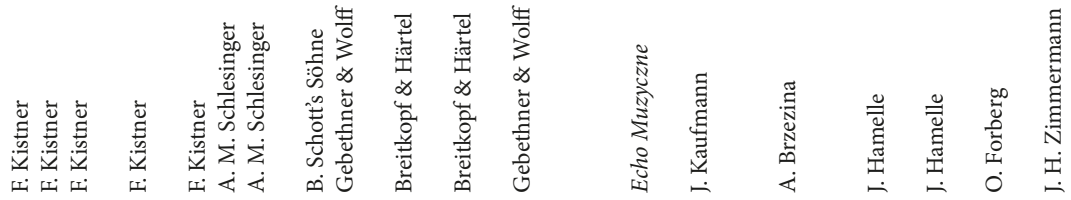

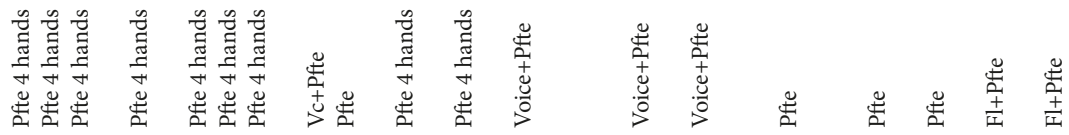

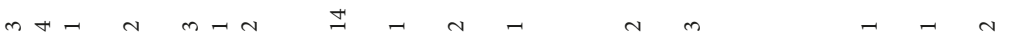

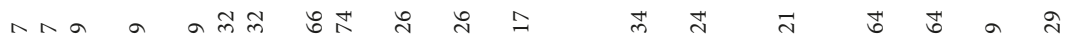

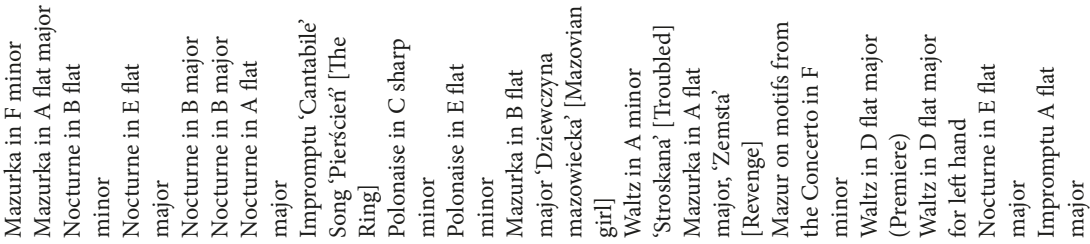

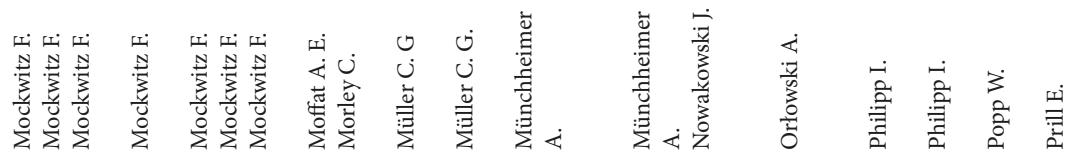




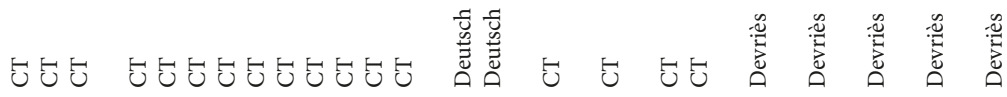

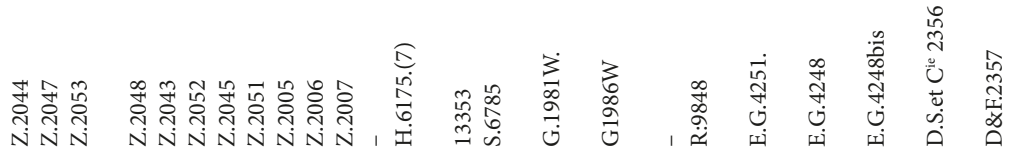

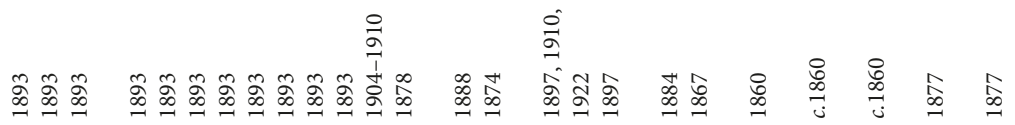

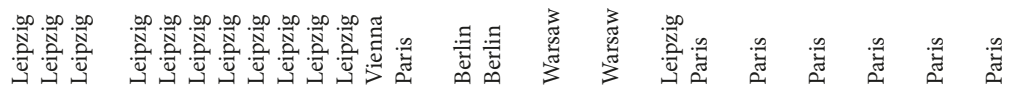

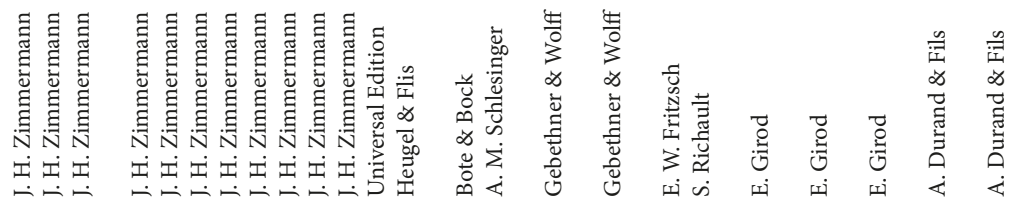

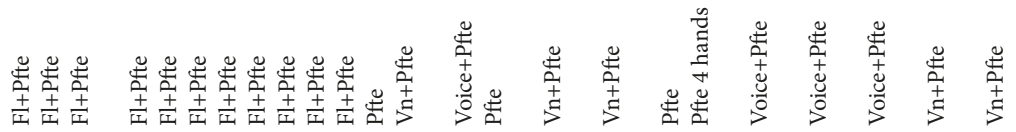
$\neg-n m-n m a m \rightarrow-\longrightarrow$

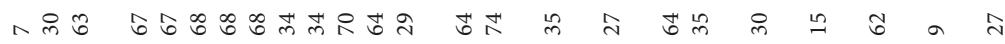

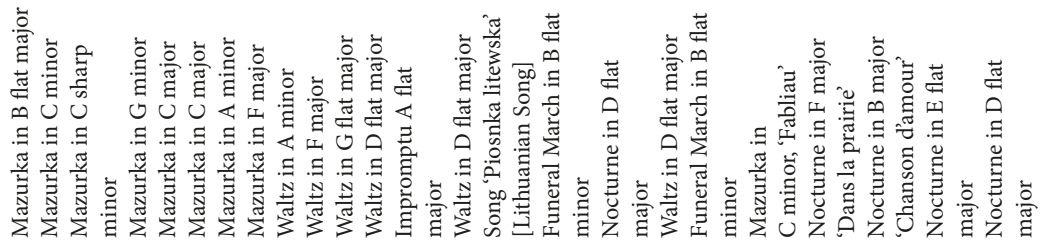

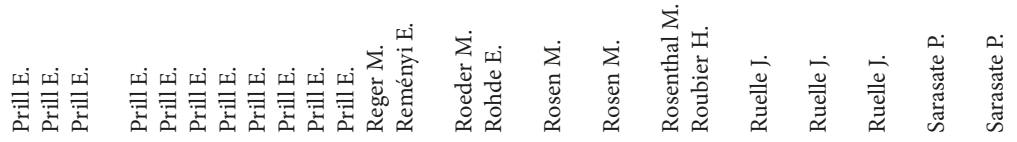




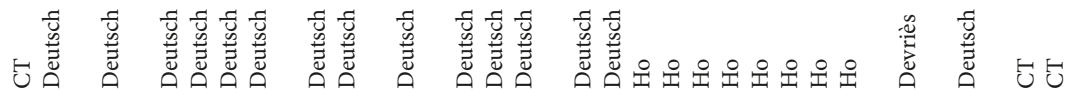

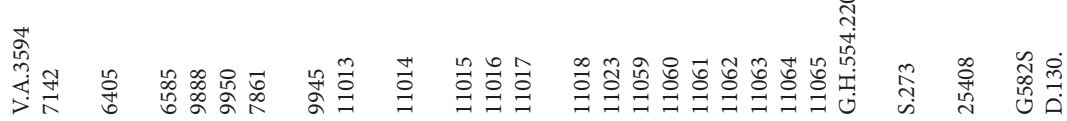

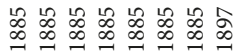

薄

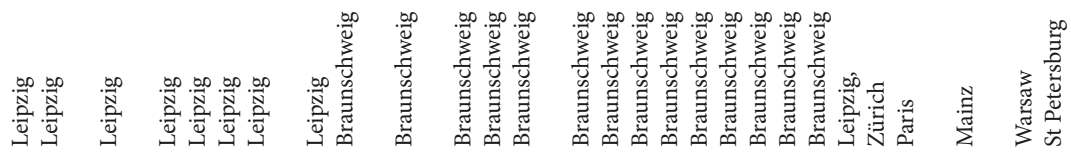

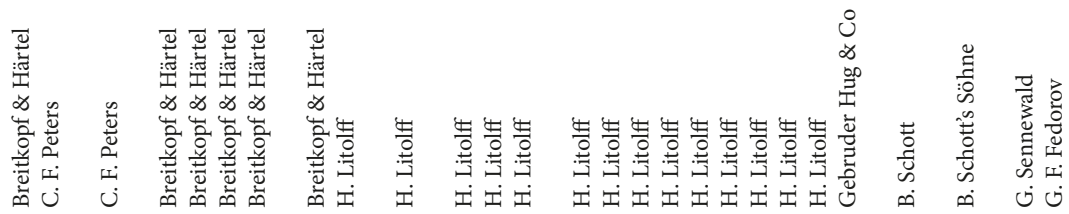

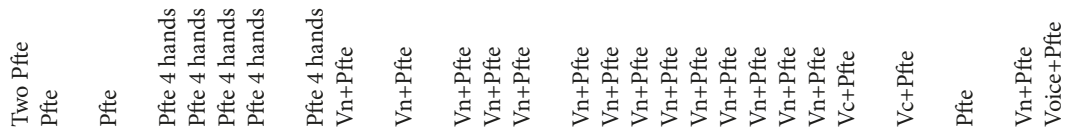

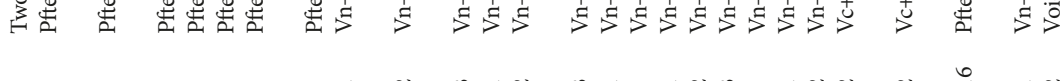

可 ニ オ

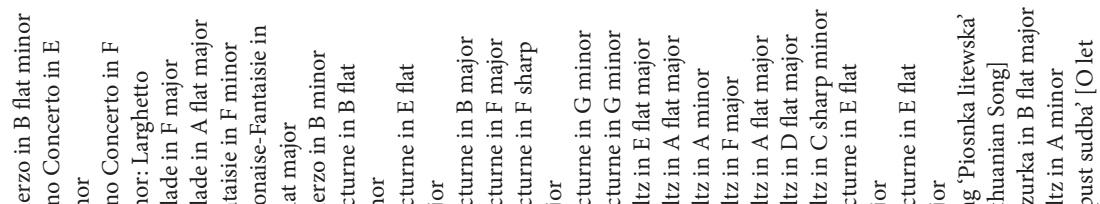

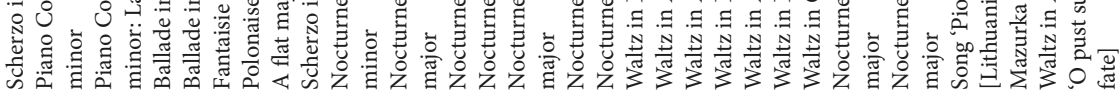

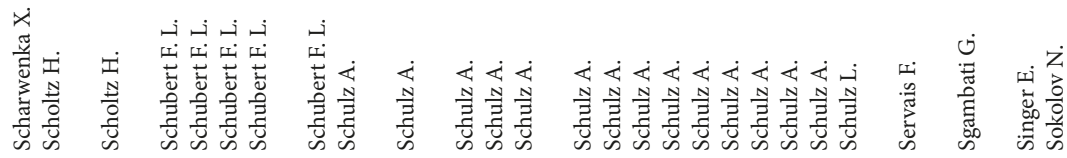




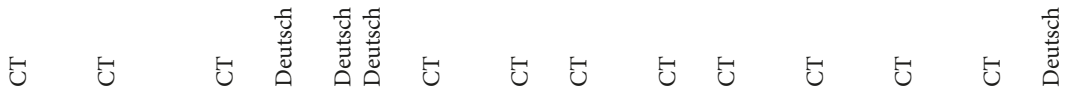

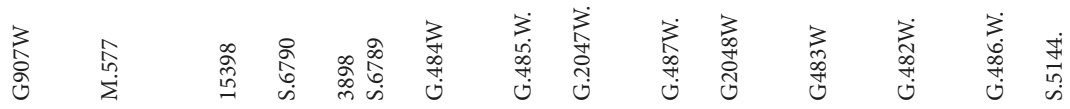

焉 焉

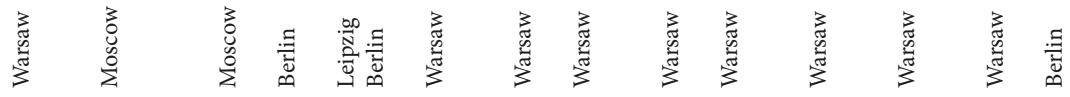

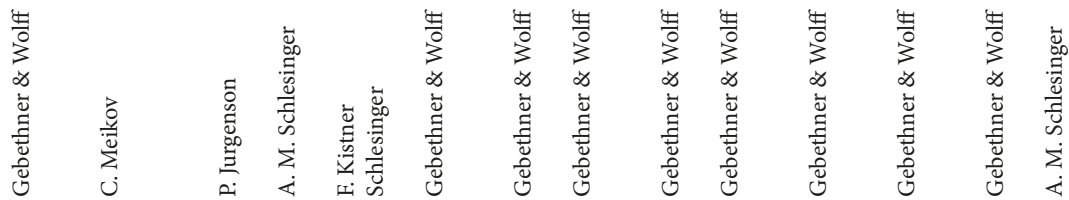

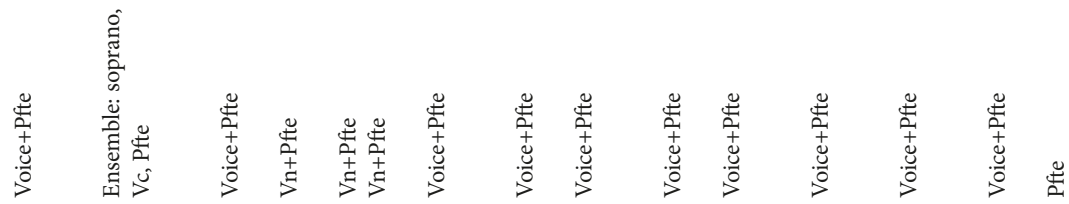

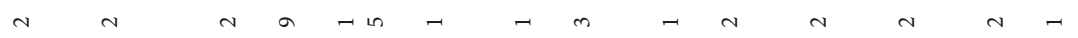

$\curvearrowleft$ 岗

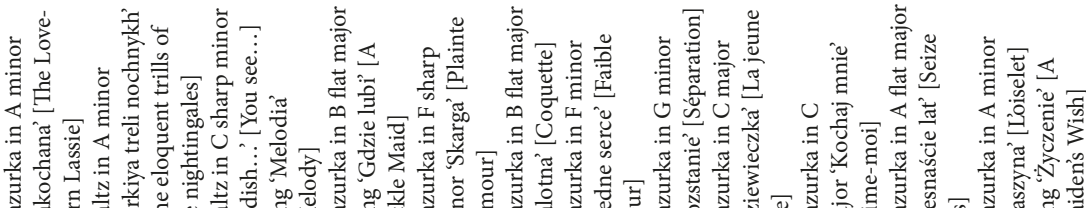

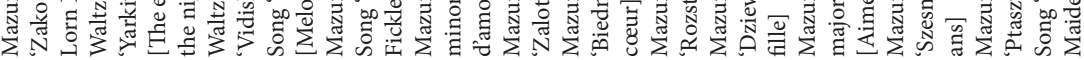

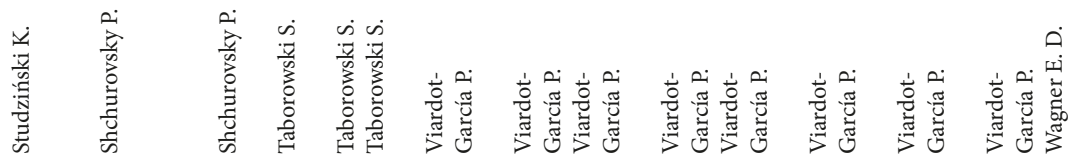




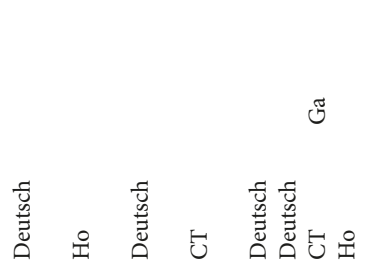

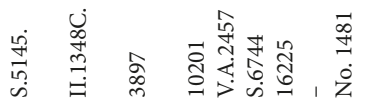

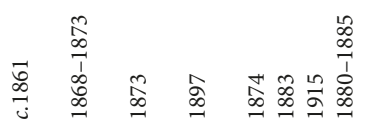

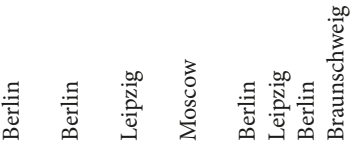

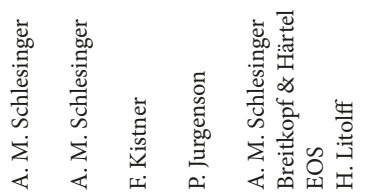

है

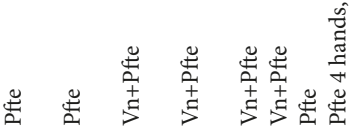

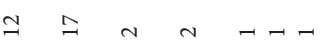

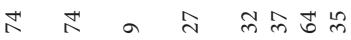

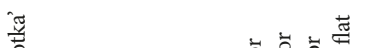

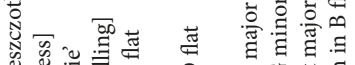

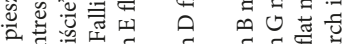

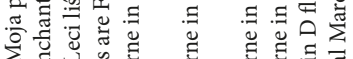

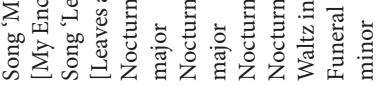

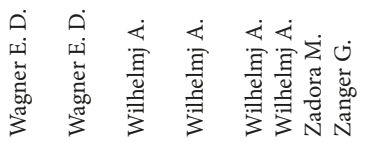

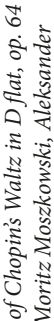

हैं के ป⿱一兀)

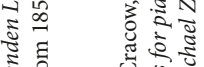

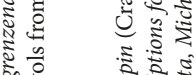

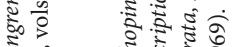

c.

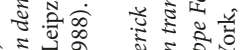

ธิ宀

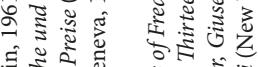

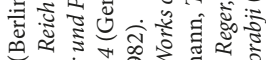

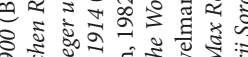

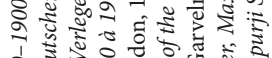

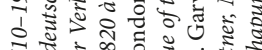

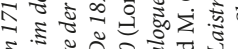

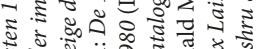

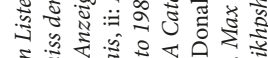

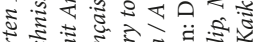

कृ के

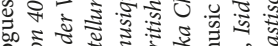
की 0

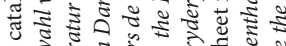

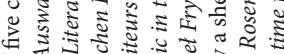
它

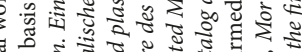

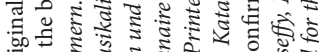

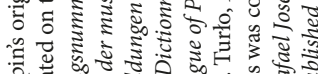

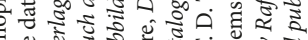

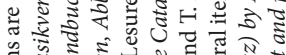

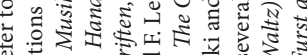

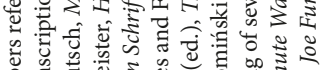

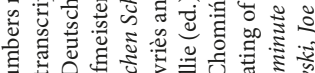

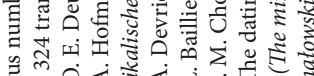

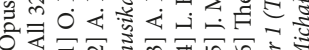




\section{Cited literature}

\section{Primary subject literature}

Andraschke, Peter, 'Chopin w opracowaniach Regera' [Chopin in arrangements by Reger], Rocznik Chopinowski, 20 (1988), 79-92.

Biernacki, Michał, 'Transkrypcje' [Transcriptions], Echo Muzyczne, Teatralne i Artystyczne, 41 (1899), 488.

Busch-Salmen, Gabriele, 'Bemerkungen zu den Flötenbearbeitungen der Werke Frédéric Chopins', Chopin Studies, 5 (1995), 224-234.

Chomiński, Józef Michał, and Turło, Teresa Dalila, Katalog dzieł Fryderyka Chopina / A Catalogue of Works by Frederick Chopin (Cracow, 1990).

Czernek, Ewa, 'Kilka uwag na temat ilościowych aspektów transkrypcji utworów Chopina' [A few remarks on quantitative aspects of transcriptions of works by Chopin], Muzyka, 42/4 (1997), 51-58.

Czernek, Ewa, 'Transkrypcje chopinowskie Karola Lipińskiego' [Karol Lipiński’s transcriptions of Chopin], MA thesis, University of Warsaw, 1996.

Czernek, Ewa, 'Transkrypcje chopinowskie Karola Lipińskiego' [Karol Lipiński’s transcriptions of Chopin], Muzyka, 42/4 (1997), 77-100.

Ginzburg, Lev, 'Rosyjskie transkrypcje Etiudy cis-moll op. $27 \mathrm{nr} 7$ F. Chopina' [Russian transcriptions of Chopin's Etude in C sharp minor, Op. 27 No. 7], Rocznik Chopinowski, 7 (1969), 45-51.

Gołąb, Maciej, 'Dziewiętnastowieczne transkrypcje muzycznych arcydzieł. Próba typologii na przykładzie utworów Fryderyka Chopina' [Nineteenthcentury transcriptions of musical masterworks: an attempted typology, taking as an example works by Fryderyk Chopin], Muzyka, 45/1 (2000), 23-45.

Gołąb, Maciej, 'Dziewiętnastowieczne transkrypcje Poloneza cis-moll op. 26 nr 1 Fryderyka Chopina na skrzypce i fortepian' [Nineteenth-century transcriptions for violin and piano of Fryderyk Chopin's Polonaise in C sharp minor, Op. 26 No. 1], Muzyka, 42/4 (1997), 59-76.

Kobylańska, Krystyna, 'Transkrypcje Mazurków Chopina' [Transcriptions of Chopin's mazurkas], Życie Śpiewacze, 5-6 (1951), 8-14.

Lissa, Zofia, 'Inspiracje chopinowskie w twórczości Regera' [Chopin inspirations in the work of Reger], Rocznik Chopinowski, 7 (1965-68), 67-99.

Literska, Barbara, 'Dziewiętnastowieczne transkrypcje utworów Chopina. Próba systematyki' [Nineteenth-century transcriptions of works by Chopin: an attempted systematics], Muzyka, 42/4 (1997), 37-50. 
Miketta, Janusz, 'Chopin zabronił' [Chopin forbade], Ruch Muzyczny, 19 (1948), 17.

Turło, Teresa Dalila, 'Transcriptions des Nocturnes de Chopin comme forme particulière de réception de la lirique instrumentale', Chopin Studies, 5 (1995), 153-157.

\section{Secondary subject literature}

Anders, Henryk Paweł, Mieczysław Karłowicz (Poznań, 1998).

Appel, Bernhard R., 'Hausmusik', in Robert Schumanns (ed.), Album für die Jugend. Einführung und Kommentar. Mit einem Geleitwort von Peter Härtling (Zurich, 1998), 27-41.

Bączyk, Andrzej Henryk, 'Z problematyki transkrypcji' [Aspects of transcription], Zeszyt Naukowy nr IV [Ignacy Jan Paderewski Academy of Music in Poznań], 1993, 7-37.

Błaszczyk, Leon Tadeusz, Dyrygenci polscy i obcy w Polsce działajacy w XIX $i$ $X X w$. [Polish and foreign conductors active in Poland during the nineteenth and twentieth centuries] (Cracow, 1964).

Chechlińska, Zofia, 'Chopin w kontekście kultury muzycznej XIX w.' [Chopin in the context of nineteenth-century musical culture], Rocznik Chopinowski, 20 (1992), 60-67.

Chomik, Irena, 'Warszawskie Towarzystwo Śpiewacze Lutnia w latach 1886-1914' [The Lutnia Choral Society of Warsaw from 1886 to 1914], in Zofia Chechlińska (ed.), Szkice o kulturze muzycznej XIX w. [Sketches of nineteenth-century musical culture] (Warsaw, 1971), 263-292.

Chomiński, Józef Michał, Chopin (Cracow, 1978).

Chomiński, Józef Michał, and Wilkowska-Chomińska, Krystyna, Historia muzyki [History of music], pt 2 (Cracow, 1990).

Dahlhaus, Carl (ed.), Studien zur Trivialmusik des 19. Jahrhunderts (Regensburg, 1967).

Dahlhaus, Carl, 'Form', tr. Stephen Hinton, in Schoenberg and the New Music, tr. Derrick Puffett and Alfred Clayton (Cambridge, 1988), 248-264.

Dahlhaus, Carl, 'Trivial music and aesthetic judgment', tr. Uli Sailer, in Christopher J. Washburne and Maiken Derno (eds.), Bad Music: The Music We Love to Hate (London, 2004), 333-362.

Dahlhaus, Carl, 'Über die "mittlere Musik” des 19. Jahrhunderts', in Carl Dahlhaus (ed.), Studien zur Trivialmusik des 19. Jahrhunderts (Regensburg, 1967), 131-147. 
Dahlhaus, Carl, 'Über musikalischen Kitsch', in Carl Dahlhaus (ed.), Studien zur Trivialmusik des 19. Jahrhunderts (Regensburg, 1967), 63-67.

Eggebrecht, Hans Heinrich, Uwagi o metodzie analizy muzycznej [Remarks on the method of music analysis], tr. Maria Stanilewicz, Res Facta, 7 (1973), 40-48.

Einstein, Alfred, Mozart: His Character, His Work, tr. Arthur Mendel and Nathan Broder (New York, London, 1945).

Einstein, Alfred, Music in the Romantic Era (London, 1947).

Ekier, Jan, Wstep do Wydania Narodowego Dzieł Chopina [Introduction to the Polish National Edition of the Works of Chopin] (Cracow, 1976).

Fellinger, Imogen, 'Die Begriffe "Salon“ und „Salonmusik“ in der Musikanschauung des 19. Jahrhunderts', in Carl Dahlhaus (ed.), Studien zur Trivialmusik des 19. Jahrhunderts (Regensburg, 1967), 131-141.

Frączyk, Tadeusz, Warszawa młodości Chopina [The Warsaw of Chopin's youth] (Cracow, 1961), 235-307.

Golianek, Ryszard Daniel, Muzyka programowa XIX wieku [Programme music of the nineteenth century] (Poznań, 1998).

Gołąb, Maciej, Dodekafonia. Studia nad teoria i kompozycja pierwszej połowy $X X$ wieku [Dodecaphony: studies of theory and composition of the first half of the twentieth century] (Bydgoszcz, 1987).

Gołąb, Maciej, 'Metodologiczne aspekty badań nad przemianami stylu Chopina' [Methodological aspects of research into changes in Chopin's style], in Gołąb (ed.), Przemiany stylu Chopina [Changes in Chopin's style] (Cracow, 1993), 19-20.

Grabowski, Krzysztof, 'Francuskie oryginalne wydania dzieł Fryderyka Chopina' [Original French editions of works by Fryderyk Chopin], Rocznik Chopinowski, 21 (1995), 115-150.

Hartmann, Nicolai, 'Warstwy w dziele muzycznym' [Layers in the musical work], Res Facta, 8 (1977).

Heinz, Rudolf, 'Der Bergriff „trivial“ und seine musikkritische Verwendbarkeit', in Carl Dahlhaus (ed.), Studien zur Trivialmusik des 19. Jahrhunderts (Regensburg, 1967), 53-61.

Hordyński, Władysław, Katalog polskich druków muzycznych 1800-1863 [A catalogue of Polish music prints 1800-1863] (Cracow, 1968).

Ingarden, Roman, The Work of Music and the Problem of its Identity, tr. Adam Czerniawski, ed. Jean G. Harrell (Basingstoke, 1986).

Jasińska, Danuta, 'Problem stylu brillant w twórczości Chopina' [The style brillant in the output of Chopin], in Maciej Gołąb (ed.), Przemiany stylu Chopina [Changes in Chopin's style] (Cracow, 1993), 137-155. 
Kallberg, Jeffrey, 'Chopin in the Marketplace', in Chopin at the Boundaries. Sex, History, and the Musical Genre (Cambridge MA, 1996), 161-214.

Kański, Józef, Dyskografia chopinowska. Historyczny katalog nagrań płytowych [Chopin discography: historical catalogue of disc recordings] (Cracow, 1986).

Kneif, Tibor, 'Das triviale Bewußtsein in der Musik', in Carl Dahlhaus (ed.), Studien zur Trivialmusik des 19. Jahrhunderts (Regensburg, 1967), 29-52.

Korespondencja Fryderyka Chopina [Correspondence of Fryderyk Chopin], ed. Bronisław Edward Sydow (Warsaw, 1955).

Korespondencja Fryderyka Chopina z rodzina [Fryderyk Chopin's correspondence with his family], ed. Krystyna Kobylańska (Warsaw, 1972).

Letter from a subscriber to the editors regarding the transposition of themes from Chopin's Prelude in A major in Zygmunt Noskowski's variations $Z \dot{z} y c i a$ narodu [From the life of the nation], Echo Muzyczne, Teatralne $i$ Artystyczne, 11 (1902), 124-125.

Lissa, Zofia, 'Problemy recepcji Chopina' [Aspects of Chopin reception], Z badań nad Chopinem. Studia i rozprawy, 3 (1973), 7-26.

Lissa, Zofia, 'Recepcja muzyczna jako współczynnik historii muzyki' [Music reception as an element of music history], in Nowe szkice z estetyki muzyki [New sketches in music aesthetics] (Cracow, 1975).

Lissa, Zofia, Wstęp do muzykologii [Introduction to musicology] (Warsaw, 1974).

Ludvová, Jitka, 'Twórczość Chopina w XIX-wiecznej Pradze. Praskie wykonania dzieł Chopina do 1849r.' [Chopin's music in nineteenth-century Prague: Prague performances of Chopin's works up to 1849], Rocznik Chopinowski, 18 (1986), 107-124.

Mazur, Krzysztof, 'Polskie edytorstwo muzyczne między powstaniem listopadowym a styczniowym' [Polish music publishing between the November and January uprisings], in Zofia Chechlińska (ed.), Szkice o kulturze muzycznej XIX w. [Sketches of nineteenth-century musical culture] (Warsaw, 1971), 51-89.

Michałowski, Kornel, Bibliografia Chopinowska 1849-1969 [Chopin bibiography 1849-1969] (Cracow, 1970).

Pisarenko, Olgierd, 'Wyraz muzyczny dzieł Chopina w opinii jego współczesnych. Paryż 1832-60' [The musical expression of Chopin's works in the opinion of his peers: Paris 1832-60], Z badań nad Chopinem. Studia $i$ rozprawy, 3 (1973), 27-43.

Pociej, Bohdan, 'Próby utrwalenia - O transkrypcjach' [Attempts to perpetuate: on transcriptions], Ruch Muzyczny, 1-2 (1995), 14-15. 
Poniatowska, Irena, 'Chopin - Paradygmaty interpretacji' [Chopin: paradigms of interpretation], Rocznik Chopinowski, 16 (1984), 11-24.

Poniatowska, Irena, Muzyka fortepianowa i pianistyka w wieku XIX. Aspekty artystyczne i społeczne [Piano music and pianism in the nineteenth century: artistic and social aspects] (Warsaw, 1991).

Poniatowska, Irena, 'Twórczość Chopina w świetle pierwszych monografii. Przyczynek do badań nad recepcją muzyki Chopina' [Chopin's music in light of the first monographs: a contribution to research into the reception of Chopin's music], Rocznik Chopinowski, 20 (1988), 100-112.

Prokopowicz, Maria, 'Wydawnictwo muzyczne Klukowskich 1816-1858' [Music publications issued by the Klukowskis 1816-1858], Rocznik warszawski (Warsaw, 1974).

Prokopowicz, Maria, 'Z działalności warszawskich księgarzy i wydawców muzycznych w latach 1800-1831' [Warsaw music booksellers and publishers 1800-1831], in Zofia Chechlińska (ed.), Szkice o kulturze muzycznej XIX w. [Sketches of nineteenth-century musical culture] (Warsaw, 1971), 33-49.

Prychodko, Ondrej, 'Bibliografia czeskich wydań dzieł F. Chopina' [Bibliography of Czech editions of the works of Fryderyk Chopin], Rocznik Chopinowski, 13 (1981), 141-151.

Rolland, Romain, Haendel, tr. Michalina Jarocińska (Cracow, 1971).

Samson, Jim, 'Chopin Reception: Theory, History, Analysis', Musica Jagellonica, 1 (1995), 91-114.

Schaeffer, Bogusław, 'Historia muzyki XX wieku w tablicach chronologicznych' [A history of twentieth-century music in chronological tables], in Mały informator muzyki XX wieku [Concise guide to twentieth-century music] (Cracow, 1987), 241-376.

Sydow, Bronisław Edward, Bibliografia F.F. Chopina [Bibliography of F. F. Chopin] (Warsaw, 1949).

Szczepańska-Malinowska, Elżbieta, 'Dyskretny zapach fermentacji' [The discreet smell of fermentation], Rocznik Chopinowski, 13 (1981), 171-173.

Taraszkiewicz, Barbara, 'Transkrypcje fortepianowe L. Godowskiego' [L. Godowsky's piano transcriptions], Rocznik Chopinowski, 8 (1969), 86-107.

Tomaszewski, Mieczysław, Chopin: The Man, his Work and its Resonance, tr. John Comber (Warsaw, 2015).

Tomaszewski, Mieczysław, 'Filiacje twórczości pieśniarskiej Chopina z polską pieśnią ludową, popularną i artystyczną' [Affiliations of Chopin's song ouput with Polish folk, popular and art song], Muzyka, 2 (1961), 79-89. 
Tomaszewski, Mieczysław, Fryderyk Chopin - życie twórcy. Leksykon multimedialny [Fryderyk Chopin: the life of a composer. Multimedia lexicon] [CD-ROM] (Cracow, 1995).

Tomaszewski, Mieczysław, 'Obecność muzyki Chopina w twórczości rówieśników i następców' [The presence of Chopin's music in the output of his peers and successors], Rocznik Chopinowski, 22-23 (1998), 112-187.

Tuchowski, Andrzej, Integracja strukturalna $w$ świetle przemian stylu Chopina [Structural integration in light of changes in Chopin's style] (Cracow, 1996).

Weber, Jan, 'Repertuar płyty a repertuar koncertów. Z badań nad początkami fonografii chopinowskiej' [Phonographic repertoire and concert repertoire: from research into the beginnings of Chopin recordings], Rocznik Chopinowski, 20 (1988), 47-55.

Worbs, Hans Christof, 'Salonmusik', in Carl Dahlhaus (ed.), Studien zur Trivialmusik des 19. Jahrhunderts (Regensburg, 1967), 121-128.

Zakrzewska-Nikiporczyk, Barbara, Muzyczny Ruch Wydawniczy w Wielkopolsce 1815-1975 [Music publishing in Wielkopolska 1815-1975] (Bydgoszcz, 1986).

Zakrzewska-Nikiporczyk, Barbara, 'Recepcja i kult Chopina w Poznaniu do 1870 roku' [The reception and cult of Chopin in Poznań up to 1870], Rocznik Chopinowski, 13 (1981), 65-95.

Zavarský, Ernest, J. S. Bach (Cracow, 1985).

Zduniak, Maria, 'Chronologiczny wykaz wykonań utworów kompozytorów polskich w XIX we Wrocławiu' [Chronological list of performances of works by Polish composers in Wrocław during the nineteenth century], typescript.

Zduniak, Maria, 'Fryderyk Chopin we Wrocławiu i popularyzacja jego dzieł w dziewiętnastowiecznej stolicy Dolnego Śląska' [Fryderyk Chopin in Wrocław and the popularisation of his works in the nineteenthcentury capital of Lower Silesia], in Kazimierz Kościukiewicz (ed.), Międzynarodowe Festiwale Chopinowskie w Dusznikach Zdroju 1946-1999 [The International Chopin Festival in Duszniki Zdrój 1946-1999] (Wrocław, 2000), 17-27.

Zduniak, Maria, Muzyka i muzycy polscy w dziewiętnastowiecznym Wrocławiu [Polish music and musicians in nineteenth-century Wrocław] (Wrocław, 1984).

'Znajomość dzieła Chopina, jego oddziaływanie i znaczenie' [Familiarity with Chopin's works, his influence and significance], Rocznik Chopinowski, 20 (1992), 262, round-table discussion. 


\section{Auxiliary literature}

Auerbach, Erich, Mimesis: rzeczywistość przedstawiona w literaturze Zachodu, tr. Zbigniew Żabicki, 2 vols (Warsaw, 1968); Eng. tr. from the Ger.

Mimesis: The Representation of Reality in Western Literature, tr. Willard Trask (Princeton, 1953).

Barta, Janusz, Dzieło muzyczne i jego twórca $w$ świetle przepisów prawa autorskiego [The musical work and its composer in light of copyright laws] (Warsaw, 1980).

Barta, Janusz, and Markiewicz, Ryszard, Prawo autorskie [Copyright] (Warsaw, 1999).

Bazylow, Ludwik, Historia powszechna 1789-1918 [World history 1789-1918] (Warsaw, 1981).

Bełszyński, Jan, Prawo autorskie [Copyright] (Warsaw, 1988).

Dąbrowski, Mieczysław, Postmodernizm: myśl i tekst [Postmodernism: thinking and text] (Cracow, 2000).

Einem, Herbert von, 'Zagadnienia interpretacji w historii sztuki' [Aspects of interpretation in art history], in Jan Białostocki (ed.), Pojęcia, problemy, metody współczesnej nauki o sztuce [The notions, issues and methods of contemporary art studies] (Warsaw, 1976), 238-261.

Friedländer, Max J., 'O granicach nauki o sztuce' [On the limits of science in art], in Jan Białostocki (ed.), Pojęcia, problemy, metody współczesnej nauki o sztuce [The notions, issues and methods of contemporary art studies] (Warsaw, 1976), 164-169.

Fubini, Enrico, Historia estetyki muzycznej, tr. Zbigniew Skowron (Cracow 1997); Eng. tr. from It. as The History of Music Aesthetics, tr. Michael Hatwell (Basingstoke, 1990).

Gołaszewska, Maria, 'Problem ekspresji w estetyce' [The problem of expression in aesthetics], Studia estetyczne, 8 (1971), 19-23.

Gołaszewska, Maria, Zarys estetyki. Problematyka, metody, teorie [An outline of aesthetics: issues, methods and theories] (Cracow, 1973).

Hofmann, Werner, 'Kicz i sztuka trywialna jako sztuki użytkowe' [Kitsch and trivial art as functional art], in Jan Białostocki (ed.), Pojęcia, problemy, metody współczesnej nauki o sztuce [The notions, issues and methods of contemporary art studies] (Warsaw, 1976), 466-484.

Ingarden, Roman, 'Wartości artystyczne i wartości estetyczne' [Artistic values and aesthetic values], in Jan Białostocki (ed.), Pojęcia, problemy, metody współczesnej nauki o sztuce [The notions, issues and methods of contemporary art studies] (Warsaw, 1976), 194-214.

Janson, Horst W., 'Oryginalność jako kryterium doskonałości' [Originality as a criterion of excellence], in Jan Białostocki (ed.), Pojęcia, problemy, 
metody współczesnej nauki o sztuce [The notions, issues and methods of contemporary art studies] (Warsaw, 1976), 215-221.

Kłoskowska, Antonina, Kultura masowa [Mass culture] (Warsaw, 1983).

Krąpiec, Mieczysław A., 'Sztuka - mimesis czy mania?' [Art: mimesis or mania?], in Marcin Podbielski (ed.), Sztuka - mimesis czy kreacja? [Art: mimesis or creation?] (Lublin, 1992), 23-38.

Kubler, Georg, The Shape of Time: Remarks on the History of Things (New Haven, 1962).

Łazuga, Waldemar, Historia powszechna. Wiek XIX [World history: the nineteenth century] (Poznań, 1999).

Makota, Janina, 'Czy mimesis w sztuce jest i dziś aktualna?' [Is mimesis in art still current today?', in Marcin Podbielski (ed.), Sztuka - mimesis czy kreacja? [Art: mimesis or creation?] (Lublin, 1992), 73-81.

Miodońska-Brookes, Ewa, Kulawik, Adam, and Tatara, Marian, Zarys Poetyki [An outline of poetics] (Warsaw, 1980), 393-440.

Mitosek, Zofia (ed.), Mimesis w literaturze, kulturze i sztuce [Mimesis in literature, culture and art] (Warsaw, 1992).

Mitosek, Zofia, Mimesis. Zjawisko i problem [Mimesis: phenomenon and problem] (Warsaw, 1997).

Morawski, Stefan, 'O kryteriach aksjologicznych w odniesieniu do dzieł sztuki' [On axiological criteria in relation to works of art], in Jan Białostocki (ed.), Granice sztuki. Z badań nad teoria i historia sztuki, kultura artystyczna oraz sztuka ludowa [The limits of art: from research into the theory and history of art, artistic culture and folk art] (Warsaw, 1972), 17-27.

Morawski, Stefan, O przedmiocie i metodzie estetyki [On the object and method of aesthetics] (Warsaw, 1973).

Morawski, Stefan, Na zakręcie: od sztuki do po-sztuki [At the crossroads: from art to post-art] (Cracow, 1985).

Morawski, Stefan, Studia z historii myśli estetycznej XVIII i XIX wieku [Studies from the history of aesthetic thought of the eighteenth and nineteenth centuries] (Warsaw, 1961).

Nycz, Ryszard (ed.), Dekonstrukcja w badaniach literackich [Deconstruction in literary studies] (Gdańsk, 2000).

Nycz, Ryszard (ed.), Odkrywanie modernizmu [Discovering modernism] (Cracow, 1998).

Nycz, Ryszard, Tekstowy świat. Poststrukturalizm a wiedza o literaturze [The textual world: post-structuralism and knowledge about literature] (Cracow, 2000). 
Pajewski, Janusz, Historia powszechna 1871-1918 [World history 1871-1918] (Warsaw, 1982).

Pieter, Józef, Zarys metodologii pracy naukowej [An outline methodology of academic work] (Warsaw, 1975).

Pietrkiewicz, Jerzy, Literatura polska $w$ perspektywie europejskiej: studia $i$ rozprawy, tr. Anna Olszewska-Marcinkiewicz and Ignacy Sieradzki, ed. Jerzy Starnawski (Warsaw, 1986).

Plesske, Hans-Martin, 'Bibliographie des Schrifttums zur Geschichte deutscher und österreichischer Musikverlage', Beiträge zur Geschichte des Buchwesens, 3 (1968), 135-222.

Podbielski, Henryk, 'Pojęcie mimesis u Platona i Arystotelesa' [The notion of mimesis in Plato and Aristotle], in Marcin Podbielski (ed.), Sztuka - mimesis czy kreacja? [Art: mimesis or creation?] (Lublin, 1992), 7-22.

Porębski, Mieczysław, 'Mechanizmy i strategie wyboru' [Mechanisms and strategies of choice], in Jan Białostocki (ed.), Pojęcia, problemy, metody wspótczesnej nauki o sztuce [The notions, issues and methods of contemporary art studies] (Warsaw, 1976), 262-279.

Read, Herbert, The Meaning of Art (London, 1972).

Sławiński, Janusz, 'Synchronia i diachronia w procesie historycznoliterackim' [Synchrony and diachrony in the process of literary history], in Henryk Markiewicz (ed.), Problemy teorii literatury [Problems of literary theory], series 2: works from the years 1965-1974 (Wrocław, 1976), 271-286.

Stróżewski, Władysław, 'Mimesis i meteksis' [Mimesis and methexis], in Marcin Podbielski (ed.), Sztuka - mimesis czy kreacja? [Art: mimesis or creation?] (Lublin, 1992), 49-64.

Tatarkiewicz, Władysław, Historia estetyki [History of Aesthetics], 3 vols (Warsaw, 1985-1991).

'THE BERNE CONVENTION OF 9 SEPTEMBER 1886 ON THE PROTECTION OF LITERARY AND ARTISTIC WORKS revised in Berlin on 13 November 1908 and in Rome on 2 June 1928, Law Gazette, 21 November 1935, no. 84, item 515.

Topolski, Jerzy, Teoria wiedzy historycznej [Theory of historical knowledge] (Poznań, 1983).

Wierzbicki, Piotr, Życie z muzyka [Life with music] (Warsaw, 1993), 161-172.

Wind, Edgar, 'Critique of Connoisseurship', in Art and Anarchy with an Introduction by John Bayley (Evanston, IL, 1985), 30-46.

Żywczyński, Mieczysław, Historia powszechna 1789-1870 [World history 17891870] (Warsaw, 1990). 


\section{Encyclopaedias and lexicons}

Brockhaus Riemann - Musiklexikon, ed. Carl Dahlhaus, Hans Heinrich Eggebrecht, Kurt Oehl (Digitale Bibliothek Directmedia, 2001), Band 38. ${ }^{536}$

The Catalogue of Printed Music in the British Library to 1980, ed. Laureen Baillie (London, 1982).

Dąbrówka, Andrzej, Geller, Ewa, and Turczyn, Ryszard, Słownik synomimów [Dictionary of synonyms] (Warsaw, 1996).

Deutsch, Otto Erich, Musikverlagsnummern. Eine Auswahl von 40 datierten Listen 1710-1900 (Berlin, 1961).

Devriès, Anik, and Lesure, François, Dictionnaire des éditeurs de musique français, ii: De 1820 à 1914 (Geneva, 1988).

Einstein, Alfred, Das Neue Musik Lexikon, nach dem 'Dictionary of modern Music and Musicians'. Herausgegeben von A. Eaglefield-Hull übersetzt und bearbeitet von Alfred Einstein, 11th edn (Berlin, 1926).

Eitner, Robert, Biographisch-Bibliographisches Quellen-Lexikon der Musiker und Musikgehlerten der christlichen Zeitrechnung bis zur Mitte des 19. Jahrhunderts, 10 vols (Leipzig, 1900-1904); repr. 11 vols (Wiesbaden, 1959-1960).

Encyklopädie der gesammten musikalischen Wissenschaften, oder Univer sal=Lexicon der Tonkunst, ed. Gustav Schilling, 6 vols + supplement (Stuttgart, 1835-1842).

Encyklopedia Multimedialna PWN [Multimedia encyclopedia PWN], ed. Piotr Senatorski, Bartłomiej Kaczorowski, CD-ROM (Warsaw 1998).

Encyklopedia Muzyczna. Część biograficzna AB [Music encyclopaedia: biographical part AB], ed. Elżbieta Dziębowska (Cracow, 1979).

Encyklopedia Muzyczna. Część biograficzna CD [Music encyclopaedia: biographical part CD], ed. Elżbieta Dziębowska (Cracow, 1984).

Encyklopedia Muzyczna. Część biograficzna HIJ [Music encyclopaedia: biographical part HIJ], ed. Elżbieta Dziębowska (Cracow, 1993).

536 Brockhaus Riemann Musiklexikon in vier Bänden und einem Ergänzungsband. Herausgegeben von Carl Dahlhaus, Hans Heinrich Eggebrecht und Kurt Oehl, 2. Auflage, Mainz: Atlantis-Schott Musikbuch-Verlag, 1995. @ 2000 Schott Musik International, Mainz. 
Encyklopedia Muzyczna. Część biograficzna KLŁ [Music encyclopaedia: biographical part KLŁ], ed. Elżbieta Dziębowska (Cracow, 1997).

Encyklopedia Muzyki [Encyclopaedia of music], ed. Andrzej Chodkowski (Warsaw, 1995).

Fétis, François-Joseph, Biographie universelle des musiciens et biblio-graphie gènèrale de la musique, 8 vols +2 supplements (Paris, 1860-1880);

Frank, Paul, Kurzgefaßtes Tonkünstlerlexikon, ed. Wilhelm Altmann, 12th edn (Leipzig, 1926).

Grove's Dictionary of Music and Musicians, ed. Eric Blom, i (London, 1954).

Hofmeister, Adolf, Handbuch der musikalischen Literatur oder Verzeichniss der im deutschen Reiche und in den angrenzenden Ländern erschienenen Musikalien auch musikalischen Schriften, Abbildungen und plastischen Darstellungen mit Anzeige der Verleger und Preise (Leipzig, vols from 1852-1919).

Hugo Riemanns Musik Lexikon, ed. Alfred Einstein, 2 vols (Berlin, 1929).

Komputerowy Słownik Języka Polskiego i Słownik Wyrazów Obcych [Computer dictionary of Polish and dictionary of foreign words], ed. Mieczysław Szymczak, CD-ROM (Warsaw, 1998)[.

Mała Encyklopedia Muzyki [Concise encyclopaedia of music], ed. Stefan Śledziński (Warsaw, 1981).

Die Musik in Geschichte und Gegenwart, ed. Friedrich Blume. Bd I (Kassel, 1949-51).

Die Musik in Geschichte und Gegenwart, ed. Friedrich Blume. Sachteil 1 (Kassel, 1994).

Die Musik in Geschichte und Gegenwart, ed. Friedrich Blume. Sachteil 9 (Kassel, 1998).

Musikalisches Conversations-Lexikon, ed. Hermann Mendel, 11 vols + supplement (Berlin, 1870-1883).

The New Grove Dictionary of Music and Musicians, ed. Stanley Sadie (London, 1980).

The New Grove Dictionary of Music and Musicians, ed. Stanley Sadie, 2nd edn (London, 2001).

Nowa encyklopedia powszechna PWN [New PWN general encyclopaedia], ed. Dariusz Kalisiewicz, iv (Warsaw, 1996).

Roguski, Gustaw, Słowniczek znakomitszych muzyków [Concise dictionary of major musicians] (Warsaw, 1906). 
Słownik muzyków polskich [Dictionary of Polish musicians], ed. Józef Michał Chomiński, 2 vols (Cracow, 1964-67).

Słownik terminów literackich [Dictionary of literary terms], ed. Janusz Sławiński, 3rd edn (Wrocław, 1998).

Słownik wyrazów obcych [Dictionary of foreign words], ed. Jan Tokarski (Warsaw, 1980).

Sowiński, Albert, Słownik muzyków polskich dawnych I nowoczesnych kompozytorów, wirtuozów, śpiewaków, instrumentalistów, lutnistów, organmistrzów, poetów lirycznych I miłośników sztuki muzycznej zawierajacy krótki rys historii muzyki $w$ Polsce [Dictionary of Polish musicians past and present: composers, virtuosos, singers, instrumentalists, lutenists, organ-masters, lyric poets and lovers of the art of music, containing a brief historical outline of music in Poland] (Paris, 1874; repr. Warsaw 1982).

Universal-Handbuch der Musikliteratur aller Zeiten und Volker. Als Nachschlagewerk und Studienquelle der Welt-Musikliteratur Eingerichtet und herausgegeben von Franz Pazdirek I. TEIL. Inhalt: Die gesammte, durch Musikalienhandlungen noch beziehbare Musikliteratur aller Volker. In ca. 18 Bänden. Wien 1904-1910, 'Universal-Handbuch der Musikliteratur': Pazdirek \& Co., Kommanditgesellschaft.

Whistling, Carl Freiderich, C. F. Whistling's Handbuch der musikalischen Literatur, ed. Adolph Hofmeister, i (Leipzig, 1844). 


\section{Index of names and musical titles}

A

Adolfson, see Sonnenfeld

Adolf Gustaw

Ahna Heinrich de 92, 95, 108, 268

Alard Jean-Delphin 54

Alboni Marietta 82

Alexandre César Léopold, see Bizet

Georges

Alkan (Morhange,

Charles-Valentin) 52

Altmann Wilhelm 10

Amadis Pietro, see Zadora

Michael von

Anders Henryk Paweł 45, 46, 65, 66

Andersen Joachim 58

Andraschke Peter 64

Appel Bernhard R. 84, 85

Arensky Anton 113

Arnold Matthew 196

Artôt-Padilla (Marguerite Joséphine)

Desirée 91, 92, 94, 95, 107, 268

Aristotle 211, 215

Auer Leopold 55, 97, 113, 269

B

Bach Johann Sebastian 52, 54, 56, 64, 87, 103, 104, 108, 109, 113, $114,117,155,190$

Bach-Liszt (also Liszt-Bach) 114

Backhaus Wilhelm 91

Bączyk Andrzej Henryk 15, 117

Balakirev Mily 46, 59, 62, 65, 164, 213, 216, 270

Banner Michael 92, 97

Barbedette Henri 45

Barge Wilhelm 58, 270

Bargiel Woldemar 78

Barta Janusz 79, 83, 84
Bazylow Ludwik 29

Bazzini Antonio 92, 93, 99, 101, 268

Beethoven Ludwig van 49, 52, $54,55,62,67,87,99,104,113$, 114,190

Bellini Vincenzo 57, 87, 114

Bełszyński Jan 80

Bendel Franz 92, 94, 104, 268

Berlioz Hector 80, 91, 102, 104, 113, 194, 223

Bial Carl 49, 53, 270

Bial Rudolf 49

Białostocki Jan 287-289

Biernacki Michał 6, 65, 80, 81, 194, 229, 243, 252-255

Bille 56

Bilse Beniamin 56, 93, 97

Bizet Georges (Alexandre César Léopold) 113

B. L. (see Literska Barbara)

Błaszczyk Leon Tadeusz 66

Bockmühl Robert Emile 57, 206, 270

Bogdani Wanda 92, 94

Böhm Teobald 58

Bohn Emil 106, 110, 112, 113

Bordèse F. Luigi 59, 61, 168, 176-181, 251, 254, 261, 262, 266, 270

Bösche Thomas 19

Boyd Malcolm 17

Brahms Johannes 50, 52, 54, 55, 62, $78,87,91,104,113,229,230$

Bristiger Michał 62

BRML, see Brockhaus

Riemann 9, 16, 46

Brockhaus Riemann (abbreviation BRML) 9

Brodsky Adolf 92, 96, 111, 112, 269 
Bronarski Ludwik 21, 269

Bruch Max 106

Bruckner Anton 233

Brzezina Antoni 21, 24, 69, 81, 280

Büchner Ferdinand 58, 59, 182-186, $189,190,212,262,270$

Bull Ole Bornemann 91

Bülow Hans von 91-93

Burmeister Richard 255

Busoni Ferruccio 46, 52, 59, 62, 66, 91, 139

Buxtehude Dietrich 52

C

Casals Pablo 91

Catalani Angelica 91

Chechlińska Zofia 20

Chęciński Jan 23, 163, 165, 166, 229, 243, 250, 254, 260, 266, 270, 271

Chomik Irena 23

Chomińska-Wilkowska

Krystyna 29, 217, 223, 286

Chomiński Józef Michał 9, 11, 13, $21,23,27-30,46,62,70,71,76$, $111,199,203,217,223,265,284$

Chopin Frederick

- Ballades:

G minor Op. 2342

F major Op. 38 42, 44, 67, 201, 206, 254

Andantino 42, 44, 201, 202

A flat major Op. 47 42, 67, 199

F minor Op. 5242

- Etudes:

C major Op. 10 No. 1 32, 140, 144

A minor Op. 10 No. 2 31, 32

E major Op. 10 No. 3 31, 32

C sharp minor Op. 10 No. 432

G flat major Op. 10 No. 5 32, 31, 184,185

E flat minor Op. 10 No. 6 32, 31,63
C major Op. 10 No. 7 32, 140, 144

F major Op. 10 No. 832

F minor Op. 10 No. 932

A flat major Op. 10 No. 1032

E flat major Op. 10 No. 1132

C minor Op. 10 No. 1232

A flat major Op. 25 No. 132

F minor Op. 25 No. 2 31, 32, 121, $185,186,252$

F major Op. 25 No. 3 32,

184,185

A minor Op. 25 No. 432

E minor Op. 25 No. 532

G sharp minor Op. 25 No. 6 32, $64,121,186$

C sharp minor Op. 25 No. 7 31, $32,44,63$

D flat major Op. 25 No. $8 \quad 32,121$

G flat major Op. 25 No. 9 32, 182, 186

B minor Op. 25 No. 1032

A minor Op. 25 No. 1132

C minor Op. 25 No. 1232

Méthode des Méthodes 32, 63

F minor No. 132

A flat major No. 232

D flat major No. 332

- Fantasies:

A major Op. 1342

F minor Op. 49 42, 67, 254

- Impromptus:

A flat major Op. 29 41, 40, 64

F sharp major Op. 36 41, 199

G flat major Op. 5141

C sharp minor Op. 66 (Impromptu-Fantasie) 40, 41

- Concertos:

E minor Op. 11 43, 44, 60, 201

movt I: Romance Larghetto 43, 44,201

F minor Op. 21 21, 28, 43, 201, 255 
movt II: Larghetto 43, 44, 94, 103, 104, 201

movt III: Allegro vivace 28, 43, 201

Allegro de concert Op. 46 43, 201

- Mazurkas:

F sharp minor Op. 6 No. 1 34, 35, 206, 224-226, 249, 253, 263

C sharp minor Op. 6 No. 235

E major Op. 6 No. 335

E flat minor Op. 6 No. 4 22, 23, 35,253

C major Op. 6 No. 535

B flat major Op. 7 No. 1 22, 26, $34,35,44,112,200,218-220$, 224, 253, 263

A minor Op. 7 No. 2 22, 35, 167, 244, 266

F minor Op. 7 No. 3 23, 35, 167, 169-175, 248, 261, 266

A flat major Op. 7 No. 135

B flat major Op. 17 No. 1 22, 35, 64, 168, 176-181, 190, 228, 247, 253, 255, 261, 262, 266

E minor Op. 17 No. 235

A flat major Op. 17 No. 335

A minor Op. 17 No. 4 23, 35, 168, 176, 266

G minor Op. 24 No. 1 34, 35, 224, 253, 254

C major Op. 24 No. 2 35, 23

A flat major Op. 24 No. 3 28, 35, 245, 253

B flat minor Op. 24 No. 435

C minor Op. 30 No. 1 35, 253

B minor Op. 30 No. 2 22, 35 , 246, 253

D flat major Op. 30 No. 335

C sharp minor Op. 30 No. 435

G sharp minor Op. 33 No. 136

C major Op. 33 No. 2 22, 36, 64, 224, 253, 255
D major Op. 33 No. 3 34, 36, 63, 190, 253

B minor Op. 33 No. 4 36, 111

E minor Op. 41 No. 1 34, 36

B major Op. 41 No. 236

A flat major Op. 41 No. 3 36, 62

C sharp minor Op. 41 No. 436

G major Op. 50 No. 1 23, 36, 64

A flat major Op. 50 No. 2 22, 36, 224, 253

C sharp minor Op. 50 No. 3 36, 63

B major Op. 56 No. 136

C major Op. 56 No. 2 36, 64

C minor Op. 56 No. 336

A minor Op. 59 No. 1 23, 36, 254

A flat major Op. 59 No. 236

F sharp minor Op. 59 No. 336

B major Op. 63 No. 136

F minor Op. 63 No. 236

C sharp minor Op. 63 No. 336

G major Op. 67 No. 1 23, 36, 254

G minor Op. 67 No. 236

C major Op. 67 No. 3 36, 63

A minor Op. 67 No. 436

C major Op. 68 No. 136

A minor Op. 68 No. 2 22, 36, 224

F major Op. 68 No. 3 36, 64, 255

F minor Op. 68 No. 436

A minor (Gaillard) 36

A minor (Notre Temps) 36

- Nocturnes:

B flat minor Op. 9 No. 1 23, 39, $60,126,163,165,166,243$, 260, 266

E flat major Op. 9 No. 2 23, 37, $39,44,64,93,95-97,101,106$, $108,109,111,126,188-190$, 220, 223, 224, 252, 262, 263, 266

B major Op. 9 No. 339

F major Op. 15 No. 1 23, 39, 63,254

F sharp major Op. 15 No. 239 
G minor Op. 15 No. 3 39, 62

C sharp minor Op. 27 No. 139

D flat major Op. 27 No. 2 39, 97, 102, 113, 190

B major Op. 32 No. 1 37, 39, 199

A flat major Op. 32 No. 2 39, 63

G minor Op. 37 No. 1 37, 39, 64, 233, 235, 264

G major Op. 37 No. 239

C minor Op. 48 No. 1 39, 63

F sharp minor Op. 48 No. 239

F minor Op. 55 No. 1 37, 39

E flat major Op. 55 No. 239

B major Op. 62 No. 1 23, 39, 254

E major Op. 62 No. 239

E minor Op. 7239

C sharp minor (Lento con gran espressione) 39

- Polonaises:

C major Op. 3 27, 37, 34, 44

E flat major Op. 2237

C sharp minor Op. 26 No. 134 , $37,104,126,285$

E flat minor Op. 26 No. 2 37, 126

A major Op. 40 No. 1 34, 37, 44, 63, 96, 255

C minor Op. 40 No. 237

F sharp minor Op. 4437

A flat major Op. 53 34, 37, 63, 64, 97, 255

A flat major Op. 61

(Polonaise-Fantaisie) 37, 67

D minor Op. 71 No. 137

B flat major Op. 71 No. 237

F minor Op. 71 No. 337

B flat major 37

G sharp minor 37,273

$\mathrm{G}$ flat major 37

- Songs Op.74:

No. 1 Życzenie [A Maiden's

Wish] 34, 38, 44, 64, 67, 110, 202, 254
No. 2 Wiosna [Spring] 38, 64

No. 3 Smutna rzeka [Troubled Waters] 38, 222

No. 4 Hulanka [Drinking

Song] 38, 64, 254

No. 5 Gdzie lubi [A Fickle

Maid] 38, 222, 254

No. 6 Precz z moich oczu

[Remembrance] 38, 222, 255

No. 7 Posel [The Messenger] 38

No. 8 Śliczny chłopiec [My

Beloved] 38, 255

No. $9 \mathrm{Z}$ gór gdzie dźwigali [Bowed 'neath their Crosses] 38, 222

No. 10 Wojak [Before the Battle] 38, 222, 255

No. 11 Dwojaki koniec [The Lovers] 38, 254, 255

No. 12 Moja pieszczotka [My Enchantress] 38, 54, 96

No. 13 Nie ma czego trzeba [Faded and Vanished] 38

No.14 Pierścień [The Ring] 34, 38, 64, 202, 222

No. 15 Narzeczony [The

Bridegroom's Return] 38, 64

No. 16 Piosnka litewska [Lithuanian Song] 38, 94, 154, $155,157,158,254,260,266$

No. 17 Leci liście z drzewa [Leaves are Falling] 38, 50, 154, 158-162, 222, 254, 260, 266

- Preludes:

C major Op. 28 No. 133

A minor Op. 28 No. 233

G major Op. 28 No. 3 33, 255

E minor Op. 28 No. 4 31, 33, 67

D major Op. 28 No. 5 31, 33

B minor Op. 28 No. 6 33, 199

A major Op. 28 No. 7 31, 33, 44, 63,254

F sharp minor Op. 28 No. 833 
E major Op. 28 No. 9 33, 67

C sharp minor Op. 28 No. 1033

B major Op. 28 No. 1133

G sharp minor Op. 28 No. 1233

F sharp major Op. 28 No.

$$
1333,67
$$

E flat minor Op. 28 No. 1433

D flat major Op. 28 No. 15 31, 33

B flat minor Op. 28 No. 1633

A flat major Op. 28 No. 1733

F minor Op. 28 No. 1833

E flat major Op. 28 No. 1933

C minor Op. 28 No. 20 31, 33, 62, $64,67,254,255$

B flat major Op. 28 No. 2133

G minor Op. 28 No. 2233

F major Op. 28 No. 2333

D minor Op. 28 No. 2433

C sharp minor Op. 4533

- Rondos:

C minor Op. 1 41, 28

F major Op. 1441

E major Op. 1641

C major Op. 7341

- Scherzos:

B minor Op. 20 42, 67

B flat minor Op. 31 42, 93, 98, 199

C sharp minor Op. 39 42, 62

E major Op. 5442

- Sonatas:

C minor Op. 442

B flat minor Op. 35 40, 42, $44,45,62$

B minor Op. 5842

G minor Op. 65 42, 47, 57

- Walzes:

E flat major Op. 18 40, 63

A flat major Op. 34 No. 140

A minor Op. 34 No. 2 37, 40, 60, 129, 131-136, 227, 252, 254, 259, 263

F major Op. 34 No. 3 40, 129
A flat major (Grande-Valse)

Op. 4240,64

D flat major Op. 64 No. 137 , $40,44,64,110,202,230,252$, 254, 266

C sharp minor Op. 64 No. $240,63,64$

A flat major Op. 64 No. 340

A flat major Op. 69 No. 140

B minor Op. 69 No. 240

G flat major Op. 70 No. 1 40, 63

F minor Op. 70 No. 240

D flat major Op. 70 No. 340

A flat major Op. 42 40, 64, 129,190

A flat major 40, 111

E minor 40

- Variations:

Op. 241

Op. 1241

E major (from Hexameron) 41

- Others:

Barcarolle Op. 6041

Berceuse Op. 57 23, 40, 41, 65

Bolero in C major Op. 19 41, 199

Ecossaises Op. 7241

Grand Duo concertant in E major $28,41,47,57,83$

Largo in E flat major 41

Funeral March Op. 35 41, 42, 254, 255

Funeral March in C minor

Op. 72 40, 41, 103

Moderato in E major (Feuille d'Album) 41

Tarantella in A flat major

Op. 43 41, 63, 102, 124, 126

Trio in G minor Op. 8 28, 41

CT, see Chomiński Józef Michał,

Turło Teresa Dalila

Chybiński Adolf 66

Conus George 55 
Conus Julius 55, 70, 271

Cornelius Peter 62

Cortot Alfred 91

Cossmann Bernhard 92-94, 101, 102,268

Cramer Johann Baptist 62

Czernek Ewa 20, 125-127, 136

Czerny Carl 49, 50, 87, 230, 271

Czersky Alexander, see Tschirch Friedrich Wilhelm

D

Dąbrowski Mieczysław 194, 214

Dahlhaus Carl 125, 152, 194, 196, 197, 204-207, 211

Damrosch Leopold 92, 93

David Ferdinand 49, 54-56, 129-133, 259, 271

Davidoff, Karl (Carl) 57, 190, 252, 271, 272

Debussy Claude Achille 77, 86, 231

Dehn Siegfried Wilhelm 50

Delibes (Clément Philibert) Léo 54

Derrida Jacques 241

Deszczyński Józef 203

Deutsch Otto Erich 9, 21, 64, 69, $129,131,154,157,158,200,218$, $221,270,271,273,276-284$

Devriès Anik 9, 21, 69, 272, 273, 281, 282, 284

Dietz Louis 255

Dmuszewski Ludwik 81

Döhler Theodor 87

Dokshitser Timofei 239

Draheim Joachim 29

Drechsler Josef 57, 92, 93

Dreyschock Alexander 49

Dudevant Aurore, see Sand George

Dulcken Louisa 49

Dulcken Ferdinand Quentin 49, 53, 253, 272

Dvořák Antonin 113
E

Eaglefield-Hull Arthur 10

Eckert Karl 102

Eggebrecht Hans Heinrich 124, 125

Ehlert Louis 87, 88

Einem Herbert von 211, 214

Einstein Alfred 10, 47, 49, 53, 223

Eitner Robert 9, 47, 48

Elsner Józef 51, 203

Enault Louis 46

Engel Hans 17-19

Ernst Heinrich Wilhelm 91

Esser Heinrich 114

F

Fellinger Imogen 85-87

Fenz 56

Ferrata Giuseppe 9, 49, 53, 229-232, 263, 272, 284

Fétis François-Joseph 9, 47, 48

Finkenstein Jettka 92, 96

Fischer Adolf 92, 94, 107, 268, 272

Flesch Karl 91

Flügel Ernst 111

Forest 82

Frączyk Tadeusz 69

Franchomme Auguste-Joseph 19, $46,47,57,70,78,82,221,225$, 263, 273

Frank Paul 10, 47

Franz (Knauth Robert) 87

Freyer August 60

Friedländer Max J. 210, 217

Friedman Ignacy 77

Fubini Enrico 194

Furst Joe 9, 284

Furtwängler Wilhelm 91

G

Gabrilowitsch Ossip 92, 97, 113, 269

Gade Niels Wilhelm 62 
Galkin Nikolay

Vladimirovich 55, 273

García-Viardot Pauline, see ViardotGarcía Pauline

Garvelmann Donald M. 9, 284

Ginzburg Lev 63

Glinka Mikhail 227

Glazunov Alexander 46, 59, 63, 65,255

Godowsky Leopold 46, 50, 53, 59, $63,65,66,90,117-121,124$, 139-152, 154, 212, 259, 260

Gołąb Maciej 14, 29, 30, 122, 124, $139,153,162,182,206,216,217$, 237, 265

Gołaszewska Maria 193, 194, 211

Goldmark Károly 62

Goldschmidt Jenny, see Lind Jenny

Goldschmidt Otto 93, 100, 101

Golinelli Stefano 78

Gounod Charles François 88, 155

Grabowski Krzysztof 20, 69, 79

Gregorowicz Charles 92, 96, 268

Grieg Edward 49, 91

Groot Jules de 48, 216, 272

Grossman Ludwik 59-61, 247, 253, 273

Grützmacher Leopold 46, 57, 58,

$$
\text { 212, 273-276 }
$$

Grzymała Wojciech 82, 100

Gutmann Adolf 100

H

Hamelin Marc-André 65

Hamm Johann Valentin 60, 61, 276

Händel George Frideric 54, 67, 101, 107,114

Hänsel August 50, 53, 200, 218, 220, 221, 263, 276

Hartmann Nicolai 125

Hasert Rudolf 50, 53, 154, 159-162, $260,266,276$
Hauptmann Moritz 54, 56, 57

Haydn Joseph 54, 67, 113

Hegel Georg Wilhelm

Friedrich 215

Heine Heinrich 80

Heller Stephen 87, 164

Hellmesberger Joseph 54

Helman Zofia 14

Henselt Adolf von 50, 87, 230

Hermann Friedrich 55, 60, 212, 276, 277

Hesse Adolf Friedrich 99-101

Hiller Ferdinand 49

Himmelstoss Richard 92, 95, 108,268

Hlavác Voizech J. 252

Hoesick Ferdynand 24, 45, 71, 270

Hoffmann Richard 66, 69

Hofmann Werner 196, 208

Hofmeister Adolf 10, 11, 21, 50, 69,284

Höhnen Lilli 92

Hordyński Władysław 69

Horn August 60, 61, 69, 129,

134-136, 259, 277, 278

Hummel Johann Nepomuk 87, 91

Huneker James 45, 65, 66, 78

I

Ingarden Roman 125, 208, 209

J

Jadassohn Salomon 66

Jagodziński Andrzej 239

Jankowska Bożena 14

Janson Horst W. 211

Jarocińska Michalina 289

Jasińska Danuta 217

Joachim Józef 54, 55, 91

Johannsen 61

Joseffy Rafael 9, 46, 50, 51, 53, 218, 230-234, 263, 264, 278, 284 
K

Kalbeck Max 107

Kalkbrenner Friedrich Wilhelm Michael 28, 50, 53, 62, 100, 217-220, 262, 278

Kallberg Jeffrey 14, 20

Kamiński 55

Kania Emanuel 253

Kański Józef 50-52

Karasowski Maurycy 45

Karłowicz Mieczysław 45, 46, 59, 65, 66

Karpiński Franciszek 229

Kashkin Nikolay 48, 72

Kaufmann Mathilde 92, 95

Kątski Apolinary 56

Kéler Béla 114

Keller Maurice 63

Kiel Friedrich 88

Kindt Paul 92, 95

Kirchner Theodor 87

Kleczyński Jan 78

Kleinmichel Richard 50, 190, 278

Klengel Julius 87, 92, 95, 108, 109,268

Klindworth Karl 77, 78

Kłoskowska Antonina 194, 196

Knauth Robert, see Franz

Kneif Tibor 194, 197, 207, 208

Kobylańska Krystyna 83

Köhler Louis 61, 62, 77, 78, 87

Kolberg Oskar 53, 83

Koussevitzky Serge

Alexandrovich 91

Kreisler Fritz 46, 47, 54, 83, 252, 278, 279

Kreutzer Rodolphe 55

Krüger Eduard 88

Kubelik Jan 91

Kubler Georg 214, 215

Kullak Theodor 50, 61

Kurpiński Karol 203, 227, 228
L

Lablache Luigi 82

Lachner Franz 102

Laistner Max 9, 279, 284

Lamond Frederic Archibald 91

Lyapunov Sergey Mikhailovich 164

Laub Ferdinand 55

Łazuga Waldemar 29

Lefébure-Wély Louis James Alfred 52

Lehmann Lilli 92, 94, 105, 268

Leichtentritt Hugo 45, 216

Lelewel Joachim 81

Leo Gustave 48, 279

Léonard Hubert 56

Lesure François 9, 21, 69, 284

Leschetizky Theodor 52

Lewandowska Teresa 14

Lind Jenny (Goldschmidt Jenny) 82, 91, 92, 100, 268

Lipiński Karol Józef 53, 58, 126, 216, 252, 279

Lissa Zofia 15, 20, 27, 64, 90, 124

Liszt Franz (Ferenc) 16, 17, 45, 46, 49-52, 56, 57, 59, 64-66, 78, 80, $83,88,90,91,93,95-98,102,104$, $110,111,113-115,139,229,230$, 237, 252, 279

Literska Barbara (also B. L.) 121

Löw (Loewe, Lebe) Johann Jacob von Eisenach

Ludvová Jitka 20

Łusakowski Jan 66, 69, 187-190, 212, 262, 266, 279

Lüstner Louis 92, 94

M

Malinowska-Szczepańska Elżbieta 121

Mario Giovanni, Cavaliere di Candia 82

Markiewicz Henryk 293 
Markiewicz Ryszard 79

Mascagni Pietro 91

Massart Joseph Lambert 54

Maszyński Piotr 22, 59, 67, 169-175, 177-181, 249, 251, 254, 255, 261, 262, 279

Mattersdorff Alice 92

Mazur Krzysztof 288

Mendel Hermann 10, 47, 50

Mendelssohn-Bartholdy Felix Jakob Ludwig 49, 54, 55, 62, 85, 88, 113,233

Menzel Elza 92, 95

Mersmann Hans 124

Mertke Eduard 78

Meyer Carl 87

Meyerbeer Giacomo (Jakob

Liebmann Meyer Beer) 57

Michaelis Alfred 48, 279

Michałowski Aleksander 9, 252, 284

Michałowski Kornel 20

Mickiewicz Adam 199

Miketta Janusz 83

Mikuli Karol 51, 53, 77, 78, 200, 201, 229, 252, 255, 279

Mitosek Zofia 215

Młodziejewski Jerzy 66

Mockwitz Friedrich 67, 69, 279, 280

Moffat Alfred Edward 67, 69, 280

Mompou Federico 62

Moniuszko Stanisław 51, 58, 66, 228

Morawski Stefan 193-195, 209, 213, 215, 239

Morelli Giovanni 209, 210, 217

Moriolówna 81

Morley Charles 48, 280

Morhange Charles Henri Valentin, see Alkan

Moscheles Ignaz 50, 54, 230

Moszkowska Regina 92, 97, 112

Moszkowski Moritz 9
Mozart Wolfgang Amadeus 19, 54, 64, 67, 113, 196

Müller Christian Gottlieb 67, 280

Müller-Berghaus 94, 97

Münchheimer Adam 59-61, 228, 248, 253-255, 263, 280

Mussorgsky Modest Petrovich 227

$\mathbf{N}$

Nägeli Hans Georg 196

Nałęcz Mariola 14

Niecks Frederick 45

Nietzsche Friedrich 196

Niewiadomski Stanisław 199

Nikiporczyk-Zakrzewska Barbara 47, 69

Noskowski Zygmunt 19, 59, 64, 66, 194, 199, 253, 255

Novácek Ottokar 62

Nowakowski Józef 51, 53, 93, 245, 253, 280

Nycz Ryszard 194, 213, 214, 241

O

Ogiński Michał Kleofas 203

Orłowski Antoni 21, 28, 43, 81, 280

Ostrowski Krystyn 49

\section{$\mathbf{P}$}

P. S. 103

Paderewski Ignacy Jan 21, 49, 269

Padilla Mariano 107

Padilla-Artôt Désirée, see ArtôtPadilla Désirée

Paganini Niccolò 52-54, 57, 91, 102, 103, 218

Pajewski Janusz 29

Patti Adelina 91

Pergolesi Giovanni Battista 104

Persiani Giuseppe 82

Philip Isidor 9, 280, 284

Pietrkiewicz Jerzy 115 
Pisarenko Olgierd 20

Pixis, brothers 91

Plato 215

Plesske Hans-Martin 69

Pleyel Camille 50, 82

Pociej Bohdan 15

Pomey Louis 224, 229, 249, 250

Poniatowska Irena $14,16,20,45,46$, 83, 89, 115, 197-200, 204, 217

Popp Wilhelm 58, 59, 280

Popper David 92, 95, 102, 107, 113, 268

Porębski Mieczysław 210

Prill Emil 46, 47, 58, 59, 129, 131, 132, 134, 135, 259, 280, 281

Prill Karl 58

Prill Paul 58

Prokopowicz Maria 69

Prychodko Ondrej 20

Pugno M. Raoul 78

Purcell Henry 67

\section{$\mathbf{R}$}

Rachmaninov Sergey 62

Radziszewski Maksymilian 254

Raff (Joseph) Joachim 103

Ravel Maurice 19

Read Herbert 214

Reger Max 9, 46, 59, 64, 66, 83, 88, $90,139,212,214,281,284$

Reinecke Karl Heinrich 77, 78, 107, 252

Reisenauer Alfred 92, 96, 109, 268

Reményi Eduard 54, 70, 281

Richter Ernst Friedrich 56, 73

Richter Ludwig 84

Riehl Wilhelm Heinrich 84

Riemenschneider Georg 96

Rimsky-Korsakov Nikolay 19, 46, $59,61,63,64,66$

Röckel Eduard 87

Roguski Gustaw 11, 47, 48
Roeder (Röder) Martin 60, 61, 154-156, 161, 254, 260, 266, 281

Rohde Eduard 48, 154, 155, 157, 158, 260, 281

Romańczyk Marek 14

Rosen Maurice 48, 281

Rosenkranz Karl 196

Rosenthal Moriz (Moritz Morice) 9, $46,51,53,65,92,96,110,111$, 269, 281

Rossini Gioachino Antonio 114

Roubier Henri 48, 281

Rubinstein Anton 88, 91

Rudorff Ernst 78

Ruelle M. Jules 23, 70, 223, 243, 254, 281

Rungenhagen Carl Friedrich 60

Ruskin John 196

S

Saint-Saëns (Charles) Camille 49, $52,88,114$

Salmen-Busch Gabriele 58

Samson Jim 20, 78, 84, 215-217, 221

Sand George (Dudevant Aurore) 115

Saphir Moritz 85

Sarasate Pablo 46, 47, 54, 58, 70, 91 , 92, 94-97, 105, 106, 111, 112, 218, 252, 268

Sauret Emile 55

Scarlatti Domenico 49, 110, 114

Schaeffer Bogusław 29

Scharwenka Ludwig 61

Scharwenka Xaver 61, 78, 282

Schenker Heinrich 125

Schiller Friedrich 195

Schilling Gustav 9, 47, 48

Schmidt Franz 57, 81

Schnabel Arthur 91

Schnecker Peter August 201

Schneider Friedrich 57 
Schneider R. 102

Scholtz Hermann (Herrmann) 52,

$53,78,201,282$

Scholz Bernhard 102

Schönberg Arnold 29

Schonberg Harold 65

Schröder Gesine 19

Schubert Carl 57

Schubert Franz Louis 51, 52, 54, 62, $64,67,69,81,88,102,104,107$, $110,114,201,231,282$

Schuberth Karl Eduard 57, 73, 75, 232-234, 263, 264, 278

Schulz August 55, 282

Schulz L. 48

Schumann Clara 91

Schumann Robert Alexander 28, 49, $52,55,62,64,84-87,89,101,103$, 104, 107, 114, 196, 207, 229

Schytte Ludvig Theodor 51

Sennewald 24, 81, 282

Sęp Józef (Tobiecki Jan) 248

Servais Adrien-François 57, 107, 252,282

Sgambati Giovanni 49, 52, 53, 229, 282

Singer Edmund 55, 282

Skowron Zbigniew 291

Sławiński Janusz 11, 241

Sokolov Nikolay Alexandrovich 61, 229, 282

Sonnenfeld Adolf Gustaw (pseud. Adolfson) 56, 60, 270

Sontag Henriette 91

Sorabji Shapurji Kaikhosru 9, 284

Sowiński Albert 11, 47-49, 51, 53, $56,60,66,267$

Spohr F. 66

Spohr Louis 54, 91

Stocks J. 87

Strauss Eduard 97, 94
Strauss Johann 114

Strauss Richard 91

Studziński Karol 56, 59, 245, 253, 283

Süssmayr Franz Xaver 19

Szafran Lora 239

Szalit Paulina 97

Szczepańska-Malinowska, see

Malinowska-Szczepańska E.

Shchurovsky Pyotr 225, 227, 229, 252, 263, 283

Sheremetiev 49

Szigeti József 91

Szulc Marcin Antoni 45

Szymanowska Maria 203

$\mathrm{T}$

Taborowski Stanisław 56, 218, 222, 263, 283

Taine Hippolyte Adolphe 215

Taraszkiewicz Barbara 121

Tartini Giuseppe 56

Tatarkiewicz Władysław 194

Tausig Carl 49, 50, 230

Tchaikovsky Pyotr Ilyich 113

Thalberg Sigismond 87, 91

Thibaud Jacques 91

Thomas Theodore 50

Tomaszewski Mieczysław 79, 164, 199, 202, 216, 222, 229

Trychoń-Cieślak Katarzyna 99

Tschirch Friedrich Wilhelm (pseud.

Czersky Alexander) 86

Tua Teresina 95, 97

Tuchowski Andrzej 14, 203

Turczyński Józef 21, 269

Turło Teresa Dalila 9, 13, 21, 23, 27-30, 46, 62, 70, 71, 76, 111, 199, 265,284

U

Ujejski Kornel 229, 245, 247 


\section{V}

Verdi Giuseppe 64, 209

Viardot-García (Michelle

Ferdinande) Pauline 22, 46, 59, $70,82,83,88,90,91,94-97,105$, $107,112,117,164,167,169-175$, 224-226, 249, 250, 253, 254, 261, 263, 266, 283

Vieuxtemps Henri 91

Vilbac Renaud de 52, 70, 233, 236, 264, 272

Viotti Giovannni Battista 54, 55

Vitali Ricardo 78

\section{W}

Wagner Ernst David 68

Wagner (Wilhelm) Richard 52, 62, $64,91,101,103,114,229,231$, 233, 283, 284

Walker Alan 17

Weber Alfred 196

Weber Carl Maria 101, 102, 114

Weber Jan 62, 203

Wedekind Erika 97, 112, 269

Weil Kurt 62

Weingartner Felix Paul 91

Wenzel E. F. 50, 230

Whistling Carl Friedrich 11, 50, 57

Wieck Friedrich 87

Wiedemann Ludwig 96, 97

Wieniawski Henryk 53, 55, 114
Wierzbicki Piotr 214

Wilhelmj August Emil Daniel 54, 70, 93-97, 102-104, 108, 201, 216, $218,220,221,223,224,233,235$, $252,263,264,268,284$

Wilkowska-Chomińska (see

Chomińska-Wilkowska K.)

Wind Edgar 209

Wisłocki Bogumił 245

Witkowska-Żórawska

Alina 14

Woyciechowski Tytus 81

Worbs Hans Christof 86, 88, 89

Woźna-Stankiewicz Małgorzata 14

Würfel Wilhelm 51

Y

Ysaÿe Eugene 91

$\mathbf{Z}$

Zadora Michael von (pseud. Pietro Amadis) 9, 52, 53, 212, 284

Zakrzewska-Nikiporczyk (see

Nikiporczyk-Zakrzewska B.)

Zanardini Zngelo 154

Zanger Gustaw 68, 284

Zduniak Maria 14, 56, 90-95, 97, 98, 114, 115

Żeleński Władysław 62, 64

Zemlinsky Alexander von 86

Żywczyński Mieczysław 29 


\title{
Eastern European Studies in Musicology
}

\author{
Edited by Maciej Gołąb
}

Vol. 1 Paweł Gancarczyk / Lenka Hlávková-Mráčková / Remigiusz Pośpiech (eds.): The Musical Culture of Silesia before 1742. New Contexts - New Perspectives. 2013.

Vol. 2 Laura Vasiliu/Florin Luchian/Loredana Iaţeşen/Diana-Beatrice Andron (eds.): Musical Romania and the Neighbouring Cultures. Traditions-Influences-Identities. Proceedings of the International Musicological Conference July 4-7, 2013, Iaşi (Romania). 2014.

Vol. 3 Barbara Przybyszewska-Jarmińska: Marcin Mielczewski and Music under the Patronage of the Polish Vasas. Translated by John Comber. 2014.

Vol. 4 Tomasz Jasiński: The Musical Rhetoric of the Polish Baroque. Translated by Wojciech Bońkowski. 2015.

Vol. 5 Bogusław Raba: Between Romanticism and Modernism. Ignacy Jan Paderewski's Compositional CEuvre. Translated by John Comber. 2015.

Vol. 6 Maciej Gołąb: Musical Modernism in the Twentieth Century. Translated by Wojciech Bońkowski. 2015.

Vol. 7 Wojciech Bońkowski: Editions of Chopin's Works in the Nineteenth Century. Aspects of Reception History. 2016.

Vol. 8 Ivana Perković / Franco Fabbri (eds.): Musical Identities and European Perspective. An Interdisciplinary Approach. 2017.

Vol. 9 Bożena Muszkalska (ed.): The Kolbergs of Eastern Europe. 2018.

Vol. 10 Renata Tańczuk / Sławomir Wieczorek (eds.): Sounds of War and Peace. Soundscapes of European Cities in 1945. 2018.

Vol. 11 Tomasz Jeż: The Musical Culture of the Jesuits in Silesia and the Kłodzko County (15811776). 2019.

Vol. 12 Magdalena Walter-Mazur: Musical Culture of Polish Benedictine Nuns in the 17th and 18th Centuries. 2018.

Vol. 13 Danuta Popinigis: Carillons and Carillon Music in Old Gdańsk. 2019

Vol. 14 Andrzej Tuchowski: Nationalism, Chauvinism and Racism as Reflected in European Musical Thought and in Compositions from the Interwar Period. 2019.

Vol. 15 Ludwik Bielawski: Time in Music and Culture. 2019.

Vol. 16 Barbara Literska: Nineteenth-Century Transcriptions of Works by Fryderyk Chopin. Translated by John Comber. 2020. 
